\title{
A FALÊNCIA E A PRESERVAÇÃO DA EMPRESA: COMPATIBILIDADE?
}

\begin{abstract}
Apresentação de tese para obtenção de título de Doutor em Direito Comercial pela Faculdade de Direito da Universidade de São Paulo, sob a orientação do Professor Doutor Paulo Fernando Campos Salles de Toledo.
\end{abstract}

FACULDADE DE DIREITO DA UNIVERSIDADE DE SÃO PAULO São Paulo, 2012 


\section{SUMÁRIO}

CAPÍTULO PRIMEIRO - Introdução

1.1 Breves considerações iniciais. 4

1.2 Algumas palavras a respeito dos institutos disciplinados na lei concursal brasileira.

\section{CAPÍTULO SEGUNDO - Tratamento jurídico da matéria no direito} estrangeiro.

$2.1 \mathrm{O}$ direito norte-americano 28

$2.2 \mathrm{O}$ direito francês 38

$2.3 \mathrm{O}$ direito italiano 57

$2.4 \mathrm{O}$ direito alemão 70

$2.5 \mathrm{O}$ direito português 80

$2.6 \mathrm{O}$ direito espanhol 97

$2.7 \mathrm{O}$ direito argentino 110

$2.8 \mathrm{O}$ direito estrangeiro e o direito brasileiro 123

CAPÍTULO TERCEIRO - A Falência na Lei brasileira em vigor 128

3.1 A empresa e o direito concursal 130

3.1.1 Conceito de 'empresa' na falência. 130

3.1.2 Os bens do falido e a constituição da massa falida objetiva. 141

3.1.3 O estabelecimento empresarial e a falência.

3.1.3.1 O estabelecimento empresarial e a massa falida: como esses conceitos se relacionam.

3.1.4 Os contratos do devedor e os interesses jurídicos da massa na falência. . 165

3.1.5 A atuação do Juiz e do administrador judicial na administração da massa falida objetiva.

3.1.5.1 Continuação provisória das atividades e lacração. 
3.1.5.2 Os créditos constituídos no período da continuidade de negócios. ....... 186

3.2 A realização do ativo. ........................................................................ 191

3.2.1 Venda antecipada de bens. ............................................................ 195

3.2.2 A ordem de preferência na alienação dos ativos. ................................... 200

3.2.3 Inexistência de sucessão na venda de ativos. ........................................ 212

3.2.4 Modalidades de alienação dos ativos. ..................................................... 223

3.2.4.1 A adjudicação prevista no artigo 111 da Lei n. 11.101/05 .................. 229

3.3 O pagamento dos credores, o encerramento da falência e a extinção das

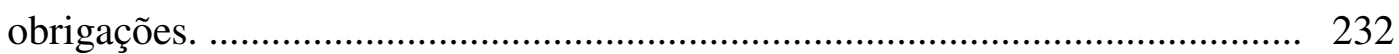

3.4 Análise do art. 75 da Lei n. 11.101/05 e as novas finalidades da Falência. 240

CAPÍTULO QUARTO - Considerações finais: A falência pode ser considerada também meio de preservação de empresas?

4.1 A falência e a Recuperação Judicial como procedimentos recuperatórios: o que as distingue? ............................................................................... 247

$4.2 \mathrm{O}$ procedimento unificado e a crise como pressuposto. ........................... 259

4.3 A falência como solução alternativa de satisfação dos credores e preservação da empresa. ................................................................................ 269

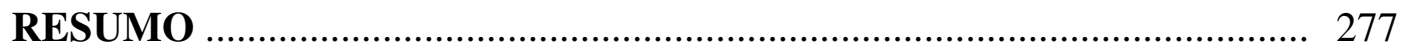

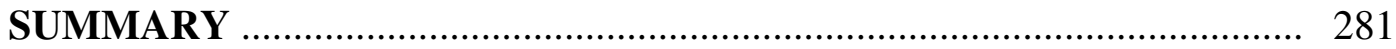

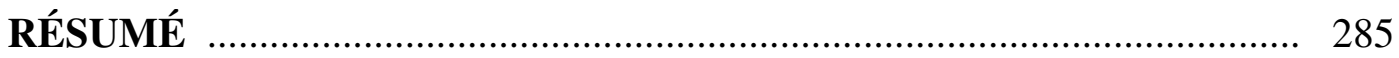

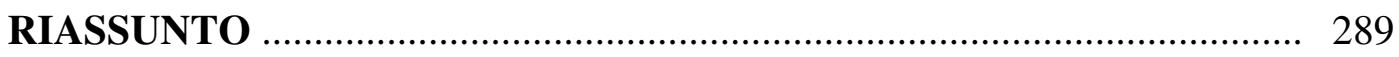

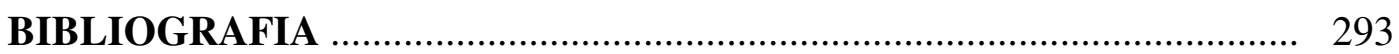




\section{CAPÍTULO PRIMEIRO INTRODUÇÃO}

\subsection{Breves considerações iniciais.}

A análise que se pretende neste trabalho consiste, precipuamente, em evidenciar a expressiva modificação que sofreu o direito da crise das empresas no Brasil a partir da vigência da Lei n. 11.101/2005, em particular, quanto ao instituto ${ }^{1}$ da falência ${ }^{2}{ }^{3}{ }_{-}^{4}$ e, inclusive, demonstrar que ainda há campo para o desenvolvimento de novas ideias que possam aperfeiçoar o direito concursal brasileiro. ${ }^{5}$

\footnotetext{
${ }^{1}$ De Plácido e Silva. Vocabulário jurídico. Rio de Janeiro: Forense, vol. II, p. 841: "Derivado do latim 'institutum' ... Na terminologia jurídica, é a expressão usada para designar o conjunto de regras e princípios jurídicos que regem certas entidades ou certas situações de direito. E com esta expressão dizemos: instituto cambial, instituto da falência, instituto da hipoteca, instituto da servidão, instituto da tutela, etc." Assim, o termo "instituto", neste trabalho, é empregado como o complexo de normas jurídicas, legais e regulamentares relativas à determinada matéria.

${ }^{2}$ A expressão falência, como lembra Nicola Jaeger, é empregada em múltiplas acepções para exprimir conceitos diversos tanto na linguagem comum, quanto técnica e, em especial, no direito. O autor expõe algumas destas acepções: "Essa significa, a volta a volta, un procedimento, vale a dire una serie di atti concatenati, compiuti da diversi soggetti (privati e organi pubblici) stimolati da moventi diversi ma cooperanti in definitiva al conseguimento di un risultato finale unico, mediante il quale si attua un pubblico interesse (causa giurudica comune a tutti gli atti-momenti e quindi all'intero procedimento); oppure un sistema di rapporti giuridici, consistenti di diritti e di obblighi, di aspettative e di oneri, di interessi destinati a prevalere ovvero a restare subordinati. Talora lo stesso termine viene usato anche per designare un patrimonio, quasi personificato, e si parla di beni appartenenti a un fallimento o di prestatori di lavoro dipendenti da un fallimento, di processi intentati contro un fallimento e così via. Altri significati richiamano il modo di essere, la situazione giuridica di uma persona o di un'impresa, che si dice trovarsi in stato di fallimento." (Il Fallimento e le altre forme di tutela giurisdizionale, Casa Editrice Dr. Francesco Vallardi, 1964, p. 61). Em tradução livre: 'Esta (a expressão falência) significa, ao mesmo tempo, um procedimento, ou seja, uma série de atos concatenados, realizados por várias partes interessadas (organismos públicos e privados) estimuladas por propósitos diferentes, mas cooperativos, para a realização de um único resultado, que se reveste de um interesse público (causa jurídica comum a todos os atos do processo e, portanto, de todo o procedimento), ou mesmo um sistema de relações jurídicas, consistente em direitos e obrigações, expectativas e ônus, de interesses destinados a prevalecer ou a se manter subordinados. Às vezes, o referido termo é utilizado para designar um patrimônio quase personificado e se fala de bens pertencentes à falência ou de trabalhadores que prestam serviços a um falido, de processos ajuizados contra um falido e assim por diante. Outro significado, que se identifica como um modo de ser, é a situação jurídica de uma pessoa ou uma empresa que se diz em estado de falência'.

${ }^{3}$ Neste trabalho, a expressão falência, empregada em língua portuguesa do Brasil, refere-se ao instituto previsto no art. 75 da Lei n. 11.101/05. Igualmente, o emprego desta expressão foi utilizado para referir a institutos análogos no direito estrangeiro.

${ }^{4} \mathrm{Na}$ tramitação do projeto que veio a resultar na Lei n. 11.101/05, em algumas versões, a terminologia "falência" havia sido substituída pelo uso da expressão "liquidação" e que é usada em diversos diplomas estrangeiros. ("Ainda a reforma da Lei de Falimentar". Revista de Direito Mercantil, Industrial, Econômico e Financeiro. São Paulo, n. 111, Ano XXXVI (nova série), pp. 203-230). Todavia, prevaleceu para o nosso direito a velha tradição da expressão antes utilizada e, talvez, não tenha sido a melhor opção, já que o sistema buscou se inovar nos fundamentos da falência.

5 Mesmo porque, como anota Lorenzo Stanghelini: "La materia delle procedure d'insolvenza è, tradizionalmente, um cantiere aperto. Più di altri settori del diritto, e persino più di altri settori di diritto
} 
Historicamente, a falência representava a "morte" ${ }^{\text {"6 }}{ }_{-}^{7}$ da empresa ${ }^{8}$. No direito brasileiro, para o devedor organizado sob a forma de sociedade, a decretação da quebra implica dissolução desta (artigos 1.044 do CC e 206, II, alínea 'c' da Lei das Sociedades por Ações) e se for empresário individual, fica inabilitado para o exercício de atividade.

Apesar de a falência não resultar na extinção imediata da personalidade jurídica - o que somente ocorre ao término do procedimento liquidatório e depois de declarada a extinção das obrigações -, o modo como o procedimento era conduzido resultava, quase que invariavelmente ${ }^{9}$, no fim da atividade empresarial explorada. Mesmo porque, em tese, todos os atos da falida, no procedimento concursal, passam a ser dirigidos, por força de lei, à extinção da pessoa jurídica pela alienação da totalidade dos ativos, com a finalidade de satisfação dos credores.

dell'economia, infatti, essa è influenziata dai continui mutamenti della realtà sociale". (STANGHELLINI, Lorenzo. Le crisi di impresa fra diritto ed economia (le procedure di insolvenza), Il Mulino, Bologna, 2007, p. 357). Em tradução livre: 'A matéria do procedimento de insolvência é, tradicionalmente, um canteiro aberto. Mais do que outros setores do direito, e ainda mais do que outros setores do direito econômico, realmente, essa é influenciada por continuada mutação da realidade social.'

${ }^{6}$ Ao se referir à finalidade liquidatória e solutória da falência, Nelson Abrão afirma: "Assim sendo, torna-se necessário o desmonte do estabelecimento ou estabelecimentos com a venda de seus componentes ao correr do martelo, aniquilando-se a atividade empresária." ( $O$ novo direito falimentar. São Paulo: Revista dos Tribunais, 1985, p. 167).

7 "Assim, a consequência natural da falência, qual seja, a cessação das atividades econômicas do falido não deve ser repudiada, porque é remédio amargo, mas necessário, na maior parte dos casos." (VILAS BOAS, Daniel Rivorêdo. A continuação dos negócios da falida: critérios e condições. Obra coletiva. Coord. DIAS DO AMARAL, Paulo Adyr e FLORIANO NETO, Alex. Direito Empresarial: Teoria, Práticas e Estratégias. Belo Horizonte: Del Rey, 2010, p. 84).

${ }^{8}$ O conceito de empresa é um "fenômeno poliédrico", conforme Asquini (RDM 104/109-126). A propósito, Paulo F. C. Salles de Toledo, ao comentar as expressões "manutenção da fonte produtora" e "preservação da empresa" referidas no artigo 47 da Lei n. 11.101/2005, lembra que "talvez o texto legal (que se presume não tenha palavras inúteis) esteja se referindo à empresa enquanto atividade, ou seja, à empresa no sentido funcional, de acordo com os célebres perfis de Asquini." ("A nova lei de falências e de recuperação de empresas". Revista do Advogado, ano XXV, n. 83, p. 103, set., 2005). Nesta linha de ideias, um dos objetivos deste trabalho será avaliar a possibilidade de utilização da expressão 'empresa', mesmo diante da falência e em quais condições isto se daria.

${ }_{9}^{9}$ Há exceções, sendo emblemático o caso da falência da sociedade Sanderson do Brasil S/A, em 1974, na qual o Estado de São Paulo declarou, por meio de decreto, o interesse social sobre os bens pertencentes à massa falida para fins de desapropriação. A justificativa do decreto considerava que "a cessação das atividades da citada empresa, de sensivel capacidade produtora, e a redução de sua integridade industrial trouxeram para o setor cítrico em geral, e, em especial para o de toda a região de Bebedouro, e Municípios circunvizinhos, prejudiciais reflexos de natureza econômico-social, atingindo toda aquela laboriosa coletividade, de um modo particular os trabalhadores da empresa e os produtores de laranja da região." (FRONTINI, Paulo Salvador. "O caso da falência da Sanderson e as tendências atuais do direito falimentar". Revista de Direito Mercantil, Industrial, Econômico e Financeiro. n. 15-16, pp. 243-251). 
Assim, na falência, com o desapossamento dos bens do devedor, em princípio, a prática de atos próprios da atividade empresarial torna-se inviável ${ }^{10}{ }^{11}$.

Realmente, até a revogação do Decreto-lei n. 7.661/1945, o direito concursal, em particular no instituto da falência, tinha por escopo principal, e talvez o mais marcante, a satisfação dos credores ${ }^{12}{ }_{-}^{13}$, mediante realização de todos os bens do devedor, o que ocorria à custa da extinção da empresa (com encerramento de suas atividades), em procedimento eminentemente liquidatório.

Essa estreita visão do direito concursal brasileiro era um dos motivos que justificava a afirmação da doutrina de que havia uma 'crise do direito falimentar ${ }^{\text {, }}{ }^{14}$, eis que a falência era considerada um processo de execução coletiva e havia meios insuficientes de salvaguarda das empresas em crise passíveis de reorganização do ponto de vista econômico e financeiro.

\footnotetext{
${ }^{10}$ Embora o regime de continuidade de negócios da falida (então previsto no artigo 74 do DL n. 7.661/45 e, atualmente, no artigo 99, inciso XI c/c artigo 109 da Lei n. 11.101/05) possa ser entendido como uma exceção a essa situação. Com efeito, esta constitui um meio de promover a preservação da organização dos bens - aqui no sentido do 'perfil objetivo' proposto por Asquini - ou mesmo dar cumprimento a algum contrato específico, a fim de minimizar prejuízos ou conservar bens da massa. É possível afirmar que a continuidade de negócios poderia ter como efeito a preservação da organização empresarial, para facilitar a alienação em bloco, como ocorre no direito argentino.

${ }^{11}$ Confira-se Rachel Sztajn em Comentários à Lei de Recuperação de Empresas e Falência. Editora Revista dos Tribunais, 2. edição, 2007, pp. 525-527 (obra coletiva, organizada por Francisco SATIRO DE SOUZA JR., Francisco e PITOMBO, Antonio Sérgio A. de Moraes).

${ }^{12}$ No entendimento de Alberto Jorio, a ideia de satisfação dos credores como finalidade principal da falência, então expressa com clareza na lei concursal italiana de 1942, evidenciava uma concepção fundamentalmente privatística do instituto. $\mathrm{O}$ autor rejeita a ideia de autores que veriam no instituto uma finalidade ulterior de "espulsione dal mercatto delle imprese insolventi, e con ciò una autonoma valenza pubblicistica che consideri appunto un 'bene colletivo' la 'pulizia' del mercato". (Le crisi d'impresa Il Fallimento. Milano: Giuffrè, 2000, pp. 05-06). Em tradução livre: 'expulsão das empresas insolventes do mercado e, com isso, um significado autônomo publicístico, que considera [a falência] como um 'bem coletivo' a 'polícia' do mercado'.

${ }^{13}$ Mas Paulo Salvador Frontini, ao comentar o revogado decreto, anotava que os aspectos prevalentes da falência eram "lograr a melhor liquidação possível para os créditos de todos os credores do devedor comerciante" e também "o do saneamento do meio econômico-empresarial, emergente do interesse coletivo em não permitir a presença de negociantes inadimplementes no meio profissional de produção e circulação da riqueza, já que o inadimplente, este ou não de má fé, prejudica, com sua impontualidade, o normal desenvolvimento dos negócios, causando embaraços à ordem econômica." (FRONTINI, Paulo Salvador. "Reflexões sobre a reforma da Lei de Falências". Revista de Direito Mercantil, Industrial, Econômico e Financeiro. São Paulo, v. 31, Ano XVII (nova série), 1978, p. 44).

${ }^{14}$ REQUIÃO, Rubens. "A crise do direito falimentar brasileiro - reforma da Lei de Falências". Revista de Direito Mercantil, Industrial Econômico e Financeiro. São Paulo, vol. 14, Ano XIII (nova série), pp. 23-33, 1974; FRONTINI, Paulo Salvador. "Reflexões sobre a reforma da lei de falências". Revista de Direito Mercantil, Industrial, Econômico e Financeiro. São Paulo, v. 31, Ano XVII (nova série), 1978, p. 43.
} 
Esta característica da falência fazia-se presente mesmo quando a tutela buscada pelo direito concursal, que variava de um diploma falimentar a outro, claudicasse entre a proteção dos interesses dos credores e a dos interesses do devedor no movimento de dualismo pendular, referido por Fábio Konder Comparato ${ }^{15}$.

Essa visão tem origem no próprio nascimento da falência, no direito medievo, em que o instituto estava associado a medidas punitivas dirigidas a retirar o devedor do mercado, enquanto seu patrimônio era liquidado e distribuído de forma equitativa aos credores.

Os traços de destaque da quebra, portanto, na origem, eram a finalidade de liquidação e o caráter punitivo, pois a falência, em si, era considerada crime ${ }^{16}$. Esse ideal desenvolveu-se de forma tão amalgamada ao instituto da falência do direito continental Europeu $^{17}$ que se tornou célebre a posição de Napoleão, quando da promulgação do Código de 1807, ao justificar a necessidade de medidas punitivas severas, pois entendia haver, em toda falência, um 'corpo de delito' ${ }^{18}{ }_{-} 19$.

Como resultado deste tradicional enfoque dado à falência, o direito brasileiro, a exemplo de outros ordenamentos ${ }^{20}$, enfatizava o caráter instrumental do instituto $^{21}$, como verdadeiro procedimento de "execução coletiva"22. De fato, o uso da tal

\footnotetext{
${ }^{15}$ Aspectos Jurídicos da Macro-Empresa. São Paulo: Revista dos Tribunais, 1970, p. 95.

${ }^{16}$ SANTARELLI, Umberto. Per la storia del fallimento nelle legislazione italiane dell'età intermédia. Padova: Cedam, 1964, pp. 118-166. O autor afirma: “... possiamo com sicurezza affermare che la legislazione statutaria in materia fallimentare è monoliticamente e senza riserve ispiratta alla maggiore severità, sicchè, forse, quello penale è uno dei suoi aspetti più appariscenti." (p. 121). Em tradução livre: "pode-se afirmar com segurança que a legislação estatutária em matéria falimentar é monoliticamente e sem reservas inspirada em maior severidade, de modo que talvez o traço penal seja o de maior relevo.'

${ }^{17}$ VIEIRA, Andréia Costa. Civil law e common law: os dois grandes sistemas legais comparados, Porto Alegre: S.A. Fabris, 2007, p. 270.

${ }^{18}$ Rubens Requião, Curso de Direito Falimentar. V. 01, 16. edição, 1995, p. 10.

${ }^{19}$ JEANTIN, Michel; LE CANNU, Paul. Entreprises en dificulté. 7. édicion, Paris: Dalloz, 2007, pp. 109112.

${ }^{20}$ Como é o caso do direito italiano, por ocasião da promulgação da Lei de 1942 e que tanto influenciou o DL n. 7661/45 (COMPARATO, Fabio Konder. Aspectos jurídicos da macro-empresa, "A separação entre empresa e empresário", p. 107, São Paulo: Revista dos Tribunais, 1970).

${ }^{21}$ Nelson Abrão destacava os 'inconvenientes do processualismo'. (ABRÃO, Nelson. "Declaração judicial da falência". Revista de Direito Mercantil, Industrial, Econômico e Financeiro. Vol. 35, Ano XVIII (nova série), jul/set, 1979, pp. 26-27). No mesmo sentido, CASTRO, Carlos Alberto Farracha de. "Uma nova visão do direito falimentar - a obrigatoriedade de adequação e interpretação à Luz da Constituição Federal". Revista de Direito Mercantil, Industrial, Econômico e Financeiro. São Paulo, vol. 118, Ano XXXIX (nova série), pp. 106-111, abril/jun, 2000; SANT'ANA, Rubens. "A falência da empresa: realidade contemporânea e perspectivas futuras". Revista de Direito Mercantil, Industrial, Econômico e Financeiro. São Paulo, vol. 64, Ano XXV (nova série), pp. 37-46, out/dez, 1986.
} 
expressão está ultrapassado, na medida em que a atual lei concursal brasileira disciplina o direito concursal sob a óptica de análise da 'viabilidade' do negócio ${ }^{23}$.

Essa premissa mostra que não se trata apenas de equacionar o problema do pagamento dos credores, mas também, e sempre que houver viabilidade, de preservar o negócio.

Mais um argumento a se acrescentar é o de que uma das defesas possíveis ao pedido de falência é o requerimento de recuperação judicial, o que afasta, por completo, a ideia de 'execução coletiva' da falência, na medida em que a prova de viabilidade é capaz de superar a instauração do procedimento liquidatório.

Em verdade, o caráter liquidatório, atualmente, constitui apenas uma das facetas de uma nova percepção que vem sendo erigida pelo moderno direito concursal ${ }^{24}{ }_{-}^{25}$ ${ }^{26}$ em torno da falência. Note-se que essa nova visão não significa afastar o objetivo de melhor satisfação dos credores, pois, é certo, o instituto continua possuindo essa finalidade.

No direito brasileiro, a Lei n. 11.101/05 modificou expressivamente o enfoque do tratamento do empresário em crise, dando destaque, efetivamente, ao tratamento da crise das empresas, levando em consideração o centro múltiplo de interesses

22 SATTA, Salvatore. Instituzione di diritto fallimentare. 3. edição, Roma, 1948, n. 10; SATA, Salvatore. Diritto processuale civile, 5. edição, Padova, 1957; MIRANDA PONTES, Francisco, Tratado de direito privado. Borsoi, 1960, vol. 27, § 2133, p. 46; FERRARA, Francesco Ferrara. Il fallimento, Milano, 1959, pp. 60-61; MIRANDA VALVERDE, Trajano de. Comentários à lei de falências. Vol. I, pp. 12-13, Rio de Janeiro, 1948; CARVALHO DE MENDONÇA, J. X. Tratado de direito comercial brasileiro. 5. edição, São Paulo: Livraria Freitas Bastos, 1954, vol. VII, pp. 163 e 203; FONSECA, José Roberto Franco da, Natureza jurídica da falência. Dissertação à livre-docência de Direito Judiciária Civil pela Fadusp, São Paulo, 1969, p. 141; PACHECO, José da Silva. Processo de falência e concordata. Forense, 1996; BEZERRA FILHO, Manoel Justino. Lei de Recuperação e Falências comentada. São Paulo: Saraiva, 7. edição, 2011, p. 299 (apesar de este último autor ressalvar que utiliza esta expressão "no sentido de procedimento destinado à satisfação de créditos pecuniários, ou por quantia certa").

${ }^{23}$ É fruto de uma nova filosofia do direito concursal. (LOBO, Jorge) "Direito da crise econômica da empresa". Revista de Direito Mercantil, Industrial, Econômico e Financeiro. São Paulo, vol. 109, Ano XXXVI (nova série), pp. 64-92, jan/mar, 1998.

${ }^{24}$ Mas, modernamente, a falência enquanto 'execução' não é o único foco do instituto, como preleciona Nelson Abrão (Curso de Direito Falimentar. São Paulo: Saraiva, 1980, p. 01), insistindo, principalmente, na substituição do caráter processual pelo substancial (Nova disciplina jurídica da crise da econômica da empresa. São Paulo: Rumo Gráfica Editora, 1984, pp. 26-28).

${ }^{25}$ TEPEDINO, Ricardo. “A recuperação da empresa em crise diante do Decreto-lei 7.661/1945". Revista de Direito Mercantil, Industrial, Econômico e Financeiro. São Paulo, vol. 128, Ano, XLI (nova série), out/dez, 2002, pp. 166-167.

${ }^{26}$ FONSECA, José Júlio Borges da. "Da recuperação da empresa em crise”. Revista de Direito Mercantil, Industrial, Econômico e Financeiro. São Paulo, vol. 87, Ano XXXI (nova série), jul/set, 1992, p. 71. 
que esta representa: "do empresário, dos empregados, dos sócios capitalistas, dos credores, do fisco, da região, do mercado em geral",27.

Essa percepção provocou inegável deslocamento da análise do direito da crise das empresas, que passou de uma feição meramente privatística (relação credores e devedor) para um caráter publicístico, trazendo a empresa (centro de atividade produtiva) para o cerne de tutela do ordenamento jurídico ${ }^{28}$, ao se buscar disciplina para a manutenção da atividade produtiva, dos postos de trabalho e da preservação da concorrência saudável ao mercado ${ }^{29}$.

Essa mudança de perspectiva resulta da constatação de que "uma empresa que encerra suas atividades - devido a uma falência, por ex. - provoca uma queda na capacidade produtiva da economia. Se suas instalações e equipamentos são sucateados, haverá uma queda permanente no produto potencial da economia."30

A atual lei concursal brasileira finalmente atualizou-se ante esse novo panorama social. O abandono do velho instituto da concordata, instituindo-se a recuperação (judicial ou extrajudicial) é uma demonstração desse movimento.

Conquanto o instituto da falência tenha se mantido, com a mesma designação do passado, é forçoso nele reconhecer uma nova feição ${ }^{31}$, que será objeto de reflexão neste trabalho.

\footnotetext{
${ }^{27}$ Aspectos jurídicos da macro-empresa. São Paulo: Revista dos Tribunais, 1970, p. 102.

${ }^{28}$ ABRÃO, Nelson. Nova disciplina jurídica da crise da econômica da empresa. São Paulo: Rumo Gráfica Editora, 1984, pp.24-25.

${ }^{29}$ É o que Nelson Abrão designa por 'terceira fase do direito concursal': "Assinala-se, então, uma terceira fase no evolver dos procedimentos concursais que, conforme o escorço histórico do Professor Gerardo Santini, catedrático da Universidade de Bolonha, 'começa após a Segunda Grande Guerra e coexiste de fato com o quanto sobrevive do segundo período, especialmente os procedimentos de acordo preventivo e de moratória'. Afigura-se-nos, porém, que este período, que é o atual, e em que a disciplina da crise econômico-financeira da empresa se apresenta com uma maneira diferente de enfocar o fenômeno e outra metodologia para enfrentá-lo, surgiu bem depois. Com o fim da Segunda Conflagração Mundial, o que ocorreu foi o clímax da revelação da influência do Direito Econômico, que tendo nascido com a Primeira Guerra Mundial, ganhou impulso na época posterior à Segunda". ( $O$ novo direito falimentar. São Paulo: Revista dos Tribunais, 1985, pp. 13-14).

${ }^{30}$ MEDEIROS, Wanderley Pinto. "A insolvência das empresas brasileiras e o papel dos bancos em desenvolvimento". Revista de Direito Mercantil, Industrial, Econômico e Financeiro. São Paulo, vol. 72, Ano XXVII (nova série), out/dez, 1998, p. 49.

${ }^{31}$ Uma vez que o modelo tradicional do regime da falência contrastava com a moderna finalidade do direito concursal, que supera a finalidade liquidatória e solutória da quebra. (FONSECA, José Júlio Borges da. "Da
} 
1.2 Algumas palavras a respeito dos institutos disciplinados na lei concursal brasileira.

Na legislação brasileira em vigor, tecnicamente, se a empresa for 'viável' (e essa é a expressão utilizada pelo legislador no artigo 47 da Lei n. 11.101/05 ${ }^{32}$ ), a solução para a crise é a recuperação (judicial ou extrajudicial). A priori, contrario sensu, se o devedor não puder demonstrar a 'viabilidade' de seu negócio, mediante elaboração de um plano de superação da crise, a lei preconiza a falência como solução ${ }^{33}$ para a crise do devedor.

A ideia é que a saúde do mercado, como um todo, depende não apenas da preservação das empresas "viáveis", mas também da retirada, célere e eficaz, daquelas outras que não tenham condições de desenvolver suas atividades ${ }^{34}$. Como acentua Fabio Ulhoa Coelho "as más empresas devem falir, para que as boas não se prejudiquem”, já que o sistema não pode permitir a permanência de empresas inviáveis, pena de se transferir o risco da atividade, do empresário para seus credores ${ }^{35}{ }_{-}^{36}$.

Em análise sob a óptica econômica, Rachel Sztajn enfatiza que nos sistemas de economia de mercado busca-se criar instrumentos que induzam alternativas de maximização da alocação dos recursos existentes ou criados na sociedade, de modo que a empresa somente cumprirá sua função social ${ }^{37}$ se puder ser "eficiente", ou seja, capaz de produzir lucro $^{38}$.

recuperação da empresa em crise". Revista de Direito Mercantil, Industrial, Econômico e Financeiro. São Paulo, vol. 87, Ano XXXI (nova série) pp. 70-86, jul/set, 1992, p. 73).

32 O verbo empregado pela lei é "viabilizar", ou seja, o ato de tornar viável ou exequível, realizável (Dicionário Aurélio, Ed. Positivo, 6. edição).

${ }_{33}$ Confira-se Francisco Satiro, em obra coletiva organizada por SATIRO DE SOUZA JR., Francisco.; PITOMBO, Antonio Sérgio A. de Moraes. Comentários à Lei de Recuperação de Empresas e Falência. São Paulo: Revista dos Tribunais, 2. edição, 2007, p. 358.

${ }_{35}^{34}$ Exposição de Motivos, Senador Ramez Tebet.

${ }^{35}$ COELHO, Fabio Ulhoa. Comentários à nova lei de falências e de recuperação de empresas. São Paulo: Saraiva, 8. edição, 2011, p. 173.

${ }^{36}$ Anote-se a observação da ministra Nancy Andrighi: "De fato, a falência não deve ser vista como um instituto necessário para impedir a dissipação dos bens da sociedade insolvente e assegurar, assim, o tratamento igualitário dos credores no pagamento de seus créditos. $O$ decreto falimentar objetiva também afastar da atividade mercantil as empresas que não são economicamente viáveis e que, por esse motivo, podem comprometer o regular desenvolvimento da economia como um todo." (Recurso Especial n. 1. 107.937-MT (2008/0278535-8), j. 28/09/10).

37 "A LREF consagrou o princípio da função social da empresa. Esse é, aliás, o pilar de sustentação dessa norma." (ALMEIDA, Gustavo Milaré. "Anotações sobre o principio da função social da empresa na 
A recuperação representa um abandono das formas rígidas de composição previstas na concordata (dilação de prazo ou desconto) para reorganização do passivo do devedor, além de permitir negociação com credores outros, além dos quirografários, o que representou um dos grandes avanços da legislação vigente.

Acrescente-se, ainda, que a recuperação prestigia a busca de uma solução negociada entre o devedor e seus credores, com o objetivo principal de permitir condições de desenvolvimento futuro da empresa em dificuldades, e não apenas solucionar as obrigações do passado.

Como já dito, a recuperação judicial tem natureza jurídica de ação, “destinada a sanear a crise econômico-financeira da empresa por meio da elaboração e apresentação de um plano de recuperação apresentado pelo devedor, e submetido à aprovação de uma assembléia geral de credores, da qual participam as categorias atingidas pelo plano, e que potencialmente são as seguintes: (i) trabalhistas, (ii) com privilégios e com garantias, e (iii) quirografários" $39{ }_{-}^{40} 41$.

Não se nega, de qualquer modo, a essência contratual, ${ }^{42}$ que é ínsita ao instituto da recuperação, na medida em que o procedimento propicia foro de negociação e acordo entre o devedor e seus credores. Todavia, essa negociação é feita sob a coordenação de um procedimento judicial e, quando o consenso não é obtido, duas alternativas afiguram-

doutrina e na jurispridência brasileira". Revista de Direito Mercantil, Industrial Econômico e Financeiro. Vols. 153/154, Ano XLIX (nova série), jan/jun 2010, p. 240).

${ }^{38}$ Comentários à lei de recuperação de empresas e falência. Obra coletiva, coord. SATIRO DE SOUZA JR, Francisco e PITOMBO, Antonio Sérgio A. de Moraes. São Paulo: Revista dos Tribunais, 2. edição, 2007, pp. 222-223.

${ }^{39}$ PUGLIESI GARDINO, Adriana Valéria. Dissertação de mestrado, A evolução do tratamento jurídico da empresa em crise no direito brasileiro. São Paulo: Fadusp, 2006, p. 124.

40 Jorge Lobo, no entanto, entende que a recuperação judicial consiste em "ato complexo", caracterizado como "ato coletivo processual" formado pela concorrência de diversas manifestações de vontade que se fundem para formar uma única e também um favor legal, na medida em que garante ao devedor que reúna os requisitos legais, o direito de sanear o seu estado de crise econômico-financeira (obra coletiva, coord. TOLEDO, Paulo Fernando Campos Salles de; ABRÃO, Carlos Henrique. Comentários à lei de recuperação de empresas e falência. São Paulo: Saraiva, 4. edição, 2010, p. 172).

${ }^{41}$ Fábio Ulhoa Coelho parece adotar o mesmo entendimento, quando afirma que "No Brasil, a lei contempla dias medidas judiciais com o objetivo de evitar que a crise da empresa acarrete a falência de quem a explora." (Comentários à nova lei de falências e de recuperação de empresas. São Paulo: Saraiva, 8. edição, 2011, p. 171).

${ }^{42}$ PENTEADO, Mauro Rodrigues. Comentários à lei de recuperação de empresas e falência. Obra coletiva coord. Francisco Satiro de Souza Jr. e Antonio Sergio M. Pitombo. São Paulo: Revista dos Tribunais. 2. edição, 2007, pp. 84-86. 
se e dependem de pronunciamento, por decisão judicial fundamentada: concessão impositiva da recuperação, pelo cram-down, desde que atendidos os requisitos legais, ou decretação da falência. Daí, inegavelmente, a natureza jurídica de ação, segundo nosso entendimento.

A recuperação extrajudicial, por sua vez, consiste em um acordo entre o devedor e os credores. Diferentemente da recuperação judicial, desenvolve-se diretamente pelo devedor e seus credores, pois a negociação se dá fora do ambiente judicial ${ }^{43}{ }_{-}^{44}$. Somente depois de formalizado é que o acordo será submetido à homologação judicial e, conforme o percentual de adesão (exige-se quorum de três quintos do valor dos créditos), poderá atingir, impositivamente, os credores não signatários.

O avanço na metodologia colocada à disposição dos diversos interessados no processo de superação da crise das empresas é inegável. A recuperação judicial, segundo penso, consiste em um método de satisfação dos credores em que regras especiais são aplicadas, ante o estado de crise econômico-financeira caracterizado da devedora ${ }^{45}$, visando à superação das dificuldades, para que o devedor possa voltar a atuar no mercado em condições saudáveis.

A situação de excepcionalidade que resulta da crise justifica a participação dos credores ${ }^{46}$ da decisão do destino do devedor, sob supervisão judicial, de modo a

\footnotetext{
${ }^{43}$ Note-se, a recuperação extrajudicial deve sempre ser homologada em Juízo. Eventuais outros acordos celebrados entre credores e devedor, de forma coletiva ou individual, sem homologação judicial, são disciplinados pelo artigo 167 da Lei n. 11.101/2005.

44 "Il debitore e i suoi creditori (di solito i più grandi) possono infatti trovar conveniente evitare i costi delle procedura d'insolvenza, contrattando privatamente una soluzione." (STANGHELLINI, Lorenzo. Le crisi di impresa fra diritto ed economia (le procedure di insolvenza). Bologna: Il Mulino, 2007, p. 183). Em tradução livre: 'O devedor e seus credores (em regra os maiores) podem, de fato, entender conveniente evitar o custo do procedimento de insolvência, contratando uma solução privada.'

${ }^{45}$ COELHO, Fábio Ulhoa. Comentários à nova lei de falências e de recuperação de empresas. São Paulo: Saraiva, 8. edição, 2011, p. 276

${ }^{46}$ Uma das justificativas da existência do direito concursal seria: "Such provisions are commonly justified by reference to problens said to be peculiar to corporate creditors, including the power of the firm's shareholders to manipulate limited liability to the detriment of creditors and the power of creditors to seize control of a defaulting firm in a way that prevents the eficiente deployment of its assets." (KRAAKMAN, Reinier (ob. coletiva). The Anatomy of Corporate Law: a comparative and functional approach. 2. edition, New York: Oxford, 2009, p. 115). Em tradução livre: 'Tais disposições são normalmente justificadas em relação aos problemas peculiares de credores de empresas, incluindo o poder de acionistas para manipular a limitação de sua responsabilidade em detrimento dos credores e o poder dos credores em tomar controle da empresa inadimplente de modo a prevenir a ineficiente alienação de seus ativos.'
} 
harmonizar a satisfação destes e o princípio da preservação da empresa ${ }^{47}$ agasalhado pela Lei n. 11.101/05, com fundamento no artigo 170 da Constituição Federal.

Não é demais reforçar que a lei não é capaz de tornar empresa alguma viável, mas apenas cria condições e mecanismos para que, em um ambiente de negociação, a devedora possa superar o estado de crise econômico-financeira em que se encontra ${ }^{48}$.

Daí porque é um erro tentar aferir a eficiência de um sistema concursal pelo percentual de sucesso de empresas cuja reorganização (recuperação) tenha sido bemsucedida, na medida em que o acesso a tais procedimentos está aberto, ao menos em tese, a negócios que poderão se revelar, posteriormente, inviáveis.

Ao lado do instituto da recuperação está o da falência, que, na essência, continua a ser um procedimento liquidatório destinado à satisfação dos credores. Resulta deste procedimento, no mais das vezes, na eliminação da empresa (inviável ? $^{49}$ ) do mercado ${ }^{50}{ }_{-}^{51}$. O fato é que, não sendo possível estabelecer foro de negociação entre o

47 "A empresa, na ordem constitucional vigente, tem - ou deve ter - uma função social, não podendo se prestar apenas à satisfação dos interesses do empresário. Acima destes estão os postulados básicos da sociedade pretendida pelo constituinte, onde a empresa se encaixa como veículo para a livre iniciativa e a livre concorrência, para a produção de riquezas compartilháveis (mercê da tributação dos resultados positivos obtidos) e para, sobretudo, a dignificação do ser humano, através da geração de empregos que permitem às pessoas valorizar-se pelo trabalho e pela renda por meio dele obtida" (sentença proferida nos autos n. 390/2005, Recuperação Judicial, $1^{a}$ Vara da Comarca de Ponta Grossa, Paraná, 02/12/2005)." (SALAMACHA, José Eli. "Débitos fiscais e a recuperação judicial de empresas". Revista de Direito Mercantil, Industrial Econômico e Financeiro. Vol. 140, Ano XLIV (nova série), out/dez 2005, p. 121).

${ }^{48}$ Eduardo Gourlart Pimenta anota que "A legislação falimentar brasileira foi alterada com o objetivo primordial de preservar a empresa, auxiliando-a em situações de crise-econômico financeira sazonais. Diante de uma ocorrência economicamente relevante e constatada (o número de falências em nosso País)m a legislação foi alterada com o objetivo de alcançar um determinado valor socialmente importante (a preservação da empresa, amparada em sua função social)." Entende-se que a premissa de que parte o autor está equivocada na medida em que a lei não tem a função de transformar uma empresa inviável em um negócio viável, mas, ao contrário, tão somente de introduzir mecanismos aptos à superação de uma situação de crise, se e desde que a empresa seja mesmo viável. Portanto, a lei não foi instituída para que o princípio da preservação da empresa seja um fim em si mesmo, mas para proporcionar métodos eficientes de superação da crise, se isto for possível. Daí ser forçoso concluir que a lei não servirá para reduzir o número de falências.

${ }^{49}$ Tal indagação será abordada logo adiante.

50 "Potrebbe dirsi, perciò, che ogni processo concursuale, e, in particolar modo, ogni fallimento costituisce, nei limiti segnati dalla maggiore o minori diligenza degli organi e dei singoli interessati, una specie di liquidazione totale di tutti i rapporti patrimoniali dell'imprenditore. Anche chi non aderisca ad una tesi, particularmente penetrante, che vede lo scopo del processo concursuale nella eliminazione delle imprese dissestate, non può certo mettere in dubio che, se non il fine, questo è almeno uno dei più frequenti resultati de processo di fallimento." (Nicola Jaeger. Il fallimento e le altre forme di tutela giurisdizionale. Casa Editrice Dr. Francesco Vallardi, 1964, pp. 72-73). Em tradução livre: 'É possível afirmar-se, por essa razão, que cada processo concursal e, em particular, cada falência constitui, nos limites marcados pela maior ou menor diligência de seus órgãos e dos interesados, uma espécie de liquidação total de todos os vínculos patrimoniais do empresario. Mesmo os que não aderem a uma tese, particularmente penetrante, que vê o 
devedor e seus credores, será necessário organizar estes últimos, para que, na liquidação, possam exercer seus direitos na ordem de prelação prevista em lei.

Mas há, com efeito, uma peculiaridade fundamental a ser lembrada e pela qual a lei concursal brasileira atual fez romper, definitivamente, com as tradicionais funções do direito concursal, tal como era disciplinada nos diplomas anteriores: o princípio $^{52}$ que inspira a norma do artigo 75 da Lei n. 11.101/05 é o mesmo retratado no artigo 47 da lei concursal vigente, ou seja, o da preservação da empresa ${ }^{53}$.

Portanto, verifica-se uma inegável intersecção entre os dois institutos do direito brasileiro: recuperação e falência. A lei oferece essas duas alternativas como solução para a crise das empresas, mas não se tratam, como se verá ao longo deste trabalho, de compartimentos estanques. Assim, exsurge a questão: há compatibilidade entre a falência e a preservação da "empresa"? Como e em que medida isso seria possível?

Em consequência, uma das questões que se coloca é: em que senso seria possível preservar a 'empresa' na falência? Na recuperação judicial esta indagação parece não despertar perplexidade alguma.

A aplicação do princípio da preservação da empresa em cada um desses institutos - recuperação e falência - dar-se-á de forma distinta e obrigatoriamente adaptada

escopo do processo concursal na eliminação das empresas devedoras, não pode colocar em dúvida que, se não é o fim, esse é pelo menos um dos mais frequentes resultados do processo de falência'.

${ }^{51}$ Fabio Ulhoa Coelho, todavia, anota que a pessoa jurídica poderá interromper os efeitos dissolutórios do procedimento falimentar antes da sentença de encerramento e desde que tenha havido declaração judicial da extinção das obrigações: "Mesmo depois de encerrado o processo, podem os antigos sócios reabilitar a sociedade empresária falida, revertendo os efeitos dissolutórios da falência, com o objetivo de fazê-la retornar à exploração da atividade - Em suma, sociedade falida que, mesmo depois de encerrada sua falência, pode requerer a extinção de suas obrigações e voltar a comerciar." (Comentários à Lei de Falências e de Recuperação de Empresas. 8. edição, São Paulo: Saraiva, 2011, pp. 384/387).

52 "Princípio é proposição que serve de base para a construção de uma regra ou norma, é um padrão para avaliação de comportamentos ou condutas." (SZTAJN, Rachel. "Codificação, Decodificação, Recodificação: A empresa no Código Civil Brasileiro". Revista de Direito Mercantil, Industrial Econômico e Financeiro. Vol. 145, Ano XLV (nova série), jul/set 2006, p.17).

${ }^{53}$ Nancy Andrighi, após referir e comentar brevemente os arts. 47 e 75 da Lei n.11.101/05 afirma que " $O s$ dois princípios, em verdade, poderiam ser resumidos em um único e maior princípio de todo o direito empresarial: a conservação da empresa." O fundamento deste princípio está, segundo a autora, apoiado na função social da atividade empresarial, que encerra um 'feixe de contratos' em que vários interesses se equilibram (de empregados, fornecedores, sócios, credores e outros). Assim, conclui-se que dois princípios norteiam a falência: a manutenção da empresa e a maximização dos ativos. (Comentários à nova lei de falências e recuperação de empresas - Lei n. 11.101/05, de 09 de fevereiro de 2005, Coord. CORRÊALIMA, Osmar Brina e CORRÊA-LIMA, Sérgio Mourão. Rio de Janeiro: Forense, 2009, pp. 491-495). 
às peculiaridades e fins de cada qual. Ao longo desta pesquisa, serão analisados os métodos e disposições legais pelos quais se faz possível, na falência, efetivá-lo.

Note-se, pode parecer intrigante a opção do legislador em informar dois institutos tão diversos - recuperação e falência - com o mesmo princípio norteador de objetivo preservacionista. Essa ponderação faz nascer o intrigante questionamento objeto desta pesquisa.

Logo, é possível afirmar - e a doutrina de forma geral acolhe tal posicionamento - que uma das finalidades do direito concursal moderno brasileiro é a preservação da empresa $^{54}$; e isto ocorre tanto na recuperação, quanto na falência. O que, efetivamente, distingue um instituto do outro? E por qual razão há procedimentos diversos para uma e outra hipótese? Seria ingenuidade satisfazer-se apenas com a resposta mais óbvia, aliás, explicitada pelo legislador de que somente a viabilidade da empresa constituiria esse marco divisor de águas ${ }^{55}$.

Mesmo porque, haveria dificuldades insuperáveis em se desenvolver um conceito preciso e objetivo de viabilidade, o qual, de fato, remete não apenas a uma noção jurídica do termo (empregada pela lei concursal brasileira), mas carrega conteúdo evidente de natureza econômico-financeira, que, certamente, impede uma fórmula de solução hermética que possa se aplicar, indistintamente, a toda e qualquer hipótese concreta ${ }^{56}{ }_{-}^{57}$.

\footnotetext{
${ }^{54}$ Waldírio Bulgarelli alerta para "o fato incontestável que a quebra das empresas põe em jogo não somente os credores, mas uma série de interesses que gravitam em torno da empresa, como os trabalhadores, os clientes, os fornecedores, os Estados, através dos tributos e da produção econômica e muitas vezes a própria comunidade onde se situa a empresa." ("A reforma da lei de falências e concordata". Revista de Direito Mercantil, Industrial, Econômico e Financeiro. São Paulo, vol., 85, XXXI (nova série), jan/mar 1992, p. 52).

55 Joaquin Bizbal Mendez entende que a correta determinação do tratamento para a crise da empresa relaciona-se com a adequada solução do problema do valor da empresa em funcionamento (going concern value), que deve ser superior ao valor obtido com a liquidação. (La empresa em crisis y el derecho de quiebras. Bolonia: Real Colegio de España, 1986, pp. 77-78).

${ }^{56}$ Tanto isso é certo que Fábio Ulhoa Coelho propõe critérios para análise da viabilidade da empresa: (i) importância social da devedora, aferida pela relevância econômica que a empresa tem na economia local, regional ou nacional, além de levar em conta também o potencial econômico que o negócio mostra para reerguer-se; (ii) volume do ativo e passivo, assim considerado o exame de viabilidade segundo o perfil da crise (econômico, financeiro e patrimonial); (iii) tempo da empresa levando-se em consideração há quanto tempo esta existe e está em funcionamento; e (iv) porte econômico representado pela participação maior ou menor da empresa no mercado (Curso de direito comercial. 5. edição, São Paulo: Saraiva, 2005, vol. III, pp. 382-385).

${ }^{57}$ Para Jorge Lobo, a viabilidade depende de uma análise de "prospecção global da empresa e de sua capacidade de crescimento", a qual engloba, dentre outros fatores, "capital reputacional; responsabilidade social; envolvimento dos empregados e prestadores de serviços no projeto de reestruturação; confiança de antigos e novos fornecedores e financiadores; apoio dos consumidores e das autoridades públicas; respeito
} 
Neste ponto, são atuais as observações de Nicola Jaeger quanto às dificuldades para conceituar a insolvência, de tal forma que, com as devidas reservas, aplicam-se tais notas ao termo viabilidade, agora adotado pela nossa lei falimentar: ${ }^{58}$ : “L'uso di questi termini, che non sono né chiari né precisi, ha dato luogo a molte controversie dottrinali. La maggior parte degli ritiene che la parola insolvenza dovrebbe essere sostituta da insolvabilità: ma si deve piuttosto osservare che nessun giudice può disporre di mezzi sicuri per accertare se un debitore non è in grado di soddisfare le sue obbligazioni o se, al contrario, ne sarebbe pienamente in grado, se non avesse, occultato, eventualmente all'estero, i propri mezzi di pagamenti." ${ }^{, 59}$

Persiste, assim, a dúvida, por impossibilidade de fixação de critérios objetivos e precisos que poderiam definir a expressão "viabilidade", com a consequente dificuldade de fixar um marco divisor entre a crise superável e a insuperável, que poderia dar ao operador do direito a certeza de que, no caso concreto, a solução se daria pela recuperação ou pela falência. Por isso, afirma-se que a viabilidade deve ser apreciada caso a caso, ante a análise da hipótese concreta. ${ }^{60-61}$

A jurisprudência brasileira não se preocupou em traçar uma definição para a expressão viabilidade utilizada na lei concursal e parece inclinar-se na mesma linha de

aos princípios de governança corporativa, etc." (Comentários à lei de recuperação de empresas e falência. São Paulo: Saraiva. Obra coletiva coord. por TOLEDO, Paulo Fernando Campos Salles de; ABRÃO, Carlos Henrique Abrão. 4. edição, 2010, pp. 211/217).

${ }^{58}$ Esta noção também reflete a proposição desenvolvida na ideia de 'caráter unitário da empresa', para concluir que "o momento negativo da empresa (sua crise) não reside no simples fato do inadimplemento, vai além, configurando uma situação que abrange todos os seus bens, direitos e obrigações e que se traduz na insolvência jurídica, ou incapacidade de pagar todas as obrigações integralmente naquele momento." (FRANCO, Vera Helena de Mello; SZTAJN, Rachel. Falência e recuperação de empresa em crise. Rio de Janeiro: Elsevier Campus, 2008, p. 05).

${ }^{59}$ Il Fallimento e le altre forme di tutela giurisdizionale, Casa Editrice Dr. Francesco Vallardi, 1964, pp. 8283 e que em tradução livre: "O uso desses termos, que não nem claros nem precisos, deu lugar a muita controvérsia doutrinária. A maior parte dos escritores entende que a palavra insolvência deveria ser substituída pela insolvabilidade; mas de deve observar que nenhum magistrado pode dispor de meios seguros para acertar se um devedor não está em condições de satisfazer suas obrigações ou se, ao contrário, estaria ele em plenas condições, se não houvesse ocultado ao exterior, os próprios meios de pagamento."

${ }^{60}$ LOBO, Jorge. (Comentários à lei de recuperação de empresas e falência. Obra coletiva coord. por TOLEDO, Paulo Fernando Campos Salles de; ABRÃO, Carlos Henrique. 4. edição, São Paulo: Saraiva, 2010, p. 177).

${ }^{61}$ Exatamente porque "debe haber una conexión entre la solución jurídica y la financiera, es decir, todo proceso concursal debe contemplar la perspectiva financiera de la situación de crisis de la empresa, sirviendo de cauce para aplicar una política financiera que pretenda la revitalización y permita alcanzar el equilíbrio financiero perdido."(PASCUAL, Julián González. El concurso de acreedores. Una nueva solución para las empresas insolventes. Madrid: Ediciones Estúdios Financeiros, 2003, p. 10). 
aplicação casuística, espelhando o entendimento adotado na doutrina de que não sendo viável a solução para a empresa em crise é a da quebra ${ }^{62}{ }_{-}{ }^{6}$.

A falência, ao lado da recuperação judicial, representa um método de organizar o pagamento dos credores (para composição do passivo), o que se fará, conforme leitura do artigo 75 da lei, mediante afastamento do devedor, ou seja, do titular da empresa (o empresário), o que ocorre como regra de aplicação obrigatória ${ }^{64}$. Mas, ainda assim, o afastamento do devedor, conquanto esteja no cerne do processo de falência do direito brasileiro, também pode acontecer na recuperação judicial.

Por esta razão, o afastamento do devedor, não parece ser critério que, isoladamente, ao menos no direito brasileiro, se preste a distinguir a falência da recuperação judicial.

Veja-se que na falência enquanto o afastamento do devedor é obrigatório, na recuperação poderá ocorrer por ato voluntário do próprio devedor (mediante previsão no plano, conforme artigo 64, VI da Lei n. 11.101/05) ou por determinação judicial, ante a incidência das hipóteses legais, previstas em 'numerus clausus' no artigo 64, incs. I a V.

O afastamento do devedor não chega a ser um elemento distintivo definitivo entre a recuperação e a falência, embora, com as ressalvas acima mencionadas, seja uma diferença importante entre os institutos. A diferença efetiva está na circunstância de que, na Falência, o afastamento do devedor é compulsório e obrigatório, enquanto na recuperação somente ocorrerá excepcionalmente nas hipóteses previstas nos incisos I a V, do artigo 64 da Lei n. 11.101/05.

\footnotetext{
${ }^{62}$ AI n. 1.0543.06.500038-1/001 do TJMG, relatora Des.Heloísa Combat, julgado em 22/5/2007: "Mais uma vez citando Waldo Fazzio Júnior, é de se ressaltar que: 'Deve ser evidenciado, sempre, que a ação de recuperação judicial é medida de prevenção. Não tem caráter de ressureição. Dirige-se a empresas viáveis. Por isso mesmo, a LRE não comtempla modalidade de recuperação suspensiva da falência. Empresa viável tem interesse na recuperação judicial. Para a inviável, a solução jurídica é a falência'."

${ }^{63}$ Apelação Cível n. 536.925-4/0, relator Des. Ênio Santarelli Zuliani, julgado em 24/7/2008: "Segundo FABIO ULHOA COELHO a recuperação impõe um sacrifício generalizado (da sociedade e de alguns credores) com o propósito de salvar uma empresa em crise, sendo que em determinadas hipóteses convém, diante da frustração desse objetivo, decretar a falência (Comentários à nova lei de falências, Saraiva, 2005, p. 48)."

${ }^{64} \mathrm{O}$ afastamento do devedor também é possível na recuperação judicial (embora em caráter de exceção), seja por previsão no plano, seja por aplicação das demais hipóteses do artigo 64 da Lei n. 11.101/05.
} 
A causa primária dos procedimentos de recuperação judicial e da falência é a mesma, ou seja, a caracterização de crise econômico-financeira é considerada sanável na recuperação (sob o abrigo da caracterização da viabilidade) e que, na falência, se diz insuperável. Como consequência da crise, o devedor será afastado (na falência em todas as hipóteses) ou poderá ser mantido à frente dos negócios (na recuperação, pois o afastamento somente ocorrerá nas hipóteses previstas em lei ou por iniciativa do próprio devedor, por previsão no plano).

Os aspectos objetivos de caracterização da falência (incisos I a III do artigo 94 da Lei n. 11.101/05), por sua vez, não colocam luz na problemática suscitada, já que no sistema brasileiro atual o requerimento de recuperação judicial constitui matéria de defesa oponível ao pedido de falência, conforme se infere da regra do artigo 95 da lei.

Então, pelo sistema brasileiro em vigor, os critérios objetivos de caracterização da falência geram uma presunção de insolvência ou de insolvabilidade ${ }^{65}$, que evidenciariam uma situação de crise insanável, autorizando, destarte, o pedido de quebra por credores e a respectiva declaração por sentença.

A presunção de insolvência, por óbvio, não é absoluta, mas, paradoxalmente e em tese, poderia levar à falência uma empresa viável ${ }^{66}$. Essa circunstância, em particular, leva-nos a questionar se, efetivamente, no sistema brasileiro vigente, a inviabilidade chega a ser, de fato, pressuposto da falência, ou seja, se no caso de quebra, haveria, necessariamente, uma situação de inviabilidade insuperável do devedor.

\footnotetext{
${ }^{65}$ Paulo Fernando Campos Salles de Toledo afirma que a insolvência caracteriza-se como " $a$ impossibilidade momentânea (ou melhor, não definitiva, eis que pode ser mais ou menos duradoura) de solver os compromissos", e "corresponde a dificuldades de natureza financeira", enquanto a insolvabilidade "refere-se à impossibilidade de solver as obrigações, em decorrência de um déficit patrimonial", razão pela qual esta é uma dificuldade "de ordem econômica: o ativo do devedor é insuficiente para cobrir o seu passivo. ("Da caracterização da insolvabilidade civil. Pressupostos objetivos e subjetivos do processo de execução concursal'. Revista de Direito Mercantil. n. 57, p. 42 (jan.-mar. 1985). Na mesma linha, Fábio Konder Comparato, " a insolvência é o inadimplemento qualificado pela falta de razão de direito; enquanto a insolvabilidade é a inaptidão econômica a adimplir, seja em virtude de deficiência patrimonial, seja pela falta de meios líquidos para cumprir a prestação. No direito falimentar brasileiro, a quebra pode ser declarada tanto pela insolvência caracterizada pelo protesto (a impontualidade) (art. 94, inciso I da Lei 11.101/05, quanto pela insolvabilidade (art. 94, incisos II e III), ensejando procedimentos diversos (\$\$ $3^{\circ}$ a $5^{\circ}$ do artigo 94)" (O poder de controle na sociedade anônima. 4. edição, Rio de Janeiro: Forense, p. 435 , nota 4).

${ }^{66}$ Em tese, ao menos, se o devedor não conseguir mobilizar instrumentos para requerer sua recuperação judicial no exíguo prazo de 10 dias da defesa ao pedido de falência.
} 
Além disso, no sistema brasileiro vigente, ao devedor cabe a faculdade de decidir, ${ }^{67}$ ao menos em um primeiro momento, se a crise é ou não superável, optando pela recuperação ou pedido de autofalência.

A autofalência é a opção dada pelo legislador ao devedor que, em crise, “julgue não atender aos requisitos para pleitear sua recuperação judicial” e, por esta razão, fique caracterizada a "impossibilidade de prosseguimento da atividade empresarial" (artigo 105 da Lei n. 11.101/05).

Há dois requisitos centrais que integram o suporte fático caracterizador do pedido de autofalência, conforme dispositivo legal acima referido: o primeiro é a impossibilidade de pleitear recuperação judicial - legitimidade que é exclusiva do devedor, em nosso sistema - e o segundo é a constatação de que o prosseguimento da atividade deixou de ser possível (o que é causa de dissolução de sociedade ${ }^{68}$ e não necessariamente relacionada, pois, a uma situação de crise insanável).

Quanto ao primeiro requisito citado, Ricardo Tepedino anota que o critério é superior ao do antigo regime, que era preso à situação de impossibilidade de pagamento de dívidas exigíveis; na opinião do autor, a hipótese de autofalência tem lugar "quando a inviabilidade da empresa ou a animosidade dos credores revelarem inútil" a alternativa da recuperação judicial ${ }^{69}$.

O autor sustenta, na sequência, a possibilidade de oposição dos credores ao pedido $^{70}$ a "fundar-se na negativa do estado de falência ou na demonstração de que ele pode ser superado mediante a recuperação que a lei oferece ao devedor (...)." ${ }^{, 71}$.

\footnotetext{
${ }^{67}$ TOMAZETTE, Marlon. Curso de direito empresarial. Vol. 3, São Paulo: Atlas, 2011, pp. 308-309.

${ }^{68}$ Artigo 206, II, b da Lei das S/A e artigo 1034 do CC.

${ }^{69}$ Obra coletiva coord. TOLEDO, Paulo Fernando Campos Salles; ABRÃO, Carlos Henrique. Comentários à lei de recuperação de empresas e falência. 4. edição, São Paulo: Saraiva, 2010, p. 396.

${ }^{70} \mathrm{O}$ que faz, apoiado na doutrina de Rubens Requião: “Tem-se indagado se à confissão de insolvência do devedor os credores se podem opor. Os conflitos de interesses e as situações peculiares, de que tão pródiga é a atividade comercial, podem levar o devedor a pedir a decretação de sua autofalência, sem que delineada perfeitamente esteja a sua insolvência. Nesse caso, pensamos que seria possível aos credores, intervindo no pedido do devedor, informarem ao juiz, deduzindo suas provas e razões, que o devedor pode perfeitamente pagar seus credores." (Curso de direito falimentar. 16. edição, São Paulo: Saraiva, 1995. vol. I, pp. 89-90).

${ }^{71}$ Obra coletiva coord. TOLEDO, Paulo Fernando Campos Salles; ABRÃO, Carlos Henrique. Comentários à lei de recuperação de empresas e falência, 4. edição, São Paulo: Saraiva, 2010, p. 401.
} 
Nesse sentido, parece ser, no mínimo, sustentável a ideia de que embora a legitimidade do pedido de autofalência caiba exclusivamente do devedor, os credores poderiam intervir e até contestá-lo, já que têm interesses jurídico e econômico no feito, pois a sentença que decide a pretensão lhes afeta diretamente.

Admitido esse posicionamento, estar-se-ia diante da peculiar situação de que ante a crise do devedor por este confessada, a autofalência poderia não ser admitida; ao mesmo tempo, o único legitimado para pleitear a recuperação judicial afirma que não tem condições de fazê-lo (como se subentende da leitura do artigo 105 da Lei n. 11.101/05), por julgar não ser possível prosseguir na atividade.

Ora, a hipótese, que parece possível na prática, é que o devedor declara não ter condições de prosseguir na atividade (daí seu afastamento ser inevitável, o que é regra na falência), mas há terceiros (credores ou não) que julgam ser possível a superação da crise econômico-financeira sob nova administração. Neste caso, o sistema brasileiro parece, prima facie, parece não conciliar a possibilidade de preservação da empresa, dada a restrição de legitimidade do pedido de recuperação judicial e de autofalência exclusivas do devedor.

Agora, voltar-se-á aos pontos de intersecção entre os institutos da recuperação judicial e da falência no direito brasileiro. Há, pelo menos mais um, de caráter procedimental. A lei concursal brasileira disciplina disposições comuns aplicáveis à falência e à recuperação judicial, conforme consta nos artigos $5^{\circ}$ ao 46 , da Lei n. $11.101 / 05$.

A disciplina contida nestes dispositivos tutela diversas regras gerais, relativas à prescrição, formação do juízo universal, verificação e habilitação dos créditos tendentes à formação do quadro geral de credores aos órgãos ${ }^{72}$ de atuação dos procedimentos (administrador judicial, comitê e assembleia de credores), mostrando inegável aproximação dos institutos do ponto de vista procedimental.

\footnotetext{
${ }^{72}$ A expressão foi plenamente acolhida pela doutrina brasileira e Erasmo Valladão A. N. de França invoca Carnelutti (Sistema di diritto processuale civile, I, Pádua, Itália, Cedam, 1936, p. 12, n. 03, V) para justificar o seu uso vinculado à ideia de "interesse comum ou coletivo". (Comentários à lei de recuperação de empresas e falência. obra coletiva coord. Francisco Satiro de Souza Jr. e Antonio Sergio M. Pitombo. São Paulo: Revista dos Tribunais, 2. edição, 2007, p. 187).
} 
A organização da lei brasileira denota que, apesar de existirem procedimentos distintos para ambos os institutos - recuperação judicial e falência -, há pontos de comunhão significativos a sugerir, que, do ponto de vista instrumental, talvez a adoção de um processo unificado seja uma possibilidade a ser investigada.

De todo o modo, propõe o artigo 75 da lei concursal brasileira: "A falência, ao promover o afastamento do devedor de suas atividades, visa a preservar e otimizar a utilização produtiva dos bens, ativos e recursos produtivos, inclusive os intangíveis, da empresa."

A simples leitura do referido dispositivo torna correto afirmar que a falência, essa antiga conhecida do direito concursal brasileiro ${ }^{73}$, está, agora, com roupagem inteiramente atualizada, sobretudo porque fixa novos objetivos, distintos daqueles previstos no DL n. 7.661/45 e nos diplomas anteriores.

A legislação vigente dirigida à tutela da crise das empresas inovou não apenas em razão do acolhimento de novos institutos (recuperação judicial e extrajudicial), mas também o fez em relação à falência, renovando seu objetivo, o que faz perquirir se há mecanismos possíveis e eficientes de sua concretização.

Espera-se, com isso, demonstrar a atualização do instituto da falência no direito brasileiro e as repercussões que tais modificações têm quanto a diversos aspectos do processo concursal e, em especial, como esta solução poderia ser considerada como um método de preservação da empresa, ao lado da recuperação judicial, verificando-se, assim, compatibilidade neste aspecto. A consequência natural dessa investigação resulta em questionamento quanto a necessidade de dúplice procedimento do direito concursal, ante a mudança de objetivos perseguidos e a atual tutela de interesses buscada na falência.

Para tanto, a falência deve ser analisada sob a óptica do direito concursal moderno, inaugurado no sistema brasileiro pela Lei n. 11.101/05. Observa-se, de fato, a reformulação deste instituto mediante renovação de seus objetivos e das prioridades

\footnotetext{
${ }^{73} \mathrm{O}$ instituto da falência ingressou no direito positivo brasileiro com o Código Comercial, em 1850, e seguiu disciplinado em todos os diplomas legislativos posteriores.
} 
envolvidas na solução dos interesses tutelados na crise, quando o afastamento do devedor, segundo a lei, deve ocorrer compulsoriamente.

A reforma do direito brasileiro está muito além da introdução do instituto da recuperação, pois atingiu as raízes do sistema concursal ao modificar a falência em aspectos fundamentais.

Enfim, parece ser possível entrever a caracterização de uma "nova" falência no direito brasileiro. Justifica-se, pois, a verificação de como esse mesmo tema vem sendo disciplinado em outros sistemas, de modo a aferir se esta é uma tendência isolada de nosso direito ou, ao contrário, se trata de um movimento palmilhado em outros regimes. A análise do instituto leva à avaliação de como seria possível evoluir e desenvolver a falência, agora com uma nova feição, cuja pedra fundamental foi instalada pela lei vigente. 


\section{CAPÍTULO SEGUNDO TRATAMENTO JURÍDICO DA MATÉRIA NO DIREITO ESTRANGEIRO}

Em matéria de direito concursal, a análise de sistemas estrangeiros é de particular interesse na medida em que o fenômeno da crise da empresa é universal.

Ainda que os efeitos da crise da empresa não encontrem fronteiras- em decorrência do progressivo aumento nas relações econômicas internacionais -, cada sistema jurídico apresenta suas próprias soluções, naturalmente adaptadas às suas respectivas realidades econômica, sociais e culturais ${ }^{74}$, mesmo que revelem traços e princípios coincidentes entre $\mathrm{si}^{75}$.

O anseio por uma regulamentação internacional, ainda que limitada a um regramento estritamente principiológico - dado os efeitos transnacionais da crise das empresas, é tema de importância, apesar de poderem ser levantados argumentos inúmeros de restrição a essa possibilidade, em razão das dificuldades de compatibilização das realidades econômicas de cada país e de seus respectivos sistemas jurídicos.

No momento atual, parece ser impraticável a elaboração de uma lei de insolvência internacional, ainda que aplicável a alguns poucos países signatários, ante as peculiaridades de cada sistema.

O regulamento comunitário europeu ${ }^{76}$, aplicável aos estados-membros, exceto a Dinamarca, não chega a ser uma resposta para uma regulamentação internacional, na medida em que se limita a regras de conflito de competência, sem normas de caráter substancial a respeito da insolvência. Sua finalidade é programar medidas de coordenação dos efeitos transfronteiriços da insolvência.

\footnotetext{
${ }^{74}$ COELHO, Fábio Ulhoa. Comentários à nova lei de falências e de recuperação de empresas. São Paulo: Saraiva, 8. edição, 2011, p. 171; DASSO, Ariel Ángel. Derecho concursal comparado, Tomo II, Buenos Aires: Legis, 2009, p. 910.

${ }_{76}^{75}$ DASSO, Ariel Ángel. Derecho concursal comparado, Tomo I, Buenos Aires: Legis, 2009, p. XII.

${ }^{76}$ Counsil Regulation EC n. 1346, de 29/05/2000, com alterações pela CE 604/2005 que alterou as listas anexas ao regulamento.
} 
Apesar de não existir uniformidade plena nos delineamentos dos diversos sistemas analisados, em linhas gerais é possível afirmar-se que o equacionamento do problema da crise das empresas encontra, basicamente, duas soluções: a via da reorganização ou a da liquidação, ${ }^{77}$ embora seja inegável que essas não constituem vias estanques de resposta, como adiante se verá na análise de cada um dos ordenamentos jurídicos avaliados.

Por outro lado, é inegável a existência de um movimento de reforma em diversas legislações concursais em busca de respostas para a crise das empresas, principalmente a partir do início da década de $1990 .{ }^{78-79}$

Esse movimento de reforma acabou por gerar a iniciativa da elaboração, pelo World Bank, das recomendações contidas no Principles and guidelines for effective insolvency and creditor rights system (abril de 2001) e que resumem princípios e diretrizes destinados a orientar a reforma de legislações concursais, em especial nos países em desenvolvimento. ${ }^{80}$

Os princípios mencionados resumem uma avaliação das boas práticas observadas em diversos sistemas de insolvência, compilando soluções e políticas nestes adotadas. Não há, contudo, vinculação alguma ou obrigatoriedade ao regramento ali compilado, mas tão somente recomendações para melhores resultados nos processos de insolvência.

Por exemplo, um dos princípios erigidos pelo Principles and guidelines for effective insolvency and creditor rights system (abril de 2001) é o de que sendo inviável a empresa, sua liquidação deve ser promovida de forma rápida e eficiente (se possível, com a preservação ou venda do negócio, a outra sociedade que possa explorá-lo). Porém, se a

\footnotetext{
${ }^{77}$ FRANCO, Vera Helena de Mello; SZTAJN, Rachel. Falência e recuperação de empresa em crise. Rio de Janeiro: Elsevier Campus, 2008, p. 02.

${ }^{78}$ Para uma visão geral de diversos sistemas que sofreram recente reforma em direito concursal consulte: RIVERA, Julio César. El derecho concursal: una rama cuya legislación está en permanente cambio, Disponível em: <http://www.rivera.com.ar/publications.pdf> (Revista de Derecho Comparado, Rubinzal Culzoni, $\mathrm{n}^{\circ} 15$, p. 11).

${ }^{79}$ DASSO, Ariel Ángel. Derecho concursal comparado, Tomo I, Buenos Aires: Legis, 2009, p. 29, pp. 909910.

${ }^{80}$ Revista de Direito Mercantil, Industrial, Econômico e Financeiro - RDM, v. 122, São Paulo: Malheiros, 2001.
} 
empresa for viável (ou seja, se puder ser reabilitada financeiramente), seu patrimônio terá maior valor, pois o socorro ao negócio preserva os empregos e potencialmente garante aos credores um resultado melhor do que na mera liquidação dos bens. ${ }^{81}{ }_{-} 82.83$.

Naturalmente, cada sistema concursal evidencia suas particularidades e respeita o princípio da soberania de cada nação ${ }^{84}$, o que se explica ante os interesses preponderantes que cada um destes ordenamentos jurídicos pretende tutelar ou assegurar.

Isto porque, o direito falimentar contempla uma disciplina dirigida a trazer soluções de tutela destinada a amplo feixe de interesses, que vão muito além das relações jurídicas entre credores e devedor. Por esta razão, atinge um número expressivo de interessados, além de regras de modificação de obrigações e contratos que alcançam investidores, trabalhadores, consumidores e afins ${ }^{85}{ }_{-}^{86}$, circunstâncias que fazem seus efeitos irradiarem na própria ordem econômica de um país.

${ }^{81}$ Deve ser vista com reservas, assim, a afirmação de que "Esta circunstância [referindo-se à oposição entre o interesse público e o interesse dos credores, diante da insolvência da empresa] resulta nas mais baixas cotas de satisfação na liquidação do patrimônio do devedor. Por todas essas razões, os próprios credores começaram a compreender que a liquidação da empresa não era o melhor modo de satisfazer as suas expectativas de receber os créditos". (GUIMARÃES, Maria Celeste Morais. "Entraves à eficacia da Lei de Recuperação de Empresas em Crise. Como superá-los?”. Revista de Direito Mercantil, Industrial Econômico e Financeiro, vol. 142, Ano XLIV (nova série), abril/junh 2006, p. 156), pois a recuperação da empresa não é um valor a ser buscado a qualquer custo. Pensa-se, nesse ponto, como Ronaldo Vasconcelos, de que a velha afirmação de quem "ninguém ganha com a falência" é, atualmente, relativa. "Isso porque, no presente regime normativo, a rápida liquidação da empresa pode ser benéfica à comunidade" (VASCONCELOS, Ronaldo, Direito Processual Falimentar (De acordo com a Lei n. 11.101, de 9 de fevereiro de 2005), São Paulo: Quartier Latin, 2008, p. 125).

82 Principle 8: Liquidation and rehabilitation. An insolvency law should provide both for efficient liquidation of nonviable businesses and those where liquidation is likely to produce a greater return to creditors, and for rehabilitation of viable businesses. Em tradução livre: 'Princípio 8: Liquidação ou reorganização. Uma lei de insolvência deveria prover ambas estas alternativas, ou seja, a liquidação eficiente de negócios inviáveis, cabível esta também para os casos em que a liquidação estiver apta a produzir melhores resultados aos credores e um sistema reorganizatório destinado a negócios viáveis.'

${ }^{83}$ Há, portanto, princípios comuns que podem ser observados nas legislações concursais modernas, como lembra Ariel Ángel Dasso: "En cada ordenamiento una nueva solución, pelo ahora, como nunca, cada vez más enmarcados en pautas y principios comunes a todos, que significan la respuesta del derecho a un mundo que demanda de la universalidad y concursualid respuestas armónicas y, sin duda, coordinadas entre los distintos ordenamientos con miras a reglas esenciales comunes a todos." (Derecho concursal comparado, Tomo I, Buenos Aires: Legis, Argentina, 2009, p. XIII).

${ }^{84}$ DASSO, Ariel Ángel. Derecho concursal comparado, Tomo I, Buenos Aires: Legis, 2009, pp. XII-XIII.

${ }^{85}$ Waldírio Bulgarelli alerta para "o fato incontestável que a quebra das empresas põe em jogo não somente os credores, mas uma série de interesses que gravitam em torno da empresa, como os trabalhadores, os clientes, os fornecedores, os Estados, através dos tributos e da produção econômica e muitas vezes a própria comunidade onde se situa a empresa." (“A reforma da Lei de falências e concordatas", RDM 85, p. 52).

${ }^{86}$ No mesmo sentido Darío J. Graziabile ao afirmar que "Así, la suerte de las atividades empresariales pasó a ser la principal preocupación de la legislación concursal, reconosciéndose que la insolvencia no era sólo un problema entre deudor e acreedores, sino que tenía afecciones multisubjetivas. En la empresa económica encontramos comprometidos interesses de los trabajadores, los provedores, interesses fiscales, clientes $e$ incluso, en la empresa de gran magnitude, pueden incorporarse intereses demográficos o poblacionales.". 
Nesta linha de ideias, justifica-se a afirmação de Eduardo Secchi Munhoz de que "o direito falimentar - ou da crise da empresa - corresponde a um dos ramos do direito empresarial em que se evidencia com maior nitidez a função social da empresa, ou a necessidade de contemplar todos os interesses afetados, que não se resumem aos interesses do empresário. Os interesses externos, no momento da crise da empresa, passam ao primeiro plano, ao lado dos internos" $" 87$.

Dessa forma, é natural que, sob alguns traços comuns, cada sistema jurídico de análise do direito concursal apresente suas particularidades, as quais refletem a tutela de interesses que lhes são preponderantes. Era necessário, pois, adotar alguns sistemas estrangeiros para análise.

O norte-americano e francês foram escolhidos ante a importância histórica que tiveram no desenvolvimento do moderno direito concursal, com a criação pioneira de modelos reorganizatórios destinados à superação da crise das empresas e consequente manutenção da atividade econômica.

O estudo destes dois sistemas é fundamental para a compreensão do moderno direito concursal ${ }^{88}$ e não poderiam deixar de ser referidos.

A opção pelo direito italiano está justificada em razão da influência que a legislação de 1942 teve sobre o revogado DL n. 7.661/45, que vigorou por quase 60 anos no direito brasileiro e muito construiu a respeito da atual mentalidade que temos em relação ao direito falimentar. A análise do sistema anterior brasileiro, sob a inspiração do

Em tradução livre: “Assim, a sorte da atividade empresarial passou a ser a principal preocupação da legislação concursal, reconhecendo-se que a insolvência não era somente um problema entre o devedor $e$ seus credores, pois desta decorrem efeitos multisubjetivos. Na empresa encontramos comprometidos interesses dos trabalhadores, fornecedores, fiscais, consumidores e, em maior magnitude, podem ser identificados interesses demográficos e populacionais" (Derecho Concursal, Tomo I, Buenos Aires: LexisNexis, 2006, p. 12).

${ }^{87}$ MUNHOZ, Eduardo Secchi. “Anotações sobre os limites do poder jurisdicional na apreciação do plano de recuperação judicial”. Revista de Direito Bancário e do mercado de capitais. Ano 10, n. 36, abr-jun/2007. São Paulo: Revista dos Tribunais, pp. 186-190.

88 Nelson Abrão propôs classificação histórica do direito concursal em três fases que, embora cronologicamente não sejam perfeitamente distintas uma da outra, por se entrelaçarem entre si no surgimento das ideias que as caracterizam, dividem-se nos seguintes períodos: (i) da idade média à primeira Guerra; (ii) entre as duas grandes guerras; e (iii) após a segunda guerra até os dias atuais, no que o autor denominou 'direito concursal moderno', caracterizada pela adoção de sistemas reorganizatórios destinados à reabilitação das empresas em crise. (Nova disciplina jurídica da empresa. São Paulo: Revista dos Tribunais, pp. 06-55). 
direito italiano é, com efeito, de relevo, para melhor compreensão das profundas alterações sofridas na reforma de 2005 de nosso sistema concursal.

Os ordenamentos alemão, espanhol e português revelam-se de particular utilidade para esta pesquisa por terem adotado um sistema de procedimento único de insolvência, no qual, em linhas gerais, o devedor submetido ao regime do concurso fica sujeito à liquidação ou sofre reorganização com a finalidade de preservação da atividade econômica. ${ }^{89}$

Finalmente, o estudo do direito argentino mostra-se útil sob dois aspectos. Primeiro, a reforma do final de 2001 no direito concursal foi uma das respostas do governo relacionada à grave crise econômica, que fez precipitar medidas destinadas a minimizar o problema da aguda falta de empregos e recessão financeira, circunstâncias que, dentre outros fatores, geraram a necessidade de estabelecer condições favoráveis à preservação das empresas (como política econômica dirigida à superação das dificuldades em que estava imerso o país à época).

Segundo, o direito argentino é territorialmente próximo e que, por integrar o Mercosul, mantém laços econômicos importantes com o Brasil, além de ter sido o pioneiro, dentre os sistemas da América do sul, a adotar procedimentos de salvaguarda das empresas.

É importante destacar, ainda, que a análise dos referidos sistemas não tem a pretensão de ser classificada como um estudo de direito comparado, mas tão somente de trazer à reflexão aspectos relevantes ao direito falimentar no que concerne ao escopo desta pesquisa, em cada um dos países referidos.

A ideia será referir, sempre que possível, as bases em que cada um desses regimes concursais está consolidada, destacando-se os meios de salvaguarda da organização de bens no seio do procedimento liquidatório.

\footnotetext{
${ }^{89}$ Seja ou não empresária. Nesse ponto, a lei brasileira perdeu a oportunidade de avançar e manteve a sujeição do empresário, na forma definida pelo Código Civil. Portanto, tem fundamento a crítica de Dora Martins de Carvalho a respeito. (CARVALHO, Dora Martins. "O anteprojeto legislativo de lei de concordatas e falências." Revista de Direito Mercantil, Industrial, Econômico e Financeiro. São Paulo, vol. 88, Ano XXXI (nova série), out/dez 1992, p. 88).
} 
2.1 O direito norte-americano

No direito norte-americano, o sistema falimentar é regulamentado, quanto ao direito substantivo, pelo Bankruptcy Code, que é dividido nos seguintes capítulos ${ }^{90}$ : Chapter 1, General Provisions, definitions and Rules of Construction; Chapter 3, Case administration; Chapter 5, creditors, the debtor and the Estate; Chapter 7, Liquidation; Chapter 9, Adjustment of the Debts of a Municipality; Chapter 11, Reorganization; Chapter 12, Adjustment of the Debts of a Family Farmer or Fishermen With Regular Income; Chapter 13, Adjustment of the Debts of an Individual With Regular Income; Chapter 15, Ancillary and Other Cross-Border Cases.

O Bankruptcy Code é um diploma de lei federal, mas se mantém a aplicação de determinadas regras estaduais pertinentes às relações de crédito entre o devedor e seus credores $^{91}$.

Em razão da multidisciplinaridade do sistema concursal, há regras específicas dispostas em leis estaduais cuja aplicação fica mantida, como, por exemplo, para litígios acerca de direito de propriedade, como ficou decidido pela Supreme Court (Butner v. United States, 1979) $)^{92}$ : "Congress has generally left the determination of property rights in the assets of a bankrupt's state to state law. Property interests are created anda defined by state law. Unless some Federal interest requires a diferente result, there is no reason why such interests should be analyzed differently simply because an interested party is involved in a bankrupcty proceeding." 93

${ }^{90}$ NICKLES, Steve H.; EPSTEIN, David G. Bankruptcy and related law. second edition, Dallas: Thomson West, 2006, pp. 153/154.

${ }^{91}$ Os Estados Unidos possuem um sistema federativo de governo, conforme previsto pela Constituição que outorga poderes específicos de organização ao Governo Federal. Entretanto, os poderes não delegados ao Governo Federal ficam, residualmente, sob a autoridade de cada Estado. Assim, cada um dos cinquenta estados do país tem sua própria constituição, estrutura de governo, códigos legais e sistema judiciário próprios. As relações ordinárias de cobrança entre credor e devedor são regidas por lei estadual (MARTIN, Nathalie; TAMA, Ocean. Inside Bankruptcy law - what matters and why, New York: Wolthers Kluwer, Aspen Publishers, 2008, p. 11).

${ }^{92}$ Conhecido como 'Butner principle'. (BAIRD, Douglas G.; JACKSON, Thomas H.; ADLER, Barry E. Bankruptcy, cases, problems and materials. 3. edition, New York: Foundation Press, 2000. University Casebook Series, p. 29).

${ }^{93}$ NICKLES, Steve H.; EPSTEIN, David G. Bankruptcy and related law, second edition, Dallas: Thomson West, 2006, p. 154. Em tradução livre: "O congresso permitiu, de forma genérica, que a determinação a respeito de direito sobre a propriedade de bens da massa falida caiba à lei estadual. O direito de propriedade é disciplinado e definido por lei estadual. A menos que algum interesse Federal demande outra 
Quanto ao procedimento, são utilizadas as regras editadas pelo Bankruptcy Rules promulgadas pela United States Supreme Court, e não aquelas do Federal Rules of Civil Procedure ${ }^{94}$. As regras procedimentais aplicáveis ao direito concursal são divididas em dez partes, sendo cada uma delas relativa a um estágio específico do procedimento.

As soluções propostas pelo direito norte-americano para a crise do devedor ${ }^{95}$ são: (i) liquidação (liquidation) ou (ii) reorganização (reoganization) ${ }^{96}{ }_{-}^{97}$. Tanto o Chapter 7 (liquidation), que disciplina a liquidação, quanto o Chapter 11 (reorganization), que disciplina a reabilitação do devedor, aplicam-se a todos os devedores, indíviduos ${ }^{98}$ e sociedades, empresárias ou não.

Os demais capítulos disciplinam métodos de reabilitação, mas se dirigem a devedores específicos, ou seja: (i) Chapter 9: aplicável a municipalidades; (ii) Chapter 12: plano de reorganização de Family Farmer e fishermen com renda regular; (iii) Chapter 13, aplicável a devedor pessoa física com renda regular.

Com o ajuizamento de qualquer procedimento concursal forma-se, imediata e automaticamente, o "bankrupt estate" ${ }^{\text {"99 }}{ }^{100}$ (também designado por property of the

solução, não há razão porque tais demandas sejam apreciadas de modo diverso, apenas porque uma das partes interessadas esteja envolvida em um procedimento falimentar."

${ }^{94}$ Com fundamento na autorização outorgada pelo '28 USCA $\$ 2075$ ' e conforme Rule 1001 do Bankruptcy Rule.

${ }^{95} \mathrm{E}$ que integram regras próprias e distintas das execuções singulares. Uma das diferenças fundamentais das regras do direito concursal, especialmente no que se refere a sociedades, é permitir que os credores sejam atendidos com a preservação do 'going concern'. (BAIRD, Douglas G.; JACKSON, Thomas H.; ADLER, Barry E. Bankruptcy, cases, problems and materials. 3. edition. New York: Foundation Press, 2000. University Casebook Series, p. 21).

96 "Banruptcy cases in the United States follow two models. They are 'sell out' or 'pay out' cases. In 'sell out' or liquidation cases, also called straight bankruptcy cases, the debtor's nonexempt assets are sold and the proceeds are distribuited to creditors, quickly ending the case. In 'pay out' cases, the debtor promises, via a plan of repayment, to pay at least some creditors from future income over time." (MARTIN, Nathalie; TAMA, Ocean. Inside Bankruptcy law - what matters and why, New York: Wolthers Kluwer, Aspen Publishers, 2008, p. 26). Em tradução livre: "O sistema concursal americano segue dois modelos, os quais são de casos de 'sell out' ou de 'pay out'. Nos casos de 'sell out' ou de liquidação, também denominados falência em sentido estrito, todos os bens penhoráveis do devedor são vendidos e o resultado é distribuído para pagamento dos credores, rapidamente encerrando-se o processo. Nos casos de 'pay out', o devedor promete, por intermédio de um plano, pagar pelo menos alguns credores com a renda futura que terá."

${ }^{97}$ EPSTEIN, David G. Bankruptcy and related law in a nutshell. 7. edição, Dallas: Thomson West, 2005, p. 124.

${ }^{98}$ Embora, na prática, o Chapter 11 seja precipuamente adotado por sociedades empresariais, em razão da complexidade do procedimento e dos custos envolvidos.

${ }^{99}$ Cujo conceito aproxima-se daquele de massa falida objetiva. Lembre-se, apenas, que com a instauração de um procedimento concursal no direito norte-americano, o devedor deixa de ser proprietário de seus bens que 
estate), que compreende todos os direitos e bens (patrimônio ativo) do devedor existentes até o momento do ajuizamento ${ }^{101}$, exceto aqueles que, por lei, sejam considerados impenhoráveis. Esse é um conceito de grande importância no direito concursal norteamericano, pois o property of the estate passa a sujeitar-se a regras de supervisão e limitações de administração pelo devedor nos procedimentos reorganizatórios e, na liquidação, será arrecadado e alienado para pagamento dos credores.

Para fins desta pesquisa, o que interessa é maior proximidade com as disciplinas do Chapter 7 (liquidation) e do Chapter 11 (reorganization).

Em linhas gerais, no Chapter 7 (liquidation), nomeia-se um trustee ${ }^{102}{ }_{-}^{103}$, cuja atuação é obrigatória neste procedimento, que tem como deveres ${ }^{104}$ localizar e tomar posse dos bens e ativos que integram a massa falida, convertê-los em dinheiro e efetuar o

passam a integrar o 'estate' (corresponde ao patrimônio de uma pessoa que faleceu ou que está sob um procedimento concursal). (TOLEDO, Paulo Fernando Campos Salles de. A empresa em crise no direito francês e americano. Dissertação de Mestrado. São Paulo: Fadusp, 1987, pp. 27-28).

100 "The bankrupt estate is a new legal entity, separeted from de debtor." (BLUM, Brian A. Bankruptcy and debtor/creditor. 4. edition, New York: Aspen Publishers, 2006, p. 281). Em tradução livre: A massa constitui uma nova personalidade, que é distinta da do devedor. Tanto assim que no Chapter 7 , os bens que venham a ser adquiridos depois do ajuizamento do procedimento concursal de uma pessoa física não integram a massa; já nos procedimentos de Chapters 12 e 13, dada a própria natureza de tais procedimentos, as receitas posteriores ao ajuizamento integrarão a massa até a conclusão do processo. (BLUM, Brian A. Bankruptcy and debtor/creditor. 4. edition, New York: Aspen Publishers, 2006, pp. 281 e 283).

${ }^{101}$ Os bens e direitos que integram ou que estão excluídos do property of the estate estão relacionados no $\S$ 541 do $B C$.

${ }^{102} \mathrm{O}$ trustee é o representante nomeado para defender e representar os interesses da property of the estate (section 323, BC). Pode ser pessoa física ou jurídica e, necessariamente, deve ser pessoa desinteressada ('disinterested person'), o que exclui: (i) credores, sócios ou pessoas relacionadas ao devedor ('insiders'); (ii) diretores, gerentes ou empregados do devedor nos últimos dois anos anteriores ao início do procedimento concursal, (iii) investment bankers ou seus empregados, ou (iv) qualquer pessoa que possua algum interesse material conflitante com a massa, alguns credores ou sócios da devedora, conforme Bankruptcy Code§101(14).

103 A nomeação ocorre imediatamente após a 'order of relief' (o momento em que o procedimento concursal é aceito e que ocorre automaticamente com o ajuizamento de um pedido pelo próprio devedor ou por uma decisão judicial, quando o pedido é feito por um credor) e o United States Trustee nomeia um trustee que atuará interinamente no processo $(\$ 701, B C)$. Esse mesmo trustee será nomeado em definitivo, a menos que, por indicação dos credores representantes de pelo menos vinte por cento dos créditos, em assembleia, seja substituído por outro indicado pelos credores.

${ }^{104} \$ 704$, BC: Duties of Trustee. "The essential duties of the trustee are enumerated in this section. Others, or elaborations on these, may be prescribed by the Rules of Bankruptcy Procedure to the extent not inconsistente with those prescribed by this section. (...) The trustee principal duty is to collect and reduce to money the property of the estate for wich he serves, and to close up the estate as expeditiously as is compatible with the best interest of parties in interest." Em tradução livre: 'Deveres do trustee. Os deveres essenciais do trustee estão enumerados nesta section. Outros, ou elaborações destes, podem estar prescritos no Rules of Bankruptcy Procedure em complementação e naquilo que não contradigam as disposições desta section. (...). O principal dever do trustee é arrecadar e transformar em dinheiro os bens da massa na qual tenha sido nomeado a atuar e promover o encerramento do procedimento o mais celeremente possível, de modo compatível com o melhor interesse das partes interessadas.' (Bankruptcy code, rules and official forms. Law School Edition, West, 2009, p. 276). 
pagamento aos credores, na ordem de preferência definida no Bankruptcy Code. Todos os bens penhoráveis do devedor ficarão sujeitos aos efeitos do procedimento e, em determinadas hipóteses, o devedor pessoa física poderá, ao final do procedimento, ser beneficiado pela discharge, ou seja, a liberação dos débitos preexistentes ${ }^{105}$.

O procedimento do Chapter 7 é largamente utilizado para as pessoas físicas, com vistas à obtenção do fresh start ${ }^{106}$, que resulta da discharge da maioria das obrigações. Uma das questões que pode surgir no curso de tal procedimento consiste em impugnação, pelo trustee, por substantial abuse, requerendo-se o encerramendo do caso, sob o fundamento de que o devedor teria condições de efetuar pagamentos mediante apresentação de um plano, sob o procedimento do Chapter 13.

Entretanto, esse procedimento é também aplicável a pessoas jurídicas, mas, nesse caso, com finalidade estritamente liquidatória, ou seja, de venda do patrimônio ativo para pagamento dos credores com o produto resultante.

Observa-se, por importante, a autorização para continuidade dos negócios (Authorization to operate business ${ }^{107}$ ) no procedimento do Chapter 7 , é prevista na lei e possível por período limitado e a requerimento do trustee. ${ }^{108}$ Contudo, tem essa o propósito específico de atender ao "best interest of the estate", ou seja, a previsão é restritiva e dirigida, hipóteses bastante particularizadas de maximização do preço de venda de cada ativo: "An example is the operation of a watch company to convert, watch movements and

\footnotetext{
${ }^{105}$ Um dos focos da reforma do direito norte-americano em 2005, com a promulgação do Bankruptcy Abuse Prevention and Consumer Protection Act of 2005, destinou-se principalmente a prevenir o uso indevido do requerimento de falência ou processos de reorganização com a finalidade de obtenção abusiva do fresh start. A reforma, por exemplo, dificultou a outorga da discharge para as pessoas físicas no pedido do Chapter 7 $(\$ 727, B C)$, ao exigir que provem a impossibilidade de pagamento de seus débitos, o que passou a ser requisito ao processamento do pedido. Igualmente, a reforma tornou menos atrativo o requerimento do Chapter 13, ao eliminar diversos créditos da discharge. No procedimento do Chapter 11, outrossim, houve acréscimo de hipóteses de não concessão da discharge (cf. Section 708, que fez acréscimos à Section 1141 (d) do Título 11 do USC, com reforma das Sections 321 e 330).

${ }^{106}$ Porém, como observa Sheila Cerezetti " $O$ uso do procedimento do Chapter 13 é preferível ao disposto no Chapter 7, uта vez que aquele permite que o devedor permaneça com algum ativo valioso, autorizando o devedor a propor um plano destinado a traçar metas para o pagamento dos credores. Referido pagamento deve ocorrer no período de três a cinco anos, após a aprovação do plano." (CEREZETTI, Sheila Cristina Neder. "O papel dos credores no Bankruptcy Code". Revista de Direito Mercantil, Industrial Econômico e Financeiro. Vols. 151/152, Ano XLVIII (nova série), jan/dez 2009, p. 166).

${ }^{107}$ Section $721, B C$.

${ }^{108}$ Section $704(8), B C$.
} 
cases into completed watches which will bring much highier prices than the component parts would have brought." ${ }^{109}$.

A razão para que assim seja é a de que a venda dos ativos em bloco para aproveitamento em outro negócio, ou da atividade em marcha para continuidade sob a gestão de um novo titular, ocorre, em geral, pela via do procedimento do Chapter $11^{110}$. Nesse procedimento, o devedor poderá requerer e ser autorizado a realizar venda de ativos (em bloco, especialmente) antes do momento de apresentação do plano, pela modalidade

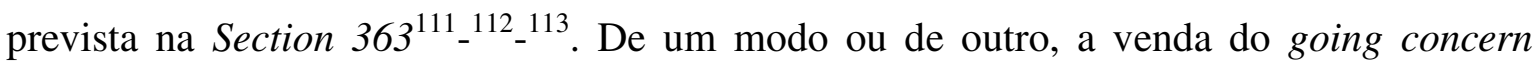
ocorre livre de sucessão ${ }^{114}$.

Em geral, o devedor prefere realizar a venda de ativos em um "plano de liquidação" levado a efeito sob o procedimento do Chapter 11, pois tal lhe permite continuar a operar o negócio até o momento em que a venda possa ser aperfeiçoada ${ }^{115}{ }^{116}$, além de, é claro, ser possível negociar os termos da alienação ${ }^{117}$.

109 § 721 do BC. Em tradução livre: 'Um exemplo é a continuação de atividade de uma fábrica de relógios para transformar peças em relógios completos, que trarão preço mais elevado do que a venda das partes traria. Senate report $n^{\circ}$ 95-989.'

${ }^{110} \S 1123$ do BC: Contents of Plan:

(a) Requirements for the contents of a plan - The following is required in a reorganization plan (regardless of any other applicable non-bankruptcy law):(...)

(b) Matters that a plan may propose (subject to (a)): (...)

(4) Sale od Property (This would be a "liquidation plan") - The plan may provide for:

a. The sale (of all or substantially all) of the estate's Property

and $b$. The distribution of the sale proceeds among Claim holders.

Em tradução livre: $§ 1123$ doBC: Conteúdos do Plano: (a) Requisitos para o conteúde do plano - O que segue é exigido conter no plano de reorganização (além de outras disposições de lei aplicáveis e não previstas na lei concursal): (...). (b) Soluções que o plano poderá propor (sujeitas ao item 'a'): (4) a. venda (de todo ou quase todo) o ativo da massa falida e b. a distribuição entre os titulares de crédito dos resultados da venda.

111 Section 363: Use, Sale, or Lease the Property.

${ }^{112}$ Sendo essa a modalidade preferida por devedor e credores, por ser a mais eficiente em termos de momento da venda (antes da apresentação do plano) e também menos custosa (EPSTEIN, David G. e NICKLES, Steve H. Bankruptcy and Related Law, 2aed., Thomson West, 2006, p. 385).

${ }^{113}$ Nesse caso, é importante frisar, o devedor deve, obrigatoriamente, obter autorização judicial para qualquer ato de disposição que não esteja contido em seu objetivo social. (TABB, Charles Jordan. The law of bankruptcy. Westbury (NY): The Foundation Press, 1997. University Textbook Series, p. 804).

114 "Section 363(b) allows assets to be sold free and clear of all liens, claims, and encumbrances, which allows the buyer to purchase the assets without fear of encumbrances, liens or sucessor liability of claims. The policy reason is that assets sold free of all claims can be sold at a higher price, thus raising more money for the debtor's creditors." (MARTIN, Nathalie; TAMA, Ocean. Inside Bankruptcy law - what matters and why, New York: Wolthers Kluwer, Aspen Publishers, 2008, p. 165). Em tradução livre: 'Section 363(b) permite que os bens sejam vendidos livres de todos os ônus, pretensões e gravames, o que permite ao comprador dos bens adquiri-los sem receio de vínculos ou sucessão de responsabilidades em pretensões. A política que fundamenta a venda de bens livre de todas as pretensões é a que obterão maior preço de venda, levantando, em consequência, mais dinheiro para pagamento dos credores.'

${ }^{115}$ Em razão do debtor in possession (DIP). 
As estatísticas de taxa de sucesso do Chapter 11 podem variar entre $10 \%$ a $25 \%$, porque "it depends on how you measure success. Some cases are filled merely to sell assets as a going concern, with no intention to survive." 118

O sistema norte-americano também prestigia, como no direito brasileiro e em outros sistemas, a solução de afastamento do devedor e alienação do estabelecimento (como um todo ou em partes). No entanto, a disciplina que rege essa solução se dá sob a égide do procedimento do Chapter 11, consistindo, pois, em uma modalidade reorganizatória.

A liquidação (prevista no Chapter 7) é reservada, residualmente, para as hipóteses em que nem o saneamento do devedor (que permanecerá à frente dos negócios), nem a cessão do estabelecimento (total ou parcial) para terceiros seja possível ou conveniente.

O Chapter 11 destina-se à reabilitação ou reorganização do devedor ${ }^{119}{ }_{-}^{120}$ por esta razão, os credores geralmente miram a possibilidade e capacidade de ganhos futuros do negócio ${ }^{121}$ (e não apenas com os recursos eventualmente apurados com a venda

${ }^{116}$ O sucesso da reorganização, geralmente, depende da continuidade da operação do negócio. (EPSTEIN, David G. e NICKLES, Steve H. Bankruptcy and Related Law, 2aed., Thomson West, 2006, p. 192).

${ }^{117}$ EPSTEIN, David G. e NICKLES, Steve H. Bankruptcy and related law. 2. edição, Dallas: Thomson West, 2006, p. 385.

118 (MARTIN, Nathalie; TAMA, Ocean. Inside Bankruptcy law - what matters and why, Wolthers Kluwer, New York: Aspen Publishers, 2008, p. 165). Em tradução livre: 'isso depende de como se mede o sucesso [do procedimento]. Alguns casos são ajuizados com a intenção puramente de venda dos bens como 'going concern', sem qualquer intenção de sobreviver.'

${ }^{119}$ BLUM, Brian A. Bankruptcy and debtor/creditor. 4. edition, New York: Aspen Publishers, 2006, p. 491.

${ }^{120}$ Uma das premissas do Chapter 11 é a de que todos os credores, o devedor, sócios, empregados e fornecedores possam beneficiar-se, se o devedor procurar a reestruturação de seus problemas financeiros por esta via, que resultará em custos aceitáveis. Anote-se o propósito histórico deste procedimento: "The purpose of a business reorganization case, unlike liquidation case, is to reestruture a business's finances so that is may continue to operate, provide its employees with jobs, pay its creditors, and provide a return for its stockholders. The premise of a business reorganization is that assets that are more used for production in the industry for wich they were designed are more valuable than those same assets sold for scrap." (H.R.Rep.n ${ }^{o}$ 595, 95th Congress, 1sess.220(1977)”.'(TABB, Charles Jordan. The law of bankruptcy. Westbury (NY): The Foundation Press, 1997. University Textbook Series, p. 757). Em tradução livre: 'O propósito da reorganização de uma empresa, ao contrário da liquidação, é reestruturar as finanças do negócio, para que este possa continuar a operar, provendo emprego a seus empregados, pagando seus credores, dando retorno aos sócios. A premissa de uma reorganização de empresa é a de que os bens utilizados em sua atividade são mais valiosos do que se fossem vendidos em retalhos.'

${ }^{121}$ EPSTEIN, David G.; NICKLES, Steve H. Bankruptcy and related law. 2. edition, Dallas: Thomson West, 2006, p. 156. 
de bens), para que possam satisfazer suas pretensões: "In Chapter 11 focus is on how the debtor's operations can support future payments to creditors" ${ }^{122}$.

Por isso, o devedor, em regra, mantém a posse e a administração de seus bens ("debtor in possession") ${ }^{123}{ }^{124}$ em um procedimento do Chapter 11, no qual se perfaz o pagamento dos credores por meio de um plano aprovado em juízo. Desde logo, mencione-se, na hipótese de afastamento do devedor, nomeia-se um 'trustee' para desempenhar o papel do devedor (e que deverá conduzir os negócios e apresentar um plano de reorganização).

No procedimento do Chapter 11 das corporações não há previsão expressa da discharge, mas, é fato que a homologação judicial de um plano já corresponde a essa solução, na medida em que altera as condições de pagamento das obrigações originariamente contratadas ${ }^{125}{ }^{126}$.

Ante as características que são próprias do Chapter 11, usualmente recorrem a este procedimento as sociedades empresárias que desejam continuar a operar suas atividades, superando uma situação de crise.

Um procedimento concursal pode ser ajuizado por iniciativa do devedor ou de credor $^{127}$ e, na primeira hipótese, é denominado por 'voluntary case,128 e, na segunda,

\footnotetext{
${ }^{122}$ MARTIN, Nathalie; TAMA, Ocean. Inside Bankruptcy law - what matters and why, New York: Wolthers Kluwer, Aspen Publishers, 2008, p. 166. Em tradução livre: 'No procedimento do Chapter 11, o foco é como a operação do devedor pode suportar os futuros pagamentos aos credores'.

${ }_{123}$ "The appointment of a trustee is a rare and drastic move in Chapter 11. Section 1104 provides that a trustee may only be appointed for "cause", such as fraud, dishonesty, incompetence, or gross mismanagement. 11 USC \$ 1104(a)(1)." (MARTIN, Nathalie; TAMA, Ocean. Inside Bankruptcy law - what matters and why, New York: Wolthers Kluwer, Aspen Publishers, 2008, p. 166). Em tradução livre: 'A nomeação de um trustee é um movimento raro e drátisco no Chapter 11. A section 1104 prevê essa solução desde que exista uma causa como fraude, desonestidade, incompetência ou erros grosseiros de administração'.

${ }^{124}$ A adoção deste mecanismo, segundo Sheila Cerezetti "reflete a crença de que o conhecimento, 'expertise' e familiaridade do devedor com os negócios praticados são fatores dotados de imenso valor e deveriam ser aproveitados quando da reestruturação de grandes empresas." (CEREZETTI, Sheila Cristina Neder. "O papel dos credores no Bankruptcy Code". Revista de Direito Mercantil, Industrial Econômico e Financeiro. Vols. 151/152, Ano XLVIII (nova série), jan/dez 2009, p. 171).

${ }^{125}$ TOLEDO, Paulo Fernando Campos Salles de. A empresa em crise no direito francês e americano. Dissertação de Mestrado. São Paulo: Fadusp, 1987, pp. 25-26.

${ }_{127}^{126}$ Section 1141 (d) prevê as hipóteses de discharge para pessoa física, no procedimento do Chapter 11.

${ }^{127}$ Confira-se, a propósito, a esquematização do procedimento do Chapter 11, em BLUM, Brian A. Bankruptcy and debtor/creditor. 4. edition, New York: Aspen Publishers, 2006, p. 495.
} 
'involuntary case ${ }^{, 129}$. O pedido por 'involuntary case' é cabível somente nos procedimentos previstos nos Chapter 7 e Chapter 11, com base no descumprimento generalizado do pagamento de obrigações na data de seus respectivos vencimentos ("equitable insolvency"130_131).

O início de um procedimento de Chapter 11 é marcado pelo imediato efeito denominado automatic stay, ${ }^{132}{ }^{133}$ que consiste na paralisação de todas as ações e pretensões individuais em curso contra o devedor ${ }^{134}$, bem como resulta no congelamento de todos os bens e direitos sob sua titularidade. Basicamente, a finalidades do automatic stay são: (i) outorgar ao devedor algum tempo para se organizar e promover um levantamento de sua situação frente aos credores, possibilitando a escolha de estratégias que possam maximizar os resultados do processo concursal; e (ii) permitir ao Judiciário decidir quais os bens que integrarão e quais serão excluídos do 'estate of property'.

O plano é o principal foco do procedimento de Chapter 11, pois determinará como os credores serão pagos e como será o tratamento que receberão. No plano, eles são divididos em diferentes classes, de acordo com a similaridade do direito que ostentem ${ }^{135}$. $\mathrm{O}$ plano poderá ser apresentado pelo devedor, que tem legitimadade exclusive para fazê-lo no prazo de 120 dias. ${ }^{136}$ Para tanto, e após esse período inicial, os credores passam a ter

\footnotetext{
${ }^{128}$ A maioria dos casos, segundo estudo realizado logo após a vigência do $B C$, era de iniciativa do próprio devedor. (CEREZETTI, Sheila Cristina Neder. "O papel dos credores no Bankruptcy Code". Revista de Direito Mercantil, Industrial Econômico e Financeiro. Vols. 151/152, Ano XLVIII (nova série), jan/dez 2009, p. 169).

${ }_{129}$ TOLEDO, Paulo Fernando Campos Salles de. A empresa em crise no direito francês e americano. Dissertação de Mestrado. São Paulo: Fadusp, 1987, pp. 17-21.

${ }^{130} \S 303(\mathrm{~h})(1)$. 'Subsection $(h)$ provides the standard for an order of relief on as involuntary petition. (...) the court orders relief after a trial, only if the debtor is generally unable to pay its debts as they mature, or if the debtor has failed to pay a major portion of his debts as they become due.' (Bankruptcy Code, Rules and Official Forms, Law School Edition, West, 2009, p. 64). Em tradução livre: 'A subsection (h) prevê os parâmetros para a decisão de order of relief nos casos de requerimento do credor (...) o juiz a determina após julgamento apenas se o devedor estiver sem condição generaliza de pagar seus débitos conforme vencimento, ou se tenha falhado com tais pagamentos na maior parte quando tenham vencido.'

${ }_{131}^{131}$ Esse conceito de 'insolvency' é diverso daquele mencionado na section 101(32), BC.

$132 \S \S 362$ (a)(b). Confira-se: BLUM, Brian A. Bankruptcy and debtor/creditor. 4. edition, New York: Aspen Publishers, 2006, pp. 237-241.

${ }^{133}$ TABB, Charles Jordan. The law of bankruptcy. Westbury (NY): The Foundation Press, 1997. University Textbook Series, p. 146.

${ }^{134}$ Há exceções que basicamente estão relacionadas a: (i) situações que não envolvam interesses dos bens e ativos do devedor, como, por exemplo, uma ação penal; (ii) ações ajuizadas por um credor e que não estejam sujeitas ao direito concursal. (cf.-se BLUM, Brian A. Bankruptcy and debtor/creditor. 4. edition, New York: Aspen Publishers, 2006, p. 242).

${ }^{135}$ Section $1122(a)$.

136 Section 1121 .
} 
legitimidade de apresentar planos. Resulta disto que diversos planos poderão ser apresentados, mas apenas um poderá ser confirmado ${ }^{137}$.

A lei estabelece exigências que o plano deverá atender como pré-requisito de admissibilidade ${ }^{138}$, tais como: (i) especificação do critério de divisão dos credores em classes; (ii) especificação das classes cujos direitos serão mantidos; (iii) indicação das classes cujos direitos serão reduzidos ou modificados pelo plano; (iv) obrigatoriedade e tratamento igualitário entre os credores participantes de uma mesma classe (a menos que o titular do direito concorde, expressamente, com tratamento inferior); (v) o plano deve ser 'fair, equitable ${ }^{139}$ and feasible ${ }^{140}$.

Depois que o plano é apresentado, e antes da votação, os credores deverão receber o disclosure statement, que consiste em um resumo das condições da proposta, contendo 'adequate information ${ }^{141}{ }^{142}$ para que possam votar. $\mathrm{O}$ exercício do direito de voto não se dá em assembleia, como ocorre no direito brasileiro, mas por cédulas na qual os credores manifestam sua aceitação ou rejeição ${ }^{143}$.

Ao término do período de votação, a lei determina a realização de uma audiência de confirmação ${ }^{144}$, na qual será proclamado o resultado do sufrágio. A confirmação do plano tem por efeito vincular todos os interessados (credores, devedor e acionistas) às obrigações ali constantes ${ }^{145}$.

\footnotetext{
${ }^{137}$ Section 1129(c).

${ }^{138}$ A propósito, confira-se: MUNHOZ, Eduardo Secchi. "Anotações sobre os limites do poder jurisdicional", Revista de Direito Bancário e do Mercado de Capitais, ano 10, n. 36, abr-jun/2007, São Paulo: Revista dos Tribunais, pp. 185/199.

139 Que diz respeito à regra da observância da ordem de pagamento, nas classes de credores, conforme prevista em lei, ou seja, disciplina as relações verticais entre os credores.

${ }^{140} \mathrm{O}$ devedor deve demonstrar que possui renda suficiente para fazer frente às obrigações assuminadas no plano. MARTIN, Nathalie; TAMA, Ocean. Inside bankruptcy law - what matters and why, New York: Wolters Kluwer Law \& Business, Aspen Publishers, 2008, p. 177.

${ }^{141}$ CEREZETTI, Sheila Cristina Neder. "O papel dos credores no Bankruptcy Code". Revista de Direito Mercantil, Industrial Econômico e Financeiro. Vols. 151/152, Ano XLVIII (nova série), jan/dez 2009, p. 176.

${ }^{142}$ Section 1125(a)(1).

${ }^{143}$ BLUM, Brian A. Bankruptcy and debtor/creditor. 4. edition, New York: Aspen Publishers, 2006, p. 499. ${ }^{144} \S 1128$.

145 BLUM, Brian A. Bankruptcy and debtor/creditor. 4. edition, New York: Aspen Publishers, 2006, p. 501.
} 
Na hipótese de rejeição do plano por todas as classes de credores, o direito norte-americano prevê a possibilidade de cram-down, desde que não seja outorgado tratamento discriminatório (unfair discrimination) ${ }^{146}$ à classe dissidente.

A atuação dos credores é bastante valorizada no procedimento do Chapter 11, em que há, por exemplo, constituição compulsória de um comitê de credores titulares de créditos não garantidos, sendo a escolha e nomeação de seus membros feita pelo $U S$ Trustee $^{147}$.

As principais atribuições do comitê de credores de créditos não garantidos são: “( $i$ ) discutir com o trustee ou o devedor sobre a administração do caso; (ii) investigar qualquer assunto relevante para o caso ou para a formação do plano, incluindo-se a atuação e a condição financeira do devedor e a condução dos negócios e a conveniência da manutenção dos negócios; (iii) participar da elaboração do plano, aconselhar os credores representados pelo comitê e obter aceitações ou rejeições do plano; (iv) solicitar a nomeação de um trustee ou examiner; e, (v) atuar de outras maneiras no interesse das partes por ele representadas." 148

Assim, "o sistema concursal norte-americano conta com variados instrumentos voltados a estabelecer equilíbrio entre as partes interessadas na solução da crise empresarial." 149 Por isso, pode-se afirmar que: "Bankruptcy law forces diverses creditors to work togheter", com o que se procura evitar que a atuação isolada de cada um resulte na venda dos bens "piecemeal, destroying whatever synergy existed betwen them." 150

\footnotetext{
${ }^{146}$ Essa voltada às relações horizontais entre os credores. A regra dos §§ 1129(b)(1)(2) prevê o nível mínimo de tratamento que deve ser outorgado aos credores. (BLUM, Brian A. Bankruptcy and debtor/creditor. 4. edition., New York: Aspen Publishers, 2006, p. 513).

${ }_{147}$ Órgão vinculado ao Departamento de Justiça, que nomeia um 'officer' que terá funções de natureza administrativa no procedimento concursal.

${ }^{148}$ CEREZETTI, Sheila Cristina Neder. "O papel dos credores no Bankruptcy Code". Revista de Direito Mercantil, Industrial Econômico e Financeiro. Vols. 151/152, Ano XLVIII (nova série), jan/dez 2009, p. 172. ${ }_{149}$ CEREZETTI, Sheila Cristina Neder. "O papel dos credores no Bankruptcy Code". Revista de Direito Mercantil, Industrial Econômico e Financeiro. Vols. 151/152, Ano XLVIII (nova série), jan/dez 2009, p. 184. ${ }^{150}$ BAIRD, Douglas G., JACKSON, Thomas H., e ADLER, Barry E. Bankruptcy, cases, problems and materials. 3. edition, New York: Foundation Press, 2000. University Casebook Series, pp. 20-21. Em tradução livre: 'A lei concursal força diversos credores a trabalharem juntos'; e mais adiante: 'em partes pequenas, destruindo qualquer sinergia que exista entre elas.'
} 
Ainda que o direito norte-americano tenha adotado um sistema dualista, que individualiza os procedimentos liquidatórios e reorganizatórios, difere do sistema brasileiro, pois lá, a solução de alienação dos estabelecimentos em bloco ou do negócio em marcha como um todo consiste em uma modalidade reorganizatória, levada a efeito sob a égide do Chapter 11. A liquidation, prevista no Chapter 7, destina-se, exclusivamente à venda dos bens isoladamente.

\section{$2.2 \mathrm{O}$ direito francês}

O direito francês foi o segundo ordenamento a acolher procedimentos reorganizatórios quando, em 1967, pela Loi 67-653 du 13 Juillet 1967 foi implementado um sistema " $d u$ redressement des entreprises viables et de favoriser l'élimination de celles qui, en situation désespérée, constituaient un fardeau pour l'economie. L'intérêt des créanciers n'était pas pour autant relégue au second plan, mais il semblait aller de pair avec celui de l'entreprise." ${ }^{151} 152$

Foi assim que o tradicional direito falimentar francês cedeu lugar ao direito das empresas em dificuldade ${ }^{153}$ ou da crise das empresas, como prefere Paulo Fernando Campos Salles de Toledo ${ }^{154}$. De fato, para o direito francês, o procedimento concursal não

\footnotetext{
${ }^{151}$ SOUWEINE, Carole. Droit de l'entreprise en difficulté. 2. edition, Grenoble: PUG - Press Universitaires de Grenoble, 2007, p. 11. Em tradução livre: 'de recuperação de empresas viáveis e favorecimento da eliminação daquelas que, em desespero, constituam um fardo para a economia.O interesse dos credores, por outro lado, não foi relegado a segundo plano, mas deve caminhar ao lado daqueles da empresa.'

${ }^{152}$ A modificação substancial desse diploma consistiu no foco que se deu à problemática 'eliminaçãoconservação’ da empresa, em particular, seguindo a orientação do relatório Houin de separação do tratamento entre a empresa e o empresário, segundo Bisbal Mendez. O autor destaca a redação do artigo $7^{\circ}$ da lei, que refletia, em grande parte, tal significado da reforma, pois o devedor deveria oferecer um 'convenio serio'. O artigo $7^{\circ}$ tinha a seguinte redação: “Le Tribunal pronence le règlement judiciaire s'il lui apparaît que le debiteur est en mesure de proposer un concordat serieux et, dans le cas contraire, la liquidation des biens."(BISBAL MENDEZ, Joaquin. La empresa en crisis y el derecho de quiebras. Bolonia: Publicaciones del Real Colegio de Espana, 1986, pp. 230-231). Em tradução livre: 'O Tribunal concede o règlement judiciaire se lhe parecer que o devedor está em condições de propor um acordo sério, caso contrario, pronuncia a liquidation dos bens.'

${ }^{153}$ SOUWEINE, Carole. Droit de l'entreprise en difficulté. 2. edition, Grenoble: PUG - Press Universitaires de Grenoble, 2007, p. 7; JEANTIN, Michel e LE CANNU, Paul. Entreprises en dificulte. 7. édicion, Paris: Dalloz, 2007, p. 01 e pp. 114-115; SAINT-ALARY-HOUIN, Corinne. Droit des entreprises en difficulté. 6. édicion, Paris: Montchrestien, 2009, p. 01.; PÉTEL, Philippe. Procédures Collectives. Paris: Dalloz, 6. édicion, 2009, pp. 01-10.

154 TOLEDO, Paulo Fernando Campos Salles de. A empresa em crise no direito francês e americano. Dissertação de Mestrado. São Paulo: Fadusp, 1987.
} 
constitui apenas um método de apuração do passivo do devedor, mas, sobretudo, um modo de tratar as dificuldades das empresas ${ }^{155}$.

O fundamento principal do direito francês das empresas em dificuldade, inaugurado pela legislação acima mencionada, foi promover a separação entre a empresa e o empresário, calcada em considerável reforço dos poderes do Tribunal no desenvolvimento do processo concursal ${ }^{156}$.

A lei em questão foi inspirada no relatório Houin, elaborado por Roger Hoiun, a pedido da Inspetoria Geral das Finanças, com a finalidade de examinar o mecanismo dos institutos de direito concursal e promover seu aprimoramento.

O resultado do relatório, que trouxe a inegável contribuição do princípio da separação entre a empresa e o empresário, influenciou a reforma, que resultou na Lei de 1967, que disciplinava dois procedimentos coletivos: a liquidation e o règlement judiciaire. O primeiro era de natureza liquidatória e resultava na eliminação da empresa, já o segundo previa a possibilidade de uma solução por concordata, com a consequente manutenção da empresa ${ }^{157}$.

Pouco depois, o sistema francês acolheu mais um procedimento concursal ${ }^{158}$ denominado suspension provisoire des poursuites, que pretendia facilitar a recuperação econômica e financeira de determinadas empresas, cuja liquidação poderia causar "grave transtorno econômico ou social", sendo que sua principal finalidade era a de reabilitação econômica do devedor ${ }^{159}{ }^{160}$.

\footnotetext{
${ }^{155}$ SOUWEINE, Carole. Droit de l'entreprise en difficulté. 2. edition, Grenoble: PUG - Press Universitaires de Grenoble, 2007, p. 91.

156 "Separatión de l'homme et de l'entreprise."(JEANTIN, Michel; LE CANNU, Paul. Entreprises en dificulte. 7. édicion, Paris: Dalloz, 2007, p. 114).

${ }^{157}$ BISBAL MENDEZ, Joaquin. La empresa en crisis y el derecho de quiebras. Bolonia: Publicaciones del Real Colegio de Espana, 1986, p. 231.

${ }_{158}$ Ordennance n.67-820 de septiembre de 1967.

${ }^{159}$ Esse procedimento é fortemente criticado por Bisbal Mendez, em particular pelo fato de que cabia ao tribunal apreciar as condições de admissibilidade do plano da empresa em crise. $\mathrm{O}$ autor aponta dados que revelaram que na maioria dos casos fracassavam os planos aprovados. (BISBAL MENDEZ, Joaquin. La empresa en crisis y el derecho de quiebras. Bolonia: Publicaciones del Real Colegio de Espana, 1986, pp. 241-243).

${ }^{160}$ Mas Michel Jeantin e Paul Le Cannu ponderam a importância do ideal inovador trazido com a referida legislação. (JEANTIN, Michel; LE CANNU, Paul. Entreprises en dificulte. 7. édicion, Paris: Dalloz, 2007, pp. 116-117).
} 
Em 1985, houve nova reforma de expressão no direito francês, com a promulgação da Loi $n$. 85-98 du 25 janvier 1985, cuja finalidade, fixada pelo artigo $1^{\circ}$ do mencionado diploma, era a seguinte: "Il est institué une procédure de redressement judiciaire destinée à permettre la sauvegarde de l'entreprise, le maintien de l'activité et de l'emploi et l'appurement du passif." ${ }^{, 161} 162$

Declaradamente, o foco da reforma de 1985 foi o de promover a preservação da empresa e, por via reflexa, a salvaguarda da atividade e dos postos de trabalho. A satisfação do passivo ocupava um papel secundário, conforme consagrou a doutrina $^{163-164-165}$, e deveria ocorrer na medida em que a manutenção da atividade econômica proporcionasse meios para tanto, o que resultaria, inclusive, na proteção ao crédito.

Numerosas reformas seguiram-se ${ }^{166}{ }^{167}{ }_{-}^{168}$ até o direito concursal vigente, sendo a de maior expressão a Loi de Sauvegard des Entreprises, du 26 julliet $2005^{169}$, cujas disposições integram o Livre VI do Code du Commerce.

${ }^{161}$ Em tradução livre: 'Fica instituído o procedimento de redressement judiciaire destinado a permitir a salvaguarda da empresa, a manutenção da atividade e dos empregos e a apuração do passivo'.

${ }^{162} \mathrm{O}$ artigo 47 da Lei n. 11.101/05 está inspirado neste dispositivo da revogada lei francesa.

163 A doutrina enfatizava que a ordem de tutela especificada pelo legislador no artigo $1^{\circ}$ da lei correspondia a uma opção legislativa das prioridades a serem atendidas no procedimento concursal. Por isso, Paulo Fernando Campos Salles de Toledo afirmou que "Toda atenção é dada à preservação da empresa". (TOLEDO, Paulo Fernando C. Salles de, Empresa em crise no direito francês e americano. Dissertação de Mestrado, São Paulo: Fadusp, 1987, p. 56).

164 A propósito, Alberto Jorio afirma que "Per il legislatore francese la conservazione degli organismi produttivi constituice obiettivo prioritário rispetto alla tutela dei creditori, le cui attese vanno sacrificate ogni qual volta sia individuabile una soluzione alternativa al falimento." Em tradução livre: 'Para o legislador francês a conservação do organismo produtivo constitui o objetivo prioritário em relação à tutela dos credores, cujas expectativas ficam sacrificadas sempre que se puder individualizar uma solução alternativa à falência" (Le crisi d'impresa e il fallimento. Milano: Giuffrè, 2000, p. 37).

${ }^{165}$ Destacam-se como objetivos perseguidos pela reforma da lei concursal francesa de 1985: (i) salvar as empresas viáveis, (ii) preservar postos de trabalho, (iii) atender aos interesses dos credores (destacando, todavia, a declarada prioridade dos dois objetivos precedentes), (iv) diminuir a função repressiva dos procedimentos coletivos. No entanto, a sistemática adotada pela lei também podia ser criticada, na medida em que não parecia realista retardar, para as empresas inviáveis, a solução da liquidação para depois do término do período de observação. A jurisprudência, todavia, encarregou-se de solucionar esse hiato. (JEANTIN, Michel; LE CANNU, Paul. Entreprises en dificulte. 7. édicion, Paris: Dalloz, 2007, pp. 120124).

${ }^{166}$ SOUWEINE, Carole. Droit de l'entreprise en difficulté. 2, edition, Grenoble: PUG - Press Universitaires de Grenoble, 2007, pp. 17-19.

167 Aliás, essa é uma característica do direito francês, como informa Paulo Fernando Campos Salles de Toledo: "A França tem demonstrado a preocupação de constantemente apurar e aperfeiçoar o sistema de normas jurídicas disciplinador das relações atinentes às empresas em dificuldade". (Empresa em crise no direito francês e americano. Dissertação de Mestrado, São Paulo: Fadusp, 1987, p. 53).

${ }^{168}$ Pode-se referir também à reforma pela Ordonnance $\mathrm{n}^{\circ}$ 2008-1345, du 18 décembre 2008, cujo objetivo principal era tornar o procedimento de sauvegard mais atrativo, pois as estatísticas revelaram pouca 
A reforma proposta pela referida legislação teve como tema principal o aperfeiçoamento do sistema de antecipação das dificuldades pela devedora ${ }^{170}{ }^{171}$, para, com isso, tentar proporcionar meios de solução para a crise das empresas antes que sua gravidade pudesse comprometer, de forma irreversível, a possibilidade de saneamento. ${ }^{172}$

A ideia era estimular uma reação mais precoce às dificuldades, até mesmo com a expectativa de tentar soluciná-las sem a necessidade de instauração de um procedimento concursal ${ }^{173}$.

Atualmente, a disciplina das empresas em crise (ou en dificulté), no direito francês, encontra os seguintes meios possíveis de superação das dificuldades: (i) mandat ad hoc; (ii) conciliation; (iii) sauvegard; (iv) redressement judiciaire. Ao lado destes, existe o procedimento de liquidation judiciaire, destinado à liquidação das empresas.

Os dois primeiros, o mandat ad hoc e a conciliation, são considerados meios preventivos de solução das dificuldades, eis que destinados a evitar que o devedor precise se valer da abertura de um procedimento concursal para tanto.

O mandat ad hoc consiste numa técnica de negociação, na qual o devedor (e somente ele detém tal legitimidade ${ }^{174}$ ) requer a designação de um mandataire ad hoc ${ }^{175}$. A

utilização da medida, pois entre 2006 e 2008, somente 1916 procedimentos haviam sido requeridos (LE CORRE, Pierre-Michel. La reforme du droit des entreprises en difficulté. Paris: Dalloz, 2009, p.11).

${ }^{169}$ Em vigor a partir de 1\%1/2006.

170 A lei disciplina também "les procedures d'alerte" (procedimentos de alerta) que servem para informar os órgãos sociais e o titular da empresa ('chef d'entreprise') de qualquer fato que possa comprometer a continuidade da exploração do negócio. (LE CORRE, Pierre-Michel; LE CORRE-BROLY, Emmanuelle, Droit des entreprises en difficulté. 2. edition, Paris: Sirey Université, 2006, p. 21).

171 "la sauvegard peut apparaître comme un redressement judiciaire anticipé, ce qui n'est pas pour lui donner un visage três original." (JEANTIN, Michel; LE CANNU, Paul. Entreprises en dificulte, 7. édicion, Paris: Dalloz, 2007, p. 139). Em tradução livre: 'a sauvegard poderia parecer um redressement judiciaire antecipado, não fosse sua feição bastante original'.

${ }_{172}$ Michel Jeantin e Paul Le Cannu destacam também que a lei de 1967 havia sido promulgada em um período de prosperidade econômica e, em um contexto posterior de recessão, experimentado na década de 1980, sentiu-se a necessidade da reforma. (JEANTIN, Michel; LE CANNU, Paul. Entreprises en dificulte. 7. édicion, Paris: Dalloz, 2007, pp. 117-118).

${ }^{173}$ SOUWEINE, Carole. Droit de l'entreprise en difficulté. 2. edition, Grenoble: PUG - Press Universitaires de Grenoble, 2007, p. 20; JEANTIN, Michel; LE CANNU, Paul. Entreprises en dificulte. 7. édicion, Paris: Dalloz, 2007, p. 3.

${ }^{174}$ Ao contrário do sistema anterior, em que o tribunal poderia, por sua iniciativa, nomear o mandataire ad hoc. Esse novo posicionamento mostra que a técnica proporcionada pelo mandat ad hoc busca um trabalho de cooperação entre o devedor e a pessoa designada para atuar, a qual não poderá ser imposta. 
missão do mandataire ad hoc não é fixada pela lei, que outorga tal atribuição ao presidente do Tribunal. Este, em comum acordo com o devedor, e em função das dificuldades identificadas, encarregar-se-á de estabelecer como se dará a atuação do referido profissional. Desse modo, o mandataire ad hoc poderá atuar em diferentes níveis de providências e, para tanto, ficará vinculado a um dever de confidencialidade ${ }^{176}$ no exercício de suas funções.

A natureza do mandat ad hoc é essencialmente contratual e nada poderá ser imposto aos credores: tudo deve ser aceito. Esse sistema de negociação envolve uma plasticidade tal que permite sua adoção como medida paralela a uma conciliation ou mesmo a um procedimento de sauvegard ou redressement ${ }^{177}$. O mandat ad hoc, outrossim, pode ser um eficiente prelúdio para futura conciliation.

O que se deve ter em mente é que, em se tratando de uma medida colocada à disposição do devedor, este terá pleno controle sobre o momento de iniciar e concluir a atuação do mandataire ad hoc. A ideia é que devedor e mandataire ad hoc atuem em regime de colaboração, com o propósito de encontrar uma solução para a crise da empresa.

A conciliacion, que substituiu o règlement amiable ${ }^{178}$ é, basicamente, uma técnica de caráter essencialmente convencional ${ }^{179}$, destinada a tentar alcançar um acordo, por meio de negociação entre o devedor em dificuldade e seus principais credores, a fim de

(SOUWEINE, Carole. Droit de l'entreprise en difficulté. 2. edition, Grenoble: PUG - Press Universitaires de Grenoble, 2007, p. 40).

${ }^{175}$ A nomeação é requerida ao 'président du tribunal de commerce' ou 'tribunal de grande instance', conforme a natureza da empresa.

${ }^{176}$ A confidencialidade é importante para que o devedor possa manter as negociações restritas a certo círculo de interessados, preservando a confiança daqueles com quem mantém relação contratual. (LE CORRE, Pierre-Michel; LE CORRE-BROLY, Emmanuelle. Droit des entreprises en difficulté. 2. edition, Paris: Sirey Université, 2006, p. 27).

${ }^{177}$ LE CORRE, Pierre-Michel; LE CORRE-BROLY, Emmanuelle, Droit des entreprises en difficulté. 2. edition, Paris: Sirey Université, 2006, p. 18.

${ }^{178}$ A Loi du 26 julliet 2005 importou reforma ao règlement amiable aplicável aos devedores em geral, exceto ao procedimento aplicável aos empresários agricultores, pois, para estes, permanece em vigor o règlement amiable agricole previsto no Code Rural (Art. L.351-1, CR).

${ }^{179}$ Embora a lei refira à "la procédure de conciliation", esse não consiste propriamente em um procedimento, uma vez que seu objetivo principal é alcançar a celebração de um acordo entre o devedor e os credores. A homologação do acordo, que lhe outorga uma força suplementar, é facultativa e, por essa razão, parte da doutrina entende que a conciliation é, na verdade, uma modalidade de tratamento das empresas em dificuldade (JEANTIN, Michel; LE CANNU, Paul. Entreprises en dificulte. 7. édicion, Paris: Dalloz, 2007, pp. 5-6). 
favorecer a superação da crise. O conciliateur ${ }^{180}$ também atua vinculado a um dever de sigilo no exercício de suas atribuições.

O requisito para a abertura da conciliacion ${ }^{181}$ é que o devedor esteja em uma situação, atual ou previsível, de dificuldade jurídica, econômica ou financeira, mas não em situação de cessação de pagamentos ${ }^{182}{ }^{183}$ há mais de 45 dias.

A grande inovação trazida pela reforma de 2005, nesse particular, foi permitir a instauração da conciliation antes mesmo de caracterizado o estado de cessação de pagamentos. No regime anterior, caracterizada a situação de cessação de pagamentos, o devedor tinha a opção entre a conciliation ou o procedimento de redressement. Verifica-se, nessa medida, claramente o tom da reforma, que foi proporcionar ao devedor opção de medidas antecipatórias para a solução das dificuldades das empresas.

O objetivo da conciliation - cujo período de duração não pode exceder quatro meses, prorrogável por mais um, por decisão motivada - é tentar proporcionar meios para que seja formalizado um acordo entre o devedor e seus principais credores (especialmente com seus fornecedores habituais), para colocar fim às dificuldades da empresa $^{184}$.

O conciliateur não se substitui ao devedor na gestão do negócio, tampouco se encarrega de elaborar um plano; mas sua missão é propor soluções (às quais, note-se, o devedor não está obrigado) que possam trazer como resultado a salvaguarda da empresa para manutenção da atividade e preservação dos empregos.

\footnotetext{
180 Também nomeado pelo 'président du tribunal de commerce' ou de 'tribunal de grande instance', conforme a natureza da empresa.

${ }^{181}$ Art. L.611-4 C.Com.

${ }^{182} \mathrm{O}$ conceito de cessação de pagamentos é acolhido pela legislação francesa há tempos como critério objetivo de caracterização da insolvência e requisito para a instauração de procedimentos concursais. Trata-se de um conceito de natureza contábil e corresponde à impossibilidade em que se encontra o devedor de fazer frente ao passivo exigível, com as suas reservas atuais de caixa ou créditos a receber. Confira-se, a propósito: JACQUEMONT, André. Droit des entreprises en difficulté, 3. edição, Paris: Litec Group Lexis Nexis, pp. 77-78; SOUWEINE, Carole. Droit de l'entreprise en difficulté. 2. edition, Grenoble: PUG - Press Universitaires de Grenoble, 2007, pp. 69-71; JEANTIN, Michel; LE CANNU, Paul. Entreprises en dificulte. 7. édicion, Paris: Dalloz, 2007, pp. 178-182; TOLEDO, Paulo F. C. Salles de. Empresa em crise no direito francês e americano. Dissertação de Mestrado, São Paulo: Fadusp, 1987, p. 72.

183 La notion de cessation de paiement est une notion purement de trésorerie, (http://www.lexinter.net/actualite/reforme_du_droit_de_la_faillite1.htm). Em tradução livre: 'A noção de cessação de pagamentos é uma novação de caráter puramente contábil'.

${ }^{184}$ Artigo 611-7, al. $1^{\text {er }}$, C. Com.
} 
Na conciliation não há suspensão das ações contra o devedor, podendo este, a qualquer momento, optar por requerer o fim da tarefa acometida ao concilateur, o qual, igualmente, poderá, ante a constatação da impossibilidade de celebrar um acordo, colocar um ponto-final ao procedimento, apresentando um relatório ao presidente do Tribunal, justificando tal opção. No encerramento da conciliation, três formas de conclusão são possíveis: (i) celebração de um acordo; (ii) inexecução do acordo celebrado; (iii) impossibilidade de conclusão de um acordo.

A celebração de um acordo implica êxito do procedimento, na medida em que este reflete convenção livremente pactuada pelos interessados, com força vinculante entre os signatários ${ }^{185}$, resultando em reestruturação de obrigações do devedor, de modo que possa adimpli-las.

Em geral, o acordo integra medidas diversas a serem adotadas pelo devedor a fim de reeguer o negócio, além de remissão ou dilação de dívidas e que tenham sido consentidas pelos credores, privados ou públicos. É possível, também, pelo acordo, promover a revisão de certos contratos com fornecedores regulares do devedor, ainda que não sejam credores, medida esta inserida com a reforma de $2005^{186}$. O acordo deve ser formalizado por escrito e assinado por todos os interessados, os quais ficam vinculados a dever de confidencialidade.

O devedor terá a faculdade de requerer a homologação do acordo celebrado, ${ }^{187}$ caso em que cessa o dever de confidencialidade. Para tanto, ele deverá demonstrar: (i) que não está em estado de cessação de pagamentos ou que o acordo lhe pôs fim, (ii) os termos do acordo são suficientes para assegurar a permanência da empresa em

\footnotetext{
${ }^{185}$ E outorga aos credores signatários, o que a doutrina denomina por "privilège de conciliation". Os credores signatários que efetivamente tenham concedido crédito ou fornecido bens ou serviços com a finalidade de colaborar com a manutenção da empresa, terão privilégio no pagamento de seus créditos na hipótese de abertura de um procedimento coletivo depois do acordo de conciliation (Artigos L.622-17 e L.641-13). ${ }_{187}^{186}$ Artigo L.611-7, al. $1^{\text {er }}$, C.Com.

${ }^{187}$ Há, com efeito, duas modalidades de conciliation: (i) constatée, a qual o presidente do tribunal outorga força executiva e (ii) homologuée, sendo um dos efeitos o de que, na hipótese de um futuro procedimento concursal, a fixação da data da cessação de pagamentos não poderá ser anterior àquela da homologação da conciliation, preservando-se, destarte, todos os atos do devedor em relação aos credores signatários. (LE CORRE, Pierre-Michel; LE CORRE-BROLY, Emmanuelle. Droit des entreprises en difficulté. 2. edition, Paris: Sirey Université, 2006, pp. 27-30).
} 
atividade e (iii) que os interesses dos credores não signatários não foram prejudicados pelo acordo.

Não obstante, o Tribunal poderá homologar o acordo e, com fundamento na legislação civil, ${ }^{188}$ determinar que o pagamento de determinadas obrigações seja diferido no tempo até o limite máximo de dois anos.

No caso de descumprimento do acordo, se o inadimplemento representa gravidade suficiente, o tribunal poderá declarar fim ao procedimento de conciliation e revogar as condições de pagamentos outrora concedidas. Os credores, desse modo, retomam suas posições jurídicas anteriores, respeitados eventuais pagamentos recebidos. Nessa hipótese, o devedor poderá requerer a abertura de um procedimento concursal, desde que reúna os requisitos de admissibilidade para tanto.

Em contrapartida, a conciliation poderá ser encerrada caso se verifique a impossibilidade de alcançar um acordo. Na hipótese de o devedor estar em estado de cessação de pagamentos e conforme o grau de dificuldade em que se encontre, poderá ser aberto um procedimento de redressement ou de liquidation tanto a pedido do próprio devedor, quanto por determinação de ofício pelo Tribunal.

Os procedimentos concursais destinados à superação das dificuldades das empresas são o sauvegard ${ }^{189}$ e o redressement judiciaire. A liquidation judiciaire, por sua vez, é o procedimento concursal típico liquidatório.

As condições de admissibilidade dos três procedimentos são, em grande parte, comuns e o desenvolvimento dos dois primeiros é assemelhado. ${ }^{190} \mathrm{Com}$ efeito, isso se dá pois o procedimento do direito concursal francês é unificado.

Do ponto de vista do pressuposto subjetivo, admite-se que qualquer pessoa que explore bens ou serviços de forma organizada com finalidade econômica possa se

\footnotetext{
${ }^{188}$ Artigos 1244-1, Code Civil c/c, e L.611-8,II, $3^{\circ}$, C. Com.

${ }^{189}$ Esse inserido no sistema pela reforma de 2005.

190 O capítulo que disciplina a sauvegard constitui uma espécie de regramento comum de todos os procedimentos e é aplicável ao redressement e à liquidation naquilo que não contrariar as disposições próprias de cada um desses dois institutos.
} 
submeter a um procedimento concursal ${ }^{191}$; Assim, são sujeitos possíveis: o empresário, qualquer pessoa que exerça atividade econômica independentemente de registro, os artesãos, profissionais autônomos, profissionais liberais, e agricultores; sejam pessoas físicas ou jurídicas ${ }^{192}$.

As condições objetivas de abertura dependem da situação econômica e financeira do devedor que justifiquem a instauração de um procedimento concursal e cada procedimento tem seus próprios requisitos.

O procedimento de sauvegard pode ser requerido pelo devedor ${ }^{193}$ que se encontre em dificuldades de qualquer natureza, ${ }^{194}$ que não esteja em condições de superar ${ }^{195}$ e que possa conduzir a uma situação de cessação de pagamentos no futuro. ${ }^{196}$

Caso esteja caracterizado o estado de cessação de pagamentos, o devedor ficará sujeito, conforme a gravidade das dificuldades, ao redressement judiciaire ou à liquidation, cujos procedimentos podem ser deflagrados por iniciativa de credor, do próprio devedor, por autoridade judiciária ${ }^{197}$ ou de ofício pelo Tribunal ${ }^{198}$.

$\mathrm{Na}$ verdade, exige-se que no momento de abertura de um procedimento concursal de redressement ou de liquidation esteja o devedor em estado de cessação de pagamentos. Não se admite a abertura de tais procedimentos se essa situação houver existido e tenha, após, por qualquer razão, cessado ${ }^{199}$.

Entretanto, há uma distinção importante a ser lembrada. Para decretar a liquidation judiciaire, o tribunal deverá constatar o estado de cessação de pagamentos do

\footnotetext{
${ }^{191}$ As pessoas jurídicas de direito público estão excluídas (Artigos L.620-2, L.631-2 e L.640-2).

${ }^{192}$ Artigos L.620-2, al. ${ }^{\mathrm{er}}$ (sauvegard), L.631-2, al.1 ${ }^{\mathrm{er}}$ (redressement judiciaire), e L.640-2, al.1 ${ }^{\mathrm{er}}$ (liquidation judiciaire).

${ }^{193}$ E somente ele é titular dessa legitimidade, o que é coerente, posto que tal procedimento pressupõe uma constante cooperação do devedor. (SOUWEINE, Carole. Droit de l'entreprise en difficulté, 2. edition, Grenoble: PUG - Press Universitaires de Grenoble, 2007, p. 76).

${ }^{194} \mathrm{Ou}$ seja, financeiras, econômicas, comerciais, industriais, sociais, de meio, que possam motivar o pedido. (JEANTIN, Michel; LE CANNU, Paul. Entreprises en dificulte. 7. édicion, Paris: Dalloz, 2007, p. 176).

195 Demonstrando que um procedimento de conciliation não seria suficiente para colocar fim às suas dificuldades. (SOUWEINE, Carole. Droit de l'entreprise en difficulté. 2. edition, Grenoble: PUG - Press Universitaires de Grenoble, 2007, p. 68).

${ }^{196}$ Artigo L.620-1, alínea $1^{\mathrm{er}}$.

197 Artigo L.631-5, al. $1^{\text {er }}$, C.Com.

198 Artigo L.631-5, al. $1^{\text {er }}$. C.Com.

199 JEANTIN, Michel; LE CANNU, Paul. Entreprises en dificulte. 7. édicion, Paris: Dalloz, 2007, p. 184.
} 
devedor e aferir que o redressement é manifestamente impossível ${ }^{200}{ }_{-}^{201}$. Portanto, pode-se afirmar que a solução liquidatória no direito concursal francês é, evidentemente, residual $^{202}$.

A finalidade tanto do procedimento de sauvegard quanto de redressement é permitir a preservação da atividade econômica, manutenção dos empregos e apuração do passivo $^{203}$.

Como já dito, o procedimento concursal é unificado, de sorte que, instaurado este, tem início um período de observação (période d'observation) de seis meses, prorrogáveis por requerimento do procureur de la République ${ }^{204}$, mediante decisão motivada por igual período.

Durante o período de observação, tomam-se medidas tendentes ao levantamento do ativo e apuração do passivo do devedor, ao mesmo tempo em que se procura manter a atividade, ${ }^{205}$ já que a finalidade precípua de tais procedimentos é a de encontrar uma solução para as dificuldades da empresa.

Em regra, "l'administration de l'entreprise est assurée par son dirigeant" 206 e o afastamento deste ocorrerá em hipóteses restritas de caracterização de incompetência ou desonestidade ${ }^{207}{ }_{-}^{208}$.

\footnotetext{
${ }^{200}$ Artigo L.640-1, al. $1^{\text {er }}$, C. Com.

${ }^{201}$ Note-se: “...c"est le redressement du debiteur, et non celui de l'entreprise, qui est manifestement impossible...”. Assim, a exigência refere-se à viabilidade de redressement para o devedor e não da empresa (negócio). (JEANTIN, Michel; LE CANNU, Paul. Entreprises en dificulte. 7. édicion, Paris: Dalloz, 2007, p. 183).

${ }^{202}$ Ainda que esse posicionamento não seja pacífico, pois, como registra Deen Gibirila, com a possibilidade de um plano de cessão na liquidation, esse procedimento deixa de representar o fim da empresa. A questão levantada parece mais de natureza semântica do que propriamente um contraponto, já que logo a seguir o autor afirma que, na liquidation, a regra é a de paralisação da empresa. (GIBIRILA, Deen. Droit des entreprises en difficulté. Paris: Defrénois, Lextenso éditions, 2009, pp. 543-544).

${ }^{203}$ Artigos L.620-1, al. 1, L.631-1, C. Com.

${ }^{204}$ Artigos L.621-3, L.631-1 e L.629-9, C.Com.

${ }^{205}$ A lei prevê diversas medidas necessárias para manter as atividades, tais como meios de preservação de contratos essenciais, normas de preservação ou reconstituição dos ativos da empresa e assim por diante. (LE CORRE, Pierre-Michel; LE CORRE-BROLY, Emmanuelle. Droit des entreprises en difficulté. 2. edition, Paris: Sirey Université, 2006, pp. 145-187; GIBIRILA, Deen. Droit des entreprises en difficulté. Paris: Defrénois, Lextenso éditions, 2009, pp. 319-325).

${ }^{206}$ Artigo L.622-1. Em tradução livre: "a administração da empresa é assegurada aos seus dirigentes".

207 JEANTIN, Michel; LE CANNU, Paul. Entreprises en difficulté. 7. édicion, Paris: Dalloz, 2007, p. 213.

${ }^{208}$ A organização de poderes de administração é disciplinada pelos artigos L.622-1 na sauvegard e L.631-12 no redressement judiciaire. No sauvegard há um relativo liberalismo, enquanto a filosofia do redressement é
} 
Em paralelo, e como o devedor não terá total liberdade de atuação por estar sob os efeitos de um procedimento coletivo, o Tribunal nomeia ao menos um administrateur ${ }^{209}{ }_{-}^{210}{ }_{-}^{211}$, cujas funções principais são: (i) examinar a situação do devedor, para o que poderá se valer da colaboração de experts, e elaborar um plano de reerguimento que será, depois, submetido à apreciação do Tribunal e (ii) atuar no redressemente judiciaire ao lado do gestor da empresa, na sua administração e na de seus bens.

No sauvegard, a nomeação do administrateur é facultativa, o que se justifica na medida em que o devedor não se encontra em estado de cessação de pagamentos. Mas poderá ocorrer com a finalidade de supervisionar a atuação da gestão do devedor, ou de assisti-lo em uma ou mais operações de gestão específicas ${ }^{212}$.

Como se vê, o período de observação tem uma finalidade essencialmente conservatória das atividades da empresa ${ }^{213}$, enquanto se busca analisar a situação de modo a encontrar uma solução para superar as dificuldades do devedor.

A extensão dos poderes do administrateur é fixada pela lei. Dentre suas atribuições, a de maior relevo é a da elaboração de um balanço econômico e social (e, se

permitir maior intervencionismo por parte dos órgãos concursais. (JEANTIN, Michel; LE CANNU, Paul. Entreprises en difficulté. 7. édicion, Paris: Dalloz, 2007, pp. 214-225).

${ }^{209}$ Conforme o procedimento ou a dimensão da devedora. Por exemplo, em empresas cujo número de empregados seja inferior a 20 e o faturamento anual inferior a 3.000.000 Euros, a designação de um administrador é facultativa.

${ }^{210}$ Ao lado destes, também atua por nomeação do tribunal um ou mais 'mandataire judiciaire', cuja função é agir no interesse dos credores, e terão poderes subsidiários aos controladores da empresa, conforme previsto em lei.

${ }^{211}$ Outro órgão que atua nos procedimentos de sauvegard e redressement é o mandataire judiciaire, cuja função é atuar no interesse coletivo dos credores (e não individualmente), podendo, por exemplo, ajuizar ação revocatória e ação de responsabilidade.

${ }^{212} \mathrm{O}$ que justifica, inclusive, uma análise dos contratos do devedor que estejam em curso, com seus parceiros, fornencedores, clientes e empregados (SOUWEINE, Carole. Droit de l'entreprise en difficulté. 2. edition, Grenoble: PUG - Press Universitaires de Grenoble, 2007, pp. 170, 178). "Le droit des prócedures collectives retient le principe de la poursuite de plein droit des contrats das les conditions initialement prévues. Ainsi, le entrepreneur ne sera pas victime d'une interruption de ses relations contractuelles que pourrait être nuisible a sa poursuit d'activité." (ob. cit., p. 179). Em tradução livre: 'O direito dos procedimentos coletivos mantém o princípio da manutenção de pleno direito dos contratos e das condições inicialmente ajustadas. Assim, o empresário não será vítima de interrupção de vínculos contratuais que poderiam ser essenciais à preservação de sua atividade.'

${ }^{213}$ SOUWEINE, Carole. Droit de l'entreprise en difficulté. 2. edition, Grenoble: PUG - Press Universitaires de Grenoble, 2007, p. 176. 
cabível, de meio ambiente ${ }^{214}$ ), além de um projeto de plano no redressement judiciaire ${ }^{215}$ 216 .

Assim, o balanço econômico e social é um documento que especifica as origens, a extensão financeira e a natureza das dificuldades do devedor ${ }^{217}$. A lógica que envolve a elaboração desse documento é a de proporcionar uma visão das medidas necessárias e compatíveis com a superação das dificuldades, a serem fixadas pelo plano.

O plano (tanto de sauvegard quanto de redressemente judiciaire) deve conter todos os meios de finalizar e concretizar as medidas necessárias para sanar a situação de dificuldade do devedor, de modo a resultar na manutenção da empresa e apuração do passivo ${ }^{218}{ }_{-}^{219}$. A diferença entre os dois procedimentos citados está no fato de que no primeiro, como o devedor não está em estado de cessação de pagamentos, sofrerá menor interferência na gestão da empresa e conseguirá ter maior poder decisório quanto ao destino desta ${ }^{220}$.

O princípio de ambos os procedimentos, de qualquer modo, é que o próprio devedor implemente as medidas reorganizatórias de maneira que possa, ele próprio, sanar as dificuldades e dar continuidade aos negócios, mais tarde, em condições saudáveis ${ }^{221}$.

Assim, o plano poderá prever diversas medidas ${ }^{222}$, tais como: aumento de capital, alienação de ativos, modificações na gestão da empresa e alteração do perfil do

\footnotetext{
${ }^{214}$ Para as empresas cuja atividade possa afetar o meio ambiente, sujeitas às obrigações previstas no Code de l'environnemental,

${ }^{215}$ No redressement judiciaire, em razão do fato de o devedor encontrar-se sob interdição no que respeita à administração de suas contas bancárias e emissão de cheques, o administrador poderá exercer tais deveres com assinatura isolada (Artigos L.622-1, V, e L.631-12, al.5, C. Com.).

${ }^{216}$ Nas hipóteses em que não seja nomeado um administrador, o plano é elaborado pelo próprio devedor, que poderá valer-se da ajuda de experts.

${ }^{217}$ Artigo L.623-1, al.2, C. Com.

${ }^{218}$ O tribunal fixará o prazo de duração do plano, que não poderá ser superior a dez anos, ou, no caso de agricultores, quinze anos.

219 JACQUEMONT, André. Droit des entreprises en difficiulté. 6. edição, Paris: Litec Group Lexisnexis, 2009 , p. 379.

${ }^{220}$ VALLENS, Jean-Luc (Direction de), obra coletiva. Crise du crédit et entreprises, les réponses du droit. France: Éditions Lamy, 2010, pp. 139-140.

${ }^{221}$ SOUWEINE, Carole. Droit de l'entreprise en difficulté. 2, edition, Grenoble: PUG - Press Universitaires de Grenoble, 2007, p. 194.

${ }^{222}$ FRAIMOUT, Jean-Jacques. Droit des entreprises en difficulté. Paris: Ellipses, 2007, pp. 149-155.
} 
passivo (com remissão e dilação de prazo de pagamento), enfim, medidas que sejam consideradas necessárias para a recuperação do devedor.

Com a reforma de 2005, houve aumento do poder dos credores ${ }^{223}$. Por um lado, aqueles habilitados no procedimento são consultados, durante o período de observação, para saber se consentiriam com algum tipo de remissão, dilação de prazo ou outra espécie de sacrifício. Além disso, o administrateur elabora propostas em relação ao débito e as envia aos credores, que devem se manifestar a respeito destas tecendo observações. Conquanto a adoção do plano não tenha como pré-requisito a aprovação de um determinado percentual de credores, não há dúvida de que eventual manifestação favorável destes acaba sendo levada em consideração pelo Tribunal.

O aumento da participação dos credores advindo com a reforma de 2005 revela-se também na retomada dos comitês, sendo um constituído pelos credores que aportam créditos ao devedor (geralmente instituições financeiras) e outro pelos principais fornecedores de bens ou serviços. Os comitês, se instalados, terão atuação relevante na apuração do passivo e poderão opinar na elaboração do plano, votando, inclusive, a respeito de eventuais proposições do devedor ao plano, as quais, para que possam ser adotadas, dependem de aprovação de dois terços dos credores.

O plano poderá prever a reorganização da exploração do negócio, mediante manutenção integral deste ou apenas em parte ${ }^{224}$. No redressement judiciaire, uma das soluções possíveis é a imposição da realização de um plano de cessão total ou parcial da empresa, hipótese em que o devedor ficará impossibilitado de assegurar, ele próprio, o êxito do redressement ${ }^{225}{ }_{-}^{226}{ }_{-} 22{ }_{-} 228$.

\footnotetext{
${ }^{223}$ Inspirado no sistema norte-americano do Chapter 11. (JEANTIN, Michel; LE CANNU, Paul. Entreprises en difficulté. 7. édicion, Paris: Dalloz, 2007, p. 133).

${ }^{224}$ Embora a manutenção dos empregos seja uma das finalidades principais do direito concursal francês, não se chega ao exagero de, a qualquer custo, manter a integralidade dos postos de trabalho, posto que isso poderia inviabilizar o sucesso do procedimento. Assim, com fundamento em motivos econômicos, admite-se a realização de demissões (Artigo L.626-2, al.3, C.Com.).

${ }^{225}$ Artigo L.631-22, al. $1^{\text {er }}$, C.Com.

${ }^{226}$ Ou seja, a cessão total ou parcial da empresa é realizada sem que seja necessário converter o procedimento em liquidation. (JEANTIN, Michel; LE CANNU, Paul. Entreprises en difficulté. 6. édicion, Paris: Dalloz, 2007, pp. 641-643).

${ }^{227}$ Tal medida é, todavia, impensável no procedimento de sauvegard. (LE CORRE, Pierre-Michel; LE CORRE-BROLY, Emmanuelle, Droit des entreprises en difficulté. 2. edition, Paris: Sirey Université, 2006, p. 259).
} 
Antes do término do período de observação, o Tribunal deverá decidir quanto à sorte da empresa ${ }^{229}$.

No procedimento de sauvegard, mesmo que um projeto de plano apresentado tenha o apoio do administrador, o Tribunal poderá não adotá-lo, sob o fundamento de que os objetivos da lei não estão sendo cumpridos. Porém, se constituídos os dois comitês de credores (um formado pelos principais fornecedores do devedor e outro por representantes das instituições de crédito $^{230}$ ), o plano aceito por ambos deverá, em princípio, ser adotado pelo Tribunal.

Disso poderá resultar um prazo de emenda ou a conversão do sauvegard em redressment judiciare, caso estejam caracterizados os requisitos de admissibilidade deste último procedimento ( $v . g$., a cessação de pagamentos). O Tribunal pode, ainda, decidir que nenhum plano de sauvegard será adotado; e se houver previsão de cessão do negócio, o Tribunal poderá rejeitar o plano e determinar a abertura de um procedimento de liquidation para implementar um plano de cessão (plan de cession). ${ }^{231}$

No procedimento de redressement judiciaire aplicam-se ao plano, no que couber, as disposições legais previstas para o plano de sauvegard (artigo L.631-19, I), o que significa dizer que há poucas diferenças entre ambos. ${ }^{232}$

\footnotetext{
${ }^{228}$ A hipótese é diferente da cessão de estabelecimento celebrada fora do ambiente de um procedimento concursal. Mesmo porque, na cessão de estabelecimento: (i) a lei não prevê a transferência de contratos; (ii) o cessionário assume responsabilidade pelo passivo do cedente. (HAUSMANN, Christian; TORRE, Philippe. Les garanties de passif, Négotiation et rédacion des conventions de garantie em matière de transmission d'entreprises. Paris: Édition Formation Entreprise, 2007, pp. 243-252).

${ }^{229}$ No procedimento de sauvegard, caso o devedor não tenha apresentado um plano em tempo hábil, o tribunal poderá colocar fim ao procedimento. Entretanto, o tribunal fica autorizado a proferir uma decisão cujo conteúdo seja aproximado ao de um plano que organize o porvir do negócio. (SOUWEINE, Carole. Droit de l'entreprise en difficulté. 2. edition, Grenoble: PUG - Press Universitaires de Grenoble, 2007, p. 204).

${ }^{230}$ Os comitês encarregam-se de promover um processo de votação, por escrito, entre os credores.

231 JEANTIN, Michel; LE CANNU, Paul. Entreprises en difficulté. 7. édicion, Paris: Dalloz, 2007, p. 600.

${ }^{232} \mathrm{O}$ projeto de plano de redressement sujeita o devedor a certos riscos, como, por exemplo, se houver necessidade de um aumento de capital, a assembleia de convocação necessária para tanto deverá ser feita antes mesmo que o tribunal aprove um plano de reerguimento. Na prática, isso significa que poderá ser necessário implementar medidas antes mesmo da concessão do redressement, para que se evite a conversão em liquidation. Por outro lado, no sauvergard, os coobrigados do devedor podem, em determinada situação, beneficiar-se das disposições do plano, o que não é permitido no redressement. (JEANTIN, Michel; LE CANNU, Paul. Entreprises en difficulté. 7. édicion, Paris: Dalloz, 2007, p. 632).
} 
O Tribunal homologará um plano "l'orsqu'il existe une possibilite sérieuse pour l'entreprise d'être sauvegardée"233. Caso contrário, se o plano for rejeitado, decretase o encerramendo do sauvegard, mas, na hipótese de o devedor estar em estado de cessação de pagamentos, poderá ocorrer conversão em redressement ou liquidation ${ }^{234}$, conforme a situação concreta.

Quando em redressement judiciaire, a rejeição ao plano importa imediata conversão do procedimento em liquidation, de modo que o devedor perde a possibilidade de conservar o negócio para si. Nesse caso, somente haverá preservação do negócio caso o Tribunal venha a decidir por uma cessão, total ou parcial, em um plano de cessão.

A liquidation é o procedimento de realização do ativo, para pagamento do passivo, aplicável ao devedor em cessação de pagamentos cujo redressement seja manifestamente impossível. Pode ser decretada após o período de observação em um procedimento reorganizatório, ou diretamente, 'ab initio ${ }^{\text {,235 }}$. Mas, "la liquidation judiciaire ne constitue plus nécessairement la mort de l'entreprise puisqu'elle peut aboutir à son sauvetage au moyen d'une cession" ${ }^{236}$.

Dessa maneira, há possibilidade de cessão da empresa, total ou parcial, na liquidation, desde que, cumulativamente, sejam atendidos os seguintes requisitos: (i) manutenção da atividade (ainda que parcialmente); (ii) conservação de postos de trabalho; e (iii) apuração do passivo.

Em princípio, na liquidation, a atividade da empresa é encerrada, de modo a impedir o agravamento do passivo. Contudo, em duas hipóteses essa solução pode ser excepcionada pelo Tribunal. A primeira delas é a possibilidade de cessão total ou parcial

\footnotetext{
233 Artigo L.626-1, C. Com. Em tradução livre: 'quando houver uma possibilidade séria de que a empresa possar ser preservada'.

${ }^{234} \mathrm{Em}$ reforma de 2006 passou a ser previsto um procedimento de liquidation simplifieé (liquidação simplicada) destinado ao devedor que não possua bens imóveis e com rendimento anual inferior a 300.000 Euros.

${ }^{235}$ Desde a reforma de 1994, a liquidation pode ser decretada desde logo, nas hipóteses previstas em lei, como, por exemplo, quando o devedor não puder propor uma solução aceitável para manutenção de sua exploração do negócio e pagamento dos credores. Nesse caso, o tribunal poderá decretar diretamente a liquidation, nomeando um mandataire judiciaire que se desempenhará o papel de liquidante.

${ }^{236}$ SOUWEINE, Carole. Droit de l'entreprise en difficulté. 2. edition, Grenoble: PUG - Press Universitaires de Grenoble, 2007, p. 85. Em tradução livre: 'a liquidation judiciaire não constitui necessariamente a morte da empresa, porque ela pode concluir seu reerguimento por meio de uma cessão.'
} 
da empresa, uma vez que, com essa medida, se espera um restabelecimento perene do negócio. A segunda é o prosseguimento do negócio por um período de três meses, prorrogável por mais um, em caso de atividade agrícola, dependendo da cultura em curso, para evitar perdas.

Após a reforma de 2005, a continuação das atividades na liquidation passou a ter um novo fundamento: preservar o negócio para venda em marcha ${ }^{237}$ e, com isso, evitar perdas para os credores. Segundo o prognóstico que se faça de viabilidade de exploração do negócio, a realização do ativo poderá ocorrer mediante cessão da empresa (total ou parcial) ou, alternativamente, pela venda dos bens do devedor em separado.

A preservação do negócio poderá se dar mediante um plan de cession (plano de cessão) $)^{238}$. Veja-se que "la loi de sauvegard fasse appaîretre le plan de cession comme une technique de réalization des actifs em liquidation judiciaire, la finalité du plan de cession n'a pas changê" ou seja, "le plan de cession a pour finalité première le maintien de l'explotation et par là même, de l'emploi". 239

Nesse caso, portanto, “L’integración du plan de cession dans la liquidation judiciaire peut sembler contradictoire avec la condiciotion d'impossibilité de redressement. En effect, la cession est, par construction, une façon de redresser l'entreprise en la vendant à une personne solvable. Au vrai, il suffit de relever que le redressement $d u$ 'débiteur' n'est pas possible, c'ést-a-dire qu'il ne peut se redresser luimême. Cela n'interdit pas qu'une autre personne redresse l'entreprise.”240

\footnotetext{
${ }^{237}$ SAINT-ALARY-HOUIN, Corinne. Droit des entreprises en difficulté. 6. édition, Paris: Montchrestien, 2009, p. 698.

${ }^{238}$ Não há consenso na doutrina a respeito da natureza jurídica do plan de cession. Para uns, tem natureza contratual, alguns defendem sua natureza judicial e, ainda, para outros trata-se de um misto de ambos. (LE CORRE, Pierre-Michel; LE CORRE-BROLY, Emmanuelle. Droit des entreprises en difficulté. 2. edition, Paris: Sirey Université, 2006, p. 260).

${ }^{239}$ LE CORRE, Pierre-Michel; LE CORRE-BROLY, Emmanuelle, Droit des entreprises en difficulté. 2. édition, Paris: Sirey Université, 2006, p. 260. Em tradução livre: 'a lei de sauvergard faz parecer que o plano de cessão é uma técnica de realização dos ativos na liquidation judiciaire, mas a finalidade deste [o plano de cessão] não mudou' (...) 'o plano de cessão tem por finalidade primeira a manutenção da exploração do negócio e, por meio desta, dos postos de trabalho'.

${ }^{240}$ JEANTIN, Michel; LE CANNU, Paul. Entreprises en difficulté. 7. édicion, Paris: Dalloz, 2007, p. 184. Em tradução livre: 'A integração do plano de cessão na liquidation judiciaire pode parecer contraditória com a condição de impossibilidade de redressement. Com efeito, a cessão é, por construção, uma invenção para reerguimento da empresa por venda a uma pessoa solvente. Em verdade, basta destacar que o redressement do devedor não é possível, ou seja, ele não pode por si superar a crise. Isso não impossibilita outra pessoa reerguer a empresa.'
} 
Desse modo, ainda que a lei discipline a cessão da empresa como uma modalidade de realização do ativo na liquidation, realmente trata-se de uma técnica de recuperação da empresa, conforme posicionamento majoritário da doutrina ${ }^{241}{ }_{-}^{242}{ }_{-}{ }^{243}$, eis que se cuida de assegurar que uma ou mais atividade susceptível de exploração autônoma sejam preservada, juntamente os postos de trabalho correspondentes, ao mesmo tempo em que se atende ao passivo do devedor ${ }^{244}{ }_{-}^{245}$.

A lei autoriza que a cessão da empresa seja total ou parcial (sendo que, nesse último caso, poderá haver mais de uma cessão parcial). ${ }^{246}$ É que o conceito de empresa, nesse particular, está relacionado, no direito concursal francês, ao de 'atividade susceptível de exploração autônoma' (conforme ideia desenvolvida inicialmente pelo direito tributário).

Com isso, pretende-se que na cessão parcial seja possível garantir a continuidade da parte da operação do devedor que seja rentável ${ }^{247}$. Um dos escopos do plano de cessão, por isso mesmo, será definir qual o conjunto de bens, ativos e contratos que sejam necessários e suficientes para suportar e manter uma 'atividade susceptível de exploração autônoma', fazendo-se, destarte, a previsão de transferência $\operatorname{parcial}^{248}{ }_{-}^{249}$ no plan de cession.

\footnotetext{
${ }^{241}$ SOUWEINE, Carole. Droit de l'entreprise en difficulté, $2^{\mathrm{a}}$ edition, Grenoble: PUG - Press Universitaires de Grenoble, 2007, p. 224; JEANTIN, Michel; LE CANNU, Paul. Entreprises en difficulté. 7. édicion, Paris: Dalloz, 2007, p. 635; SAINT-ALARY-HOUIN, Corinne. Droit des entreprises en difficulté. 6. édition, Paris: Montchrestien, 2009, p. 701; LE CORRE, Pierre-Michel; LE CORRE-BROLY, Emmanuelle, Droit des entreprises en difficulté. 2. édition, Paris: Sirey Université, 2006, p. 258.

${ }^{242}$ Mas André Jacquemont considera a cessão da empresa uma modalidade de liquidação do ativo do devedor. Assim, para o autor, a liquidation é uma renovação apenas parcial da vocação histórica da faillite (falência) como execução coletiva. (JACQUEMONT, André. Droit des entreprises en difficiulté. 6. édition, Paris: Litec Group Lexisnexis, 2009, p. 400).

${ }^{243} \mathrm{Na}$ mesma linha, outros autores consideram a cessão da empresa realizada na liquidation como um método de realização global dos ativos. (VALLANSAN, Jocelyne. Difficultés des entreprises, commentaire article par article du livre VI du code de commerce (avec la collaboration de Pierre Gagnoli, Laurence FonLanger et Corinne Regnaut-Moutier). 5. édition, Paris: LexisNexis, 2009, p. 348).

${ }^{244}$ Para alguns, um plano de cessão total importa a 'morte' do devedor e isso é causa de sua liquidação. Portanto, a cessão total é que daria ensejo à liquidation do devedor. (LE CORRE, Pierre-Michel e LE CORRE-BROLY, Emmanuelle, Droit des entreprises en difficulté. 2. édition, Paris: Sirey Université, 2006, p. 259).

${ }_{245}$ Artigo L.642-1, al. ${ }^{\mathrm{er}}$, C. Com.

${ }^{246}$ LE CORRE, Pierre-Michel; LE CORRE-BROLY, Emmanuelle. Droit des entreprises en difficulté. 2. édition, Paris: Sirey Université, 2006, p. 269.

${ }^{247}$ JEANTIN, Michel; LE CANNU, Paul. Entreprises en difficulté. 7. édicion, Paris: Dalloz, 2007, p. 656.

${ }^{248}$ JACQUEMONT, André. Droit des entreprises en difficiulté. 6. édicion, Paris: Litec Group Lexisnexis, 2009 , p. 439.
} 
Trata-se de uma solução de preservação do negócio quando o devedor esteja "dans l'impossibilité d'én assurer lui-même le redressement." 250

É importante destacar que a declaração da liquidation, sob a interpretação que a doutrina francesa faz do artigo L.640-2, revela que não há inviabilidade do negócio, mas tão somente do devedor que o explora, em prosseguir na atividade. ${ }^{251}$ Essa situação dá ensejo ao plano de cessão da empresa, sob a égide de um procedimento liquidatório, em que um terceiro se encarregará do reerguimento da parte ou do negócio que seja rentável e tenha perspectiva de continuidade ${ }^{252}$.

Para esse fim, o liquidante elabora um plano de cessão, pelo qual se buscará preservar, do modo mais duradouro possível, a atividade e os empregos (por essa razão, o plano poderá conter obrigações de fazer e não fazer, por exemplo). Inclusive, o plano de cessão poderá prever locação global do estabelecimento (location-gérance) pelo prazo de até dois anos, findo o qual o locatário terá a obrigação de aquisição da empresa por meio das condições então previstas no plano de cessão.

A cessão da empresa poderá envolver os ativos, materiais e intangíveis, além de transferência forçada de certos $\operatorname{contratos}^{253}{ }_{-}^{254}$, ou seja, de todos os elementos que sejam considerados necessários e suficientes à manutenção da atividade (ou parte dela).

\footnotetext{
${ }^{249}$ O conteúdo da oferta de cessão deve ser: (i) a designação precisa dos bens e contratos que integram a cessão, (ii) previsão de atividade e financiamentos; (iii) preço da cessão; (iv) data de realização da cessão, especialmente se esta é precedida de um contrato de arrendamento, (v) indicação dos postos de trabalho que serão preservados, (vi) as garantias oferecidas pelo cumprimento dos termos da cessão, pelo cessionário; (vii) eventual previsão de cessão de ativos nos dois anos que se seguirem à cessão. (LE CORRE, Pierre-Michel; LE CORRE-BROLY, Emmanuelle, Droit des entreprises en difficulté. 2. édition, Paris: Sirey Université, 2006, pp. 263-264).

${ }^{250}$ Artigo L.631-22. Al. $1^{\mathrm{er}}$, C. Com. Em tradução livre: 'na impossibilidade de ele próprio [o devedor], assegurar o redressement'.

251 “... le plan de cession était l'illustration paroxystique de la distinction du sort de l'homme et l'entreprise." (LE CORRE, Pierre-Michel; LE CORRE-BROLY, Emmanuelle, Droit des entreprises en difficulté. 2. édition, Paris: Sirey Université, 2006, p. 258). Em tradução livre: ‘...o plano de cessão foi a ilustração paroxística da distinção entre o destino do titular (empresário) e o da empresa'.

${ }^{252}$ JEANTIN, Michel; LE CANNU, Paul. Entreprises en difficulté. 7. édicion, Paris: Dalloz, 2007, p. 640.

${ }^{253}$ Artigo L.642-7, al. $1^{\text {er }}$, C. Com.

${ }^{254}$ Como regra de exceção ao princípio da livre contratação, admite-se tal transferência compulsória apenas para contratos que sejam essenciais para a continuidade da atividade objeto do plano de cessão. Assim, o contratante in bonis tem o direito de se opor, para demonstrar que o contrato do qual é parte não preenche tal requisito. (JEANTIN, Michel; LE CANNU, Paul. Entreprises en difficulté. 7. édicion, Paris: Dalloz, 2007, p. $658)$.
} 
Entretanto, é preciso ter em conta que a cessão da empresa realizada sob o âmbito de um procedimento de redressement coloca foco na manutenção da atividade com a continuação pelo próprio devedor; ao passo que, na liquidation, esta ocorre principalmente para atender aos interesses dos credores, mediante obtenção do melhor preço de venda ${ }^{255}{ }_{-}^{256}$.

O cessionário, em decorrência do negócio, assume a obrigação de pagamento do preço da cessão ${ }^{257}$ e também de adimplir as providências que sejam necessárias à recuperação da empresa, com a manutenção da atividade e dos postos de trabalho. É importante dizer que a cessão opera-se mediante decisão judicial, cujos efeitos são oponíveis erga omnes a todos os interessados no processo concursal ${ }^{258}$.

Apesar de não existir, em princípio, sucessão das obrigações do devedor ${ }^{259}$ ${ }^{260}$, o cessionário assume o compromisso de dar continuidade ao negócio, exatamente porque a oferta de aquisição é global.

O Tribunal poderá determinar que o cessionário ofereça garantias de cumprimento das obrigações assumidas no plano de cessão. Em todo o caso, na hipótese de inadimplemento, poderá ser decidida a resolução de pleno direito do plano de cessão, mas a lei não explicita as consequências decorrentes ${ }^{261}{ }_{-}^{262}$. Em teoria, e sem prejuízo das perdas

\footnotetext{
${ }^{255}$ SOUWEINE, Carole. Droit de l'entreprise en difficulté. 2. édition, Grenoble: PUG - Press Universitaires de Grenoble, 2007, p. 228; JEANTIN, Michel; LE CANNU, Paul. Entreprises en difficulté. 7. édicion, Paris: Dalloz, 2007, p. 640.

${ }^{256}$ Dominique Vidal anota ainda uma dificuldade adicional: a de trazer um justo equilíbrio entre a burocacria (e a segurança decorrente) que envolve o processo de cessão e, ao mesmo tempo, atender com equilíbrio as oportunidade de manutenção do negócio e atender aos interesses dos credores. (VIDAL, Dominique. Droit de l'entreprise en difficulté. 4. édition, Paris: Gualino Lextenso Éditions, 2010, p. 299).

${ }^{257}$ A cessão se dá por preço global, fixado pelo tribunal, mediante avaliação. O cessionário poderá apresentar uma avaliação e o tribunal poderá ou não se inspirar nela. Os credores, por sua vez, não terão qualquer meio de contestar a avaliação do preço fixada pelo tribunal. (SOUWEINE, Carole. Droit de l'entreprise en difficulté. 2. édition, Grenoble: PUG - Press Universitaires de Grenoble, 2007, p. 246).

${ }^{258}$ LE CORRE, Pierre-Michel; LE CORRE-BROLY, Emmanuelle, Droit des entreprises en difficulté. 2. édition, Paris: Sirey Université, 2006, p. 267.

${ }^{259}$ A cessão não é realizada a título universal, mas se limita a transferência dos bens e ativos do devedor e o passivo permanece ligado ao procedimento concursal, circunstância que representa uma das maiores vantagens desta técnica de transmissão da empresa (JACQUEMONT, André. Droit des entreprises en difficiulté. 6. édition, Paris: Litec Group Lexisnexis, 2009, p. 445).

${ }^{260}$ O Artigo L.642-12, alínea 4 do C. Com. prevê a transmissão da garantia hipotecária sobre imóveis ao cessionário.

${ }^{261}$ A lei de 1985 era totalmemte omissa quanto às consequências do descumprimento do plano de cessão. A jurisprudência encarregou-se de orientar no sentido de perda do preço pago pelo cessionário. Em 1994, a lei passou a prever a possibilidade de resolução do plano de cessão que o tribunal terá a faculdade de decretar. De qualquer modo, a resolução do plano de cessão não tem o efeito imediato de instaurar, contra o
} 
e danos a serem apuradas, retorna-se ao status quo ante ao da cessão, com a perda do preço pago pelo cessionário, continuando o devedor em procedimento de liquidação, para venda dos ativos ${ }^{263}{ }^{264}$.

Percebe-se, claramente, que o direito concursal francês prioriza a salvaguarda da empresa enquanto "negócio", o qual reconhece como fonte de produção de riquezas e postos de trabalho. Há clara preferência pelos procedimentos reorganizatórios, já que a liquidação é solução residual, conforme a lei textualmente conceitua.

No direito concursal francês, a nota distintiva entre um procedimento reorganizatório e um liquidatório é, indubitavelmente, o afastamento do devedor, uma vez que na liquidation, fica este impossibilitado de dar continuidade a qualquer modalidade de manutenção do negócio. Esta se dá por intermédio do plan de cession, que, de fato, representa autêntica modalidade reorganizatória (e não apenas um método de alienação de ativos), já que sua implementação depende do atendimento do requisito de preservação da atividade e de postos de trabalho.

\subsection{O direito italiano}

A reforma italiana, iniciada com o DL n. 35, de 14/03/2005 ${ }^{265}{ }^{266}$ e concluída com a edição do DL n. 05 de 09/01/2006, ao contrário da legislação brasileira,

cessionário, um procedimento concursal poderá ser deflagrado se os requisitos estiverem presentes, mas, nesse caso, os credores do devedor original não são credores do cessionário. (LE CORRE, Pierre-Michel; LE CORRE-BROLY, Emmanuelle, Droit des entreprises en difficulté. 2. edition, Paris: Sirey Université, 2006, p. 292).

${ }^{262}$ Há consequências de natureza penal fixadas por lei ao cessionário que dá causa ao inadimplemento da cessão.

${ }^{263}$ JACQUEMONT, André. Droit des entreprises en difficiulté. 6. édition, Paris: Litec Group Lexisnexis, 2009, pp. 455-456.

${ }^{264}$ LE CORRE, Pierre-Michel; LE CORRE-BROLY, Emmanuelle, Droit des entreprises en difficulté. 2. édition, Paris: Sirey Université, 2006, p. 290.

${ }^{265}$ Convertido na Legge n. 80, de 15/05/2005.

${ }^{266}$ Pelo referido decreto-lei, o governo italiano pretendia relançar a competitividade econômica da Itália, do que resultaram inovações em matéria falimentar. Assim, o Parlamento outorgou poderes ao governo para realizar a reforma dos procedimentos judiciais de insolvência (ou seja, os procedimentos administrativos de amministrazione straordinaria e suas variantes, não foram atingidos na reforma). Como anota Lorenzo Stanghellini, "le direttive che il Parlamento há impartito erano principalmente i seguinti: limitare il numero dei soggetti che possono falire, rendere piú stringente il controllo dei creditori sullo svolgimento della procedura di fallimento, migliorare gli strumenti per conservare l'eventule valore dell'azienda, rendere più flessibile il concordato falimentare, consentire ao fallito-persona fisica (e dunque non alle società) di liberarsi daí debiti non soddisfatti, qualora abbia tenuto un comportamento correto e collaborativo con gli organi della procedura." (STANGHELLINI, Lorenzo. Le crisi di impresa fra diritto ed economia (le 
que reformulou inteiramente o sistema concursal, optou por manter vigente o Reggio Decreto $n .267 / 45^{267}$, mediante revogação de alguns institutos (foram suprimidos os artigos 187 a 193, com extinção da 'amministrazione controllata'), além de modificação e inserção de outros.

A conotação da reforma foi, sem dúvida, a de acentuar o caráter privatístico nos institutos de disciplina da crise das empresas, outorgando-se ao devedor e seus credores instrumentos de negociação na busca de uma solução. Em consequência, houve mitigação dos poderes do juiz, cuja atuação permanece como condutor do processo, no papel de decidir as possíveis controvérsias entre os interessados e controle da legalidade.

Outra característica da reforma, como destaca Luigi Farenga, constitui na ideia “ $C i$ si è accordi che il fulcro del mercato e dell'economia è l'impresa e non l'imprenditore; che l'impresa è un "bene" che deve essere difeso sin che è possibile, separandone le sorti da quelle dell'imprenditore, il quale peraltro non deve essere necessiariamente "punito" per il solo fato di averte operato delle scelte sbagliate o semplicemente perchè vittima di situazioni economiche e di mercato avverse. „268

Eis a versão italiana do princípio da separação entre a empresa e o empresário orindo do direito francês.

procedure di insolvenza). Bologna: Il Mulino, 2007, pp. 351-352). Em tradução livre: 'as diretrizes que o Parlamento outorgou eram principalmente as seguintes: limitar o número de sujeitos que podem falir, tornar mais estreito o controle pelos credores sobre o desenvolvimento do procedimento falimentar, melhorar os instrumentos para conservação de eventual valor do estabelecimento, dar maior flexibilidde para a concordata suspensiva, consentir que o empresário individual (e não as sociedades) de se liberar do passivo não satisfeito, desde que tenha tido um comportamento correto e colaborativo com os órgãos do procedimento.'

267 “Le reformi del 2004, del 2005 e del 2006 hanno impresso al sistema italiano um'accelerazione straordinaria, portandolo avanti di decenni. Esse, anche per la loro genesi (emergenza Parmalat) e la loro forma (decreto legge e quindi legge delega parziale), non hanno tuttavia portato un'organica sistemazione della materia, che soffre ancora de incoerenze, di difficoltà interpretative, di eccessi e lacune anche gravi." (STANGHELLINI, Lorenzo. Le crisi di impresa fra diritto ed economia (le procedure di insolvenza). Bologna: Il Mulino, 2007, p. 365). Em tradução livre: 'As reformas de 2004, 2005 e 2006 imprimiram ao sistema italiano uma aceleração extraordinário, levando-o décadas adiante. Esta, também por sua gênese (emergência Parmalat) e por sua forma (decreto-lei e delegação parcial), não trouxe, entretanto, uma sistematização orgânica da matéria, que sofre de incoerências, dificuldades interpretativas, excessos e lacunas graves.'

${ }^{268}$ FARENGA, Luigi. "La reforma del diritto fallimentare in Italia: una visione de mercato". Revista de Direito Mercantil, Industrial Econômico e Financeiro. Vol. 145, Ano XLVI (nova série), jan/mar 2007, p. 12. Em tradução libre: "Há consenso que o fulcro do mercado e da economia é a empresa e não o empresario; que a empresa é um "bem” que deve ser defendido, sempre que possível, separando sua sorte do empresário, o qual, por outro lado, não deve ser necessariamente 'punido' somente pelo fato de haver operado por escolhas equivocadas ou por ser vítima de situações econômicas e de mercado adversas". 
De fato, as modificações introduzidas no regime de 'concordato preventivo' e a introdução do acordo de reestruturação de débitos (accordi di ristrittirazione dei debiti e dei piani di risanamento $)^{269}$, revelam, outrossim, a faceta de estímulo das soluções privadas no âmbito do vigente direito concursal italiano havida na reforma.

Atualmente, estão disciplinados os seguintes institutos judiciais para o sistema de insolvência do empresário na Itália: (i) a falência (Fallimento, disciplinado nos arts. 5 a 117 e 146 a 152); (ii) a concordata suspensiva (Concordato Fallimentare, previsto nos arts. 124 a 141); (iii) a concordata preventiva (Concordato Preventivo, conforme arts. 160 a 166); e (iv) os acordos de reestruturação de dívidas sujeitos à homologação judicial (Accordi di ristrutturazione dei debiti, de acordo com o artigo 182 bis).

O sistema italiano manteve, ainda, o procedimento de caráter administrativo denominado 'amministrazione straordinaria delle grandi imprese in crisi' (DL $\mathrm{n}$. 270/1999) ${ }^{270}$, aplicável às grandes empresas (com, pelo menos, 300 empregados vinculados ao devedor pelos últimos doze meses) e cuja quebra resultaria em expressivo impacto social negativo; além do procedimento, também administrativo, de 'liquidazione coatta $^{271}$.

A propósito, observa-se a semelhança deste procedimento com o já então revogado do direito francês, instituído pela Ordennance n.67-820 de septiembre de 1967, denominado suspension provisoire des poursuites, destinado à recuperação de devedor, cuja liquidação pudesse causar "grave transtorno econômico ou social".

\footnotetext{
${ }^{269}$ Opções estas sob as bases dos princípios e regras da autonomia da vontade das partes. (STANGHELLINI, Lorenzo. Le crisi di impresa fra diritto ed economia (le procedure di insolvenza). Bologna: Il Mulino, 2007, p. 361).

${ }_{270}$ Do qual existem algumas variantes, como é o caso da amministrazione straordinaria. Esta tem finalidade liquidatória do patrimônio, mas com a particularidade de ter como pressuposto a manutenção da atividade da empresa na pendência do procedimento, com a finalidade de venda do estabelecimento. Em consequência, a tutela dos interesses dos credores é enfraquecida, pois a atividade poderá mesmo gerar perdas para estes. A venda, igualmente, ocorre ao ofertante que se obrigar a manter os postos de trabalho, ainda que por menor preço de outras ofertas. Todavia, o procedimento é criticado, pois mesmo pretendendo uma solução de reestruturação, peca por demandar adesão de todos os credores para seu sucesso, o que é uma verdadeira contradição. (STANGHELLINI, Lorenzo. Le crisi di impresa fra diritto ed economia (le procedure di insolvenza). Bologna: Il Mulino, 2007, p. 360).

${ }^{271}$ Trata-se de uma alternativa a falência por se tratar de um procedimento liquidatório, com a distinção de que os credores têm menor poder de controle e o juiz não possui nenhum, já que se trata de um procedimento administrativo. A autoridade administrativa fica responsável pela liquidação dos ativos e, se houver manutenção de atividade, pela sua fiscalização. Pode converter-se em concordata, mas não mediante aprovação dos credores, e sim do tribunal. (STANGHELLINI, Lorenzo. Le crisi di impresa fra diritto ed economia (le procedure di insolvenza). Bologna: Il Mulino, 2007, pp. 358-359).
} 
As soluções objetivadas no referido procedimento de 'amministrazione straordinaria delle grandi imprese in crisi' são de caráter eminentemente preservacionista, pois o objetivo nele pretendido será alcançar uma reestruturação ou uma solução de caráter liquidatório-solutório, porém mediante cessão do complexo empresarial a um terceiro que mantenha o negócio em atividade.

Note-se, a finalidade claramente buscada por este diploma é a de minimizar os efeitos econômicos e sociais da crise das grandes empresas, colocando em destaque a repercussão social que resultaria da quebra e, evidentemente, reposicionando o interesse principal de tutela jurídica da crise do devedor para além da relação com os credores.

No procedimento de 'Amministrazione Straordinaria delle grandi imprese in crisi', DL n. 270/1999 272 , o propósito da preservação da empresa busca a manutenção dos postos de trabalho, pois, como anota Lorenzo Stanghellini, a cessão da empresa ali realizada não tem a intenção de maximazação do interesse dos credores com a venda; tratase de solução diversa daquela prevista nos procedimentos de concordata ou falência, nos quais a alienação do estabelecimento tem por objetivo a melhor realização no interesse dos credores $^{273}$.

$\mathrm{O}$ autor citado assegura "nella procedura di amministrazione straordinaria delle grandi imprese, invece, la finalitá non è il massimo realizo, ma la conservazione dei complessi aziendali in attivittà (art. 55 D.L 270/1999), perseguita tutte le volte che sia concretamente possibile. Tale finalità si traduce, per quanto qui ci interessa, nel fato che in caso di vendita de aziende in esercizio da parte del commissario straordinário l'acquirente riceve uno 'sconto' quale corrispectivo del suo impegno a perseguire la

272 Cuja origem está na "Legge Prodi" (L. n ${ }^{\circ}$ 95, de 03/04/1979), condenada pela Corte de Justiça da Comunidade Europeia, da qual a Itália foi signatária desde 1998, sob o fundamento de que referido procedimento consistia em ajuda ilegítima do Estado, o que levou à sua retificação em 1999. (STANGHELLINI, Lorenzo. Le crisi di impresa fra diritto ed economia (le procedure di insolvenza). Bologna: Il Mulino, 2007, p. 347).

${ }^{273}$ STANGHELLINI, Lorenzo. Le crisi di impresa fra diritto ed economia (le procedure di insolvenza). Bologna: Il Mulino, 2007, pp. 74/75. Assim, após um período de observação da empresa em crise, a ideia central do procedimento é a venda a um preço muito baixo, desde que a atividade seja mantida e preservados pelo menos alguns postos de trabalho. A sistemática é a de "tutela dos empregados às custas dos credores" ('tutela dei dipendenti a spese dei creditori'). (obra citada, p. 347). 
gestione, anche se in perdita, e a mantenere $i$ livelli occupazionali (art. 63, CL 279/1999),274.

Essa ideia denota, sem dúvida, um deslocamento do centro de interesses do direito concursal italiano, antes precipuamente focado na relação entre credores e devedor (como resultado da insolvência) e agora dirigido à empresa (atividade ${ }^{275}$, que, ao sofrer os efeitos da crise do devedor, merece tutela apropriada ${ }^{276}$.

Tanto isso é certo que na reforma deixou-se de exigir, como requisito de admissibilidade ao pedido de concordata, prova do registro de empresário, de regularidade fiscal e contábil ou de inexistência de condenação penal, o que sinaliza o ideal da distinção entre a empresa (atividade) e o empresário (titular da atividade).

É claro que os credores, cujos poderes foram sensivelmente aumentados, com o propósito de estimular sua participação no processo concursal, possivelmente levarão em conta e deduzirão juízo de valor a respeito do comportamento do devedor ou de seus dirigentes no momento da apreciação de propostas de composição (plano de reorganização). Mas o fato é que a supressão de prova dos requisitos acima declinados para ajuizamento da concordata caracteriza nítida adoção do princípio de separação entre a empresa e o empresário.

Isto significa que, acima do juízo de valor ou deméritos que possa ter o empresário, está a possibilidade de uma solução negociada que possa resultar na superação da crise da empresa. Primeiro prestigia-se a autonomia da vontade das partes e segundo, outorga-se valor à empresa (atividade) como objeto de tutela do direito.

\footnotetext{
${ }^{274}$ STANGHELLINI, Lorenzo. Le crisi di impresa fra diritto ed economia (le procedure di insolvenza). Bologna: Il Mulino, 2007, p. 76. Em tradução livre: "No procedimento de 'adminitração extraordinária de grandes empresas', ao contrário, a finalidade não é a máxima realização, mas a conservação do complezo aziendal em atividade (artigo 55 do DL n. 270/99), perseguida tanto quanto possível. Tal finalidade se traduz, no que ora interessa, no fato de que em caso de venda da azienda em exercício pelo comissário extraordinário, o adquirente recebe um 'desconto' quase correspondente ao seu empenho em prosseguir a gestão, mesmo que com prejuízo e a manter o nível de trabalho."

${ }^{275}$ E com tendência preservacionista, mesmo que a custa de sacrifício, em certa medida, do interesse dos credores (STANGHELLINI, Lorenzo. Le crisi di impresa fra diritto ed economia (le procedure di insolvenza). Bologna: Il Mulino, 2007, p. 101).

${ }^{276}$ Esta é uma tendência do direito italiano que vem se desenvolvendo desde a década de 1970, sendo possível lembrar, no início dos anos 1980, o "proggeto Pajardi".
} 
$\mathrm{Na}$ falência, e em benefício dos credores, abre-se a possibilidade de conservação de valores representada pela organização dos ativos, mediante modalidades de alienação que tornam possível sua manutenção. ${ }^{277}$

Há uma importância substancial neste movimento palmilhado pelo direito italiano, na medida em que se evidencia a busca de múltiplas possibilidades de solução destinada à preservação do negócio desenvolvido pelas empresas. Além da melhoria observada nos procedimentos reorganizatórios, verifica-se a existência de métodos, na falência, de manutenção da organização dos bens, por cessão a terceiros ou alienação dos ativos em bloco.

É nesse senso que Luigi Farenga destaca as mudanças realizadas na reforma, comentando: “La sorte dell'impresa, considerata null'altro che parte del patrimonio dell'imprenditore fallito, era necessariamente la liquidazione, essendo in principio escluso un suo risanamento o, quantomeno, una cessione dell'azienda in funzionamento, non prevedendo la previgente disciplina alcuna norma in tema di cessione in blocco o di affitto dell'azienda, e, posto che l'esercizio provvisorio dell'impresa constituiva evento del tutto eccezionale e subordinato all'autorizzazione del giudice delegato, prévio parere favorevole (vincolante del comitato dei creditore (art. 90 vecchio texto) ${ }^{278, "}$.

Na mesma linha, segue a opinião de Arnoldo Kleidermarcher, para quem “Los rasgos positivos, según nuestra opinión, están dados por un favorecimiento a la continuación de la actividad empresaria y que fuera el fundamento del instituto originado en la doctrina italiana de la continuación de la explotación de la empresa"279.

\footnotetext{
277 STANGHELLINI, Lorenzo. Le crisi di impresa fra diritto ed economia (le procedure di insolvenza). Bologna: Il Mulino, 2007, pp. 341-342.

${ }^{278}$ FARENGA, Luigi. "La reforma del diritto fallimentare in Italia: una visione de mercato". Revista de Direito Mercantil, Industrial Econômico e Financeiro. Vol. 145, Ano XLVI (nova série), jan/mar 2007, p.10. Em tradução livre: "A sorte da empresa, considerada nada mais do que parte do patrimônio do empresário falido, era necessariamente a liquidação, sendo, em princípio, excluída a ideia de saneamento, e, muito menos, a cessão da 'azienda' em funcionamento, não prevendo a disciplina precedente nenhuma regra de cessão em bloco ou arrendamento do estabelecimento, posto que a continuidade dos negócios era um evento de todo excepcional e subordinado à autorização do 'guidice delegato' e prévio parecer (vinculante) do comitê de credores (Artigo 90 do antigo texto).

${ }^{279}$ PAJARDI, Piero; KLEIDERMARCHER, Arnoldo; FARCHÍ DE MONTALBÁN, Diana; GEBHARDT, Marcelo; HUALDE, Paula M; MARTÍN PARDUCCI, Diego. Derecho Concursal, verificación, liquidación, distribuición y clausura - Tomo 3, Buenos Aires: Editorial Ábaco de Rodolfo de Palma, 2011, p. 39).
} 
$\mathrm{Na}$ esteira deste raciocínio, na reforma iniciada em 2005, promoveu-se sensível modificação na concordata preventiva (il concordato preventivo) ${ }^{280}$ no que diz respeito ao pressuposto do procedimento, que abandonou o conceito de insolvência e passou a centrar-se na noção de cris $^{281}{ }_{-}^{282}{ }_{-}^{283}$. Outrossim, na reforma de 2006, foi introduzida a possibilidade de atribuir aos credores participação na empresa, mediante extinção de todo o passivo, em decorrência da emissão de ações ${ }^{284}$.

Neste procedimento, ${ }^{285}$ o devedor apresenta um plano, com amplas modalidades de satisfação dos credores, tais como: reestruturação do débito, cessão de bens, assunção, operações societárias e outras.

Os credores poderão ser divididos em classes $^{286}{ }_{-}^{287}$, para fins de apreciação e aprovação, por sistema de maiorias, da proposta contida no plano. A proposta de

280 "È evidente che la procedura di concordato preventivo constituice un'ultima, e ottima, occasione per il debitore di continuare a gestire il suo patrimônio anche in una situazione in cui, verosilmilmente, i creditori dovrebbero assumerme il controllo, visto che esso è com tutta probabilità insufficiente a soddisfarli tutti. Non solo: il controllo sul suo patrimonio e il potere di formulare la proposta como ritiene più opportuno consentono al debitori di indirrizare la soluzione (non solo nell'interesse dei creditori, ma) anche nel proprio interesse. (STANGHELLINI, Lorenzo. Le crisi di impresa fra diritto ed economia (le procedure di insolvenza). Bologna: Il Mulino, 2007, pp. 354-355). Em tradução livre: 'É evidente que o procedimento de concordato preventivo constitui uma última, e ótima, oportunidade para o devedor de continuar a gerir seu patrimônio, mesmo em uma situação na qual, verdadeiramente, os credores deveriam assumir o controle deste, visto que este é com toda certeza insuficiente para satisfazer a todos eles. Não apenas: o controle sobre o seu patrimônio e o poder de formular proposta como melhor julgar oportuno, autoriza aos devedores encaminharem uma solução (não apenas no interesse dos credores, mas) também do próprio devedor' .

${ }^{281}$ Artigo 160, caput, da lei concursal italiana. Para Barbara Ianniello, "secondo questa impostazione le strade sarebbero due ed alternativa tra loro: se l'imprenditore è in crisi, la via è quella del concordato preventivo, se è invece insolvente quella del fallimento". (Il nuovo diritto fallimentare (guida alla reforma delle procedure concursuali). Milano: Giuffrè, 2006, p. 374). Em tradução livre: 'segundo esta disposição, as vias seriam duas alternativas entre ambas as possibilidades: se o empresário está em crise, a via é a da concordata preventiva, se, ao contrário, está insolvente, a via é a da falência'.

${ }^{282}$ Paolo Felice Censoni entende que o conceito de 'estado de crise' não difere daqueles da 'insolvência' (antiga concordata) e tampouco da 'temporária dificuldade de inadimplemento' (procedimento de administração extraordinária), mas, fundamentalmente, se há reversibilidade da situação de crise patrimonial, financeira ou econômica e que dependerá da efetiva possibilidade de execução do plano e do consenso dos credores em torno desta circunstância. (La Riforma della Legge Falimentare, obra coletiva coord. por BONFATI, Sido; FALCONI, Giovanni. Milano: Giuffrè, 282 - Quaderni di Giurisprudence Commerciali, 2005, p. 202).

${ }^{283}$ Apesar de parte da doutrina considerar a insolvência uma das possíveis manifestações do estado de crise. (Stefano Ambrosini e Paolo Giovanni Demarchi, Il Nuovo Concordato Preventivo e Gli Accordi di Ristrutturazione dei Debiti. Milano: Giuffrè, 2005, pp. 16-17; Paolo Felice Censoni, La Riforma della Legge Falimentare, obra coletiva coord. por BONFATI, Sido; FALCONI, Giovanni, Giuffrè, 282 - Quaderni di Giurisprudence Commerciali, 2005, pp. 200-205; PACCHI, Stefania, palestra proferida em janeiro de 2005, em congresso na Espanha "La reforma del derecho concursal italiano").

${ }^{284}$ STANGHELLINI, Lorenzo. Le crisi di impresa fra diritto ed economia (le procedure di insolvenza). Bologna: Il Mulino, 2007, p.357.

${ }^{285}$ STANGHELLINI, Lorenzo. Le crisi di impresa fra diritto ed economia (le procedure di insolvenza). Bologna: Il Mulino, 2007, pp. 355-357. 
pagamento deverá prever, pelo menos, pagamento integral ou oferta de garantias aos credores privilegiados, além de quitação, no mínimo, de $40 \%$ do passivo quirografário em seis meses da homologação da concordata ou, se em prazo maior, mediante acréscimo de juros.

Uma das possíveis soluções de satisfação dos credores na concordata preventiva, além da proposta de pagamento pelo devedor, poderá ser a transferência das atividades da concordatária a um terceiro (denominado 'assuntore ${ }^{288}$ ).

O assuntore que avoca para si, em nome pessoal, a obrigação de pagar os credores, subrogando-se na posição do devedor, mediante recebimento, por cessão, do patrimônio ativo que integra o estabelecimento da concordatária ${ }^{289}$. Admite-se que o 'assuntore' possa ser um credor (ou um grupo de credores) ou mesmo uma sociedade de credores constituída ou a ser constituída durante o processo concursal. O sistema, evidentemente, foi aperfeiçoado para atrair a participação dos credores, de modo que possam deliberar a respeito de mecanismos de minimizar perdas.

A respeito das possibilidades de pagamento por proposta (plano) do devedor ou por assunção por terceiro, Barbara Ianniello pontua que "il ventaglio di opzione per l'uscita non traumatica dalla situazione di crisi resulta decisamente piú ampio rispetto alle proposte de concordato preventivo vincolate, nell'ancora attuale disciplina"290.

\footnotetext{
${ }^{286}$ A lei não estabelece de forma fixa a formação das classes de credores, mas disciplina critérios de sua constituição, com base na "posição jurídica" e no "interesse econômico homogêneo" (artigos 124, 2, 'a', e 160,1 , 'c' e 'd'), deixando o devedor com maior flexibilidade na proposição de acordo. Inclusive, por esta razão, Paolo Felice Censoni afirma que houve derrogação do princípio da par condicio creditorum ( $L a$ Riforma della Legge Falimentare, obra coletiva coord. por BONFATI, Sido; FALCONI, Giovanni. Milano: Giuffrè, 282 - Quaderni di Giurisprudence Commerciali, 2005, p. 191).

${ }^{287} \mathrm{O}$ devedor terá liberdade para fixar as classes de credores, de acordo com a homogeneidade de cada qual, de modo que estas possam receber uma oferta personalizada, no seguinte sentido: de acordo com interesses econômicos diversos, por exemplo, entre fornecedores estratégicos e outros credores que possam ter um período de espera mais longo ou, na hipótese de posições jurídicas similares, como credores com preferência, dentre os quais, alguma preferência imponha uma satisfação mais célere e assim por diante.

${ }^{288}$ Artigo 160, 1, b da lei concursal italiana.

${ }^{289}$ Barbara Ianniello refere-se ao 'accollo' (ou assunção), como modalidade possível de satisfação dos credores como 'cessio bonorum', em evidente referência ao instituto do direito romano. (Il nuovo Diritto Fallimentare (Guida ala Riforma delle procedure concursuali). Milano: Giuffrè, 2006, pp. 372).

${ }^{290}$ Em tradução livre: "o leque de opções para uma saída não traumática da situação de crise resulta, definitivamente, mais amplo no que respeita à concordata preventiva, em sua atual disciplina.' (Il nuovo Diritto Fallimentare (Guida ala Riforma delle procedure concursuali). Milano: Giuffrè, 2006, pp. 372).
} 
Também na concordata suspensiva (ou, concordato falimentare), é possível a realização de proposta para composição do passivo, que, como novidade da reforma de 2005 , pode ser feita tanto pelo devedor, quanto por um terceiro ${ }^{291}$, que, então, assume a obrigação de pagar os credores, em nome próprio, mediante liberação ou não do falido.

Veja-se, assim, que o procedimento de concordato falimentare e que resulta da convolação da quebra em concordata - admitida pelo sistema italiano, ao contrário do nosso - é considerado, por parte da doutrina, como uma alternativa de satisfação dos credores que não seja tão ruim quanto a da liquidação pela falência ${ }^{292}{ }_{-}^{293}$.

Na hipótese, há dois momentos distintos na solução de proposta por terceiro, realizada sob o procedimento de concordata falimentar. Primeiro, o terceiro propõe a assunção das obrigações dos credores admitidos ao concurso mediante subrrogação em todas as obrigações do devedor no processo concursal (em relação aos quirografários no percentual convencionado no plano e em relação aos privilegiados, mantendo-se suas garantias).

Depois, em um segundo momento, ocorre o ato traslativo dos bens que integram a massa falida, que pode incluir todo o patrimônio ativo ou parte dele apenas. É comum, ainda, que o ato translativo dos ativos fique, por cláusula do acordo, condicionado ao pagamento das obrigações assumidas na concordata ${ }^{294}$, ou sujeito à prestação de garantia real ou pessoal pelo 'assuntore', tendo em vista que a cessão dos ativos constitui garantia dos credores $^{295}$.

\footnotetext{
${ }^{291}$ Artigo 124, 4 da lei concursal italiana.

${ }^{292}$ STANGHELLINI, Lorenzo. Le crisi di impresa fra diritto ed economia (le procedure di insolvenza), Il Mulino, Bologna, 2007, p. 357.

${ }^{293}$ Muito embora Lorenzo Stanghellini pondere que se a proposta consiste em uma proposta de pagamento em dinheiro, não é esta nada além de uma variante do processo de liquidação: "invece di liquidare il patrimonio in varie vendite, il curatore lo cede in blocco a un prezzo che l'assuntore paga diretamente ai creditori, o lo "restituisce" al fallito in quanto egli offre una somma superiore a quella che si ricaverebbe dalla liquidazione". (STANGHELLINI, Lorenzo. Le crisi di impresa fra diritto ed economia (le procedure di insolvenza). Bologna: Il Mulino, 2007, p. 220). Em tradução livre: 'ao invés de liquidar o patrimônio em várias vendas, $\mathrm{o}$ administrador $\mathrm{o}$ cede em bloco a um preço que o assuntor paga diretamente aos credores, ou o "devolve" ao falido, na hipótese em que este oferece uma quantia superior à que se haveria como resultado da liquidação.'

${ }^{294}<$ http://www.studiolegaleriva.it/public/concordato-fallimentare.asp >. Consultado em 28/12/2010.

${ }^{295}$ IANNIELLO, Barbara. Il nuovo diritto fallimentare (Guida ala riforma delle procedure concursuali). Milano: Giuffrè, 2006, pp. 343-344.
} 
Já na falência ${ }^{296}$ está prevista, na disciplina que regula a liquidação dos $\operatorname{ativos}^{297}$ a possibilidade de cessão do estabelecimento em bloco, o que pode incluir tanto determinada organização de bens, quanto certas relações jurídicas específicas.

Para tanto, "Il fallimento non appare più come uma procedura disregrativa dell'impresa, finalizzata unicamente al soddifacimento dei creditori; assume, invece ora una fisionomia di procedura per quanto possibile conservativa dell'impresa, nella consapevolezza che l'impresa é un "bene" che gioca un ruolo importante nell'economia di una nazione." 298

$\mathrm{Na}$ sistemática atual do direito italiano, nota-se considerável aumento do poder dos credores, que envolve até a possibilidade de substituição do curatore e de necessidade de autorização dos atos deste, permanecendo o juiz na posição de solucionador dos conflitos entre os credores, ${ }^{299}$ cuja atuação, sempre com foco nos melhores resultados da liquidação, é elemento de destaque.

Assim, a reforma trouxe novidades quanto aos métodos de liquidação dos ativos, ${ }^{300}$ norteada pelas seguintes ideias: (i) redução da jurisdicionalização, mediante aumento das atribuições e poderes dos órgãos falimentares, em particular do 'curatore,301, além de reforçar o papel do comitê de credores, que passa a opinar (sobretudo em caráter vinculativo) quanto à conveniência econômica da venda dos bens, e (ii) criação de um

\footnotetext{
${ }^{296}$ Artigo 104 terc, alínea d e o art. 105 da lei concursal italiana.

${ }^{297}$ A finalidade é liquidatória, pois visa transformar a venda dos ativos em dinheiro, no tempo mais breve possível, para evitar dano aos credores. (STANGHELLINI, Lorenzo. Le crisi di impresa fra diritto ed economia (le procedure di insolvenza). Bologna: Il Mulino, 2007, p. 355).

${ }^{298}$ FARENGA, Luigi. "La reforma del diritto fallimentare in Italia: una visione de mercato". Revista de Direito Mercantil, Industrial Econômico e Financeiro. Vol. 145, Ano XLVI (nova série), jan/mar 2007, p.14. Em tradução livre: "A falência não aparece mais como um procedimento desagregador da empresa, com a finalidade única de satisfação dos credores; assume, ao invés, uma fisionomia de procedimento, tanto quanto possível, de conservação da empresa, que, sabidamente, é um 'bem' que possui um papel importante na economia de uma nação."

${ }^{299}$ STANGHELLINI, Lorenzo. Le crisi di impresa fra diritto ed economia (le procedure di insolvenza). Bologna: Il Mulino, 2007, p. 356.

${ }^{300}$ Em relação à liquidação dos ativos na falência, a reforma adotou soluções que já vinham sendo praticadas no judiciário e que prestigiam a eficiência e a rapidez. (IANNIELLO, Barbara. Il nuovo diritto fallimentare (Guida ala riforma delle procedure concursuali). Milano: Giuffrè, 2006, pp. 252-253).

${ }^{301} \mathrm{O}$ curatore é um dos órgãos do direito concursal italiano com características assemelhadas ao administrador judicial no Brasil. É nomeado na sentença de falência (artigo 27) e pode ser substituído por decisão judicial. Desenvolve função de caráter público (artigo 30) e podem ser nomeados para o cargo, por exemplo, advogados, dottori commercialisti, sociedades profissionais desde que com indicação de um responsável pessoa física, administradores de empresas com prova de capacidade em tal área. (IANNIELLO, Barbara. Il nuovo diritto fallimentare (Guida ala Riforma delle procedure concursuali). Milano: Giuffrè 2006, pp. 69-72).
} 
programa de liquidação (como um plano de alienação) a ser proposto pelo curatore e aprovado pelo giudice delegato ${ }^{302}$, após parecer do comitê de credores.

A perspectiva de alienação dos ativos em bloco motivou a reforma da disciplina da continuidade provisória dos negócios do falido (esercizio provvisorio dell'impresa $)^{303}$, que poderá ser autorizada para determinados ramos de atividade, sempre que a interrupção das atividades puder resultar em danos graves e desde que não decorra prejuízo aos credores. Igualmente, poderá ser proposta a continuação provisória pelo curatore, ao giuduce delegato, com parecer vinculante do comitê de credores, sempre que conveniente aos credores, para atingir melhor proveito na alienação.

Barbara Ianniello anota que a reforma acentua, além do interesse dos credores no resultado da venda, também o caráter publicístico envolvido na conservação na organização dos ativos (no todo ou em parte), que impede a perda do aviamento, ${ }^{304}$ Muito embora deva-se pontuar o posicionamento de Lorenzo Stanghellini no sentido de que "Fra i molti interessi in gioco nell'insolvenza di un'impresa la procedura di fallimento deve prioritariamente perseguire quelli dei creditori.",305

Como se disse, com a reforma, a administração (e a consequente alienação) dos ativos na falência passou a ser de responsabilidade do curatore, em conjunto com o comitê de credores, quando em funcionamento. Veja-se, portanto, o deslocamento das atividades não jurisdicionais para fora do âmbito decisório do magistrado.

O curatore deverá, assim, elaborar um programma di liquidazione, que conterá previsão de prazos e modalidades de liquidação dos bens, ${ }^{306}$ sendo-lhe outorgado

\footnotetext{
${ }^{302}$ É o magistrado que diretamente exerce a função de fiscalizar a regularidade do procedimento concursal, dando cumprimento aos atos previstos em lei (artigo 25 da lei concursal italiana). IANNIELLO, Barbara. $I l$ nuovo diritto fallimentare (Guida ala riforma delle procedure concursuali), Milano: Giuffrè, 2006, pp. 5762.

${ }^{303}$ Artigo 104 da lei italiana.

304 IANNIELLO, Barbara. Il nuovo diritto fallimentare (Guida ala Riforma delle procedure concursuali). Milano: Giuffrè, 2006, pp. 253-254.

305 STANGHELLINI, Lorenzo. Le crisi di impresa fra diritto ed economia (le procedure di insolvenza). Bologna: Il Mulino, 2007, p. 357. Em tradução livre: 'Dentre os múltiplos interesses em jogo na insolvência de uma empresa, no procedimento falimentar deve prioritariamente perseguir aqueles dos credores."

${ }^{306}$ O programa de venda dos bens elaborado pelo curatore conterá, em suma: (i) avaliação da possibilidade de continuação provisória dos negócios, (ii) avaliação de possibilidade de proposta de concordata e seu eventual conteúdo, (iii) indicação de ações revocatórias eventualmente cabíveis, (iv) possibilidade de cessão, como um todo, do estabelecimento ou de determinadas partes deste, (v) condições de venda dos ativos
} 
relativo grau de discricionariedade, com o objetivo de evitar a desagregação desnecessária dos bens. Por parecer vinculante, o comitê de credores avalia o mérito de oportunidade e conveniência do modelo de alienação proposto e poderá, inclusive, conter sugestões de modificação do programa. ${ }^{307}$

Observa-se, assim, o aumento do poder dos credores ${ }^{308}$ e o evidente incentivo de sua participação, com o intuito de maximizar os resultados da liquidação. Uma das possibilidades, que é inovação da reforma, consiste na possibilidade de constituição de nova sociedade mediante versão do patrimônio da falida (que podem incluir bens ou créditos, ou ambos), com posterior alienação de sua participação a terceiros ou aos próprios credores.

O objetivo da alienação de bens em bloco é dúplice, ou seja, de um lado manter ativos, sempre que possível, os núcleos produtivos da falida e, de outro, proporcionar melhor satisfação dos credores $^{309}$, resultante do valor de venda agregado decorrente.

A reforma declaradamente optou por prestigiar a alienação em bloco dos ativos, como ocorre no direito brasileiro. Tanto assim que Barbara Ianniello lembra que "in funzione della scelta della conservazione, la strada liquidatoria privilegiata dal legislatore della reforma è quella vendita dell'intero complesso aziendale, di suoi rami, di beni o rapporti giuridici individuabili in bloco: la liquidazione "atomistica" dei singoli beni individuabili - esordisce il primo comma del articolo 105 - è un'opzione residuale cui ricorrere solo quando non risulti più conveniente la cessione dell'intero complesso o di suoi rami. "310

individualmente considerados. (IANNIELLO, Barbara. Il nuovo Diritto Fallimentare (Guida ala Riforma delle procedure concursuali). Milano: Giuffrè, 2006, p.261).

${ }^{307}$ Artigo 104, ter da lei italiana.

${ }^{308}$ FARENGA, Luigi. "La reforma del diritto fallimentare in Italia: una visione de mercato". Revista de Direito Mercantil, Industrial Econômico e Financeiro. Vol. 145, Ano XLVI (nova série), jan/mar 2007, pp. 910 .

309 " da un lato le procedure di falimento e di concordato preventivo, le cui norme in materia do liquidazione prevedono (implicitamente, ma chiaramente) che nella vendita dell'azienda deve essere perseguito l'obietivo del massimo realizzo." (STANGHELLINI, Lorenzo. Le crisi di impresa fra diritto ed economia (le procedure di insolvenza). Bologna: Il Mulino, 2007, p. 74). Em tradução livre: "de um lado, o procedimeto de falência e de concordata preventiva, dos quais as normas em matéria de liquidação preveem (implicita, mas claramente) que na venda do estabelecimento deve ser perseguido o objetivo de máxima realização."

310 IANNIELLO, Barbara. Il nuovo Diritto Fallimentare (Guida ala Riforma delle procedure concursuali). Milano: Giuffrè, 2006, p. 264. Em tradução livre: 'Em função da escolha preservacionista, a via liquidatória 
Em decorrência, poderá ser ajustada, entre o curatore e o adquirente do estabelecimento (com participação dos representantes sindicais), a transferência parcial de contratos de trabalho de funcionários da então falida. Em relação ao passivo da falida, o adquirente por eles não responde, salvo convenção diversa em contrário, de modo que fica excepcionada a disposição do Código Civil italiano a respeito. ${ }^{311}$

Sob a óptica de tentar evitar, sempre que possível, a dispersão da organização dos bens que integra o estabelecimento, a lei admite a locação deste, o que poderá ter lugar antes mesmo da apresentação do programma di liquidazione pelo curatore.

Veja-se, no direito concursal italiano há oportunidade, em três procedimentos distintos (concordato preventivo, concordato falimentar, e fallimento), destinadas a tentar manter-se hígida a atividade ou a organização de bens preexistentes à falência.

De qualquer modo, tanto a sistemática de preservação da atividade nos procedimentos reorganizatórios, quanto da manutenção da organização de bens e ativos na falência, no direito italiano, caminham em evidente estímulo da maior atuação dos credores e, igualmente, na busca da melhor satisfação de seus interesses.

Além disso, percebe-se uma desordenada adaptação de regras sobrepostas ao Reggio Decreto n. 267/45, o que constitui uma situação de óbice ao acolhimento de uma nova mentalidade para o direito concursal. Por exemplo, ao se manter a possibilidade de conversão de falência para um procedimento de concordato falimentare, impede-se a alienação célere dos ativos, o que poderá ser de grande prejuízo para os credores.

Registre-se, portanto, parece-nos que houve pouca sistematização na adoção do princípio da separação entre a empresa e seu titular pelo direito concursal italiano. Veja-

prestigiada pelo legislador na reforma é a de venda dos bens do complexo aziendal por inteiro, de seus ramos, de bens ou relações jurídicas individualizados em bloco: a venda 'atomística' de bens individualizados - art. 105, 1 - é uma opção residual a qual se recorre somente quando não resultar mais conveniente a cessão do complexo de bens unitariamente ou de parcelas deste'.

${ }^{311}$ Artigo 2560 do Código Civil Italiano. 
se que na tentativa (embora louvável) de se buscar inúmeros meios de manter o negócio do devedor, por exemplo, ao prever possibilidades de cessão da empresa ou alienação em bloco, tais soluções foram estabelecidas de forma isolada e estanque em cada procedimento (falimento, concordato falimentare e concordato preventivo), do que poderá resultar ineficiente aplicação do postulado.

Julga-se que a melhor solução teria sido a realização de uma reforma com total revogação do Reggio Decreto n. $267 / 45$ e implementação de um novo regime ${ }^{312}$, como ocorreu no direito brasileiro, até mesmo com a finalidade de romper com o velho sistema concursal de "execução coletiva", que, no direito italiano, parece intacto.

A reforma iniciada em 2005 fez sentir ao direito concursal italiano apenas leve brisa dos ares do moderno direito concursal.

\subsection{O direito alemão}

O direito concursal alemão, antes de 1994, era regulado de forma esparsa ${ }^{313}$, tanto que um dos objetivos da reforma promovida à época foi o da unificação.

A Konkursordnung (KO), com vigência a partir de 01/10/1879, previa a solução liquidatória, que excluía a participação dos credores titulares de direito de garantia; já a Vergleichsordnung (VerglO), que regulava a Lei do Acordo e foi incorporada ao sistema em 26/02/1935, tinha por objetivo evitar a liquidação, prevendo a possibilidade, ao devedor que previamente provava sua honestidade e capacidade de pagamento, de proposta de quitação de, no mínimo, $35 \%$ do passivo quirografário ${ }^{314}$.

\footnotetext{
312 BRUSCHETTA, Ernestino. "L'esenzione' contrattuale dal fallimento", in "La riforma della Legge Falimentare" - Quaderni di Giurisprudenza Commerciale 282. Coord. BONFATI, Sido Bonfati; FALCONI, Giovanni, Milano: Giuffrè, 2005, pp. 239-243.

${ }^{313}$ As regras pertinentes aos créditos da Fazenda Pública ainda hoje são disciplinadas em várias legislações. Em princípio, a regra geral é a seguinte: os créditos fiscais constituídos antes da abertura do processo de insolvência integram a categoria de credor da insolvência, ao passo que os créditos constituídos após a abertura do procedimento são considerados créditos da massa e pagos com preferência a todos os demais. (BERGER, Dora. A insolvência no Brasil e na Alemanha. Porto Alegre: Fabris, 2001, p. 127).

${ }^{314} \mathrm{O}$ acordo admitia também proposta por dilação de prazo, mas se o pagamento proposto fosse de quantia inferior a $50 \%$ do passivo quirografário, deveria esta ser aprovada por quarto quintos destes créditos.
} 
É importante destacar, como anota Susana Corotto, que a ideia de "saneamento de empresa",315_316 surgiu no procedimento de liquidação (KO), mediante a possibilidade de "alienação parcial ou total da empresa a terceiro, enquanto o antigo titular é liquidado", solução que tangencia o ideal preservacionista suscitado pelo artigo 75 da atual lei brasileira.

Muito embora tenha sido considerada uma das mais perfeitas leis concursais de seu tempo ${ }^{317}$, denominada por "pérola das Leis do Império"318_319, a KO mostrou-se insuficiente para atender seus fins, o que levou o Ministério da Justiça alemão a formar uma comissão de estudos para análise do direito da insolvência e de proposta de soluções para a crise das empresas. Essa iniciativa resultou em diversos documentos produzidos em meados dos anos oitenta, culminando com um projeto oficial que foi amplamente analisado, até a sanção legal da lei de 1994.

As deficiências do direito concursal alemão ficaram fortemente evidenciadas quando, na crise do petróleo de 1973, diversas empresas sofreram abalo financeiro e econômico, e disto resultou expressivo aumento no número de pedidos de processos de insolvência.

Constatou-se, assim, na maioria dos casos, o arquivamento por juízo de cognição sumária e antes mesmo da instauração do procedimento concursal, ante a insuficiência de patrimônio que pudesse sequer atender às despesas da massa ${ }^{320}$.

315 E que a doutrina alemã denominou por übertragende Sanierung ou sarierende Liquidation (COROTTO, Susana, Modelos de Reorganização Empresarial Brasileiro e Alemão. Porto Alegre: Fabris, 2009, p. 57).

${ }^{316}$ Note-se, a primeira expressão referida poderia ser considerada inadequada, do ponto de vista da terminologia, já que a medida não implica, propriamente, hipótese de saneamento da atividade econômica (COROTTO, Susana. Modelos de reorganização empresarial brasileiro e alemão. Porto Alegre: Fabris, 2009 , p. 57, em especial nota de rodapé 141). A crítica feita pela autora parece, com efeito, apropriada, pois a hipótese não é de saneamento, mas traduz um ideal preservacionista no seio do procedimento liquidatório, pela manutenção da organização de bens preexistentes sob um novo titular, em aproximação evidente com o texto do artigo 75 da lei concursal brasileira.

${ }^{317}$ ESCUTI, A. Ignacio e BAS, Francisco Junyent. Derecho concursal. Buenos Aires: Astrea, 2006, pp. 1819.

${ }^{318}$ COROTTO, Susana, Modelos de reorganização empresarial brasileiro e alemão. Porto Alegre: Fabris, 2009 , p. 53.

${ }^{219}$ Ariel Ángel Dasso anota que a KO foi considerada como o ordenamento concursal de melhor técnica no âmbito do direito comparado por mais de um século. (Derecho concursal comparado, Tomo I, Buenos Aires: Legis, 2009, p.06).

${ }^{320}$ COROTTO, Susana, Modelos de reorganização empresarial brasileiro e alemão. Porto Alegre: Fabris, 2009, pp. 58-59; ESCUTI, A. Ignácio; BAS, Francisco Junyent. Derecho concursal, Buenos Aires: Astrea, 2006, pp. 18-19. 
Paralelamente, o sistema revelou, na prática, a ineficiência da VerglO em atender sua finalidade, que era evitar a liquidação pelo concurso. ${ }^{321}$

Neste cenário, estavam os fundamentos para a reforma da lei concursal alemã promulgada em 1994, a Insolvenzordnung (InsO) ${ }^{322}$, os quais, segundo Dora Berger, foram: (i) concentrar, em um único diploma, a disciplina concursal, (ii) introduzir a possibilidade de saneamento extrajudicial (aplicável somente à pessoa natural não empresária e ao empresário titular de um pequeno negócio); (iii) fixar medidas de combate à insuficiência de ativos da massa; (iv) fortalecer o poder dos credores; (v) eliminar privilégios, mediante modificação da classificação dos credores e (vi) introduzir um sistema de exoneração das obrigações residuais para os devedores pessoa natural e titulares de pequeno negócio ${ }^{323}$.

Susana Corotto coloca em evidência, pela importância do tema na reforma, a necessidade de redução do arquivamento de processos por insuficiência da massa. ${ }^{324}$ Isso significa que, do ponto de vista dos credores, o pior cenário da insolvência é aquele da insuficiência de ativos, sequer para sustentar o desenvolvimento do procedimento concursal. O viés pro credor do sistema alemão é, destarte, inegável. ${ }^{325}$

A reforma inaugurou, também, o sistema unitário de solução para a crise das empresas, ou seja, em um mesmo procedimento, decide-se pela liquidação ou solução reorganizatória. ${ }^{326} 327$

\footnotetext{
${ }^{321}$ As estatísticas demonstravam que apenas 3\% a 5\% do passivo eram pagos, de modo que a exigência legal de pagamento mínimo de $35 \%$ não vinha sendo atendida, o que, decerto, contribuiu para a desmoralização do procedimento. As causas da ineficiência do instituto, apontadas pela doutrina, eram, basicamente: (i) exclusão dos credores com garantia, (ii) rigidez no preenchimento dos requisitos legais, e (iii) inexistência de previsão de mecanismos de alteração de estrutura econômico-financeira do devedor. (COROTTO, Susana, Modelos de reorganização empresarial brasileiro e alemão, Porto Alegre: Fabris, 2009, pp. 59-60).

${ }^{322}$ Promulgada em 18/10/1994, com vigência a partir de 1\%10/1999.

${ }^{323}$ BERGER, Dora. A insolvência no Brasil e na Alemanha. Porto Alegre: Fabris, 2001, p. 26.

${ }^{324}$ COROTTO, Susana, Modelos de reorganização empresarial brasileiro e alemão. Porto Alegre: Fabris, 2009, pp. 58-59.

${ }^{325}$ Nesta linha de ideias, Lorenzo Stanghellini anota que a análise de diversos sistemas mostra que na hipótese de conflito de interesses entre a manutenção de postos de trabalho (um dos focos de tutela do moderno direito concursal) e o interesse dos credores, em regra, prevalece este último. É o caso do direito alemão, em que a alienação do estabelecimento a um adquirente que se obrigue a manter postos de trabalho pode ser vetada pelos credores, caso exista outro pretendente, com preço maior e à custa da extinção de empregos. (STANGHELLINI, Lorenzo. Le crisi di impresa fra diritto ed economia (le procedure di insolvenza). Bologna: Il Mulino, 2007, p. 79).

${ }^{326}$ GRAZIABILE, Darí J. Derecho concursal, Tomo I, Buenos Aires: LexisNexis, 2006, p. 33.
} 
Certamente, o objetivo principal da InsO, conforme expresso no $\operatorname{artigo~}^{328} 1^{\text {o }}$ da lei, é a satisfação dos credores, apesar de ser esta a primeira legislação alemã a mencionar a manutenção da empresa ${ }^{329}$, de forma expressa, como uma de suas finalidades.

Tanto isso é certo que Alberto Jorio defende: "Nel suo insieme la nuova legge traghetta il sistema tedesco verso i sistemi di disciplina dell'insolvenza che possono definirsi “debtor oriented”, e cioè più comprensivi verso le ragioni del debitore e le opportunità di conservazione dell'impresa: il che há sollevato e solleva non poche critiche nei commentatori tedeschi, abituati da sempre ad un sistema "creditor oriented". Peraltro la volontà del legislatore tedesco non sembra quella di sottrarre l'impresa alla liquidazione attraverso il sacrificio dei creditori, quando piuttosto di favorire una decisione di tutte le parti, la cui autonomia viene preservata nell'ambito di una procedura rispetto alla quale il giudice è chiamato ad esercitare um ruolo di garanzia”330.

Esse posicionamento explica, em parte, o fato de que a InsO prevê um procedimento de insolvência unificado, que tanto pode resultar na falência (liquidação) quanto em uma solução recuperatória (de preservação) da empresa ${ }^{331}$.

\footnotetext{
327 Ariel Angél Dasso anota que uma das conclusões da comissão de reforma foi a de que era necessário "Eliminar el dualismo institucional entre la quiebra y el concordato, ya que este último resulta inoperante para salvaguardar la empresa." (Derecho concursal comparado, Tomo I, Buenos Aires: Legis, 2009, p. $07)$.

${ }^{328} \mathrm{Na}$ lei alemã, o artigo é representado pelo símbolo $\S$, que, por esta razão, será também utilizado neste trabalho como sinônimo.

${ }^{329}$ COROTTO, Susana, Modelos de reorganização empresarial brasileiro e alemão, Porto Alegre: Fabris, 2009 , pp. 61 e 74.

${ }^{330}$ JORIO, Alberto. Le crisi d'impresa e il fallimento. Milano: Giuffrè, 2000, pp. 51-52. Em tradução livre: "No seu conjunto, a nova lei transporta o sistema alemão na direção da disciplina da insolvência que pode ser definida como "debtor-oriented", isto é, mais simpática do ponto de vista das razões do devedor e das oportunidades de conservação da empresa: o que levantou e levanta não poucas críticas dos comentaristas alemães, habituados a um sistema 'creditor-oriented'. Além disso, a vontade do legislador alemão não parece ser aquela de subtrair a empresa da liquidação à custa do sacrifício dos credores, mas apenas de favorecer uma decisão envolvendo todas as partes, cuja autonomia fica preservada no âmbito de um procedimento sob o qual o juiz é chamado a exercitar um papel de garantia."

331 "Ma è anche significativo che la nuova struttura della legge tedesca registri l'abbandono del sistema tradizionale impostato sulla distinzione tra fallimento e concordato preventivo, e adotti, invece quello di un unico procedimento, che prende avvio dell'accertamento dell'insolvenza e che ha come obiettivo la ricerca delle oportunittà di conservazione degli elementi ancora vitali dell'impresa nel rispetto della tutela delle ragioni dei creditori." (JORIO, Alberto Jorio. Le crisi d'impresa e il fallimento. Milano: Giuffrè, 2000, p. 48). Em tradução livre: 'Mas é também significativo que a nova estrutura da lei alemã registre o abandono do sistema tradicional imposto pela distinção entre falência e concordata preventiva e adote, ao invés, aquele de um procedimento único, que promove a verificação da insolvência e que tem como objetivo a busca da oportunidade de conservação dos elementos vitais da empresa e visando a tutela das razões dos credores'.
} 
É nesse sentido, aliás, que Susana Corotto afirma que "o caminho para a melhor satisfação coletiva dos credores, no processo de insolvência para empresas pode se dar através das prescrições legais (\$\$ 159 e ss.) e do plano de insolvência (\$§ 217 e ss.), que são instrumentos equivalentes de realização do ativo. Eles podem ser utilizados individualmente ou combinados entre si, pois o plano de insolvência pode contemplar qualquer modalidade de realização do ativo e ter a sua implementação combinada com as prescrições legais (\$\$ 159 e ss.)." 332

A propósito, Ariel Ángel Dasso preleciona que o sistema alemão "mantiene los dos procedimientos: liquidativo y preventivo, pelo los unifica en um nuevo procedimiento que se denomina de insolvencia, abarcativo de las dos soluciones. ${ }^{333}$

É preciso compreender que a reforma acolheu métodos de saneamento "através da insolvência", exatamente como medida destinada a reduzir o número de arquivamento de processos por insuficiência de patrimônio do devedor, um dos maiores obstáculos até então enfrentados pelo direito concursal alemão. O sistema, evidentemente, não pretende o saneamento em vez da insolvência. ${ }^{334}$

Mas, como lembra Ariel Ángel Dasso, "La 'ratio' de la unificación legislativa reside en el atemperamiento del derecho de los acreedores a su inmediata satisfacción, con la posibilidad de saneamiento de la empresa.". Mesmo assim, o autor destaca que o foco fundamental do direito concursal alemão é, sem dúvida, a satisfação dos credores, o que revela um posicionamento diverso de outras legislações que prestigiam a salvaguarda da empresa, ${ }^{335}$ como é o caso do direito francês, por exemplo.

Isso significa que a lei concursal alemã, com a reforma de 1994, sofreu um temperamento no seu objetivo primordial de satisfação dos credores, para admitir que, em determinados casos, o atendimento dos interesses destes poderá ocorrer mediante

\footnotetext{
${ }^{332}$ COROTTO, Susana, Modelos de reorganização empresarial brasileiro e alemão. Porto Alegre: Fabris, 2009, p. 74.

${ }^{333}$ Derecho concursal comparado, Tomo I, Buenos Aires: Legis, 2009, p. 08.

${ }^{334}$ COROTTO, Susana, Modelos de reorganização empresarial brasileiro e alemão. Porto Alegre: Fabris, 2009, p. 76.

${ }^{335}$ DASSO, Ariel Angel. Derecho concursal comparado, Tomo I, Buenos Aires: Legis, 2009, pp. 09-10.
} 
preservação da empresa, ${ }^{336}$ ou seja, a salvaguarda da empresa deve ser consequência do melhor resultado para os credores ou, então, não deveria ser um resultado a ser perseguido. A óptica de prevalência é, assim, a melhor satisfação dos credores.

Desse modo, na lei alemã em vigor, há duas formas de salvaguarda do devedor insolvente empresário (Sanierungsplan ou Übertragungsplan) ou a solução pela liquidação (Liquidationplan), de modo que um plano de insolvência poderá acolher qualquer uma dessas três modalidades distintas. ${ }^{337}$

De um lado, é possível promover uma reorganização por meio de um plano de insolvência (Sanierungsplan), de modo a sanear as atividades do devedor e, com isso, preservar a empresa em funcionamento, mantendo seu titular originário. Note-se que a elaboração do plano não fica adstrita às regras da lei de insolvência e há ampla liberdade de seu conteúdo.

Por outro lado, o saneamento pode dar-se mediante transferência (parcial ou total) dos ativos organizados para um novo titular de direito, o que poderá ocorrer tanto por intermédio do processo regular ( $\$ \$ 159$ e seguintes), quanto por meio de um plano de insolvência (Übertragungsplan, §§ 217 e seguintes).

Essa última modalidade (Übertragungsplan, §§ 217 e seguintes) é considerada, claramente, como forma de realização do ativo para satisfação dos credores.

No entanto, e porque a venda dos bens está sujeita às regras do BGB (Código Civil alemão), o adquirente assume e se torna obrigado por toda a responsabilidade trabalhista do antigo titular existente até a data da transferência, ${ }^{338}$ circunstância que, em muito, dificulta, na prática, o êxito desta previsão legal.

Mas o plano poderá simplesmente prever a liquidação da empresa ou a venda dos ativos da massa insolvente (Liquidationplan). O plano, nesse caso, é elaborado

\footnotetext{
336 "El nuovo régimen legal apunta a la satisfación colectiva de acreedores mediante la liquidación del patrimonio del deudor y su reparto, o al plan de insolvencia que tende a la conservación de la empresa." ESCUTI, Ignácio A. e BAS, Francisco Junyent. Derecho concursal. Buenos Aires: Astrea, 2006, p. 19.

${ }^{337}$ BERGER, Dora. A insolvência no Brasil e na Alemanha. Porto Alegre: Fabris, 2001, pp. 46-47.

${ }_{338}$ COROTTO, Susana, Modelos de reorganização empresarial brasileiro e alemão, Porto Alegre: Fabris, 2009, pp. 76-77.
} 
pelo administrador da insolvência ${ }^{339}$, com intervenção do comitê de credores, do devedor e dos representantes dos empregados ( $§ 123$ e 124$)$.

Aos credores caberá, reunidos em uma audiência de informação, deliberar a escolha entre as modalidades de realização do ativo a serem adotadas na insolvência ( $\$ 29$, $(1), 1)$, bem como sobre a forma de sua realização, ou seja, mediante um plano (§ 217) ou em processo regular ( $§ 159$ e seguintes).

A ideia da lei alemã, assim, parece ser a de individualizar alternativas, diversificadas em relação à simples liquidação tradicional, mas sempre buscando a melhor forma de satisfação dos credores.

A adoção de um plano no processo de insolvência, tanto quanto a insolvência por processo regular, portanto, terão sempre a finalidade de otimizar a satisfação dos credores. O procedimento foi estruturado de modo a conceder e valorizar a autonomia da vontade dos credores ${ }^{340}$, buscando atingir tal finalidade.

As atribuições dos credores na InsO vão desde a decisão quanto a modalidade a ser adotada na ação de insolvência (pela qual se decide o destino da devedora) e incluem a: (i) manutenção do administrador interino nomeado pelo juiz na abertura do processo ou a sua substituição; (ii) continuidade ou paralisação dos negócios da devedora; (iii) delegação, ao administrador da insolvência, da atribuição de poderes para elaboração de um plano de insolvência; (iv) avaliação dos créditos habilitados.

Adicionalmente, e como um dos objetivos da InsO, instituiu-se a possibilidade de exoneração das obrigações residuais do devedor, que, sendo pessoa natural, poderá obtê-la desde que requerida no início do procedimento e mediante cumprimento de certas condições, poderá ser deferida pelo juiz (parte final do $\S 1^{\circ}$ da Lei

\footnotetext{
${ }^{339} \mathrm{Na}$ decisão de abertura do procedimento e como consequência do desapossamento do devedor, o juiz nomeia o administrador da insolvência, que é pessoa física com expertise em negócios e independente dos credores e devedora ( $\$ 56, \mathrm{I})$. A continuidade da administração pelo próprio devedor depende de pedido deste, a ser apreciado pelo juiz, e que passará a ser exercida sob a supervisão do administrador da insolvência.

${ }^{340}$ JORIO, Alberto. Le crisi d'impresa e il fallimento, Milano: Giuffrè, 2000, pp. 49-50.
} 
c/c § 286), posto que, nos demais casos, dependerá de regulamentação prevista no plano ( $\S$ 227). ${ }^{341}$

A InsO aplica-se indistintamente a empresários e não empresários, pessoas jurídicas (com ou sem personalidade) ou naturais. As instituições financeiras privadas e as companhias de seguro privado possuem regulamentação própria, pois somente os órgãos governamentais aos quais estão vinculadas é que têm competência para decidir sobre o ajuizamento de uma ação de insolvência ${ }^{342}$.

As instituições financeiras de direito público estão excluídas do âmbito da InsO, por terem regras específicas que lhes são aplicáveis. Já as pessoas jurídicas de direito público, em regra, estão sujeitas à InsO, mas, como há competência da Federação e dos Estados para legislar em matéria de insolvência, algumas destas ficaram excluídas da incidência da lei concursal.

Uma das inovações da InsO foi a reclassificação dos credores, a fim de promover uma forma de pagamento mais justa. ${ }^{343}{ }^{344} \mathrm{Na}$ nova classificação, os credores foram divididos em dois grupos: (i) credores da massa (Masseglaübiger) e (ii) credores da insolvência (Insolvenglaübiger).

Os credores da massa representam os créditos que devem ser satisfeitos antecipadamente, sob pena de indeferimento do processo, com fundamento na inexistência ou insuficiência da massa.

Esses créditos da massa são, portanto, representados pelos encargos da massa (tais como: custas judiciais, remuneração do administrador da insolvência, despesas realizadas no interesse da massa) e dívidas da massa (como, por exemplo, o direito à

\footnotetext{
${ }^{341}$ Dora Berger anota, conforme $§ 286$ da InsO, que a exoneração das obrigações residuais não se aplica às pessoas jurídicas, mas a doutrina sustenta em sentido contrário, ou seja, de que a exoneração é sim possível (A insolvência no Brasil e na Alemanha. Porto Alegre: Fabris, 2001, p. 131).

342 BERGER, Dora. A insolvência no Brasil e na Alemanha. Porto Alegre: Fabris, 2001, p. 84.

343 BERGER, Dora. A insolvência no Brasil e na Alemanha. Porto Alegre: Fabris, 2001, pp. 38-39; e COROTTO, Susana, Modelos de reorganização empresarial brasileiro e alemão, Porto Alegre: Fabris, 2009, p. 68 .

${ }^{344}$ A classificação ora proposta é a mesma adotada por Dora Berger (A insolvência no Brasil e na Alemanha. Porto Alegre: Fabris, 2001, pp. 124-129).
} 
compensação, ${ }^{345}$ que é devida ao credor com garantia real que ficou impedido de realizar o bem, em benefício da massa, por decisão judicial - $\$ 21, \mathrm{n} .5 \mathrm{c} / \mathrm{c} \$ 169$ - e os créditos fiscais com fato gerador posterior à data de abertura da insolvência), conforme previsto nos $\S \S 53$ a 55 da InsO.

São considerados privilegiados os credores titulares de direito real, os quais deverão ser satisfeitos com o produto da venda do bem ( $\S 49$ e 51).

Os credores da insolvência, por sua vez, podem ser subdivididos em titulares de direitos pessoais ( $\S 38$ ) e os credores titulares de créditos subordinados (relacionados no $§ 39$, I da InsO). ${ }^{346} \mathrm{Na}$ primeira categoria estão incluídos os credores trabalhistas e os créditos fiscais, relativamente ao período anterior à data de abertura do processo de insolvência.

O procedimento de insolvência pode ter início por requerimento de credor ou por iniciativa do próprio devedor. Se requerido por credor, o pedido deverá fundamentar-se em inadimplência ( $\$ 17$ da InsO), que consiste na impontualidade de pagamento de obrigação vencida, ou em insolvência ( $\$ 19$ da $\mathrm{InsO})^{347}$, conceito relacionado à relação patrimonial do devedor, em que o passivo supera o ativo e que, em princípio, é um critério que deve ficar restrito à pessoa jurídica.

Quando requerida pelo próprio devedor, além do fundamento acima mencionado, a ação de insolvência poderá ser instaurada com base na ameaça de inadimplência ( $\$ 18$ da InsO), a qual consiste em uma presunção de que o devedor não estará em condições de cumprir as obrigações vincendas na data pactuada.

\footnotetext{
${ }^{345}$ No sistema alemão, a compensação na falência relaciona-se ao direito real de garantia: "de fato, para o sistema alemão, o devedor, quase que institivamente, muitas vezes fornece ao seu credor um crédito destacando no patrimônio deste a própria dívida que ele tem para com o seu agora devedor e também credor. Pensando: 'se ele não me pagar, eu também não pagarei, compensarei!. Engedrando, assim, uma 'garantia real' de solvência da obrigação". A situação é oposta à do sistema francês, em que a compensação é uma modalidade de pagamento. (GONTIJO, Vinícius José Marques "A compensação na falência: subclasse no quadro geral de credores". Revista de Direito Mercantil, Industrial Econômico e Financeiro. Vol. 147, Ano XLVI (nova série), jun/set 2007, pp. 182-183).

${ }^{346}$ Por exemplo: juros de créditos de natureza pessoal devidos desde a abertura do processo de insolvência, despesa de cada credor para participar no processo de insolvência e afins.

${ }^{347}$ Esse pressuposto material de caracterização do concurso foi modificado pela reforma legal de novembro de 2008, com vigência a partir de 01-01-2011. (DASSO, Ariel Ángel. Derecho concursal comparado, Tomo I, Buenos Aires: Legis, 2009, pp. 09 e 28-34).
} 
Todavia, o pressuposto de instauração do processo concursal com fundamento na insolvência foi alterado pela reforma legal de novembro de 2008, voltada esta à "estabilização do mercado financeiro" (finanzmarktstabilisierungsgesetz) e que foi promulgada como resposta à crise do mercando financeiro, deflagrada em 2008, em decorrência das hipotecas subprime nos Estados Unidos.

A reforma em questão suspendeu o critério de "insolvência" ( $\$ 19$ da InsO) como pressuposto material da instauração do concurso, com vistas a evitar que os administradores de sociedades fossem compelidos a requerê-la em consequência da desvalorização automática que sofreram os ativos como resultado da crise global.

A referida alteração é profunda, pois autoriza o administrador da sociedade, livrando-o das sanções penais e civis previstas em lei, a deixar de requerer a instauração do concurso se a continuidade da empresa puder ser considerada "bastante provável", apesar do estado patrimonial negativo constatado. ${ }^{348}$

A derrogação do critério de insolvência evidencia um movimento no sentido de procurar o instante mais adequado para deflagrar o procedimento concursal, de forma a assegurar, ou pelo menos favorecer, melhores resultados na reorganização empresarial. De certa forma, portanto, assemelha-se ao movimento palmilhado pelo direito francês na reforma de 2005.

Portanto, é forçoso concluir que a aplicação do direito concursal sofre reflexo direto das circunstâncias macroeconômicas, fazendo com que seja necessário buscar soluções de contrapeso em sua aplicação, como ocorreu no direito concursal alemão. $^{349}$

Nota-se, desse modo, que o direito concursal alemão, embora preponderante e inegavelmente voltado à proteção dos interesses dos credores, não está completamente

\footnotetext{
${ }^{348} \mathrm{O}$ critério conceitual de 'provável continuação' da atividade empresarial que se havia firmado na antiga jurisprudência alemã estava relacionado a "la capacidade financiera de la sociedad alcanza para garantizarla por medio de un plan de liquidez con prospectivas de resultados, que acreditare que la sociedad en el mediano plazo no estará en incapacidad de pago"(Tribunal Superior de Justicia - BGH, Fallo del 13 de julio de 1992), citado por DASSO, Ariel Ángel. Derecho concursal comparado, Tomo I, Buenos Aires: Legis, 2009, pp. 31-32.

${ }^{349}$ (DASSO, Ariel Ángel. Derecho concursal comparado, Tomo I, Buenos Aires: Legis, 2009, pp. 32-33).
} 
distanciado da realidade de que a 'empresa', enquanto atividade, representa um valor a ser tutelado pelo direito.

Tanto assim que se mobilizou, rapidamente, resposta mediante reforma legislativa adaptada à realidade econômica resultante da crise mundial para impedir a instauração de concurso para empresas que estivessem em condições de prosseguir em atividade (ou seja, com perspectivas de, a médio prazo, manter-se em condições de honrar suas obrigações), apesar de se subsumirem ao critério de insolvência fixado em lei.

Desse modo, é importante destacar que, mesmo para esse sistema declaradamente pró-credor, identifica-se a noção de que a empresa (enquanto negócio, fonte geradora e de circulação de riquezas) constitui um interesse a ser tutelado, ainda que isto se faça no interesse dos credores, precipuamente.

\section{$2.5 \mathrm{O}$ direito português}

O direito concursal português, diga-se de início, optou pela adoção de um sistema declaradamente pro credor, como fica claro do relatório preambular do diploma vigente ${ }^{350}$, o CIRE - Código da Insolvência ou da Recuperação de Empresas.

$\mathrm{O}$ artigo $1^{\mathrm{o}}$ da referida lei declina, como finalidade única ${ }^{351}$ do concurso, a satisfação dos credores. O modo pelo qual este objetivo poderá ser alcançado dar-se-á ou pela liquidação integral do patrimônio do devedor ou por intermédio da elaboração de um plano, que poderá prever, alternativamente, a (i) liquidação do patrimônio do devedor por um modo especial, diverso daquele originariamente previsto na lei, ou (ii) manutenção da empresa, sob a titularidade do próprio devedor ou de terceiros.

\footnotetext{
${ }^{350}$ Itens 03 e 06, respectivamente, do Decreto-lei n. 53/2004 de 18 de março: “3 - O objectivo precípuo de qualquer processo de insolvência é a satisfação, pela forma mais eficiente possível, dos direitos dos credores. (...) Sendo a garantia comum dos créditos o patrimônio do devedor, é aos credores que cumpre decidir quanto à melhor efectivação dessa garantia, e é por essa via que, seguramente, melhor se satisfaz o interesse público da preservação do bom funcionamento do mercado.”; “6 - (...) Fugindo da errônea ideia afirmada na actual lei, quanto a suposta prevalência da via da recuperação da empresa, o modelo adoptado pelo novo Codigo explicita, assim, desde o seu início, que é sempre a vontade dos credores a que comanda todo o processo. (...) Aos credores compete decidir se o pagamento se obterá por meio de liquidação integral do patrimônio do devedor, nos termos do regime disposto neste Código ou nos de que constem de um plano de insolvência que venham a aprovar, ou através da manutenção da actividade e reestruturação da empresa, na titularidade do devedor ou de terceiros, nos moldes também constantes de um plano."

351 FERNANDES, Luís A. Carvalho; LABAREDA, João. Código da insolvência e da recuperação de empresas anotado, Lisboa: Quid Juris, reimpressão, 2009, p. 58.
} 
Há, assim, uma distinção fundamental no sistema em vigor em relação ao precedente, como anota Catarina Serra, e que consiste no "[...] desaparecimento da viabilidade económica como condição objectiva para a recuperação e a (consequente) impossibilidade de controlar a razoabilidade da decisão de recuperar."

A mesma autora prossegue esclarecendo que "Na prática, isto significa que é possível optar pela recuperação mesmo que não se verifique a sua condição natural de aplicabilidade (a viabilidade da empresa) e, inversamente, deixar o processo (supletivo) de insolvência seguir seu curso, preordenando à liquidação, não obstante ela se verificar. $" 352$

De um modo geral, a doutrina proclama, criticamente, o retorno à fase de falência-liquidação com a vigência do $\operatorname{CIRE}^{353}$ no direito português ${ }^{354}$.

Em oposição a essa ideia está o sistema designado por falência-saneamento que havia dado seus primeiros passos, no direito português, com o Código de Processo Civil de 1961, com os institutos da concordata e do acordo de credores, reconhecidos como meios preventivos à declaração da falência ${ }^{355}$ e que, embora incipientes, poderiam ser considerados como precursores de um novo ideal.

Historicamente, a partir de 1976, o sistema concursal acolheu a recuperação de empresas por vias administrativas pela declaração de "situação económica difícil",

\footnotetext{
352 SERRA, Catarina. O novo regime português da insolvência: uma introdução. 4. edição, Coimbra, Almedina, 2011, p. 21.

${ }^{353}$ FERNANDES, Luís A. Carvalho; LABAREDA, João. Colectânea de estudos sobre a insolvência, Lisboa: Quid Juris, reimpressão, 2011, pp. 42, 62, 65 e dos mesmos autores em Código da insolvência e da recuperação de empresas anotado. Lisboa: Quid Juris, reimpressão, 2009, pp. 58-59; SERRA, Catarina. $O$ novo regime português da insolvência: uma introdução. 4. edição, Almedina, Coimbra, 2011, p. 18; LEITÃ̃, Luís Manuel Teles de Menezes. Direito da insolvência. 3. edição, Coimbra: Almedina, 2011 , p. 81. 354 " $O$ código de insolvência e da recuperação de empresas - CIRE tem subjacente uma filosofia totalmente distinta do anterior Código dos processos especiais de recuperação de empresa e da falência. Enquanto antes se encarava a falência como a última ratio, dando-se primazia à recuperação e estruturando-se o processo do ponto de vista da protecção do credor (existindo um processo específico de recuperação de empresa), hoje privilegia-se a liquidação do patrimônio do devedor (equivalente a anterior falência) estando o processo estruturado na perspectiva da proteção dos credores."(COSTEIRA, Maria José ( coautora, Miscelânias $n^{\circ} 06$ do Instituto de Direito das Empresas e do Trabalho - IDET). O código da insolvência e da recuperação de empresas revisitado. Coimbra: Almedina, 2010, p. 51).

${ }^{355}$ FERNANDES, Luís A. Carvalho; LABAREDA, João. Colectânea de estudos sobre a insolvência. Lisboa: Quid Juris, reimpressão, 2011, p. 49.
} 
admitindo acordo por meio dos chamados "contratos de viabilização", ${ }^{356}$ demonstrando evidente preocupação com o saneamento de empresas em dificuldades. ${ }^{357}$

Sob a inspiração do mesmo ideal de viabilização das empresas em situação de crise, criou-se a PARAEMPRESA, ${ }^{358}$ sociedade anônima com a subscrição de capitais por instituições de crédito, tendo por objeto a "recuperação de empresas de estatuto privado em dificuldades financeiras, mas economicamente viáveis."

Após, e pela primeira vez, com o DL n. 177/86, de 2 de julho, criou-se no CPC/61, um sistema judicial de apreciação de viabilidade econômica da empresa, com fixação de medidas reorganizatórias voltadas à sua recuperação, por intermédio da gestão controlada, que consistia "num plano de recuperação económica da unidade empresarial, a executar por nova administração, eventualmente fiscalizada por uma comissão designada, para o efeito, pela assembleia de credores. "359

Naquela oportunidade, estavam lançadas as bases sobre as quais o direito concursal português solidificava uma tendência para a falência-saneamento ${ }^{360}$ e que veio a ser integralmente acolhida com a promulgação do CPEREF - Código de Processos Especiais de Recuperação da Empresa e da Falência, diploma que veio a ser revogado pelo CIRE, atualmente em vigor.

O CPEREF, diploma revogado pelo sistema vigente, foi inovador no direito concursal português, porquanto assentado sob a óptica da "prevalência da recuperação das empresas economicamente viáveis sobre a declaração da falência (art. $1^{o}, n$. 2)" que “revelava uma nova dimensão da empresa que passou a ser considerada na sua projecção

\footnotetext{
${ }^{356}$ DL n. 864/76, de 23 de dezembro e o DL n. 124/77, de $1^{\circ}$ de abril.

${ }^{357}$ FERNANDES, Luís A. Carvalho; LABAREDA, João. Colectânea de estudos sobre a insolvência. Lisboa: Quid Juris, reimpressão, 2011, pp. 42 e 62-65.

${ }^{358}$ DL N. 125/79, de 10 de maio.

${ }^{359}$ FERNANDES, Luís A. Carvalho; LABAREDA, João. Colectânea de estudos sobre a insolvência. Lisboa: Quid Juris, reimpressão, 2011, p. 56.

360 “Como noutra oportunidade se esclareceu, entende-se por 'falência-liquidação' o sistema em que a falência funciona unicamente como meio de liquidação dos bens para satisfação dos credores; por 'falênciasaneamento' entende-se o sistema em que a falência tem por missão principal o saneamento da economia. Este último pode assumir duas formas: uma, em que a preocupação é conservar, a todo o custo, as unidades empresariais e se afirma a preferência absoluta para a recuperação sobre a liquidação; outra, mais moderada, em que, sem prejuízo da prioridade da recuperação, algumas empresas são imediatamente eliminadas em virtude da inexistência de condições objetivas favoráveis à sua recuperação." (SERRA, Catarina. A falência no Quadro da Tutela jurisdicional dos Direitos de Crédito. Coimbra Editores, 2009, p. 197.)
} 
social, enquanto veículo de produção de riqueza e de emprego, que importava preservar, quando possível, afastando as inviáveis."361_362

O referido diploma inovou quanto ao seu alcance do ponto de vista subjetivo, já que nele o conceito de empresa (atividade) passou a ser tomado em sentido amplo, ou seja, abrangia a pessoa singular ou jurídica, empresária ou não, mas que desenvolvesse atividade econômica de qualquer natureza. Assim, por empresa, conforme definia o artigo $2^{\circ}$ do CPEREF, entendia-se "toda a organização dos factores de produção destinada ao exercício de qualquer atividade agrícola, comercial ou industrial ou de prestação de serviços."

Portanto, a própria adoção de um critério subjetivo mais abrangente refletia a preocupação com a possibilidade de saneamento de qualquer atividade que fosse geradora ou promovesse a circulação de riquezas.

Em contrapartida, no diploma atualmente em vigor, como anotam Luís A. Carvalho Fernandes e João Labareda, "o certo é que, globalmente considerado, o regime do Código (CIRE) é dominado pela finalidade da liquidação da massa insolvente. A confirmá-lo está o facto significativo de o $n^{\circ} 1$ do art. 192, quando descreve genericamente o conteúdo do plano de insolvência, não referir, sequer, a recuperação da empresa, ao contrário do que seria legítimo esperar, em face do art. $1^{\text {o., }}, 363$

Catarina Serra assegura que "O Código da Insolvência e da Recuperação de Empresas abre uma nova fase: elimina o primado da recuperação”, explicando, em nota, que "não é tanto a medida de eliminação do primado que merece ser criticada (a recuperação não pode ser imposta a qualquer custo) e sim a medida de eliminação dos critérios objectivos para a recuperação - designadamente, a eliminação das condições da

\footnotetext{
361 FERNANDES, Luís A. Carvalho e LABAREDA, João. Colectânea de estudos sobre a insolvência. Lisboa: Quid Juris, reimpressão, 2011, p. 59.

${ }^{362}$ Mas António Menezes Cordeiro afirma, em relação às "reformas vintistas das leis da falência, a problemática sócio-económica ligada aos temas concursais levou os legisladores a privilegiar soluções que permitissem a recuperação das empresas" que "A prática do sistema mostrou ser mau caminho. As empresas em dificuldades não se recuperam, pela natureza das coisas, por si só. A obrigatoriedade de percorrer o calvário da recuperação para, depois, encarar a fase concursal, traduzia-se, em regra, num sorvedouro de dinheiro, com especiais danos para os credores e os próprios valores subjacentes à empresa". (CORDEIRO, António Menezes. Manual de direito comercial. 2. edição, Coimbra: Almedina, 2009, p. 447)

${ }^{363}$ FERNANDES, Luís A. Carvalho; LABAREDA, João. Colectânea de estudos sobre a insolvência. Lisboa: Quid Juris, reimpressão, 2011, p. 66.
} 
viabilidade económica e da recuperação financeira - e a insusceptibilidade de controle judicial da decisão de recuperação., 364

Na mesma linha de ideias, a referida autora critica o diploma agora vigente, por seu viés privatista: “o CIRE tem um pendor claramente liberal: por força da insolvência, os credores convertem-se em proprietários econômicos da empresa e devem prevalecer os mecanismos próprios de regulação de mercado. Daí que se desjudicialize a recuperação da empresa e se dê ampla margem de manobra aos credores. Mas, não havendo um critério objectivo nem um (mínimo) de controlo judicial da decisão sobre o destino da empresa, estabelece-se o domínio absoluto dos interesses privados. „365_366

Para os autores acima mencionados, assim, a recuperação da empresa, no CIRE, passou a ser instrumento de satisfação dos credores, consagrando-se um retorno ao sistema falência-liquidação, em evidente retrocesso, segundo proclama parte da doutrina ${ }^{367}{ }^{368}$.

Mas o ponto central da questão, pelo que parece, relaciona-se com a exclusão do critério de viabilidade econômica do sistema, deixando livre a atuação pela

\footnotetext{
${ }^{364}$ SERRA, Catarina, A falência no Quadro da Tutela jurisdicional dos Direitos de Crédito. Coimbra, Coimbra Editores, 2009, p. 201.

365 SERRA, Catarina. O novo regime português da insolvência: uma introdução. 4. edição, Coimbra, Coimbra, 201, p. 21.

${ }^{366}$ A crítica está na mesma linha daquela feita por Fábio Ulhoa Coelho, para quem, em princípio, quando a crise da empresa não encontra solução de mercado, a falência deveria ser a solução adequada. Mas o autor alerta que nem sempre esta afirmação é válida, pois: "Quando as estruturas do sistema econômico não funcionam convenientemente, a solução de mercado simplesmente não ocorre. Nesse caso, o estado deve intervir, através do Poder Judiciário, para zelar pelos vários interesses que gravitam em torno da empresa (dos empregados, consumidores, fisco, comunidade, etc.)". Curso de direito comercial. São Paulo: Saraiva, 12. edição, $2^{\mathrm{a}}$ tiragem, 2011, vol. III, p. 253.

367 " a ideia da recuperação é secundária ou subalternizada e a recuperação não é um processo, dado que o processo de insolvência é o único admissível, sendo a recuperação apenas um fim possível, entre outrosl, do plnao de insolvência, que constitui a verdadeira alternativa à liquidação.” (LEITÃO, Luís Manuel Teles de Menezes. Direito da insolvência, 3. edição, Coimbra: Almedina, 2011, p. 81).

368 "Doutro passo, a perspectiva predominantemente institucional da empresa que era privilegiada pela lei anterior surge agora claramente substituída pela óptica objectivista que conduz a que ela seja encarada essencialmente como objecto de direitos por partes do empresário, desvalorizando-se a circunstância de, no plano sócio-jurídico, configurar um centro autónomo de congregação de interesses de várias categorias de sujeitos e, nessa medida, justificadora de uma consideração 'a se'." (FERNANDES, Luís A. Carvalho; LABAREDA, João. Código da insolvência e da recuperação de empresas anotado. Lisboa: Quid Juris, reimpressão, 2009, pp. 83-84).
} 
vontade dos credores, isto sim um retrocesso, e que não se confunde com um retorno ao sistema de falência-liquidação, anterior ${ }^{369}$.

Há um evidente movimento pendular em curso no direito português, na busca de um ponto de equilíbrio nas relações entre o devedor e os credores no procedimento concursal. Esse movimento ainda mantém como norte a salvaguarda da empresa.

Não se pode olvidar que um sistema excessivamente "pró-devedor" pode ter efeitos perversos, na medida em que empresas que não estejam em condições de prosseguir no exercício da atividade empresarial devem ser liquidadas, pois a sua preservação não pode ser um fim em si mesmo nem um conceito absoluto. A manutenção da saúde do mercado depende da célere retirada daquelas empresas que não estejam em condições de prosseguir de forma saudável em suas atividades.

Veja-se que Catarina Serra defende que a posição atual do sistema concursal português está justificada nos excessos ocorridos durante a vigência do sistema anterior e que acabaram por dar causa a esse movimento atual, de proteção dos credores. A autora afirma que "hiperbolizou-se de tal forma o propósito de recuperação da empresa que se perderam de vista os seus critérios e os seus limites de aplicabilidade." ${ }^{370 \_371}$

De qualquer modo, toda a sistemática envolvida no concurso português passa por esta lógica da supremacia de poderes dos credores e, principalmente, de uma definição clara de objetivo, qual seja, o procedimento concursal é meio de satisfação dos interesses dos credores.

E não é outra a razão pela qual o artigo $1^{\circ}$ do CIRE proclama que “ $O$ processo de insolvência é um processo de execução universal', pois logo de início

\footnotetext{
${ }^{369}$ Entretanto, essa posição não é unânime, pois a “(re)valorização dos interesses privados, sobretudo por contraste com o sistema imediatamente anterior, não pode ser vista como um pleno retorno ao esquela rudimentar da 'falência-liquidação'."(SERRA, Catarina, A falência no Quadro da Tutela jurisdicional dos Direitos de Crédito, Coimbra, Coimbra Editores, 2009, p. 222)

${ }^{370}$ SERRA, Catarina. O novo regime português da insolvência: uma introdução. 4. edição, Coimbra: Coimbra, 2011, p. 17.

${ }^{371}$ É também a posição de CORDEIRO, António Menezes, Manual de direito comercial. 2. edição, Coimbra: Almedina, 2009, p. 447.
} 
reafirma o caráter executivo do processo, focando sua atenção na satisfação dos credores $^{372}{ }^{373}$.

De fato, o relatório preambular do CIRE enfatiza, com firmeza, que todo o sistema concursal está erigido em torno da finalidade de satisfação dos credores, atribuindo-lhes os poderes necessários para atingir tal desiderato. ${ }^{374}$

Assim, sob tal óptica, referimos alguns dos aspectos que a doutrina de Luís A. Carvalho Fernandes e João Labareda ${ }^{375}$ afirmam constituir os pontos mais significativos da reforma introduzida pelo CIRE: (i) a finalidade do processo de insolvência como meio de satisfação dos credores, o que teria acarretado sua unificação ${ }^{376}$; (ii) mudança nos pressupostos objetivos e subjetivos da insolvência; (iii) reforço do papel dos credores; (iv) a desjudicialização. A reforma que levou à promulgação do CIRE está evidentemente inspirada no direito alemão, como pontua António Menezes Cordeiro, que considera tal influência como 'vantajosa, 377 .

\footnotetext{
${ }^{372}$ Embora seja uma execução de caráter particular, na medida em que pode "não haver necessariamente liquidação de todo o patrimônio do devedor. Por um lado, pode vir a ser aprovado no processo um plano de insolvência que não preveja a liquidação do património do devedor. Por outro lado pode a insolvência ser decretada e, se logo nesse momento se concluir que o devedor não tem património suficiente para satisfazer as despesas e custas do processo, não haver lugar sequer à apreensão do seu património, nem, consequentemente, sua liquidação". (COSTEIRA, Maria José (coautora, Miscelânias no 06 do Instituto de Direito das Empresas e do Trabalho - IDET). O código da insolvência e da recuperação de empresas revisitado. Coimbra: Almedina, 2010, p. 75).

${ }^{373}$ Há, de fato, três hipóteses em que não haverá liquidação no processo concursal. São os casos em que há: (i) dispensa da liquidação, ou seja, a satisfação dos credores é atingida por outro meio; (ii) interrupção da liquidação por ser a massa falida insuficiente para satisfazer as custas do processo, do que resulta seu encerramento, e (iii) a suspensão da liquidação, por fato que a enseje, como por exemplo por decisão da assembleia de credores, para que o administrador da insolvência elabore um plano. (EPIFÂNIO, Maria do Rosário. Manual de direito da insolvência. 2. edição, Coimbra: Almedina, 2010, p. 229).

374 "Na jurisprudência, no sentido de que 'a nova codificação falimentar (CIRE), delineada em função do objetivo precípuo da eficiente e célere satisfação dos direitos dos credores, veio consolidar a vontade destes como informando o comando de todo o processo, assim, relegando o administrador para alguma subalternidade', veja-se o Ac. Rel. Guim. De 29-11-2007, (Gomes da Silva), in http://www.dgsi.pt." (citado por EPIFÂNIO, Maria do Rosário. Manual de direito da insolvência, 2. edição, Coimbra: Almedina, 2010, p. 13).

${ }^{375}$ FERNANDES, Luís A. Carvalho e LABAREDA, João. Colectânea de estudos sobre a insolvência. Lisboa: Quid Juris, reimpressão, 2011, p. 64.

${ }^{376}$ Neste ponto, concorda-se apenas em parte com essa afirmação dos autores. A unificação do processo não resulta da mudança na finalidade do sistema concursal (satisfação dos credores), mas sim como afirma Catarina Serra, da supressão do conceito de viabilidade econômica como requisito objetivo da insolvência, conforme acima mencionado. Além disso, o direito francês é também unificado e se trata de sistema declaradamente pró-devedor. Desse modo, nosso entendimento é o de que a unificação do sistema não resulta, necessariamente, em uma forma de proteção do interesse dos credores.

${ }^{377}$ Manual de direito comercial. 2. edição, Coimbra: Almedina, 2009, p. 411.
} 
As mudanças realizadas no sistema agora em vigor estão, por assim dizer, amalgamadas umas às outras, pois erigidas para integrar um verdadeiro procedimento de execução coletiva, no interesse dos credores.

É o caso da desjudicialização promovida pelo CIRE, realizada sob o argumento de que contribuiria para a celeridade ${ }^{378}{ }^{379}$ do processo. Na verdade, isto resultou em manifesto enfraquecimento dos poderes do juiz, com a respectiva concentração nas prerrogativas dos credores (em particular, pelo aumento das atribuições da assembleia), além de aumento expressivo dos poderes do administrador da insolvência ${ }^{380}$.

Ao ser declarada a insolvência, por sentença, o juiz nomeia o administrador da insolvência ${ }^{381}$, a quem incumbirá elaborar: (i) o inventário dos bens e direitos que integram a massa insolvente (ou massa falida objetiva); (ii) a relação de credores, com indicação do valor e classificação de seus créditos (massa falida subjetiva); e, de particular importância, (iii) um relatório, conforme especificado no artigo 155 da lei.

\footnotetext{
378 "O fator tempo adquire, na falência, uma dimensão de primeiro plano. Desde o momento em que se anuncie algum dos motivos de declaração de falência até o ao termo da liquidação do património responsável, verifica-se uma situação de incerteza que paralisa os bens e veda as iniciativas dos agentes envolvidos. Os meios produtivos implicados são afectados, sendo ainda de aguardar deteriorações $e$ desperdícios. E enquanto o processo se arrastar, acumulam-se, naturalmente, as próprias despesas motivadas por ele, pelos seus incidentes e pela manutenção e administração da massa falida" (CORDEIRO, António Menezes. Manual de direito comercial. 2. edição, Coimbra: Almedina, 2009, p. 425).

${ }^{379}$ A propósito da celeridade do processo concursal como um dos pontos de foco da reforma: "Sobre tudo isto vão, depois, assentar os "custos de transacção": tanto maiores quanto mais complexos, mais demorado e mais inseguro for o processo de insolvência. Fica bem claro que estes "custos de transaç̧ão" podem comprometer todos os outros objetivos do processo falimentar. Pede-se um processo eficaz, que respeite a verdade material, mas que conduza a um epílogo rápido. Quanto mais depressa for possível entregar a falência aos credores, mais cedo ficará o Estado - particularmente na sua vertente jurisdicional - exonerado de uma responsabilidade que, de todo, não lhe incumbe.." Ao final, o autor conclui justificando como correta a adoção da atual primazia dos interesses dos credores no processo concursal: "O processo de recuperação era lento; durante muitos meses, a empresa via aumentar o seu défice, de tal modo que a recuperação ia se desvanecendo". (CORDEIRO, António Menezes. Manual de direito comercial. 2. edição, Coimbra: Almedina, 2009, pp. 446-447).

380 "Em particular, neste domínio, a deslocação de poderes dá-se para o administrador da insolvência, cuja competência se estende às mais diversas fases e actos do processo, cabendo-lhe as operações de administração, liquidação e partilha da massa insolvente, mas, também, como se dirá de seguida, uma muito importante intervenção na verificação dos créditos.", sendo que quanto a este último aspecto, a autora tece crítica, tendo por excessiva a interferência no procedimento de verificação dos créditos. (SERRA, Catarina. O novo regime português da insolvência: uma introdução. 4. edição, Coimbra, 2011, pp.73-74).

${ }^{381}$ Ainda que o juiz faça a nomeação do administrador da insolvência na sentença declaratória da insolvência, escolhido dentre uma lista de pessoas inscritas como autorizadas a atuar, conforme previsto no Estatuto do Administrador da Insolvência, a assembleia de credores poderá mudar a indicação (artigo 53, n. 1), evidenciando-se, portanto, mais um aspecto da supremacia dos poderes dos credores. Catarina Serra anota, inclusive, que parte da doutrina tem afirmado ser inconstitucional o referido dispositivo por se permitir que a assembleia de credores modifique uma decisão judicial. (SERRA, Catarina. O novo regime português da insolvência: uma introdução. 4. edição, Coimbra, 2011, p. 39).
} 
Em razão da importância de referido relatório elaborado pelo administrador da insolvência (artigo 155), detenhamo-nos nas linhas gerais de seu conteúdo. Dentre outros elementos, o relatório deverá conter: (i) uma análise dos registros contábeis do devedor, com manifestação de opinião a respeito dos documentos respectivos; (ii) a indicação das perspectivas de manutenção da empresa, no todo ou em parte, e da conveniência da aprovação de um plano de insolvência, indicando-se, desde logo, aos credores, os possíveis cenários decorrentes de tal plano.

Não é difícil de aquilatar que os poderes atribuídos pela lei concursal portuguesa ao administrador da insolvência concedem a este grande discricionariedade e verdadeira força de orientação quanto ao destino da empresa. E não é só: seus atos não comportam revisão por decisão judicial ${ }^{382}{ }_{-}^{383}$, já que o legislador preferiu optar pela responsabilização por eventuais danos causados ${ }^{384}{ }^{385}$ ou possibilidade de destituição ${ }^{386} \mathrm{em}$ caso de descumprimento dos deveres que a lei lhe impõe.

Com efeito, na primeira assembleia de credores $^{387}$, o administrador da insolvência apresenta o relatório de que trata o artigo 155 e os credores deliberam sobre o encerramento ou a manutenção da atividade empresarial, bem como sobre a eventual atribuição, ao próprio administrador da insolvência, da tarefa de elaboração de um plano,

${ }^{382}$ COSTEIRA, Maria José (coautora, Miscelânias no 06 do Instituto de Direito das Empresas e do Trabalho - IDET). O código da insolvência e da recuperação de empresas revisitado. Coimbra: Almedina, 2010, p. 55.

383 “Outra manifestação da desjudicialização, que o próprio Relatório do decreto preambular destaca (último parágrafo do $n^{\circ} 10$ ), é a inexistência de reclamação, para o juiz, dos actos do administrador da insolvência e das deliberações da comissão de credores." FERNANDES, Luís A. Carvalho; LABAREDA, João. Colectânea de estudos sobre a insolvência. Lisboa: Quid Juris, reimpressão, 2011, p. 94). Vide ainda p. 31 da mesma obra.

384 SERRA, Catarina. O novo regime português da insolvência: uma introdução. 4. edição, Coimbra, 2011, pp. $39-40$.

35 Além do CIRE, há disciplina ao administrador da insolvência em lei própria: EAI - Estatuto do Administrador da Insolvência, estabelecido pela Lei n. 32/2004, com alterações pelo DL n. 282/2007 e DL n. 34/2009. O sistema, portanto, é de profissionalização desta atividade, tanto que se encontra sob a fiscalização de uma comissão, de âmbito nacional (Comissão de Apreciação e Controlo de Actividade dos Administradores da Insolvência) que está sob dependência direta do Ministério da Justiça. (SERRA, Catarina. O novo regime português da insolvência: uma introdução. 4. edição, Coimbra, 2011, p. 41).

386 "O administrador da insolvência (nomeado pelo juiz ou eleito pelos credores) pode ser destituído pelo juiz, a todo tempo, e ser substituído por outro, com fundamento em justa causa, desde que tenham sido ouvidos a comissão de credores, o devedor e o próprio administrador da insolvência (art. $56^{o}$, n.1). A lei não define 'justa causa' e nem tampouco apresenta critérios norteadores para o seu preenchimento, por um lado, e, por outro lado, não associa qualquer sanção à destituição por justa causa." (EPIFÂNIO, Maria do Rosário. Manual de direito da insolvência. 2. edição, Coimbra: Almedina, 2010, p. 59).

${ }^{387}$ E que Catarina Serra diz ser o momento decisivo do processo de insolvência, que ocorre entre 45 e 75 dias (artigo $36^{\circ}$, alínea ' $\mathrm{n}$ ') após a sentença de declaração. (O novo regime português da insolvência: uma introdução. 4. edição, Coimbra, 2011, p. 23). 
caso em que poderá ser deliberada a suspensão da alienação dos ativos (artigo 156, n. $03)^{388}$.

Em contrapartida, vale lembrar que como efeito da declaração de insolvência, o devedor foi desapossado de seus bens e, como consequência, perdeu o direito de administrá-los. Os poderes de administração da massa insolvente passam, assim, desde logo, ao administrador da insolvência (artigo 81, n. $1^{\circ}$ ), que os exercerá com a colaboração da comissão de credores (se instaurada, artigo 55, n. 01) e sob a fiscalização do juiz (artigo 58), até a deliberação a respeito da continuidade ou encerramento da atividade.

Portanto, a administração da massa insolvente, pelo devedor, ocorre em caráter de exceção e somente se dará se, cumulativamente, concorrerem as seguintes condições (artigos 36, alínea 'e', e 223): (i) existência de empresa (conforme conceito expresso no artigo $5^{\circ}$ do CIRE); (ii) requerimento expresso do devedor; (iii) apresentação de um plano de insolvência pelo devedor, ou comprometimento de apresentá-lo, no prazo legal; (iv) manifestação de concordância do credor que tenha requerido a instauração do procedimento concursal; (v) inexistência de razões para recear atrasos no processo ou outras desvantagens para os credores (artigo 224, n. 02, alínea 'c').

Desse modo, a supremacia dos interesses dos credores fica destacada não apenas na escolha do destino da empresa, mas também na gestão da massa insolvente, logo após a declaração judicial do processo com a decretação da insolvência.

Do ponto de vista do pressuposto objetivo, o CIRE adota o critério da insolvência do devedor ${ }^{389}$, que poderá ser atual ou iminente (artigo $3^{\circ}$ ), sendo que “ $a$ primeira verifica-se quando o devedor se encontre impossibilitado de cumprir suas obrigações vencidas e, tratando-se de pessoa colectiva, também quando o seu passivo for

\footnotetext{
${ }^{388}$ SERRA, Catarina. O novo regime português da insolvência: uma introdução. 4. edição, Coimbra, Coimbra Editora, 2011, pp. 116-117.

389 "I - Para se verificar insolvência, a impossibilidade de cumprimento não tem de abranger todas as obrigações assumidas pelo insolvente e já vencidas. II - O que releva para se decretar a insolvência é a insusceptibilidade de satisfazer as obrigações que, pelo seu significado conjunto do passivo do devedor, evidenciam a impotência para o obrigado de continuar a satisfazer a generalidade de seus compromissos." (Tribunal de Relação do Porto, 17/11/2008, Proc. N. 5583/2008, Comarca de Lousada - 2o juízo, em "Contratos Comerciais, Direito Bancário e Insolvência (CIRE) - Jurisprudência 200-2009, Coord. ESPÍRITO SANTO, Luís Filipe, Colectânea de Jurisprudência Edições, p. 595).
} 
manifestamente superior ao seu activo. A segunda quando ainda não se verifique uma impossibilidade de cumprimento das obrigações vencidas, mas for expectável e mesmo inevitável que tal aconteça num futuro próximo." $390 \_391$

Veja-se, o critério da insuficiência patrimonial é admitido pela lei (artigo $3^{\circ}$, n. 2) como um acessório para a definição de insolvência, na medida em que é aplicável somente às pessoas jurídicas e patrimônios autônomos (como é o caso do espólio, por exemplo ${ }^{392}$ ). Adicione-se, ainda, que, para efeito de insolvência, a leitura dos balanços de insuficiência patrimonial sofre um ajuste às regras tradicionais de contabilidade, pois se admite a inclusão de certos elementos identificáveis pelo ‘justo valor' e a avaliação da empresa pode ser realizada sob uma perspectiva de continuidade (trespasse) ${ }^{393}$.

A exemplo do que ocorre no direito concursal alemão (InsO), no qual o direito português foi fortemente inspirado, como já dito, o requerimento com fundamento no pressuposto da insolvência iminente só pode ser deduzido pelo próprio devedor, “com vista a evitar que os credores detenham qualquer tipo de poder de pressão na antecâmara da insolvência" ${ }^{394}{ }_{-}^{395}{ }^{396}$. Por outro lado, no pedido com fundamento na insolvência atual, têm legitimidade ativa o devedor, os legalmente responsáveis ${ }^{397}$, qualquer credor, e o Ministério Público.

\footnotetext{
${ }^{390}$ COSTEIRA, Maria José ( coautora, Miscelânias no 06 do Instituto de Direito das Empresas e do Trabalho - IDET). O código da insolvência e da recuperação de empresas revisitado. Coimbra: Almedina, 2010, p. 57.

${ }^{391}$ Em relação à adoção dos pressupostos objetivos de caracterização de insolvência, também se observa a forte influência do direito concursal alemão.

${ }^{392}$ Note-se, no plano subjetivo, a personalidade jurídica do devedor não constitui critério relevante para fixação da insolvência, sendo importante a autonomia patrimonial. (SERRA, Catarina. O novo regime português da insolvência: uma introdução, $4^{\mathrm{a}}$ edição, Coimbra, Coimbra Editora, 2011, p.69).

${ }^{393}$ LEITÃO, Luís Manuel Teles de Menezes. Direito da Insolvência, 3. edição, Coimbra: Almedina, 2011, pp. 86-86.

${ }^{394}$ EPIFÂNIO, Maria do Rosário. Manual de Direito da Insolvência. 2. edição, Coimbra: Almedina, 2010, p. 25.

${ }^{395}$ Porém, Maria José Costeira critica esse posicionamento, afirmando que "essa opção do legislador de permitir apenas ao devedor a propositura do processo quando a situação é de insolvencia é iminente é contrário ao próprio espírito do código, na medida em que contraria a pretensão de encontrar soluções rápidas e eficazes para as empresas que se encontram em situação económica difícil." (COSTEIRA, Maria José (coautora, Miscelânias no 06 do Instituto de Direito das Empresas e do Trabalho - IDET). O código da insolvência e da recuperação de empresas revisitado. Coimbra: Almedina, 2010, p. 57).

${ }^{396}$ Catarina Serra também defende a restrição, pois, segunda a autora, atribui tal legitimidade também aos credores "significaria dar a outros sujeitos o poder de iniciar o processo de insolvência em face de uma situação que só é perceptível, com segurança, pelo devedor." (O novo regime português da insolvência: uma introdução. 4. edição, Coimbra, 2011, p. 28).

${ }^{397}$ Aqui o legislador refere-se aos sócios que respondem pessoal e ilimitadamente pelas obrigações de sociedade que admitam esse tipo de sócio, o que tem alcance limitado, conforme anota COSTEIRA, Maria
} 
Outra característica semelhante ao direito alemão foi a de unificação do procedimento $^{398}$, cuja vantagem seria a "supressão da duplicação de chamamento dos credores ao processo e o desaparecimento da fase preambular comum aos dois processos existentes no regime anterior. Há agora uma fase única de citação dos credores com vista à reclamação dos créditos, que tem lugar até trinta dias após a sentença de declaração de insolvência (art. 36 ${ }^{\text {, al. J) }}{ }^{\text {,399. }}$.

Assim, os processos de insolvência têm uma tramitação inicial comum novidade trazida pelo CIRE - conducente a uma decisão de possível declaração de insolvência do devedor.

Na hipótese de declaração do estado de insolvência, os credores passam a ter o direito de decidir quanto ao destino da empresa, ou seja, deliberam se deverá esta ser liquidada ou submetida a um plano de insolvência (artigo $192^{\circ}$ e ss), o qual poderá tanto prever modo especial de liquidação da empresa no interesse dos credores, quanto estabelecer uma reorganização, para continuação das atividades, sob um novo ou o mesmo titular.

$\mathrm{Na}$ decisão que declara a insolvência designa-se uma assembleia na qual os credores deliberam a respeito da continuidade ou não da empresa e, se for o caso de insuficiência da massa, pela extinção do processo, sob tal fundamento ${ }^{400}$.

José (coautora, Miscelânias no 06 do Instituto de Direito das Empresas e do Trabalho - IDET). O código da insolvência e da recuperação de empresas revisitado. Coimbra: Almedina, 2010, p. 59.

${ }^{398}$ Que também não é absoluta, eis que: (i) os procedimentos de reestruturação do passivo do consumidor estão previstos em lei especial, (ii) vigora ainda o DL n. 315/98, que disciplina o procedimento de conciliação, de caráter administrativo, (iii) há legislação específica para contratos de garantia financeira. (SERRA, Catarina. O novo regime português da insolvência: uma introdução. 4. edição, Coimbra, Coimbra Editora, 2011, p. 67).

399 SERRA, Catarina. O novo regime português da insolvência: uma introdução. 4. Edição, Coimbra, Coimbra Editora, 2011, p.24.

400 "Acontece que em mais de $90 \%$ dos casos a Assembleia de Credores delibera o encerramento dos estabelecimentos da insolvente (sendo que na maior parte dos casos, nesse momento, já não há estabelecimentos em atividade) e o prosseguimento do processo para liquidação do activo ou, perante o relatório apresentado pelo Administrador da Insolvência, e por requerimento do próprio, formulado no relatório ou na própria assembleia, pronuncia-se desde logo pelo encerramento do processo por insuficiência da massa, nos termos do art. 232.". (COSTEIRA, Maria José (coautora, Miscelânias no 06 do Instituto de Direito das Empresas e do Trabalho - IDET). O código da insolvência e da recuperação de empresas revisitado. Coimbra: Almedina, 2010, p. 53). 
A impugnação da sentença, pelo devedor, poderá realizar-se, simultaneamente, por recurso ${ }^{401}$ ou por embargos ${ }^{402}$ e, enquanto não decididos ambos, nenhum ato de liquidação dos ativos poderá ocorrer (artigo 158, n. 01), exceto se se tratarem de bens perecíveis ou deterioráveis.

Um aspecto importante da propalada desjudicialização do processo concursal português fica evidenciado no procedimento de verificação e graduação dos créditos.

$\mathrm{Na}$ decretação da insolvência, a sentença fixa prazo aos credores para que apresentem seus créditos diretamente ao administrador da insolvência que, por sua vez, apresentará nos 15 dias subsequentes ao término do prazo, uma lista dos credores reconhecidos (com sua respectiva classificação e valor), e também dos credores não reconhecidos. A declaração, pelo administrador da insolvência, dos credores não reconhecidos exige que a exclusão de crédito seja fundamentada.

Somente depois, o credor que não concordar com a relação apresentada pelo administrador da insolvência tem direito de impugnação, este dirigido ao juiz. As impugnações são autuadas em um único apenso e julgadas simultaneamente, após realização de provas, se necessário. Como se vê, o procedimento de formação do quadro geral de credores, com preponderância da atuação do administrador judicial e reserva da atuação jurisdicionalmente somente na hipótese de conflito, é bastante similar ao da lei concursal brasileira atualmente em vigor. Mas há outras semelhanças.

No capítulo que disciplina a liquidação dos bens, no artigo $162^{\circ 403}$, o CIRE trata da venda em bloco dos ativos, sob o título "alienação da empresa". A doutrina interpreta o dispositivo como uma orientação de venda, com critério gradativo, tomando-se

\footnotetext{
401 "Se considerar que a sentença é ilegal, que enferma de uma qualquer nulidade processual ou porque, face aos elementos disponíveis, a decisão deveria ter sido outra." (COSTEIRA, Maria José (coautora, Miscelânias $\mathrm{n}^{\circ} 06$ do Instituto de Direito das Empresas e do Trabalho - IDET). O código da insolvência e da recuperação de empresas revisitado. Coimbra: Almedina, 2010, p. 73).

402 “Já se pretender alegar factos novos, requerer novos meios de prova ou pôr em causa o facto de que o tribunal não ter tido em contao determinados meios de prova, terá de embargar." (COSTEIRA, Maria José (coautora, Miscelânias $\mathrm{n}^{\circ} 06$ do Instituto de Direito das Empresas e do Trabalho - IDET). O código da insolvência e da recuperação de empresas revisitado. Coimbra: Almedina, 2010, p. 73).

${ }^{403}$ Disposição semelhante já era identificada no diploma anterior, o CPEREF, no art. $181^{\circ}$, n. 03.
} 
inicialmente como objetivo primeiro a alienação da empresa como um todo, na acepção do disposto no artigo $5^{\circ}$ e, após, de seus diversos estabelecimentos em separado ${ }^{404}$.

Assim, "o legislador insolvencial previu um conjunto de regras especiais para a alienação da empresa”, conforme anota Maria do Rosário Epifânio ${ }^{405}$. A autora critica, entretanto, já que entende que essa solução poderia ter sido colocada aos credores, no processo, muito antes do início da fase de liquidação. Para a autora, o momento adequado teria sido na oportunidade de apresentação do relatório do administrador da insolvência (artigo 155), pelo qual este deveria ter apresentado as perspectivas de manutenção da empresa, no todo ou em parte, com proposição de medidas a serem submetidas à assembleia de credores.

É nesse sentido que tão logo o administrador da insolvência seja nomeado e aceite o encargo fica autorizado a promover "diligencias para a alienação da empresa do devedor ou dos seus estabelecimentos." (artigo 162, 2). Não significa isto que o administrador deverá iniciar a venda dos ativos, mas diligenciar pesquisas de mercado para aferir quanto à possibilidade e conveniência da alienação em bloco, como meio de satisfação dos credores e concomitante preservação da empresa.

A preterição da venda da empresa como um todo ou de estabelecimento deve estar amparada em uma das duas hipóteses seguintes: (i) inexistência de proposta satisfatória, ou (ii) reconhecimento de vantagem na venda separada das partes. A ideia central, obviamente, é da obtenção de melhor resultado de venda, no interesse e a benefício dos credores.

Luís A. Carvalho Fernandes e João Labareda questionam a quem caberá a decisão sobre a insuficiência da proposta ou o reconhecimento da vantagem na venda em partes, já que a atividade de liquidação cabe ao administrador da insolvência.

Referidos autores sustentam, com fundamento na relevância que envolve o momento da alienação dos bens da devedora, que tal decisão deveria ser submetida

404 FERNANDES, Luís A. Carvalho; LABAREDA, João. Código da tnsolvência e da recuperação de empresas anotado. Lisboa: Quid Juris, reimpressão, 2009, p. 539.

${ }^{405}$ EPIFÂNIO, Maria do Rosário. Manual de direito da insolvência. 2. edição, Coimbra: Almedina, 2010, pp. 234-235. 
previamente à comissão de credores ou assembleia: "de nada serviria considerar a venda da empresa ou dos estabelecimentos como um acto de especial relevo, com a consequência de fazer intervir os creores ou seus representantes para o autorizar, se paralelamente fosse dada ao administrador da insolvência, a seu critério, a possibilidade de escolher a via da venda separada, pois, dessa forma, lograr-se-ia a frustração substantiva dos objectivos da lei, que se traduzem na vontade dos credores, a cuja satisfação o processo se dirige, terem uma palavra determinante no que mais releva em sede de liquidação do património do devedor." ${ }^{406}{ }_{-}^{407} 408$

Porém, e apesar do empenho que o legislador parece ter demonstrado para incentivar a manutenção da empresa como um todo, na prática, dificilmente a alienação em bloco poderia ensejar interesse em potenciais adquirentes.

É que "em caso de transmissão, por qualquer título, da titularidade da empresa, do estabelecimento ou da parte da empresa ou estabelecimento que constitua uma unidade económica, transmite-se para o adquirente a posição jurídica de empregador nos contratos de trabalho dos respectivos trabalhadores, assim como a responsabilidade pelo pagamento de coima correspondente à prática de contra-ordenação laboral (art. 285, n. 1.). Durante o ano posterior à transmissão, pelas obrigações vencidas até a data dessa transmissão respondem solidariamente o transmitente e o adquirente (art. 285 , n. 2), ${ }^{409}$.

A sucessão do passivo trabalhista pode constituir-se em óbice insuperável para a efetiva concretização do dispositivo que prevê a venda em bloco dos ativos, já que a lei trabalhista aplica-se, indistintamente, tanto às hipóteses de cessão ordinária da empresa, quanto às de alienação em processo de insolvência.

\footnotetext{
${ }^{406}$ Código da insolvência e da recuperação de empresas anotado. Lisboa: Quid Juris, reimpressão 2009, p. 540.

${ }^{407}$ No mesmo sentido posiciona-se Luís M. Martins. Processo de insolvência. 2. edição, Coimbra: Almedina, 2010, p. 327).

${ }^{408}$ Confira-se, também, o artigo 161, alíneas 1 e 2, do CIRE.

${ }^{409}$ EPIFÂNIO, Maria do Rosário. Manual de direito da insolvência. 2. edição, Coimbra: Almedina, 2010, pp. 169-170).
} 
Além disso, o plano poderá resultar na manutenção de apenas alguns contratos de trabalho, considerando que a manutenção dos postos de trabalho é considerada pela jurisprudência uma das finalidades do direito da insolvência ${ }^{410}$.

Por outro lado, a alienação de bens objeto de garantia real depende de manifestação do respectivo credor, seja quanto a modalidade de sua realização, seja para informá-lo quanto ao valor de avaliação projetado para a venda.

E o credor com garantia real poderá propor a aquisição do bem, por si ou por terceiro, por preço superior ao de avaliação, desde que apresente caução em dinheiro correspondente a, pelo menos, $20 \%$ do valor da proposta. O administrador da Insolvência terá a faculdade de recusar tal proposta do credor com garantia real, mas a lei prevê que, se o bem vier a ser alienado por valor inferior, o primeiro fica obrigado a colocar o credor na situação que decorreria da proposta.

A lei, portanto, assegura verdadeiro direito de preferência ao credor titular de garantia real, o que, em tese, poderia interferir negativamente na alienação em bloco da empresa $^{411}$.

Relativamente aos créditos fiscais, sujeitam-se estes ao concurso, admitindo-se, inclusive, a redução ou perdão de dívidas de natureza fiscal no plano de insolvência, como se infere do seguinte aresto: "Não se verifica qualquer impedimento na homologação judicial do plano de insolvência aprovado pela assembléia de credores se, nesse plano, estiver prevista redução ou perdão de dívidas, de natureza fiscal" ${ }^{, 12}$.

\footnotetext{
410 "I - O Código de Insolvência e de Recuperação de Empresas (CIRE) permite que os credores aprovem um plano de insolvência alternativo à liquidação do patrimônio insolvente. II - Nos termos de seu art. 194, esse plano deve respeitar o princípio da igualdade dos credores, sem prejuízo das diferenciações justificadas por razões objectivas. III - Verificando-se tais razões, não há obstáculo à homologação do plano que preveja a manutenção apenas de alguns dos contratos de trabalho de trabalhadores da insolvente na empresa adquirente do patrimônio desta e diferentes percentagens de pagamento imediato a certos credores privilegiados." (Acórdão de 12 de julho de 2007, Lisboa, Recurso 5228/07, Comarca de Caldas da Rainha, 1o Juízo Cível), em "Contratos Comerciais, Direito Bancário e Insolvência (CIRE) - Jurisprudência 2002009, Coord. ESPÍRITO SANTO, Luís Filipe, Colectânea de Jurisprudência Edições, p. 698.

411 "A autorização de venda por negociação sem o credor com garantia real e respectivo crédito verificado e graduado tenha sido dada a possibilidade de ser pronunciar sobre o preço proposto pelo administrador da insolvência, integra nulidade susceptível de determinar a anulação do processo posterior incluindo a venda assim realizada." (MARTINS, Luís M. Processo de insolvência. Coimbra: Almedina, 2010, 2. edição, p. 329).

${ }^{412}$ STJ, Acórdão de 04 de junho de 2009, em “Contratos Comerciais, Direito Bancário e Insolvência (CIRE) - Jurisprudência 200-2009, Coord. ESPÍRITO SANTO, Luís Filipe, Colectânea de Jurisprudência Edições, p.
} 
De modo geral, que o direito português consagrou, a exemplo do direito alemão e sob direta influência deste, um sistema de insolvência que está, antes de tudo, comprometido com a satisfação dos credores. A preservação da empresa é um mero instrumento desta, deixando, claramente, de ter lugar de destaque no diploma vigente, o CIRE, em evidente contraste ao sistema revogado do CPEREF.

E é muito importante que se diga para concluir esse tópico que, em nosso sentir, as críticas levantadas pela doutrina ao atual sistema concursal vigente não se relacionam à adoção de um sistema procedimental unificado, que não pode, per se, ser identificado com a orientação de sistema pró-credor.

O sistema atual português, como consequência de abusos incorridos na aplicação do diploma anterior, cuja finalidade principal de preservação de empresas acabou sendo, de alguma sorte, desvirtuada, sofreu drástica reorientação. Na verdade, a mudança de rumos, para adoção de um sistema pró-credor, talvez tenha sido excessiva, quando, na verdade, quiçá se pudesse ter encontrado uma solução de aplicação mais rigorosa de salvaguarda de empresas, que, efetivamente, pudessem provar sua viabilidade aos credores.

A situação enfrentada pelo direito português, assim, pode ser de grande valia para a experiência brasileira. É preciso estabelecer a consciência de que a preservação da empresa não é um valor absoluto a ser perseguido a qualquer custo.

A opção do legislador português por um sistema pró-credor, em contraposição ao precedente, evidencia a busca por melhor equilíbrio entre o saneamento da empresa e a tutela dos interesses dos credores.

676. No acórdão extrai-se o seguinte trecho: "No processo de insolvência, a Fazenda Nacional aceita o concurso de outros credores num quadro excepcional, caracterizado, não já por um elevadíssimo risco, mas pela apurada inviabilidade de não satisfação de todos os créditos sobre o insolvente, neles estando incluídos os créditos do Estado, designadamente os de índole fiscal. Não está aqui - por isso - em causa apenas uma simples relação Estado-contribuinte, mas antes um procedimento visando uma composição de interesses especialmente destinada a minimizar os efeitos da degradação da garantia do crédito de que aquele é titular, e que poderiam conduzir à total impossibilidade de sua realização. Não se trata de uma qualquer faculdade concedida a uma maioria de credores num processo de insolvência de alterar a obrigação contributiva, mas de acautelar a garantia patrimonial dos credores do insolvente, uma que esta já é reconhecidamente insuficiente." 
Com efeito, a supressão do critério de viabilidade, para aferição de uma solução entre a possível liquidação e o saneamento, é um indicativo de total prevalência da decisão dos credores. Isso sim revela um criticável retrocesso do processo concursal, reduzido à forma de execução coletiva, em evidente desalinho das modernas tendências legislativas a respeito da matéria.

\subsection{O direito espanhol}

Os principais fundamentos da reforma de 2003 do direito concursal espanhol que resultaram na promulgação da Ley 22/2003 $3^{413}$, conforme explicitados na exposição de motivos, foram: (i) a necessidade de superação de um sistema legislativo arcaico que não mais atendia as realidades social e econômica do país; e (ii) a unificação da legislação.

A unificação, sob influência do direito alemão, deu-se tanto do ponto de vista procedimental ${ }^{414}$, então previstos em diversos diplomas e, portanto, carente de um corpo sistematizado de regras $^{415}$, quanto do ponto de vista subjetivo, superando-se a dicotomia entre empresários e não empresários.

Neste último aspecto da reforma, elogiável, diga-se de passagem, o legislador não ignora "determinadas especialidades de concurso de los empresarios sometidos a un estatuto próprio (llevanza obligatoria de contabilid, inscrición en el Registro Mercantil) y la existencia en la masa activa de unidades productivas de bienes o

\footnotetext{
${ }^{413}$ Com vigência a partir de $1 \%$ o9/2004.

${ }^{414}$ Segundo Ana Alemán Monterreal, a unidade de procedimento impõe a fixação de um pressuposto objetivo único e que, em princípio, no direito espanhol gira em torno do conceito de insolvência. Todavia, a lei distingue os conceitos de insolvencia actual e insolvencia inminente, de modo que, em determinados casos, refere-se a um conceito de estado patrimonial do devedor e, em outros, se refere à impossibilidade de cumprimento de obrigações. ALEMÁN MONTERREAL, Ana. La insolvencia, una cuestión de terminología jurídica. Santiago de Compostela: Andavira Editora, 2010, pp. 384-385.

415 Antes da reforma, o direito concursal espanhol contava com as seguintes fontes normativas: "Suspensiones de pagos: Ley de Suspensión de Pagos, de 26/07/1922; Código de Comercio, Libro IV, Sección Primeiro; (II) Quiebras: Código de Comercio, Libro IV, arts 1017 y seguintes del Código de Comercio de 1829, y de una forma genérica y subsidiaria por el Título XVIII del Código Civil. Em este sentido, hay que hacer constar que el 8 de enero de 2001 entró en vigor una nueva Ley de Enjuicimiento Civil, en la que se regulam aspectos relativos a los precesos concursales.” (PASCUAL, Julián González. El concurso de acreedores. Una nueva solución para las empresas insolventes. Madrid: Ediciones Estúdios Financeiros, 2003, 17).
} 
de servicios, especialidades que son tenidas en cuenta a lo largo de la regulación del concurso, desde su solicitude hasta su solución mediante convenio o liquidación. „416

A unificação do direito concursal espanhol foi uma das bandeiras da reforma, que levou em consideração não apenas a atividade empresária, mas toda e qualquer atividade negocial que possa ter valor econômico decorrente da organização dos bens ou prestação serviços.

Nota-se, pelos sistemas até aqui analisados, que essa é uma tendência mundial e, segundo penso, de total coerência, pois a crise de um negócio, principalmente para os que desempenham função de circulação ou criação de riquezas, deve ser objeto de tutela única pelo direito.

Em paralelo, a reforma optou pela adoção de um procedimento unificado, pelo qual, após processo de conhecimento, uma vez declarada a instauração do 'concurso,417 - situação que não interrompe, por si só, o exercício da atividade do devedor -, poderá este resultar em uma solução por 'convenio' ou por 'liquidación'.

Assim, logo depois de instaurado o concurso por sentença, segue-se uma fase inicial do procedimento denominada fase común (artigo 26), na qual, fundamentalmente, nomeiam-se os órgãos do processo e são tomadas providências para formação do quadro geral de credores, com delimitação das massas ativa e passiva ${ }^{418}{ }^{419}$.

\footnotetext{
${ }^{416}$ Exposição de motivos da Ley 22/2003, item II.

417 Segundo referido na exposição de motivos, a opção pelo uso da expressão 'concurso' resulta de uma inovação, ao mesmo tempo em que mantém um vínculo com o passado e a tradição do sistema concursal espanhol. O texto menciona que se trata de uma expressão clássica, adotada desde os tratadistas espanhóis do século XVII (Amador Rodrígues (Tratactus de Concursu, 1616) e Francisco Salgado de Somoza (Labirintus Creditorum Concurrentium, 1646)), que descreve a concorrência de todos os credores sobre o patrimônio do devedor. O texto refere, assim, que "no se persigue con ello solamente rescatar un vocablo tradicional en la terminología jurídica española, sino utilizarlo para significar el fenómeno unificador de los diversos procedimientos de insolvencia e identificar así gráficamente el procedimiento único, como ha ocurrido en otras legislaciones". (Exposição de motivos da Ley 22/2003, item II).

${ }^{418}$ Em resumo, com a sentença que declara o concurso e da qual se dá ampla publicidade, seguem-se os seguintes atos que integram a fase común do processo: nomeação dos órgãos de administração e entrega da documentação da devedora a estes; elaboração de um 'informe' que conterá o inventário dos bens e a relação de credores; publicidade do 'informe', impugnação e decisão quanto à relação de credores e inventário de bens e sentença que julga tais impugnações. (GONZÁLEZ PASCUAL, Julián. El concurso de acreedores.Una nueva solución para las empresas insolventes. Madrid: Ediciones Estúdios Financeiros, 2003, 46).

${ }^{419}$ Ressalvando-se, todavia, que em razão do princípio da universalidade (Artigo 76.1, da Ley 22/2003), pelo qual todos os credores até o encerramento do procedimento serão integrados à massa e também como
} 
O convenio consiste em uma metodologia de pagamento dos credores por acordo, que, segundo a exposição de motivos, "es la solución normal del concurso" "420 ao passo que "la liquidación es siempre una solución subsidiaria, que opera cuando no se alcanza o se frustra la de convenio". $421 \_422$

Na mesma linha de ideias, mas sob o ângulo da liquidação, Ibon Hualde López anota que "La Ley Concursal altera desde diferentes perspectivas la noción y el encaje clássicos de la liquidación dentro del proceso concursal. Por un lado, deja de ser la finalidad natural del concurso de acreedores, cedendo protagonismo ante el convenio, que es la solución preferida por el legislador."423

Contudo, como anota Edorta J. E. Herrera, "la proclividad del concurso a una función conservativa de las empresas o actividades professionales, por resultar éstas viables, en tanto que beneficioso para los mismos acreedores, el concursado, sus trabajadores, y acreedores, a cuyo servicio está el convenio negociado entre deudor y acreedores, lo cual expressamente no se quiere confundir con una vocación de saneamento como objeto concursal." 424

Para o citado autor, a partir do século XXI, observou-se uma clara tendência de sobreposição da proteção dos direitos dos credores em relação à salvaguarda da empresa

consequência de alterações no inventário (por reintegração de ativos ou por perda de bens decorrentes do exercício de direitos de créditos com privilégio), é possível que a formação da relação de bens e direitos sofra modificações até o final do procedimento. (HUALDE LÓPEZ, Ibon. Régimen jurídico de la administración concursal en la fase de liquidación del concurso. Estudios de Derecho Concursal. 1. edición, Espanha: Thomson Civitas, 2009, p. 302).

${ }^{420}$ Exposição de motivos da Ley 22/2003, item VI.

${ }^{421}$ Exposição de motivos da Ley 22/2003, item VII.

${ }^{422}$ Todavia, em tom de crítica, Ibon Hualde López anota: "Yes que, como se dirá en páginas posteriores, la prioridade teórica del convenio resulta cuestionada por la gran discricionariedade que ostenta el deudor concursado para arruinar toda la expectativa de que el proceso se resulva a través de dicha solución. La Ley Concursal pone a disposición del deudor todo un abanico de possibilidades para eludir o abortar cualquier intento de los acreedores de obtención de un acordo de esa naturaliza; possibilidades que se materializan en una serie de secuencias procesales a que el deudor puede acogerse con el fim de solicitar la apertura de la fase de liquidación, en contra de aquella otra solución. Todo ello con independencia de la viabilidade futura de la empresa, circunstancia que nos es tomada en consideración a la hora de fijar el rumbo des procedimiento." (HUALDE LÓPEZ, Ibon. Régimen jurídico de la administración concursal en la fase de liquidación del concurso. Estudios de derecho concursal. 1. edición, Espanha: Thomson Civitas, 2009, p. 19). ${ }^{423}$ HUALDE LÓPEZ, Ibon. Régimen jurídico de la administración concursal en la fase de liquidación del concurso. Estudios de derecho concursal, 1. edición, Espanha: Thomson Civitas, 2009, p. 19.

${ }^{424}$ ETXARANDIO HERRERA, Edorta J. Manual de derecho concursal. 2. edición, Madrid: La Ley, 2009, p. 734 . 
em crise, notadamente como resultado da percepção de um “valor social de la exclusión de proyectos patrimoniales inviables". ${ }^{2} 5$

Em resumo, a coexistência de uma finalidade conservativa da empresa não poderia implicar, em hipótese alguma, em uma opção de secundarização dos interesses e direitos dos credores, na medida em que o processo concursal "se endereza a la mejor satisfacción de los acreedores". ${ }^{426}$

A tônica e o foco de tutela principal do direito concursal espanhol é promover a satisfação do direito dos credores e, por via reflexa, quando possível, preservar a empresa $^{427}$.

A circunstância de o convenio ser a solução idealizada pelo legislador como a mais prestigiada resulta da inegável vantagem de se obter um encaminhamento da crise entre devedor e seus credores, por acordo. Presume-se que a solução consentida seja melhor $^{428}$ do que qualquer resposta por imposição do juiz ou do legislador.

Do ponto de vista da legitimação ativa, o concurso pode ser classificado em voluntario $^{429}$, quando a iniciativa do pedido for do devedor, ou necesario, quando a medida for deflagrada pelo credor. Ainda assim, o convenio constitui, como acima dito, o principal método de equacionamento do direito dos credores na situação de crise do devedor ${ }^{430}{ }^{431}$; e

${ }^{425}$ ETXARANDIO HERRERA, Edorta J. Manual de derecho concursal. 2. edición, Madrid: La Ley, 2009, pp. 734-735.

${ }^{426}$ ETXARANDIO HERRERA, Edorta J. Manual de derecho concursal. 2. edición, Madrid: La Ley, 2009, p. 737.

${ }^{427}$ HUALDE LÓPEZ, Ibon. Régimen jurídico de la administración concursal en la fase de liquidación del concurso. Estudios de derecho concursal. 1. edición, Espanha: Thomson Civitas, 2009, p. 20.

${ }^{428}$ HUALDE LÓPEZ, Ibon. Régimen jurídico de la administración concursal en la fase de liquidación del concurso. Estudios de derecho concursal, 1. edición, Espanha: Thomson Civitas, 2009, p. 36; AZNAR GINER, Eduardo. La comunicación del artículo 5.3 de la ley concursal. Valencia: Tirant lo Blanch, 2011, p. 18.

429 "En ciertos casos la solicitude de concurso puede ser obligatoria para el deudor. Entramos así en una nueva modalidade de estos concursos que denominamos 'concursos obligatorios'. La obligación de solicitar concurso de acreedores afecta a aquellos deudores que hubieram conocido o debido conocer su estado de insolvência y deberán efectuarla 'dentro de los meses seguintes' a dicho conocimiento." (GONZÁLEZ PASCUAL, Julián. El concurso de acreedores.Una nueva solución para las empresas insolventes. Madrid: Ediciones Estúdios Financeiros, 2003, pp. 31-32).

${ }^{430}$ Ainda assim, segundo José Luis Vélaz Negueruela, a liquidação é o modo como terminam a maioria das empresas no processo de concurso. (VÉLAZ NEGUERUELA, José Luis. El concurso de acreedores y la insolvencia. Barcelona: Bosch, 2009, p. 132).

${ }^{431}$ As estatísticas apontam baixo êxito da via concursal: “(...) unos mil expedientes por año -, que los concursos orientados hacia en convenio son menos - 8,4\% en 2006 y 7,8\% en 2007-y los que acaban en 
isso se evidencia na circunstância em que o sistema institui diversas medidas facilitadoras de sua implementação.

Desse modo, inicialmente, o devedor poderá, ainda no curso da fase común do procedimento propor a solução por convenio $^{432}$. Nessa hipótese, se o concurso for voluntario, o convenio pode ser requerido juntamente com o pedido de instauração do procedimento; no caso de concurso necesario, o devedor poderá fazer a proposta de convenio até o final do prazo de habilitação dos créditos.

De qualquer modo, se o convenio não houver alcançado as adesões necessárias para sua implementação na fase común (convenio antecipado) ${ }^{433}$, essa porta não se fecha, pois poderá ser a proposta mantida e aproveitada pelo comitê de credores, para futura apreciação, mais tarde no procedimento, como se verá a seguir.

Depois de concluída a fase de impugnação da relação de credores e inventário dos bens, o devedor poderá, novamente, propor a solução por convenio, caso não tenha optado expressamente pela liquidación. Se o devedor não apresentar proposta por convenio nem requerer a abertura da fase de liquidación $n^{434}$, os credores que representarem parte significativa dos créditos admitidos ao procedimento poderão apresentar propostas para a solução do processo.

O conteúdo do convenio poderá consistir em proposta de pagamento, dilação de prazo ou combinação de ambas essas hipóteses. Outras propostas, tais como

liquidación los más - un 91,6\% en 2006 y 92,2\% en 2007. Por otro lado, en los mismos períodos, la autoria de la propuesta de convenio procede casi siempre del deudor - uns 93\%-, y los convênios de trámite em su fase son la sua inmensa maioria, mientras que los de propuesta antecipada son el escasso resto, 5,1\% en 2007 y 1,7\% en 2008." E por isso, concluir-se: “Todo apunta que las empresas viables em crisis no acuden al procedimiento concursal" (ETXARANDIO HERRERA, Edorta J. Manual de derecho concursal, 2. edición, Madrid: La Ley, 2009, pp. 737-738).

432 "La regulación de esta propuesta antecipada permite, incluso, la aprobación judicial del convenio durante la fase común del concurso, con una notória economía del tempo y gastos respecto de los actuales procedimientos concursales.” (Exposição de motivos da Ley 22/2003, item VI.)

${ }^{433}$ Há um aspecto bastante criticável quanto aos requisitos de admissibilidade do convenio anticipado: o devedor, ou seus administradores, se pessoa jurídica, não podem estar incursos em delito contra o patrimônio, a ordem socioeconômica, ou de falsidade documental contra a fazenda pública. Nesse caso, como se vê, a sorte da sociedade ficará vinculada à de seus administradores. SERRANO SÁNCHEZ, Manuela. Aspectos concursales del patrimônio del insolvente. El concurso de acreedores tras cinco años de vigencia de la ley concursal. Granada: Editorial Comares, 2009, p. 204.

${ }^{434}$ Ainda que o juiz também possa, de ofício, nas hipóteses albergadas de forma taxativa pelo artigo 143.1 da Ley 22/2003 determinar a abertura da fase de liquidación. 
conversão de crédito em participação societária, venda de bens, cessão do estabelecimento, enfim, operações societárias que envolvam transferência do negócio, deverão vir, necessariamente, acompanhadas de um plano de pagamento aos credores. Essa ideia, evidentemente, reforça a tese de que a finalidade do concurso é a satisfação dos credores e, quando possível, por via reflexa, torne-se possível preservar a empresa.

Note-se, portanto, o viés eminentemente pro credor, que coloca como finalidade precípua o equacionamento do passivo à frente da preservação da empresa. $\mathrm{O}$ fato de o convenio ser a via preferencial do sistema resulta da circunstância de que, por esta, o interesse dos credores será melhor atendido, já que a manutenção da empresa, em tese, faz com que se criem novos recursos para pagamento.

A perspectiva do direito concursal espanhol mostra, claramente, que a preservação da empresa é valor reflexo e vinculado à satisfação dos credores. É no interesse destes que ocorre aquela, se viável, e com o objetivo de atender ao direito de crédito destes últimos.

Assim, em se tratando de convenio que envolva algum tipo de atividade, empresária ou não, sua conservação ficará condicionada à demonstração de viabilidade desta, por meio de um 'plan de viabilidad'. Nesse particular, a exposição de motivos salienta que "Aunque el objeto de concursal no sea el saneamento de empresas, un convenio de continuación puede ser instrumento para salvar las que se consideren total o parcialmente viables, en benefício non solo de los acreedores, sino del proprio concursado, los trabajadores y de otros intereses. " 435

Como já se disse, o direito concursal espanhol considera que a melhor forma de atender ao interesse dos credores, se houver negócio viável, dar-se-á pela preservação da organização negocial. Mesmo porque, a aprovação do convenio não depende apenas da apreciação dos credores, mas também do juiz, que o decreta por sentença, mediante apreciação de juízo de legalidade e de oportunidade e conveniência de seu conteúdo ${ }^{436}$.

\footnotetext{
${ }^{435}$ Exposição de motivos da Ley 22/2003, item VI.

${ }^{436}$ GUTIERREZ GILSANZ, Andrés. Tutela de los acreedores frente al convenio concursal: oposición, nulidade y declaración de incumplimiento. Madrid: La Ley grupo Wolters Kluwer, 2008, pp. 117-120. Ao contrário do que ocorria no regime revogado, em que o juiz ficava adstrito tão somente a um juízo de legalidade quanto ao convenio. (idem, p. 118).
} 
Esse mesmo ideal é também levado em consideração na fase de liquidación concursal. ${ }^{437}$ Embora não perca sua função primordial de satisfação dos credores, pode-se afirmar, de modo coerente com o cenário econômico atual em que se inserem as empresas, que há um interesse público que mobiliza soluções conservativas, em especial com a finalidade de manutenção dos postos de trabalho ${ }^{438}$.

Embora exista, nitidamente, um incentivo para a manutenção da empresa, não se pode deixar de anotar que o efetivo móvel do legislador na lei concursal é a satisfação dos credores ${ }^{439}$, eis que a preservação do negócio pode ser, em certas hipóteses, um efeito daquele objetivo primeiro (de atendimento do passivo), caso se mostre mais vantajoso para os credores $^{440}$.

Logo, a cessão da empresa como um todo, com fundamento na Ley 22/2003, poderá ocorrer tanto na fase de convenio $^{441}$, quanto na fase de liquidación de um procedimento concursal ${ }^{442}{ }_{-}^{443}$. A finalidade conservativa da empresa, desse modo e sempre

${ }^{437}$ HUALDE LÓPEZ, Ibon. Régimen jurídico de la administración concursal en la fase de liquidación del concurso. Estudios de derecho concursal. 1. edición, Espanha: Thomson Civitas, 2009, p. 298.

${ }^{438}$ HUALDE LÓPEZ, Ibon. Régimen jurídico de la administración concursal en la fase de liquidación del concurso. Estudios de Derecho Concursal. 1. edición, Espanha: Thomson Civitas, 2009, pp. 23-25.

${ }^{439}$ Até mesmo em relação à manutenção dos postos de trabalho, como acentua Marta Fernández Prieto: "El sistema concursal español, frente a la tónica del Derecho comparado, se dirige primordialmente a la satisfacción de los acreedores, de tal manera que el mantenimiento de los contratos de trabajo está en un segundo plano respecto a la mejor realización posible del activo en interés de los acreedores, por lo que la lógioca del sistema se orienta más a la extinción del vínculo contractual con los trabajadores que a la conservación - aunque sea mediante modificación de condiciones o movibilidad geográfica o funcional - o suspensión del mismo.” (FERNÁNDEZ PRIETO, Marta. La transmissión de empresas en crisis: incidencia de la ley concursal. Espanha: Ediciones Laborum, 2004, p. 157).

${ }^{440}$ HUALDE LÓPEZ, Ibon. Régimen jurídico de la administración concursal en la fase de liquidación del concurso. Estudios de derecho concursal. 1. edición, Espanha: Thomson Civitas, 2009, p. 299.

441 Artigo 102.2 da Ley 22/2003: "La propuesta de convenio podrá contener, además, proposiciones alternativas para todos o algunos de los acreedores, incluidas las ofertas de conversión del crédito en acciones, participaciones o cuotas sociales, o en créditos participativos. También podrán incluirse en la propuesta de convenio proposiciones de enajenación, bien del conjunto de bienes y derechos del concursado afectos a su actividad empresarial o profesional o de determinadas unidades productivas a favor de una persona natural o jurídica determinada.Las proposiciones incluirán necesariamente la asunción por el adquirente de la continuidad de la actividad empresarial o profesional propia de las unidades productivas a las que afecte y del pago de los créditos de los acreedores, en los términos expresados en la propuesta de convenio. En estos casos, deberán ser oídos los representantes legales de los trabajadores." (com a nova redação dada pelo artigo 72 da Ley 38/2011, de 10 de octubre).

${ }^{442}$ CONDE TEJÓN, Antonio. La cesión global de activo y passivo como operación de modificación estructural (Procedimiento aplicable, sucesión universal y protección de acreedores), Madrid: Colégio de Registradores de la Propriedad, Mercantiles y Bienes Muebles de España, 2004, pp. 145-151.

${ }^{443}$ HUALDE LÓPEZ, Ibon. Régimen jurídico de la administración concursal en la fase de liquidación del concurso. Estudios de derecho concursal. 1. edición, Espanha: Thomson Civitas, 2009, p. 306. 
como viés da melhor solução para os credores, existe e é prevista em ambas as soluções possíveis de um procedimento concursal.

Verifica-se, assim, na fase de liquidación previsão legal de preferência de alienação global do estabelecimento, exceto se houver vantagem na venda de certas unidades produtivas ou dos bens individualmente considerados.

É importante acrescentar, na fase de liquidación incidem todos os efeitos regulares de um procedimento dessa natureza, tais como o afastamento do devedor, a impossibilidade de administração e disposição dos bens sujeitos ao concurso, o vencimento antecipado das obrigações e assim por diante ${ }^{444}$.

Por isso, o protagonista desta fase do processo passa a ser a administração $\operatorname{concursal}^{445}$, que será responsável pela elaboração de um 'plan de liquidación', respaldado nas impressões resultantes da situação da empresa e dos empregados a esta vinculados ${ }^{446}$.

O que se preserva, nesse caso, é a organização de bens preexistentes, como reiterado na exposição de motivos, quando mencionados os objetivos possíveis de um 'plan de liquidación': “Aun en este último caso, la ley procura la conservación de las empresa o unidades productivas de bienes o servicios integrados a la masa, mediante su enajenación como un todo (...) con preferencia a las soluciones que garanticen la continuidade de la empresa". ${ }^{447}$

Nesse procedimento, prevê-se a possibilidade de elaboração de um "plan de liquidación" ${ }^{448}{ }_{-}^{449}{ }^{450}$ que, fundamentalmente, consiste na disposição dos modos de

\footnotetext{
${ }^{444}$ HUALDE LÓPEZ, Ibon. Régimen jurídico de la administración concursal en la fase de liquidación del concurso. Estudios de derecho concursal. 1. edición, Espanha: Thomson Civitas, 2009, p. 21.

${ }_{445}$ "Para llevar a término essas actuaciones, los administradores concursales actuarón colegiadamente y adoptarán las decisiones por mayoría, pudiéndose atribuir, en atención a su especialidade, determinadas competencias a alguno de sus membros (Art.35.2LC)." (HUALDE LÓPEZ, Ibon. Régimen jurídico de la administración concursal en la fase de liquidación del concurso. Estudios de derecho concursal. 1. edición, Espanha: Thomson Civitas, 2009, pp. 300-301).

${ }^{446}$ HUALDE LÓPEZ, Ibon. Régimen jurídico de la administración concursal en la fase de liquidación del concurso. Estudios de derecho concursal. 1. edición, Espanha: Thomson Civitas, 2009, p. 308.

${ }^{447}$ Exposição de motivos da Ley 22/2003, item VII.

${ }^{448}$ Artigo 148.1 da Ley 22/2003.

449 "Se trata de una planificiación, que ha de presentar la administración concursal, para la realización de los bienes y derechos integrados de la masa activa del concurso que, siempre que sea factibile, deberá contemplar la enajenación unitaria del conjunto de los establicimientos, explotaciones y calquiera otras
} 
realização dos ativos na liquidación, mediante "ordenación sistemática y económicamente racional de realización forzosza de los bienes del deudor concursado para, con sus resultas, satisfacer los intereses de los acreedores del deudor común, es decir, pagarles." 451

O "plan de liquidación" "452 é apresentado pela administração concursal ${ }^{453}$ nos 15 dias $^{454}$ que seguem ao decreto do início da fase de Liquidación e, no mesmo prazo subsequente, o devedor, os credores e trabalhadores poderão apresentar observações ou modificações que serão apreciadas pelo juiz antes de sua aprovação.

Se aprovado, referido plano de liquidação será adotado como guia da fase de liquidação, mas, caso contrário, deverão prevalecer as regras cogentes previstas no artigo 149 da Ley 22/2003 para a realização dos ativos. Acrescente-se, tanto em uma como em outra alternativa, outorga-se preferência na venda agregada dos ativos que integram o acervo patrimonial do devedor, de forma a prestigiar a solução de conservação da empresa e dos postos de trabalho ${ }^{455}$.

Por outro lado, na fase de convenio, a cessão da empresa se dá por meio de um plan de reestructuración. A propósito, Antonio Conde Tejón ensina: “Esta operación resulta uma forma de salvar la situciación de insolvência que presenta múltiplas ventajas y beneficia a bastantes de los colectivos implicados. De esta forma el acreedor cesionario

unidades produtivas de bienes y servicios del concursado o de algunos de ellos." (VÉLAZ NEGUERUELA, Jose Luis. El concurso de acreedores y la insolvencia. Barcelona: Bosch, 2009, p. 136).

450 "El plan de liquidación tiene por objeto el diseño de las pautas y de los tempos con arreglo a los que esa realización patrimonial há de llevarse a término." E mais adiante: "El plan de liquidación ha de albergar uma regulamentación suficiente como para dar respuesta a todas las situaciones que cabalmente sean susceptibles de acontecer en el contexto de la realización de las operaciones de liquidación concursal..." (HUALDE LÓPEZ, Ibon. Régimen Jurídico de la administración concursal en la fase de liquidación del concurso. Estudios de derecho concursal. 1. edición, Espanha: Thomson Civitas, 2009, p. 301 e 304).

${ }^{451}$ BLASCO GASCÓ, Francisco de Paula. "Comentario al articolo 148", in: Comentarios a la Ley Concursal, (Coord. SAGRERA TIZÓN, J.M.; SALA REIXACHS, A.; FERRER BARRIENDOS, A., Barcelona: Bosch, tomo II, 2004, p. 1546.

${ }^{452}$ Embora o plan de liquidación seja elaborado pela administração concursal, os credores e o devedor poderão formular observações e propostas de modificação. Igualmente, os trabalhadores poderão manifestarse a respeito, em especial se houver previsão de modificação ou suspensão de contratos de trabalho. (SERRANO SÁNCHEZ, Manuela. Aspectos concursales del patrimônio del insolvente. El concurso de acreedores tras cinco años de vigencia de la ley concursal. Granada: Editorial Comares, 2009, p. 237).

${ }^{453} \mathrm{Em}$ relação a um procedimento concursal em andamento no exterior, o administrador responsável por este poderá apresentar um 'plan de liquidación' para empresas e seus ativos que estejam localizados no território espanhol. (artigo 228.3 da Ley 22/2003).

${ }^{454}$ Prorrogáveis por igual período, por decisão judicial, em casos de hipóteses mais complexas.

${ }^{455}$ HUALDE LÓPEZ, Ibon. Régimen jurídico de la administración concursal en la fase de liquidación del concurso. Estudios de derecho concursal. 1. edición, Espanha: Thomson Civitas, 2009, p. 34. 
no ve satisfechos sus créditos pero recibe a cambio una empresa en funcionamento por la que tiene interés." 456

A este respeito, Edorta Herrera destaca que "debe tenerse en cuenta que el convenio puede dar lugar a la cesión de la empresa a terceiro (convenios de asunción), puesto que se autorizan enajenaciones de conjuntos patrimoniales del concursado afectos a sua actividad empresarial o professional, o de determinadas unidades productivas, a favor de terceiro (art. 100.2 pfo. $2^{\circ}$ LECO). ${ }^{, 457}$

O mesmo autor prossegue: "Y como por outro lado, la liquidación puede representar que un terceiro adquiera la empresa en funcionamento (liquidación traslativa), según se desenvuelve en su lugar, la solución conservativa igualmente puede conseguirse a través de la liquidación, de modo que el arriba mencionado principio de alternatividade es formal, y en lo material, el concurse conosce tres géneros de opciones, que se cruzan: entre conservación y cesse de la actividad (a); entre convenio y liquidación (b); y entre deudor concursado o empresário y empresa de su titularidade (c)."

Em uma operação de cessão global da empresa, fora do ambiente de um procedimento concursal, Antonio Conde Tejón ensina que esta consiste em uma transferência do ativo e do passivo a título universal e, por isso, "Los restantes acreedores probablemente deberán renunciar a una parte de sus créditos y aplazar el cobro de los restantes para conseguir que el acreedor cesionario acepte hacerse cargo de al empresa, pero también resultarán beneficiados en comparación con la proporción que hubieran cobrado en caso de haber optado por la liquidación de la sociedade, puesto que la empresa continua en funcionamento, y por tanto, obtendrá nuevos recursos. Por ultimo esta opción resulta ventajosa porque permite salvar da situación de insolvência conservando la empresa."

${ }^{456}$ CONDE TEJÓN, Antonio. La cesión global de activo y passivo como operación de modificación estructural (Procedimiento aplicable, sucesión universal y protección de acreedores). Colégio de Registradores de la Propriedad, Mercantiles y Bienes Muebles de España, Madrid: 2004, p. 146.

${ }^{457}$ ETXARANDIO HERRERA, Edorta J. Manual de derecho concursal. 2. edición, Madrid: La Ley, 2009, p. 735 .

${ }^{458}$ ETXARANDIO HERRERA, Edorta J. Manual de derecho concursal. 2. edición, Madrid: La Ley, 2009, p. 735 .

${ }^{459}$ Idem nota acima. 
Todavia, estando o devedor incurso em um procedimento concursal, a lei veda a cessão da empresa como meio de pagamento a credores ${ }^{460}{ }_{-}^{461}$. Por isso, o mesmo autor critica a opção do legislador, entendendo que a restrição constitui óbice de difícil superação à operação de cessão da empresa, pois, o mais provável, é que somente credores (e não terceiros) demonstrem interesse em adquirir um negócio em situação de insolvência ${ }^{462}$.

Assim, somente terceiros são admitidos como cessionários de empresa submetida a um procedimento concursal de convenio, o que, de fato, é um limitador desnecessário para a solução da crise.

Antonio Conde Tejón cogita que a restrição teria fundamento "posiblemente porque se recela de que esta situación sea susceptible de un uso fraudulento beneficiando al acreedor cessionário en prejuicio de los restantes acreedores. La razón se de ser de esta limitación al posible contenido del convenio probablemente se encuentre en que se desea evitar la situación que se venía dando en la práctica por la que un acreedor mayoritario que gozaba de una especial relación con el deudor (por ejemplo porque se trata de una sociedade matriz) se aprovechaba de las circunstancias para imponer a los restantes acreedores un convenio especialmente beneficioso para sus intereses."

É de se mencionar que a restrição, se motivada pelo receio de abusos como o acima mencionado, torna o dispositivo altamente criticável $^{464}$, na medida em que

\footnotetext{
${ }^{460}$ Artigo 100.3 da Ley 22/2003, com a redação dada pelo artigo 73 da Ley 38/2011, de 10 de octubre: “En ningún caso la propuesta podrá consistir en la cesión de bienes y derechos a los acreedores en pago o para pago de sus créditos con la excepción del supuesto previsto en el artículo 155.4, ni en cualquier forma de liquidación global del patrimonio del concursado para satisfacción de sus deudas, ni en la alteración de la clasificación de créditos establecida por la ley, ni de la cuantía de los mismos fijada en el procedimiento, sin perjuicio de las quitas que pudieran acordarse y de la posibilidad de fusión, escisión o cesión global de activo y pasivo de la persona jurídica concursada."

461 “(...) no se permiten las daciones de toda la empresa a los acreedores para pago." (ETXARANDIO HERRERA, Edorta J. Manual de derecho concursal. 2. edición, Madrid: La Ley, 2009, p. 734).

${ }^{462}$ CONDE TEJÓN, Antonio. La cesión global de activo y passivo como operación de modificación estructural (Procedimiento aplicable, sucesión universal y protección de acreedores), Colégio de Registradores de la Propriedad, Mercantiles y Bienes Muebles de España, Madrid, 2004, pp. 148-149.

${ }^{463}$ CONDE TEJÓN, Antonio. La cesión global de activo y passivo como operación de modificación estructural (Procedimiento aplicable, sucesión universal y protección de acreedores), Colégio de Registradores de la Propriedad, Mercantiles y Bienes Muebles de España, Madrid, 2004, p. 148.

${ }^{464}$ Embora Ibon Hualde López entenda tal restrição coerente, anotando que a nova disciplina do artigo 100.3 da Ley 22/2003 deu fim a uma prática largamente admitida pela doutrina e jurisprudência à época da vigência da lei concursal revogada, semelhante ao abandono do ativo a título de 'datio pro soluto', para que os credores pudessem, de forma privada, alienar os ativos da melhor forma e do modo como lhes aprouvesse,
} 
inviabiliza soluções que poderiam mostrar-se benéficas para a conclusão de um procedimento concursal.

De fato, a proibição de cessão da empresa a credores poderia ser dirigida e atingir apenas aqueles com os quais o devedor, ou seus dirigentes, mantivessem algum tipo de vínculo que justificasse, verdadeiramente, abusos ou fraudes. A propósito, diga-se 'mutatis mutandi' da hipótese, o legislador brasileiro encontrou solução muito superior na disciplina de inexistência da sucessão das obrigações ao obstá-la apenas a parentes e agentes do devedor ou pessoas relacionadas à administração do devedor.

Além da cessão da empresa como um todo, a lei prevê ainda a possibilidade de alienação de "determinadas unidades productivas". A expressão é utilizada para a hipótese de a devedora possuir diversos estabelecimentos, autorizando-se sua alienação separadamente. ${ }^{465}$ Essa solução poderia garantir a continuidade de parte do negócio quando o saneamento total esteja fora de alcance ${ }^{466}$.

A ideia da cessão total ou parcial é a de que se mantenha a funcionalidade dos ativos, de alguma forma, para que se possam ser aproveitados certos ativos intangíveis, tais como a clientela e organização de recursos humanos ${ }^{467}$. A ideia é a de que essa solução possa gerar novos recursos para pagamento dos credores.

Em qualquer das hipóteses, seja de cessão a título universal quanto de parte do estabelecimento da concursada, a sucessão fiscal é regra, solução firmemente criticada por Antonio Conde Tejón. Para o autor, há uma evidente incongruência na lei, que declinou como uma de suas finalidades o fomento da continuação da empresa em crise, mas, ao mesmo tempo, deixou de criar mecanismos que tornassem isso possível, como é o

liberando o devedor desde o momento da cessão dos bens. (HUALDE LÓPEZ, Ibon. Régimen Jurídico de la administración concursal en la fase de liquidación del concurso. Estudios de Derecho Concursal. 1. edición, Espanha: Thomson Civitas, 2009, pp. 29-30).

${ }^{465}$ HUALDE LÓPEZ, Ibon. Régimen jurídico de la administración concursal en la fase de liquidación del concurso. Estudios de derecho concursal. 1. edición, Espanha: Thomson Civitas, 2009, p. 349.

${ }^{466}$ HUALDE LÓPEZ, Ibon. Régimen jurídico de la administración concursal en la fase de liquidación del concurso. Estudios de derecho concursal. 1. edición, Espanha: Thomson Civitas, 2009, p. 309.

${ }^{467}$ HUALDE LÓPEZ, Ibon. Régimen Jurídico de la administración concursal en la fase de liquidación del concurso, Estudios de Derecho Concursal, Thomson Civitas, $1^{\text {a }}$ edición, Espanha, 2009, pp. 309-310. 
caso da manutenção de sucessão fiscal plena, na hipótese de cessão do estabelecimento da devedora. $^{468}$

Do ponto de vista da sucessão trabalhista, não existe regulamentação específica para a alienação da empresa ou de estabelecimentos quando incursa em procedimento concursal. Daí prevalecer o regramento ordinário fixado no artigo 44 do Estatuto de los Trabajadores, pelo qual é prevista a sub-rogação, de todos os direitos e obrigações laborais e relativas à seguridade social, pelo adquirente. ${ }^{469}{ }_{-} 470$

O mencionado dispositivo prevê a sub-rogação das obrigações trabalhistas sempre que houver mudança de titularidade na empresa, ou na unidade produtiva, ou no 'centro de trabalho, ${ }^{471}$, pouco importando o modo por meio do qual se operaria a transmissão, do que resulta a sucessão em hipótese de arrendamento do negócio, venda judicial, operações societárias e transferência de qualquer espécie ${ }^{472}$. Há, inquestionavelmente, sucessão das obrigações trabalhistas, na hipótese de cessão unitária ou de estabelecimento da concursada ${ }^{473}$.

Entretanto, uma das questões que o plan de liquidación deverá abordar é o tema da continuidade de contratos de trabalho, que são transferidos para o adquirente da unidade produtiva com preservação de todos os direitos que o trabalhador já houvera adquirido.

É importante lembrar até mesmo na venda judicial no âmbito de um procedimento concursal, mesmo que fora da previsão de um 'plan de liquidación', basta

\footnotetext{
${ }^{468}$ CONDE TEJÓN, Antonio. La cesión global de activo y passivo como operación de modificación estructural (Procedimiento aplicable, sucesión universal y protección de acreedores), Colégio de Registradores de la Propriedad, Mercantiles y Bienes Muebles de España, Madrid, 2004, pp. 150-151.

${ }^{469}$ FERNÁNDEZ PRIETO, Marta. La transmissión de empresas en crisis: incidencia de la ley concursal. Espanha: Ediciones Laborum, 2004, pp. 130, 150.

${ }^{470}$ HUALDE LÓPEZ, Ibon. Régimen jurídico de la administración concursal en la fase de liquidación del concurso. Estudios de derecho concursal. 1. edición, Espanha: Thomson Civitas, 2009, pp. 30-31.

${ }^{471}$ Eis que não é necessário que a transferência seja de toda a empresa, mas somente de alguma parte essencial que permita a continuidade imediata de alguma atividade, conforme previsão da Ley 12/2001, que modificou parcialmente o artigo 44 do ET (Estatuto de los Trabajadores). (FERNÁNDEZ PRIETO, Marta. La transmissión de empresas en crisis: incidencia de la ley concursal. Espanha: Ediciones Laborum, 2004, p. 143).

${ }^{472}$ FERNÁNDEZ PRIETO, Marta. La transmissión de empresas en crisis: incidencia de la ley concursal. Espanha: Ediciones Laborum, 2004, pp. 137, 416, 422.

${ }^{473}$ HUALDE LÓPEZ, Ibon. Régimen Jurídico de la administración concursal en la fase de liquidación del concurso. Estudios de derecho concursal. 1. edición, Espanha: Thomson Civitas, 2009, pp. 315, 327, 344.
} 
que o objeto da venda incorpore elementes necessários e suficientes para assegurar a continuidade imediata de exploração da devedora para que a sucessão trabalhista se caracterize plena $^{474}$.

Há ainda mais uma alternativa de manutenção do negócio da devedora. A lei autoriza que trabalhadores da empresa submetida a um procedimento de liquidación manifestem sua intenção de prosseguir com a atividade que esta vinha desenvolvendo, o que seria viabilizado por meio de uma sociedade anônima laboral ou mediante cooperativa. ${ }^{475}$ Nesses casos, em particular, e dado o regime especial de exploração da atividade, ficaria afastado o regramento do artigo 44 do Estatuto de los Trabajadores, que prevê a sucessão destas mesmas obrigações, como reiteradamente a jurisprudência tem firmado orientação ${ }^{476}$.

Em linhas gerais, nota-se que o direito concursal espanhol, embora declaradamente pro credor, encampa finalidade preservacionista, mesmo diante da fase de liquidación do processo de concurso.

No entanto, peca, como visto, na concretização deste fundamento, na medida em que mantém a sucessão das obrigações fiscais e trabalhistas para o adquirente da empresa, seja por cessão total ou parcial. Convém deixar claro que tal solução é coerente, com a finalidade precípua do concurso, ou seja, a de satisfação dos credores.

\subsection{O direito argentino}

A Ley de Concursos e Quiebras (Ley n. 24.522 de 20/07/1995 ou LCQ), com inúmeras alterações posteriores ${ }^{477}$, regula a quiebra, na qual se prevê a liquidação dos bens do devedor insolvente para pagamento dos credores e também os institutos do concurso preventivo (que consiste na aprovação, pelos credores, de um plano de reestruturação do passivo denominado acuerdo preventivo) e do acuerdo preventivo

\footnotetext{
${ }^{474}$ FERNÁNDEZ PRIETO, Marta. La transmissión de empresas en crisis: incidencia de la ley concursal. Espanha: Ediciones Laborum, 2004, pp. 164-176.

${ }^{475}$ Artigo 149.2 da Ley 22/2003.

${ }^{476}$ HUALDE LÓPEZ, Ibon. Régimen jurídico de la administración concursal en la fase de liquidación del concurso. Estudios de derecho concursal. 1. edición, Espanha: Thomson Civitas, 2009, pp. 423-425.

${ }^{477}$ Alterada pelas Leis n. 22.760, n. 25113, n. 25.563, n. 25.589 e n. 26.086.
} 
extrajudicial $^{478}$ (ou APE, pelo qual o devedor em dificuldades econômicas de caráter geral fica autorizado a celebrar acordo com a totalidade ou com parte de seus credores, podendo submetê-lo à homologação judicial ${ }^{479}$ ).

Nesse sentido, prevalece no direito argentino o sistema procedimental dualista, com previsão de duas linhas definidas e distintas, um de caráter liquidatório, denominado quiebra, e outro de natureza reorganizatória, designado por concurso ${ }^{480}$.

Já tivemos ocasião de salientar ${ }^{481}$ que a reforma da lei concursal argentina foi deflagrada em 2001 como resposta legislativa à grave crise econômica então enfrentada pelo país ${ }^{482}{ }_{-}^{483}$ e que se refletiu, no direito concursal, com a criação de procedimentos que pudessem outorgar condições favoráveis à preservação das empresas, com foco, principalmente, na manutenção de postos de trabalho, ante a grave situação generalizada de desemprego no país.

O cenário econômico-financeiro do país, à época, explica a evidente tendência preservacionista da lei concursal argentina, que, em parte, se inspirou nas soluções do direito concursal norte-americano ${ }^{484}$.

O sistema concursal argentino, assim, está estruturado para tutela da preservação de empresas, em particular, como meio de preservação de empregos e dos interesses dos trabalhadores ante a situação de crise das empresas ${ }^{485}{ }_{-}^{486} \_487 \_488$.

\footnotetext{
${ }^{478}$ Artigo 69 da Lei n. 24.522/1995.

${ }^{479}$ A homologação opera-se apenas quando o devedor obtiver a assinatura da maioria absoluta dos credores e que representem dois terços do valor do passivo total. Se o acordo não for homologado, os credores que não aderiram conservarão todos os seus direitos e ações individuais.

${ }^{480}$ BARBIERI. Pablo C., Concursos y quiebras (Ley 24.522 comentada y concordada). Buenos Aires: Editorial Universidad, 2006, introdução, p.13.

${ }^{481}$ Dissertação de mestrado, A evolução do tratamento jurídico da empresa em crise no direito brasileiro. São Paulo: Fadusp, 2006.

482 "La ley de concursos, en concreto, no és solo un texto legal. Es, antes, y además, un instrumento de política legislativa dentro del universo económico, que debe estar dirigido a dar satisfacción a concretas aspiraciones del cuerpo de la comunidad". (ALEGRIA, Héctor. Algunas cuestiones de derecho concursal, Bs. As., Ábaco, 1991, p.22).

483 Porém, o primeiro sistema que buscou soluções reorganizatórias data de 1972, conforme pontos levantados em análise feita por Nelson Abrão. "A nova Lei Argentina sobre procedimentos concursais". (Revista de Direito Mercantil, Industrial, Econômico e Financeiro, São Paulo, vol. 9, Ano XII (nova série), pp. 143-145, 1973).

${ }^{484}$ ESCUTI, A. Ignacio e BAS, Francisco Junyent. Derecho concursal. Buenos Aires: Astrea, 2006, pp. 26-
} 
Resulta disto que a lei se foca em um esforço de criação de meios de preservação da atividade econômica ${ }^{489}$. Luis Porcelli sustenta que o regime concursal argentino está apoiado nos seguintes princípios: (i) de não agravamento, (ii) da reversibilidade e (iii) da finalização da crise ou extinção definitiva das obrigações envolvidas $^{490}$.

Um bom exemplo de aplicação do princípio da preservação da atividade econômica é o sistema de aprovação impositiva de um acuerdo preventivo ${ }^{491}$. Como regra, exige-se o voto favorável da maioria absoluta dos credores em cada classe, além de dois terços dos votos favoráveis, pelo valor, dentro de cada categoria para aprovação da proposta. A falta de obtenção deste duplo quorum de aprovação ${ }^{492}$ resultaria, em princípio,

485 “...la preservación de las fuentes de trabajo debe ser uno de los intereses que se pongan en juego en los procesos concursales, sobre todo en países como la Argentina, donde los índices de desocupación alcanzan guarismos preocupantes; ténga-se en cuenta que, al momento de la sanción de la ley 25.589, la economía nacional estaba sumida en una crisis histórica y el aumento de estos índices era claramente denotativo de ello" (BARBIERI. Pablo C., Concursos y quiebras (Ley 24.522 comentada y concordada). Buenos Aires: Editorial Universidad, 2006, pp. 408-409).

486 "La crisis se iba extendiendo ya de manera evidente en la Argentina; así, más allá del interés del deudor y el interés del acreedor, debía pensarse en un interés superior, el del mantenimiento de las fuentes de trabajo." (ESCUTI, A. Ignacio e BAS, Francisco Junyent. Derecho concursal. Buenos Aires: Astrea, 2006, p.255)."

${ }^{487}$ MORO, Carlos E. Ley 26.086. Concursos y quiebras. Modificación de la ley 24.522, Buenos Aires: Adhoc, 2006, pp. 17-20.

${ }^{488} \mathrm{Na}$ mesma linha de ideias, o credor trabalhista, na falência, possui "superprivilegio" na medida em que o recebimento de seu crédito fica sujeito ao regime de "pronto pago" previsto no artigo 16 da LCQ, os quais são satisfeitos mediante requerimento do credor e independentemente da existência de uma sentença trabalhista que liquide o valor correspondente (a partir da reforma pela Lei n. 26.086, de 2006, há um procedimento sumário perante o próprio juiz da falência). Tão logo existam fundos disponíveis em caixa pela falida, tais pagamentos devem ser realizados e há jurisprudência entendendo que tais recursos poderão até mesmo advir das primeiras receitas decorrentes de eventual regime de continuidade de negócios. (VÍTOLO, Daniel R.; BOQUIN, Gabriela F.; DUBOIS, Eduardo M. Favier; BALONAS, Daniel; VILLOLDO, J. Marcelo e MORO, Carlos E. La tutela de los acreedores en los procesos concursales. Buenos Aires: Adhoc, 2006, pp. 100-109).

489 “El debate de la doctrina contemporánea, tal como hemos demostrado, se ha centrado en la problemática del saneamiento de las empresas en crisis como forma de evitar la dispersión de esfuerzos y la dilapidación de riquezas, especialmente referidas a las grandes empresas." (ESCUTI, A. Ignacio e BAS, Francisco Junyent. Derecho concursal. Buenos Aires: Astrea, 2006, p.25)."

490 No original: "La legislación falencial erige a los criterios a la categoría de principios y han sido utilizados en todas las leyes concursales promulgadas en la Nación y en muchos outros países. Se denominan: 1 - De no agravamiento. 2 - De reversión. 3 - De finalización de la crisis o de extinción definitiva de las obrigaciones en reclamo." (PORCELLI, Luis A. Régimen falencial - análisis metodológico. Buenos Aires: Editorial Hammurabi, 2010, p. 20).

${ }^{491}$ Tanto que Darío Graziabile trata o cramdown como solução alternativa à quebra, na insolvência. (Derecho Concursal, Tomo I, Lexisnexis, Buenos Aires, Argentina, 2006, pp. 207 e 213).

${ }^{492}$ A homologação de um acordo é particularmente importante, pois, na sistemática anterior (Ley 19.551), se houvesse quebra por descumprimento deste, os direitos dos credores eram restituídos ao seu valor e condições originais, ao passo que, na lei vigente (Ley 24.522), se opera novação e, se decretada a falência, os 
na quebra do devedor, exceto pela hipótese de imposição judicial, ou cramdown, prevista no artigo 52 da Ley de Concursos e Quiebras ${ }^{493}$.

Em complementação, o artigo 48 da Ley de Concursos e Quiebras ${ }^{494}$ prevê um mecanismo impositivo e impropriamente denominado por "cramdown" pela doutrina, já que em nada se assemelha àquele do direito norte-americano ${ }^{495}{ }_{-}^{496}$, onde se originou o instituto $^{497}$.

$\mathrm{Na}$ realidade, a hipótese prevista no artigo 48 da lei concursal, também designada por "salvatage", consiste na possibilidade de que um terceiro ${ }^{498}$, credor ou não, obtenha as maiorias exigidas por lei para aprovação de um acuerdo preventivo e, em decorrência, passe a ter o dever (e o direito) de adquirir, mesmo à revelia dos titulares originários, a totalidade da participação societária da devedora. O preço de aquisição, ao contrário do que seria de se esperar, é fixado por critério imposto pela lei e não depende de aquiescência dos então titulares da devedora.

credores ficam vinculados aos direitos estabelecidos no acordo antes homologado. (DASSO, Ariel Ángel. Derecho concursal comparado, Tomo I, Buenos Aires: Legis, 2009, p.133).

${ }^{493}$ A homologação impositiva do plano pelo juiz, conforme artigo 52, exige a cumulação de quatro requisitos legais: (i) aprovação do plano por, pelo menos, uma categoria de credores, (ii) aprovação por, pelo menos, três quartos do valor dos créditos, (iii) ausência de discriminação em relação aos créditos das categorias dissidentes e (iv) que o pagamento dos credores não seja inferior ao que estes obteriam em caso que falência.

${ }^{494}$ Incorporado na reforma de 2005, pela Ley 24.522. Ariel Angel Dasso anota que a segunda condição é de difícil cumprimento, o que torna o instituto estéril (Derecho concursal comparado, Tomo I, Buenos Aires: Legis, 2009, p. 132).

${ }_{495}$ No direito norte-americano, a imposição do plano às minorias dissidentes, pelo magistrado, envolve decisão discricionária, como anota Alberto Camiña Moreira: "Nos EUA, a lei em relação ao cramdown diz que o plano deve ser justo, equiitativo e não discriminatório. Quem fala em plano justo e eqüitativo usa conceitos indeterminados, amplos, genéricos, que dão margem à mais ampla interpretação. Por isso, diz a doutrina que o juiz do processo de reorganização norte-americano é dotado de extraordinários poderes para impor o plano aos credores discordantes".(Direito Falimentar e a Nova Lei de Falências e Recuperação de Empresas. Obra coletiva coord. PAIVA, Luiz Fernando Valente de. São Paulo: Quartier Latin, 2005, pp. 259${ }_{496}^{259)}$.

${ }^{496} \mathrm{O}$ direito brasileiro também se afastou das linhas traçadas pelo instituto no direito norte-americano, como lembra Eduardo Secchi Munhoz: "ao contrário do que se verifica na disciplina adotada por outros países acerca do mesmo instituto, mantém fundamentalmente o poder de decisão com a assembléia geral de credores, quase que estabelecendo um 'quorum' alternativo de aprovação do plano em relação ao previsto no art. 45; não se abre nenhuma margem para a apreciação pelo juiz da situação econômico-financeira concreta do devedor". (in SATIRO DE SOUZA JR., Francisco e PITOMBO, Antonio Sergio A. de Moraes (Coord.). Comentários à lei de recuperação de empresas e falência. São Paulo: Revista dos Tribunais, 2. edição, 2007, p. 289).

${ }^{497}$ Ariel Angel Dasso, a propósito, anota que a previsão do artigo 48 da lei concursal argentina, em verdade, mais se aproxima do 'acordo por terceiro', previsto na Section 1129 do Bankrupticy Code. (Derecho Concursal Comparado. Tomo I, Buenos Aires: Legis, 2009, pp.133 e 631).

${ }^{498} \mathrm{O}$ procedimento da Ley 24.522 previsto para o artigo 48 excluía a intervenção da sociedade devedora, mas a reforma promovida pela Ley 24.589 passou a autorizar a participação da própria concursada, em igualdade de condições com eventuais terceiros interessados. 
Parte da doutrina chegou a questionar a constitucionalidade desta previsão legal ${ }^{499}$, sob o argumento da inviolabilidade da propriedade privada dos titulares do capital da sociedade devedora ${ }^{500}{ }^{501}$.

Todavia, Ariel Ángel Dasso posiciona-se no sentido de que " $E l$ procedimiento del art. 48 de la ley 24.552 constituye el paso más avanzado en las legislaciones de derecho comparado en torno a la transferencia de la empresa insolvente a un nuevo empresario, antes de producida la quiebra, por lo que se califica como arbitrio 'preventivo'.,"502

$\mathrm{O}$ autor conclui sua ideia afirmando que: "El sistema constituye desde el punto de vista dogmático el aporte más importante en el derecho comparado en orden a la transferencia de la empresa a un tercero con separación del empresario, auspiciado con particular énfasis a partir del ordenamiento frances de 1960" 503.

\footnotetext{
${ }^{499}$ Mónica Sofía Rodriguez aponta outros argumentos suscitados pela inconstitucionalidade do dispositivo em questão: "1) El método de valuación de la empresa impiede a los socios afectados la revisión de los cálculos; 2) Existe una sensible disminución del valor patrimonial de la empresa, tanto en lo concerniente a la estimación del activo como por el sacrificio que debe soportar el socio transmitente, como resultado de una negociación que les resulta totalmente ajena; 3) Una mayoría de socios puede imponer a las minorías un precio de venta menor al fijado judicialmente, sin límites de ninguna espécie; 4) $Y$ en otro sentido, también se ha criticado al procedimiento establecido en el artículo 48 de la ley $N^{\circ} 24.522$, en cuanto podría facilitar maniobras dolosas por el administrador, por el socio mayoritario o por terceiros". A autora, entretanto, finaliza esclarecendo que "Algunas de aquellas críticas fueron superadas oportunamente por nuestros tribunales con fundamento en que la declaración de inconstitucionalidad del artículo 48 de la ley $N^{o} 24.522$ requiere que el peticionante demuestre y acredite fehacientemente en la causa el perjuicio que le origina la aplicación de la regla en controversia, pues la invocación de reparos meramente conjeturales o hipotéticos son insuficientes para sustentar el pedido formulado. A ello se agrega además que la posible aplicación del artículo 48 de la ley $N^{o} 24.522$ sólo afectaría a los accionistas de la sociedad, pero no a esta última, en virtud de lo cual el agravio tampoco es atendible en tanto se lo invoca en interés de terceros cuya representación no se inviste." ("Armonización Legislativa en materia de salvataje de empresas en el MERCOSUR: ¿Una quimera o una necesidad?", Edición electrónica gratuita, 2010, Texto completo em $<$ www.eumed.net/tesis/2010/msr/>.

${ }^{500}$ BARBIERI. Pablo C., Concursos y quiebras (Ley 24.522 comentada y concordada). Buenos Aires: Editorial Universidad, 2006, introdução, p.171.

${ }^{501}$ Mónica Sofía Rodriguez critica o dispositivo do cram down ao confrontá-lo com a alienação da empresa em bloco na falência, prevista no artigo 205: "La diferencia radical que existe entre el cramdown y la adjudicación de bienes radica en que en ésta última, los acreedores podían asignarse los bienes del deudor, quedando canceladas las deudas de él; mientras que en el cramdown el deudor no se libera de sus deudas, y el incumplimiento del acuerdo lleva a su declaración de quebra".(em "Armonización Legislativa en materia de salvataje de empresas en el MERCOSUR: ¿Una quimera o una necesidad?", Edición electrónica gratuita. Texto completo em <www.eumed.net/tesis/2010/msr/>, 2010).

${ }^{502}$ DASSO, Ariel Ángel. Derecho concursal comparado, Tomo I, Buenos Aires: Legis, 2009, pp. 133.

${ }^{503}$ DASSO, Ariel Ángel. Derecho concursal comparado, Tomo I, Buenos Aires: Legis, 2009, pp. 134-135.
} 
A polêmica gerada pelo dispositivo foi de tal ordem que sua vigência veio a ser suspensa pela Ley n. 25.563 (publicada em 15/03/2002) e, apenas três meses depois, na reforma promovida pela Ley n. 25.589, veio a ser restituído ao sistema.

A análise do mecanismo de "salvatage" adotado pelo direito argentino revela, claramente, a preocupação do legislador em evitar os nocivos efeitos decorrentes da quebra em decorrência de eventual fracasso do concurso preventivo. Essa mesma inquietação fica evidenciada na possibilidade de pedido de conversão (conversión, artigo 90 da LCQ) da falência para um procedimento de concurso preventivo ${ }^{504}$.

O viés fortemente preservacionista do direito argentino resulta da ideia de que "La quebra ya no recoge - al menos em algunos supuestos - solo aquellos objetivos de liquidar lo más prolijamente possible el patrimonio do deudor y de efectuar su reparto igualitário entre todos los acreedores. La empresa no es hoy solo el conjunto de bienes que la componen, sino que hay otros factores objetivos y subjectivos que, en la economía de nuestros días, tornan procedente la aplicación de este instituto, como la conservación de las fuentes de trabajo, la incidência en el mercado de la eliminación de una determinada unidad económica, el interés público, los efectos de la falencia sobre los distintos sujetos vinculados con el quebrado ("efecto propagador"), etc. Todos ellos son valores a tener en cuenta al momento de decidir la aplicación de una solución liquidativa o, de otro modo, continuativa." 505

Desse modo, a finalidade preservacionista expressamente acolhida pela lei concursal argentina não fica restrita ao incentivo pela adoção e sucesso dos procedimentos de concurso, mas se estende a mecanismos que, na falência, possam viabilizar a salvaguarda da atividade econômica ${ }^{506}$. A título de exemplo, podem ser citadas: a possibilidade de continuidade de negócios da falida (arts. 189 a 195), a venda antecipada

\footnotetext{
504 BARBIERI. Pablo C., Concursos y quiebras (Ley 24.522 comentada y concordada). Buenos Aires: Editorial Universidad, 2006, introdução, pp.170, 171 e 253.

505 BARBIERI. Pablo C., Concursos y quiebras (Ley 24.522 comentada y concordada). Buenos Aires: Editorial Universidad, 2006, p. 401.

506 "La ley 24.522 imprimió al procedimiento falencial algunas características distintivas respecto de sus precedentes derrogados, pudiendose resumir los lineamentos en los seguintes pontos: ...omissis..., - La incorporación de institutos tendentes a modificar el tinte marcadamente liquidatorio y repressivo que la quiebra tenía en la normativa derrogada..." 506 BARBIERI. Pablo C., Concursos y quiebras (Ley 24.522 comentada y concordada). Buenos Aires: Editorial Universidad, 2006, p. 230.
} 
dos ativos do devedor (artigo 203), a prioridade na alienação em bloco (artigos 204 e 205) e a possibilidade de venda direta dos bens (artigo 213).

A exploração da atividade por regime de continuidade de negócios da falida não é novidade no direito argentino ${ }^{507}$ e se divide em duas espécies: a chamada continuação imediata (artigo 189) e a denominada ordinária ou comum (artigo 190). Além disso, a lei prevê a continuidade imediata de negócios, como obrigatória, para empresas que explorem serviços públicos imprescindíveis (artigo 189, $\$ 2^{\circ}$ ).

Em qualquer dos casos, o pedido de continuidade de negócios pode abranger todos ou apenas um dos estabelecimentos da falida e sua finalidade é garantir melhor resultado na liquidação do ativo da devedora, mediante venda do negócio em marcha ${ }^{508}$.

É importante destacar que a continuidade de negócios imediata constitui medida de exceção, a ser aplicada restritivamente ${ }^{509}$, eis que destinada a hipóteses nas quais a interrupção das atividades da devedora, em decorrência da quebra, poderia causar grave dano ao interesse dos credores ou à conservação do patrimônio ${ }^{510}$.

Mas, com a exigência de tais pressupostos cumulativos, segundo a doutrina, a hipótese de continuação imediata dos negócios torna-se de difícil aplicação prática ${ }^{511}$. Entretanto, justifica-se essa opção do legislador, tendo em vista que a decisão por esta

\footnotetext{
${ }^{507}$ Barbieri certifica que foi prevista no Código Comercial e depois na Lei n. 4.156. Posteriormente, na Lei n. 11.719 (artigo 195), previa-se a obrigatoriedade da continuação de negócios para sociedades prestadoras de serviços públicos. Na Lei n. 18.832, de 1970, o Estado ficava encarregado, na pessoa de um administrador designado pelo Poder Executivo, da gestão da continuidade de negócio da falida 'por razões de interesse público e com o fim de assegurar a paz social'. Mais tarde, na Lei n. 19.551 iniciou-se uma sistematização do regime de continuidade de negócios, o qual foi aperfeiçoado na Lei n. 24.522 com a incorporação de tendências do direito estrangeiro, em particular como meio de melhorar o procedimento liquidatório da falência, possibilitando a venda do negócio em marcha. (Concursos y quiebras (Ley n. 24.522 comentada y concordada), Buenos Aires: Editorial Universidad, 2006, pp. 401-402).

${ }^{508}$ DASSO, Ariel Ángel. Derecho concursal comparado, Tomo I, Buenos Aires: Legis, 2009, p.143.

${ }_{509}$ NEDEL, Oscar. Ley de concursos y quiebras comentada. 2. edicion, Buenos Aires: La Ley, 2007, p. 628.

${ }^{510}$ Barbieri critica a redação do artigo 189 da LCQ, dizendo-a 'vaga'. (Concursos y quiebras (Ley n. 24.522 comentada y concordada). Buenos Aires: Editorial Universidad, 2006, p. 404).

${ }^{511}$ ESCUTI, A. Ignacio e BAS, Francisco Junyent. Derecho concursal. Buenos Aires: Astrea, 2006, p.250; MARTÍNEZ, Roberto García. Derecho concursal. Buenos Aires: Abeledo-Perrot, 1997, p. 467; BARBIERI. Pablo C., Concursos y quiebras (Ley 24.522 comentada y concordada). Buenos Aires: Editorial Universidad, 2006, p. 404.
} 
solução cabe apenas ao síndico, que deve comunicá-la ao juiz em 24 horas da decretação da quebra para decisão definitiva a respeito ${ }^{512}$.

Na continuidade ordinária, que segue uma tendência de caráter de exceção estatuída pela Lei n. $24.522^{513}$, a decisão será tomada pelo juiz "solo en caso de que de su interrupción pudiera emanar um grave diminuición del valor de realización o se interrupiera un ciclo de producción que puede concluirse ${ }^{\text {,514. }}$.

Justifica-se o posicionamento restritivo imposto pela lei na medida em que “comprobada la insostenible explotación, el juez no puede admitir que prosiga uma actividad que no pone limites a la insolvencia, sino que la agrava, siendo inconcebible una consciente actividad deficitaria, desarrollada bajo jurisdicción judicial, cumplida mediante actos que en otra situación los jueces reprochan a los fallidos. $" 515$

Nesta modalidade, no prazo de até vinte dias contados da nomeação, o síndico manifesta-se sobre a possibilidade da continuação de negócios, por relatório, em que deve referir, dentre outros aspectos, os seguintes: (i) a possibilidade de manter a exploração do negócio sem que disto resulte agravamento do passivo da devedora; (ii) as vantagens que poderiam advir aos credores pela possibilidade de venda do negócio em marcha; (iii) as vantagens que resultariam para terceiros da manutenção da atividade; (iv) os contratos cuja execução deveria ser mantida.

Nesta linha de ideias, prevê-se que o síndico deva, ainda, apresentar um 'plano de exploração' (plan de explotación), indicando a viabilidade da continuidade de negócios ${ }^{516}$.

\footnotetext{
512 "La ley adopta un criterio subjetivo, a través de la opinión del síndico, que es quien toma la decisión. No habrá controversia: ni el deudor ni los acreedores pueden discutir da decisión. Solamente el juez, a quien debe comunicarse lo decidido dentro de las veintequatro horas, decidirá en definitiva, adoptando las medidas que estime pertinentes, incluso la cesación de la explotación." (MARTíNEZ, Roberto García. Derecho concursal. Buenos Aires: Abeledo-Perrot, 1997, p. 468).

${ }_{513}$ No regime anterior, a continuidade de negócios poderia ser determinada de ofício pelo juiz.

514 Artigo 190 da LCQ.

515 MARTÍNEZ, Roberto García. Derecho concursal. Buenos Aires: Abeledo-Perrot, 1997, p. 480.

516 Como explica Barbieri quanto ao plano de exploração: "En el que deberán presupuestarse los recursos con los que cuenta la quiebra, la possibilidad de obtener nuevas entradas, y las deudas existentes y que podrían generarse; además, el plan deberá hacer mención de las atividades que se llevarán a cabo, de la forma de comercialización y distribuición de los produtos, de las modificaciones en los processos de produción, del resultado estimado de la explotación, etc." (Concursos y quiebras (Ley 24.522 comentada y concordada). Buenos Aires: Editorial Universidad, 2006, p. 410).
} 
A exploração da atividade tanto poderá ser realizada pelo próprio síndico (com a colaboração de terceiros que sejam experts (auditores, assessores financeiros, economistas), como por coadministradores ${ }^{517}$, inclusive pessoas jurídicas especializadas na gestão de empresas em crise ${ }^{518}$.

Após a apresentação do referido relatório pelo síndico, o juiz decide ${ }^{519}$ pela continuação, ou não, das atividades da falida. Uma vez determinada a continuação das atividades e para viabilizar essa solução, a lei sistematiza seu funcionamento, detalhando certos aspectos de como deve evoluir a exploração do estabelecimento da falida, possibilitando a futura alienação do negócio em marcha.

Nesse ponto, revela-se superior o direito concursal argentino em relação ao brasileiro, que nada menciona a respeito do funcionamento de eventual continuidade das atividades do falido.

A sistemática é direcionada a proporcionar a organização de bens do devedor, de modo a proporcionar a venda com melhor resultado. Nesse período, por exemplo, fica suspenso o direito de retirada e venda de bens hipotecados ou gravados com garantia real, desde que o síndico cumpra as obrigações vencidas decorrentes do contrato $^{520}$.

Disciplina-se, ainda, a relação de locação, estabelecendo a lei que tais contratos permaneçam em vigor, nas mesmas condições originariamente contratadas, e o aluguel devido após a quebra será suportado pela massa ${ }^{521}$.

\footnotetext{
517 Os quais se sujeitam à ação de responsabilidade por eventuais danos que venham a causar, conforme artigo 175 da LCQ. (BALBÍN, Sebastián. Quiebra y responsabilidad de administradores y terceros. Buenos Aires: Adhoc, 2005, pp. 21-22).

${ }^{518}$ Artigo 190, 4 c/c 191, 1 e 5 da LCQ.

${ }^{519}$ Artigo 191 da LCQ.

${ }^{520}$ Artigo 195 da LCQ. Na falência, o credor hipotecário ou com garantia real tem o direito de, a qualquer momento, executar seu crédito e promover a venda, em separado, dos bens vinculados, conforme artigo 209, parágrafo $1^{\circ}$. Excepcionalmente, no regime da continuidade de negócios, se o síndico mantiver os pagamentos vencidos em dia, fica suspenso esse direito.

${ }_{521}$ Artigos 193 e 194 da LCQ.
} 
Além disso, a quebra não resolve, desde logo e per se, os contratos de trabalho, já que, na hipótese de regime de continuidade de negócios, o síndico deverá eleger os trabalhadores que serão mantidos em suas funções.

Em razão dos inúmeros aspectos envolvidos na continuação de negócios da falida, Barbieri anota que esta é uma decisão de caráter eminentemente econômico, e não apenas jurídico. Por tal razão, parte da doutrina defende que a formação dos juízes concursais deveria incluir conhecimentos nas áreas econômica e social ${ }^{522}$.

Tanto isso é certo que a lei legitima os trabalhadores vinculados à falida a requerer a continuidade de negócios, caso em que, se deferida pelo magistrado, deverão organizar-se em regime de cooperativa ${ }^{523}{ }_{-}^{524}$.

A continuação de negócios, por sua própria natureza, deve ter prazo determinado de duração ${ }^{525}$, podendo concluir-se por duas alternativas: cessação do regime ou aquisição, por terceiro, do estabelecimento da falida.

Em qualquer dos casos de término do regime de continuação, cessa, em definitivo, o contrato de trabalho daqueles que permaneceram vinculados nesse período, e os créditos laborais decorrentes desta fase terão privilégio no pagamento, como se se tratasse de dívida da massa ${ }^{526}$, tratamento semelhante ao do direito brasileiro.

Entretanto, e como meio de incentivar a alienação, o adquirente de uma unidade em funcionamento por continuidade de negócios não assume as obrigações

522 (Concursos y quiebras (Ley 24.522 comentada y concordada). Buenos Aires: Editorial Universidad, 2006, p. 412).

523 "En la continuidad de la empresa se tomará en consideración el pedido formal de los trabajadores en relación de dependência que representen las dos terceras partes de personal en atividade o de los acreedores laborales quienes deberán actuar en el período de continuidad bajo la forma de una cooperativa de trabajo" Artigo 190, $2^{\mathrm{a}}$ parte).

${ }^{524}$ É o caso do Frigorífico Yaguané, localizado em Virrey de Pino, que à partir de 1995 passou a ser conduzido por uma cooperativa de trabalhadores e que, em 2006, contava com mais de quinhentos associados que "no solo recuperando el prestigio perdido por malas gestiones empresarias, sino también consolidando su emprendimiento como el modelo de empresa solidaria que impulsa otros intentos de raíz similar em distintos puntos del país" (ESCUTI, A. Ignacio e BAS, Francisco Junyent. Derecho concursal. Buenos Aires: Astrea, 2006, pp. 255-256).

${ }^{525}$ Artigo 191, 2, da LCQ: "no podrá exceder de necessário para la enajenación de la empresa".

${ }^{526}$ Artigos 198 c/c e 240 da LCQ. 
trabalhistas da falida (que deverão ser reclamadas exclusivamente no concurso), seja resultante do período da continuidade de negócios ou anterior a esta ${ }^{527}$.

Outrossim, a continuidade imediata de negócios da falida prevista no direito concursal argentino visa a facilitar a alienação em bloco dos ativos da falida, de modo a se obter melhor resultado no valor dos ativos, a benefício dos credores ${ }^{528}$.

A lei argentina busca, inegavelmente, a conservação do negócio economicamente útil, mesmo na falência, conforme fica evidenciado no seguinte aresto: “Continuación de la explotación de la empresa. Finalidad. La conservación de la empresa está prevista hasta en las formas de liquidación preceptuadas para la quiebra cuando se dispone la enajenación de la empresa como unidad o como conjunto de bienes que integran el establecimiento del fallido"(CNCcom., sal E, Abril 15-982, - Silos Y Elevadores, S.A. s/ quiebra-ED, 99-426) ${ }^{529}$.

É, na verdade, disso que trata a previsão de prioridade da alienação em blocos dos ativos da falida, do artigo 204 da LCQ. Pelo dispositivo, preferencialmente, o magistrado deve optar pela venda: (i) da empresa como unidade, (ii) de estabelecimento, (iii) isolada dos bens ou partes destes, ou (iv) sob mais de uma forma de realização, sempre que as circunstâncias do caso concreto, do ponto de vista do resultado, o recomendem.

É preciso esclarecer, ainda, que a lei concursal argentina distingue a alienação da empresa como unidade daquela denominada alienação da empresa como estabelecimento $^{530}$.

\footnotetext{
${ }^{527}$ Barbieri anota, ainda, em complementação que: "El adquirente que desee continuar su vinculo laboral con algún ex dependente de la fallida podrá hacerlo ingresándolo desde la fecha de compra de la quebrada - o en cualquier otra posterior -, considerando que esa relación laboral es "nueva", y podendo ignorar las condiciones de monto remuneratório, antigüedad, categoria de trabajo, etc. que registrava." (BARBIERI, Pablo C. Concursos y quiebras (Ley 24.522 comentada y concordada). Buenos Aires: Editorial Universidad, 2006, p. 428).

${ }_{528}$ PETRAZZINI, Verónica F. Martínez. Ley de concursos y quiebras $n$. 24.522: comentario analítico y comparativo de la reforma. Buenos Aires: Ediciones Macchi,1995, p. 223; NEDEL, Oscar. Ley de concursos y quiebras comentada, 2. edicion, Buenos Aires: La Ley, 2007, pp. 618-619 e 623; e BARBIERI. Pablo C., Concursos y quiebras (Ley 24.522 comentada y concordada). Buenos Aires: Editorial Universidad, 2006, pp. 404-405.

${ }^{529}$ Decisão referida por NEDEL, Oscar. Ley de concursos y quiebras comentada. 2. edicion, Buenos Aires: La Ley, 2007, p. 620).

${ }^{530}$ Mas esse entendimento não é pacífico, conforme anotado por MARTíNEZ, Roberto García. Derecho concursal. Buenos Aires: Abeledo-Perrot, 1997, pp. 513-515.
} 
A primeira hipótese, de venda como unidade, é disciplinada como alienação da empresa em funcionamento, ou seja, de um negócio em marcha, em decorrência do regime da continuidade de negócios pela falida, como acima mencionado e amplamente disciplinado pela lei. Já a segunda hipótese é considerada simplesmente como uma alienação de um conjunto de bens organizados, ou seja, como estabelecimento ${ }^{531}$.

Percebe-se que há uma sutileza envolvida na diferenciação e que, nesse particular, revela a superioridade do direito argentino em relação ao brasileiro.

De fato, como o nosso sistema silencia por completo a respeito do regime de continuidade de negócios, fica claro que a previsão de venda em bloco disciplinada no artigo 140 da Lei n. 11.101/05 consiste apenas em uma modalidade de venda de ativo. Já a hipótese de venda como unidade prevista no direito argentino mais se aproxima da cessão de bens prevista no direito francês, na qual o objetivo é a manutenção dos postos de trabalho e a continuação das atividades.

Voltando à análise do direito argentino, Barbieri anota que a decisão judicial que decida por afastar-se da ordem de preferência recomendada pela lei deve ser fundamentada ${ }^{532}$, mas esse posicionamento não é pacificado ${ }^{533}$.

A lei exige que a venda da unidade em funcionamento seja precedida de uma avaliação, que deve fixar um 'preço de mercado ${ }^{, 534}$. Em seguida, será realizada a

531 VÍTOLO, Daniel R. RICHARD, Efraín H (Directores) e ANDREANI, Patricia Fernandéz de (Coordinadora). Acciones de recomposición patrimonial y conflictos laborales em la quiebra. Buenos Aires: Adhoc, 2005 (obra coletiva): "Algunas precisiones sobre la enajenación de la empresa como unidade en la quiebra”, pp. 263-269: ROMERO, Raúl e HUALDE, Fernando Pérez.

532 Apoiado no seguinte aresto: "corresponde autorizar la venta directa de los bienes materiales $e$ inmateriales de la fallida a la cooperativa de trabajo constituida por los ex dependientes que conforman la mayoría de los acreedores laborales verificados - en el caso, cerca del $70 \%$ que laboraban para una empresa editorial - toda vez que la oferta efectuada no acarrea prejuicio para el resto de los acreedores al asegurar la base establecida por el Tribunal, considerando además que en caso de venta por licitación deviene incierto que ella sea alcanzada y existe la posibilidad de que el llamado quede desierto y deba convocarse a una nueva licitación sin base" (JCiv y Com., 7 a Nominación, Córdoba, 21-8-03, "Comercio y Justicia Editores S/A - hoy quiebra), BARBIERI. Pablo C., Concursos y quiebras (Ley 24.522 comentada y concordada). Buenos Aires: Editorial Universidad, 2006, p. 439.

${ }^{533}$ E é contraposto por MARTíNEZ, Roberto García. Derecho concursal. Buenos Aires: Abeledo-Perrot, 1997, p. 513.

534 "Se ha dicho que ese valor no deriva del precio de reposición de sus elementos, sino en su productividad normal y estimada", conf. Juzg. Nac. Com. Cap. 13, firme, 3-VII-1978, E.D., t.78, pág. 759 (MARTÍNEZ, Roberto García. Derecho concursal. Buenos Aires: Abeledo-Perrot, 1997, p. 516). 
venda dos bens, por hasta pública judicial, por procedimento de propostas a serem apresentadas de forma lacrada ao juiz ${ }^{535}$ ou por venda direta ${ }^{536}$.

O que deve efetivamente prevalecer é a maior transparência possível no sistema de alienação ${ }^{537}$. Assim, a venda direta torna-se viável sempre que a natureza dos bens assim o recomendar, tal como na hipótese de perecíveis ou ativos de pequeno valor, ou mesmo quando frustradas as formas anteriores, podendo ser efetuada pelo síndico diretamente ou por um intermediador.

No que diz respeito ao início do procedimento de venda dos ativos na falência, o artigo 203 da Ley de Concursos y Quiebras prevê sua 'imediata' realização. Todavia, a lei fixa duas exceções que, na prática, tornam esse dispositivo inócuo: a venda dos ativos não poderá ser iniciada se o devedor houver requerido conversão da quebra em concurso, ou se houver interposto recurso contra a decisão que decretou a falência.

Nesse aspecto, ante o regime de conversibilidade de procedimentos acolhido pelo sistema argentino, a lei revela-se inferior à brasileira, na medida em que a célere alienação dos ativos é requisito fundamental para possibilitar a sua efetiva reinserção ativa e útil no mercado.

Talvez, nesse caso, o sistema argentino, na busca de melhor proporcionar oportunidades de recuperação das empresas em crise tenha pecado pelo excesso. Na verdade, a impossibilidade de venda antecipada de bens, ante a viabilidade de reversão dos efeitos da quebra, pode acabar resultando em um efeito contrário ao objetivo da preservação. Isso porque, se o devedor não estiver apto a implementar medidas de saneamento, melhor solução é a do direito francês, que possibita a um terceiro fazê-lo, mediante um plan de cession.

Mesmo assim, em suma, são inúmeras as medidas previstas na lei concursal argentina que buscam preservar o negócio. Mesmo na falência essa é uma realidade, como anota Verónica F. Martínez Petrazzini ao afirmar que "por un lado, se procura la

\footnotetext{
${ }^{535}$ Artigo 205 da LCQ.

${ }^{536}$ Artigo 213 da LCQ.

${ }^{537}$ DASSO, Ariel Ángel. Derecho concursal comparado. Tomo I, Buenos Aires: Legis, 2009, p.147.
} 
conservación de la empresa economicamente útil y el empleo que ésta genera, cumpliendo con un fin social. También se intenta así la liquidación de la misma como unidad, o empresa en marcha, lo cual debería significar que se obtiene un mayor precio por la misma..." 538 .

Desse modo, anota-se o pendor pró-devedor acolhido pelo direito argentino, que, na verdade, é resultado de uma política legislativa eminentemente preservacionista, em particular dirigida à salvaguarda dos postos de trabalho, como ocorre no direito francês.

$2.8 \mathrm{O}$ direito estrangeiro e o direito brasileiro

Acredita-se terem sido evidenciados, nos sistemas estrangeiros analisados, pontos de destaque que os particulariza e outros aspectos que revelam certos traços em comum entre alguns deles.

Enquanto o direito alemão, o português e o espanhol claramente declinam tendência pró-credor (o objetivo primeiro é o de satisfação do passivo), os demais sistemas estudados indicam pendor para a salvaguarda da atividade, circunstância que torna lícito afirmar, por via reflexa, sua aproximação com uma tendência pró-devedor.

O direito brasileiro vigente, ante as regras dos artigos 47 e 75 da Lei n. $11.101 / 05$, evidentemente, revela seu viés preservacionista ${ }^{539}$.

Há uma particularidade que merece referência, no que respeita à fixação do critério subjetivo de sujeição ao direito concursal. Nesse ponto, o sistema brasileiro merece

\footnotetext{
${ }^{538}$ Ley de concursos y quiebras n. 24.522: comentario analítico y comparativo de la reforma. Buenos Aires: Ediciones Macchi, 1995, p. 223.

539 "Comercial e Processual Civil. Pedido de Falência. Decreto-Lei n. 7661/45. Valor ínfimo. Princípio da preservação da empresa. Indeferimento. I. O Superior Tribunal de Justiça rechaça o pedido de falência como substitutivo de ação de cobrança de quantia ínfima, devendo-se prestigiar a continuidade das atividades comerciais, uma vez que não caracterizada situação de insolvência, diante do princípio da preservação da empresa. II. Recurso Especial conhecido, mas desprovido. (...) Em razão do princípio da preservação da empresa, o qual inspirou a doutrina, a jurisprudência a Lei $n$. 11.101/05, art. 94, não basta a impontualidade para o requerimento de falência; deve-se levar em consideração também os sinais de insolvência da empresa, como bem delineou o aresto estadual.". (REsp. 920.140-MT, Relator Ministro Aldir

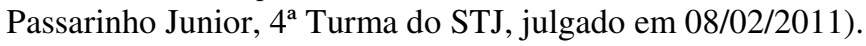


crítica. Há uma tendência mundial de ampliação do critério subjetivo de sujeição às regras de direito concursal ${ }^{540}{ }_{-}^{541}$.

De fato, em muitos dos sistemas estudados o direito concursal é aplicável à atividade negocial de qualquer natureza (empresária ou não), sociedades profissionais, sujeitos que exercem atividade rural, pessoas físicas e até entes despersonalizados, como se observa no direito germânico $^{542}$.

Constata-se que há regras especiais dirigidas à disciplina da crise de organismos responsáveis pela criação ou circulação de riquezas, de bens ou serviços na medida em que os ordenamentos reconhecem uma função social desses entes, já que os efeitos das dificuldades, em regra, ultrapassam as restritas relações entre credores e devedor.

O direito brasileiro, ainda centrado no subjetivismo do conceito de empresário $^{543}$ adotado pelo vigente Código Civil - este inspirado no direito italiano da década de $1940^{544}$ - manteve a opção legislativa de segregação entre atividade civil (não empresária) e empresária ${ }^{545}$.

Em consequência, a Lei n. 11.101/05 é aplicável somente ao empresário, ficando excluído de seu âmbito de incidência quem não o seja: "Nesse aspecto, $a$

\footnotetext{
540 Confira-se: direito norte-americano, francês, alemão, português, espanhol e argentino. No direito argentino, vale a referência de Pablo Barbieri: "La distinción entre sujetos comerciantes y no comerciantes y a forma parte da la historia de la legislación concursal argentina, como también aquella división entre personas jurídicas privadas y las que tengam participación estatal, ya que éstas se encontran absolutamente incluidas dentro del regimén de la $L C y Q$, habiéndo-se presentado notórios ejemplos de aplicación práctica, como el de Argentina Televisora Color." (BARBIERI. Pablo C., Concursos y quiebras (Ley 24.522 comentada y concordada), Editorial Universidad, Buenos Aires, Argentina, 2006, p. 43).

${ }^{541} \mathrm{O}$ direito concursal italiano permanece vinculado a noção de "imprendittore commerciali", excluindo-se os empresários que exercem atividade agrícola, as sociedades de que participe o governo e também 'i piccoli imprenditori'. (artigo 1, da LF).

${ }^{542}$ Anote-se, entretanto, a exceção da insolvência de entidades, cuja atuação implica risco sistêmico (instituições financeiras, seguradoras e afins) que possuem disciplina própria sempre.

${ }^{543}$ Privilegia-se o cunho subjetivo da matéria (GONÇALVES NETO, Alfredo de Assis. Direito de Empresa - Comentários aos artigos 966 a 1.195 do Código Civil, $2^{\mathrm{a}}$ edição, Editora Revista dos Tribunais, 2008, p. 68).

${ }_{544}^{5}$ Inspirado no artigo 2238 do CC italiano de 1942.

545 "A distinção entre sociedade simples e empresária, do ponto de vista do direito material, faz-se em razão da diversidade de registros, que, como se verá nos comentários ao art. 1.150 é resquício do regime jurídico anterior, que pode poderia ter sido eliminado." (GONÇALVES NETO, Alfredo de Assis. Direito de empresa - comentários aos artigos 966 a 1.195 do Código Civil. 2. edição, São Paulo: Revista dos Tribunais, 2008, pp. 67-68).
} 
unificação do direito privado não superou a diferença entre comerciantes e não comerciantes, que permanece atualmente, travestida de outra terminologia"546_547.

Nesse particular, o direito brasileiro permanece na contramão da moderna tendência de ampliação do critério subjetivo de sujeição ao direito concursal.

Veja-se, por exemplo, no que se refere à atividade rural, a sujeição ao regime concursal somente ocorre para os que houverem optado pela inscrição no registro público de empresas, conforme lhes autoriza o artigo 971 do CC. A solução legal, portanto, é 'sui generis ${ }^{548}$, mas releva o fato inegável de que a vigente definição de empresário não é apta a alcançar, como deveria, toda e qualquer atividade negocial.

Outro exemplo, provável resultado dessa mesma estreita visão restrituiva, é a exclusão da incidência da Lei n. 11.101/05 para as sociedades de economia mista, que, por expressa disposição constitucional atuam no mercado e concorrem, lado a lado, com outras de capital privado $^{549}$. A exclusão dessas empresas ao regime da lei concursal, como anota Paulo Fernando Campos Salles de Toledo, constituiu verdadeiro "retrocesso", afirmando textualmente o professor que, "A LRE deu um passo atrás nessa matéria, exatamente no momento em que se procura valorizar a atividade empresarial" ${ }^{550}$.

A empresa, no dizer de Paula Andrea Forgioni é agente econômico ${ }^{551}{ }_{552}$ e, como tal, deveria ter sido tratada pela lei concursal brasileira vigente, porque esse conceito

\footnotetext{
${ }^{546}$ FORGIONI, Paula Andrea. A evolução do direito comercial: da mercancia ao mercado. São Paulo: Revista dos Tribunais, 2009, p. 115.

${ }^{547}$ Como acentua o seguinte aresto do TJSP: "Falência. Sociedade Civil Ltda. prestadora de serviços de medicina, especialização em cardiologia e exames complementares. Sociedade-ré não sujeita a falência sob a óptica do Código Civil, que a considera sociedade simples, bem como sob a disciplina do DL $7661 / 45$ e sob o regime da Lei $n$. 11.101/05. A sociedade prestadora de serviços intelectuais-científicos (medicina), mesmo na forma de atividade econômica organizada e com auxílio de colaboradores e empregados, ainda que adote o modelo legal de sociedade empresária, no caso vertente sociedade limitada, não esta sujeita a pedido de falência com fundamento no $D L$ n. 7661/45, seja com supedâneo na Lei de Recuperação e Falências. A circunstância de a sociedade exercer atividade econômica, com finalidade lucrativa, por si só, não confere a ela a qualidade de sociedade empresária." (Rel. Des. Pereira Calças, Apelação n. 360.281-4/200, j. 25/08/2005).

${ }^{548}$ TOLEDO, Paulo Fernando Campos Salles de.; ABRÃO, Carlos Henrique (Coord.). Comentários à lei de recuperação de empresas e falência. 4. edição, São Paulo: Saraiva, 2010, p. 52.

${ }^{549}$ Artigo $173, \S 1^{\circ}$, II da CF/88.

${ }^{550}$ TOLEDO, Paulo Fernando Campos Salles de.; ABRÃO, Carlos Henrique (Coord.). Comentários à lei de recuperação de empresas e falência, 4. edição, São Paulo: Saraiva, 2010, p. 54.

551 FORGIONI, Paula Andrea. A evolução do direito comercial: da mercancia ao mercado. São Paulo: Revista dos Tribunais, 2009, p. 128.
} 
é mais abrangente do que o de empresário. Com efeito, algumas das deficiências identificadas na Lei n. 11.101/05 devem-se, exatamente, à ausência desta percepção.

Isto, sobretudo, porque não faz sentido que a finalidade da lei brasileira seja a de preservação da empresa (conforme se lê nos artigos 47 e 75) e, anacronicamente, exclua importantes organismos de produção do âmbito de sua incidência - como, por exemplo, as sociedades de economia mista e a atividade não empresária (que, muitas vezes, promove a criação e circulação de riquezas) -, por não ostentarem a qualificação de empresa no senso da definição do Código Civil vigente.

Além disso, mesmo para pessoas que não exercem atividade econômica organizada, embora não seja da tradição de nosso direito, seria o caso de avaliar a possibilidade de ampliação do critério subjetivo de aplicação da lei concursal.

Veja-se, por exemplo, o caso do consumidor, esse elemento fundamental que integra a rede de elos de uma cadeia econômica: ele é o destinatário final dos bens e serviços de consumo. O direito alemão e o direito norte-americano, por exemplo, disciplinam, no seio do direito concursal, as situações de crise econômico-financeira de pessoa física (consumidor).

Note-se, o superendividamente do consumidor é uma patologia do crédito, e não há disciplina, no direito brasileiro, de tratamento concursal desta situação ${ }^{553}$; de modo que não existem mecanismos de reabilitação do indivíduo do ponto de vista socioeconômico, o que fere, em tese, o princípio da dignidade humana, constitucionalmente tutelado, como já tive ocasião de salientar ${ }^{554}$.

\footnotetext{
${ }^{552}$ No direito concursal espanhol travou-se interessante discussão a respeito da capacidade concursal, ante a disposição do artigo $1^{\circ}$ da lei, que sob o título de pressuposto objetivo, sujeita ao procedimento "cualquier deudor, sea persona natural o jurídica". O debate girou em torno da possibilidade (que é expressamente adotada pelo direito alemão) de que entidades sem personalidade jurídica, mas que atuam como centro de imputação de atividade negocial, pudessem se sujeitar ao regime de direito concursal. (PARRA, Maria Ángeles. Persona y patrimonio en el concurso de acreedores. Estudios de derecho concursal. Espanha: Thomson Reuters, 1. edição, 2009, pp. 80-88).

${ }^{553}$ A única disciplina disponível é a insolvência civil, que não passa de um procedimento de execução coletiva do devedor, mas que, de modo algum socorre a problemática da reabilitação econômica do devedor.

${ }^{554}$ PUGLIESI GARDINO, Adriana Valéria. "Superendividamento do consumidor: breves reflexões". Revista da Ajuris (Associação dos juízes do Rio Grande do Sul), Porto Alegre, vol. 121, Ano XXXVIII, pp. 13-46, março 2011.
} 
Portanto, há campo de aperfeiçoamento possível para o direito concursal brasileiro, a começar pela superação da dicotomia entre empresa e atividade civil (não empresária), consoante tendência nos ordenamentos estrangeiros analisados.

Por outro lado, e de um modo geral, ressalvadas críticas tópicas, já exaustivamente apontadas pela doutrina, a Lei n. 11.101/05 colocou o sistema concursal brasileiro no patamar das modernas legislações de disciplina da crise das empresas ao lado dos demais sistemas antes analisados e, em muitos aspectos, mostrando-lhes superioridade nas soluções encontradas.

No que respeita à falência, a alteração é profunda, na medida em que o instituto deixa de ser um procedimento de execução coletiva para ser alçado a um método de satisfação dos credores temperado pelo princípio da preservação da atividade econômica (ainda que cincuncrita ao conceito de empresa), o qual permeia todo o sistema concursal, como será visto a seguir. 


\section{CAPÍTULO TERCEIRO \\ A FALÊNCIA NA LEI BRASILEIRA EM VIGOR}

3.1 A empresa e o direito concursal.

A empresa, como centro de interesses do direito comercial, é resultado da evolução histórica deste ${ }^{555}$.

Lembremos que o nascimento do direito comercial, no período medieval, resultou da necessidade de regulamentação das relações entre os comerciantes e surgiu baseada nos usos e costumes praticados nas corporações de mercadores, porque o direito romano civil, preso em sua rigidez de formas, não era capaz de atender às necessidades dos então mercadores para dirimir suas controvérsias. Nesta primeira fase, denominada período subjetivo (centrado no sujeito, na pessoa do comerciante ${ }^{556}$ ), o direito comercial era o direito dos comerciantes.

O natural desenvolvimento da mercancia fez com que determinadas práticas, fruto da criatividade dos mercadores, se deslocassem do quotidiano destes para quem não era comerciante (como os títulos cambiais, por exemplo), trazendo para o centro de interesses do direito comercial a disciplina dos atos de comércio, no período histórico denominado objetivo, focado, pois, no objeto das regras disciplinadoras.

Modernamente, acolhe-se a concepção qualificadora do direito comercial por intermédio da empresa ${ }^{557}{ }^{558}$.

\footnotetext{
555 FORGIONI, Paula Andrea. A evolução do direito comercial: da mercancia ao mercado. São paulo: Revista dos Tribunais, 2009, pp. 55-98.

${ }^{556} \mathrm{O}$ direito comercial era um direito corporativo, profissional, especial, autônomo e consuetudinário, como disse Rubens Requião (Curso de direito comercial. Vol. 01, 14. edição, São Paulo: Saraiva, 1984, p. 10).

${ }_{557}$ Rubens Requião classifica essa fase do direito comercial como período subjetivo moderno. (Curso de direito comercial. Vol. 01, 14. edição, São Paulo: Saraiva, 1984, p. 13).

${ }^{558}$ Mas, para Paula Forgioni, o direito já alcançou uma nova época. O elemento qualificador do direito comercial é o mercado. A empresa é "centro de imputação" de direitos, deveres e obrigações, que independem do empresário ou da sociedade empresária. Para a autora, na economia contemporânea, não é possível conceber a empresa de forma isolada, pois é "agente econômico que atua no mercado", eis que "a empresa não apenas "é", ela "age", "atua" no mercado, e o faz principalmente por meio dos contratos." (FORGIONI, Paula Andrea. A evolução do direito comercial brasileiro: da mercancia ao mercado. São Paulo: Revista dos Tribunais, 2009, pp.125-128).
} 
O conceito de empresa, todavia, procede originalmente da ciência econômica ${ }^{559}{ }_{-56}^{560}$, mas desperta inegável interesse ao direito na medida em que as organizações que produzem e comercializam bens e serviços, contratam e aparelham fatores de produção, exigem tutela, a fim de disciplinar o crédito e as relações originárias da circulação de bens ou serviços.

O artigo 996 do Código Civil não oferece conceito de empresa, mas sim de empresário $^{562}$, inspirado no artigo 2084 do Codice Civile italiano, de 1942. Na conceituação de empresa, do ponto de vista jurídico, ainda se mostra útil invocar os célebres perfis de Asquini ${ }^{563}$, para quem esta é um fenômeno poliédrico; enquanto do ponto de vista econômico, seu conceito é uno ${ }^{564-565}$.

No direito concursal moderno, a empresa está inquestionavelmente ligada à noção de instituição, na medida em que se lhe reconhece uma função social, posto que atrelada à finalidade de "construir riqueza para a comunidade, oferecer trabalho, melhorar a técnica, favorecer o progresso científico - e não simplesmente buscar lucros para distribuição aos sócios. " ${ }^{566}$ Nesse cenário, a noção de empresa desponta sob a lógica publicista que envolve o direito concursal moderno, como "instrumento de desenvolvimento econômico geral ${ }^{\text {"567. }}$.

\footnotetext{
${ }^{559}$ COASE, Ronald. The Nature of the firm: Origins, evolution and developments, edited by WILLIAMSON, Oliver E. and WINTER, Sidney G., Oxford University press, 1991.

${ }^{560}$ Fábio Nusdeo ensina que "a empresa é a unidade produtora cuja tarefa é combinar fatores de produção com o fim de oferecer ao mercado bens e serviços, não importa qual o estágio da produção." (Curso de economia: introdução ao direito econômico, São Paulo: Revista dos Teibunais, 1997, p. 285).

561 "O Direito é tradução da vida social nos seus múltiplos aspectos, inclusive o econômico, e, por isso, o fenômemo jurídico não pode ser fixado senão à luz desses pressupostos, donde a utilidade de examinar o conceito econômico da empresa, tal como se formou no tempo e é hoje dominante." (MARCONDES, Sylivio. Problemas de direito mercantil, São Paulo: Max Limonad, 1970, p. 01).

${ }_{562}$ ASCARELLI, Tulio. "O empresário" (tradução de Fábio Konder Comparato). Revista de Direito Mercantil, Industrial, Econômico e Financeiro, São Paulo, vol. 109, Ano XXXVI (nova série), pp. 183-189, $\mathrm{jan} / \mathrm{mar} 1998$.

${ }_{563}$ Profilli dell'impresa. Rivista di diritto commerciale, Vol. XLI - Parte I, pp.1-20, 1943.

${ }_{565}^{564}$ ASQUINI, Alberto. Profilli dell'impresa. Rivista di diritto commerciale, Vol. XLI - Parte I, p. 2.

${ }^{565}$ A propósito, Rachel Sztajn tece paralelo entre a conceituação de empresa elaborada pelo economista britânico Ronald Coase (1937) e os perfis de Asquini (1942). ("Teoria furídica da empresa: atividade empresária e mercados" São Paulo: Atlas, 2004, pp. 173-225).

${ }_{566}$ FORGIONI, Paula Andrea. A evolução do direito comercial: da mercancia ao mercado. São Paulo: Revista dos Tribunais, 2009, pp. 75-76. Confira-se, também, as referências de pp. 97-98.

${ }^{567}$ FORGIONI, Paula Andrea. A evolução do direito comercial: da mercancia ao mercado. São Paulo: Revista dos Tribunais, 2009, p. 77.
} 
No direito falimentar brasileiro, antes de tudo, uma questão semântica deve ser enfrentada quanto ao emprego da expressão empresa. O texto da Lei n. 11.101/05 não a utilizou com a precisão técnica que seria desejável, tanto que Mauro Rodrigues Penteado tece crítica ácida a respeito do uso "encabulhado" do termo e indica critérios orientadores dirigidos a facilitar a tarefa do intérprete ${ }^{568}$.

Ainda que a terminologia adotada em certas passagens demonstre, efetivamente, pouca "qualidade do estilo do legislador", 569 , também é verdade que isso não impede o estudioso atento de chegar a uma interpretação sistemática coerente.

Desse modo, enquanto no artigo 47 da Lei n. 11.101/05 a expressão empresa está claramente empregada na acepção do perfil funcional proposto por Asquini $^{570}$, parece que essa não pode ser a interpretação para o mesmo termo, mencionado no artigo 75 da Lei, e nas demais disposições que tratam da falência.

\subsection{1 - Conceito de 'empresa' na falência.}

De fato, não é possível entender, ao menos em tese, a empresa enquanto atividade $^{571}$, na falência, pois com a decretação, o devedor é afastado e desapossado de seus bens ${ }^{572}$.

\footnotetext{
568 Comentários à Lei de Recuperação de Empresas e Falência, $\mathrm{r}$ ao artigo 35 da Lei n. 11.101/2005, obra coletiva coord. SATIRO DE SOUZA JR., Francisco; PITOMBO, Antonio Sergio M., Revista dos Tribunais, 2. edição, 2007, pp. 102-103.

${ }^{569}$ Como também anota Paulo Fernando Salles de Toledo ("A preservação da empresa, mesmo na falência", em obra coletiva coord. por LUCCA, Newton de; DOMINGUES, Alessandra de Azevedo. Direito recuperacional aspectos teóricos e práticos. São Paulo: Quartier Latin, 2009, pp. 519-520).

${ }^{570}$ Como lembra Paulo Fernando Campos Salles de Toledo ao comentar o uso das expressões "manutenção da fonte produtora" e "preservação da empresa" referidas no artigo 47 da Lei n. 11.101/2005: "talvez o texto legal (que se presume não tenha palavras inúteis) esteja se referindo à empresa enquanto atividade, ou seja, à empresa no sentido funcional, de acordo com os célebres perfis de Asquini" ("A nova lei de falências e de recuperação de empresas", Revista do Advogado, ano XXV, n. 83, p. 103, set. 2005).

${ }^{571}$ Ascarelli, a propósito, ensina: 'L'impresa costituice l'attivitá dell'impreditore (art. 2082) e perciò non può piú attenere alle modalitá dell'atto (come l'impresa del codice abrogato); ma alla qualifica di una attività . (...) Attività non significa atto, mas uma seria di atti tra loro coordinabili in relazione ad una comune finalittà. (Corso di diritto commerciale - introduzione e teoria dell'impresa, terza edizione, Milano: Giuffrè, 1962, p. 147). Em tradução livre: 'A empresa é a atividade do empresário (art. 2082) e, por esta razão, não mais pode se ater à modalidade do ato (como a empresa do código revogado), mas à qualificação de uma atividade. (...) Atividade não significa ato, mas uma série de atos coordenados entre si sob a relação de uma finalidade comum'.

572 "Embora a lei atual não traga dispositivo idêntico, é claro que continua em vigor a proibição contida no $\$ 1^{\circ}$ do art. 40 do DL n. 7661/45, ou seja, 'não pode o devedor, desde aquele momento (decretação quebra ou do seqüestro), praticar qualquer ato que se refira direta ou indiretamente aos bens, interesses, direitos $e$
} 
O desapossamento dos bens, portanto, terá como efeito prático a impossibilidade do exercício da empresa (atividade), ao menos pelo devedor, em razão da vedação que a este se impõe para administrar ou dispor dos ativos que passam a integrar a massa falida objetiva, o que inclui o estabelecimento ${ }^{573}$, conforme artigo 103 da Lei $n$. $11.101 / 05$.

Para reforçar essa ideia, vale lembrar que o devedor fica inabilitado $574 \_575$ para o exercício de qualquer atividade empresarial. É o que se infere expressamente do comando do artigo 102 da Lei n. 11.101/05. Nosso entendimento é o de que a inabilitação é efeito que atinge tanto o empresário individual quanto a sociedade empresária, embora não haja pacificação a respeito na doutrina ${ }^{576577}$.

Portanto, por força da decisão judicial de decretação da falência, há compulsória cessação do desenvolvimento de atividade pelo devedor, fato que faz repelir,

obrigações compreendidos na falência, sob pena de nulidade, que o juiz pronunciará de ofício, independente de prova de prejuízo."” (TJSP, AI 576.078-4/6-00, rel. Des. Romeu Ricupero, j. 24/09/08).

573 Artigo 1142 do CC.

574 " $O$ falido atingido por esse efeito não se torna incapaz, mas apenas sofre uma restrição para o exercício de certas atividades. A inabilitação próbe a pessoa do falido de ser empresário individual, isto é, pró́be o falido de exercer a atividade empresarial em seu nome próprio, não impedindo a condição de sócio ou mesmo de administrador de sociedade. (...) Em decorrência dessa inabilitação, o falido também fica impedido para ser corretor de seguros (art. 3, d da Lei 4594/64), corretor de navios ( art. 20 do DL 20.881/31), leiloeiro (art. 3, d do D n. 21.981/32. Além disso, ele fica impedido de exercer a tutela e a curatela (CC, arts. 1735, I e 1774).” (TOMAZETTE, Marlon. Curso de direito empresarial. Vol. 3, São Paulo: Atlas, 2011, p. 363).

${ }^{575}$ A inabilitação de que ora se trata é distinta daquela que resulta da condenação criminal prevista no artigo 181, I da Lei n. 11.101/05, eis que esta última: é pena, tanto que deve ser motivada na sentença penal condenatória; perdura até cinco anos após a extinção da punibilidade do delito (ou, antes disso, por reabilitação penal, nos termos do artigo 94 do CP); estende-se ao exercício de cargo ou função de gestão de empresa, tais como: diretoria, conselho de administração e até por mandato ou gestão de negócios.

576 De fato, parte da doutrina entende que a inabilitação prevista no art. 102 da Lei 11.101/05 aplica-se somente ao empresário individual: VIGIL NETO, Luiz Inácio. Teoria falimentar e regimes recuperatórios, Porto Alegre: Livraria do Advogado, 2008, pp. 235-236 e 24; e MILANI, Mario Sergio. Lei de recuperação judicial, recuperação extrajudicial e falência comentada. São Paulo: Malheiros, 2011, p. 424.

${ }^{577}$ Por outro lado, há autores que sustentam a posição contrária, de que a inabilitação atinge também a sociedade empresária: FERES, Marcelo Andrade, in: CORRÊA-LIMA, Osmar Brina, LIMA, Sérgio Mourão Corrêa (Coord.), Comentários à nova lei de falências e recuperação de empresas, Rio de Janeiro, Forense, 2009, pp. 759-799; e COELHO, Fabio Ulhoa, Comentários à Lei de Falências e de Recuperação de Empresas, 2011, pp. 384/387, 8. edição, São Paulo: Saraiva. A respeito do tema, há um aresto do TJ/SP com o seguinte posicionamento, dando a entender que a inabilitação atinge a sociedade, pela leitura a 'contrario sensu': "Mesmo depois de encerrado o processo, podem os antigos sócios reabilitar a sociedade empresária falida, revertendo os efeitos dissolutórios da falência, com o objetivo de fazê-la retornar à exploração da atividade - Em suma, sociedade falida que, mesmo depois de encerrada sua falência, pode requerer a extinção de suas obrigações e voltar a comerciar." (TJSP, Ap. Cível n. 555.048-4/6-00, rel. Des. Romeu Ricupero, J. 28.05.2008). 
ao menos em tese, o conceito de "empresa" enquanto atividade, na falência, segundo a noção proposta por Asquini.

Em outras palavras, a falência tem como efeito imediato ${ }^{578}{ }_{-}^{579}$ e ope legis a impossibilidade de o devedor exercer a atividade empresarial.

Entretanto, e como a própria lei explicita, a falência não acarreta, necessariamente, a paralisação dos negócios da falida, conforme artigos 99, XI, e $109^{580}$ da Lei n. 11.101/05.

Mesmo assim, curiosamente, o artigo 109 refere à continuação provisória "das atividades do falido", ou seja, pela letra da lei, o falido exerceria atividade. É claro que se poderia argumentar tratar-se de falta de técnica do uso da terminologia, mas também é inegável que surge clara a ideia do legislador de que há possibilidade de negócios mediante a exploração do conjunto de bens organizados que é objeto da arrecadação. E é essa a imagem que deve prevalecer para fins desta análise, no momento.

Nessa mesma linha de ideias, Paulo Fernando Campos Salles de Toledo indaga se "Poderia a massa falida ser igualmente considerada sujeito de direitos $e$ obrigações?". Pontua, após, inúmeras referências, dentre as quais a mais significativa é o exemplo dos contratos bilaterais, que não se resolvem com o decreto da quebra, e "a partir do momento em que o síndico decide dar continuidade à execução do contrato, não se desprende este de um de seus antigos sujeitos, passando a figurar, na posição por ele antes ocupada, a massa falida?",581

\footnotetext{
${ }^{578}$ Marcelo Feres sustenta que somente depois de publicada a sentença é que passaria esta a surtir efeitos, com o que não concordamos, pois a publicidade da sentença tem eficácia meramente processual (da qual passará a fluir o prazo recursal do devedor, por exemplo) e não se confunde com o resultado material expressamente consignado nos arts. 102 e 103 da Lei concursal brasileira. (FERES, Marcelo Andrade, in CORRÊA-LIMA, Osmar Brina, LIMA, Sérgio Mourão Corrêa (Coord.), 'in' Comentários à nova lei de falências e recuperação de empresas, Rio de Janeiro, Forense, 2009, pp.758-799 e 770-771)

579 "Embora a lei atual não traga dispositivo idêntico, é claro que continua em vigor a proibição contida no $\$ 1^{\circ}$ do art. 40 do DL $n .7661 / 45$, ou seja, 'não pode o devedor, desde aquele momento (decretação quebra ou do seqüestro), praticar qualquer ato que se refira direta ou indiretamente aos bens, interesses, direitos $e$ obrigações compreendidos na falência, sob pena de nulidade, que o juiz pronunciará de ofício, independente de prova de prejuizo."” (TJSP, AI 576.078-4/6-00, rel. Des. Romeu Ricupero, j. 24/09/08).

${ }^{580}$ A lacração somente ocorre se houver risco para a fase de arrecadação dos ativos, e tal decisão fica ao prudente critério do juiz, na análise do caso concreto (TJPR, AI n. 0375155-7, Rel. Des. Lauri Caetano Silva, j. $7 / 3 / 07)$.

581 TOLEDO, Paulo Fernando Campos Salles. "Da personificação da massa falida". Revista de Direito Mercantil, n. 78, ano XXIX (nova série), abril-junho/1990, pp. 49-50.
} 
Ante o cenário que resulta da quebra, torna-se necessário investigar como o uso do termo empresa poderia ser aplicado na falência, até de modo a pavimentar o caminho para justificar, adiante, como se sustentaria a possibilidade de preservação desta, no âmbito da quebra.

Nesse senso, Paulo Fernando Campos Salles de Toledo ${ }^{582}$ entende que o uso do termo empresa, na falência, é perfeitamente adequado se tomado na acepção do perfil objetivo proposto por Asquini ${ }^{583}$.

Nesta linha de ideias, o sentido empregado para o termo empresa equivale ao conceito de estabelecimento proposto por Oscar Barreto Filho, que consiste no “complexo de bens, materiais e imateriais, que constituem o instrumento utilizado pelo comerciante para a exploração de determinada atividade mercantil" ${ }^{584}$.

E a natureza jurídica de tais bens organizados é de universalidade de fato, circunstância que colabora na compreensão da possibilidade de sua "manutenção" na falência, na medida em que a supressão de um ou de alguns bens não desnatura a essência do estabelecimento. Igualmente, a mudança de titular em nada modifica sua natureza ou características.

Desse modo, está claro que a falência não desfaz nem altera a natureza jurídica do estabelecimento, que é organizado pelo empresário para o exercício da empresa, embora o devedor seja afastado de sua administração.

É preciso abrir um parêntese para esclarecer que a falida pode ser titular de ativos outros que não integrem o estabelecimento (por exemplo, um terreno que tenha sido adquirido para construção de futuras instalações). Todavia, essa situação em nada interefere nos argumentos aqui expostos, na medida em que o foco de análise de

\footnotetext{
582 “A preservação da empresa, mesmo na falência”, em obra coletiva coord. por Newton de Lucca e Alessandra de Azevedo Domingues. Direito recuperacional aspectos teóricos e práticos. São Paulo: Quartier Latin, 2009, p. 521-522.

${ }^{583}$ ASQUINI, Alberto. Os perfis da empresa. Trad. Fábio Konder Comparato. Revista de direito mercantil, $\mathrm{n}$. 104, pp. 109-126.

${ }^{584}$ Teoria do estabelecimento comercial. São Paulo: Max Limonad, 1969, p. 75.
} 
possibilidade da preservação da empresa na falência está jungido ao complexo de bens que integra o estabelecimento (e possibilita a exploração de um negócio). Nesse senso, a ideia de preservação que existe na falência está intimamente relacionada à manutenção da organização que possui sentido econômico, pois permite exploração destinada à produção ou circulação de bens ou serviços, para o mercado.

Parece interessante lembrar a originalidade do direito concursal francês, que adota a noção de empresa - para fins de sustentar o plan de cession (levado a efeito no procedimento de liquidation) - como sendo “des activités susceptibles d'explotation autonome, ${ }^{, 585}$.

Dessa forma, coloca-se o acento do conceito de empresa na exploração de uma atividade econômica, que pode ou não ser empresária, conforme fixação dos critérios subjetivos daquele sistema. Isto porque, como antes acentuado, no direito francês a cessão da empresa inclui a transferência compulsória de certas relações contratuais necessárias à continuação da exploração do negócio, o que implica cessão de elementos outros, além do estabelecimento.

Nesse sentido, torna-se possível, desde logo, afirmar que, na falência, há possibilidade de preservar-se a organização do estabelecimento. Esta organização deixa de ser feita pelo empresário (falido e, como tal, desapossado dos bens e inabilitado ao exercício da atividade empresarial) e passa a ser gerida, no interesse dos credores, sob a orientação e atuação do administrador judicial, sob a fiscalização do juiz.

Mas, no hiato em que a falência se processa, se houver continuidade de negócios, há, indubitavelmente, operação de um negócio, embora não exista empresa (no sentido de atividade, tal como se pode extrair da concepção adotada pelo Código Civil). O conceito em questão, ligado a uma 'atuação operativa', mais se aproxima da acepção de 'atividade negocial', tal como vinha contida na versão do anteprojeto do Código Civil proposta por Sylvio Marcondes $586{ }_{-}^{587} 588$.

\footnotetext{
585 JEANTIN, Michel; LE CANNU, Paul. Entreprises en difficulté. 7. édicion, Paris: Dalloz, 2007, p. 655. Em tradução livre: 'das atividades susceptíveis de exploração autônoma'.

${ }_{587}^{586}$ MARCONDES, Sylvio. Questões de direito comercial. São Paulo: Saraiva, 1977, p. 7.

${ }^{587}$ E que Waldírio Bulgarelli considerou um equívoco ter sido excluída do então anteprojeto que veio a tornar-se o Código Civil em vigor. "A atividade negocial no projeto de Código Civil Brasileiro". Revista de
} 
Ao tratar do conceito econômico de empresa, o autor a comparava com a produção artesanal destinada a consumo próprio e referia que a atividade negocial "surge, ao invés, com a produção para o mercado" "589, pouco importando, assim, se à frente desta está o empresário, pois o foco de análise é o da organização da operação, diferentemente do critério subjetivo (centrado na pessoa), que norteia a noção de empresa adotada pelo Código Civil.

A noção de atividade negocial, desse modo, vai além do conceito de empresa (atividade) adotado no atual Código Civil. Foi nesse sentido que Barros Leães afirmou que "a substituição da denominação 'atividade negocial' eliminada do artigo inaugural do livro dedicado aos empresários e às sociedades tiraram do anteprojeto a sua contribuição mais original, ou seja, a noção de atividade negocial - embora esse conceito se mantenha tacitamente preservado como elemento informativo fundamental."

Observa-se, conforme se extrai da leitura do artigo 966 do Código Civil, que a lei civil brasileira não define a empresa, mas o empresário. Por conseguinte, optou-se por uma sistematização do direito de empresa que coloca em evidência a figura do empresário ao tomá-lo como elemento definidor do exercício da atividade econômica organizada. A opção legislativa, embora tenha manietado a análise do tema, não pode restringir o foco de análise possível por meio do direito de empresa ${ }^{591}$.

Não se pode esquecer de que o direito comercial surgiu como resposta de oposição à rigidez de formas estabelecidas no direito civil, que não era capaz de atender ao dinamismo necessário ao desenvolvimento dos negócios praticados pelos mercadores, nas corporações de ofício do direito medievo.

direito mercantil, industrial econômico e financeiro, São Paulo, vol. 56, Ano XXIII (nova série), out/dez 2004, p. 119.

${ }^{588}$ Paulo Salvador Frontini anota, por isso, que o Direito Comercial pode ser compreendido como "um sistema de normas disciplinadora da atividade negocial dos particulares." ("A atividade negocial e seus pressupostos ecônomicos e políticos". Revista de direito mercantil, industrial, econômico e financeiro, São Paulo, vol. 18, Ano XIV (nova série), 1975, p. 33).

${ }^{589}$ Problemas de direito mercantil, São Paulo: Max Limonad, 1970, p. 2.

${ }^{590}$ LEÃES, Luiz Gastão Paes de Barros. "A disciplina do direito de empresa no novo código civil brasileiro". Revista de Direito mercantil, industrial econômico e financeiro, vol. 128, Ano XLI (nova série), out/dez 2002, p.11.

${ }^{591}$ Livro II do Código Civil brasileiro. 
Não é possível enclausurar o direito comercial em definições legais tipificadas e rígidas, afastando-se das necessidades e, principalmente, da criatividade que envolve o desenvolvimento dos "negócios empresariais", ou seja, da organização de bens e pessoas destinados à produção e circulação de mercadorias e serviços, ao mercado ${ }^{592}$.

Assim, é preciso lançar uma perspectiva de análise mais ampla e recordar que conceito de atividade negocial é gênero de que a atividade empresarial é espécie ${ }^{593}$. Desse modo, cabe afirmar que a manutenção, e mesmo a exploração, da organização de bens sob a diretriz dos órgãos da falência (e com a finalidade nela propalada, que não é o lucro, mas a satisfação dos credores) é, também, perfeitamente admissível.

Por isso, como afirmou Barros Leães, "a prática, quando continuadamente reiterada, de negócios jurídicos, de modo organizado e estável, por um mesmo sujeito, na busca de uma finalidade unitária e permanente, cria, em torno desta, uma série de relações interdependentes que, conjugando o exercício coordenado dos atos ou negócios jurídicos, o transubstancia em 'atividade negocial", 594

Pensamos, ainda, que mesmo quando essa organização coordenada de atos ou negócios somente exista por prazo determinado de duração e não seja explorada por um sujeito (pessoa), a ideia concebida de existência de empresa, é perfeitamente válida e aplicável.

Rachel Sztajn, invocando a doutrina de Oppo - para quem "não há um direito de empresa, mas um direito de mercado" - sustenta que "Toda e qualquer atividade econômica organizada e voltada para mercado é empresa; algumas são comerciais, outras

\footnotetext{
592 "O direito comercial é dedutivo, de índole cosmopolita e ligado à celebração massificada de negócios. Suas regras são estratificadas a partir do surgimento concreto de questões geradas pela contínua atividade negocial, (...). Suas normas renovam-se incessantemente, com acelerado dinamismo, sempre tendendo para a internacionalização, vinculadas às alterações das formas de produção e acumulação capitalista, sistema que provocou o nascimento do direito comercial e ao qual continua umbilicalmente ligado". (destaquei, FORTES BARBOSA FILHO, Marcelo. Código civil comentado, coor. Ministro Cezar Peluso, Manole, $3^{\mathrm{a}}$ edição, 2009, p. 935).

${ }^{593}$ TOLEDO, Paulo Fernando Campos Salles de. "A empresa e o empresário no código civil", obra coletiva Coord. ACCIOLI, Elizabeth. Direito no século XXI - Em homenagem ao professor Werter Faria, Curitiba: Juruá Editores, 2009, p. 599.

${ }^{594}$ LEÃES, Luiz Gastão Paes de Barros. "A disciplina do Direito de empresa no novo Código Civil Brasileiro". Revista de Direito mercantil, industrial econômico e financeiro. Vol. 128, Ano XLI (nova série), out/dez 2002, p.12.
} 
não e a qualificação se dá segundo os usos e a definição do que seja atividade comercial." 595

A noção de empresa referida na falência, portanto, claramente não é a mesma adotada pela lei civil brasileira, eis que, evidentemente, é mais ampla e vai além desta. A questão, assim, está em retirar da pessoa (subjetivismo adotado pelo Código Civil) o centro definidor e qualificador da empresa.

A ideia contida na conservação de bens organizados no âmbito da falência pode ser identificada com a expressão 'business', utilizada nos princípios de insolvência elaborados pelo Banco Mundial ${ }^{596} 597$. Em sentido lato, a existência de bens organizados de forma produtiva, cuja coordenação está apta a fornecer bens ou serviços, representa um ‘negócio', um business.

A palavra negócio é, ainda, referida por Nelson Abrão ${ }^{598}$, que lembra ser esta de uso da linguagem comum e de significado genérico, mas que também aproveita ao direito, pois "indica todo comportamento juridicamente relevante e economicamente unitário".

Assim, a noção de empresa tratada na falência mais se aproxima de sua origem na definição econômica do termo, estreitando-se com a ideia de organização, como resume Rachel Sztajn: "A estreita relação entre empresa e organização é, para Buonocore, exemplo de economicidade e profissionalidade, atributo da atividade, mas tem

595 SZTAJN, Rachel. "Codificação, decodificação, recodificação: a empresa no código civil brasileiro". Revista de Direito mercantil, industrial econômico e financeiro. Vol. 145, Ano XLV (nova série), jul/set 2006, p. 18.

${ }^{596}$ Principle 13: "Where an enterprise is not viable, the main thrust of the law should be swift and efficient liquidation to maximize recoveries for the benefit of creditors. Liquidation can include the preservation and sale of the business, as distinct from the legal entity. On the other hand, where an enterprise is viable, meaning it can be rehabilitated, its assets are often more valuable if retained in a rehabilitated business that if sold in a liquidation. (...). (Principles and guidelines for effective insolvency and creditor rights systems, April 2001, World Bank). Tradução livre: ' Quando uma empresa não é viável, o principal impulse da lei deve ser a rápida e eficiente liquidação com a finalidade de maximizar a recuperação do crédito, em benefício dos credores. A liquidação pode incluir a preservação e venda do negócio, à pessoa jurídica distinta. Por outro lado, quando uma empresa é viável, significando que pode ser reorganizada, seus bens são frequentemente mais valiosos se mantidos em um negócio reorganizado do que vendidos em liquidação'.

597 TOLEDO, Paulo Fernando Salles de. "A preservação da empresa, mesmo na falência", em obra coletiva coord. por LUCCA, Newton de; DOMINGUES, Alessandra de Azevedo. Direito recuperacional aspectos teóricos e práticos. São Paulo: Quartier Latin, 2009, p.530.

${ }^{598}$ A continuação do negócio na falência. São Paulo: Leud, 1975, pp. 69-70. 
autonomia porque tem existência objetiva externa ao sujeito e pode servir, sucessivamente, à atividade de sujeitos diferentes"

De fato, essa autonomia da empresa em relação ao sujeito é fundamental na compreensão do conceito de empresa relacionado à falência, pois, como acima demonstrado, o afastamento do devedor é obrigatório no processo falimentar.

A organização é o foco central da ideia da preservação, na medida em que esta poderá ser destinada a sujeito diverso, que é exatamente o que se pretende na falência (se possível): promover uma transição de titularidade dos bens organizados. Essa transição tem dúplice finalidade: melhor atender aos credores (maximizando o valor dos ativos) e preservar e otimizar a utilização produtiva dos bens.

Como nesse conceito não há destaque algum para o sujeito que explora o negócio, possibilita-se, na fase de transição e em pleno curso do processo falimentar, em que a organização do negócio passará a um novo sujeito, que a empresa permaneça ativa, gerida pelos órgãos da falência.

Segundo Rachel Sztajn, a "organização parece ser o elemento central, essencial, necessário e suficiente para determinar a existência da empresa, porque gera o aparato produtivo estável, estruturado por pessoas, bens e recursos, coordena os meios para atingir o resultado visado. ${ }^{600,}$

Isso porque, a própria manutenção de contratos, por opção do administrador judicial, denota que o exercício da empresa, pela massa falida, vai além da mera exploração do estabelecimento do devedor. Mais ainda: a alienação da empresa (em bloco) poderá ensejar a transferência de certos contratos estratégicos para a preservação da atividade, em benefício do adquirente ${ }^{601}$.

\footnotetext{
${ }^{599}$ Teoria jurídica da empresa: atividade empresária e mercados. São Paulo: Atlas, 2004, p. 127 (esta ideia está também desenvolvida às pp. 177-181).

${ }^{600}$ Teoria Jurídica da Empresa: atividade empresária e mercados. São Paulo: Atlas, 2004, p. 129.

${ }^{601}$ Confira-se, a propósito, as anotações de Jorge Lobo a respeito da lei falimentar, como norma excepcional que derroga certas regras do direito comum, como ocorre com a possibilidade de dar-se continuidade aos contratos bilaterais. (LOBO, Jorge. "Efeitos da concordata e da falência em relação aos contratos bilaterais do concordatário e do falido". Revista de Direito mercantil, industrial, econômico e financeiro, São Paulo, vol. 110, Ano XXXVI (nova série), pp. 32-42, abril/jun 1998).
} 
Essas situações reforçam a ideia de que é a organização que está no centro da determinação da existência da empresa na falência.

Igualmente, a noção da empresa que está tutelada na falência implica na realização de movimento inverso àquele proposto por Asquini, para reunir as acepções dos perfis, de modo que refletim um único fenômeno ${ }^{602}{ }^{603}$, voltando, portanto, às origens do conceito, de caráter econômico.

O conceito econômico ${ }^{604}{ }^{605}$, desse modo, é o que efetivamente inspira a disciplina jurídica da empresa na falência, de modo que essa "ferramenta"606 de análise não pode ser desconsiderada em sua apreciação ${ }^{607}$.

Sob esse ângulo de análise, fica atendida a finalidade que se buscou na reforma da lei concursal brasileira, como lembra Humberto Lucena Pereira da Fonseca, que era a de "aumentar a eficiência do processo de falência e recuperação de empresas".

${ }^{602}$ SZTAJN, Rachel. Ensaios sobre a natureza da empresa - organização contemporânea da atividade, São Paulo, Tese para concurso de professor titular do departamento de Direito Comercial da Faculdade de Direito da Universidade de São Paulo, 2001, p. 87. Na mesma obra, a autora afirma: "Atividade empresarial há de ser atividade econômica, uma vez que empresa é organização econômica criada para a produção e circulação de bens e serviços a serem oferecidos ao mercado." (p. 73). Essa ideia revela um conceito de empresa mais amplo do que o de atividade, e para o qual o direito não pode ficar alheio, na medida em que se torna necessário para justificar a tutela legal da empresa na falência, por exemplo.

${ }^{603}$ A propósito, vide anotações de Jorge Lobo a respeito do conceito unitário de empresa, que coincide com o conceito econômico. (LOBO, Jorge."A empresa: novo instituto jurídico". Revista de Direito mercantil, industrial, econômico e financeiro, São Paulo, vol. 125, Ano XLI (nova série), pp. 29-40, jan/mar 2002, p. 31). No mesmo sentido: BOITEUX, Fernando Netto. "Função social da empresa e o novo código civill". Revista de Direito mercantil, industrial, econômico e financeiro, São Paulo, vol. 125, Ano XLI (nova série), pp. 48-57, jan/mar 2002.

${ }^{604}$ Oscar Barreto Filho já ensinava que "o conteúdo ou substrato do direito mercantil é essencialmente econômico." (BARRETO FILHO, Oscar. "A dignidade do direito mercantil”. Revista de Direito Mercantil, Industrial, Econômico e Financeiro, São Paulo, vol. 11, Ano XII (nova série), 1973, p. 12).

${ }^{605}$ No mesmo sentido: PENALVA SANTOS. "O novo projeto de Recuperação da Empresa". Revista de direito mercantil, industrial, econômico e financeiro, vol. 117, Ano XXXIX (nova série), pp. 126-135, jan/mar 2000; SIMIONATO, Frederico Augusto Monte. "A reforma da Lei de Falências frente à reorganização econômica da empresa". Revista de direito mercantil, industrial, econômico e financeiro, São Paulo, vol. 108, Ano XXXVI (nova série), out/dez 1997, pp. 39-41.

${ }^{606}$ SZTAJN, Rachel. "Law and economics", em Direito e Economia: análise econômica do direito e das Organizações, obra coletiva coord. ZYLBERSZTAJN, Decio e SZTAJN, Rachel, São Paulo: Elsevier, 2005 , p. 75.

607 "No que diz respeito à eficiente circulação da riqueza, o critério usual é o proposto por Pareto segundo o qual os bens são transferidos de quem os valoriza menos a quem lhe dá mais valor." (...)"A racionalidade dos agentes, um dos postulados econômicos, que leva à procura da maximização de utilidades, e a eficiência alocativa, segundo essa visão, vão ao encontro da ideia de solidariedade e geração de bem estar coletivo." (SZTAJN, Rachel. "Law and Economics", Revista de direito mercantil, industrial econômico e financeiro, vol. 137, Ano XLIV (nova série), jan/março 2005, p. 228). 
Segundo o autor, o processo legislativo "tomou-se como princípio norteador promover o soerguimento das empresas em dificuldades ou possibilitar a continuação da atividade produtiva pela preservação da empresa, distinta da figura de seus administradores" ${ }^{\circ 08}$.

$\mathrm{Na}$ falência, "A eficiência significa a maximização dos resultados, contemplando a maior quantidade possível de créditos" $" 609$ e uma das formas de atingir tal desiderato está na preservação da organização dos ativos, posto que esta, em si, tem valor.

Assim, no caso de "a recuperação mostrar-se inviável, um processo de falência eficiente deve promover a realização do ativo e o rateio do produto da forma mais célere possível, procurando maximizar o valor obtido para, assim, diminuir o risco de mercado, com evidentes benefícios econômicos à sociedade, especialmente no que tange ao custo do crédito, à circulação das riquezas e ao estílulo ao investimento."610

Na mesma linha de ideias, "o objetivo de se propor um regime de falência ágil e com a participação dos credores é facilitar a transferência da empresa, ou se suas partes viáveis, para uma gestão melhor capacitada para administrá-la."611

De início, parece de clareza cristalina que o uso da expressão empresa, na falência, não é apenas possível, mas desejável, considerando-se o resultado econômico que se pretende atingir. Resultado esse que é o de gerenciar, por meio dos órgãos da falência, meios de preservar a organização preexistente dos bens que integram o estabelecimento e das relações jurídicas que este envolve, para possibilitar seu aproveitamento, de forma independente do sujeito que explorava a atividade anteriormente (o devedor falido).

A ideia é manter no mercado a organização (ou parte dela), de forma útil, por meio de alienação na falência, para que sejam melhor atendidos os credores, maximizando-se o valor dos ativos a serem liquidados.

\footnotetext{
${ }^{608}$ FONSECA, Humberto Lucena Pereira. "Alienação da empresa na falência e sucessão tributária”. Revista de Direito mercantil, industrial econômico e financeiro. Vol. 132, Ano XLII (nova série), out/dez 2003, p.87.

${ }^{609}$ BARROS LISBOA, Marcos de, 'in' VALENTE DE PAIVA, Luiz Fernando (Coord.). Direito falimentar e a nova lei de falências e recuperação de empresas. São Paulo: Quartier Latin, 2005, p. 54.

${ }^{610}$ FONSECA, Humberto Lucena Pereira. "Alienação da empresa na falência e sucessão tributária". Revista de Direito mercantil, industrial econômico e financeiro, vol. 132, Ano XLII (nova série), out/dez 2003, p.87.

611 BARRICHELLO, Stefania Eugenia. "Análise econômica da nova lei brasileira de falências e recuperação de empresas". Revista de Direito Mercantil, Industrial Econômico e Financeiro, vol. 147, Ano XLVI (nova série), julh/set 2007, p. 204.
} 
3.1.2 - Os bens do falido e a constituição da massa falida objetiva.

O patrimônio ${ }^{612}$ do devedor, como um todo, é atingido pela falência, que inclui o ativo e o passivo que o integram. Nesse sentido, a massa falida que se forma com a quebra e passa a ser gerida pelo administrador judicial é constituída por todo o patrimônio do devedor, destacando-se, de um lado, o patrimônio ativo, formado pelos bens e direitos $^{613}$, e, por outro, o patrimônio passivo, composto pelas obrigações do devedor, representado pelos créditos de titularidade dos credores.

Como anota Miranda Valverde, a falência "que se positiva pela sentença, (...) absorve esse patrimônio, o complexo dos elementos ativos e passivos sujeitos aos seus efeitos." $" 614$

Sob essa óptica e do ponto de vista do patrimônio ativo, o processo falimentar "compreende todos os bens do devedor, inclusive direitos e ações, tanto os existentes na época de sua declaração, como os que forem adquiridos no curso do processo" ${ }^{15}$, exceção feita, naturalmente, aos bens impenhoráveis, em se tratando de falência de empresário individual ${ }^{616}$, já que excluídos da constrição por expressa disposição legal.

Com o decreto da quebra, o falido é desapossado dos bens e perde o direito de deles dispor ou administrar; este é um dos traços essenciais da falência, ou seja, o afastamento compulsório do devedor. O instituto do desapossamento do devedor nasceu

\footnotetext{
612 "Patrimônio é o complexo das relações jurídicas de uma pessoa que tiverem valor econômico. Assim, compreende-se no patrimônio tanto os elementos ativos quanto os passivos, isto é, os direitos de ordem privada economicamente apreciáveis e as dívidas. É a atividade econômica de uma pessoa sob o seu aspecto jurídico, ou a projeção economica da personalidade civil." (BEVILAQUA, Clovis. Teoria geral do direito civil, 4. edição, Rio de Janeiro, Imprensa Nacional, 1972, p. 173).

${ }^{613} \mathrm{O}$ que inclui até mesmo o direito de exigir a integralização do capital social subscrito pelo sócio inadimplente, que caberá à massa falida. (PEREIRA CALÇAS, Manoel de Queiroz. Sociedade Limitada no Código Civil, São Paulo, Atlas, 203, pp. 32-33).

${ }^{614}$ VALVERDE, Trajano de Miranda. Comentários à Lei de Falências. 4a. edição atualizada por J. A. Penalva dos Santos e Paulo Penalva Santos. Rio de Janeiro: Forense, 1999, vol. I, p. 278.

${ }^{615}$ REQUIÃO, Rubens. Curso de direito falimentar. Vol. 01, 16. edição, 1995, São Paulo: Saraiva, p. 151.

${ }^{616616} \mathrm{Em}$ nosso entendimento, a impenhorabilidade somente se aplica ao empresário individual. O fundamento da impenhorabilidade é a manutenção da dignidade da pessoa humana e são considerados afastados da responsabilidade patrimonial os bens imprescindíveis a tanto. Assim, uma interpretação literal do artigo 649 do CPC poderia levar ao equivocado entendimento de que a sociedade poderia ter bens impenhoráveis.
} 
praticamente junto com a sistematização do direito falimentar e estava presente em diversos estatutos das cidades medievais ${ }^{617}$.

É oportuno lembrar, nesse momento e para que não se perca de vista, que o falido "não perde a propriedade dos bens, senão quando vendidos e por efeito da venda." 618 Sabe-se que desde os primórdios do direito medievo já se distinguia o desapossamento dos bens em relação à perda de sua propriedade, a que se sujeitava o falido, como estava bem delineado, por exemplo, no estatuto comasco, de $1336^{619}$.

Diante dessa situação, com o decreto de falência, forma-se, de um lado, a coletividade de credores sujeita ao concurso, denominada massa falida subjetiva ${ }^{620}{ }^{621}$. Este conceito está amalgamado e é resultado das relações que constituem o patrimônio passivo da devedora, que consiste nas obrigações pecuniárias que serão classificadas pelo administrador judicial, a fim de que sejam atendidas, tanto quanto possível, no processo falimentar, em conformidade com a ordem de prelação legal.

617 SANTARELLI, Umberto. Per la storia del fallimento nelle legislazione italiane dell'età intermédia, Padova: Cedam, 1964, pp. 107-113.

${ }^{618}$ FERREIRA, Waldemar. Instituições de direito comercial. Vol. 5. São Paulo: Livraria Freitas Bastos, 1951, p. 157. O autor prossegue, sustentando a seguinte ideia: "A massa falida não passa de coisa universal, como a herança ou o patrimônio. Ela não é mais do que o patrimônio do falido, confiado à administração de terceiro, o síndico. Não tem este, diga-se de passagem, papel nem atribuições distintas, em sua natureza jurídica, das do inventariante, Ou do administrador do Condomínio. Posto sob a direção e superintendência do juiz, não se equipara aos representantes legais ou órgãos das pessoas jurídicas de direito privado."

${ }^{619} \mathrm{O}$ estatuto da cidade de Coma, na Itália, previa: "Dunque, tutti i beni sono sottratti alla disponibilità del fallito e destinati al soddisfacimento dei creditori, tanto vero che la apprehensio del Podestà viene fatta, non solo nel loro interesse, ma anchè in loro nome...". "La norma (...) dispone che questi (beni) ne sia spossessato e che la loro possessio passi ad un organo pubblico preposto alla tutela degli interessi dei creditori; i quali tuttavia, pur possessori per interposta persona in virtù dello spossessamento officioso, non per questo divengono proprietari dei beni del fallito, nè hanno alcuna facoltà di autotuela, atteso il preminente interesse pubblico a garantire, con la officiosità, la legalità e imparzialità del procedimento." (SANTARELLI, Umberto. Per la storia del fallimento nelle legislazione italiane dell'età intermédia, Padova, Cedam, 1964, pp. 109-110). Em tradução livre: 'Portanto, todos os bens são subtraídos da disposição do falido e destinados à satisfação dos credores, tanto que a apreensão pelo Podestà é feita, não apenas no interesse destes, mas também em nome deles (os credores)...' (...) 'A norma dispõe que ocorre o desapossamento dos bens e a posse destes passa a um órgão público preposto de tutela dos interesses dos credores; os quais, todavia, na qualidade de possuidores por interposta pessoa em virtude do desapossamento oficial, nem por isso se tornam proprietários dos bens do falido, nem possuem qualquer faculdade de autotutela, em razão do prevalente interesse público a ser garantido, com a oficialidade, a legalidade e a imparcialidade do procedimento'.

620 "A communhão dos credores do falido chama-se massa falida subjectiva, porque é o sujeito dos direitos que competem à communhão dos credores. (...). A massa fallida subjectiva offerece uma particularidade curiosa, que ora é uma continuação da pessoa do fallido, ora é considerada terceiro em relação ao fallido, para ter o direito de atacar certos actos deste, praticados em prejuízo da massa geral dos credores." (MENDES, Octavio. Fallencias e concordatas. São Paulo: Saraiva, 1930, p. 133).

${ }^{621}$ Artigo 115 da Lei n. 11.101/05. 
Em paralelo, torna-se necessário, para sustentar, na prática, a previsão legal de que o patrimônio ativo do devedor constitui garantia do direito dos credores, efetivar o ato de apreensão dos bens e direitos que o integram, promovendo sua arrecadação (artigo 108 da Lei n. 11.101/05).

A arrecadação é o ato pelo qual se concretiza a indisponibilidade dos bens do falido. Isso não quer dizer, naturalmente, que ele possa dispor ou administrar os ativos entre a quebra e o momento da arrecadação que lhe é posterior, pois " a constrição pela arrecadação é apenas material, concreta, pois, com a publicação da sentença de abertura da falência, se inicia o penhoramento abstrato de todos os bens do falido, antes mesmo de serem arrecadados", como ensina Pontes de Miranda ${ }^{622}$.

Desse modo, a arrecadação é ato de constrição coletiva que abrange todo o patrimônio ativo do devedor que, em decorrência do efeito ope legis da quebra, a esta se sujeite.

Fique claro, portanto, que a arrecadação atinge somente o patrimônio ativo, ou seja, os direitos e bens, formando a massa falida objetiva ${ }^{623}$, a qual resulta do desapossamento que destes ativos sofre o devedor. A reunião dos bens que integram a massa falida objetiva, e que resulta do desapossamento do devedor, possui fundamento no princípio geral de que todo o patrimônio do devedor constitui garantia do direito da coletividade de credores ${ }^{624}$.

Forma-se, destarte, a massa falida objetiva, que é composta pelos elementos que integram o patrimônio ativo do devedor. A arrecadação materializa o desapossamento e agrega os ativos para a formação da massa falida objetiva. É preciso lembrar que a massa

\footnotetext{
${ }^{622}$ Tratado de Direito Privado, tomo XXIX, § 3375, São Paulo: Revista dos Tribunais, 1984, p. 20.

623 "Os bens são arrecadados pelo síndico, que os conserva e administra durante o período de informação da falência, em cujo decurso se configura definitivamente a massa falida, que legitimamente concorre ao produto proveniente da venda dos bens arrecadados. Assim, com a arrecadação dos bens se compõe a 'massa falida'."'(REQUIÃO, Rubens. Curso de direito falimentar. 16. edição, São Paulo: Saraiva, 1995, vol. I., pp. 151-152).

${ }_{624}$ SANTARELLI, Umberto. Per la storia del fallimento nelle legislazione italiane dell'età intermédia, Padova, Cedam, 1964, p.191. É desta mesma ideia que tem origem a ação revocatória, como meio de preservação dos ativos que farão compor o patrimônio destinado à satisfação dos credores, o que justifica perquirir a respeito dos atos praticados pelo falido, antes da quebra, para verificar se houve depauperamento do patrimônio, em lesão aos credores. (ob.cit. pp. 194 e 199).
} 
é composta pelos bens ativos do falido, tenham ou não sido arrecadados ${ }^{625}$. Do mesmo modo, o raciocínio inverso vale: bens de terceiros arrecadados não integram a massa falida objetiva e dela serão destacados por provocação do interessado, mediante procedimento de restituição.

A massa falida objetiva é universalidade de bens ${ }^{626}$, que, curiosamente, continuam sob a propriedade do devedor até a alienação no processo falimentar. Assim, o falido - titular da propriedade dos bens - fica impossibilitado de praticar atos de disposição ou administração destes ativos, que passam à gestão do administrador judicial e são denominados de massa falida objetiva.

De tal sorte, é possível concluir-se pela existência de três conceitos distintos largamente utilizados pelo direito concursal e que a doutrina parece ter consolidado e sobre os quais parece não haver discussão acadêmica de interesse mais profundo.

Trata-se do conceito amplo, genérico, de massa falida, a qual é gerida pelo administrador judicial, e é composta pelo patrimônio (ativo e passivo) do devedor. Esta, por sua vez, desdobra-se em outros dois diferentes aspectos, como se fossem dois lados da mesma moeda: a massa falida objetiva (ou o conjunto de bens e direitos, integrantes do patrimônio ativo do devedor, objeto da arrecadação); e a massa falida subjetiva, que é representada pela coletividade de credores e resulta do conceito de patrimônio passivo do devedor, ou das obrigações do devedor que deverão ser atendidas na falência.

\footnotetext{
${ }^{625}$ Gera perplexidade a redação do $\S 3^{\circ}$ do artigo 108 da Lei n. 11.101/05. A lei anterior previa, no artigo 24 , $\S 1^{\circ}$, que se já estivesse designada praça de bem sujeito à arrecadação, esta deveria ser realizada e o resultado da alienação entregue à massa. No sistema atual, com a previsão de suspensão das execuções, em tese, a hipótese somente poderia ocorrer em execução fiscal, existindo inclusive a súmula 44 do TRF ("Ajuizada a execução fiscal anteriormente à falência, com penhora realizada antes desta, não ficam os bens penhorados sujeitos a arrecadação no Juízo falimentar; proposta a execução fiscal contra a massa falida, a penhora farse-á no rosto dos autos do processo da quebra, citando-se o síndico"). Em todo o caso, a aplicação da súmula em questão é, no mínimo, criticável, por autorizar ato que pode, tem tese, ser lesivo à massa por permitir alienação fora do concurso: (i) se houvesse venda a preço vil, a massa poderia opor embargos à arrematação; (ii) se o bem for necessário para a venda de estabelecimento como um todo, o que deve prevalecer: a venda na hasta pública fiscal ou o princípio insculpido no artigo 75 da lei vigente?

${ }^{626}$ Mas não é pacífica na doutrina a natureza jurídica da massa falida, sendo que para alguns é universalidade de direito e para outros, patrimônio separado. (TOLEDO, Paulo Fernando Campos Salles de Toledo. "Da personificação da massa falida". Revista de direito mercantil. n. 78, ano XXIX (nova série), abriljunho/1990, pp. 48-49).
} 
No momento, interessa-nos breve digressão a respeito das características da massa falida objetiva, que é, como se disse, composta pelo patrimônio ativo, ou seja, dos bens e direitos do falido.

A massa falida objetiva é o patrimônio que responderá pelas obrigações do devedor na falência, o que é uma afirmação óbvia. Mas, características importantes resultam desta obviedade meramente aparente: (i) trata-se de um patrimônio segregado da pessoa de seu titular (o proprietário foi desapossado dele), muito embora este permaneça interessado em sua administração (§ único, do artigo 103 da Lei n. 11.101/05) ${ }^{627}$ até o momento da alienação judicial; (ii) não obstante seja um patrimônio de que uma das finalidades ${ }^{628}$ seja garantir o pagamento dos credores, estes não são responsáveis por sua gestão, mas estão autorizados a fiscalizá-la; (iii) a administração deste patrimônio é feita pelo administrador judicial, sob a fiscalização do juiz, dos credores e do devedor; (iv) os interesses da gestão deste patrimônio poderão, em tese, conflitar com os de seu titular (o falido) e também, em tese, poderão se contrapor aos interesses de parte dos credores, eis que estes não são homogêneos.

Portanto, a massa falida --- aqui em sentido amplo --- poderá possuir interesses próprios, distintos das demais partes envolvidas no processo falimentar. É nesse senso que Paulo Fernando Campos Salles de Toledo afirmou, colocando a questão em um plano substancial, que "a massa falida é, pois, um centro de interesses.",629

Atento à nova situação jurídica que se forma com a falência, Miranda Valverde anota que "O essencial é salientar que ambos esses elementos (ativo e passivo) fazem parte de um mesmo patrimônio, que se separa desde o dia da abertura da falência, do seu dono, para constituir um patrimônio autônomo - a massa falida - disciplinado pelas regras que tendem a solucionar a nova situação jurídica" ${ }^{930}$. Para o autor, é correto afirmar que tanto o patrimônio ativo é garantia do patrimônio passivo, quanto este último onera e grava o primeiro.

\footnotetext{
${ }^{627}$ Pela simples razão de que no regime concursal brasileiro a extinção das obrigações do devedor está vinculada, dentre outros fatores, ao pagamento dos credores, conforme artigo 158 da Lei n. 11.101/05.

${ }^{628}$ Mas não a única finalidade, conforme expressa o artigo 75 da Lei n. 11.101/05.

629 TOLEDO, Paulo Fernando Campos Salles de Toledo. "Da personificação da massa falida". Revista de direito mercantil. n. 78, ano XXIX (nova série), abril-junho/1990, p.50.

${ }^{630}$ VALVERDE, Trajano de Miranda. Comentários à lei de falências. 4. edição atualizada por J. A. Penalva dos Santos e Paulo Penalva Santos. Rio de Janeiro: Forense, 1999, vol. I, pp. 278-279.
} 
Especificamente quanto à massa falida objetiva, a opinião de Miranda Valverde é que esta consiste no patrimônio do falido submetido a um novo regime legal, pois forma um patrimônio autônomo que "não significa patrimônio sem dono, mas o complexo de direitos e obrigações especialmente separados pela lei, para a consecução de determinado fim." 631

Rubens Requião, por sua vez, sustenta que a massa falida objetiva tem natureza jurídica de patrimônio separado, composto por todos os bens penhoráveis do falido, os quais são destacados e afetados a um determinado fim (satisfação dos credores), sob a administração do síndico (DL n. 7.661/45) ${ }^{632}$.

A tese defendida pelo autor, de que a massa falida objetiva tem natureza de patrimônio separado, apoia-se, fundamentalmente, nas seguintes premissas: (i) sua existência é temporária, enquanto organização de bens, sob a administração dos órgãos da falência; (ii) destina-se a um fim específico, que pode consistir na transferência, parcial ou total, a um outro titular que a explore mantendo o negócio preexistente ou, ainda, na simples venda em partes; mas, em qualquer caso, para que o produto da alienação seja partilhado entre os credores; (iii) não possui personalidade jurídica; (iv) os bens continuam sob a titularidade do falido (até a alienação), já que deles foi apenas desapossado.

O autor, apoiado em Candian, sustenta que patrimônio separado "é aquele que tem débitos próprios, no qual se localizam as obrigações e responsabilidades que deles nascem, e que não sofre os efeitos de obrigações diversas do sujeito do patrimônio.",633

Em semelhante linha caminhava Oscar Barreto Filho, para quem "somente se pode configurar no direito pátrio, como 'universitas iuris' o patrimônio, seja o patrimônio geral do sujeito, sejam os patrimônios especiais ou separados, de que é exemplo a massa falida."

\footnotetext{
${ }^{631}$ VALVERDE, Trajano de Miranda. Comentários à lei de falências. 4. edição atualizada por J. A. Penalva dos Santos e Paulo Penalva Santos. Rio de Janeiro: Forense, 1999, vol. I, p. 279.

${ }^{632}$ REQUIÃO, Rubens. Curso de direito falimentar, Vol. 01, 16. edição, 1995, São Paulo: Saraiva, p. 154.

${ }^{633}$ REQUIÃO, Rubens. Curso de direito falimentar. 16. edição, São Paulo: Saraiva, 1995, vol. I., p. 152.

${ }^{634}$ BARRETO FILHO, Oscar. Teoria do estabelecimento comercial. São Paulo: Max Limonad, 1969, p. 105.
} 
Para efeito desta análise, entretanto, importa destacar que o que se busca preservar na falência não é a massa falida objetiva, propriamente, mas a organização que pode haver sobre os bens que a integram: a sinergia que outorga à união desses ativos um valor intangível, que poderá beneficiar os credores no momento da venda.

Assim, dois elementos integram essa organização passível de alienação na falência: (i) o estabelecimento ${ }^{635}$, (composto apenas por elementos ativos) ${ }^{636}$ e, (ii) determinadas posições jurídicas decorrentes de contratos estratégicos firmados pelo devedor.

Ou seja, o conceito de massa falida (patrimônio ativo e passivo) é mais abrangente do que o de massa falida objetiva. Todavia, interessa-nos focar neste último, já que a massa falida objetiva poderá ser mais abrangente do que o estabelecimento do devedor $^{637}$ ou com este ser coincidente, quando um e outro se confundirem. Entretanto, a organização passível de alienação na falência pode abranger somente o estabelecimento (total ou parcial), ou também integrar certas relações jurídicas (contratos).

\subsection{3 - O estabelecimento empresarial e a falência.}

$\mathrm{O}$ estabelecimento existe "em função da atividade desenvolvida pelo empresário" e, por esta razão, o vínculo que relaciona os bens que o integram é funcional, como ensina Oscar Barreto Filho ${ }^{638}$, constituindo uma universalidade de fato que é composta por bens organizados (e não de um complexo de relações jurídicas) por vontade do empresário.

\footnotetext{
${ }^{635}$ Com esta ideia Oscar Barreto Filho já afirmava que "o estabelecimento não é uma 'unversitas iuris', mas sim uma 'universitas facti'. Esta universalidade de fato, por sua vez, se integra no patrimônio do comerciante, o qual constitui uma universalidade de direito." (BARRETO FILHO, Oscar. Teoria do estabelecimento comercial. São Paulo: Max Limonad, 1969, p. 108).

${ }^{636}$ De modo que as mutações nos elementos componentes, se não desnaturarem a finalidade a que se destina o conjunto, são irrelevantes. Confira-se, a respeito: TOLEDO, Paulo Fernando Campos Salles de. "Lei de Falências - alienação de estabelecimento da concordatária". Revista de Direito Mercantil, Industrial, Econômico e Financeiro, São Paulo, vol. 128, Ano XLI (nova série), pp. 275-286, out/dez 2002.

${ }^{637}$ A massa falida poderia, por exemplo, ser titular de um ativo que não integra o estabelecimento, como por exemplo, um terreno, adquirido para fins de instalação de uma futura filial.

${ }^{638}$ BARRETO FILHO, Oscar. Teoria do estabelecimento comercial. São Paulo: Max Limonad, 1969, p. 138.
} 
Além disso, são distintas e inconfundíveis as noções de fundo de negócio e estabelecimento. O primeiro corresponde ao saldo residual da liquidação do segundo, ou seja, cessado o exercício da "atividade" ${ }^{639}$ extingue-se o estabelecimento.

Desse modo, o pressuposto necessário da existência do estabelecimento é, segundo o autor citado, a sua exploração ${ }^{640}$. Assim, "É importante distinguir entre a titularidade do estabelecimento e sua exploração, pois é esta última que qualifica o empresário como tal", como ensina Oscar Barreto Filho ${ }^{641}$. Continuo a ideia para afirmar que a exploração pode ser realizada tanto por um empresário (conforme preconiza o artigo 966 do Código Civil), quanto por qualquer outro titular (ente personificado ou não) que lhe suceda $^{642}$.

O mesmo autor citado já anotava que "A falência do comerciante envolve o estabelecimento ou estabelecimentos que possua, confluindo todos os elementos ativos e passivos para formar uma única massa, que compreende todas as relações ativas e passivas ${ }^{643}$.

Waldemar Ferreira, por sua vez, afirma "Que o estabelecimento se confunde às vezes com o patrimônio do falido, ou dele faz parte", prosseguindo na ideia e explicando que "Esse patrimônio, porque efetivamente o é, forma-se pelo fundo de comércio ou indústria. O estabelecimento. Os bens móveis, coisas e direitos", para

\footnotetext{
639 “Atente-se, porém, para o restrito significado da expressão 'fundo de negócio', que corresponde ao saldo remanescente da liquidação do estabelecimento. No antigo direito francês (séc. XVII), unicamente o conjunto de mercadorias de estoque e as instalações do negócio eram designadas pela expressão 'fonds de boutique', que significaria hoje apenas o conjunto dos elementos corpóreos do estabelecimento." (BARRETO FILHO, Oscar. Teoria do estabelecimento comercial. São Paulo: Max Limonad, 1969, p. 66). ${ }_{640}$ BARRETO FILHO, Oscar. Teoria do estabelecimento comercial. São Paulo: Max Limonad, 1969, pp. 140.

${ }^{641}$ No mesmo sentido Paulo Fernando Campos Salles de Toledo: "Cumpre notar que titularidade não se confunde com exploração, uma vez que o titular do estabelecimento pode não ser aquele que os explora. $O$ empresário é quem explora o estabeleciemento". ("A preservação da empresa, mesmo na falência", in ob. coletiva DE LUCCA, Newton; DOMINGUES, Alessandra de Azevedo (Coord.). Direito recuperacional aspectos teóricos e práticos. São Paulo: Quartier Latin, 2009, p. 525).

${ }_{642}$ "O estabelecimento existe como entidade objetiva, independentemente de seu titular, pessoa física ou jurídica, e não se confunde com o patrimônio do titular. (...) Por força da alienação, verifica-se apenas a transferência de mãos do complexo de constitutivos do estabelecimento, ou seja, a mudança de titular da 'universitas facti'. (BARRETO FILHO, Oscar. Teoria do estabelecimento comercial. São Paulo: Max Limonad, 1969, p. 147).

${ }^{643}$ BARRETO FILHO, Oscar. Teoria do estabelecimento comercial. São Paulo: Max Limonad, 1969, p. 86.
} 
concluir o autor: "Tudo, enfim, suscetível de liquidar-se e converter-se em dinheiro para o pagamento dos credores"

Desse modo, a decretação da falência, ante a possibilidade de continuação dos negócios e também da alienação em bloco dos ativos da falida, não implica na imediata e tampouco em necessária extinção do estabelecimento. O que resultaria na extinção do estabelecimento seria a cessação de sua destinação unitária ou a alienação da totalidade de seus elementos essenciais que imporia a impossibilidade do exercício de algum negócio, desfazendo-se a organização ${ }^{645}$.

A compreensão destes conceitos leva à inarredável conclusão de que há sim atividade negocial (possível) a ser exercida na falência, e isso se realiza, se for o caso, com vistas a manter viva a organização dos bens para possibilitar sua transferência a um novo titular, no futuro, mediante venda dos ativos, que é ainda um dos fins do processo falimentar.

Se o estabelecimento não se extingue ope legis com a quebra e um dos objetivos preconizados pela lei é manter ativas as 'unidades produtivas ${ }^{646}$, quando possível, por certo, pretende-se tornar viável a possibilidade de exercício de atividade negocial pela falida. Embora a massa falida não possua personalidade jurídica ${ }^{647}$, mas, a toda evidência possui interesses, os quais, por vezes, são distintos do devedor ou, potencialmente, até por parte dos credores ${ }^{648}$.

${ }^{644}$ FERREIRA, Waldemar. Instituições de Direito Comercial, Vol. 5, Livraria Freitas Bastos, São Paulo, 1951, p. 156.

${ }^{645}$ BARRETO FILHO, Oscar. Teoria do estabelecimento comercial. São Paulo: Max Limonad, 1969, pp.148-149.

646 "Lembramos que o estabelecimento na sua unidade (universalidade de fato) é um conceito dinâmico que não se confunde com a ideia de fundo de negócio, posto que somente se tem estabelecimento enquanto a atividade de seu titular estiver qualificada pelo aviamento. Isto é, quando o estabelecimento estiver apto a produzir lucros e a atrair a clientela. Portanto, todo estabelecimento é uma unidade produtiva". (FRANCO, Vera Helena de Mello. "Liquidação, encerramento e extinção das obrigações do falido". Revista de direito mercantil, industrial econômico e financeiro. Vol. 140, Ano XLIV (nova série), out/dez 2005, p. 113).

${ }^{647}$ TOLEDO, Paulo Fernando Campos Salles de Toledo, "Da personificação da massa falida". Revista de Direito Mercantil, n. 78, ano XXIX (nova série), abril-junho/1990, pp.48-50.

${ }^{648}$ Como por exemplo, de um credor com garantia real, que entenda que o bem objeta da garantia possa alcançar melhor preço de venda se alienado isoladamente, ao invés de integrar o estabelecimento para venda em bloco. 
E o estabelecimento, portanto, mesmo depois da quebra, continua a ser organização de bens meio (instrumento) ao exercício de atividade negocial, que, por certo lapso de tempo, poderá ser operacionalizada pelos órgãos da falida ${ }^{649}$.

Para tanto, o estabelecimento é dotado de plasticidade, um de seus atributos mais interessantes. Tanto do ponto de vista subjetivo (pouco importa o sujeito que o explore), quanto do objetivo (mantidos os elementos essenciais que garantam a exploração de um negócio e sua destinação unitária), torna-se possível sua cessão, total ou parcial, exatamente como previsto nos incisos I e II do artigo 140, da Lei n. 11.101/05 $5^{650}$.

Abre-se um parêntese para anotar que a disciplina jurídica falimentar da alienação de 'estabelecimento' (artigo 140, incisos I e II) consiste, na verdade, em uma especialização daquela prevista no artigo 1.142 do Código Civil, ante a situação particular que resulta da falência.

É que declarada a falência, a situação de insolvência do devedor concretiza o interesse que os credores têm sobre o patrimônio do devedor. Na hipótese de venda de estabelecimento, conforme previsto na lei civil, o interesse dos credores é meramente potencial $^{651}$.

Isso porque na venda de estabelecimento prevista na lei civil (artigo 1142 do $\mathrm{CC}$ ), os credores somente têm interesse em obstar a concretização do negócio se

\footnotetext{
${ }^{649}$ A propósito, Lorenzo Stanghellini anota: “Qualora un'impresa in crisi abbia un valore positivo, in quanto produce ricchezza (ancorché tale ricchezza non basti all'imprenditore per pagare i debiti in scadenza), si usa dire che essa è dotata di un valore di 'going concern', nel senso che il suo valore in attività (mantenuta in esercizio) è superiore al suo valore di liquidazione (al valore della somma dei suoi componenti). Il concetto di valore di 'going concern', pur non coincidindo completamente com quello di 'avviamento', si avvicina a questo, che pertanto useremo." (STANGHELLINI, Lorenzo. Le crisi di impresa fra diritto ed economia (le procedure di insolvenza). Il Mulino, Bologna, 2007, pp. 68/69). Em tradução livre: "Sempre que uma empresa em dificuldades tem um valor positivo, enquanto apta a produzir riqueza (embora apenas esta riqueza não baste ao empresário para pagar dívidas vencidas), diz-se que essa é dotada de um valor de "going concern", no sentido de que seu valor em atividade (manutenção em exercício) é superior ao seu valor de liquidação (ao valor da soma de seus componentes). O conceito de valor do 'going concern', embora não completamente coincidente com aquele de 'aviamento', aproxima-se deste e, portanto, é como o utilizaremos".

${ }^{650}$ Confira-se, a propósito, FRANCO, Vera Helena de Mello. "Liquidação, encerramento e extinção das obrigaçães do falido". Revista de direito mercantil, industrial econômico e financeiro. Vol. 140, Ano XLIV (nova série), out/dez 2005, pp. 111-114.

${ }^{651}$ FRANCO, Vera Helena de Mello. "Liquidação, encerramento e extinção das obrigações do falido". Revista de Direito mercantil, industrial econômico e financeiro, vol. 140, Ano XLIV (nova série), out/dez 2005, p. 111.
} 
entenderem que há risco de insolvência (artigo 1145 do $\mathrm{CC}$ ), da qual resulte impossibilidade de adimplemento da obrigação da qual são titulares. $\mathrm{O}$ fato de o adquirente ser sucessor das obrigações preexistentes regularmente contabilizadas pelo alienante (artigo 1.146 do CC) e também de existir solidariedade entre ambos no adimplemento de tais obrigações, em tese, faz com a venda de estabelecimento prevista na lei civil reforce a garantia dos credores.

Já na falência, ante a presunção de que não haverá ativos para atender todos os credores, perfaz-se a venda de todos os bens do devedor compulsoriamente, na medida em se trata de um procedimento liquidatório, com o intuito de pagar credores segundo os critérios previstos em lei. Nesse contexto, a alienação de estabelecimento (bens materiais e imateriais organizados) surge como uma faculdade, que resulta de análise de conveniência, pelos credores, com o intento de maximização do preço de venda.

Em ambas as hipóteses de alienação de estabelecimento e resguardadas as peculiaridades casuísticas de casos concretos, há possibilidade de transferência de contratos. $\mathrm{Na}$ falência por cessão compulsória ( $\S 3^{\circ}$ do artigo 140), sem o que a transferência do estabelecimento poderia ser inócua, e no suporte fático da lei civil por sub-rogação do adquirente, desde que o contrato não tenha caráter personalíssimo (artigo 1148 do CC).

Portanto, há pontos de intersecção entre a venda de estabelecimento empresarial (artigo 1.142 do Código Civil) e a alienação dos ativos organizados que integram a massa falida objetiva (artigo 140 da Lei n. 11.101/05), sendo esta última, como se disse, uma especialização da primeira. A principal distinção, segundo o nosso ponto de vista, é a de que na alienação do estabelecimento na falência não há espécie alguma de sucessão das obrigações do devedor (o titular originário do estabelecimento), conforme será abordado mais adiante.

Por isso, em particular na falência, o legislador poderia ter utilizado a expressão 'estabelecimento' - conceito técnico e já acolhido no ordenamento jurídico brasileiro - para se referir à previsão de venda mencionada nos incisos I e II do artigo 140 da Lei n. 11.101/05. Ao contrário, preferiu adotar as expressões 'empresa', 'filiais' e 
'unidade produtiva ${ }^{952}{ }_{-}^{653}$. Se isso puder ser considerado como uma deficiência do texto legal, o fato é que elas não chegam a impedir uma análise sistemática e lógica dos conceitos envolvidos, como anota Vera Helena de Mello Franco ${ }^{654}$, em relação aos efeitos da alienação de estabelecimento na falência.

O importante é destacar, como anota Oscar Barreto Filho, que o estabelecimento possui um 'vínculo econômico' que relaciona todos os bens que o integram em função de sua finalidade, de modo que constitui este "um fenômeno de coordenação de vários elementos entre si complementares, em função de uma comum destinação econômica" e conclui que neste se integram "bens heterogêneos, inclusive de natureza imaterial, ${ }^{, 655}$.

E desta coordenação dos bens agregados que compõem o estabelecimento resulta um valor agregado, que, em tese, é superior ao da soma dos bens individualmente considerados ${ }^{656}{ }_{-}^{657}$.

E é precisamente esse valor agregado que se pretende tutelar quando a lei diz que a falência "visa a preservar e otimizar a utilização produtiva dos bens" 658 , princípio este que, dentre outras hipóteses, se concretiza com a venda de estabelecimento

\footnotetext{
${ }^{652}$ A expressão 'unidade produtiva' é utilizada pela lei para referir-se a 'estabelecimento' e o STJ já acolheu a sinonímia: "COMERCIAL E ROCESSUAL CIVIL. Agravo Regimental no Agravo de Instrumento. Princípio da preservação da empresa. Valores Insignificantes. Quebra de empresa. Descabimento. Unidade produtiva. Preservação. Lei n. 11.101/05. Agravo Regimental Improvido." (AgRg no AI 1.022.464, Rel. Min. Aldir Passarinho Junior, j. 02/06/2009).

${ }^{653}$ O Tribunal de Justiça de São Paulo também já consagrou a expressão 'unidade produtiva', conforme diversos arestos: AI 429.620-4/2 (ou n. 9037810-80.2005.8.26.0000), Relator Desembargador Galdino Toledo Júnior, $10^{\mathrm{a}}$ Câmara de Direito Privado, j. 01/06/2006, TJSP); AI 670.247.4/3-00, Relator Des. Pereira Calças, Câmara Reservada à Falência e Recuperação do Tribunal de Justiça de São Paulo, j. 26/01/2010; AI n. 0253722-82.2011.8.26.0000, Relator Des. Pereira Calças, Câmara Reservada à Falência e Recuperação do Tribunal de Justiça de São Paulo, j. 22/11/2011.

${ }^{654}$ FRANCO, Vera Helena de Mello. "Liquidação, encerramento e extinção das obrigações do falido". Revista de Direito Mercantil, Industrial Econômico e Financeiro, vol. 140, Ano XLIV (nova série), out/dez 2005, pp. 110-114.

${ }^{655}$ BARRETO FILHO, Oscar. Teoria do estabelecimento comercial. São Paulo: Max Limonad, 1969, p. 99.

${ }^{656}$ BARRETO FILHO, Oscar. Teoria do estabelecimento comercial. São Paulo: Max Limonad, 1969, p. 141.

${ }^{657}$ E que consiste no aviamento, segundo Rubens Requião (Curso de direito falimentar, v. 01, 14. edição, 1995, p. 230).

${ }^{658}$ Artigo 75 da Lei n. 11.101/05.
} 
da devedora e, inclusive, autoriza transferência de contratos ${ }^{659}$, mão de obra, tecnologia, enfim, de elementos que formem uma "unidade indissolúvel",660.

Essa tutela desdobra-se em dois aspectos que correspondem a duas faces ou dois lados de uma mesma moeda. De um lado, preserva-se a atividade negocial já existente, poupando os esforços destinados a sua (re)organização ${ }^{661}$; e, de outro lado, potencializa-se o valor correspondente a esse ativo para fins de venda no processo falimentar, em benefício dos credores ${ }^{662}$. Note-se, esses dois aspectos que constituem objeto de tutela na lei concursal são indissociáveis e se complementam entre si.

Nesse sentido, afirma Rachel Sztajn que "o ordenamento deve oferecer meios para a continuidade, composição de situações e interesses, preservação de relações cujo conteúdo se explica apenas pela unidade da função que desempenham."663

A proteção legal estende-se a todos os bens e direitos que integram o estabelecimento e, portanto, inclui também os intangíveis, como, por exemplo: marca, sinais distintivos, ponto comercial, patentes, invenção, modelo de utilidade, desenhos industriais e afins. Talvez o legislador pudesse ter deixado de fazer a referência aos ativos imateriais, já que integrados ao conceito de estabelecimento. Entretanto, não há mal em reforçar a ideia e impedir digressões a respeito do tema.

Já em relação aos contratos que podem ser objeto de transferência específica, a lei foi feliz em dispor expressamente. A propósito, Rubens Requião ${ }^{664}$ ensina que os contratos não integram o estabelecimento comercial, na medida em que o exercício da empresa (atividade) não se confunde com o fundo de comércio (instrumento desta).

\footnotetext{
${ }^{659}$ Anote-se que a transferência do contrato de locação já era prevista pelo DL n. $7.661 / 45$, conforme $\S 1^{\circ}$ do artigo 116. Na nova lei, portanto, a possibilidade foi ampliada para qualquer contrato. Essa circunstância faz reconhecer que os vínculos contratuais possuem, em certos casos, valor econômico.

${ }^{660}$ FRANCO, Vera Helena de Mello. "Liquidação, encerramento e extinção das obrigações do falido". Revista de direito mercantil, industrial econômico e financeiro. Vol. 140, Ano XLIV (nova série), out/dez 2005 , p. 112.

${ }^{661} \mathrm{Na}$ medida em que também reduz os custos de entrada no mercado, como atesta Rachel Sztajn (obra coletiva organizada por TOLEDO, Paulo Fernando Campos Salles de; ABRÃO, Carlos Henrique. Comentários à lei de recuperação de empresas e falência. São Paulo: Saraiva, 4. edição, 2010, p. 495).

${ }^{662}$ FRANCO, Vera Helena de Mello. "Liquidação, encerramento e extinção das obrigaçães do falido". Revista de direito mercantil, industrial econômico e financeiro. Vol. 140, Ano XLIV (nova série), out/dez 2005, p. 110.

${ }^{663}$ Teoria furídica da empresa: atividade empresária e mercados. São Paulo: Atlas, 2004, p. 167.

${ }^{664}$ REQUIÃO, Rubens. Curso de direito falimentar, v. 01, 14. edição, 1995, pp. 203-204.
} 
Assim, cuidou a lei também de disciplinar a possibilidade de transferência dos contratos, como acima já mencionado, para que os elementos imateriais (e o valor que estes possuem) vinculados a estes pactos não se percam.

O autor, com sua insuperável didática, evidencia a sutileza que distingue esses conceitos, invocando o exemplo da locação com direito a renovação compulsória: o contrato de locação não integra o estabelecimento (é elemento da empresa, resultado do exercício da atividade), mas dá origem a um bem imaterial, que é o ponto comercial ${ }^{665}$, este sim parte intangível integrante do estabelecimento (instrumento pelo qual se exerce a empresa).

O aviamento não integra o estabelecimento, mas corresponde ao resultado que a organização de bens (estabelecimento) é capaz de trazer e, consequentemente, quanto mais eficiente esta, em tese, maior a capacidade de lucros futuros, como decorrência do exercício da empresa ${ }^{666}{ }^{667}$.

Já a clientelaconstitui um dos atributos do aviamento, na medida em que, na mesma linha de raciocínio, é resultado da eficiência da organização, que, por sua vez,

\footnotetext{
${ }^{665} \mathrm{O}$ ponto comercial é um bem intangível que resulta do exercício da atividade empresarial, por meio do contrato celebrado pelo empresário. Assim, a Lei n. 11.101/05 disciplina a possibilidade de "transferência de contratos específicos" a ser realizada na alienação da empresa ( $\$ 3^{\circ}$ do artigo 140); e o DL n. 7.661/45 dispunha a respeito da transferência de contrato de locação com direito à renovação compulsória legal (artigo $\left.116, \S 1^{\circ}\right)$.

${ }^{666}$ Há empresas cujo ativo mais valioso é composto por bens intangíveis, como é o caso do WallMart, uma das maiores empresas norte-americanas. Baird refere que o WallMart nada produz, mas desenvolveu um sistema de distribuição de produtos manufaturados, do produtor ao consumidor final, a custos extremamente competitivos. O going concern value da empresa resulta da habilidade que a empresa desenvolveu em sua estrutura para auferir esta vantagem competitiva. ("The end of Bankruptcy", BAIRD, Douglas e RASMUSSEN, Robert K. em <http://law.uchicago.edu/Lawecon/index.html>.

${ }^{667} \mathrm{O}$ espírito daquilo que se pretente preservar é, nesse senso, o "going concern value", que é também um dos objetivos do procedimento previsto no Chapter 11, conforme BAIRD, Douglas G.; JACKSON, Thomas H. e ADLER, Barry E.. Bankruptcy, cases, problems and materials, 3. ed., University Casebook Series, New York, Foundation Press, 2000, p. 563: "Chapter 11 of Bankruptcy Code is designed to ensure the survival of those firms in financial distress that are worth keeping intact as going concerns. A railroad that has proved unexpeltedly costly to buid, but that is otherwise a success is a prototypical exemple. While its revenue exceeds its operating costs, the railroad cannot generate enough income to meet its debts obligations. Its assets, however, are worth more if kept togheter as a railroad than if used for anything else". Em tradução livre: "O Chapter 11 do Bankruptcy Code é destinado a assegurar a sobrevivência das empresas em crise nas quais valha a pena manter o 'value concern' intacto. Um exemplo modelo é o da estrada de ferro que tenha sido construída mediante custos adicionais inesperados, mas que, de outro modo, é um sucesso. Enquanto a sua receita exceder os seus custos operacionais, a estrada de ferro não consegue gerar receita suficiente para pagar as suas obrigações. Seus bens, todavia, são mais valiosos se mantidos juntos, do que se fossem utilizados para qualquer outra coisa." A digressão serve para mostrar como a falência prevista na lei brasileira em vigor aproxima-se de um procedimento de preservação (reorganizatório), o que faz questionar a adoção de duplo procedimento (falência versus recuperação) para se atingir o mesmo fim.
} 
culmina com o prestígio que as marcas e sinais distintivos passam a ter; e que se traduzem em um valor econômico ${ }^{668}$. Ou seja, o significado econômico que a eficiência de tais bens organizados passa a ter forma um conjunto de pessoas relacionadas às qualidades objetivas da empresa ${ }^{669}$, e que corresponde à clientela.

Todos esses argumentos levam a reafirmar que a existência de uma organização da qual o devedor é titular resulta em valor econômico que é, segundo a norma do artigo 75, protegido pela lei de falências. E a lei dirige essa tutela aos ativos, incluindo os intangíveis e as relações contratuais estratégicas da devedora, na medida em que considera, explicitamente, tais elementos relevantes para formar o instrumento necessário ao exercício de atividade negocial, que poderá ser preservada e transferida a terceiros.

Todavia, a lei foi omissa quanto à elaboração de uma disciplina de atividade negocial no curso da falência (que apenas denominou por 'continuação provisória das atividades do falido'). Essa disciplina seria fundamental para tutelar convenientemente o feixe de interesses e contratos correlatos necessários para manter hígidos os elementos agregados e organizados, bem como o valor que daí resulta, com vistas à alienação para novos sujeitos, sem que isso pudesse resultar em agravamento da situação dos credores.

A viabilidade de uma solução de continuidade de um negócio, com afastamento do devedor e transferência a novo sujeito, em certos casos, poderia depender dessa disciplina que já era bastante simplificada no diploma anterior e, agora, foi quase que suprimida pela lei vigente, como mais adiante será abordado.

Em suma, a lei somente trata 'en passant' quanto ao modo e as balizas pelos quais a falida deveria preservar a unidade do estabelecimento e dos contratos que sustentam sua existência (diante do valor econômico que certos vínculos representam e que podem ser essenciais para a preservação da organização útil dos ativos). Para essa análise, é preciso avaliar como a massa falida se comporta diante dos possíveis negócios que

\footnotetext{
${ }^{668}$ Francisco Campos refere, em relação ao patrimônio imaterial representado pelo "nome, marca, insígnia e outros sinais distintivos", ao seu valor econômico que é expresso pela significação que adquirem para a clientela, ou seja, por seu uso efetivo na prática mercantil. (CAMPOS, Francisco. Direito comercial, São Paulo: Livraria Freitas Bastos, 1957, p. 39/70).

${ }_{669}$ BARRETO FILHO, Oscar. Teoria do estabelecimento comercial. São Paulo: Max Limonad, 1969, pp. 178-184.
} 
possam ou devam ser realizados, de modo a preservar a organização, no interesse dos credores.

3.1.3.1 - O estabelecimento empresarial e a massa falida: como esses conceitos se relacionam.

Embora o legislador tenha, expressamente, eleito a otimização e utilização produtiva dos bens como uma das finalidades da falência, não se preocupou em erigir uma sistematização, de forma técnica, com regras especificamente destinadas a promover a manutenção da organização dos ativos, como unidade, desempenhando uma função econômica.

A noção do estabelecimento, como acima se concluiu, só faz sentido se a unidade que caracteriza sua finalidade, por vínculo econômico, e que relaciona os bens que o integram, puder ser mantida ${ }^{670}$.

Em certos casos, é possível que a manutenção do estabelecimento somente seja factível se mantida alguma atividade produtiva, mantendo-se aquecido e vivo o vínculo econômico que justifica a organização dos ativos. Para tanto, teria sido necessário, por exemplo, disciplinar o exercício de atividade negocial pela massa falida, o que a lei não fez. Há dispositivos esparsos, sem nenhuma ou de pouca sistematização, mas que não chegam a formar um corpo de normas.

De qualquer modo, a opção do legislador foi a de manter a massa falida como ente despersonalizado ${ }^{671}$, de tal sorte que resta a possibilidade de entendê-la como centro de imputação ${ }^{672}{ }_{-}^{673} 674$.

\footnotetext{
${ }^{670}$ BARRETO FILHO, Oscar. Teoria do estabelecimento comercial. São Paulo: Max Limonad, 1969, p. 99. ${ }^{671}$ O que somente seria possível, por expressa disposição de lei. (TOLEDO, Paulo Fernando Campos Salles de Toledo, "Da personificação da massa falida". Revista de direito mercantil, n. 78, ano XXIX (nova série), abril-junho/1990, pp.46-51).

672 "Restrita em sua função social como produtora de utilidades, permanece a pergunta sobre a categoria jurídica em que se insere a empresa. Há interesses coletivos referidos à empresa e, talvez, se pudesse pensar em regra semelhante ao 'Zurechnungsprinzip', princípio ou critério de imputação, que permitisse caracterizá-la como ente despido de personalidade jurídica e ainda assim passível de imputação que incide sobre a atividade." (SZTAJN, Rachel. Teoria jurídica da empresa: atividade empresária e mercados. São Paulo: Atlas, 2004, p. 127 (esta ideia está também desenvolvida na p.162 da mesma obra).

${ }^{673}$ Ao comentar o artigo 141 da Lei n. 11.101/05 Rachel Sztajn assinala: "A palavra "empresa" aparece novamente empregada como definidora de um centro de imputação de direitos, poderes, faculdades, deveres
} 
A propósito, cumpre lembrar que a legislação outorga à massa falida capacidade judiciária (ou seja, possibilidade de estar em juízo para defesa de interesses, tal como o faz com o espólio, o condomínio e outras entidades jurídicas não personificadas ${ }^{675}$ ). É evidente que essa solução não resulta na aquisição de personalidade jurídica (atributo da pessoa), com capacidade plena para os atos da vida civil e, em particular, para possibilitar a titularidade de direitos e obrigações.

Há interesse evidente na distinção e compreensão destes conceitos, na medida em que a lei brasileira em vigor, a exemplo do que já ocorria no diploma revogado, prevê a possibilidade de celebração de negócios jurídicos pela massa falida (então, como centro de imputação).

De fato, ora a massa figura como objeto de direito, ora como centro de imputação de interesses, conforme se lê, por exemplo, no artigo 114 da Lei n. 11.101/05 ${ }^{676}$. A confusa redação do referido dispositivo diz que " $O$ administrador poderá alugar ou celebrar outro contrato", prosseguindo para afirmar que o objeto da contratação será "referente aos bens da massa falida", para concluir que tal se faz "com o objetivo de produzir renda para a massa falida".

e obrigações. Organização econômica destinada à exploração de algum empreendimento ou ao exercício de uma atividade, não definida como sujeito de direito, espelha melhor o fenômeno 'empresa' do que a insistência em associá-la a pessoas, naturais ou jurídicas, estas sim sujeito de direito". ('in' Comentários à lei de recuperação de empresas e falência. São Paulo: Saraiva, obra coletiva coord. por TOLEDO, Paulo Fernando Campos Salles de; ABRÃO, Carlos Henrique Abrão, 4. edição, 2010, p. 503).

${ }^{674}$ Ou centro de interesses, como prefere Paulo Fernando Campos Salles de Toledo (TOLEDO, Paulo Fernando Campos Salles de Toledo. "Da personificação da massa falida". Revista de direito mercantil. n. 78, ano XXIX (nova série), abril-junho/1990, p. 50).

${ }^{675} \mathrm{O}$ que se verifica, destarte, e é inegável, é a existência de interesses perfeitamente distintos, que nascem com a decretação da falência entre o devedor e a massa falida. Tanto isso é certo que já se afirmou que " $A$ empresa falida e a massa falida são entes distintos e, sendo esta última representada em juízo, ativa e passivamente, pelo síndico - art. 63, XIV e XVI, DL 7661-45, art. 12, III do CPC (ou administrador judicial, segundo a nova Lei de Falências - art. 22, II, ' $n$ '), inadmissível o arquivamento dos autos antes de intimada a substituta da autora na pessoa de seu representante." (TJSP, Ap. Cível n. 466,996-5/1-00, relator Des. Renato Nalini, j. 30/01/2007).

${ }^{676}$ Em redação semelhante está o $§ 5^{\circ}$ do artigo 192 da Lei n. 11.101/05, acrescentado pela Lei n. 11.127/05: "O juiz poderá autorizar a locação ou arrendamento de bens imóveis ou móveis a fim de evitar a sua deterioração, cujos resultados reverterão em favor da massa." Entende-se que o dispositivo em questão, alocado ao capítulo das Disposições Finais e Transitórias, tem a finalidade de autorizar a celebração de negócios também nas falências que devam permanecer, por força do disposto no caput e no $\S 4^{\circ}$ do artigo 192, disciplinadas pelo DL n. 7.661/45; ou seja, as falências decretadas sob a égide do revogado decreto seguirão o regime ali previsto, mas, conforme o $\S 5^{\circ}$ do artigo 192, será possível a celebração de contratos de locação ou arrendamento, tendo por objeto os bens que integram a massa. Na verdade, a praxe já havia sedimentado esse costume e o dispositivo pouco ou nada acrescenta em termos de sistematização da matéria. 
A ideia contida na pragmática, embora tecnicamente criticável, previsão do artigo 114 da Lei n. 11.101/05 é a de trazer recursos para a massa, que serão destinados ao pagamento dos credores.

Uma questão que se coloca, então, é a de quem celebra esse negócio jurídico que tem por objeto o estabelecimento, ativo que integra a massa falida objetiva. O devedor, evidentemente, não é, pois foi desapossado de seus bens e não pode administrá-los, sendo inquestionável que quaisquer negócios por este celebrados seriam nulos ${ }^{677}$.

A letra do artigo 114 da Lei n. 11.101/05 diz que "O administrador poderá alugar ou celebrar outro contrato referente aos bens da massa falida....". Naturalmente, nem se cogita de que o administrador seja parte contratante, de modo que a interpretação literal do dispositivo deve ser afastada, eis que é evidente a impropriedade da redação do dispositivo legal.

Ora, a única resposta aceitável, portanto, é a de que o negócio é mesmo celebrado pela massa falida (que não tem personalidade jurídica e não é pessoa, razão pela qual não poderia, em tese, ser capaz de direitos e obrigações). Mesmo assim, a lei, claramente, outorga capacidade à massa falida para celebração de contratos, presentada pelo administrador judicial.

Assim, a imprecisa redação do artigo 114 deve ser interpretada: “ $O$ administrador poderá alugar ou celebrar outro contrato" (leia-se, a massa falida celebra contrato, presentada pelo administrador); "referente aos bens da massa falida" (na verdade, reporta-se ao estabelecimento do devedor, como elemento da massa falida objetiva), o que se faz "com o objetivo de produzir renda para a massa falida" (ou seja, reconhece novamente a massa como centro de imputação, como titular do direito de receber a remuneração pelo contrato celebrado).

\footnotetext{
677 “Embora a lei atual não traga dispositivo idêntico, é claro que continua em vigor a proibição contida no $\$ 1^{\circ}$ do art. 40 do DL $n .7661 / 45$, ou seja, 'não pode o devedor, desde aquele momento (decretação quebra ou do seqüestro), praticar qualquer ato que se refira direta ou indiretamente aos bens, interesses, direitos e obrigações compreendidos na falência, sob pena de nulidade, que o juiz pronunciará de ofício, independente de prova de prejuízo."” (TJSP, AI 576.078-4/6-00, rel. Des. Romeu Ricupero, j. 24/09/08).
} 
Dois são os desdobramentos decorrentes dessas ideias. O primeiro é o de que o estabelecimento que integra a massa falida objetiva pode ser objeto de negócio jurídico $^{678}$. O segundo é que a massa atua como centro de imputação, já que, embora não tenha personalidade jurídica, celebra contrato e aufere os rendimentos provenientes (ou seja, é titular de direitos e obrigações, mesmo sendo ente despersonalizado) ${ }^{679}$.

Partindo dessa premissa, convém voltar a alguns conceitos já aqui discorridos: a massa falida objetiva consiste no patrimônio ativo, formado pelos bens e direitos em decorrência do desapossamento do devedor, que é consequência imediata e ope legis da sentença de falência.

Com a decretação da quebra forma-se a massa falida subjetiva, que é composta pela coletividade de credores (como uma unidade). Finalmente, a massa falida patrimônio ativo e passivo sob a gestão do administrador judicial - integra um feixe de interesses que é distinto daqueles do devedor, dos credores (isoladamente considerados ou mesmo dentro de suas classes) e do administrador judicial (que simplesmente presenta a massa, como auxiliar do juízo ${ }^{680}$ ).

A distinção destes conceitos, de fato, tem utilidade para criação de uma disciplina de relações jurídicas tendo a massa objetiva como objeto de direito, enquanto a massa falida (patrimônio ativo e passivo, sob a gestão do administrador judicial) atuaria como centro de imputação, passível de exercer atividade negocial. A ideia que possibilita a construção dessa solução é, precisamente, o deslocamento do conceito de empresa de seu aspecto subjetivo (da pessoa) para a ideia de sua função econômica, dirigida ao $\operatorname{mercado}^{681}$.

\footnotetext{
${ }^{678}$ A validade do negócio jurídico depende de agente capaz, objeto lícito e forma prescrita ou não defesa em lei (artigo 104 do CC).

679 "É, por sua vez, econômica, no meu entender, a atividade de gestão, quando ela (como relativamente a um estabelecimento comercial administrado diretamente e não, ao invés, concedido a fruição a outros que o administrem) utiliza o bem qual instrumento para produção de nova riqueza e, portanto, a exploração do estabelecimento implica a qualificação do empresário àquele ou àqueles em cujo nome tem lugar a exploração." (ASCARELLI, Tullio. "A atividade do empresário" (tradução de Erasmo Valladão A. N. e França). Revista de direito mercantil, industrial econômico e financeiro. São Paulo, vol. 132, ano XLII (nova série), out/dez, 2003, p. 204).

${ }^{680}$ TOLEDO, Paulo Fernando Campos Salles de e ABRÃO, Carlos Henrique (Coord.), Comentários à lei de recuperação de empresas e falência. São Paulo: Saraiva, 4. edição, 2010, pp. 101 e 107.

${ }^{681}$ FORGIONI, Paula Andrea. A evolução do direito comercial: da mercancia ao mercado. São Paulo: Revista dos Tribunais, 2009, p. 100.
} 
A letra do artigo 114 da Lei n. 11.101/05 não deixa dúvida de que a massa falida está autorizada a celebrar negócio jurídico.

Na mesma linha de ideias, a disciplina dos efeitos da falência sobre as obrigações do falido leva a essa mesma conclusão, ao permitir que o administrador judicial mantenha determinados contratos, cuja continuidade se dá com a massa falida ${ }^{682}{ }_{-}^{683}$.

Embora a massa falida não seja dotada de personalidade jurídica, o que resulta de mera opção legislativa, parece que seria apropriado disciplinar, de forma técnica, as condições em que poderia esta atuar negocialmente, de modo a proporcionar segurança aos agentes que tenham interesse em tais relações jurídicas.

A fixação de uma disciplina própria de atuação da massa falida como ente autorizado a celebrar negócios seria fator de maximização dos resultados da falência, outorgando a segurança que somente regras preestabelecidas podem oferecer, a todos os interessados de um processo concursal, em especial, à coletividade de credores.

Isto principalmente para permitir que tais possíveis negócios sejam geridos separadamente em relação às obrigações da massa (dos credores originais da falência), de modo a impedir que estes últimos possam ser atingidos por eventuais resultados negativos que provenham dos primeiros.

Uma solução possível seria a de instituir, de lege ferenda, para a massa falida objetiva, a natureza de patrimônio de afetação que, nessa concepção, admitiria a formação "de mais de uma massa patrimonial, com tratamento e finalidades diferentes, com capacidade para estabelecer relações jurídicas e dívidas próprias, mantendo-se essa massa patrimonial destacada completamente afastada das vicissitudes a que esteja sujeito o patrimônio geral. ${ }^{, 684}$

\footnotetext{
${ }^{682}$ Porém, a lei civil exige, para a validade de negócio jurídico, agente capaz, objeto lícito e forma prescrita ou não defesa em lei (artigo 104 do Código Civil).

${ }^{683}$ TOLEDO, Paulo Fernando Campos Salles de Toledo. "Da personificação da massa falida". Revista de direito mercantil. n. 78, ano XXIX (nova série), abril-junho/1990, pp. 48-50.

${ }^{684}$ STURZENEGGER, Luiz Carlos. Doutrina do patrimônio de afetação e o novo sistema de pagamentos brasileiro. Revista de direito bancário, do mercado de capitais e da arbitragem, v. 11, São Paulo: Revista dos Tribunais, 2001, p. 239.
} 
A gestão de tal patrimônio dar-se-ia por regras estabelecidas e dirigidas à atuação do administrador judicial, mediante fiscalização do comitê de credores (se instalado), ou, em determinados temas de maior relevo, com previsão de sufrágio em assembleia de credores.

Vale lembrar que o patrimônio de afetação caracteriza-se pelo fato de se tornar possível segregar certo rol de direitos e obrigações, afetando-os ao cumprimento de uma destinação específica. Por esta razão, tal patrimônio deve obedecer rigorosamente às regras que o disciplinam, permanecendo destacado dos demais ativos e passivos de seu titular (no caso, o devedor, mas sob a gestão da massa falida), até o advento do termo ou cumprimento da finalidade para a qual foi constituído ${ }^{685}$.

Do ponto de vista do direito concursal, uma vez fosse possível instituir (ainda de lege ferenda) patrimônio de afetação sobre alguns ou todos os ativos que integram a massa falida objetiva (destacando-os como um estabelecimento afetado a determinado contrato celebrado pela massa falida), seria possível implementar as regras de disciplina da continuação provisória dos negócios. A finalidade seria proporcionar, ao final do processo, a venda em marcha dos negócios, em perfeita harmonia com a preferência de alienação em bloco de referidos ativos ${ }^{686}$.

Ainda que o direito brasileiro atual reconheça a possibilidade de constituição de patrimônio de afetação, como ocorre nas incorporações de imóveis ${ }^{687}{ }^{688}$, é

\footnotetext{
${ }^{685}$ A teoria clássica a respeito do patrimônio, vinculava uma personalidade a um complexo de direito e obrigações, razão pela qual somente admitia a existência de um único patrimônio ligado à pessoa (princípio da unidade). A teoria moderna supera essa ideia e como ensina Orlando Gomes, "No patrimônio geral, os elementos unem-se pela relação subjetiva comum com a pessoa. No patrimônio especial, a unidade resulta objetivamente da unidade do fim para o qual a pessoa destacou, do seu patrimônio geral, uma parte dos bens que o compõem, como o dote e o espólio. A ideia de afetação explica a possibilidade da existência de patrimônios especiais. Consiste numa restrição pela qual determinados bens se dispõem, para servir a fim desejado (...)." (Introdução ao direito civil. 7. edição, Rio de Janeiro: Forense, 1983, p. 178).

${ }^{686}$ Voltar-se-á a esse debate no item que trata da análise da continuação provisória das atividades do falido. Contudo, é forçoso reconhecer que, nessa matéria, houve retrocesso na disciplina brasileira concursal. Apenas para citar um exemplo, o DL n. 7.661/45 determinava que as operações de venda e compra pela massa no regime da continuação provisória da falida fossem realizadas a dinheiro, que seria recolhido diariamente $\left(\$ \S 4^{\circ}\right.$ e $5^{\circ}$, do artigo 74$)$, ao passo que a lei vigente trata do tema laconicamente no artigo 150 , ainda que tenha erigido a falência a meio de preservação e otimização da organização dos ativos, dando preferência à venda em bloco destes.

${ }^{687}$ Modificação da Lei n. 4.591/64, pela Medida Provisória 2221/2001, posteriormente convertida na Lei $n$. 10.931/2004, com a seguinte redação: Artigo 31-F: "Os efeitos da decretação da falência ou da insolvência civil do incorporador não atingem os patrimônios de afetação constituídos, não integrando a massa
} 
certo que sua instituição, no seio da falência para a gestão segregada de certos ativos da massa falida, dependeria de lei expressa nesse sentido.

No direito italiano ${ }^{689}$, a disciplina "[de]i patrimoni destinati ad uno specifico affare" tinha como uma de suas finalidades a criação de novas formas de gestão e controle societário e, com isso, facilitar o financiamento de determinadas atividades empresariais.

Como anota Francesco Gennari, no patrimônio destinado ocorre "un fenomeno di separazione nell'ambito di un patrimonio facente capo ad un unico soggeto, si differenciano notevolemente fra loro per quanto attiene al contenuto della disciplina ed alla funcionalità pratica. Nella prima ipotesi, come sottolinea la relazione, siamo essenzialmente in presenza di una particolare operazione economica, sostanzialmente equivalente alla costituizione di una nova società, col vantaggio dell'eliminazione dei costi; nella seconda ipotesi, invece, si tiene maggiormente conto dei profili finanziari dell'esercizio dell'impresa. ${ }^{690,}$

Para trazer essa noção para o direito concursal, convém recordar que com o decreto da falência e consequente afastamento do devedor, ocorre separação entre a gestão e a propriedade ${ }^{691}$, o que não é novidade no direito e não deve causar perplexidade alguma. Ora, nada impede que esse patrimônio ativo destacado da esfera de gestão do devedor possa ser reorganizado e afetado a finalidades específicas, notadamente quando parte da atividade negocial seja rentável e passível de ser preservada e parte não tenha mesmo

concursal o terreno, as acessões e demais bens, direitos creditórios, obrigações e encargos objeto da incorporação."

${ }^{688}$ Outros exemplos de patrimônio de afetação no direito brasileiro: créditos que lastreiam a emissão de Certificados de recebíveis tmobiliários (artigos $9^{\circ}$ e seguintes, da Lei n. 9.514/97) e as obrigações constituídas pelas câmaras e prestadoras de serviços de compensação e de liquidação (clearing houses ou clearings), para cumprimento destas em cada um dos sistemas em que estiverem operando ( $\operatorname{artigo} 5^{\circ}$ da Lei $\mathrm{n}$. 10.214/2001).

${ }^{689}$ Decreto Legge n. 06 del 13 gennaio 2003 (articoli dal 2447bis al 2447decies5 dal Codice Civile).

${ }^{690}$ I patrimônio destinati ad uno specifico affare. Padova: Cedam, 2005, pp.3-4. Em tradução livre: "um fenômeno de separação no contexto de um patrimônio à testa de um único sujeito, diferenciando-se notavelmente entre si, no que diz respeito ao conteúdo da disciplina e na funcionalidade prática. Na primeira hipótese, como enfatiza a relação, fica-se essencialmente na presença de uma particular operação econômica, substancialmente equivalente à constituição de uma nova sociedade, com a vantagem de eliminação dos custos envolvidos. Na segunda hipótese, ao contrário, levam-se substancialmente em consideração os perfis financeiros do exercício da empresa".

${ }^{691}$ Que fica, aliás, bastante envidente na hipótese de empresário individual, já que os bens impenhoráveis não são atingidos pela arrecadação e permanecem sob a administração do devedor. No caso de sociedade, o devedor não perde a propriedade dos bens, mas sofre seu desapossamento. 
condições de manter-se sob a unidade de vinculação econômica, que caracteriza o estabelecimento $^{692}$.

Apenas para ilustrar o raciocínio, não nos esqueçamos da figura jurídica do fideicomisso, em que o fiduciário não é proprietário, mas exerce titularidade - qualidade de quem exerce um poder-dever - sobre os bens, a qual deve ser levada a efeito estritamente no interesse do fim pelo qual foi o patrimônio separado constituído. ${ }^{693}$

Francesco Gennari assegura ser positiva "la scelta di ricorrere ad una forma di separazione patrimoniale, che rappresenta una soluzione che già ha sollevato problemi de compatibilità con il principio della responsabilità patrimoniale (...), per perseguire finalità difficilmente individuabili e che, comunque, sembrano confinate nell'ambito di forme alternative di finanziamento dell'impresa. ${ }^{694,}$.

A ideia é, mutantis mutandi, aplicável ao direito concursal para justificar a atuação da massa falida como centro de imputação que atua no mercado, sem que isso possa resultar em prejuízo aos credores originários do devedor: "che una parte del patrimonio sociale viene sottrata alla sua funzione di garanzia per tutti i creditori sociali, a beneficio di una più ristretta cerchia di creditori, derivanti dalla realizzazione dello specifico affare. ${ }^{695,}$

Para que a arguta ideia inicialmente desenvolvida por Requião pudesse ser reconhecida para qualificar a massa falida objetiva como patrimônio de afetação ${ }^{696}$, seria

\footnotetext{
${ }^{692}$ Veja-se o exemplo da Parmalat, em que havia negócios extremamente rentáveis, cuja operação somente era deficitária porque vinha suportando os custos de parte insolvente do negócio. (STANGHELLINI, Lorenzo. Le crisi di impresa fra diritto ed economia (le procedure di insolvenza). Bologna: Il Mulino, 2007, pp.215-218).

${ }^{693}$ STURZENEGGER, Luiz Carlos. Doutrina do patrimônio de afetação e o novo sistema de pagamentos brasileiro. Revista de direito bancário, do mercado de capitais e da arbitragem, v. 11, São Paulo: Revista dos Tribunais, 2001, pp. 239-241.

${ }^{694}$ I patrimônio destinati ad uno specifico affare. Padova: Cedam, 2005, p. 5. Em tradução livre: "a escolha de recorrer a uma forma de separação patrimonial, que representa uma solução que já levantou problemas de compatibilidade com o princípio da responsabilidade patrimonial (...), por perseguir uma finalidade dificilmente individualizável e que, de qualquer modo, parece ficar confinada no âmbito de formas alternativas de financiamento da empresa."

${ }^{695}$ I patrimônio destinati ad uno specifico affare. Padova: Cedam, 2005, p. 11. Em tradução livre: "uma parte do patrimônio social fica subtraída de sua função de garantia de todos os credores da sociedade, em benefício de uma parte mais restrita de credores, derivada da realização do negócio especifico."

${ }^{696}$ REQUIÃO, Rubens. Curso de direito falimentar. 16. edição, São Paulo: Saraiva, 1995, vol. I., p. 154.
} 
preciso implementar legislação específica que regulasse a possibilidade de sua instituição, afetando os bens que integram a massa falida objetiva.

É inegável o mérito da ideia (de lege ferenda) na medida em que possibilitaria afetar um determinado patrimônio ativo, consistente em bens e direitos que integram a massa falida objetiva, formando um estabelecimento passível de exploração, mantendo viva a finalidade econômica que os agrega e tornando possível a celebração de contratos pela massa falida. Os resultados ficariam afetados ao pagamento dos credores, possibilitando negócios totalmente apartados (e principalmente esterelizados) das obrigações dos credores originais da falência.

Essa solução, ainda, adequa-se perfeitamente ao fato de que a afetação poderia englobar o estabelecimento como um todo ou apenas parte dele --- já que este é dotado de plasticidade, ou seja, "a mudança parcial dos elementos é um fenômeno natural na existência do fundo de comércio e constitui emsmo condição para seu funcionamento" 697 --- de modo que a continuidade negocial poderia ser direcionada a algum negócio específico da falida que seja particularmente rentável e, por isso, de maior interesse para alienação conjunta, no futuro.

Enfim, a lei afirma que a falência tem como um de seus objetivos preservar a utilização produtiva dos bens, ou seja, do estabelecimento da falida, que, com efeito, não se extingue, em princípio, com a quebra ${ }^{698}$.

Entretanto, a disciplina da continuação provisória das atividades não foi minimamente disciplinada e as regras esparsas que podem ser interpretadas para sua concretização carecem de sistematicidade.

O operador do direito enfrenta a problemática da ausência de disciplina sistematizada a respeito dos meios de como poderá ser preservada a utilização produtiva dos bens, o que pode ser causa de desestímulo de potenciais interessados, por falta de regras explícitas do jogo.

${ }_{697}^{69}$ BARRETO FILHO, Oscar. Teoria do estabelecimento comercial. São Paulo: Max Limonad, 1969, p149. ${ }^{698}$ BARRETO FILHO, Oscar. Teoria do estabelecimento comercial. São Paulo: Max Limonad, 1969, p.148. 
A omissão de regramento quanto à possibilidade de continuação provisória das atividades da falida é causa de perplexidade ante o novo objetivo fixado pelo artigo 75 da Lei n. 11.101/05. Fica a sugestão de reforma legal para instituição de uma disciplina de atividade negocial a ser exercida pela massa falida, especificando os métodos e meios com que poderia ser implementada e fixando como finalidade, em benefício dos credores, a venda em marcha da organização econômica rentável do devedor.

3.1.4 - Os contratos do devedor e os interesses jurídicos da massa na falência.

Um aspecto que precisa ser abordado é o tratamento que a lei concursal outorga aos contratos celebrados pelo devedor antes da quebra e que, por força da disciplina que outorga ao administrador judicial a faculdade de lhes dar continuidade no curso da falência, traz a matéria para o foco de interesse da presente análise.

A situação de excepcionalidade que se instaura como resultado da falência torna fundamental atribuir consequências jurídicas a determinados contratos celebrados anteriormente à falência e que estejam ativos e em vigor ${ }^{699}$ no momento da quebra, tendo em vista a repercussão econômica da quebra sobre aquelas relações. Por esse motivo, a lei disciplina os efeitos da falência sobre as obrigações anteriormente assumidas pelo devedor, tanto do ponto de vista processual ${ }^{700}$, quanto do direito material ${ }^{701}$.

Antes de tratar do tema, deve-se assinalar que esta disciplina - dos efeitos da falência sobre as obrigações do devedor - não se confunde com eventuais interesses que possa ter a massa falida como novo centro de imputação e titular de interesses, apta a atuar

\footnotetext{
699“'A Falência de uma empresa não é por si só fato apto a alterar as cláusulas dos contratos firmados pelo falido, a não ser nos limites previstos na lei especial que a disciplina (ver arts. 115 e 117, caput, da NLF). $\mathrm{Na}$ economia de mercado, a insolvência é risco tanto para a empresa que fica insolvente quanto para seus credores. No caso sob exame, os credores sujeitam-se às regras da lei especial (ver arts. 77 e 115 da NLF), independentemente de a bancarrota do devedor ter sido previsível ou não." TJSP, Ap. Cível n. 479.046-4/300, rel. Des. Lino Machado (25/06/2008).

700 "O juízo da recuperação ou da falência observa três princípios reitores: unidade, indivisibilidade e universalidade. Tanto a recuperação como falência processam-se perante um único juízo, para onde devem acorrer todas as pretensões decorrentes dos negócios do agente econômico insolvente.(...) Atribuindo exclusivamente ao magistrado que processará a recuperação ou a falência a competência para processamento e julgamento das ações concorrentes ao ativo do devedor, a lei visa à solução célere e eficiente dos conflitos das pretensões que o estado jurídico da insolvência desperta. Assim, no juízo da falência devem concorrer todos os credores do devedor comum, alegando e provando seus direitos. É o princípio da universalidade." (TJMG, AI n. 1.0024.04.507.833-4/001, rel. Des. Marcia de Paoli Balbino).

${ }^{701}$ Artigos 115 a 128 da Lei n. 11.101/05.
} 
como feixe de contratos ${ }^{702}$, mesmo após a quebra ${ }^{703}$. Há pontos de intersecção entre esses dois polos de interesse, mas, em princípio, não se confundem entre si.

Um dos pontos de intersecção a serem lembrados é a possibilidade de transferência de contratos específicos, na hipótese de alienação do estabelecimento, prevista no $\S 3^{\circ}$ do artigo 140 da Lei n. 11.101/05. A preocupação do legislador, nesse caso, foi preservar certos contratos estratégicos formalizados pela devedora antes da falência - e que, indiscutivelmente, têm valor econômico -, tendo em vista possibilitar a manutenção de atividade pelo eventual adquirente dos ativos em bloco.

Nessa hipótese, há um contrato firmado antes da falência, cuja importância para a possível manutenção dos negócios da devedora é de tal ordem que justifica sua transferência compulsória para o adquirente de estabelecimento da devedora ${ }^{704}$. O vínculo contratual, assim, é mantido não apenas ex ante e ex post a falência, mas ao terceiro adquirente do estabelecimento, como ativo que integra a alienação.

${ }^{702}$ SZTAJN, Rachel. Teoria Jurídica da Empresa: atividade empresária e mercados, São Paulo, Atlas, 2004, p. 155.

${ }^{703}$ Nesse sentido, é emblemática a decisão do STJ, que autorizou adesão ao programa de parcelamento fiscal para a falida, sob o argumento de que prevalece o princípio da preservação da empresa: "Tributário. Programa de Parcelamento de Débito junto à Receita Federal, Lei 10.684/03. (...) Empresa sob regime falimentar. Pedido administrativo de adesão negado. (...). Inexistência de disposição específica Art. 111 e 155-A do CTN. Princípio da Preservação e Recuperação Econômica da Empresa. (...). 1. As empresas em recuperação judicial podem aderir aos programas de parcelamento de débitos fiscais, nos termos do art. 155-A e $\$ \S 3^{\circ}$ e $4^{\circ}$ do CTN; (...) 2. A Lei 10.684/00, que instituiu o Programa Especial de Parcelamento PAES, diferentemente da Lei 9.964/00, que criou o REFIS, deixou de vedar a adesão de empresas, em situação falimentar, ao benefício de parcelamento fiscal. 3. O art. 38, § 11 da Lei 8.212/91 resta inaplicável quando a Lei 10.684/00, que constitui lei específica sobre matéria de parcelamento fiscal, não opõe óbices a empresas sob regime falimentar. (...) 6. Ademais, esse entendimento coaduna-se com o princípio da preservação da entidade empresarial, que restou assim insculpido no art. 47 da Lei 11.101/05: "A recuperação judicial tem por objetivo viabilizar a superação da situação de crise econômico-financeira do devedor, a fim de permitir a manutenção da fonte produtora, do emprego dos trabalhadores e dos interesses dos credores, promovendo, assim, a preservação da empresa, sua função social e o estímulo à atividade econômica." (...) 8. O artigo 187 do CTN trata da preferência da execução fiscal sobre outros créditos habilitados na falência e inexiste ofensa a esse dispositivo ante a concessão do parcelamento fiscal, visto que o crédito continua com seus privilégios, mas passa a ser recolhido de maneira diferida, justamente para que se garanta à empresa em situação falimentar, a possibilidade de adimplir a obrigação tributária de maneira integra. 9. A tendência da atual doutrina e legislação brasileiras sobre o regime falimentar das empresas, especialmente o art. $6^{o}$, $\$ 7^{\circ}$ da Lei 11.101/05, a Lei Complementar 118/05 e a Medida Provisória 449 de 04.12.08, orienta-se no sentido de viabilizar que as empresas, ainda que estejam em situação falimentar, devem ter garantido seu direito ao acesso aos planos de parcelamento fiscal, no sentido de manterem seu ciclo produtivo, os empregos gerados, a satisfação de interesses econômicos e consumo da comunidade." (REsp 844279/SC, Relator Ministro Luiz Fux, $1^{\text {a }}$ Turma, STJ, j. 05/02/2009).

${ }^{704}$ A propósito, Vera Helena de Mello Franco, no que diz respeito à locação, entende que somente contratos que outorguem direito à renovação compulsória, nos termos do artigo 51 da Lei n. 8251/91, podem ser objeto de transferência forçada no processo falimentar. (FRANCO, Vera Helena de Mello. "Liquidação, encerramento e extinção das obrigações do falido". Revista de Direito Mercantil, Industrial Econômico e Financeiro. Vol. 140, Ano XLIV (nova série), out/dez 2005, p. 112). 
Como lembra Rachel Sztajn, a disposição tem a finalidade de "preservação das operações" $" 705$ e, com isto, garantir a continuação da atividade antes exercida pela falida, o que justifica, segundo a professora, plenamente a imposição de manter o vínculo contratual, em exceção ao regime da liberdade de contratar estabelecida no artigo 421 do Código Civil ${ }^{706}$. Assim, por exemplo, “contratos de fornecimento com exclusividade serão mantidos apenas no interesse do adquirente, e não do outro contratante. É que o agente 'in bonis' dispensa tutela extraordinária, que, por outro lado, é estendida àquele que adquire bens do falido no procedimento de liquidação." 707

Desse modo, os contratos celebrados pelo devedor antes da quebra, em princípio, não se confundem com a nova situação jurídica que se estabelece no curso da falência, com a fixação de novas relações jurídicas, como, por exemplo, trata a hipótese do já comentado artigo 114 da Lei n. 11.101/05, que prevê a possibilidade de arrendamento dos bens do falido ${ }^{708}{ }^{709}$. Neste último caso, é a própria massa falida que atua como centro de imputação, com interesses próprios, diversos daqueles que mobilizaram o devedor na celebração de contratos antes da falência.

\footnotetext{
${ }^{705}$ SZTAJN, Rachel, 'in' TOLEDO, Paulo Fernando Campos Salles de, e ABRÃO, Carlos Henrique Abrão (coord). Comentários à lei de recuperação de empresas e falência, São Paulo: Saraiva, 4. edição, 2010, p. 500 .

${ }^{706}$ A propósito, a mesma autora relata que “... o contrato, é uma instituição social cuja função serve para dar segurança aos agentes econômicos nas relações patrimoniais que entre si venham a ajustar." (...) E a autora afirma que a função social do contrato "aparecerá quando decorrer do exercício de atividades econômicas, precipuamente da empresa. É que, nesse campo, a previsibilidade e a segurança dos efeitos das operações, que sempre são repetidas ou tendencialmente uniformes, são fatores que pesam na aferição do risco."( "Função Social do Contrato e Direito de Empresa". Revista de Direito Mercantil, Industrial Econômico e Financeiro. Vol. 139, Ano XLIV (nova série), julh/set 2005, pp. 29-30). Assim, sob essa óptica, justifica-se a restrição à liberdade de contratar, no regime da falência, em que a lei possibilita a transferencia de contratos ao adquirente do estabelecimento no processo.

${ }^{707}$ SZTAJN, Rachel, 'in' TOLEDO, Paulo Fernando Campos Salles de; ABRÃO, Carlos Henrique Abrão (coord). Comentários à lei de recuperação de empresas e falência. São Paulo: Saraiva, 4. edição, 2010, p. 501.

708 "O administrador judicial poderá alugar ou celebrar outro contrato referente aos bens da massa falida, com o objetivo de produzir renda para a massa falida, mediante autorização do Comitê. $\S 1^{\circ} \mathrm{O}$ contrato disposto no caput deste artigo não gera direito de preferência na compra e não pode importar disposição total ou parcial dos bens. $\S 2^{\circ} \mathrm{O}$ bem objeto da contratação poderá ser alienado a qualquer tempo, independentemente do prazo contratado, rescindindo-se, sem direito a multa, o contrato realizado, salvo se houver anuência do adquirente".

${ }^{709} \mathrm{E}$ a prova de que a hipótese não é meramente cerebrina está no caso da falência da Companhia Americana Indústria de ônibus - Caio (autos n. 661/1999, 3. ${ }^{a}$ Vara Cível de Botucatu, São Paulo) decretada sob a égide do DL 7661/45. Após a decretação da quebra houve autorização judicial para locação do parque industrial e da marca. Aproximadamente três anos após a falência, ocorrida em 2002, a falida era responsável pela geração de 1.200 empregos diretos, e o valor locativo recebido respondeu pelo pagamento de expressiva quantia do passivo trabalhista, sem que os ativos precisassem ter sido até então alienados.
} 
Abre-se um ou dois parênteses para anotar que o arrendamento da massa falida é uma solução que vem deixando de ser incomum por se constituir medida que evita a deterioração e perda de valor dos ativos; ao mesmo tempo em que permite manter o funcionamento do negócio, impedindo a desvinculação da finalidade unitária e econômica que justifica a organização dos ativos.

Além disso, há hipóteses em que a cessação abrupta das atividades, com lacração do estabelecimento da falida, nem sempre é tarefa fácil de ser realizada. Um bom exemplo a ser mencionado é o da falência do Hospital Nossa Senhora da Penha, atualmente arrendado, e que, à época, tinha cerca de sessenta pacientes internados que não podiam ser ignorados. A respeito desta falência, o promotor de justiça que atua no processo confirmou que "todos ganharam com essa solução [o arrendamento], pois a ninguém interessaria o fechamento de um hospital. Serão gerados cerca de mil empregos, os bens da massa falida serão preservados, fora o fato de a população continuar a ser atendida" $^{710}$.

A regra do artigo 114 da Lei n. 11.101/05 denuncia, declaradamente, as seguintes teses: (i) a massa falida atua como se fosse sujeito titular de direitos patrimoniais (ao menos, como centro de imputação), apesar de destituída de personalidade jurídica; (ii) o conjunto de bens organizados (de que podem ser destacadas partes, sem que disto resulte prejuízo de sua essência) é instrumento (meio) de que se serve a massa para exercer uma atividade negocial; (iii) a atuação da massa, como agente econômico, deve ter por finalidade precípua o atendimento dos interesses dos credores (possibilitando sua alienação), e nunca de se substituir ao papel do devedor.

Voltemos ao tema dos contratos celebrados pelo devedor (antes da quebra) e que sofrem os efeitos da falência, conforme previsão dos artigos 117 e seguintes da Lei $n$. 11.101/05. Primeiro, deve-se ter em mente que o princípio geral que norteia essa disciplina é o da "conveniência da massa"

\footnotetext{
${ }^{710}$ Matéria publicada no jornal "O Valor Econômico", em 10/10/2011. Outro caso de arrendamento citado é a do parque fabril da 'Laticínios Letícia', cuja falência ocorreu em janeiro de 2007, arrendado em 2009.

${ }^{711}$ Expressão utilizada no direito anterior (artigo 43 e $§$ ún. do DL n. 7661/45): "Os contratos bilaterais não se resolvem pela falência e podem ser executados pelo síndico, se achar conveniente para a massa." $\mathrm{O}$ contratante tinha o direito de interpelar a massa quanto ao cumprimento do contrato e, na omissão ou negativa, este resolvia-se em perdas e danos, constituindo crédito quirografário a favor do contratante in bonis.
} 
critérios em relação aos contratos de prestação bilateral: (i) reduzir ou evitar o aumento do passivo; e a (ii) necessidade de manutenção ou preservação de ativos. Exige-se, ainda, autorização do comitê de credores, se instalado, o que revela que a disciplina está focada na tutela dos interesses dos credores.

A regra geral aplicável aos contratos bilaterais é a da continuidade ${ }^{713}$, exceto se, por manifestação tácita ou expressa do administrador judicial, como representante da massa, resulte rescisão. Em relação aos contratos de prestação unilateral, sua continuidade depende dos mesmos critérios fixados para os contratos bilaterais, acima referidos. Ricardo Tepedino anota, entretanto, a estreita utilização deste dispositivo ${ }^{714}$.

Como resultado da falência, destarte, a massa falida passa a ter o direito de resilir unilateralmente o contrato, impedindo que o outro contratante possa exigir o adimplemento forçado da obrigação, restringindo o direito deste, a perdas e danos. ${ }^{715} \mathrm{~A}$ mudança ope legis ao direito do contratante in bonis é expressiva na medida em que há perda do direito ao adimplemento compulsório.

A decisão de cumprimento ou não do vínculo contratual do devedor falido passa a ser, em certa medida, ato de discricionariedade do administrador judicial, norteada pelos seguintes condutores: (i) preservação dos ativos ou redução do passivo, e (ii) autorização do comitê.

É interessante notar que, em princípio, a lei não exige prévia decisão judicial a respeito da decisão de continuidade ou não dos vínculos contratuais do devedor, pela massa falida. Nada impede, entretanto, que na ausência do comitê ou impossibilidade de

\footnotetext{
712 Ao comentar a decisão do acórdão no MS n. 380.876, rel. Juiz Costa de Oliveira $1^{\text {o }}$ TACivilSP, (RT 629/148), Ricardo Tepedino noticia que "as normas de uma lei falimentar, não são, por natureza, dispositivas, porque visam à proteção de interesses coletivos, inclusive de natureza social." (Comentários à lei de recuperação de empresas e falência. 4. edição, São Paulo: Saraiva, 2010, p. 362).

${ }^{713}$ Artigo 117 e $\S \S$ da Lei n. 11.101/05.

714 Limitada a contrato de mútuo com alienação fiduciária, pois do cumprimento de outros contratos gratuitos, tais como doação, comodato ou depósito a massa não poderá cogitar (TOLEDO, Paulo Fernando Campos Salles de e ABRÃO, Carlos Henrique (Coord.). Comentários à lei de recuperação de empresas e de falência, obra coletiva, São Paulo: Saraiva, 4. edição, 2010, p. 427).

${ }_{715}$ TEPEDINO, Ricardo. Comentários à lei de recuperação de empresas e de falência, obra coletiva Coord. SALLES DE TOLEDO, Paulo e ABRÃO, Carlos Henrique, Saraiva, 4. edição, 2010, p. 420.
} 
decisão majoritária, ou havendo controvérsia a respeito da matéria, o magistrado seja instado a proferir decisão ${ }^{716}$.

Todavia, se o administrador judicial comunica o cumprimento do contrato, a massa falida se subrroga na posição contratual do falido, tanto que os créditos do outro contratante serão considerados extraconcursais, por expressa disposição de lei ${ }^{717}$.

Aqui, novamente, a lei revela que a massa falida atua como centro de imputação de direito, ainda que destituída de personalidade jurídica, ao mesmo tempo em que constitui uma obrigação excepcionada daquelas sujeitas ao concurso. Reconhece-se que o sentido econômico desta atuação não é, em princípio, a obtenção de lucro, mas o da manutenção da organização de bens (e o valor agregado que isto representa), potencializando a melhor venda, no interesse dos credores. É fundamental que esse foco não se perca, pois não se pretende alçar a massa falida a agente econômico, na medida em que não se pode impor aos credores a assunção do risco inerente à atividade empresarial. A atividade da massa não pode, em hipótese alguma, onerar o passivo.

Logo, as relações jurídicas de interesse da massa podem ser classificadas, sob o enfoque aqui abordado: (i) os negócios jurídicos para os quais o administrador decide dar continuidade, mantendo o vínculo contratual celebrado pelo devedor antes da falência; (ii) os negócios jurídicos celebrados no interesse da massa falida, como é o exemplo do arrendamento dos bens; (iii) os vínculos contratuais que poderão ser transferidos ao eventual adquirente do estabelecimento, na realização do ativo, levada a efeito no processo falimentar.

Para atender as obrigações nascidas como resultado de atividade negocial praticada por iniciativa da massa falida (como o arrendamento do estabelecimento, por exemplo), já foi registrada, acima, a sugestão de instituição, por lei, de patrimônio separado, por meio de previsão de regras de gestão e destinação dos resultados.

\footnotetext{
${ }^{716}$ Confira-se, a respeito, Paulo Salvador Frontini (FRONTINI, Paulo Salvador, 'in' Comentários à lei de recuperação de empresas e falência, obra coletiva coord. SATIRO DE SOUZA JR., Francisco; PITOMBO, Antonio Sergio M. São Paulo: Revista dos Tribunais, 2. edição, 2007, p. 443).

${ }^{717}$ Artigo 84, V da Lei n. 11.101/05.
} 
Por outro lado, pelas obrigações assumidas pela massa em decorrência da continuidade de contratos do devedor, permanece a disciplina existente, de crédito extraconcursal, conforme artigo 150 da Lei n. 11.101/05. A medida justifica-se, eis que tal iniciativa tem a finalidade de proporcionar a preservação dos vínculos contratuais para alienação em bloco, o que resulta em direto benefício aos credores da massa.

Desse modo, e sob qualquer ângulo de análise (ou seja, tanto a gestão dos contratos anteriores à falência, quanto a celebração de novos negócios), o reconhecimento da massa falida como centro de imputação de interesses próprios é obrigatório.

Seria, dessa forma, de rigor, de lege ferenda, insista-se, a criação de uma disciplina jurídica própria que pudesse atender a essa situação de fato, absolutamente natural da vida econômica (e da qual a massa falida participa), resultado das relações geradas por uma cadeia de interesses jurídicos que não se rompe com a quebra.

Mais ainda: a própria lei concursal qualifica e reconhece existir essa continuidade de interesses negociais posteriores à falência - embora deficientemente trate do tema, dada a ausência de uma categoria jurídica em que se enquadrem -, evidenciandose a necessidade de tutela própria, com regras consistentes e claras que possam consolidar a manutenção da organização dos ativos (e interesses decorrentes) após a quebra.

É importante reforçar, mesmo correndo o risco de repetir, que os negócios celebrados pela falida devem ter como base fundamental os seguintes princípios, que ficam ora sugeridos: (i) a massa falida não pode ser onerada com déficit decorrente de novas obrigações, em especial se decorrentes de atuação de iniciativa da massa (como é o caso do arrendamento, que é fator de geração de tributos e verbas salariais, cujo cumprimento deve ser rigorosamente fiscalizado); (ii) os credores devem, necessariamente, ser beneficiados com o gerenciamento dos ativos; (iii) nenhuma atividade negocial deve ser impeditiva de atos de alienação, ao contrário, deverão atuar como elementos facilitadores desta (venda dos negócios em marcha). 
3.1.5 - A atuação do juiz e do administrador judicial na administração da massa falida objetiva.

Há ainda um dispositivo legal que merece referência, na medida em que trata das obrigações do devedor e procura dar solução para "outras relações patrimoniais" não expressamente disciplinadas, de interesse da falida ${ }^{718}$.

Trata-se de norma-princípio $^{719}$, pela qual todas as relações obrigacionais ${ }^{720}$ que possam resultar da falência e que não tenham sido expressamente disciplinadas permanecem sob o crivo da apreciação do juiz, cujas decisões atenderão ao norte dos princípios insculpidos no artigo $75^{721}$ e deverão levar em consideração: a unidade ${ }^{722}$, a universalidade do juízo e a igualdade de tratamento dos credores.

Embora assim seja, quem se encarrega de examinar, no dia a dia, as necessidades práticas da massa falida é o administrador judicial ${ }^{723}$, órgão auxiliar da justiça e de confiança do juízo ${ }^{724}$.

\footnotetext{
${ }^{718}$ Corresponde ao artigo 126 da Lei: Nas relações patrimoniais não reguladas por esta Lei, o juiz decidiráo caso atendendo à unidade, à universalidade do concurso e à igualdade de tratamento dos credores, observado o disposto no art. 75 desta Lei.

${ }^{719}$ Como lembra Miguel Reale Jr., encontram-se inseridos no ordenamento jurídico, como norma ou não, "os princípios são 'verdades fundantes' de um sistema de conhecimento, como tais admitidas, por serem evidentes ou por terem sido comprovadas, mas também por motivos de ordem prática e de caráter operacional, isto é, como pressupostos exigidos pelas necessidades de pesquisa e da práxis." (REALI JR., Miguel. Lições preliminares de direito, 7. edição, São Paulo: Saraiva, 1980, p. 299). Na mesma linha, o ministro Marco Aurélio, em julgamento do Recurso Extraordinário n. 160.381/SP: “Os princípios podem ou não estar explicitados em normas. Normalmente, sequer constam de texto regrado. Defluem no todo do ordenamento jurídico. Encontram-se ínsitos, implícitos no sistema, permeando as diversas normas regedoras de determinada matéria" (RTJ 153/1030, STF).

${ }^{720}$ Como prefere Paulo Salvador Frontini (FRONTINO, Paulo Salvador 'in'obra coletiva coord. SATIRO DE SOUZA JR., Francisco e PITOMBO, Antonio Sérgio A. de Moraes. Comentários à Lei de recuperação de empresas e falência. São Paulo: Revista dos Tribunais, 2. edição, 2007, p. 460).

${ }^{721}$ Como anota Ricardo Tepedino, o legislador deixa claro que os princípios que constituem a pedra angular do processo de falência devem se sobrepor aos princípios gerais do contrato que disciplinam cada vínculo. (obra coletiva, Coord. TOLEDO, Paulo Fernando Campos Salles e ABRÃO, Carlos Henrique. Comentários à lei de recuperação de empresas e falência. 4. edição, São Paulo: Saraiva, 2010, p. 451).

${ }^{722} \mathrm{~A}$ unidade refere-se à massa falida visando a futura realização do ativo em bloco, como preconizam FRONTINI, Paulo Salvador (obra coletiva organizada por SATIRO DE SOUZA JR., Francisco; PITOMBO, Antonio Sérgio A. de Moraes, Comentários à lei de recuperação de empresas e falência. São Paulo: Revista dos Tribunais, 2. edição, 2007, p. 460) e BEZERRA FILHO, Manoel Justino (Lei de recuperação e falências comentada. São Paulo: Revista dos Tribunais, 7. edição, 2011, pp. 187-189).

723 "Não somente figurando como fiscal do procedimento jurisdicional, o administrador judicial passou a assumir a função de acompanhar 'pari passu' a execução do plano de recuperação judicial da sociedade em crise, uma vez aprovado pelo Poder Judiciário e credores, bem como realizar os atos de gestão investidos de natureza econômico-financeira e administrativa em prol da pretendida celeridade do processo falimentar." (MENDES, Bernardo Bicalho de Alvarenga. "A importância do administrador judicial como órgão auxiliar
} 
Como já referido, o administrador judicial terá certa discricionariedade de atuação, ainda que sob a fiscalização direta do juiz e do comitê de credores, se instalado. Essa diretriz está perfeitamente afinada com a moderna tendência do direito concursal de manter o juiz mais diretamente ligado à prestação jurisdicional, para solução de possíveis conflitos.

É por isso que se justifca que o administrador judicial somente possa ser nomeado e destituído pelo juízo, que atua na sua fiscalização direta, ao lado do comitê de credores $^{725}$, quando constituído. Além disso, quando necessário, o administrador judicial poderá valer-se de profissionais que o auxiliem no desempenho de suas funções ${ }^{726}$.

Repita-se, a ideia de permitir ao administrador judicial certa discricionariedade de atuação, sem prejuízo de que seja levada ao crivo de decisão judicial qualquer controvérsia, está albergada na noção de que deve o magistrado concentrar sua atuação na prestação jurisdicional ${ }^{727}$.

Logo, uma das atribuições de maior relevo do administrador judicial na falência consiste na prática "dos atos necessários à realização do ativo"728, incumbindolhe arrecadar os bens e avaliá-los, em um primeiro momento e, a seguir, coordenar sua alienação, nos moldes adiante analisados ${ }^{729}$.

Esse é um dos aspectos de aferição de eficiência do processo falimentar, eis que diretamente relacionado à capacidade de maximização dos ativos, razão pela qual a

ao juízo falimentar na busca da eficacia dos procesos falimentares e de recuperação judicial de empresas". Revista de direito mercantil, industrial econômico e financeiro. Vols. 155/156, ago/dez 2010, p. 263).

${ }^{724}$ Confira-se, a propósito, o AI n ${ }^{\circ}$ 1.0024.96.074689-9/001, TJMG, relator Desembargador Guilherme Luciano Baeta Neves).

${ }_{725}$ Artigo 22 da Lei n. 11.101/05.

726 A atuação do administrador judicial é indelegável, mas poderá socorrer-se de auxiliares, sob sua orientação e responsabilidade no desempenho de suas funções.

${ }^{727}$ TOLEDO, Paulo Fernando Campos Salles de. Obra coletiva, coord. TOLEDO, Paulo Fernando Campos Salles e ABRÃO, Carlos Henrique. Comentários à lei de recuperação de empresas e falência. 4. edição, São Paulo: Saraiva, 2009, p. 75.

${ }^{728}$ Artigo 22, III, i da Lei n. 11.101/05.

${ }^{729} \mathrm{O}$ administrador judicial tem "a função de agir em prol dos intereses dos credores, maximizando e preservando a massa falida em vista ao atendimento do deslinde falimentar." (MENDES, Bernardo Bicalho de Alvarenga. "A importância do administrador judicial como órgão auxiliar ao juízo falimentar na busca da eficacia dos procesos falimentares e de recuperação judicial de empresas". Revista de direito mercantil, industrial econômico e financeiro. Vols. 155/156, ago/dez, 2010, p. 267). 
boa atuação do administrador judicial tornou-se fundamental para o bom êxito do procedimento falencial.

Um dos modos de alcançar esse objetivo, de maximização dos ativos, se traduz exatamente pela "determinação da nova lei para manter a empresa em funcionamento, quando possível, mesmo depois de decretada a falência. (...) A nova lei oferece a possibilidade de a empresa continuar em funcionamento, evitando a desvalorização das máquinas e equipamentos e elevando seu valor com a venda. $O$ objetivo principal é vender a empresa, ou suas partes, pelo maior valor possivel, distribuindo-se os recursos entre os credores.",730

A continuação provisória dos negócios, em oposição à lacração, ganha uma nova dimensão no regime atual e o seu maior protagonista será o administrador judicial, sob a fiscalização direta do juiz, como adiante se passa a expor.

\subsubsection{1 - Continuação provisória das atividades e lacração.}

A continuação provisória do negócio era disciplinada no diploma anterior, no artigo 74. A lei atual faz referência à "continuação provisória das atividades do falido", mencionando-a, tão somente, nos incisos VI e XI do artigo 99 (prevê o conteúdo da sentença que decreta a falência), além de, laconicamente, aludir que as despesas necessárias e decorrentes desta "serão pagas pelo administrador judicial com os recursos disponíveis em caixa" (artigo 150). No mais, a lei silencia por completo em relação à disciplina da continuação provisória das atividades do falido.

Como já constatado, a massa falida, em determinadas circunstâncias, comporta-se (embora evidentemente não o seja) como se fosse sujeito de direito, o que se verifica com maior ênfase no regime de continuidade provisória da atividade. Nesse período, aumentam as possibilidades de a massa celebrar contratos ou dar prosseguimento a outros vínculos preexistentes.

\footnotetext{
730 BARRICHELLO, Stefania Eugenia. "Análise econômica da nova lei brasileira de falências e recuperação de empresas". Revista de direito mercantil, industrial econômico e financeiro. Vol. 147, Ano XLVI (nova série), julh/set 2007, p. 204.
} 
É inegável, portanto, a atuação da massa falida como agente econômico e a atividade econômica na qual deverá atuar terá a finalidade de manter ativa a organização, que caracteriza a unidade de destinação econômica do estabelecimento, enquanto unidade produtiva, viabilizando a sua futura alienação como preservação deste valor agregado ${ }^{731}$.

Nesse sentido, a lei deveria ter se ocupado de disciplinar as condições de desenvolvimento de uma disciplina de negócios ${ }^{732}$ a ser conduzida pela falida ${ }^{733}$, sob o comando do administrador judicial (fiscalizado pelo juiz e credores), de modo a preservar a independência de seus resultados em relação às obrigações que devam ser atendidas na falência.

No sistema anterior, a lei impunha que as operações de compra e venda, em regra, fossem realizadas "a dinheiro contado". O gestor encarregado deveria prestar contas diariamente das importâncias recebidas no dia anterior e, semanalmente, apresentá-las em juízo $^{734}$. Ainda que de forma incipiente, o regime anterior trazia algum regramento para a matéria.

É evidente que na época do revogado decreto a atividade empresarial preponderante era exercida pelo empresário individual, precipuamente de negócio de pequeno porte. A disciplina então prevista para a continuação provisória das atividades do falido, naturalmente, não se adapta ao atual cenário econômico em que se insere a Lei n. 11.101/05.

Não se trata de tentar reavivar aquelas normas, mas de chamar a atenção para o fato de até mesmo o revogado decreto, que disciplinava uma economia insipiente e

\footnotetext{
${ }^{731}$ Em razão do foco desta pesquisa optou-se por não abordar outros enfoques de menor repercussão relativos à continuação provisória de atividades. É evidente, portanto, que essa pode existir para determinar-se a finalização de um determinado bem de produção ou para atender situações isoladas que proporcionem redução das despesas da massa ou evitar-se a deterioração de certos insumos. De qualquer modo, fica a ressalva, sob o argumento de que tais circunstâncias refogem ao tema da pesquisa.

${ }_{733}^{732}$ Embora o artigo 99, XI da Lei n. 11.101/05 utilize a expressão 'atividade'.

733 "A personificação das sociedades que, exercentes de atividade negocial, são ditas empresárias serve, como técnica jurídica, para definir um centro de imputação de negócios juridícos, em geral de conteúdo patrimonial, ainda presa a uma visão antroposoformista do fenômeno. Separar patrimônios e determinar diferentes centros de imputação de responsabilidades patrimoniais não se confunde com fazer, com continuidade, com manifestação volitiva, próprias dos seres humanos". (SZTAJN, Rachel. Teoria jurídica da empresa: atividade empresária e mercados. São Paulo: Atlas, 2004, p. 169).

${ }^{734} \S \S 4^{\circ}$ e $5^{\circ}$ do artigo 74 do DL n. 7.661/45.
} 
de pouca expressão, ocupou-se de erigir uma sistematização para a continuação provisória das atividades do falido.

O que importa destacar é que, em certos casos, a atuação econômica da falida pode constituir medida preparatória essencial para o sucesso da alienação em bloco dos ativos, sem o que poderia não ser possível conservar a organização econômica unitária dos bens até o momento de sua alienação.

A continuação provisória de atividades faz com que se adicionem novos interesses ao processo concursal, decorrentes de relações contratuais novas celebradas por terceiros com a massa falida; ao lado e em paralelo ao direito dos credores que já compõem a massa falida subjetiva.

Assim, a necessidade de uma disciplina específica para a continuação provisória das atividades do falido é de rigor para: (i) direcioná-la à finalidade de alienação em bloco dos ativos, como elemento facilitador desta solução em prol dos credores; (ii) impedir que os credores da massa possam ser negativamente afetados pelas novas relações jurídicas iniciadas ou continuadas após o decreto de falência.

A disciplina para as regras da continuidade provisória das atividades deve ser tal que impeça o agravamento do passivo, o que seria inaceitável no concurso de credores. Ao mesmo tempo, deve fomentar a preservação do estabelecimento e dos vínculos contratuais que lhe sejam estratégicos, para que se possa atingir o objetivo almejado pela lei, de conservação, por viabilização da venda de ativos como unidade produtiva.

Uma possibilidade seria erigir a disciplina da continuação provisória das atividades do falido mediante necessidade de elaboração de um plano de gestão. $\mathrm{O}$ vínculo entre a atividade e o patrimônio seria objetivo (ou seja, resultante da unidade e finalidade econômica da organização dos bens), até que se formalize sua alienação, em conjunto.

A partir dessa ideia, seria possível tentar separar o risco que resulta dos contratos ex ante e ex post falência, estabelecendo-se menor perigo de constituição de 
déficit em detrimento dos credores, ao mesmo tempo em que se possibilita manter viva a organização de bens até alienação e venda para pagamento do passivo.

A decretação da falência cria, per se, um patrimônio separado (em relação ao titular, que é o devedor), o qual constitui garantia de todos os credores (que formam a massa falida subjetiva).

A gestão desse patrimônio, por via da disciplina de continuação provisória das atividades do falido, é matéria a ser apreciada e instituída por reforma legal, para a qual se sugerem os seguintes fundamentos: (i) que as relações de débito e crédito decorrentes deste negócio possam alimentar-se e se sustentar de forma isolada em relação àquelas precedentes (que deverão ser satisfeitas na falência); (ii) as obrigações eventualmente nascidas para credores (empregados e tributos, v.g.) resultantes desta operação devem ser satisfeitas apenas e tão somente com recursos gerados pela própria atividade econômica desenvolvida pela massa; e, finalmente, que (iii) a administração de tal negócio, tanto do ponto de vista de gestão subjetiva quanto da contabilização, seja totalmente desvinculada e separada dos credores da falida ${ }^{735}$.

O fato de o administrador judicial estar autorizado a representar (processualmente) a massa falida em juízo como autora ou ré ${ }^{736}$ não atende, sequer minimamente, a necessidade de uma disciplina de continuação provisória das atividades do falido, a qual pode, em tese, até mesmo gerar disputas envolvendo interesses da massa falida.

\footnotetext{
${ }^{735}$ Como recomenda Francesco Gennari aplicando a ideia ao tema do patrimônio de afetação na lei italiana: "prevedendo una gestione separata anche dal punto de vista sostanziale, oltre che daquello contabile, come avviene in uno degli instituti con i quali il paralelo è piú immediato, ovvero, il 'trust', le cui affinità con $i$ patrimoni destinati già sono estate evidenziate, nel quale la gestione della parte di patrimonio che viene separato da quello complessivo del disponente viene affidata a um soggetto diverso, il 'trustee', che si occupa dell'amministrazione di tali beni sulla base di un rapporto di natura fiduciaria, in maniera tale da definire e separare nettamente i ruoli dei due titolari i dei patrimoni." (GENNARI, Francesco. I patrimônio destinati ad uno specifico affare, Cedam, Padova, 2005, p.111). Em tradução livre: "prevendo uma gestão separada, seja do ponto de vista substancial, seja do contábil, como ocorre em um dos institutos com o qual o paralelo é mais imediato, ou seja, o 'trust'”, cuja afinidade com o patrimônio de afetação já foi evidenciada, e no qual a gestão de parte do patrimônio que é separada daquele que integra o do instituinte, e é confiada a um sujeito distinto, o 'trustee', o qual se ocupa da administração de tais bens sob a base de uma relação de natureza de confiança, de tal modo a definir e separar lealmente os papeis dos dois titulares e dos patrimônios".

${ }^{736}$ Artigo 12, III do Código de Processo Civil c/c Artigo. 22, III, alínea ‘n’ da Lei n. 11.101/05.
} 
Somente uma disciplina, que a lei não traz, com regras de orientação das transações contratuais celebradas pela massa falida (limitações, responsabilidade e riscos entre os contratantes), é que proporcionaria um adequado e consistente regime de implementação da continuação provisória das atividades do falido, proporcionando segurança de atuação aos agentes envolvidos.

A finalidade de tal regramento deve sempre ser a de direcionar e viabilizar a venda dos negócios em marcha, como se verifica no direito espanhol, argentino e italiano. Anote-se, essa solução poderia até mesmo demandar a nomeação de um gestor especializado em empresas em crise, o que a lei anterior ao menos mencionava ${ }^{737}$, e destaca, ainda, mais a inaceitável omissão da lei vigente a respeito do tema.

A lei em vigor, infelizmente, deixou muito a desejar no regramento da 'continuação provisória da atividade da falida', pois, embora tenha elegido a preservação da empresa como um dos objetivos da falência, foi precária na disciplina da contratação da massa falida com terceiros ${ }^{738}$, providência esta que pode ser essencial para viabilizar a venda dos negócios em marcha ${ }^{739}$. A lei brasileira vigente deixou, portanto, enorme lacuna nessa matéria.

A sistematização da continuação da atividade do falido (artigo 99, XI da Lei n. 11.101/05) é medida essencial, destinada a disciplinar as possíveis relações jurídicas e o feixe de $\operatorname{contratos}^{740}$ que esta é autorizada a celebrar, fixando condições e responsabilidades.

Outro desdobramento direto dessa omissão da lei consiste no fato de que a continuação provisória das atividades é situação alternativa à de lacração, conforme se lê no inciso XI, do artigo 99 da lei concursal vigente. De fato, em princípio, a lacração é

\footnotetext{
${ }_{737}^{737} 2^{\circ}$ do artigo 74 do DL n. 7.661/45.

${ }^{738}$ Situação que não se confunde com a disciplina geral dos efeitos da falência em relação aos contratos do falido (artigos 117 a 121 da Lei n. 11.101/05), eis que esta trata apenas da rescisão ou não dos vínculos celebrados e preexistentes à quebra. $\mathrm{O}$ artigo 114 , por sua vez, apenas autoriza a contratação, mas a lei não traz nenhuma disciplina sobre as formas, limites e condições desta.

${ }^{739}$ CAMPINHO, Sérgio. Falência e recuperação de empresa - o novo regime da insolvência empresarial, 5. edição, São Paulo: Renovar, 2010, p. 304.

${ }^{740}$ Como prefere Rachel Sztajn (Ensaios sobre a natureza da empresa - organização contemporânea da atividade. São Paulo, Tese para concurso de professor titular do Departamento de Direito Comercial da Faculdade de Direito da Universidade de São Paulo, 2001, p. 87).
} 
incompatível com a continuação provisória de atividades, exceto se, existindo mais de um estabelecimento, seja a lacração parcial, o que é perfeitamente admissível, apesar de a lei silenciar a respeito.

Seguramente, ficará a critério do juiz determinar ou não a lacração no momento da sentença. Em razão disso, o primeiro momento em que o magistrado pode se pronunciar a respeito do tema da continuação dos negócios da falida é no ato de prolação da sentença de falência.

Mas nada impede que posteriormente, e tendo sido melhor avaliada a situação do falido e ao entrever a possibilidade de benefício aos credores, seja autorizada a continuação provisória das atividades, levantando-se à lacração - que é facultativa -, caso tenha sido realizada.

Veja-se que, em certos casos, no momento da sentença, poderá haver ainda dúvida a respeito da conveniência ou não da continuação das atividades do falido. Daí porque não convém adotar uma interpretação restritiva e literal do inciso XI do artigo 99 da Lei n. 11.101/05, para entender possível sua autorização somente no momento da decisão de quebra.

A lacração era obrigatória no sistema anterior ${ }^{741}{ }_{-}^{742}$ e deveria ser realizada antes de eventual autorização para a continuidade dos negócios ${ }^{743}$. A obrigatoriedade relacionava-se à ideia de proteger a integridade dos ativos que compunham a massa ${ }^{744}{ }^{745}$, ou seja, era prevista como medida assecuratória para impedir o extravio dos bens, a fim de

\footnotetext{
741 A lacração era obrigatória na lei revogada, e era formalizada pelo ato de afixar-se, na porta do estabelecimento do falido, o resumo da sentença de quebra, e à partir de então o ingresso no local dependeria de autorização expressa do juiz da falência (artigo 15, I do DL n. 7661/45, BEZERRA FILHO, Manoel Justino. Lei de falências comentada. São Paulo: Saraiva, 2. edição, 2003, p. 146).

${ }_{742}$ FERREIRA, Waldemar. Instituições de direito comercial. Vol. 5, São Paulo: Livraria Freitas Bastos, 1951, p. 167.

${ }_{743}$ Artigo 74, $\S 1^{\circ}$ do DL n. 7.661/45.

744 FERREIRA, Waldemar. Instituições de direito comercial. Vol. 5, São Paulo: Livraria Freitas Bastos, 1951, p. 154; VALVERDE, Trajano de Miranda. Comentários à lei de falências. 4.. edição atualizada por J. A. Penalva dos Santos e Paulo Penalva Santos. Rio de Janeiro: Forense, 1999, vol. II, p. 26.

${ }^{745}$ Conforme a opinião de Daniel Rivorêdo Vilas Boas, a lacração teria também a finalidade de interromper a execução do objeto social para cessar o endividamento. (A continuação dos negócios da falida: critérios e condições, obra coletiva, coord. DIAS DO AMARAL, Paulo Adyr; FLORIANO NETO, Alex. Direito empresarial: teoria, práticas e estratégias. Belo Horizonte: Del Rey, 2010, p. 83).
} 
que se pudesse concretizar, na sequência, o ato formal de sua apreensão pela arrecadação. A prática, no entanto, demonstrou que esse sistema nem sempre funcionava.

Por isso, na vigente lei, a lacração do estabelecimento do devedor passou a ser facultativa ${ }^{746}$. Esta somente se dá, conforme previsão do artigo 109, se "houver risco para a execução da etapa de arrecadação, ou para a preservação dos bens da massa falida, ou dos interesses dos credores ${ }^{, 747}$.

De qualquer modo, doutrina e jurisprudência cada vez mais se inclinam ao entendimento de que, em certas hipóteses, a interrupção abrupta das atividades do devedor pode resultar em malefício maior aos interessados no concurso, o que justifica a posição agora adotada pelo legislador ${ }^{748}{ }^{749}$. Mais ainda: nesses casos, a própria continuidade das atividades pode consistir em método bastante eficiente de vigilância dos ativos, protegendo-os de extravio, já que ficam sob a supervisão direta dos empregados e do administrador judicial, realizando-se, destarte, tranquilamente a arrecadação.

Apesar de a continuação de negócios caracterizar-se como hipótese de excepcionalidade $^{750}{ }^{751}$, está ela intimamente relacionada, no regime atual ${ }^{752}$, à

\footnotetext{
${ }^{746} \mathrm{Ou}$ seja, quando houver risco para a realização da arrecadação, ou necessária para a preservação dos bens da massa ou dos interesses dos credores, conforme se infere dos arts. 106 c/c 99, XI da Lei 11.101/05.

${ }^{747}$ TOMAZETTE, Marlon. Curso de Direito Empresarial, vol. 3, Editora Atlas, São Paulo, 2011, pp. 343344.

${ }^{748}$ ABRÃO, Carlos Henrique. Comentários à lei de recuperação de empresas e falência, obra coletiva organizada por SALLES DE TOLEDO, Paulo Fernando Campos e ABRÃO, Carlos Henrique, São Paulo: Saraiva, 4. edição, 2010, p. 372; COELHO, Fábio Ulhoa. Comentários à nova lei de falências e recuperação de empresas, São Paulo: Saraiva, 8. edição, 2011, p. 373.

749 "Vislumbrada a possibilidade de continuidade dos negócios das falidas porque a paralisação do ativo de maior valor (frigorífico) acarretaria prejuízos aos credores, por não alcançar valor correspondente à construção, conveniente a autorização para funcionamento emanada do presidente do feito." (AI n. 527956/186(200603231262), TJGO, Rel. Des. Beatriz Figueiredo Franco, j. 13/09/2007).

750 "A continuação provisória das atividades do falido se justifica em casos excepcionais, quando ao juiz parecer que a empresa em funcionamento pode ser vendida com rapidez, no interesse da otimização dos recursos do falido. Se, pela tradição da marca explorada ou pela particular relevância social e econômica da empresa, parecer ao magistrado, no momento da decretação da quebra, que o encerramento da atividade agravará não só o prejuízo dos credores como poderá produzir efeitos deletérios à economia regional, local ou nacional, convém que ele autorize a continuação provisória dos negócios." (COELHO, Fábio Ulhoa, Comentários à nova lei de falências e recuperação de empresas, São Paulo: Saraiva, 8. edição, 2011, p. 373). 751 "Cuida-se de possibilidade de continuação da atividade do devedor por certo tempo, uma vez que a falência é procedimento de liquidação para solver o passivo. Contudo, há casos em que a interrupção imediata da atividade é mais perversa para os credores, empregados, clientes/consumidores, porque matérias-primas ou produtos em elaboração, cujo processo produtivo não tenha sido completado, nem sempre, no momento da venda, alcançarão os melhores lanços dos arrematantes. De outro lado, permitir a continuação por tempo indeterminado não se compadece com falência." (SZTAJN, Rachel, 'in' obra coletiva, Coord. TOLEDO, Paulo Fernando Campos Salles de, e ABRÃO, Carlos Henrique Abrão. Comentários à lei de recuperação de empresas e falência. São Paulo: Saraiva, 4. edição, 2010, p. 525).
} 
possibilidade de gerar melhor resultado na realização do ativo ${ }^{753}$. Presume-se que o melhor resultado na alienação seja uma consequência natural e direta da manutenção da atividade negocial, que é um dos meios possíveis de concretização do princípio preconizado no artigo 75 da lei concursal vigente.

A lei dispõe, expressamente, que o regime de exploração da atividade negocial deve ser provisório $^{754}$, o que parece reforçar sua natureza de medida preparatória da alienação em bloco dos ativos e, portanto, realizada diretamente no interesse da coletividade de credores ${ }^{755}$ e não diretamente do devedor ${ }^{756}$. Mesmo porque, no sistema anterior, pela letra da lei, somente o devedor estava autorizado a pleitear a continuidade dos negócios ${ }^{757}$, e no regime vigente a medida pode ser determinada de ofício pelo $\operatorname{magistrado}^{758}$.

Essa distinção entre o antigo e o atual sistema legal é interessante, na medida em que pontua a diferença de objetivos da continuidade provisória de atividade da falida: enquanto no sistema da lei revogada era meio viabilizador da concordata

\footnotetext{
${ }^{752}$ Em relação ao regime anterior, Sergio Campinho pontua que a realização da continuidade de negócios respaldava-se nos seguintes critérios: "(a) acautelamento do patrimônio comercial ou industrial de maiores prejuízos, decorrentes da paralisação da empresa; (b) não ser aconselhável a suspensão inopinada da atividade, tendo um volume de produtos e serviços a acabar; (c) viabilidade da concordata suspensiva." (CAMPINHO, Sergio. Falência e Recuperação de Empresa - o novo regime da insolvência empresarial. 5. edição, São Paulo: Renovar, 2010, p. 303).

753 "É relevante destacar que a continuação dos negócios do falido deve ser adotada com um único fim: a eficiência da liquidação falimentar." (VILAS BOAS, Daniel Rivorêdo, A continuação dos negócios da falida: critérios e condições, obra coletiva Coord. DIAS DO AMARAL, Paulo Adyr e FLORIANO NETO, Alex. Direito empresarial: teoria, práticas e estratégias. Belo Horizonte: Del Rey, 2010, p. 86)

${ }^{754}$ Portanto, discordamos do posicionamento de Daniel Rivorêdo Vilas Boas quando afirma: " $O$ ideal é que a continuação dos negócios se faça seguir de algum plano para extinção da falência, com a reabilitação do falido ou a recuperação da empresa." (VILAS BOAS, Daniel Rivorêdo, A continuação dos negócios da falida: critérios e condições, obra coletiva Coord. DIAS DO AMARAL, Paulo Adyr e FLORIANO NETO, Alex. Direito empresarial: teoria, práticas e estratégias. Belo Horizonte: Del Rey, 2010, p. 86).

${ }^{755}$ Por isso, Lorenzo Stanghellini anota que a utilidade da continuidade de negócios deve focar somente a possibilidade de venda do negócio em marcha (impedindo a destruição de riqueza), para melhor satisfação dos credores. Destaca também que, em razão dos conhecidos riscos de que a continuidade pode gerar despesas maiores do que as receitas, a continuidade somente deveria ocorrer se houvesse alguém disposto a assumir tais riscos. (STANGHELLINI, Lorenzo. Le crisi di impresa fra diritto ed economia (le procedure di insolvenza). Bologna: Il Mulino, 2007, pp. 187-188).

${ }^{756}$ Embora este tenha um benefício indireto, qual seja, o de liberação de suas obrigações, vinculada ao pagamento do maior número de credores possível, resultado este da melhor realização dos ativos.

757 Artigo 74, caput, embora, ao longo do tempo, parte da doutrina e da jurisprudência tenham temperado esse entendimento, como anotavam Nelson Abrão (A continuação do negócio na falência. São Paulo: Leud, 1975, p. 95) e Miranda Valverde (Comentários à lei de falências. 4. edição atualizada por J. A. Penalva dos Santos e Paulo Penalva Santos. Rio de Janeiro: Forense, 1999, vol. I, p. 25).

${ }^{758}$ CAMPINHO, Sergio. Falência e recuperação de empresa - o novo regime da insolvência empresarial. 5. edição, São Paulo: Renovar, 2010, p. 303; TOMAZETTE, Marlon. Curso de direito empresarial. Vol. 3, São Paulo: Atlas, 2011, p. 343.
} 
suspensiva $^{759}$, na lei vigente é método de viabilização da preservação da empresa, a fim de que seja possível promover a venda em marcha do negócio.

Atualmente, realiza-se a continuação de negócios com maior foco no interesse dos credores $^{760}$, o que justifica que o juiz possa mesmo autorizá-la de ofício, decidindo ainda pela extensão, total ou parcial do regime, em relação aos estabelecimentos da falida ${ }^{761}$.

O regime da continuação de negócios na falência, hoje, revela uma dupla função, cujos aspectos são indissociáveis, ou seja, de um lado, maximizar o valor de realização pela possibilidade de venda do negócio em marcha ${ }^{762}{ }_{-}^{763} \mathrm{e}$, de outro, reflete "medida concreta que permite a preservação da empresa"764.

A lei concursal em vigor refere de modo superficial ao regime da continuação provisória de negócios (artigos 99, incisos VI e XI, e150) sem discipliná-lo minimamente. Nesse particular, como já dito, mostrava-se superior a lei revogada ${ }^{765}$.

\footnotetext{
${ }^{759}$ E era instrumento viabilizador da concordata suspensiva, como anota Miranda Valverde (Comentários à Lei de Falências. 4a. edição atualizada por J. A. Penalva dos Santos e Paulo Penalva Santos. Rio de Janeiro: Forense, 1999, vol. I, pp. 26-27).

${ }^{760}$ TOMAZETTE, Marlon. Curso de Direito Empresarial, vol. 3, São Paulo: Atlas, 2011, p. 343.

${ }^{761}$ Enfatizando que: "Deve ainda constar da sentença que decreta a falência uma decisão sobre a continuação provisória dos negócios do falido ou sobre a lacração do estabelecimento. Embora a lei use a conjunção alternativa 'ou', levando a crer que o juiz terá que decidir necessariamente pela lacração ou pela continuação, na verdade, acreditamos que o juiz terá ampla liberdade. Ele poderá decidir pela lacração, pela continuação das atividades, pela lacração de certas unidades e pela continuação em outras ou ainda pela não continuação das atividades, sem a necessidade de lacração de qualquer unidade produtiva." (TOMAZETTE, Marlon. Curso de Direito Empresarial. Vol. 3, São Paulo: Atlas, 2011, p. 342).

${ }^{762}$ Note-se que a preservação da atividade negocial é meio de preservação de intangíveis, porque possibilita manter o valor agregado que decorre da organização patrimonial da empresa. Há importância na disciplina explicitada pelo legislador, pois, na ausência de previsão legal, corre-se o risco de incorrer na hipótese mencionada na seguinte decisão do Tribunal de Justiça de São Paulo (Falência da Casa Centro): "Continuação de Negócio da falida - Decisão que concede liminar em agravo de instrumento para fazer cessar a continuação dos negócios da falida - Ausência de lesividade - Denegação - Quanto à preservação do fundo de comércio que seria representado pelo ponto comercial, também não é causa justificadora da continuidade do negócio, uma vez que está ele afetado pela decretação da falência, fazendo com que a clientela se dispersasse e fosse arrebatada pela concorrência que é bastante forte no ramo de eletrodomésticos, de forma que, nem de longe, tem ele o valor estimado pela impetrante" (6. Câmara de Direito Privado do TJSP, Agravo Regimental n. 49.628.4/0-01, Relator Testa Marchi, j. em 8/5/1997).

763 "Trata-se, então, de se extrair melhores resultados do patrimônio destinado à liquidação, antes que a ela se dê início." (VILAS BOAS, Daniel Rivorêdo, A continuação dos negócios da falida: critérios e condições, obra coletiva Coord. DIAS DO AMARAL, Paulo Adyr e FLORIANO NETO, Alex. Direito Empresarial: Teoria, Práticas e Estratégias, Editora Del Rey, Belo Horizonte, 2010, p. 85).

${ }^{764}$ BALBINO, Márcia De Paoli, Comentários à Nova Lei de Falências e Recuperação de Empresas - Lei n. 11.101/05, de 09 de fevereiro de 2005, Coord. CORRÊA-LIMA, Osmar Brina e CORRÊA-LIMA, Sérgio Mourão, Editora Forense, Rio de Janeiro, 2009, p. 745.

${ }_{765}$ Que no artigo 74 do DL n. 7661/45 trazia a disciplina mínima correspondente.
} 
Trata-se de verdadeira incongruência do regime essa omissão do legislador, na medida em que o princípio da preservação da empresa foi eleito como corolário da falência. A fixação da regra de priorização de realização em bloco dos ativos claudica ante o silêncio a respeito dos meios necessários a manter os negócios ativos, preservando sua unidade econômica para a futura venda.

A lacuna é grave na medida em que eventual continuidade provisória de negócios não pode, em hipótese alguma, trazer agravamento da situação dos credores, de modo que a fixação de balizas legais para sua implementação, de lege ferenda, seria imprescindível ao bom termo de seu desenvolvimento.

Diante desse cenário, em que se pretende alçar a preservação da empresa como um dos objetivos da falência, a natureza jurídica da continuação provisória das atividades do falido, diretamente ligada ao êxito de uma possível venda em bloco do estabelecimento do devedor, é questão que não pode ser considerada filigrana teórica ${ }^{766}$, principalmente porque a massa falida pode ter interesses distintos (e mesmo contrapostos) aos da falida ou de determinado grupo de credores ${ }^{767}$.

Nelson Abrão discorre a respeito da natureza jurídica da continuidade de negócios ${ }^{768}$, classificando-a em duas correntes: a primeira que a qualifica como 'atividade de liquidação' e a outra que a compreende por ato de 'administração da falência'. Na primeira visão, a natureza jurídica da continuidade de negócios consiste em um modo subsidiário de liquidação, frequentemente adotado como meio preparatório desta. Já na

\footnotetext{
$766 \mathrm{O}$ interesse prático na qualificação jurídica de um determinado instituto decorre do fato de que os problemas relativos aos negócios jurídicos, sejam estes celebrados com ou sobre o instituto, "dependem quanto à forma de realização e quanto aos efeitos jurídicos - da natureza de que o mesmo se revista perante a lei." (como anotava Oscar Barreto Filho, reportando-se, no contexto, ao estabelecimento. Teoria do estabelecimento comercial. São Paulo: Max Limonad, 1969, p. 78).

${ }^{767}$ É possível tecer um paralelo, pois por esta mesma razão, Miranda Valverde criticava a tese de alguns autores que consideravam o síndico 'representante' da massa falida (objetiva e subjetiva), na medida em que "o síndico, como representante dos credores, não atua sempre no interesse de seus representados, pois que se opõe e é obrigado a opor-se a muitas de suas pretensões, e deve mesmo denunciar crimes praticados por estes e contra eles promover ações revocatórias...", acrescentando o autor, ainda, "o mesmo ocorre na pseudo-representação do falido pelo síndico, que, simultaneamente, exercida com a outra, a dos credores, forja a figura do mandatário que procura, por interesses contrários, coisa repelida pelo direito e pela moral." (Comentários à lei de falências. 4. edição atualizada por J. A. Penalva dos Santos e Paulo Penalva Santos. Rio de Janeiro: Forense, 1999, vol. I, pp. 282-283).

${ }^{768}$ A continuação do negócio na falência. São Paulo: Leud, 1975, pp. 67-93.
} 
segunda noção, há administração do patrimônio falimentar, mediante atividade de gestão, com possibilidade de celebração de novos contratos.

Para o autor, o sistema brasileiro sempre foi adepto da vertente que considera a continuidade de negócios uma 'atividade de administração', na medida em que "ela se dá em caráter substitutivo, isto é, com o afastamento obrigatório do falido ou dirigentes da sociedade falida, outra pessoa sendo designada pelo órgão judicante para assumi-la. Administração substitutiva judicial, portanto."769

Mas, com a nova lei, que supera a concepção da falência enquanto mera execução coletiva, cuja finalidade única era a satisfação dos credores, há que se analisar tais digressões sob nova perspectiva.

Hoje, a falência é método de satisfação dos credores, entretanto, norteada por uma nova principiologia, de preservação da empresa, de tal modo que estão amalgamadas uma e outra ideia: satisfação dos credores e preservação da empresa. Buscase, na lei concursal brasileira, alcançar um ponto de equilíbrio entre essas duas vertentes que se contrapõem como dois pesos de uma única balança.

Por essa razão, entendemos que a continuação provisória de negócios, no regime vigente, é simultaneamente 'atividade de liquidação' (eis que com ela não se pretende substituir o falido na atividade econômica, mas proporcionar a sua alienação em melhor proveito dos credores) e ato de 'administração da falência' (na medida em que autoriza verdadeira gestão). Como já anotava Nelson Abrão, "o fenômeno do prosseguimento da atividade negocial na falência é de ordem econômica, subordinado a uma ordem jurídica" ${ }^{\text {770 }}$, ordem jurídica essa que é a de melhor satisfação dos credores.

Enquanto na lei revogada o critério de conveniência da autorização da continuidade provisória de negócios era aferido pelo interesse dos credores e do devedor (possibilitar concordata suspensiva) ${ }^{771}$, na óptica da lei vigente, pretende-se atingir também

\footnotetext{
${ }^{769}$ ABRÃO. Nelson. A continuação do negócio na falência. São Paulo: Leud, 1975, p. 88.

${ }^{770}$ ABRÃO. Nelson. A continuação do negócio na falência. São Paulo: Leud, 1975, p. 102.

${ }^{771}$ Como ensinava Miranda Valverde: "tratando-se de medida que visa acautelar o patrimônio comercial ou industrial de maiores prejuízos, que podem facilmente ocorrer da paralisação ou interrupção da empresa ou do estabelecimento, interessando, portanto, a continuação dos negócios tanto ao falido quanto, e
} 
o objetivo de preservação da empresa (enquanto 'negócio'). Esse último objetivo será, em tese, alcançado na mesma medida em que se busca atender ao interesse dos credores (como consequência do melhor resultado da realização do ativo).

Repita-se, portanto, é preciso cautela para que, no sopesar destes interesses, não resulte agravamento do passivo com a continuação provisória das atividades. Deve-se ter em mente que o objetivo de preservação da empresa não pode vir a se constituir em assistencialismo $^{772}$.

Se a continuidade provisória vier a mostrar-se deficitária, disto não resultará benefício a ninguém (e aos credores não se pode impor esse fardo), razão pela qual, configurada tal hipótese, deve o juiz determinar a cessação imediata da medida ${ }^{773}$. O foco deve ser sempre a venda dos negócios em marcha, de modo que disto possa resultar um plus aos credores, jamais agravamento de sua situação.

A lei concursal vigente disciplina vagamente o regime da continuação provisória, incluindo-o na vala comum de pagamentos prioritários, como despesa necessária à administração da massa" ${ }^{774}$; limita-se a dizer que as "despesas" geradas na continuação de atividade devem ser "antecipadas",775.

Além disso, a lei vigente refere, no artigo 99, VI, à situação de excepcionalidade aos atos de venda de bens da falida, desde que necessários à continuação provisória de atividade. De modo a viabilizar o regime de continuidade, os bens do ativo

principalmente, aos seus credores...” (MIRANDA VALVERDE, Trajano. Comentários à lei de falências. 4. edição atualizada por J. A. Penalva dos Santos e Paulo Penalva Santos. Rio de Janeiro: Forense, 1999, vol. II, p. 25).

772 SZTAJN, Rachel, Comentários à lei de recuperação de empresas e falência, SATIRO DE SOUZA JR., Francisco e PITOMBO, Antonio Sergio A. de Moraes (coord.), São Paulo: Revista dos Tribunais, 2. edição, 2009, p. 223.

${ }^{773}$ Rachel Sztajn alerta que é preciso verificar a relação custo/benefício da continuação da atividade, e "se o resultado por positivo, é melhor autorizar; (...) e se negativo, melhor vetá-la" (Comentários à lei de recuperação de empresas e falência. São Paulo: Saraiva, obra coletiva coord. TOLEDO, Paulo Fernando Campos Salles de.; ABRÃO, Carlos Henrique, 4. edição, 2010, p. 526).

${ }_{775}^{774}$ Artigo 150 da Lei n. 11.101/05.

${ }^{775}$ Em relação ao pagamento dos credores sujeitos ao concurso, como anota SATIRO de SOUZA JR., Francisco. Comentários à lei de recuperação de empresas e falências, SATIRO DE SOUZA JR., Francisco e PITOMBO, Antonio Sergio A. de Moraes (Coord.), p. 509. 
circulante (relacionados estritamente à atividade negocial em desenvolvimento) poderão ser negociados (comprados e vendidos), independentemente de autorização judicial ${ }^{776}$.

Pode-se tecer um paralelo entre esse dispositivo e aquele outro que regula os atos de alienação (ou oneração), na recuperação judicial, quando do afastamento do devedor, em que o comitê deve submetê-los à apreciação judicial. Nesta hipótese, a restrição engloba os "atos de endividamento necessários à continuação da atividade empresarial durante o período que antecede a aprovação do plano" ${ }^{777}$, para os quais a lei exige autorização judicial. A restrição parece incluir a aquisição de bens do ativo circulante, necessários à atividade em andamento.

É curioso que no regime de continuação provisória de negócios previsto na falência são admitidos atos de alienação que compreendam a gestão ordinária, enquanto na recuperação judicial, tendo sido afastado o devedor, a restrição parece ser maior. Não vislumbrei justificativa para essa distinção de tratamento, mesmo porque ambas as hipóteses são de gestão de patrimônio alheio, por terceiros, susceptíveis de gerar responsabilidade por danos causados por culpa ou dolo.

De qualquer modo, o tema está diretamente ligado ao receio de gestão do patrimônio capaz de gerar passivo ou resultado deficitário. No momento, interessa só a análise da repercussão desta circunstância na falência.

3.1.5.2 - Os créditos constituídos no período da continuidade de negócios.

Inicialmente, é preciso esclarecer que aqui se tratará especificamente dos créditos constituídos depois da decretação da quebra. Com efeito, obrigações por créditos antes da quebra e depois desta não se confundem e já era assim no sistema revogado, tanto que Rubens Requião já as distinguia, com sua costumeira clareza: os credores da massa falida (por obrigações surgidas no interesse do processo falimentar) e os credores da falência (sujeitos ao processo concursal) ${ }^{778}$.

\footnotetext{
${ }^{776}$ Como refere Carlos Henrique Abrão (ABRÃO, Carlos Henrique 'in' Comentários à lei de recuperação de empresas e falência. São Paulo: Saraiva, obra coletiva coord. por TOLEDO, Paulo Fernando Campos Salles de.; ABRÃO, Carlos Henrique Abrão. 4. edição, 2010, p. 368).

${ }^{777}$ Artigo 27, II, alínea 'c', da Lei n. 11.101/05.

${ }^{778}$ Curso de direito falimentar. 16. edição, São Paulo: Saraiva, 1995, vol. I, p. 325.
} 
A distinção de tratamento entre os créditos com fato gerador antes e depois da quebra é feita pela própria lei, tanto que ao comentar o artigo 83, Francisco Satiro ensina que "a classificação deste artigo refere-se somente aos chamados 'créditos concursais' ou 'falenciais' (credores do falido - Insolvengläubiger), ou seja, àqueles créditos originários de atos ou fatos ocorridos durante o período de exercício da atividade empresarial do falido, cujo pagamento estará necessariamente sujeito a concurso". 779

E prossegue o professor: "Diferem-se, assim dos créditos "extraconcursais"; que incluem aqueles decorrentes de fatos geradores ocorridos após a quebra (credores da massa - Massegläubiger), bem como aqueles não sujeitos ao concurso, como as restituições em dinheiro (art. 86), os créditos compensáveis (art. 122), os créditos estabelecidos no âmbito de câmaras ou prestadores de serviços de compensação e liquidação (arts. 193 e 194) ${ }^{780 ", ~}$

Note-se, portanto, que os pagamentos a serem realizados na falência, no sistema brasileiro em vigor, comportam classificação por duas classes distintas, pelo critério da ordem de pagamento: (i) credores sujeitos ao rateio do concurso (por créditos constituídos antes da quebra); e os (ii) extraconcursais ${ }^{781}$. Nesta última categoria, como assinalado pelo mencionado professor, estão incluídos tanto os "encargos da massa" (Massenkosten), ou seja, aquelas despesas necessárias para a efetivação do procedimento concursal, quanto os credores por "dívidas da massa" (Massenshulden), decorrentes de obrigações assumidas pela massa falida no curso da falência.

Já era esse o entendimento de Rubens Requião na vigência da lei revogada, para quem "Os créditos tributários resultantes das atividades economônicas da massa falida, decorrentes da continuação do negócio do falido - tais como tributos sobre imóveis, o IPI, o ICM o Imposto de Renda - são efetivamente encargos tributários da

\footnotetext{
${ }^{779}$ SATIRO DE SOUZA JR.; Francisco; PITOMBO; Antonio Sérgio A. de Moraes (coord). Comentários à lei de recuperação de empresas e falência. São Paulo: Revista dos Tribunais, 2. edição, 2007, p. 360.

${ }^{780}$ SATIRO DE SOUZA JR., Francisco; PITOMBO, Antonio Sérgio A. de Moraes (coord). Comentários à lei de recuperação de empresas e falência. São Paulo: Revista dos Tribunais, 2. edição, 2007, p. 360.

${ }^{781}$ Ou seja, aqueles que "o administrador judicial deve atender antes do pagamento dos credores do falido." (COELHO, Fábio Ulhoa. Comentários à nova Lei de Falências e de Recuperação de Empresas. São Paulo: Saraiva, 8. edição, 2011, p. 324).
} 
massa falida. (...) A massa falida, nesse caso, é a contribuinte, e não pagamento ou o seu atraso importa na obrigação de pagar as multas moratórias."

Assim, as obrigações assumidas em decorrência de novos contratos ou mesmo pela manutenção de vínculos contratuais precedentes ${ }^{783}$ constituem créditos extraconcursais, conforme disposição do artigo 84, V da lei em vigor, e o seu pagamento é feito com precedência aos credores concursais. Dentre estes, há os pagamentos denominados 'despesas' (art. 150), que podem ser realizados “com recursos disponíveis no caixa" e incluem verbas "indispensáveis à administração da falência, inclusive na hipótese de continuação provisória das atividades".

A opção do legislador foi instituir, dentre os credores extraconcursais, uma ordem de prioridade de pagamento, fixando um concurso próprio entre estes ${ }^{784}$, dentro das categorias especificadas e taxativamente relacionadas nos incisos I até $\mathrm{V}$ do artigo $84^{785}$.

Desse modo, os créditos “decorrentes de atos jurídicos válidos praticados pelo administrador judicial após a decretação da falência, desde que não incluídos em alguma das classes relativas aos incisos I a IV do art. 84" precedem o pagamento dos concursais. E a "aplicação desse dispositivo é semelhante à dos créditos quirografários, definidos por exclusão: todo crédito validamente constituído após a decretação da falência será extraconcursal nos termos do art. 84, V, se a ele não se aplicar uma melhor classificação" $^{, 786}$.

\footnotetext{
${ }^{782}$ Curso de direito falimentar, 16. edição, São Paulo: Saraiva, 1995, vol. I, p. 327.

${ }^{783}$ Ou seja, continuidade de relações contratuais, conforme previsto nos artigos 117 a 120 da Lei n. $11.101 / 05$.

784 "Note-se que a expressão escolhida pela lei para identificar essa categoria de beneficiários ("extraconcursais") não é por tudo apropriada porque pode eventualmente haver concurso entre alguns desses créditos". (COELHO, Fábio Ulhoa. Comentários à nova lei de falências e de recuperação de empresas. São Paulo: Saraiva, 8. edição, 2011, p. 324).

${ }^{785}$ SATIRO, Francisco. Comentários à Lei de Recuperação de Empresas e Falência, Obra coletiva coord.por Francisco Satiro de Souza Jr. e Antonio Sérgio A. de Moraes Pitombo, Editora Revista dos Tribunais, 2a edição, 2007, p.371.

${ }^{786}$ SATIRO, Francisco. Comentários à lei de recuperação de empresas e falência. Obra coletiva coord. por Francisco Satiro de Souza Jr. e Antonio Sérgio A. de Moraes Pitombo. São Paulo: Revista dos Tribunais, 2. edição, 2007, p. 376.
} 
Todavia, essa regra é excepcionada quando se tratarem de "despesas" indispensáveis à administração da massa, dentre as quais o legislador incluiu expressamente as que sejam decorrentes da continuação provisória das atividades ${ }^{787}$.

A lei autoriza o seu pagamento antecipado, afastando-se da regra da par condicio creditorum. Nesse sentido, e após citar alguns exemplos de cabimento da hipótese ${ }^{788}{ }^{789}$, Francisco Satiro conclui que há "interesse em permitir-se que possam ser pagas imediatamente despesas consideradas necessárias à administração da falência, se de outra forma não for possível ou conveniente o pagamento. Daí porque, não obstante o texto do artigo qualificar como 'indispensável' o 'pagamento antecipado', não a despesa, por tratar-se de exceção ao princípio da 'par conditio creditorum', somente em casos de gastos justificadamente necessários pode-se admitir o uso da prerrogativa desta norma."

A ruptura com o princípio da paridade de credores revela, por primeiro, o acolhimento de uma atividade negocial separada daquela precedente que era exercida pelo devedor, e agora sob a 'gestão' da massa falida (impondo-se, destarte, distinção no cumprimento de uma e outra obrigação, forçosamente separando a que resulta desta última do concurso dos credores); e, segundo, evidencia a exigência de uma organização contábil e patrimonial separada e, principalmente, excluída do concurso falimentar.

Essa não é uma tarefa simples, pois bens que integram a massa poderão ser consumidos (insumos) para sustentar a atividade da continuação provisória de negócios.

Assim, os gastos dirigidos a manter a atividade negocial da massa devem fixar objetivo na possibilidade de tornar efetiva a alienação dos bens em bloco. Além disso,

787 É como entende Fábio Ulhoa Coelho ao comentar o artigo 150 da lei. (Comentários à nova lei de falências e de recuperação de empresas. São Paulo: Saraiva, 8. edição, 2011, p. 502).

${ }_{788}$ Francisco Satiro define-a como a "assunção de um débito como contrapartida de certa utilidade imediata para a massa." E adiante, após citar exemplos de cabimento da hipótese, conclui: "Há, portanto, interesse em permitir-se que possam ser pagas imediatamente despesas consideradas necessárias à administração da falência, se de outra forma não for possível ou conveniente o pagamento. Daí porque, não obstante o texto do artigo qualificar como 'indispensável' o 'pagamento antecipado', não a despesa, por tratar-se de exceção ao princípio da 'par conditio creditorum', somente em casos de gastos justificadamente necessários pode-se admitir o uso da prerrogativa desta norma." (Comentários à lei de recuperação de empresas e falência. Obra coletiva organizada por SATIRO DE SOUZA JR., Francisco; PIMTOMBO, Antonio Sérgio A. de Moraes, São Paulo: Revista dos Tribunais, 2. edição, 2007, p. 508).

${ }^{789}$ Ricardo Negrão parece ter uma visão mais liberal, assinalando que "uma vez determinada a continuação provisória, o administrador judicial fica autorizado a realizar pagamentos que forem indispensáveis a sua consecução, com recursos disponíveis em caixa (LF, art. 150)”. (NEGRÃO, Ricardo. Aspectos objetivos da lei de recuperação de empresas e de falências. 5. edição, São Paulo: Saraiva, 2010, p. 113). 
o resultado da atividade provisória deve ser, necessariamente, superavitário, caso contrário torna-se inadmissível submeter os credores do concurso ao risco de uma provável realização a maior preço que justifique a antecipação de recursos ${ }^{790}$.

A ideia, como acentua Rachel Sztajn, é que "do ponto de vista econômicofinanceiro, a norma reconhece que a necessidade imediata tem preço e que o ganho futuro justifica dispêndio atual, ${ }^{, 791}$.

Nessa situação, a dificuldade que se entrevê ocorrerá quando houver conflito de interesses entre os próprios credores. Haverá credores dispostos a sacrificar um interesse imediato para um ganho futuro e outros não ${ }^{792}$.

Daí a demanda imperiosa de uma sistematização, de lege ferenda, que pudesse regular essa dificuldade e dar ao aplicador do direito as balizas necessárias para a solução destes conflitos. A ausência de disciplina é grave, na medida em que pode dar espaço a medidas e decisões assistencialistas, sem considerar que alguém terá de 'pagar a conta'.

Diante da atual sistemática do regime da continuação provisória dos negócios, e que caracteriza verdadeira atividade econômica exercida pela falida, não é possível admitir que a massa falida venha a responder pelas obrigações decorrentes daquela, que devem ser afetadas a uma finalidade específica, e por esta razão dela separada, como acima se sustentou, embora tal posicionamento não seja pacífico ${ }^{793}$.

Dentre os créditos extraconcursais, os tributários foram classificados juntamente com o fato gerador que lhes corresponde ${ }^{794}$, eis que seu pagamento está

\footnotetext{
${ }^{790}$ Como anota Sérgio Mourão Corrêa Lima (Comentários à Nova Lei de Falências e Recuperação de Empresas - Lei n. 11.101/05, de 09 de fevereiro de 2005, Coord. CORRÊA-LIMA, Osmar Brina e CORRÊA-LIMA, Sérgio Mourão. Rio de Janeiro: Forense, 2009, pp. 1014-1015).

${ }^{791}$ Comentários à lei de recuperação de empresas e falência, São Paulo: Saraiva, obra coletiva coord. TOLEDO, Paulo Fernando Campos Salles de.; ABRÃO, Carlos Henrique, 4. edição, 2010, p. 526.

${ }^{792}$ À guisa de exemplo, um credor com crédito decorrente de alienação fiduciária sobre determinado ativo essencial à produção não terá interesse algum em deixar com que o bem permaneça à disposição da falida, exceto se as prestações contratuais estiverem sendo cumpridas.

${ }^{793}$ PROVINCIALI entende que a massa deve responder pelo fracasso do exercício provisório (Il Diritto Fallimentare e delle Società Commerciali, nov-dez, 1972, p. 405).

${ }^{794}$ HARADA, Kiyoshi. Aspectos tributários da nova lei de falências - comentarios à LC 118, de 09/02/2005, $2^{\mathrm{a}}$ tiragem, Curitiba: Juruá, 2006.
} 
previsto no inciso $\mathrm{V}$ do artigo 84 , de modo que há outros créditos precedentes a serem satisfeitos.

A disciplina em análise, portanto, reforça a ideia de que há atividade econômica na falência e que esta se desenvolve com interesses próprios (em relação aos do devedor e às obrigações que integram o concurso). Isso se dá porque o seu objetivo principal é proporcionar a possibilidade de venda do estabelecimento ativo (ou seja, do negócio em marcha) e, por esse meio, atingir os dois propósitos do concurso, ou seja, a satisfação dos credores e a preservação da empresa.

Não é possível perder de vista que uma das finalidades essenciais da continuação provisória das atividades é propiciar a melhor realização dos ativos e, como tal, os créditos nela gerados devem sempre trazer resultados positivos, visando a alienação em bloco dos bens.

A ideia por trás desse postulado é a de que seria possível, juntamente com o atendimento dos interesses dos credores, manter vivo o negócio naquilo que seja rentável, sob uma nova gestão e, por consequência, preservar a utilização produtiva dos bens (mantendo a possibilidade de relações contratuais, vínculos de empregos, bens e serviços oferecidos ao mercado), atendendo aos demais interesses que gravitam em torno da empresa, mesmo na falência.

Há outros meios pelos quais o legislador tentou viabilizar este postulado de preservação da utilização produtiva dos bens. Passemos a uma análise desses mecanismos.

3.2 A realização do ativo.

O princípio da preservação da empresa concretiza-se, na falência, nos atos de alienação do ativo: "é pela disciplina que se estatuiu para a realização do ativo que se irá procurar atingir essa finalidade", como anota Paulo Fernando Campos Salles de Toledo $^{795}{ }_{-} 796$.

795 "A preservação da empresa, mesmo na falência", em obra coletiva coord. por Newton de Lucca e Alessandra de Azevedo Domingues. Direito recuperacional aspectos teóricos e práticos. São Paulo: Quartier Latin, 2009, p. 528. 
Porém, esta não é a única finalidade a ser perseguida na falência, pois, como lembra Manoel Justino, "realizar o ativo é dar início à venda dos bens para propiciar o pagamento aos credores." ${ }^{\text {797 }}$, de tal forma que o procedimento falimentar, inegavelmente, é meio de satisfação dos credores.

Este pensamento está em harmonia com a lição de Trajano de Miranda Valverde, para quem a realização do ativo "consiste, normalmente, na conversão em dinheiro dos bens arrecadados para pagamento do passivo"798.

Para atingir esse desiderato, "entre os objetivos do processo falimentar, encontra-se a definição do ativo e do passivo da falida" ${ }^{\text {,799 }}$; portanto, é preciso formar uma fotografia exata da situação patrimonial do devedor, de um lado, relacionando todos os bens susceptíveis de arrecadação e, de outro, promovendo a verificação de créditos para formar o quadro geral de credores.

Adicione-se, o maior ou menor êxito no pagamento dos credores está diretamente relacionado aos resultados que poderão ser alcançados com a alienação, o que só faz reforçar a importância desta fase da falência ${ }^{800}{ }^{801}$. Daí porque a deliberação sobre a forma de realização, que no diploma anterior também cabia aos credores, foi mantida na lei em vigor, já que, em última análise, é no interesse destes que se faz a conversão dos bens em dinheiro ${ }^{802}$.

\footnotetext{
${ }^{796}$ No mesmo sentido, em relação ao direito concursal espanhol. (HUALDE LÓPEZ, Ibon. Régimen Jurídico de la administración concursal en la fase de liquidación del concurso. Estudios de derecho concursal, Espanha: Thomson Civitas, 1. edición, 2009, p. 69).

${ }^{797}$ Lei de recuperação e falências comentada. São Paulo: Revista dos Tribunais, 7. edição, 2011, p. 299.

798 VALVERDE, Trajano de Miranda. Comentários à lei de falências. 4. edição atualizada por J. A. Penalva dos Santos e Paulo Penalva Santos. Rio de Janeiro: Forense, 1999, vol. II, p. 166.

${ }^{799}$ COELHO, Fábio Ulhoa. Comentários à nova lei de falências e de recuperação de empresas. São Paulo: Saraiva, 8. edição, 2011, pp. 478.

${ }^{800}$ BERNANDI, Ricardo. Comentários à lei de recuperação de empresas e falência, obra coletiva organizada por SOUZA JR., Francisco Satiro de e PITOMBO, Antonio Sérgio A. de Moraes. São Paulo: Revista dos Tribunais, 2. edição, 2007, p. 484.

${ }^{801}$ BERNANDI, Ricardo. Comentários à lei de recuperação de empresas e falência, obra coletiva organizada por SOUZA JR., Francisco Satiro de.; PITOMBO, Antonio Sérgio A. de Moraes. São Paulo: Revista dos Tribunais, 2. edição, 2007, p. 487.

${ }^{802}$ Como anota PEIXOTO, Euler da Cunha, 'in' Comentários à nova lei de falências e recuperação de empresas - Lei n. 11.101/05, de 09 de fevereiro de 2005, Coord. CORRÊA-LIMA, Osmar Brina; CORRÊALIMA, Sérgio Mourão. Rio de Janeiro: Forense, 2009, p. 965.
} 
Nesta fase do procedimento, talvez mais do que em outras, a disciplina da coordenação legal dos atos entre os credores mostra que a falência não tem apenas o intuito de impedir que somente alguns realizem seus créditos (em respeito ao princípio da par condicio creditorum).

O procedimento falimentar destina-se a obstar que o negócio seja desmantelado (pela ação individualizada de credores) nas hipóteses em que se verifique que os bens têm maior valor se mantidos juntos e organizados do que se fossem liquidados em separado ${ }^{803}$.

Desse modo, não se pode deixar de levar em consideração que deverá ser levada em consideração a nova finalidade da falência propalada pelo artigo 75 da lei, que é de manutenção e utilização produtiva dos ativos da devedora.

Assim, "se entende actualmente la conservación de la empresa como una solución de fondo: no como un médio de lograr una mejor liquidación de la empresa, sino como una de las miras del derecho concursal moderno, como solución de la crisis económica y de preservación de la empresa en dificultades, apartándola incluso de la figura y de la suerte del empresário. Ya no se trata de liquidar para repartir, sino de conservar para salvar." 804

Nesse ponto, questiona-se se, de algum modo, seria possível identificar conflito entre a venda dos bens organizados (e a preservação do negócio que daí decorre) e o interesse dos credores (de maximização do preço de venda dos ativos). Entendo que raramente isso poderia ocorrer ${ }^{805}$, mas na hipótese de conflito, caberá ao juiz decidir caso a caso, sopesando os interesses em jogo e verificando qual é a tutela que merece proteção hierárquica mais relevante, inclusive, valendo-se da Constituição (por exemplo, invocando o princípio da dignidade humana, se a questão envolver relações trabalhistas, e assim por diante).

\footnotetext{
${ }^{803}$ ARMOUR, John; HERTIG, Gerard; KANDA, Hideki, in KRAAKMAN, Reinier (ob. coletiva). The Anatomy of Corporate Law: a comparative and functional approach. 2. edition New York: Oxford, 2009, p. 121.

${ }^{804}$ GARCÍA MARTÍNEZ, Roberto. Derecho concursal. Buenos Aires: Abeledo-Perrot, 1997, p. 36.

${ }^{805}$ Conforme tema abordado mais adiante, no subitem 3.2.4, que trata das 'modalidades de alienação dos ativos'.
} 
Isto porque, a regra é a de que a realização dos ativos, com adição do valor agregado que resulta de sua organização, redunde em movimento de maximização do preço (nunca de sua redução), no interesse dos credores. Além disso, há um benefício indireto para certa categoria de credores - que mantinha vínculo econômico com o devedor -, na medida em que a preservação do negócio poderá manter vivo esse elo da cadeia produtiva.

$\mathrm{Na}$ falência, não se pretende que a preservação da empresa seja um postulado a ser atingido a qualquer custo ${ }^{806}{ }_{-}^{807}$, uma vez que a realização dos ativos tem por fim o pagamento dos credores. Essa é uma realidade inegável e sempre presente na liquidação que decorre da quebra. Presume-se que a venda dos ativos em bloco lhes será favorável.

A maximização do valor dos ativos, na falência, é um objetivo que deverá ser perseguido sempre, e a tanto se destina a alienação em bloco (com consequente preservação do negócio) que favorece o alcance do primeiro desiderato.

O momento e a forma de realização do ativo na lei atual ${ }^{808}$ são fundamentais ao bom termo e êxito do processo falimentar, sendo lícito afirmar que constituem espinha dorsal da reforma, sem o que não seria possível entender a falência como meio apto e compatível com a preservação da empresa.

Convém, pois, analisar o momento e as formas de realização do ativo, para possibilitar esse novo traço do instituto - de preservação -, agora prestigiado como propósito possível na falência.

\footnotetext{
806 "O princípio da preservação da empresa deve aplicado em harmonia com o postulado que determina a retirada do mercado das empresas que se mostrarem economicamente inviáveis de recuperação. Inteligência do art. 47 da Lei n. 11.101/05. Agravo desprovido, para manter a convolação da concordata preventiva em falência." (AI n. 512.560 4/8-00, relator Des. Pereira Calças, Câmara Especial de Falências e Recuperações Judiciais, TJSP, j. 19/12/2007).

807 "O princípio da preservação da empresa, pedra angular da Lei $n$. 11.101/05, que decorre do princípio constitucional da função social da propriedade e dos meios de produção, denominado pela doutrina de "função social da empresa", não pode ser invocado para justificar de forma ampla, abstrata e ilimitada, a manutenção da empresa que, em recuperação judicial, ostensivamente, não cumpre as obrigações assumidas no plano de recuperação. Verificado o inadimplemento das obrigações pactuadas no plano de recuperação que se venceram no biênio da supervisão judicial, o juiz, de ofício, deverá convolar a recuperação judicial em falência." (AI n. 601.295.4/1-00, relator Des. Pereira Calças, Câmara Especial de Falências e Recuperações Judiciais, TJSP, j. 05/05/2009).

${ }^{808}$ Confira-se considerações a respeito do tema no REsp n. 746.754-SC, STJ, Rel. Min. Carlos Alberto Menezes Direito, j. 25/10/2005.
} 


\subsubsection{Venda antecipada de bens.}

A hipótese em análise não trata da alienação sumária que decorre das circunstâncias especiais (bens perecíveis, deterioráveis ou sujeitos à desvalorização ou de difícil conservação) previstas no artigo 113 da lei concursal brasileira ${ }^{809}$. Semelhante disposição já era encontrada no artigo 74 do DL n. 7.661/45, de modo que, neste aspecto, não há novidade digna de nota no sistema concursal.

A disciplina de que ora se trata diz respeito à realização imediata dos ativos como resultado da decretação da falência, prevista no artigo 139 da Lei n. $11.101 / 05^{810}$, ou seja, logo após o ato de arrecadação e depois de terem sido avaliados.

É evidente que a leitura do dispositivo não pode ser feita pela literalidade das palavras utilizadas pelo legislador. O que se pretendeu foi distanciar a disciplina atual da previsão legal anterior, em que a venda dos ativos somente tinha início depois da formação do quadro geral de credores.

A inovação da lei em vigor é importantíssima, na medida em que a venda dos bens não mais depende da prévia elaboração do quadro geral de credores, providência que, por vezes, levava anos a fio para ser concluída e resultava no sucateamento dos bens arrecadados, com desvalorização e até mesmo inutilidade pelo decurso do tempo.

Pela atual opção legislativa, não há possibilidade de migração da falência para a recuperação judicial, ao contrário do que previa a lei revogada, que admitia a

\footnotetext{
${ }^{809}$ A propósito, Euler da Cunha Peixoto taxa de 'esdrúxulo' o dispositivo do artigo 113 da Lei n. 11.101/05, por entender que a hipótese ali prevista não difere daquela referida no art. 139. Com efeito, não se concorda com a crítica, na medida em que pode haver bens que não possam aguardar a avaliação de todos os demais bens arrecadados, inclusive com valoração a respeito da conveniência da venda em bloco de alguns deles, justificando-se a previsão de venda sumária contida na lei atual, segundo se pensa. (PEIXOTO, Euler da Cunha. 'in' Comentários à nova lei de falências e recuperação de empresas - Lei n. 11.101/05, de 09 de fevereiro de 2005, Coord. CORRÊA-LIMA, Osmar Brina; CORRÊA-LIMA, Sérgio Mourão. Rio de Janeiro: Forense, 2009, p. 964).

${ }^{810} \mathrm{Em}$ decisão proferida pelo STJ, entendeu-se que a venda antecipada somente é aplicável ao procedimento falimentar iniciado na vigência da lei atual. O fundamento do acórdão está calcado na possibilidade de pedido de concordata suspensiva pela devedora, de modo que a venda de todos os bens sob a previsão do artigo 73 do DL n. 7.661/45 não seria possível. (REsp. 746.754-SC, rel. Ministro Carlos Alberto Menezes Direito, j. 25/10/2005, www.st.jus.br). Mas parece que a decisão não atentou para a impossibilidade desta, conforme $\S 1^{\circ}$ do artigo 192, que disciplina as disposições transitórias.
} 
concordata suspensiva dos efeitos da quebra ${ }^{811}$. Nesse ponto, portanto, a legislação brasileira supera as soluções do direito argentino e italiano, que admitem a reversibilidade.

Certamente, a possibilidade de conversão da falência em concordata suspensiva, como previa o diploma revogado brasileiro, impedia a alienação de bens antes do momento processual em que poderia ocorrer o pedido do favor legal, sob pena de, caso o patrimônio houvesse sido desfalcado, tornar impossível a continuação da atividade pelo devedor.

De acordo com a opção atual do legislador brasileiro que manteve na lei vigente o sistema de duplo procedimento - um destinado à liquidação e outro à reorganização das empresas em crise -, tornou-se necessário impossibilitar a migração da quebra para a recuperação. Fora dessa solução, não seria possível adotar a venda antecipada dos ativos, mecanismo fundamental para viabilizar a preservação da organização de bens na falência.

Nesse ponto, parece importante anotar que a irreversibilidade do decreto da quebra $^{812}$, no sistema procedimental dualista como o nosso, faz com que tal decisão reflita o peso de sua responsabilidade, o que, em tese, atua como um dosador de cautela do julgador na sua aplicação, levando-se a possível desvio, por exacerbação, do princípio da preservação da empresa.

Uma vez decretada a quebra, a Lei n. 11.101/05 fixou novo olhar para regulamentar o momento da venda dos ativos: sua realização deve ocorrer tão brevemente quanto possível após a decretação da quebra. A celeridade que daí se pretende atingir tem por fim que não se percam, pela obsolescência, os ativos, possibilitando sua utilização, com proveito, por uma nova organização.

O tratamento que a atual lei concursal dispensa aos bens que integram a massa é muito diferente do da anterior, pois cria uma sistemática de proteção da organização dos bens, ao possibilitar que continuem a ter utilidade produtiva, ao ponto de que haja continuidade da atividade econômica, sob nova gestão.

\footnotetext{
${ }^{811}$ Artigo 114 do DL n. 7.661/45.

${ }^{812}$ Uma vez apreciado o recurso cabível.
} 
Não há dúvida que o mecanismo de venda imediata dos bens arrecadados constitui método essencial de aplicação do princípio de preservação da empresa na falência, conforme previsto no artigo 75 da Lei n. 11.101/05.

$\mathrm{Na}$ vigência da lei anterior, a experiência mostrou que a venda tardia dos bens resultava em irremediável obsolescência. Essa situação afetava os bens negativamente e era incompatível com os interesses dos credores (já que nada ou quase nada se apurava com sua venda) e as necessidades da moderna economia (eis que tais bens, em regra, não tinham serventia alguma nem podiam ser aproveitados por outro agente econômico).

O retardamento da alienação dos ativos no antigo sistema, para aguardar a elaboração do quadro de credores e a possibilidade de pedido de concordata suspensiva, resultou em verdadeiro "desastre" 813 para o interesse dos credores, como pontua Fabio Ulhoa Coelho.

Por isso mesmo é que Rachel Sztajn anota que o questionamento a ser feito quanto à regra do artigo 139 da lei concursal brasileira será "observar se a norma tende à eficiência na liquidação, se cria os estímulos adequados para que as pessoas mantenham a congruência entre ativo e passivo patrimonial, se há estímulo a oportunismos ou outros comportamentos indesejáveis. "814

A regra da venda antecipada, ao impedir a obsolescência dos ativos, resulta em duplo benefício a ser colhido no processo falimentar: ao mesmo tempo em que proporciona a venda dos bens em valor compatível com o de mercado, resultando em inegável benefício aos credores pelo melhor resultado, também enseja sua recolocação imediata, permitindo sua utilização eficiente por outro agente econômico.

Note-se, a alienação antecipada não opõe óbice, de forma alguma, a eventual adoção de regime de continuidade provisória dos negócios do falido, na medida

${ }^{813}$ COELHO, Fábio Ulhoa. Comentários à nova lei de falências e de recuperação de empresas. São Paulo: Saraiva, 8. edição, 2011, pp. 477/479.

${ }^{814}$ Comentários à lei de recuperação de empresas e falência, São Paulo: Saraiva, obra coletiva coord. TOLEDO, Paulo Fernando Campos Salles de.; ABRÃO, Carlos Henrique. 4. edição, 2010, p. 493. 
em que, sendo aquela situação de excepcionalidade, deve mesmo ser transitória, de duração passageira e destinada a proporcionar a venda dos bens em bloco.

Outro benefício que resulta da venda antecipada dos ativos é a desnecessidade de ônus com sua guarda e conservação e que caberia à massa suportar, como lembra Ricardo Bernardi ${ }^{815}$. Trata-se, portanto, de mais um benefício indireto aos credores, na medida em que sendo a massa menos oneradas, aumentam as possibilidades de pagamentos a estes.

A venda antecipada dos ativos permite, em tese ao menos, que os efeitos da sentença de quebra não sejam exteriorizados de maneira negativa, (sobretudo se houver continuação dos negócios), colaborando-se, pois, na preservação da clientela e dos ativos intangíveis da devedora, como eventual prestígio de que goze a marca, por exemplo. Em relação a esses aspectos que se exteriorizam rapidamente na situação de crise das empresas, a agilidade na resposta do sistema é fundamental, ainda mesmo na falência.

Aliás, um dos grandes desafios da lei concursal brasileira, segundo penso, será superar o estigma ruinoso que a falência traz consigo, conduzindo-se a uma nova ideia - preconizada pelo sistema atual - de que a quebra representa simples afastamento do devedor. Incutir esse novo ideal será tarefa árdua. Mas a verdade é que na falência, muito mais do que no instituto da recuperação, é que o princípio da separação entre a empresa e o empresário verifica-se com maior evidência e se traduz como efetiva realidade.

O dispositivo de venda antecipada, ainda, está em perfeita harmonia com a profissionalização da figura do administrador judicial, pois a concretização da norma, na prática, dependerá, em boa parte, das "qualidades e aptidões" deste na definição da forma e realização do ativo ${ }^{816}$.

O início imediato da realização dos ativos consiste em uma das mais relevantes conquistas e reflete progresso, da lei atual, no seio da falência.

\footnotetext{
${ }^{815}$ Comentários à lei de recuperação de empresas e falência, obra coletiva coord. por SATIRO DE SOUZA JR., Francisco; PITOMBO, Antonio Sérgio A. de Moraes. São Paulo: Revista dos Tribunais, 2. edição, 2007, p. 485.

${ }^{816}$ Como pontua Luiz Augusto de Souza Queiroz Ferraz, "Da arrecadação, avaliação e realização do ativo". Revista do advogado - AASP, ano XXV, n. 83, pp. 66-72, set. 2005, p. 70.
} 
Diz a lei que a alienação é "imediata", mas daí não deve advir crítica alguma: o que se desejou foi acentuar, dar destaque ao fato de que os atos de realização dos ativos serão implementados a breve termo. Naturalmente, a venda dos bens somente terá lugar depois da arrecadação e avaliação. O iter processual, para tanto, desvinculado da formação do quadro geral de credores, será expressivamente menor, com imenso benefício aos credores.

Além disso, é evidente que o legislador não pretendeu que a realização dos ativos seja feita sem qualquer critério e às pressas, pois a celeridade não é o único princípio a ser respeitado.

É possível que o administrador judicial - a quem incumbe os atos de arrecadação e realização dos ativos - precise de algum tempo a mais para elaborar um cronograma de alienação, respeitando-se a ordem de preferência recomendada pelo artigo 140 da Lei n. 11.101/05.

Por outro lado, também é razoável que os próprios credores necessitem mais prazo para melhor avaliar quanto a conveniência de adoção de outras modalidades de realização do ativo (artigo 145 da Lei n. 11.101/05) ${ }^{817}$, o que será abordado mais adiante.

Então, a venda dos ativos logo após a arrecadação significa que a celeridade que se espera deste ato seja compatível com o cumprimento do ideal de preservação da organização de bens, evitando-se, sempre que possível, a desagregação desnecessária dos ativos e a perda de sua unidade econômica.

A previsão de alienação antecipada dos ativos é mecanismo destinado a atender ao binômio que atualmente caracteriza o equilíbrio a ser buscado na falência, ou seja, a satisfação dos credores e a preservação do negócio, quando possível. Vejamos, agora, outros desdobramentos desse mesmo objetivo.

${ }^{817}$ PEIXOTO, Euler da Cunha. 'In': Comentários à nova lei de falências e recuperação de empresas - Lei n. 11.101/05, de 09 de fevereiro de 2005, coord. CORRÊA-LIMA, Osmar Brina; CORRÊA-LIMA, Sérgio Mourão. Rio de Janeiro: Forense, 2009, p. 965. 
3.2.2 A ordem de preferência na alienação dos ativos.

O caput do artigo 140 da Lei n. 11.101/05 destaca a forma em que preferencialmente deverão ser alienados os ativos da falida, estabelecendo um critério que prestigia a manutenção da atividade econômica, ante a previsão de venda dos bens $\operatorname{organizados}^{818}$.

A alienação poderá dar-se da empresa ou de estabelecimentos, hipóteses essas a que se outorga preferência, conforme incisos I e II do mencionado dispositivo legal. A venda dos bens poderá, ainda, ser feita mediante organização de certos ativos em particular, que, por exemplo, possibilitem uma determinada linha de produção, conforme inciso III, do artigo 140 da Lei n. 11.101/05, e finalmente, dos bens individualmente considerados.

O dispositivo do artigo 140 da Lei n. 11.101/05 é um dos pilares do princípio da preservação da empresa na falência do direito brasileiro.

A previsão legal de venda dos ativos em bloco não é inteiramente nova, já que o artigo 116 do DL n. 7.661/45 tratava do tema, ainda que de forma significativamente incipiente, agora aperfeiçoada na lei vigente.

A propósito daquele dispositivo, Miranda Valverde dizia que "A escolha pela venda dos bens englobada ou separadamente dependerá da natureza dos bens, da ligação ou conexão que entre eles existir ou do fim econômico a que se destinarem. Assim, será mais vantajosa a venda de uma fábrica, com todas as suas máquinas e instalações inclusive o imóvel em que funciona, do que a venda separadamente, do imóvel, dos maquinismos, instalações e demais coisas que a compuserem."

\footnotetext{
818 "A lei deve estabelecer normas e mecanismos que assegurem a obtenção do máximo valor possível pelos ativos do falido, evitando a deterioração provocada pela demora excessiva do processo e priorizando a venda da empresa em bloco, para evitar a perda dos intangíveis. Desse modo, não só se protegem os interesses dos credores de sociedades e empresários insolventes, que têm por isso sua garantia aumentada, mas também se diminui o risco das transações econômicas, o que gera eficiência e aumento da riqueza geral." (Relatório apresentado pelo Senador Ramez Tebet à CAE do Senado Federal, na apresentação do Projeto LC n. 71/2003).

${ }^{819}$ Comentários à Lei de Falências. 4a. edição atualizada por J. A. Penalva dos Santos e Paulo Penalva Santos. Rio de Janeiro: Forense, 1999, vol. I, pp. 167-168.
} 
Na sistemática adotada pela lei vigente "Caberá ao administrador judicial, como responsável pela prática dos atos necessários à realização do ativo (art. 22, inc. III, alínea ' $i$ '), formatar um plano adequado de venda dos bens, sempre imbuído de alcançar uma melhor forma e uma modalidade mais eficiente a serem adotadas para a alienação." 820

Note-se a propriedade da expressão escolhida por Sergio Campinho ${ }^{821}$ : plano, destinado a programar a realização da venda dos bens. A propósito, no direito italiano, a lei prevê como uma das obrigações do curatore (em conjunto com o comitê de credores) a elaboração de um programma di liquidazione, para evitar a desagregação desnecessária dos ativos.

Importante dizer que a lei brasileira não estabelece a obrigatoriedade da alienação em bloco na falência, pois esta depende de prévia avaliação de critério de conveniência, já que seu norte será, simultaneamente, atender ao interesse dos credores e possibilitar a manutenção da organização dos ativos.

Neste particular, merece nota o fato de que o legislador brasileiro não prevê, expressamente, a atuação do comitê de credores nesta fase do procedimento - como ocorre no direito italiano -, momento fundamental para o interesse destes. Nada impede, evidentemente, que o órgão, se instalado, requeira medidas que julgue essenciais à tutela do interesse dos credores, pois tem o dever de fiscalizar a aplicação da lei (artigo 27, I, b) ${ }^{822}$, além de atuar como órgão de fiscalização das atividades do administrador judicial, a quem incumbe os atos necessários à realização do ativo do falido (artigo 22, III, i).

\footnotetext{
${ }^{820}$ CAMPINHO, Sergio. Falência e recuperação de empresa - o novo regime da insolvência empresarial. 5. edição, São Paulo: Renovar, 2010, p. 431.

${ }^{821}$ A mesma expressão já era utilizada por Rubens Requião (Curso de direito falimentar, 16. edição, São Paulo: Saraiva, 1995, vol. I, p. 311).

822 "Tais atribuições, até certo ponto, assemelham-se às do Ministério Público, quando este atua como 'custos legis'. A distinção está em que o Ministério Público, intervindo como fiscal da lei nos processos concursais, atua na defesa da ordem jurídica, e não em benefício de uma determinada parte, ao passo que o comitê, ao propugnar pela observância da Lei, age na defesa dos interesses dos credores." (TOLEDO, Paulo Fernando Campos Salles de. In: TOLEDO, Paulo Fernando Campos Salles de.; ABRÃO, Carlos Henrique (coord.). Comentários à lei de recuperação de empresas e falência. 4. edição, São Paulo: Saraiva, 2010, p. 128).
} 
Em relação à solução prevista no inciso III do artigo 140, a opção do legislador não suscita maiores controvérsias. Aliás, é irretocável na medida em que preserva a agregação de certos ativos, aumentando a chance de alcançarem preço de venda mais vantajoso em benefício dos credores, ao mesmo tempo em que possibilita seu uso por outro agente econômico.

É o caso de se deter na análise das previsões dos incisos I e II, do mesmo artigo 140, já que por intermédio dessas é que, efetivamente, é possível concretizar a preservação da empresa.

Não existe, na lei, previsão expressa de necessidade de formatação de um "plano" de alienação, como se identifica em outros sistemas (italiano, espanhol e francês, v.g.).

Assim, o administrador judicial, a quem incumbe a organização da venda do ativo, ficará livre para avaliar e sugerir as medidas mais adequadas, de modo a atingir as finalidades propaladas pela lei. Em alguns processos de falência com que tive contato, observei que a avaliação dos ativos é feita, por orientação do administrador, sob dois critérios, em um mesmo laudo: um com indicação do valor de cada bem isoladamente; e outro, de avaliação geral, incluindo todos os ativos e atribuindo a este valor maior do que o da soma dos bens considerados.

A ideia é atraente, mas, ainda assim, deixa a desejar. Esses laudos de avaliação não consistem, verdadeiramente, em um plano de venda, com recomendação de possível organização útil para venda que possibilite a um novo agente explorar o negócio preexistente.

Apesar de a lei ser omissa a respeito, o laudo de avaliação que integra o auto de arrecadação e cuja elaboração cabe ao administrador judicial (que poderá nomear experts para auxiliá-lo) poderia, desde logo, indicar razões de conveniência e oportunidade de uma possível alienação em bloco $^{823}{ }^{824}$.

${ }^{823}$ E nesse aspecto, a lei italiana foi muito feliz ao estabelecer a figura de um plano de alienação ('programma di liquidazione', conforme art. 104ter), de modo a possibilitar uma análise das melhores condições de venda dos ativos. 
A decisão a respeito caberá ao juiz, mas o administrador judicial desempenhará papel fundamental nesta fase do procedimento falimentar, pois a ele cabe a atribuição de elaboração do auto de arrecadação, conforme se lê do artigo 108 da Lei n. $11.101 / 2005$.

É importante, assim, destacar que na lei brasileira vigente coube ao administrador judicial um papel de extrema relevância na falência. Suas atribuições incluem não apenas a organização do perfil do passivo da devedora (com a elaboração do quadro geral de credores), mas, notadamente, o gerenciamento, da forma mais vantajosa possível, de manutenção e alienação dos ativos, norteado pelo princípio da preservação da empresa.

Não foi por acaso que a Lei n. 11.101/05, acertadamente, profissionalizou ${ }^{825}$ a atividade do administrador judicial, admitindo a nomeação de pessoa jurídica "especializada" 826 .

Apesar de ser indiscutível que a função do administrador judicial corresponde a cargo de confiança do Juízo, a nomeação deverá basear-se na idoneidade (moral e financeira ${ }^{827}$ ) aliada à competência técnica ${ }^{828}$, para que o múnus seja

\footnotetext{
${ }^{824}$ No mesmo sentido, Fábio Ulhoa Coelho, ao comentar o artigo140, relata que "cabe aos órgãos da falência a escolha da melhor alternativa dentro dessa ordem legal. Para tanto, o administrador judicial pode elaborar uma proposta, devidamente fundamentada, dirigida à assembleia de credores. Na proposta deve indicar as razões pelas quais considera a alternativa por ele escolhida a que melhor otimizará os negócios da massa." (COELHO, Fabio Ulhoa. Comentários à nova lei de falências e de recuperação de empresas. São Paulo: Saraiva, 8. edição, 2011, p. 482).

825 "Uma das inovações mais aplaudidas da Lei consiste na profissionalização imprimida aos órgãos a quem compete tanta a administração judicial, na falência, quanto a fiscalização na recuperação judicial." (PENTEADO, Mauro Rodrigues, in Comentários à Nova Lei de Falências e Recuperação de Empresas - Lei n. 11.101/05, de 09 de fevereiro de 2005, obra coletiva Coord. CORRÊA-LIMA, Osmar Brina e CORRÊALIMA, Sérgio Mourão, Editora Forense, Rio de Janeiro, 2009, p. 160).

${ }^{826}$ Artigo 21 da Lei n. 11.101/2005. A propósito, o comentário de Paulo F. Campos Salles de Toledo: "Atuam no mercado diversas sociedades dedicadas à reestruturação de empresas, com profissionais especializados em corporate finance, em gestão temporária, em reorganizações. Etc. Este segmento não poderia ser ignorado pela LRE. Desse modo, em casos de especial complexidade, poderá a nomeação recair em pessoa jurídica que preencha os requisitos exigíveis." (Comentários à lei de recuperação de empresas e falência. São Paulo: Saraiva, obra coletiva coord. por TOLEDO, Paulo Fernando Campos Salles de: ABRÃO, Carlos Henrique Abrão. 4. edição, 2010, p. 103).

${ }^{827}$ TOLEDO, Paulo Fernando Campos Salles de Toledo. Comentários à lei de recuperação de empresas $e$ falência. São Paulo: Saraiva, obra coletiva coord. por TOLEDO, Paulo Fernando Campos Salles de; ABRÃO, Carlos Henrique Abrão. 4. edição, 2010, p. 103.
} 
desempenhado criteriosamente, e possa alcançar, em relação aos atos de alienação - e cujo planejamento deve ter início no momento mesmo da arrecadação -, os melhores resultados.

O novo requisito de capacitação técnica do administrador judicial aplica-se tanto na recuperação judicial quanto na falência e está em perfeita harmonia com a necessidade de "administração" da massa falida. A expressão é ora empregada no sentido de gerenciamento da melhor forma de organização na venda dos ativos do devedor (o que inclui todas as decisões e atos tendentes à sua realização, inclusive de continuidade de negócios ou celebração de contratos no interesse da massa), no menor tempo possível, sob pena de se tornar a previsão legal de venda antecipada em letra morta.

Os melhores resultados a serem alcançados dizem respeito não apenas ao maior valor de venda (em benefício dos credores), mas ao equilíbrio entre este e a preservação da empresa, com a tutela dos múltiplos interesses e feixes de contratos relacionados à falida.

Em falências de grande porte, não se poderia prescindir da organização de um plano de alienação ${ }^{829}$, o que poderia, como acima debatido, até mesmo incluir a continuidade de negócios com vistas à preservação do good will e outros valores intangíveis do negócio. A hipótese pode não ser frequente, mas também não pode ser tida como inexistente.

Fica evidente que a lei brasileira poderia ter ido além nessa matéria. Optou, de forma simplista, pela limitada solução de prestigiar a venda dos ativos em bloco ao indicar que desse modo, preferencialmente, deve ser levada a cabo a alienação.

Era o caso de se prever, de forma expressa, a elaboração de um plano de venda (nos dizeres de Campinho) após análise da efetiva possibilidade de manutenção da finalidade econômica de certos bens organizados, incentivando a participação dos credores, ao lado do administrador judicial, nessa incumbência.

${ }^{828}$ Confira-se decisões do TJ/SP: AI n. 462.694-4/00, relator Desembargador Boris Kauffman, j. 17/01/2007; Ap. Cível n. 549.635-4/6-00, relator Desembargador Luiz Antônio Costa, j. 4/06/2008; e AI n. 582.469-4/000, relator Desembargador Romeu Ricupero, j. 19/11/2008.

${ }^{829}$ Lamentavelmente, o legislador brasileiro não se ocupou do tema, como o fez o italiano. 
As soluções do direito italiano e espanhol, por exemplo, que prevêm a elaboração de um plano para liquidação dos bens na falência, no qual se possibilita uma análise de conveniência justificada da alienação, total ou parcial, dos ativos organizados, é superior à nossa.

Realmente, pode ser útil promover ao levantamento da estrutura de funcionamento da devedora (por intermédio de análise por um plano de liquidação) e, com isso, organizar o negócio (ou partes deste), que se mostre rentável.

Não é incomum, na crise das empresas, que estruturas rentáveis venham a pique por terem sustentado parte deficitária da mesma empresa. A análise da atividade da devedora possibilitaria a elaboração de um plano de transferência dos ativos suficiente para manter a parte rentável da estrutura, no que a previsão ativa de comitê de credores poderia ser bastante eficiente.

A experiência do direito francês, nesse aspecto, merece ser lembrada. Naquele sistema, a solução adotada é bastante diferente da nossa. O plan de liquidación, inquestionavelmente, alcança uma solução que, na raiz (e não apenas no efeito), é preservacionista. De fato, o adquirente dos ativos organizados assume a obrigação de dar continuidade ao negócio e manter postos de trabalho. Talvez o direito brasileiro não esteja, ainda, pronto para acolher, nessa extensão, o princípio da preservação da empresa na falência, mas, mesmo assim, a referência não poderia deixar de ser realizada.

Dado o caráter de recomendação da norma do artigo 140, o que é correto, em não havendo interessados na aquisição da empresa como um todo, ou de unidades produtivas, será feita a venda fracionada do ativo ${ }^{830}$.

\footnotetext{
${ }^{830}$ Embora não contrarie essa afirmação, Ricardo Bernardi acentua mais o aspecto da alienação em bloco enquanto meio de preservação da unidade produtiva, na medida em que entende que somente se não houver interessados é que se deve partir para o fracionamento ou venda individualizada. (Comentários à Lei de Recuperação de Empresas e Falência, obra coletiva coord. por SATIRO DE SOUZA JR. Francisco; PITOMBO, Antonio Sérgio A. de Moraes. São Paulo: Revista dos Tribunais, 2. edição, 2007, p. 486).
} 
Mas, o que importa é destacar que, também na falência, a preservação da empresa é um objetivo a ser perseguido, sempre que possível, não como um valor absoluto, mas como uma possibilidade.

Desse modo, a condição lógica para a hipótese de preservação da empresa, que resulta da venda em bloco dos ativos, é a de que exista possibilidade de desenvolvimento de uma atividade econômica profícua mediante a (re)utilização da organização de bens preexistentes (ou pelo menos, de parte dela).

A regra contida no $\S 3^{\circ}$ do artigo 140 da Lei $n$. 11.101/05 menciona, expressamente, que a venda da empresa terá por objeto o conjunto de bens necessários " $a ̀$ operação rentável" da unidade de produção.

Não nos parece, entretanto, que o dispositivo possa ser tomado como limitador para a alienação em bloco. Trata-se, na realidade, de fixação de baliza orientadora para o administrador judicial, a fim de que possa elaborar o critério com que fará a avaliação e venda dos ativos.

É que deve haver uma sinergia tal entre os bens avaliados conjuntamente que disto resulte a circunstância de estarem aptos a formar uma 'operação rentável'. Aliás, a eficiente organização das estruturas conjuntas dos bens reflete-se, depois, diretamente no sucesso da venda, pois é importante que possam despertar o interesse de potenciais adquirentes.

Isto porque, "o mercado valoriza, na verdade, o potencial de geração de riqueza que a empresa oferece ${ }{ }^{831}$, de tal sorte que a lei, corretamente, prevê preferência pela desarticulação gradativa, seja parcial ou total, do estabelecimento no momento de alienação.

Outra questão que merece destaque, particularmente em relação à previsão de venda do estabelecimento como um todo (artigo 140, I), é: Por qual razão não teria sido

${ }^{831}$ COELHO, Fábio Ulhoa. Comentários à nova Lei de falências e de recuperação de empresas. São Paulo: Saraiva, 8. edição, 2011, pp. 480/481. 
exitosa uma recuperação judicial para este negócio, já que, em tese, se a reorganização constituía uma alternativa viável, não teria sido necessário chegar-se à falência ${ }^{832}$ ?

Em outras palavras, se o negócio como um todo se reflete como economicamente viável (tanto que encontra mercado na alienação em bloco, como empresa, na falência), de duas uma: ou o devedor não buscou solução pela recuperação judicial, ou, tendo buscado, os credores rejeitaram o plano, não tendo sido atingidas as maiorias necessárias.

Neste último caso, parece que, mesmo diante de um negócio viável, os credores provavelmente não se mostraram interessados no sacrifício que teriam de fazer para aprovar o plano, resultando na falência.

Mas não se trata apenas disso. A melhor resposta que encontrei para esse questionamento reside na solução preconizada pelo direito francês, que coloca a plena separação entre a empresa e o empresário como pilar de seu direito concursal. Naquele sistema, a hipótese de cessão da empresa no plano de liquidação justifica-se plenamente, segundo a doutrina, pois, mesmo sendo viável o negócio, o devedor não estava em condições de perfazer a sua reorganização. Isso significa que o negócio é viável, mas o devedor não está em condições de tomar as medidas necessárias para a reabilitação, daí, possibilitar-se que terceiros o façam.

De certo modo, essa solução assemelha-se àquela do direito argentino, denominada por "salvatage" ${ }^{\text {" } 33}$, com a diferença de que ali esta ocorre acontece no procedimento de 'acuerdo preventivo'; e há cessão compulsória da sociedade devedora

\footnotetext{
${ }^{832}$ E a hipótese não é cerebrina, como evidencia a experiência da falência da 'Möller Indústria Metalurgica Ltda.', autos n. 1566/2006, do foro regional de Colombo, Curitiba, Paraná. No caso, a falida constituiu sociedade subsidiária integral, com versão de todos os ativos que compõe a massa, e alienou a totalidade da participação da sociedade anônima constituída, aprovada em assembleia geral de credores. O Juízo, assim, determinou à Junta Comercial o registro dos atos constitutivos da companhia, bem como ao Cartório responsável o registro traslativo dos imóveis, inclusive, independentemente de apresentação de CND da falida. (A propósito, registro meu agradecimento ao advogado Luiz Augusto de Souza Queiroz Ferraz que, gentilmente, me fez chegar às mãos esse rico material, para estudo e finalidade estritamente acadêmica).

${ }_{833}$ Conforme artigo 48 da lei concursal argentina, consiste na possibilidade de que um terceiro, credor ou não, obtenha as maiorias exigidas por lei para aprovação de um acuerdo preventivo e, em decorrência, passe a ter o dever (e o direito) de adquirir, mesmo à revelia dos titulares originários da devedora, a totalidade da participação societária da desta.
} 
para terceiros que obtenham os quóruns necessários para a aprovação de um plano. A originalidade dessa saída é a de que sua implementação se dá à revelia do devedor.

Há, ainda, outro aspecto a ser considerado na análise do tema da alienação em bloco, conforme prevista nos incisos I e II do artigo 140, da lei brasileira, especialmente sob o ângulo da preservação da empresa.

A preservação da empresa objetivada na recuperação judicial pode resultar, por previsão no plano, da venda total ou parcial do estabelecimento da devedora. Do ponto de vista dos credores e em relação à venda prevista na alienação em bloco na falência, a única diferença substancial, entre uma e outra hipótese, está no resultado da ordem de pagamento a ser seguida.

Na recuperação judicial, os credores serão pagos em conformidade com as disposições do plano aprovado por eles, ao passo que, na falência, serão pagos com a ordem de prelação rigidamente fixada em lei pelos artigos 83 e 84 .

Acidentalmente ou não, parece que o modo como o nosso sistema procedimental dualista brasileiro dispôs sobre a alienação de bens, na falência e na recuperação judicial, incentiva os credores ao ambiente da negociação. Caso contrário, terão de enfrentar o rigor da ordem legal prevista na quebra.

A análise permite afirmar do ponto de vista de alienação da emprea em bloco, que a recuperação judicial, quando comparada à falência, representa um afrouxamento do princípio da par condicio creditorum no direito brasileiro ${ }^{834}$, na medida em que permite ao devedor convencionar com seus credores, quase que livremente ${ }^{835}$, uma forma de pagamento diferente daquela prevista na falência.

\footnotetext{
834 "I creditori hanno quindi interesse a subire la violazione dell'ordine di priorità di rimborso, se questo evita la distruzione di valore conseguente a una liquidazione e consente loro una miglior soddisfazione." (STANGHELLINI, Lorenzo. Le crisi di impresa fra diritto ed economia (le procedure di insolvenza), Il Mulino, Bologna, 2007, pp. 232-233). Em tradução livre: 'Os credores possuem interesse em admitir a violação da ordem de prioridade de pagamento, se isto evita a destruição de valores que resulta da liquidação e permite a eles uma melhor satisfação.'

${ }^{835}$ Fábio Ulhoa Coelho refere quatro balizas de restrição, impostas por lei, ao plano de recuperação judicial: (i) créditos trabalhistas vencidos na data de apresentação do plano devem ser pagos em um ano; (ii) possibilidade de parcelamento do crédito fiscal conforme lei específica que disporá a respeito; (iii) a previsão de alienação de bens onerados depende de concordância do credor titular da garantia; e, (iv) nos
} 
Fábio Ulhoa Coelho critica o modelo atual da recuperação judicial, dizendoo vulnerável na medida em que, por temor à falência, os credores tenderiam a aprovar qualquer "rabisco malfeito" como plano de recuperação judicial ${ }^{836}$. Ora, esse possível e fundamentado receio dos credores está diretamente relacionado com o fato de que os recursos da falida, no mais das vezes, são insuficientes para atender mais de uma ou duas das classes de credores declinadas nos incisos do artigo 83 da lei concursal em vigor.

O modelo brasileiro adotado para a recuperação judicial admite, no que respeita à venda da empresa como um ou de algum estabelecimento, a fixação de uma ordem de pagamento dos credores, com solução privada inteiramente divorciada da regra do artigo 83, da Lei n. 11.101/05. O sistema brasileiro, infelizmente, tornou possível que credores com maior potencial decisório em um processo de recuperação judicial possam impor a opção que melhor lhes favoreça na hipótese de reorganização por venda de estabelecimento.

Chama-se a atenção para o fato de que, no direito norte-americano, o problema acima levantado, relativo à venda da empresa ou de estabelecimento, jamais ocorreria. Isso porque, como anota Eduardo Secchi Munhoz, aquele sistema não permite o fenômeno da 'deviation from absolute priority rule ${ }^{, 837}$, que o autor define como sendo " $a$ modificação das obrigações e dos contratos, que definem as condições e a ordem de preferência dos créditos, em decorrência do regime falimentar ou de recuperação". 838

No direito norte-americano, as restrições impostas ao devedor no momento de apresentação do plano de reorganização (pelo Chapter 11) incluem regras de prioridade na proposta.

créditos em moeda estrangeira, a sua conversão para moeda nacional depende de concordância do credor (COELHO, Fabio Ulhoa. Curso de direito comercial, 5. ed., Saraiva, 2005, vol. III, p. 420-421).

${ }^{836}$ Comentários à nova lei de falências e de recuperação de empresas, São Paulo: Saraiva, 8. edição, 2011, p. 173

${ }_{837} \mathrm{Ou}$, em tradução livre, o desvio da regra da precedência no pagamento dos créditos.

${ }^{838}$ MUNHOZ, Eduardo Secchi. "Anotações sobre os limites do poder jurisdicional na apreciação do plano de recuperação judicial". Revista de direito bancário e do mercado de capitais, ano 10, n. 36, abr-jun/2007, São Paulo: Revista dos Tribunais, p. 188. 
Essas normas são minudentemente disciplinadas no Bankruptcy $\operatorname{Code}^{839} \mathrm{e}$ vedam o pagamento de qualquer quantia a uma classe de credores com prioridade inferior na classificação dos créditos, antes que aquelas que lhe precedem sejam satisfeitas. É o que Munhoz denomina, referindo-se ao direito norte-americano, de princípio que rege as relações verticais que integram o plano do devedor ${ }^{840}$.

Situação semelhante é encontrada no direito alemão, pois o plano, que é instrumento alternativo à liquidação regular ${ }^{841}$, deve apresentar uma solução de pagamento que seja, no mínimo, equivalente à que teriam os credores na liquidação ${ }^{842}$.

Isto equivale dizer que o plano deve respeitar, para cada grupo de credores, as preferências legais de pagamento fixadas para a hipótese liquidatória do processo de insolvência alemão. Por isso, um dos fundamentos para a concessão do cram down, no sistema germânico, é que o credor em posição inferior na classificação dos créditos não receba valor algum antes dos que lhe precedem na ordem de vocação dos pagamentos ${ }^{843}$.

Para Munhoz, "há consenso em torno da ideia de que o procedimento falimentar é indispensável para assegurar um sistema de concurso coletivo e coordenado dos credores sobre o patrimônio do devedor, evitando-se o fenômeno conhecido na literatura econômica como 'asset grabbing'. ${ }^{844}$

O professor conclui, adiante, que na falência procura-se "assegurar ao conjunto de credores uma liquidação ordenada, evitando-se o favorecimento de uns frente aos outros (par conditio creditorum) e a perda de valor que decorreria de uma corrida

\footnotetext{
${ }^{839} \S 1129,(\mathrm{~b}),(2)$.

840 MUNHOZ, Eduardo Secchi. “Anotações sobre os limites do poder jurisdicional na apreciação do plano de recuperação judicial”. Revista de direito bancário e do mercado de capitais, ano 10, n. 36, abr-jun/2007, São Paulo: Revista dos Tribunais, p. 196.

${ }^{841}$ COROTTO, Susana. Modelos de reorganização empresarial brasileiro e alemão. Porto Alegre: Fabris, 2009 , p. 96.

${ }_{842} \S 251, \mathrm{I}$ c/c $\$ \S 159$ e seguintes da InsO.

$843 \S 245$ da InsO.

${ }^{844}$ MUNHOZ, Eduardo Secchi. “Anotações sobre os limites do poder jurisdicional na apreciação do plano de recuperação judicial”. Revista de direito bancário e do mercado de capitais, ano 10, n. 36, abr-jun/2007, São Paulo: Revista dos Tribunais, p. 188.
} 
desordenada sobre os bens integrantes do patrimônio da empresa (valores intangíveis como marca, clientela, entre outros).,"

A opção feita pelo modelo brasileiro, portanto, conduz à necessidade de reflexão para melhor avaliação e aperfeiçoamento do sistema. Mas, mesmo diante da inconsistência acima apontada, não há dúvida quanto à importância de previsão expressa, tanto na falência, quanto na recuperação judicial ${ }^{846}$ de possibilidade de venda da empresa como um todo ou de estabelecimento (filial ${ }^{847}$ ou unidade produtiva), em particular ante o fato de que o sistema brasileiro optou pela via procedimental dúplice.

De outra forma, na falência, não seria possível materializar o ideal de preservação da empresa, pois a metodologia do sistema de alienação em bloco é mecanismo indispensável para tanto. Além disso, repita-se, o ideal de preservação da empresa na falência, em hipótese alguma significa derrogar sua finalidade de pagamento dos credores, mas, ao contrário, busca destacar esse corolário, pois institui métodos de efetuar tais pagamentos da melhor maneira possível.

A salvaguarda do negócio por intermédio da venda em bloco recomendada na falência é também meio de maximização do preço de venda dos ativos, feita, portanto, no interesse de toda a coletividade de credores.

A realização da função pública do direito concursal - de preservação do crédito $^{848}$ e da cadeia de relações negociais, além da criação de um sistema organizado e

\footnotetext{
${ }^{845}$ MUNHOZ, Eduardo Secchi. "Anotaçães sobre os limites do poder jurisdicional na apreciação do plano de recuperação judicial". Revista de direito bancário e do mercado de capitais, ano 10, n. 36, abr-jun/2007, São Paulo: Revista dos Tribunais, p. 188.

${ }^{846}$ É a hipótese prevista na recuperação judicial da Pantanal Linhas Aéreas S/A, em que o plano previa a instituição de "unidade produtiva isolada (UPI), para alienação juntamente com os contratos de concessão de exploração dos 'slots' e 'hotrans'. O acórdão proferido pelo TJSP autorizou a realização da venda conforme prevista no plano, negando a objeção feita pela ANAC e da União Federal, sob o argumento de a alienação, tal como proposta, era "relevante para a obtenção de um maior valor de alienação do estabelecimento", terminando por concluir que a "Anac e a União Federal devem cumprir o princípio constitucional da preservação da empresa que decorre da função social desta." (AI 670.247.4/3-00, Relator Des. Pereira Calças, Câmara Reservada à Falência e Recuperação do Tribunal de Justiça de São Paulo, j. 26/01/2010.)

${ }^{847} \mathrm{O}$ conceito de estabelecimento é plástico, do que resulta, portanto, que o empresário pode explorar sua atividade em vários locais distintos. $\mathrm{O}$ conceito de filial, assim, pode ser admido em contraposição ao de 'principal estabelecimento', ou seja, como o de um local auxiliar e dependente do primeiro. (MIGUEL, Paula Castello. O estabelecimento comercial. Revista de direito mercantil, industrial econômico e financeiro, São Paulo, vol. 118, Ano XXXIX (nova série), abril/jun 2000, pp. 17-20).

848 "O instituto da falência não se resume a "resguardar o interesse dos credores. Os falencistas, ao revés, apregoam para a falência a função saneadora do crédito coletivo, muito mais do que simples meio
} 
coordenado de pagamento - pode ser atingida na quebra e um de seus instrumento de realização é a venda dos ativos organizados, como prevê o artigo 140 da lei concursal brasileira vigente.

\subsubsection{Inexistência de sucessão na venda de ativos.}

A inexistência de sucessão, pelo adquirente, de obrigações de qualquer natureza, na venda de ativos na falência, é opção legislativa sem a qual jamais seria possível concretizar o princípio da preservação da empresa nesse instituto ${ }^{849}{ }_{-}^{850}{ }_{3}^{851}$. Naturalmente, a única exceção a ser admitida para a regra da inexistência de sucessão das obrigações do falido é aquela contida no $\S 1^{\circ}$ do artigo 141 da Lei n. $11.101 / 05^{852}{ }^{853}$, pelo qual a aquisição é feita pelo próprio devedor ou pessoas a ele umbilicalmente ligadas.

A efetividade da preservação da empresa na falência apoia-se, inquestionavelmente, nesta previsão legal expressa pelo artigo 141, II da Lei $n$. $11.101 / 05^{854}$. Trata-se, bem assim, de uma das maiores conquistas do sistema concursal

processual de cobrança de créditos". Comentário de REQUIÃO, Rubens a acórdão in: Revista de direito mercantil, industrial econômico e financeiro, Ano XI (nova série), n. 07, 1972, p. 77.

${ }_{849}$ Tanto isso é certo que Manoel Justino Bezerra Filho sustentava a desnecessidade de revogação do DL 7661/45, entendendo que bastaria a implementação do regime da ausência de sucessão das obrigações (em particular daquelas de natureza fiscal e trabalhista), mantendo-se a letra dos arts. 122 e 123 do revogado diploma, o que seria suficiente abrir caminho para a sucessão da empresa, logo após a falência, o que se faria com o "objetivo de manter viva a célula empresarial, mesmo depois do decreto falimentar. A lei atual seria alterada para permitir que os artigos 122 e 123 também fossem aplicados aos casos de concordata preventiva.". (Exame crítico do projeto da Lei de Falências - "Recuperação de empresa" ou "Recuperação do crédito bancário”. São Paulo: Revista dos Tribunais, abril/04, v. 822, pp. 131-132).

${ }^{850}$ GORON, Lívio Goellner. "Constituição e Interpretação: Uma análise da decisão do STF sobre a nova lei de falências e recuperação de empresas (ADI 3934-DF)". Revista de direito mercantil, industrial econômico e financeiro, São Paulo, vol. 157, ano L, jan/mar 2011, pp. 152-154.

${ }^{851}$ Como já anotava o pragmático posicionamento de Renato Mange, ainda à época da vigência da lei revogada, pois a inexistência de sucessão tem a finalidade de "facilitar a venda de bens pela empresa em dificuldades para gerar condições de honrar suas dívidas." (MANGE, Renato Luiz de Macedo Mange. "Sobre recuperação e falência de empresas no Brasil". Revista de direito mercantil, industrial econômico e financeiro, São Paulo, vol. 127, Ano XLI (nova série), julh/set 2002, p. 60).

${ }^{852}$ A respeito, tanto o STJ quanto o STF têm reconhecido que a competência para decidir se há ou não sucessão cabe ao juízo falimentar, sob o argumento de que o que se discute não é a sucessão propriamente dita, mas os efeitos da alienação ocorrida na falência. (TOMAZETTE, Marlon. Curso de direito empresarial. Vol. 3, São Paulo: Atlas, 2011, p. 514).

${ }^{853}$ A inexistência de sucessão, nas hipóteses dos incisos I e II do $§ 1^{\circ}$ do artigo 141, é afastada de plano, ante a situação objetiva que se caracteriza, ao passo que, para o agente do falido (inciso III), há necessidade de prova do 'consilum fraudis'. (FRANCO, Vera Helena de Mello; SZTAJN, Rachel. Falência e recuperação de empresa em crise. Rio de Janeiro: Elsevier/Campus, 2008, p. 188).

${ }_{854}$ Julio Mandel afirma que "Talvez esse seja o artigo mais importante em relação à falência." (MANDEL, Julio. Nova lei de falências e recuperação de empresas anotada. São Paulo: Saraiva, 2005, p. 241). 
brasileiro no que respeita ao princípio da preservação da empresa, sob a óptica do direito concursal.

Tanto isso é certo que Miranda Valverde e Rubens Requião já teciam críticas ácidas quanto à interpretação jurisprudencial trabalhista, que chegava ao extremo de considerar o adquirente do estabelecimento da falida sucessor, a ponto de ficar obrigado a manter os contratos de trabalho então existentes ${ }^{855}{ }_{-}^{856}$.

Como não se pode deixar de referir, havia uma verdadeira inversão de valores, pois essa rigidez de interpretação, evidentemente, terminava por afugentar qualquer possível interessado, e o resultado era, invariavelmente, o desemprego generalizado, ante o apagar das luzes que resultava da falência.

A lei atual, ao contrário, proporciona a inexistência de sucessão trabalhista e, ao mesmo tempo, autoriza a contratação de empregados do falido por novo vínculo contratual (artigo 141, III, $\S 2^{\circ}$ ), o que estimula a preservação dos postos de trabalho. A solução da lei vigente, portanto, é inovadora e digna do mérito de proporcionar proteção aos interesses dos trabalhadores.

Especificamente no que concerne ao crédito trabalhista, o juiz do trabalho Marcelo Papaléo de Souza agrega construção interpretativa bastante sólida ao invocar a antinomia aparente entre as regras dos artigos 448 da CLT e 141, II, da Lei n. 11.101/05.

Apoiado em Norberto Bobbio, o autor sustenta que a solução para antinomia das regras legais está apoiada em três critérios: cronológico, hierárquico e da especialidade $^{857}$. Na sua opinião, ainda que ambas as regras sejam hierarquicamente equivalentes, quanto aos outros dois critérios, a interpretação que deve prevalecer é a da inexistência de sucessão, ante a excepcionalidade da situação de falência.

\footnotetext{
${ }^{855}$ MIRANDA VALVERDE, Trajano de. Comentários à lei de falências. Vol. II, 3. edição, Rio de Janeiro: Forense, 1962, p. 236; REQUIÃO, Rubens. Curso de direito falimentar. 16. edição, São Paulo: Saraiva, 1995 , vol. I., p. 322.

${ }^{856}$ No sistema concursal vigente, a contratação de funcionários da falida é faculdade do adquirente (COELHO, Fabio Ulhoa. Comentários à nova lei de falências e de recuperação de empresas. São Paulo: Saraiva, 8. edição, 2011, p. 488) e, se havida, resulta em novo vínculo contratual, conforme $\S 2^{\circ}$ do artigo 141 da Lei n. 11.101/05.

${ }^{857}$ SOUZA, Marcelo Papaléo de. A nova lei de recuperação e falência e as suas consequências no direito e no processo do trabalho. São Paulo: LTR, 2006, p. 248.
} 
É de se notar a isenção da interpretação criteriosa feita pelo citado magistrado, tanto que, no seu enteder, "a regra do art. 141, II e $\$ 2^{\circ}$ da LRF representa uma restrição a um direito fundamental, que são os direitos dos trabalhadores" ${ }^{\prime 258}$, mas, mesmo assim, reputa a norma de inquestionável legalidade.

Vinícius José Marques Gontijo anota que a quebra do empregador resulta em até quatro soluções possíveis para o crédito trabalhista: (i) na continuação de negócio, os créditos resultantes do trabalho são extraconcursais (artigo 84, I); (ii) verbas trabalhistas até 150 salários mínimos são créditos concursais a serem pagos na primeira classe (artigo 83, I); (iii) os créditos concursais que excederem tal valor são quirografários; (iv) novo contrato de trabalho, sem qualquer vínculo com o anterior, com o adquirente do estabelecimento da falida. ${ }^{859}$

Para o citado autor, não há possibilidade de reconhecimento de direito do trabalhador diferente das quatro alternativas acima mencionadas, reconhecendo, então, a inexistência de sucessão que resulte da aquisição de ativos na falência.

Assim, conclui sua análise afirmando que "a eventual responsabilização ou mesmo a desconsideração da personalidade jurídica, em caso de falência de sociedade, soemnte poderá ser decretada no juízo universal falimentar, na medida em que o produto deverá se verter para o benefício de todos os credores, e não apenas um deles, isoladamente considerado"; o autor sustenta que na execução trabalhista, uma vez decretada a quebra, nenhum ato processual deverá se seguir ${ }^{860}$.

Como regra geral, Rubens Requião assegurava que, em razão da extinção da sociedade que resulta da falência, "seja por leilão público ou propostas, seja pela constituição de nova sociedade pelos credores, ou cessão, não importa a transferência de

\footnotetext{
${ }^{858}$ SOUZA, Marcelo Papaléo de. A nova lei de recuperação e falência e as suas consequências no direito e no processo do trabalho, São Paulo, LTR, 2006, p. 252.

${ }_{859}$ GONTIJO, Vinícius José Marques. "Efeitos da falência do empregador na ação de execução de crédito trabalhista". Revista de direito mercantil, industrial econômico e financeiro. Vol. 146, Ano XLVI (nova série), abril/junh 2007, p. 143.

${ }^{860}$ GONTIJO, Vinícius José Marques. "Efeitos da falência do empregador na ação de execução de crédito trabalhista". Revista de direito mercantil, industrial econômico e financeiro. Vol. 146, Ano XLVI (nova série), abril/junh 2007, pp. 144-145.
} 
seus ônus para o adquirente. Surgirá, sempre, "novo empresário" que encetará pela sua atividade, nova empresa."

Nessa esteira, a lei vigente, atendendo ao reclamo destas fundamentadas críticas, optou pela inexistência irrestrita e completa de sucessão de todas as obrigações da falida, na venda de ativos da devedora (artigo 141 da Lei n. 11.101/05).

A redação dada ao dispositivo legal não foi, no entanto, das mais felizes. O uso, ao final do caput do referido artigo 141, da equivocada expressão "sob qualquer das modalidades de que trata este artigo" induziu respeitáveis estudiosos a uma interpretação literal e equivocada, de que somente estariam livres de sucessão os bens cuja venda ocorresse na forma descrita no referido dispositivo.

Considera-se importante que o artigo 141 da lei concursal brasileira sequer dispõe acerca de modalidades de alienação, as quais, realmente, estão previstas nos artigos 142, 144 e 145 da Lei n. 11.101/05.

Caberia indagar, no que respeita à interpretação da atécnica redação do artigo 141, se, efetivamente, a modalidade de alienação autorizada pelo juiz justificaria levar a diferentes resultados no que se refere à sucessão das obrigações para o adquirente na falência.

Para Alexandre Husni, por exemplo, há sucessão das obrigações na hipótese por ele denominada 'alienação extrajudicial', que corresponde às modalidades escolhidas em assembleia de credores com fundamento no artigo 145 da Lei n. 11.101/05, em contraposição à que designa por 'alienação judicial', que corresponde ao pregão, leilão e $\operatorname{propostas}^{862}$.

Para o citado autor, em se tratando de regime de aplicação de caráter excepcional, a inexistência de sucessão trabalhista e fiscal somente alcançaria, além daquelas denominadas por "alienação judicial", as vendas realizadas por modalidade de

861 REQUIÃO, Rubens. Curso de direito falimentar. 16 ${ }^{\mathrm{a}}$. edição, Saraiva, 1995, vol. I., pp. $322-323$ (destaques do texto original).

${ }^{862}$ DE LUCCA, Newton; SIMÃO FILHO, Adalberto (Coord.). Comentários à nova lei de recuperação de empresas e de falências. São Paulo: Quartier Latin, 2005, pp. 538-540. 
constituição de sociedade de credores ou empregados (ou seja, que seria uma exceção dentro do próprio artigo 145) e as previstas no artigo 142 da lei concursal brasileira.

Para Jorge Lobo, em duas hipóteses - e embora versem sobre o procedimento de recuperação judicial, valem ser lembradas -, o adquirente é sucessor das obrigações da devedora: (i) se houver alienação do estabelecimento como um todo, hipótese em que a venda estaria sujeita às regras ordinárias dos artigos 1.142 do Código Civil, 448 da CLT e 133 do CTN; (ii) na alienação extrajudicial de estabelecimento, filial ou unidade produtiva. Na falência, o mesmo autor sustenta a ampla inexistência de sucessão, exceto nas hipóteses que são expressamente mencionadas no $§ 1^{\circ}$ do artigo 141 da lei vigente ${ }^{863}$.

Contudo, fazendo interpretação sistemática e axiológica do dispositivo, Sergio Campinho declara, categoricamente, em relação à falência, não ter "dúvida que a desoneração se aplica a qualquer das modalidades de venda judicial do ativo, não se limitando às intituladas ordinárias.", sob o fundamento de que o artigo 141, na verdade, não disciplina modalidade alguma de alienação e o termo foi ali utilizado por equívoco do legislador. $^{864}$

O autor, acrescenta, ainda, que a regra do CTN, que disciplina a matéria da inexistência de sucessão, não faz distinção alguma quanto à espécie ou modalidade de venda prevista na lei concursal, razão pela qual esse princípio de ordem geral leva à interpretação de que a ausência de sucessão tributária aplica-se a toda e qualquer modalidade de alienação na falência ${ }^{865}$.

Afina-se a esse entendimento Marlon Tomazette, para quem "Em qualquer das modalidades de alienação da massa falida, os adquirentes não devem ser

\footnotetext{
${ }^{863}$ LOBO, Jorge. "Responsabilidade por obrigações e dívidas da sociedade empresária na recuperação extrajudicial, na recuperação judicial e na falência". Revista de direito mercantil, industrial econômico e financeiro. Vol. 144, Ano XLV (nova série), out/dez 2006, pp. 142-144.

${ }^{864}$ CAMPINHO, Sergio. Falência e recuperação de empresa - o novo regime da insolvência empresarial. 5. edição, São Paulo: Renovar, 2010, p. 438.

${ }^{865}$ Parece ser no mesmo sentido a orientação de Vera Helena de Mello Franco e Rachel Sztajn, posto que somente excepcionam a hipótese de aquisição prevista no $\S 1^{\circ}$ do artigo 141 da Lei n. 11.101/05. (FRANCO, Vera Helena de Mello; SZTAJN, Rachel. Falência e recuperação de empresa em crise. Rio de Janeiro: Elsevier/Campus, 2008, pp. 187-188).
} 
responsabilizados pelas obrigações do falido, sob pena de não atrair nenhum interessado para essa aquisição. "866

$\mathrm{O}$ autor arremata o raciocício afirmando que "Cuida-se da mais clara aplicação dos princípios da função social e da preservação da empresa, na medida em que, como estabelecimento de alguma sucessão, dificilmente a atividade poderia prosseguir." $" 867$

Por certo, a inexistência de sucessão das obrigações do falido é um dos pilares essenciais de concretização do princípio de manutenção da fonte produtora insculpido no artigo 75 da Lei n. 11.101/05.

Compartilha-se, assim, do posicionamento adotado pelos professores Sergio Campinho e Marlon Tomazette, eis que inteiramente afinadas com o princípio dorsal, que ilumina a interpretação do direito falimentar, declinado no artigo 75 , de preservação da empresa.

Não é razoável, em hipótese alguma, fazer restrição à inexistência de sucessão, por interpretação literal do artigo 141, a uma ou outra modalidade de alienação, nem mesmo se mostra possível particularizar a inexistência de sucessão a alguma espécie de crédito em particular ${ }^{868}$, devendo esse princípio ser este estendido, igualmente, tanto ao crédito trabalhista, quanto ao crédito fiscal.

A norma da inexistência de sucessão tem o intuito de atuar como elemento viabilizador da venda de estabelecimento (ou de bens organizados que possam ser aproveitados ou reutilizados por outro empresário).

\footnotetext{
866 TOMAZETTE, Marlon. Curso de direito empresarial. Vol. 3, São Paulo: Atlas, 2011, p. 512. ${ }^{867}$ TOMAZETTE, Marlon. Curso de direito empresarial. Vol. 3, São Paulo: Atlas, 2011, p. 513.

868 “FALÊECIA - Débitos condominiais - Hasta pública - Inclusão do bem sem referência a obrigações arcadas pelo adquirente - Impossibilidade - Inteligência do art. 141, II, da atual Lei de Falências - Recurso não provido" (TJSP, AI n. 903.4772-89.2007.8.26.0000, Relator Desembargador Joaquim Garcia). O acórdão determinou que o agravante habilitasse seu crédito, correspondente à taxa condominial de imóvel arrecadado, com fundamento na inexistência de sucessão. Ressalvou, todavia, os valores vencidos após a decretação da quebra, como créditos de natureza extraconcursal.
} 
Para tanto, a regra da sucessão de obrigações é restrita somente ao próprio falido ou a pessoas próximas a ele, e nenhuma outra hipótese, além dessa. De outro modo, proporcionar e fomentar discussões nada profícuas em torno de interpretações literais e distantes da principiologia da lei somente terá como resultado afugentar potenciais adquirentes e frustar o princípio de preservação da empresa, impossibilitando que se possa manter vivo o negócio então empreendido pelo devedor.

A previsão legal, de inexistência de sucessão das obrigações, traduz da forma mais cristalina possível, a necessária distinção que uma lei concursal deve fazer entre o devedor e o negócio por ele operado: entre a empresa e o empresário.

Pelas obrigações da falida, devem responder os ativos arrecadados, pagando-se os credores com o que da venda se apurou. Se os mesmos bens podem ser alocados e aproveitados em outra atividade econômica, precisam estar sob a proteção de total esterilização com os vínculos do passado.

Neste sentido, a sutileza da parte final do artigo 145, pela qual é disciplinada a modalidade de alienação pela constituição de sociedade de empregados ou credores "com a participação, se necessária, dos atuais sócios ou de terceiros". A inexistência de sucessão aplica-se, na hipótese, por força do $\S 1^{\circ}$ do mesmo dispositivo.

Em situação excepcionada pela própria lei, até os sócios da falida poderão participar desta modalidade de alienação e a exceção se justifica: nem todos os sócios da falida terão sido responsáveis pela situação de crise insuperável que resultou na quebra.

Aqui o legislador foi sensível à possibilidade de separação entre poder de controle e titularidade da empresa. Pode haver sócios minoritários que nunca participaram da gestão e que, em virtude disso, não podem ser penalizados pelos efeitos da quebra, uma vez que sua posição jurídica mais se aproxima daquela dos demais credores, ou seja, pessoas que proveram recursos à devedora (seja por concessão de crédito, seja por 
investimento no capital social). A interpretação legal não pode ficar presa ao sentido literal das palavras, mas deve buscar a razão e o sentido do direito sob tutela ${ }^{869}$.

Além de todos os argumentos já suscitados para encorajar a inexistência de sucessão decorrente da venda dos ativos em bloco na falência, há o fato incontestável de tal previsão legal ser vantajosa para os credores ${ }^{870}$.

Invoca-se a lição contida no aresto do tribunal paulista, pelo qual foi autorizada a aplicação da inexistência de sucessão em procedimento de falência decretado sob o regime do revogado DL n. $7.661 / 45^{871}$. Mais ainda: há decisão da mesma corte autorizando a venda de ativos que sequer integram a atividade operacional da devedora, protegendo-os da sucessão ${ }^{872}$.

A previsão de inexistência de sucessão é norma que traz benefício aos credores na medida em que busca "tanto quanto possível, aumentar o montante arrecadado com a venda dos bens da massa" ${ }^{, 873-874 .}$

\footnotetext{
${ }^{869}$ Note-se, caberá, no caso de se verificar a participação de sócios que deram causa ou que atuaram ou contribuíram para a falência, a prova de tal situação, para impedir que seja afastada a hipótese do $\S 1^{\circ}$ do artigo 141 da Lei n. 11.101/05. Há, aqui, inversão do ônus da prova, que milita a favor dos sócios, na forma do artigo 145 do mesmo diploma.

${ }^{870} \mathrm{O}$ excessivo protecionismo ao crédito fiscal sempre foi objeto de crítica pela doutrina. Confira-se, a propósito, FRONTINI, Paulo Salvador, "Novas vantagens para o fisco em matéria falimentar". Revista de direito mercantil, industrial, econômico e financeiro, São Paulo, vol. 44, Ano XX (nova série), pp. 123-125, out/dez 1981.

871 "De outra forma, registre-se que é possível, também, quando da alienação, a observância da norma contida no artigo 142, II, da Lei 11.101/05, para permitir que a venda se faça livre de qualquer ônus e sem sucessão do arrematante nas obrigações do devedor, inclusive as de natureza tributária, as derivadas da legislação do trabalho e as decorrentes de acidentes do trabalho. Como anotado por Manoel Justino Bezerra Filho (Lei de Recuperação e Falências, Editora Revista dos Tribunais, $7^{a}$ edição, 2011, p. 318), "Este dispositivo, no âmbito tributário, tornou-se possível diante da alteração do art. 133 do Código de Tributário Nacional, pela Lei Complementar 118, de 09.02.2005, que acrescentou um $\S$ ao ao artigo, dizendo: 'O disposto no caput deste artigo não se aplica na hipótese de alienação judicial: em processo de falência; de filial ou unidade produtiva isolada, em processo de recuperação judicial'. Por determinação do art. 133 do $C T N$, no sentido de que a pessoa adquire o fundo de comercio ou estabelecimento comercial, continuando a respectiva exploração, responde pelos tributos relativos, não se aplica à alienação judicial em processo falimentar". Essa nova abertura legal, como igualmente bem explicitado nas razões de inconformismo, trará igualmente maiores vantagens à riassa e seus credores, já que permitirá lanços maiores e livres de ressalva, posto que dispensada a apresentação de certidões negativas fiscais para a concretização da transferência do domínio." AI 429.620-4/2 (ou n. 9037810-80.2005.8.26.0000), Relator Desembargador Galdino Toledo Júnior, $10^{a}$ Câmara de Direito Privado, j. 01/06/2006, TJSP).

${ }^{872}$ A hipótese é de recuperação judicial, mas a ideia adequa-se ao tema em debate. Confira-se o Acórdão do $\mathrm{AI} \mathrm{n}^{\circ} \mathrm{n}^{\circ}$ 624.330-4/0-00, julgado em 05/09/2009, rel. Des. Pereira Calças.

${ }^{873}$ SZTAJN, Rachel, 'in' Comentários à lei de recuperação de empresas e falência, São Paulo: Saraiva, obra coletiva coord. por TOLEDO, Paulo Fernando Campos Salles de.; ABRÃO, Carlos Henrique Abrão. 4. edição, 2010, p. 509.
} 
A própria Fazenda beneficia-se, pois, ante a inexistência de sucessão, terá maior probabilidade de êxito de receber seu crédito na falência (ante a melhor venda dos ativos), ao passo que, com a sucessão, dificilmente um novo negócio para exploração de atividade similar se instalaria na antiga sede ou filial da devedora, fazendo com que o fisco não tenha de quem cobrar tal passivo.

Além disso, não se pode desconsiderar o fato que a sucessão fiscal dificulta, se é que não arruína por completo, a possibilidade de continuação da atividade produtiva, do que resulta inegável prejuízo à arrecadação.

A sucessão fiscal é situação estática que se fixa somente na cobrança do passado, quando seria preciso e mais vantajoso estimular novos empreendimentos que, potencialmente, serão boas fontes arrecadadoras de tributos. Isto porque, a ausência de sucessão na falência não impede que o credor fiscal tente buscar pagamento dos demais responsáveis pelo crédito, conforme previsto no artigo 134 do $\mathrm{CTN}$, se cabível a hipótese ${ }^{875}{ }^{876}$.

Portanto, "Na verdade, a sucessão tributária traz mais detrimentos que benefícios à Fazenda Pública. Ao estabelecer a oferta pela empresa, os interessados, normalmente os próprios concorrentes da empresa à venda, evidentemente levam em consideração todos os fatores que possam diminuir o valor do negócio. (...) Assim, no que tange ao volume das garantias do Fisco, a sucessão não traz vantagens aos cofres públicos. ${ }^{~} 877$

Há mais um elemento que não pode ser esquecido na análise do tema da inexistência da sucessão das obrigações, quando da venda de ativos na falência. É que no processo de falência, todos os credores, respeitada a ordem de prelação de pagamento

\footnotetext{
${ }^{874} \mathrm{Na}$ mesma linha sustenta Fabio Ulhoa Coelho (COELHO, Fabio Ulhoa. Comentários à nova lei de falências e de recuperação de empresas. São Paulo: Saraiva, 8. edição, 2011, pp. 485-487).

${ }^{875}$ FONSECA, Humberto Lucena Pereira. "Alienação da empresa na falência e sucessão tributária". Revista de Direito mercantil, industrial econômico e financeiro. Vol. 132, Ano XLII (nova série), out/dez 2003, p.90. 876 ARAÚJO, Luiz Antonio Mattos Pimenta. "A responsabilidade tributária na sucessão das empresas". Revista de direito mercantil, industrial, econômico e financeiro, vol. 76, Ano XXVIII (nova série), pp. 93101, out/dez, 1989.

${ }^{877}$ FONSECA, Humberto Lucena Pereira. “Alienação da empresa na falência e sucessão tributária”. Revista de direito mercantil, industrial econômico e financeiro, vol. 132, Ano XLII (nova série), out/dez, 2003, p.88.
} 
prevista em lei, se subrrogam no produto que resulta da alienação dos ativos da massa, conforme inciso I do artigo 141 da Lei n. 11.101/05.

É inegável que há uma vinculação entre o valor obtido com a venda e o pagamento dos credores. Sob esse ponto de vista, há que haver, como contrapartida da venda de todos os ativos do devedor, a completa liberação (em relação às obrigações do falido) das obrigações do passado. $\mathrm{O}$ terceiro de boa-fé que adquire o estabelecimento no processo de falência tem o direito de receber um ativo esterizado das relações do passado.

Não é demais destacar que o adquirente de boa-fé recebe a titularidade dos bens da falida por força de ato judicial e, portanto, em relação a este, as obrigações precedentes da devedora constituem "res inter alios acta".

Trata-se de duas faces de uma mesma moeda: de um lado, todos os credores se subrrogam no produto da venda dos ativos na falência (e com este deverão ser satisfeitos, conforme a ordem de pagamentos estabelecida no artigo 83 da Lei $n$. 11.101/05) e, de outro, paralelamente, o adquirente de tais ativos fica totalmente liberado das obrigações reclamadas no processo concursal. Há, por assim dizer, nas palavras de Rachel Sztajn um "rompimento de um certo vínculo que prende ativo e passivo patrimoniais." 878

Nesta linha de ideias, a inexistência de sucessão das obrigações da falida é "mecanismo voltado à chamada reorganização externa da empresa e que tem por fundamento a salvaguarda dos inúmeros interesses que em torno dela gravitam. Consiste na transmissão da empresa ou de parte dela a novo empresário, operação estimulada pela garantia de não transmissão de encargos, salvo aqueles expressamente relacionados no instrumento do negócio." 879

\footnotetext{
${ }^{878}$ Comentários à lei de recuperação de empresas e falência, São Paulo: Saraiva, obra coletiva coord. por TOLEDO, Paulo Fernando Campos Salles de.; ABRÃO, Carlos Henrique Abrão 4. edição, 2010, p. 503. 879 TJSP, Apelação Cível 1.210.377-0/7 (ou n. 1210377007), relator Desembargador Ricardo Pessoa de Mello Belli, j. 4/11/2008. Na hipótese, o relator entende que o dispositivo em análise é também aplicável às instituições financeiras em liquidação extrajudicial, por força do artigo $6^{\circ}$ da Lei n. 9.447/97. O aresto, ainda, sustenta que desde que haja pagamento de preço justo na alienação dos ativos, a finalidade da lei é a preservação da empresa: "a lei não contém palavras vãs e tendo em conta que o mecanismo instituído pelo art. 141 da sobredita Lei n. 11.101/05 objetiva, a par da preservação externa da empresa, a proteção dos interesses dos credores, só cabe concluir que, para o ordenamento jurídico, a alienação indiscriminada de ativos pelo falido ou pela instituição financeira em liquidação extrajudicial, sem que se demonstre o
} 
A melhor interpretação ao dispositivo que trata do tema é a de liberação ampla do passivo, para todos os gêneros de alienação. Mesmo porque, a venda isolada dos bens, quando há possibilidade de alienação em bloco, é prejudicial aos próprios credores.

Nesse sentido, Fabio Ulhoa Coelho anota que "Se o adquirente da empresa anteriormente explorada pela falida tiver que honrar todas as dívidas dessa, é evidente que menos empresários terão interesse no negócio. Aliás, é provável que a própria alienação da empresa se inviabilize: se tiver que pagar tudo a que se obrigara o falido, o adquirente tende a falir também." $880 \_881$

Um dos fundamentos principais para a regra de inexistência de sucessão é viabilizar a alienação em bloco dos $\operatorname{ativos}^{882}{ }_{-}^{883}$ (ou do estabelecimento e contratos estratégicos a este vinculados) para possibilitar a existência de compradores interessados e, com isto, beneficiar os credores e proporcionar a preservação da empresa na falência.

Desse modo, a exclusão da sucessão tributária na falência “contribui para o desenvolvimento nacional, ao ensejar maior agregração de valor à empresa falida a ser vendida e promover a continuação da atividade econômica." $\$ 84$

pagamento do justo preço, implica a sucessão do adquirente nas obrigações relacionadas aos bens e direitos adquiridos".

${ }^{880}$ COELHO, Fabio Ulhoa. Comentários à nova lei de falências e de recuperação de empresas. São Paulo: Saraiva, 8. edição, 2011, p. 483.

${ }^{881} \mathrm{Na}$ mesma linha de ideias, Julio Mandel critica, em particular, quanto aos créditos tributários: "Pela cegueira de alguns em buscar "novas" fontes de arrecadação para os créditos fiscais e pelo insano medo de fraudes, os ativos não eram vendidos, ficando a fazenda sem os créditos e sem sucessor para responder por eles." (MANDEL, Julio. Nova lei de falências e recuperação de empresas anotada. São Paulo: Saraiva, 2005, p. 241).

${ }^{882}$ BERNARDI, Ricardo, 'in' SATIRO DE SOUZA JR.; Francisco; PITOMBO, Antonio Sergio A. de Moraes (Coord.). Comentários à lei de recuperação de empresas e falência. São Paulo: Revista dos Tribunais, 2. edição, 2007, p. 492.

${ }^{883}$ No mesmo sentido: "Visando a preservar a sociedade empresária, para que a mesma possa continuar operando após a decretação de sua quebra, gerando com isso recursos e empregos e preservando os já existentes, o legislador inovou, com acerto, ao afastar a sucessão trabalhista e tributária para o adquirente de qualquer bem da massa falida." (SPINELLI, Andráa Martins Ramos, 'in’ APPROBATO MACHADO, Rubens (Coord). Comentários à nova lei de falências e recuperação de empresas. São Paulo: Quartier Latin, 2005, p. 217).

${ }^{884}$ FONSECA, Humberto Lucena Pereira. “Alienação da empresa na falência e sucessão tributária”. Revista de Direito mercantil, industrial econômico e financeiro. Vol. 132, Ano XLII (nova série), out/dez, 2003, p. 93. 
A regra da inexistência de sucessão corresponde à "tentativa de tornar $o$ procedimento mais eficiente no que diz respeito ao pagamento de credores, uma vez que se facilita a aquisição dos bens da massa sem o risco de sucessão." ${ }^{885}$

A melhor exegese do artigo 141 não é a da literalidade do dispositivo, mas a de sua interpretação sistemática, que conduz à inafastável leitura de que toda e qualquer alienação judicial na falência está exonerada das obrigações do devedor. Com isto, o legislador fincou um dos mais importantes pilares da preservação da empresa, na falência. Mas, há mais.

\subsubsection{Modalidades de alienação dos ativos.}

Constituem modalidades de alienação dos ativos na falência, aquelas previstas nos artigos 142, 144 e 145 da Lei n. 11.101/05. Admite-se, assim, expressamente que o pagamento dos credores seja feito por meios diversos, e não apenas em dinheiro ${ }^{886}$.

Em todas as modalides de alienação, a divulgação do ato é elemento essencial para dar publicidade aos credores e potenciais interessados ${ }^{887}$, embora a lei somente exija a publicação em jornais de grande circulação para as hipóteses previstas no artigo 142 , conforme reza o $\S 1^{\circ}$.

Não se justifica, evidentemente, que as modalidades de venda previstas nos artigos 144 e 145 não tenham divulgação pelos meios de comunicação, em especial porque terceiros, e não apenas os credores, devem ser convocados para a disputa. Daí porque, embora a lei não faça menção expressa, a venda dos ativos, por qualquer modalidade,

\footnotetext{
${ }^{885}$ SZTAJN, Rachel, 'in' Comentários à lei de recuperação de empresas e falência. São Paulo: Saraiva, obra coletiva coord. por TOLEDO, Paulo Fernando Campos Salles de.; ABRÃO, Carlos Henrique Abrão. 4. edição, 2010, p. 509.

${ }^{886}$ Anote-se, a respeito, na vigência do diploma anterior, as críticas de Rubens Requião à decisão que autorizou dação em pagamento por imóvel, em concordata, apesar da oposição de um credor. Discorrendo sobre a falência, o autor anota: "Podemos, pois, afiançar a opinião de que no procedimento de falência, o meio regular da extinção das obrigações do falido é o pagamento dos credores em dinheiro, produto da alienação judicial dos bens do mesmo falido, que constituíam a garantia comum de seus credores. (...). O Tribunal paranaense, talvez, sem o percebre, acaba de ressucitar a técnica falencial de cessão de bens." (in Comentário ao AI n. 37/73, TJPR. Revista de Direito mercantil, industrial econômico e financeiro, Ano XII (nova série), n. 12, 1973, p. 134).

${ }^{887}$ A respeito já anotava Requião: "Em todas essas formas de realização do ativo, a lei falimentar impõe o maior acesso às informações pelos interessados ou pretendentes, obrigando o síndico a efetuar a mais ampla divulgação e publicidade das alienações a serem efetuadas, assegurando assim efetiva concorrência do público." (Curso de direito falimentar. 16. edição, São Paulo: Saraiva, 1995, Vol. 1, p. 314).
} 
dever ser objeto de ampla divulgação, com fundamento na regra geral do artigo $191^{888}$, a fim de outorgar transparência ao ato.

Outra incongruência a ser apontada é a da previsão do artigo 143, pela qual "Em qualquer das modalidades de alienação referidas no art. 142 desta Lei, poderão ser apresentadas impugnações", como se nas demais hipóteses, previstas nos artigos 144 e 145, não houvesse tal oportunidade. É inquestionável que há legitimidade do Ministério Público, que atua no feito como 'custos legis', dos credores e de qualquer interessado para impugnar, em caso de irregularidade, em qualquer modalidade de alienação dos ativos.

Feitas essas considerações iniciais quanto ao tema, passa-se à análise das modalidades de alienação dos ativos. Dentre as modalidades que parte da doutrina denomina por 'comum' ou 'ordinária' ${ }^{889}$, a lei disciplina: (i) o leilão por lances orais, (ii) as propostas fechadas e, como inovação da lei vigente, e o (iii) o pregão, que consiste em espécie híbrida que conjuga procedimentos das outras duas.

No leilão, determina a lei concursal sejam observadas, subsidiariamente e naquilo que não forem contrárias, as regras previstas no Código de Processo Civil ${ }^{890}{ }_{-}^{891}$. Basicamente, o leilão consiste em uma convocação pública, em hora e local determinados, para que o bem seja alienado pelo melhor lance oral proferido.

Aplica-se, assim, a disposição que veda a alienação a preço vil. Na situação especial da falência, não será fácil a tarefa de apreciar eventual alienação a preço vil.

\footnotetext{
${ }^{888}$ MIGLIARI, Arthur, 'in' Comentários à lei de recuperação de empresas e falência. São Paulo: Saraiva, obra coletiva coord. por TOLEDO, Paulo Fernando Campos Salles de.; ABRÃO, Carlos Henrique Abrão. 4. edição, 2010, p. 623.

${ }^{889}$ COELHO, Fabio Ulhoa. Comentários à nova lei de falências e de recuperação de empresas. São Paulo: Saraiva, 8. edição, 2011, p. 490; CAMPINHO, Sergio. Falência e recuperação de empresa - o novo regime da insolvência empresarial. 5. edição, São Paulo: Renovar, 2010, pp. 432-433; TOMAZETTE, Marlon. Curso de direito empresarial. Vol. 3, São Paulo: Atlas, 2011, p. 504.

${ }^{890}$ Todavia, após a promulgação da Lei falimentar, o sistema processual foi reformado, passando a admitir a alienação por iniciativa particular, promovida pelo credor. A respeito, Marlon Tomazette anota possível acolher essa modalidade, desde que aprovada em assembleia de credores (TOMAZETTE, Marlon. Curso de direito empresarial, vol. 3, São Paulo: Atlas,, 2011, p. 505). Em sentido contrário, Euler da Cunha Peixoto, sob o argumento de que como a falência não tem um credor, não é possível cogitar desse procedimento. ('In' Comentários à nova lei de falências e recuperação de empresas - Lei $n$. 11.101/05, de 09 de fevereiro de 2005, Coord. CORRÊA-LIMA, Osmar Brina e CORRÊA-LIMA, Sérgio Mourão. Rio de Janeiro: Forense, 2009, p. 986).

${ }^{891}$ O que é uma inovação da lei, pois como anotava Rubens Requião referindo-se ao regime anterior, "Na falência não se aplicam as regras do Código de Processo Civil, em matéria de arrematação, pois estabelece as suas próprias normas." (Curso de direito falimentar. 16. edição, São Paulo: Saraiva, 1995, vol. 1, p. 317).
} 
Nesse particular, em observação arguta, Rachel Sztajn lembra que “Pensando a massa falida como um 'going concern', como atividade criadora de riqueza, o valor atribuível ao conjunto prende-se à sua aptidão para produzir lucros ao longo de certo tempo", para concluir que "Inexistindo atividade, porque a continuidade depende de autorização judicial, a comparação ou estimação da aptidão para produzir lucros fica sujeita à análise de mercado em que a empresa atuava, à necessidade, ou não, de novos investimentos, prazo de maturação, entre outros." $892 \_893$

Na modalidade de alienação por proposta, os interessados entregam, em cartório, em período preestabelecido, envelopes lacrados contendo propostas por escrito, os quais serão abertos pelo juiz em dia e hora designados.

Como já anotava Trajano de Miranda Valverde a respeito do tema, " $A$ melhor proposta não será sempre aquela que oferecer preço mais alto. Conforme as condições da venda constantes dos anúncios da concorrência, pode suceder que uma proposta de preço inferior à de outras seja mais conveniente para a massa falida, dadas as vantagens que o proponente haja prometido. Não se trata, com efeito, de concorrência para a obtenção do mais alto preço e, sim, da proposta mais vantajosa aos interesses da massa falida. "894

\footnotetext{
${ }^{892}$ SZTAJN, Rachel, 'in' Comentários à lei de recuperação de empresas e falência. São Paulo: Saraiva, obra coletiva coord. por TOLEDO, Paulo Fernando Campos Salles de.; ABRÃO, Carlos Henrique Abrão. 4. edição, 2010, p. 514.

${ }^{893}$ Em contraponto a essa ideia, a decisão proferida no AI 580.632-4/0-00 de relatoria do Desembargador Hamilton Eliot Akel, TJSP: "De qualquer modo, assinale-se que em hipótese como a dos autos não há propriamente perícia avahatóna, em que devam ser observadas as regras processuais atinentes à produção de prova técnica, mas estimativa dos bens arrecadados, que poderá ser repetida quando provado erro ou dolo do avaliador ou no caso de se verificar, posteriormente, que houve considerável diminuição do valor dos bens Nova avaliação poderá, ainda, ser admitida, se houver fundada dúvida sobre o valor atribuído ao bem. Como já decidido, "as avaliações judiciais são feitas para determinado fim (alienação de bens penhorados, em praça pública), que não coincide necessariamente com aqueles que levam os comerciantes a atuar no mercado, comprando e vendendo bens Sempre existe uma diferença prejudicial ao executado. Vendendo-se as mesmas coisas no mercado, o resultado poderia ser melhor Entretanto, o objeto da penhora é vendido em praça pública, em execução judicial, em condições diversas, nas quais os preços correntes de mercado nem sempre fornecem os parâmetros de valor aceitáveis no átno do foro Os compradores são outros e as regras são de um mercado específico Não constitui isso nenhuma novidade" (Agravo de Instrumento n ${ }^{\circ} 462$ 831/9, julgado em 12.11 90, 2a Câmara, Relator Juiz Senna Rebouças)".

${ }^{894}$ VALVERDE, Trajano de Miranda. Comentários à lei de falências. 4. ed., Rio de Janeiro: Forense, 2001, vol. II, p. 176.
} 
E o autor prossegue, para completar seu raciocínio, noticiando que a "razão fundamental" para se chegar à decisão de venda por intermédio de propostas "deve estar na impossibilidade ou, pelo menos na inconveniência de separar coisas ou objetos, que se completam, ou de desorganizar a empresa ou o estabelecimento do falido."

Daí porque nem sempre será fácil ao juiz promover a apreciação das propostas. Evidentemente, o magistrado poderá ser instado a decidir se a proposta vencedora é a de preço mais elevado ou se é a que prevê a manutenção da organização de certos bens, sem que, pela venda, seja preciso desmantelar o estabelecimento do falido ${ }^{896}$.

Com relação ao pregão, novidade trazida pelo atual sistema, trata-se de modalidade que se inicia com o recebimento de propostas lacradas, das quais são selecionadas outras com valor de, pelo menos, $90 \%$ da maior oferta, realizando-se, entre estas, lances orais para se chegar ao vencedor.

Em todas as modalidades de venda analisadas e, em especial, no pregão, a finalidade será sempre obter o melhor equilíbrio no resultado de alienação, levando-se em consideração o benefício dos credores e a preservação da empresa. É impostante destacar que caberá ao juiz decidir, enquanto o administrador judicial e o comitê de credores têm função opinativa quanto à modalidade e às condições da alienação a serem adotadas ${ }^{897}$.

É relevante referir que há possibilidade de adoção simultânea de mais de uma modalidade de venda ${ }^{898}$ se a circunstância concreta assim o demandar. Parte dos bens seria vendida por uma modalidade e o restante por outra.

Tudo dependerá de equilibrar os interesses entre o melhor resultado financeiro da venda e a possibilidade de manutenção dos ativos organizados. A adoção de

\footnotetext{
${ }^{895}$ VALVERDE, Trajano de Miranda. Comentários à lei de falências, 4. ed., Rio de Janeiro: Forense, 2001, vol. II, p. 176.

${ }^{896}$ Em setores de atividade rentáveis e com crescimento, o valor dos ativos individualmente considerados tende a ser menor que o seu conjunto; em setores decadentes, espera-se o contrário (COPELAND, Tom; KOLLER, Tim; MURRIN, Jack. Valuation: measuring and managing the value of companies, 2. edition, New York: John Wiley \& Sons, 1995, p. 295).

${ }^{897}$ Anote-se a opinião em contrário de NEGRÃO, Ricardo. Manual de direito comercial e de empresa. Vol. 3, 5. edição, Saraiva, 2010, p. 539.

${ }^{898}$ COELHO, Fabio Ulhoa. Comentários à nova lei de falências e de recuperação de empresas. São Paulo: Saraiva, 8. edição, 2011, p. 492.
} 
qualquer modalidade de alienação dos ativos na falência deve atuar como meio de atingir os fins propalados no artigo 75 da lei concursal.

O objetivo foi otimizar a venda dos ativos. Há outras modalidades de alienação que a doutrina nomeou de "extraordinárias", especificadas nos artigos 144 e 145 da lei; não constituem inteira novidade, já que as disposições tentaram aprimorar a previsão do artigo 123 do revogado DL n. 7.661/45.

$\mathrm{Na}$ primeira delas, conforme previsto no artigo 144, ficam autorizadas “modalidades de alienação diversas das previstas no art. 142 desta lei", desde que existam motivos justificados e o administrador judicial ou o comitê de credores a requeiram. Como bem colocado por Ricardo Bernardi, deverão "consunstanciar-se em razões de natureza econômica ou mercadológica." 899

Parece cabível, portanto, na situação de bens de pequeno valor ou que possam despertar interesse em reduzido círculo de interessados. Mesmo assim, e como já sustentado acima, a alienação deve ser cercada de um mínimo de publicidade $^{900}$, a fim de se outorgar transparência ao ato e a certeza de sua regularidade, mediante fiscalização de todos os interessados.

A propósito da hipótese, Euler da Cunha Peixoto recorda sobre a possibilidade de aplicação de venda por negociação particular, inspirado no direito francês "quando o tipo dos bens, sua localização (se imóveis) e a natureza da oferta forem de tal forma que se possa presumir a possibilidade de melhores resultados através da negociação particular, a qual só poderia ser concretizada por um preço mínimo fixado pelo juiz, acima do de avaliação do bem." $" 901$

\footnotetext{
${ }^{899}$ Comentários à lei de recuperação de empresas e falência, obra coletiva organizada por Francisco Satiro de Souza Jr. e Antonio Sérgio A. de Moraes Pitombo. São Paulo: Revista dos Tribunais, 2. edição, 2007, p. 499.

${ }^{900}$ É importante referir que há meios de publicidade de pequeno custo e bastante eficientes. A criatividade dos operadores do direito fez instituir-se a divulgação de informações de recuperações judiciais de grande porte em sites criados para essa finalidade. Assim, nada impede que o administrador judicial se encarregue da criação de um site, além de correspondência eletrônica, para divulgação, aos representantes dos credores e demais interessados no processo, das informações e atos processuais. Estabelecer-se-ia, assim, a um custo bastante reduzido, uma eficiente divulgação de certos atos do processo falimentar.

901 'In' CORRÊA-LIMA, Osmar Brina, LIMA, Sérgio Mourão Corrêa (coord.). Comentários à nova lei de falências e recuperação de empresas. Rio de Janeiro: Forense, 2009, p. 991.
} 
$\mathrm{Na}$ outra modalidade de alienação extraordinária, prevista no artigo 145, podem os credores, reunidos em assembleia, deliberar a aprovação, desde que atingido o quórum mínimo de dois terços dos créditos presentes, conforme estabelece o artigo 46 da "constituição de sociedade de credores ou dos empregados", com a "participação dos atuais sócios ou de terceiros".

Nesse caso, a divulgação desta modalidade de alienação resulta do próprio ato de convocação de assembleia de credores. Disto resulta a importância de que a convocação se faça com menção a todos os detalhes de importância que resultarão na forma de pagamento escolhida. A propósito, Sergio Campinho anota que, se aprovada regularmente essa modalidade de venda dos ativos, ao juiz caberá somente homologá-la ${ }^{902}$.

Todavia, a lei é omissa quanto à solução de pagamento para os credores dissidentes (que não desejarem se integrar à sociedade) ou que não exercerem seu direito de voto. É evidente, se aprovada alienação pela modalidade de constituição de sociedade da qual façam parte os credores, não podem ser compelidos a integrar a sociedade os credores omissos e tampouco os dissidentes ${ }^{903}$.

Sergio Campinho entende que os credores que não desejarem participar da sociedade "devam ser pagos pela maioria, em dinheiro, respeitado o preço de avaliação, com dedução das quantias correspondentes às restituições e ao pagamento dos créditos extraconcursais." ${ }^{904}$, solução que é compatível com o que previa o $§ 5^{\circ}$ do artigo 123 do revogado DL n. 7.661/45.

$\mathrm{Na}$ visão de Marcelo Papaléo, a sociedade formada por empregados do próprio devedor evidencia a finalidade pretendida pelo legislador de preservação dos postos de trabalho ${ }^{905}$, sendo viável sua constituição sob a forma de cooperativa, inspirado no direito concursal argentino, que passou a prever expressamente essa modalidade, na reforma pela Ley 25.589/02 (artigo 190).

\footnotetext{
${ }^{902}$ CAMPINHO, Sergio. Falência e recuperação de empresa - o novo regime da insolvência empresarial. 5. edição, São Paulo: Renovar, 2010, p. 437.

903 TOMAZETTE, Marlon. Curso de direito empresarial. Vol. 3, São Paulo: Atlas, 2011 , p. 509.

${ }^{904}$ CAMPINHO, Sergio. Falência e recuperação de empresa - o novo regime da insolvência empresarial. 5. edição, São Paulo: Renovar, 2010, p. 438.

905 SOUZA, Marcelo Papaléo de. A nova lei de recuperação e falência e as suas consequências no direito e no processo do trabalho. São Paulo: LTR, 2006, p. 307.
} 
Na mesma linha caminha Manoel Justino Bezerra Filho, para quem “ $a$ possibilidade de formação de sociedade de empregados deve ser prestigiada, pois, mesmo no regime da lei anterior, diversos casos ocorreram nos quais os próprios empregados, normalmente agregados em cooperativa, passaram a cuidar da empresa, propiciando o regular prosseguimento das atividades."

Por fim, o artigo 146 estabelece, pragmaticamente, a dispensa de apresentação das certidões negativas para realização dos atos registrários decorrentes de alienação em processo de falência, medida esta necessária para, de um lado, concretizar a alienação e, por outro, reafirmar a inexistência de sucessão de qualquer obrigação. A disposição evita controvérsia a respeito do tema, como houve no passado ${ }^{907}$.

Registra-se, assim, que os dispositivos que regulam a alienação dos bens na falência procuram equilibrar a satisfação dos credores com a possibilidade de preservação da empresa.

\subsubsection{A adjudicação prevista no artigo 111 da Lei n. 11.101/05.}

O artigo 111 da Lei n. 11.101/05 autoriza o juiz a proceder à alienação dos bens arrecadados, no interesse da massa falida, mediante aquisição ou adjudicação pelos credores (de forma individual ou coletiva) pelo valor da arrecadação, justificada nos “custos e no interesse da massa falida". A lei determina, ainda, que seja atendida a regra de classificação e preferência entre os credores nessa modalidade de alienação.

A doutrina, de modo geral, nomeou a hipótese de 'liquidação sumária', justificada pela arrecadação de poucos ativos ou bens de valor pouco expressivo e que

\footnotetext{
${ }^{906}$ Lei de Recuperação e Falências comentada. São Paulo: Revista dos Tribunais, 7. edição, 2011, p. 308.

907 "Processual Civil e comercial - Venda de bens da massa falida - Desnecessidade de apresentação de prova de quitação de débitos previdenciários - Interpretação do art. 31 da Lei n. 6830/80 - Não é absoluta a proibição contida no art. 31 da Lei $n$. 6830/80, por isso mesmo que a norma nela inserta deve ser interpretada com temperamento, daí ser possível a alienação judicial de bem da massa falida sem a prova de quitação da dívida ativa ou concordância da Fazenda Pública, desde que realizada, como no caso, obedecendo a todos os requisitos do art. 117 e seus $\$ \S$ da lei de falências, não verificada qualquer irregularidade - Recurso não conhecido." (REsp. n. 25799/SP, relator Ministro Cesar Asfor Rocha, j. 18/12/1997).
} 
seriam, em tese, insuficientes para custear todo o trâmite procedimental da falência, o que justificaria a venda direta aos credores ou a um credor.

Nessa linha de ideias segue Sergio Campinho, para quem "a decretação da falência de micro e pequenos empresários não raras são as vezes em que o diminuto patrimônio arrecadado sugere a inviabilidade de se arcar com os custos necessários a uma venda ordinária ou extraordinária do ativo."908

A verdade é que o dispositivo será de remota aplicação, ante outras restrições feitas pelo legislador. De qualquer forma, algumas considerações a respeito do tema merecem ser feitas.

A começar pela circunstância de que tal modalidade de alienação, aquisição ou adjudicação aos credores excepciona, expressamente, as regras dos artigos 46 e 145 da Lei n. 11.101/05. Vejamos.

A conjugação dos artigos 46 e 145 da lei concursal vigente determina que qualquer modalidade de alienação diversa do leilão, proposta ou pregão ${ }^{909}$, deve ser aprovada por assembleia geral de credores, com quórum mínimo de dois terços dos créditos presentes. $\mathrm{O}$ artigo 35 , II, 'c' igualmente prevê que a adoção de modalidade 'extraordinária' de realização do ativo constitui atribuição da assembleia geral de credores.

$\mathrm{Na}$ hipótese em análise, há expressa exceção ao princípio da indelegabilidade das atribuições da assembleia de credores $^{910}$, eis que incumbe ao magistrado autorizar a arrecadação ou adjudicação aos credores, na modalidade prevista pelo artigo 111 da lei concursal vigente.

Obviamente, a visão pragmática do legislador, no caso, impôs tal solução, em particular, porque a lei vigente não faz qualquer alusão ao que a doutrina denominou de

\footnotetext{
${ }^{908}$ CAMPINHO, Sergio. Falência e recuperação de empresa - o novo regime da insolvência empresarial. 5. edição, São Paulo: Renovar, 2010, p. 432.

909 Artigo 142 da Lei n. 11.101/05.

${ }^{910}$ VALLADÃO A. N. E FRANÇA, Erasmo. Comentários à lei de recuperação de empresas e falência, obra coletiva coord. Francisco Satiro de Souza Jr.; Antonio Sergio M. Pitombo. São Paulo: Revista dos Tribunais, 2. edição, 2007, p. 198.
} 
"processamento sumário da falência"911, como era previsto no artigo 200 do revogado DL n. 7.661/45, com fundamento no que dispunha o artigo 75 do mesmo diploma ${ }^{912}$.

Outra questão a ser analisada diz respeito ao fato de que a liquidação sumária prevista no artigo 111 somente poderia ser implementada se atingisse a totalidade dos bens arrecadados. A doutrina divide-se a respeito do tema, sendo que alguns sustentam afirmativamente $^{913}$, embora exista quem, em visão mais liberal, julgue possível a venda de apenas alguns dos bens ${ }^{914}$.

Partilha-se desta última opinião, apoiados na visão pragmática que a medida envolve. Não parece razoável dificultar a aplicação da solução, razão pela qual se recomenda permitir que alguns bens possam ser, de algum modo, reaproveitados, por venda parcial, sem que isto implique no custeio do regular trâmite procedimental da falência, que poderia até mesmo anular o pequeno resultado que a alienação sumária proporcionaria.

A venda dos bens poderia ser parcial, porque a garantia formal de que não haverá prejuízo aos interesses dos credores está prevista na conjugação dos seguintes fatores: o valor de venda será o de avaliação e, necessariamente, serão atendidas as regras de classificação e preferência entre os credores.

A questão de maior dificuldade, e para a qual não há outra solução, é a de que a obrigatoriedade de atender as regras de classificação e preferência entre os credores tornará a aplicação prática deste dispositivo muito improvável, senão impossível.

\footnotetext{
911 BEZERRA FILHO, Manoel Justino. Lei de falências comentada. São Paulo: Revista dos Tribunais, 2. edição, 2003, pp. 283, 521, 522 .

912 "Se não forem encontrados bens para serem arrecadados, ou se os arrecadados forem insuficientes para as despesas do processo, o síndico levará imediatamente o fato ao conhecimento do juiz, que, ouvido o representante do Ministério Público, marcará por editais o prazo de dez dias para os interessados requererem o que for a bem dos seus direitos".

${ }^{913}$ Como é o caso de TEPEDINO, Ricardo. Obra coletiva coord. TOLEDO, Paulo Fernando Campos Salles; ABRÃO, Carlos Henrique. Comentários à lei de recuperação de rmpresas e falência. 4. edição, São Paulo: Saraiva, 2010, p. 413) e FRANCO, Vera Helena de Mello e SZTAJN, Rachel. Falência e recuperação de empresa em crise. Rio de Janeiro: Elsevier/Campus, 2008, p. 197.

${ }^{914}$ TOMAZETTE, Marlon. Curso de direito empresarial. Vol. 3, São Paulo: Atlas, 2011, p. 510.
} 
Se houver algum credor que não tenha sido satisfeito em cumprimento à ordem de preferência do artigo 84 da Lei n. 11.101/05 (depois de atendidos os créditos extraconcursais, previstos no artigo 83), dificilmente existirá condição de se autorizar a arrematação ou a adjudicação dos ativos na forma prevista pelo artigo 111 em análise.

Neste ponto, não há como deixar de invocar o disposto no $§ 5^{\circ}$ do artigo 123 do DL n. 7.661/45, que dispunha quanto à possibilidade de pagamento em dinheiro dos credores dissidentes da liquidação decorrente da formação de sociedade de credores ${ }^{915}$. É difícil saber se, na prática, o eventual pagamento, em dinheiro, de credores não interessados na adjudicação ou arrematação poderia favorecer a aplicação da solução proposta pelo artigo 111 .

Em geral, a solução encontrada pelo legislador para encaminhar a falência com pequena arrecadação é salutar; essa linha de pensamento tem sido acolhida pela doutrina $^{916}$, apesar da crítica que se pode fazer a essa forma de pagamento típica do processo de execução singular $^{917} \mathrm{e}$, portanto, com dificuldade de incidência ante a especialização das regras do direito concursal.

3.3 O pagamento dos credores, o encerramento da falência e a extinção das obrigações.

Não há como negar, mesmo ante a nova principiologia que rege a falência, estabelecida nas balizas do artigo 75 da Lei n. 11.101/05 - que, curiosamente, nada menciona a respeito dos direitos dos credores ${ }^{918}$-, que o pagamento destes ainda constitui

\footnotetext{
${ }^{915}$ Embora a solução daquele dispositivo seja criticada por Julio K. Mandel, que entendia tal pagamento em dinheiro inviabilizador da solução legal. (MANDEL, Julio. Nova lei de falências e recuperação de empresas anotada. São Paulo: Saraiva, 2005, p. 78).

916 TEPEDINO, Ricardo. Obra coletiva coord. TOLEDO, Paulo Fernando Campos Salles; ABRÃO, Carlos Henrique. Comentários à lei de recuperação de empresas e falência. 4. edição, São Paulo: Saraiva, 2010 , p. 413); FRANCO, Vera Helena de Mello. (obra coletiva, SATIRO DE SOUZA JR., Francisco; PITOMBO, Antonio Sergio A. de Moraes (coord.). Comentários à lei de recuperação de empresas e falência. 2. edição, São Paulo: Revista dos Tribunais, 2007, p. 432; e, TOMAZETTE, Marlon. Curso de direito empresarial. Vol. 3, São Paulo: Atlas, 2011, p. 510.

917 PUGLIESI GARDINO, Adriana Valéria. A evolução do tratamento jurídico da empresa em crise no direito brasileiro. Dissertação de mestrado, Universidade de São Paulo, 2006, p. 195, nota 601.

${ }^{918}$ Ao contrário do artigo 47 da Lei n. 11.101/01, que menciona, expressamente, o interesse dos credores como um dos objetivos a ser atendido na recuperação judicial. Embora, e baseada na interpretação que a doutrina francesa fez do artigo. $1^{\circ}$ do artigo da Lei 85-95, no qual o artigo 47 foi inspirado, a doutrina brasileira posiciona-se no sentido de que o dispositivo legal estabelece uma ordem de prioridade de interesses, no qual o dos credores é o último, em relação aos outros dois: manutenção da fonte produtora e dos empregos.
} 
uma das finalidades do instituto ${ }^{919}$. Deixou de ser, com a lei concursal brasileira atual, a única finalidade ${ }^{920}$.

Talvez, a menção ao interesse dos credores não tenha sido feita pelo legislador por ser desnecessária, ante o fato evidente de que a realização dos ativos realizase para atender ao pagamento dos credores. Não é por outra razão que Rubens Requião registra que "o processo falimentar pretende realizar a garantia que o patrimônio do devedor constitui para os credores" $" 921$.

Os poderes outorgados aos credores no procedimento falimentar evidenciam, claramente, que é no interesse destes - conquanto temperado pelas diretrizes do artigo 75 da lei -, que o procedimento se desenvolve.

Uma vez realizados os bens do devedor, o administrador judicial deverá providenciar o pagamento dos credores da falência. Observa-se que o pagamento destes, como já referido, somente será realizado depois de terem sido atendidos os créditos não sujeitos ao concurso $^{922}$ e os credores da massa pelos créditos denominados extraconcursais $^{923-924}$.

919 “... seu objetivo mais amplo é o pagamento de todos os credores do devedor empresário de acordo com a ordem legal de preferência. (...). A falência teria como objetivo principal assegurar a igualdade entre os credores de um devedor juridicamente insolvente (..........) A falência tem, portanto, como principal objetivo a segurança do crédito." (TOMAZETTE, Marlon. Curso de direito empresarial. Vol. 3, São Paulo: Atlas, 2011, p. 264).

920 "Na falência, o principal objetivo não é manter a atividade, mas afastar o devedor e maximizar seus ativos para pagar o maior número possível de credores." (TOMAZETTE, Marlon. Curso de direito empresarial. Vol. 3, São Paulo: Atlas, 2011, p. 272).

${ }_{921}$ Curso de direito falimentar. 16. edição, São Paulo: Saraiva, 1995, vol. 1, p. 325.

922 Como é o caso das restituições em dinheiro (artigo 86 da Lei n. 11.101/05), dos créditos compensáveis (art. 122 da Lei n. 11.101/05) e dos créditos sujeitos à atividade das clearing houses (arts. 193 e 194, da Lei n. 11.101/05). (cf.-se SATIRO DE SOUZA JR., Francisco; PITOMBO, Antonio Sérgio A. de Moraes (coord). Comentários à lei de recuperação de empresas e falência. São Paulo: Revista dos Tribunais, 2. edição, 2007, p. 360). Acrescenta-se, ainda, o pagamento em antecipação dos créditos trabalhistas, conforme previsto no artigo 151 da Lei n. 11.101/05).

${ }_{923}$ Mencionadas no artigo 84 da Lei n. 11.101/05.

924 " $O$ artigo 149, com efeito, deixa entrever uma ordem de prioridades. Alinha, em sequência, a realização das restituições, pagamento dos credores extraconcursais e, por fim, o pagamento dos credores concorrentes, atendido o sistema legal de classificação. A ideia que emerge do preceito vem referida no artigo 84 e pelo $\S$ único do artigo 86. No primeiro, tem-se assegurada a precedência dos créditos extraconcursais tão somente em relação aos créditos concorrentes. No segundo, fica patenteado que o atendimento das restituições em dinheiro somente tem como condição a antecipação dos créditos trabalhistas de natureza puramente salarial, naqueles limites explicitados, constantes dos artigo 151, não se lhe condicionando ao prévio pagamento dos créditos extraconcursais."(CAMPINHO, Sergio. Falência e recuperação de empresa - o novo regime da insolvência empresarial. 5. edição, São Paulo: Renovar, 2010, p. 442). 
Assim, abre-se a fase de encerramento do processo de falência, depois de realizado todo o ativo e efetuados os pagamentos possíveis aos credores. O administrador judicial deverá apresentar, então, suas contas e, a seguir, o relatório final, no qual "indicará o valor do ativo e o produto de sua realização, o montante do passivo e o dos pagamentos realizados, especificando, outrossim, as responsabilidades com que continuarão o falido e os sócios de responsabilidade solidária e ilimitada da sociedade falida." 925.

Uma vez feito o pagamento possível aos credores, o juiz decretará, por sentença, o encerramento do processo de falência ${ }^{926}$, conforme prevê o artigo 156 da Lei n. $11.101 / 05$.

Como relata Manoel Justino, “A sentença de encerramento de falência tem caráter meramente processual, permanecendo o devedor falido com todas as obrigações em aberto. A sentença de encerramento tem natureza processual, homologatória, continuando o devedor falido com a responsabilidade pelos débitos em aberto, de tal forma que, se forem encontrados novos bens, o processo de falência será reaberto para arrecadação e venda desses bens, para rateio entre os credores ainda não satisfeitos." 928 -929.

De qualquer modo, concluída a fase de pagamento dos credores, três possíveis situações podem ocorrer, como já lembrava Rubens Requião ${ }^{930}$ ainda na vigência

\footnotetext{
${ }^{925}$ CAMPINHO, Sergio. Falência e recuperação de empresa - o novo regime da insolvência empresarial. 5. edição, São Paulo: Renovar, 2010, p. 444.

926 "Todo proceso como hecho jurídico de naturaleza dinâmica, o sea, como contexto de actividades dirigidas a un fin debe, por definición, encontrar su momento de conclusión. Este problema se impone también en términos especiales para el proceso de quebra, ya sea con referencia a la metodologia, ya sea en orden a la compleja importancia jurídica de la etapa de clausura." (PAJARDI, Piero; KLEIDERMARCHER, Arnoldo; FARCHÍ DE MONTALBÁN, Diana; GEBHARDT, Marcelo; HUALDE, Paula M; MARTÍN PARDUCCI, Diego. Derecho concursal, verificación, liquidación, distribuición y clausura - Tomo 3, Buenos Aires: Editorial Ábaco de Rodolfo de Palma, 2011, p. 265).

${ }_{927}$ Lei de recuperação e falências comentada. São Paulo: Revista dos Tribunais. 7. edição, São Paulo, 2011, p. 320

928 No mesmo sentido: MANDEL, Julio. Nova lei de falências e recuperação de empresas anotada. São Paulo: Saraiva, 2005, pp. 254/255; ROUX AZEVEDO, Luis Augusto. In SATIRO DE SOUZA JR., Francisco; PITOMBO, Antonio Sergio A. de Moraes (coord.). Comentários à lei de recuperação de empresas e falência. 2. edição, São Paulo: Revista dos Tribunais, 2007, p. 517.

${ }^{929}$ Em sentido contrário, SZTAJN, Rachel in SALLES DE TOLEDO, Paulo Fernanco Campos; ABRÃO, Carlos Henrique (coord.). Comentários à lei de recuperação de empresas e falência. 4. edição, São Paulo: Saraiva, 2010, p. 532.

${ }_{930}$ Curso de direito falimentar, $16^{\mathrm{a}}$ edição, Saraiva, 1995, Vol. 1, p. 336.
} 
da lei revogada, ideias que são secundadas por Sérgio Campinho ${ }^{931}$ na apreciação do tema sob a óptica da lei vigente: (i) o ativo apurado foi suficiente ao pagamento do passivo; (ii) o ativo é inferior ao passivo, de modo que remanescem obrigações inadimplidas do devedor; (iii) o ativo é superior ao passivo, ou seja, há saldo a ser restituído ao falido.

Na primeira situação, o processo falimentar é encerrado, ficando desde logo autorizada a sentença de declaração de extinção das obrigações. Os credores foram pagos e não há saldo da venda a ser destinado ao devedor. Nesse caso, em se tratando de sociedade e por força de lei, fica autorizada a extinção da personalidade jurídica (depois da sentença que declare extintas as obrigações), e se empresário individual, poderá requerer sua reabilitação ${ }^{932}{ }^{933}$ e retomar o exercício da atividade empresarial.

Porém, se o ativo não bastar para pagamento do passivo, o devedor permanece obrigado pelo saldo remanescente dos créditos não atendidos na falência, o que é consequência do princípio acolhido pelo direito brasileiro de que o patrimônio do devedor, presente e futuro, responde por suas obrigações.

Nessa hipótese, as obrigações do falido remanescerão: (i) até a prescrição das obrigações (sendo que o prazo prescricional que estava suspenso com a decretação da quebra retoma sua fluência com o trânsito em julgado da sentença de encerramento); (ii) se não for possível declarar, por sentença, a extinção das obrigações por força de pagamento de mais da metade dos créditos quirografários (e que o falido está autorizado a complementar, mediante depósito do saldo necessário); (iii) até o decurso do prazo fixado nas hipóteses dos incisos III e IV do artigo 158 da Lei n. 11.101/05.

Somente depois de extintas as obrigações do devedor é que poderá, se empresário individual, retomar a atividade empresária, se desejar; ou, se sociedade

\footnotetext{
${ }^{931}$ CAMPINHO, Sergio. Falência e recuperação de empresa - o novo regime da insolvência empresarial. 5. edição, São Paulo: Renovar, 2010, pp. 445-446).

$932 \S$ único do artigo 102 da Lei n. 11.101/05.

${ }^{933}$ A inabilitação de que trata o artigo 102 da Lei n. 11.101/05 não se confunde com aquela que resulta da condenação criminal prevista no artigo 181, I do mesmo diploma. Esta última tem caráter de pena, tanto que deve ser motivada na sentença penal condenatória. Mas o que importa destacar é que esta perdura até cinco anos após a extinção da punibilidade ou, antes disso, por reabilitação penal (artigo 94 do CP). Acrescente-se mais uma distinção em relação à primeira: a inabilitação estende-se ao exercício de cargo ou função de gestão de empresa, tais como: diretoria, conselho de administração e até por mandato ou gestão de negócios (artigo 181. III).
} 
empresária, requerer e obter a extinção da personalidade jurídica ou retomar a atividade empresarial.

Cumpre lembrar, embora a decretação da falência seja causa de dissolução ${ }^{934}$ da sociedade empresária, a extinção da personalidade jurídica somente se operará ao final do procedimento liquidatório, depois de declaradas extintas as obrigações do falido $935{ }_{-}^{936}{ }_{-}^{937}{ }_{-}^{938}{ }_{-} 939$.

934 "A dissolução constitui ato declaratório decorrente de causas supervenientes à constituição da companhia, de natureza voluntária (deliberação da assembleia geral) ou coativa (judicial ou administrativa), que tem como efeito a cessação das atividades voltadas à consecução do objeto social, que são substituídas por aqueles procedimentos tendentes à liquidação do patrimônio social, gerido por liquidante. Terá como efeito a extinção da companhia se o processo de liquidação prosseguir até o final, ou seja, se não houver cessação do estado de liquidação." (CARVALHOSA, Modesto, Comentários à lei de sociedades anônimas. 3. edição atualizada, São Paulo: Saraiva, vol. 4, 2002, p. 18).

${ }^{935}$ Para Sergio Campinho essa afirmação não se aplica, pois o autor entende que a sociedade se extingue com a sentença de encerramento da falência: "A sociedade, por certo, não está sob essa regra, porquanto restará dissolvida e liquidada, desaparecendo a personalidade jurídica com o encerramento do processo falencial. Mas, a consequência só se tornará efetiva se o devedor vier a utilizar novos bens." (CAMPINHO, Sergio. Falência e recuperação de empresa - o novo regime da insolvência empresarial, 5. edição, São Paulo: Renovar, 2010, p. 446).

${ }^{936}$ Todavia, em posição contrária, está já referida decisão do AI n. 555.048-4/6-00, do TJ/SP, de relatoria do Desembargador Romeu Ricupero, que tem a seguinte ementa: Falência - Sentença de encerramento Pretensão de extinção da personalidade jurídica da sociedade falida - Inadmissibdidade - Mesmo depois de encerrado o processo, podem os antigos sócios reabilitar a sociedade empresária falida, revertendo os efeitos dissolutórios da falência, com o objetivo de fazê-la retornar à exploração da atividade — Em suma, sociedade falida que, mesmo depois de encerrada sua falência, pode requerer a extinção de suas obrigações e voltar a comerciar - Apelação não provida. (j. 28/05/2008).

${ }^{937}$ Marlon Tomazette também tem posicionamento diverso de Sergio Campinho: "Encerrado o processo de falência, Sérgio Campinho entende que a sociedade poderá ser extinta com a devida baixa no registro. Ousamos discordar desse entendimento. A nosso ver, a baixa só será possível com a extinção das obrigações do falido." (TOMAZETTE, Marlon. Curso de direito empresarial. Vol. 3, São Paulo: Atlas, 2011, p. 376).

938 "FALÊECIA. SENTENÇA DE ENCERRAMENTO. PRETENSÃO DE EXTINÇÃO DA PERSONALIDADE JURÍDICA DA SOCIEDADE FALIDA EM RAZÃO DA COMUNICAÇÃO DO ATO À JUNTA COMERCIAL. DESCABIMENTO. O mero encerramento da falência, com a comunicação do ato ao registro comercial, não conduz à dissolução da sociedade, à extinção das obrigações do falido ou à revogação do decreto de quebra. A personalidade jurídica da falida não desaparece com o encerramento do procedimento falimentar, pois a sociedade pode prosseguir no comércio a requerimento do falido e deferimento do juízo, ou mesmo, conforme determinava a anterior lei falimentar, requerer o processamento de concordata suspensiva. A sociedade falida perdura até que se promova o processo extintivo de suas obrigações, nos termos dos artigos 134 e 135 da anterior Lei Falimentar. A expedição de ofício comunicando o encerramento do procedimento falimentar à Junta Comercial não impede a cobrança dos créditos remanescentes ou que o falido ou o sócio da sociedade falida requeira a declaração judicial da extinção de suas obrigações. Recurso especial a que se nega provimento." (STJ, relatora Ministra Nancy Andrighi, RESP 883.802/DF, j. 24/4/2010).

939 No direito francês, opera-se idêntico mecanismo: "Le jugement de liquidation judiciaire emporte dissolution de la société, qui conserve néanmoins sa personalitté juridique pour le besoins de la liquidation et jusqu'à la clôture de celle-ci (art. L.1844-7, 7º, C.Civ.)."(SOUWEINE, Carole. Droit de l'entreprise en difficulté. 2. edition, PUG - Press Universitaires de Grenoble, 2007, p. 220). Em tradução livre: 'O julgamento de liquidation judiciaire importa dissolução da sociedade, que conserva, todavia, sua personalidade jurídica para os fins da liquidação e até o encerramento desta (artigo L.1844-7, $7^{\circ}$ C. Civ).' 
Vale a pena anotar a abordagem do tema feita por Paulo Fernando Campos Salles de Toledo, que desenvolveu, em sala de aula ${ }^{940}$, uma comparação com o procedimento de dissolução das sociedades, previsto no Código Civil ${ }^{941}$ e na Lei das Sociedades por Ações ${ }^{942}$. Na dissolução ordinária de sociedade, a extinção da personalidade jurídica tem lugar logo após o término do procedimento de liquidação (que se segue ao ato dissolutório). Após, concluída a liquidação, não há mais providência alguma a ser tomada nem como responsabilizar a sociedade ou os sócios por eventual passivo não atendido ${ }^{943}$.

A diferença em relação à falência está no fato de que essa é uma espécie particular de liquidação das sociedades, com regramento próprio, ou seja, por disposição expressa do artigo 158 da Lei n. 11.101/04, remanesce a responsabilidade da devedora até a sentença de encerramento das obrigações.

Para o professor Paulo Fernando Campos Salles de Toledo, apesar de haver uma proximidade entre os temas, são situações distintas. Na falência, há um momento posterior ao da liquidação dos ativos, que é o da sentença de extinção das obrigações e, somente depois disto, é que poderá a personsalidade jurídica ser extinta. Isso porque, acrescente-se ao argumento, se a falência fosse superavitária, haveria possibilidade, ao menos em tese, de reabilitação, caso em que a extinção da personalidade jurídica poderia não ocorrer, desde que houvesse ativo suficiente para o exercício de alguma atividade empresária.

Finalmente, a última alternativa possível para encerramento da falência. Ainda que raríssima, tem-se a hipótese de que, realizados todos os pagamentos aos

\footnotetext{
${ }^{940}$ Ministrada pelo professor Paulo Fernando Campos Salles de Toledo, no curso da pós-graduação da Universidade de São Paulo ("Recuperação de empresas e falências: análise da solução brasileira II"), no segundo semestre do ano de 2011, e do qual tive a honra de participar como aluna ouvinte.

${ }^{941}$ Artigo 51, $\S 3^{\circ}$ do CC.

${ }^{942}$ Artigo 219, I da Lei n. 6.404/76.

${ }^{943}$ Muito embora, Modesto Carvalhosa entenda diversamente: "Com a extinção cessa de existir um sujeito de direito autônomo e um patrimônio autônomo. Desaparecem os bens, os direitos e, assim, os créditos e os débitos sociais. Os acionistas tornam-se sucessores legais da companhia, na forma do quinhão que receberam de seu patrimônio remanescente (artigo 218). Não obstante a sucessão, não pode haver extinção se subsistirem credores conhecidos não satisfeitos. De qualquer forma, conhecidos ou desconhecidos, a extinção será irregular, recaindo responsabilidade sobre os acionistas e o liquidante." Mais adiante, entretanto, o mesmo autor afirma: "Em consequência de débitos desconhecidos, os respectivos credores terão legitimidade para agir somente contra os sócios e no limite do valor recebido na partilha, como sucessores legais que são da companhia extinta." (CARVALHOSA, Modesto. Comentários à lei de sociedades anônimas, 3. edição atualizada, São Paulo: Saraiva, vol. 4, 2002, pp. 171-173).
} 
credores, remanesça saldo em dinheiro. A lei prevê que esses recursos sejam entregues ao devedor, na forma prevista pelo artigo 153 da Lei n. 11.101/05. Nesse caso, se não houver inabilitação criminal, o empresário individual poderá retomar o exercício da atividade empresarial, depois de proferida sentença que declara a extinção das obrigações.

Mas se houver saldo e se se tratar de sociedade empresária, Sérgio Campinho registra que "Com a sentença que decretar a falência, tem-se verificada a causa dissolutória, desencadeando a liquidação do ativo para pagamento do passivo"944. Na mesma linha de ideias, Marlon Tomazette explica que "Nesse momento [decretação da falência] opera-se uma alteração no objetivo da sociedade. Ao invés de objetivar a produção dos lucros, a sociedade passa a objetivar o acerto de sua situação patrimonial. ${ }^{, 945}$.

Com posicionamento diverso, Fabio Ulhoa Coelho ${ }^{946}{ }_{-}^{947}$ sustenta que “Mesmo depois de encerrado o processo, podem os antigos sócios reabilitar a sociedade empresária falida, revertendo os efeitos dissolutórios da falência, com o objetivo de fazêla retornar à exploração da atividade - Em suma, sociedade falida que, mesmo depois de encerrada sua falência, pode requerer a extinção de suas obrigações e voltar a comerciar". Entretanto, o próprio autor ressalva que, na prática, talvez, essa não seja a melhor opção, pois seria mais simples mobilizar os recursos para constituir uma nova sociedade.

O caminho natural, portanto, e mesmo que resulte saldo da venda dos ativos, é que a sociedade se dissolva e seja extinta a personalidade jurídica, depois da sentença de extinção das obrigações.

\footnotetext{
${ }^{944}$ CAMPINHO, Sergio. Falência e recuperação de empresa - o novo regime da insolvência empresarial. 5. edição, São Paulo: Renovar, 2010, p. 445.

945 TOMAZETTE, Marlon. Curso de direito empresarial. Vol. 3, São Paulo: Atlas, 2011, p. 376.

946 Comentários à lei de falências e de recuperação de empresas. 8. edição, São Paulo: Saraiva, 2011, pp. $384 / 387$.

947 “.... se o empresario individual ou a sociedade empresária entra em falência com patrimônio de valor suficiente para atender à condição do art. 158, II da LF, poderá obter a declaração de extinção das obrigações logo após a realização do ativo (venda de bens e cobrança dos devedores), pagamento dos credores preferenciais e rateio em favor dos quirografários do produto apurado. Se, em seguida, reconstituir seu patrimônio, os credores existentes ao tempo da falência não poderão comprometê-lo, ao passo que o devedor não empresário na mesmíssima situação poderia ter seu patrimônio reconstituído executado até integral pagamento do passivo(..)." (COELHO, Fábio Ulhoa. Comentários à nova lei de falências e de recuperação de empresas. São Paulo: Saraiva, 8. edição, 2011, pp. 275-276). E o autor considera essa situação como um "privilégio que o procedimento falimentar concede aos falidos."
} 
Mesmo porque, a empresa não mais disporia de estabelecimento (todos os ativos foram alienados), ou seja, não lhe restariam elementos necessários e suficientes ao exercício da empresa (atividade), pois, como lembra Marlon Tomazette, a falência acarreta o "fim do patrimônio social e, consequentemente, à inexiquibilidade de qualquer objetivo a que se tenha proposto a sociedade."948

Ao final do processo de liquidação iniciado com a falência, a dissolução da sociedade e extinção da personalidade jurídica da falida serão uma consequência natural e, nisto, o procedimento concursal não difere do sistema anterior. A falência ainda é um procedimento liquidatório com propósito de pagamento dos credores.

A diferença fundamental no instituto da falência no regime vigente está, como já dito, no fato de que a finalidade liquidatória deixou de ser a única, pois o artigo 75 da Lei n. 11.101/05 destaca outra, de igual relevo. A verdade é que, ao dispor sobre o novo objetivo da falência, o referido dispositivo induz o aplicador do direito a uma hermenêutica diferenciada do procedimento liquidatório.

Nesse sentido, pode-se afirmar que a falência deixou de ser execução coletiva, na medida em que tal definição é deficiente e incompleta, posto que desconsidera o atual enfoque que imprime ao instituto novos ares, pois, como certifica Julio Mandel: "Na nova lei, essa visão foi substituída pelo interesse maior de preservar a unidade produtiva, e, na impossibilidade de manter o devedor na atividade" 949.

Tanto isso procede que Sergio Campinha assevera, com razão, que " $O$ sistema de liquidação do ativo sofreu profunda alteração na disciplina introduzida pela Lei $n$. 11.101/05" "950. Isso porque, as fases de "informação" e "liquidação" que antes eram perfeitamente distintas na falência no regima do DL n. 7.661/45 atualmente deixaram ser ser autônomas.

\footnotetext{
${ }^{948}$ TOMAZETTE, Marlon. Curso de direito empresarial. Vol. 3, São Paulo: Atlas, 2011, p. 376.

${ }^{949}$ MANDEL, Julio. Nova lei de falências e recuperação de empresas anotada. São Paulo: Saraiva, 2005, p. 148.

${ }^{950}$ CAMPINHO, Sergio. Falência e recuperação de empresa - o novo regime da insolvência empresarial. 5. edição, São Paulo: Renovar, 2010, p. 430.
} 
Tudo isso porque o processo falimentar deverá conduzir-se prestigiando a solução de liquidação, mas sem descuidar da possibilidade de aproveitamento da organização de bens preexistentes. Eis aí o elemento central de mudança do instituto.

3.4 Análise do artigo 75 da Lei n. 11.101/05 e as novas finalidades da falência.

É preciso reiterar, logo de início, que a principiologia que regula a Lei n. 11.101/05 é a da preservação da empresa, aplicável tanto à recuperação judicial quanto à falência ${ }^{951}$.

Não que tal fundamento se traduza em escapismo ou solução assistencialista para se tentar preservar a empresa em qualquer situação, como antes já se aduziu. Na recuperação judicial, a preservação da empresa é reservada às que demonstrarem viabilidade econômico-financeira e na falência, o mecanismo é de preservação da organização dos ativos e dos contratos correlatos que sejam importantes para sustentar a atividade econômica. Mas nem sempre a melhor solução de mercado seja a de preservação. O importante é destacar que, mesmo na falência, há possibilidade de preservação da empresa.

Carlos Henrique Abrão anota que "embora decretada a falência, isso não significa, em absoluto, a deterioração do parque industrial, das instalações, enfim dos bens corpóreos e incorpóreos, e, nesse passo a legislação avançou com grande capacidade de percepção.", pois, como observa, esta busca "a preservação dos bens integrantes do acervo patrimonial" com a finalidade de dar "aos credores instrumentos seguros de chace quanto ao recebimento de seu crédito." 952

$\mathrm{Na}$ mesma linha está o pensamento de Marlon Tomazette, para quem o artigo 75 da lei outorga outro viés à falência, assegurando existir "um objetivo mais específico, no sentido da maximização do valor dos recursos produtivos do devedor. Essa maximização atenderá aos interesses dos credores, na medida em que permitirá a obtenção de mais recursos e, consequentemente, o pagamento de mais credores." $\mathrm{O}$ autor

\footnotetext{
${ }^{951}$ Vide nota de rodapé n. 53, citação de Nancy Andrighi.

952 'In' obra coletiva coord. TOLEDO, Paulo Fernando Campos Salles de.; ABRÃO, Carlos Henrique, Comentários à lei de recuperação de empresas e falência. São Paulo: Saraiva, 4. edição, 2010, pp. $286-287$.
} 
conclui que "essa maximização poderá permitir a continuação da atividade com outro sujeito. Não se busca apenas a eliminação de empresas arruinadas, mas sim a otimização dos recuros produtivos com a possível continuação da atividade com outros sujeitos."

Não é diferente a ideia expressa por Carlos Klein Zanini, para quem a regra do artigo 75 "põe em evidência a preocupação da Lei com a preservação da empresa, ainda que seja necessário cometer sua exploração a outro sujeito". Prossegue afirmando que "De modo absolutamente compatível com os propósitos que a inspiraram, a Lei empresta ao fenômeno do desapossamento do devedor de seus bens uma coloração mais amena, justificando-a como meio necessário para a preservação dos bens ${ }^{954} d a$ empresa." 955

Como acentua Manoel Justino, “dentro do espírito da nova lei, que pretende recuperar a empresa, preservando-a, na falência a mesma busca existe, agora por preservação não mais da empresa, que é dissolvida pela falência (art. 1044 do Código Civil), e sim da atividade produtiva." 956

Sergio Campinho, por sua vez, noticia que "Deflui do artigo 75 da Lei a visão da preservação, otimização e utilização produtiva dos bens, ativos e recursos financeiros, econômicos e de pessoal -, inclusive os intangíveis que se encontram dispostos no exercício da empresa" 957 . O professor finaliza esclarecendo que "A ruína financeira nem sempre vai abalar certas unidades de produção que compõem, como um todo, a empresa." 958

O pragmatismo, que é atributo indissociável do direito comercial, mostrava, já à época da vigência da lei revogada, que o ideal de continuidade da atividade negocial constituía mesmo uma exigência, como aponta Manoel Justino, lembrando diversos casos

\footnotetext{
953 TOMAZETTE, Marlon. Curso de direito empresarial. Vol. 3, São Paulo: Atlas, 2011, p. 265.

${ }_{954} \mathrm{O}$ autor provavelmente quis dizer da organização dos bens da empresa.

955 ZANINI, Carlos Klein, 'in' SATIRO DE SOUZA JR., Francisco e PITOMBO, Antonio Sérgio A. de Moraes (coord). Comentários à lei de recuperação de empresas e falência, São Paulo: Revista dos Tribunais, 2. edição, 2007, p. 338.

${ }^{956}$ Lei de recuperação e falências comentada. São Paulo: Revista dos Tribunais, 7. edição, São Paulo, 2011, p. 188

957 CAMPINHO, Sérgio. Falência e recuperação de empresa - o novo regime da insolvência empresarial. 5. edição, São Paulo: Renovar, 2010, p. 304.

${ }^{958}$ CAMPINHO, Sérgio. Falência e recuperação de empresa - o novo regime da insolvência empresarial. 5. edição, São Paulo: Renovar 2010, p. 304.
} 
de "recuperação" tentados ou em efetivo andamento no Judiciário em procedimentos falimentares: "São casos nos quais a criatividade das partes e de seus advogados recebeu também criativo agasalho jurisdicional, de tal maneira que as empresas, mesmo após a falência, continuam se mantendo em funcionamento, com a tentativa de preservação da produção, dos empregos e com a consequente satisfação dos credores." 959

Em razão das mudanças no foco da lei, Nancy Andrighi, que partilha do mesmo entendimento em relação à falência, realça que "Fica claro, portanto, que estão superadas as visões clássicas da falência, que a tratam ora como um favor legal ao empresário, ora como um mero concurso em favor dos credores. O foco da falência passa a ser a intervenção na administração de uma organização que, em crise, não consegue mais harmonizar os interesses de todos aqueles que com ela se relacionam (credores, empregados, sócios, administradores e clientes). Prioriza-se a manutenção da organização empresarial, mesmo no caso de falência, para buscar nova harmonia em seu seio. $" 960$

Indubitavelmente, o sistema concursal brasileiro vigente inaugurou uma nova perspectiva em relação à falência ${ }^{961}$. Houve abandono do regime que a caracterizava como uma mera execução coletiva, conforme tom que lhe imprimia o DL n. 7.661/45, por força da influência do direito concursal italiano da época ${ }^{962}$.

\footnotetext{
959 BEZERRA FILHO, Manoel Justino. "Exame crítico do projeto da Lei de Falências - "Recuperação de empresa" ou "Recuperação do Crédito Bancário.", São Paulo: Revista dos Tribunais, abril/04, v. 822, p. 132. 960 'In' Comentários à nova lei de falências e recuperação de empresas - Lei n. 11.101/05, de 09 de fevereiro de 2005, coord. CORRÊA-LIMA, Osmar Brina; CORRÊA-LIMA, Sérgio Mourão. Rio de Janeiro: Forense, 2009, pp. 491-492.

961 Em relação ao direito concursal espanhol, Ibon Hualde López anota no mesmo senso: "Consequentemente, se puede entender que la nueva regulación concursal está desvirtuando, de alguna forma, la tradicional concepción de la liquidación, entendida como aquella parte del proceso concursal cuyo objeto consiste, unicamente, en la integra realización del patrimônio del deudor para satisfacer los créditos de sus acreedores con respeto al orden legal." (HUALDE LÓPEZ, Ibon. Régimen jurídico de la administración concursal en la fase de liquidación del concurso. Estudios de derecho concursal. 1. edición, Espanha: Thomson Civitas, 2009, p. 35). Veja-se, também: "la naturaleza del proprio procedimiento concursal ha variado sensiblemente, dejando de ser um proceso estrictamente executivo para convertirse en una instituición jurídica compleja; instituición a través de la cual se van a desarollar actuaciones de tipo ejecutivo, aunque ello no es óbice a que, junto al objetivo de satisfacción de los créditos de los acreedores, coexistam otro tipo de intereses protegibles. En última instancia, estos intereses se concretan en la conservación de la empresa y de los puestos de trabajo que se encuentran enpeñados en la misma." (idem, p. 49).

${ }^{962}$ E que lhe valeu a crítica de Fábio Konder Comparato: "é imperdoável que o legislador do século XX se deixe deslumbrar pelos ouropéis da moderna processualística, olvidando os problemas especificamente econômicos que a insolvência não deixa de suscitar, mormente quando atinge as grandes empresas" (COMPARATO, Fábio Konder. Aspectos jurídicos da macro-empresa. São Paulo: Revista dos Tribunais, 1970, p. 107).
} 
Tanto é certo que o exacerbado processualismo foi abandonado que a orientação pacificada do STJ destaca que o simples cumprimento dos requisitos objetivos prescritos no artigo 94 da Lei n. 11.101/05 já não é suficiente para impor a decretação da quebra, conforme se lê nos seguintes arestos:

“Comercial. Recurso Especial. Falência. DL 7.661/45. Títulos de valor insignificante frente ao princípio da preservação da empresa. Decreto de qubra. Descabimento. Precedentes. I. Nos termos da jurisprudência do STJ, “Apesar de o art. $1^{o}$ do Decreto-lei $n^{o} 7.661 / 45$ ser omisso quanto ao valor do pedido, não é razoável, nem se coaduna com a sistemática do próprio Decreto, que valores insignificantes provoquem a quebra de uma empresa. Nessas circunstâncias, há de prevalecer o princípio, também implícito naquele diploma, de preservação da empresa." (REsp 959695/SP, Relatora Ministra Nancy Andrighi, DJe 10/03/2009). II. Recurso especial não conhecido",963_964.

“Recurso Especial. Falência. Execução Frustrada. Não caracterização. Bens nomeados à penhora a destempo. Circunstância insuficiente para a decretação da falência do devedor. 1. A nomeação de bens à penhora na execução singular, ainda que realizada de forma intempestiva, descaracteriza a execução frustrada, circunstância que impede o prosseguimento do pedido de falência com base no art. $2^{o}$, inciso I, da antiga Lei de Quebras. 2. Nos requerimentos de decretação de falência, um dos princípios é o de que não pode a ação ser mero substitutivo de cobrança. Além do mais, deve-se ter em mira o princípio da preservação da empresa, afigurando-se desarrazoada a decretação da falência de quem não se

\footnotetext{
${ }^{963}$ REsp 598881/SC, Relator Ministro Aldir Passarinho Junior, $4^{\mathrm{a}}$ Turma, STJ, j. 15/12/2009.

${ }^{964}$ No mesmo sentido: AGRAVO REGIMENTAL. RECURSO ESPECIAL. PEDIDO DE FALÊNCIA. ÉGIDE DO DL 7.661/45. DÉBITO DE PEQUENO VALOR. INADMISSIBILIDADE. APLICAÇÃO DO PRINCÍPIO DA PRESERVAÇÃO DA EMPRESA. RECURSO DESPROVIDO. 1. A jurisprudência dominante desta Corte Superior é no sentido de que a decretação da falência, mesmo na sistemática da antiga Lei de Quebras (DL 7.661/45), apenas pode se dar quando a dívida não paga representar um valor considerável, haja vista a incidência do princípio da preservação da empresa. 2. Agravo regimental a que se nega provimento. (AgRg no REsp 997234/SP, Relator Ministro Vasco Della Giustina (desembargador convocado do TJ/RS), $3^{\mathrm{a}}$ Turma, STJ, j. 13/03/2011); EMPRESARIAL. FALENNCIA REQUERIDA SOB A ÉGIDE DO DECRETO-LEI $N^{o}$ 7.661/45. PEQUENO VALOR. PRINCÍPIO DA PRESERVAÇÃO DA EMPRESA IMPLÍCITO NAQUELE SISTEMA LEGAL. INVIABILIDADE DA QUEBRA. - Apesar de o art. $1^{o}$ do Decreto-lei $n^{o} 7.661 / 45$ ser omisso quanto ao valor do pedido, não é razoável, nem se coaduna com a sistemática do próprio Decreto, que valores insignificantes provoquem a quebra de uma empresa. Nessas circunstâncias, há de prevalecer o princípio, também implícito naquele diploma, de preservação da empresa. Recurso Especial não provido. (REsp 959695/SP, Relatora Ministra Nancy Andrighi, 3ª Turma, STJ, j. 17/02/2009).
} 
manteve absolutamente inerte na execução individual. 3. Recurso especial não conhecido"965.

É com esse mesmo enfoque que Sergio Campinho critica a adoção do critério da impontualidade como apto a caracterizar a falência, o que, segundo o autor, se manteve por pura tradição do direito brasileiro ${ }^{966}$.

Enfatize-se que a falência é um procedimento liquidatório, mas nem por isso significa o término ou a morte do negócio que, originariamente, era manejado pelo falido. Identifica-se, no instituto, uma perfeita separação entre a empresa e o empresário, na medida em que o afastamento deste último (e a consequente dissolução e extinção da personalidade jurídica de uma sociedade empresária) não acarreta, obrigatoriamente, o fim da atividade econômica que era desenvolvida pelo devedor.

Sempre que possível, o sistema concursal brasileiro procura preservar a organização de bens preexistentes. Destaque-se, por importante, esse não é um movimento isolado palmilhado pelo direito brasileiro. Como acima analisado, cada sistema estrangeiro abordado possui mecanismos próprios de manutenção da organização econômica, que é objeto de exploração pela empresa, mesmo na liquidação pela quebra. Diante da falência, buscam-se métodos que possam ser eficientes para manter essa organização, sempre que possível.

A ideia por trás desta tutela jurídica buscada pelo direito concursal, repitase, é de dúplice abordagem: de um lado, busca-se atender aos interesses dos credores e, de outro, conserva-se o valor agregrado que resulta da organização econômica dos bens que existe na empresa. Isso ocorre porque a empresa atende inúmeros outros interesses correlatos, além daqueles dos credores ${ }^{967}$.

\footnotetext{
${ }^{965}$ REsp 741053/SP, Relator Ministro Luis Felipe Salomão, 4ª Turma, STJ, j. 20/10/2009.

966 CAMPINHO, Sérgio. Falência e recuperação de empresa - o novo regime da insolvência empresarial. 5. edição, São Paulo: Renovar, 2010, pp. 260-263.

967 Waldírio Bulgarelli alerta para "o fato incontestável que a quebra das empresas põe em jogo não somente os credores, mas uma série de interesses que gravitam em torno da empresa, como os trabalhadores, os clientes, os fornecedores, os Estados, através dos tributos e da produção econômica e muitas vezes a própria comunidade onde se situa a empresa." ("A reforma da Lei de falências e concordatas", RDM 85, p. 52).
} 
A origem dessa ideologia, ínsita à preservação da empresa está intimamente relacionada à função social da propriedade, que, no ordenamento jurídico, é constitucionalmente tutelada ${ }^{968}$.

Como já tive ocasião de afirmar, "Parte-se, assim, do princípio de que a insolvência do devedor surte efeitos que transcendem aos interesses individuais entre o empresário e os seus credores, e por esta razão o instituto da falência não pode tratar exclusivamente da liquidação da empresa, mas, ao contrário deve encontrar meios de tutelar também a manutenção da atividade produtiva, dos postos de trabalho e da preservação da concorrência saudável ao mercado."969

Paralelamente, o desdobramento que revela a outra faceta da preservação da organização de bens preexistentes corresponde à possibilidade de manter o valor agregado que desta resulta. A consequência natural reflete-se no resultado da venda dos ativos na falência e a mais valia proveniente, em tese, resultará em melhor condição de pagamento dos credores.

Enquanto no Código Civil preferiu-se abordar o direito de empresa a partir da pessoa do empresário ${ }^{970 \_971}$, conceitualmente o direito concursal foi além, centrando a tutela da empresa na figura do agente econômico ${ }^{972}$, cuja atuação é voltada ao mercado e que funciona como um dos elos de uma verdadeira rede de relações jurídicas ${ }^{973}$. Essa afirmação, com efeito, pode ser extraída de uma primeira leitura do artigo 75 da Lei n. $11.101 / 05$.

\footnotetext{
968 Confira-se, a propósito PUGLIESI GARDINO, Adriana Valéria. A evolução do tratamento jurídico da empresa em crise no direito brasileiro. Dissertação de Mestrado, Universidade de São Paulo, 2006, pp. 3746.

969 PUGLIESI GARDINO, Adriana Valéria. A evolução do tratamento jurídico da empresa em crise no direito brasileiro. Dissertação de Mestrado, Universidade de São Paulo, 2006, p. 42.

${ }_{970}$ Artigo 966 do CC.

${ }^{971}$ FORTES BARBOSA FILHO, Marcelo. Código civil comentado, coor. Ministro Cezar Peluso. São Paulo: Manole, 3. edição, 2009, p. 936.

972 Considerando a empresa um "fenômeno sócio-econômico", Betyna Ribeiro de Almeida afirma que " $A$ noção jurídica da empresa foi inspirada em sua função como agende da produção e da circulação de bens $e$ serviços, que é inegável e deve ser destacada em todos os campos da realidade". (ALMEIDA, Betyna Ribeiro de. "Aspectos da Teoria Jurídica da Empresa". Revista de Direito Mercantil, Industrial Econômico e Financeiro, São Paulo, vol. 119, Ano XXXIX (nova série), jul/set 2000, p. 245).

973 A propósito, aliás, confira-se o excelente estudo de Fabio Konder Comparato a respeito da função social dos bens de produção, pela qual, classifica os bens organizados à produção de riquezas por sua finalidade $\mathrm{e}$ conclui pela existência de uma função social destes, posto que integram o ciclo econômico. (COMPARATO, Fabio Konder. "Função Social da propriedade dos bens de produção". Revista de direito mercantil, industrial, econômico e financeiro. São Paulo, vol.63, Ano XXV (nova série), pp. 71-79, jul/set 1986).
} 
É lamentável, pois, no que se refere ao critério subjetivo de alcance da lei brasileira, ter ficado restrita a adoção da teoria da empresa nos termos acolhidos pelo Código Civil ${ }^{974}$. Deveria o legislador ter estendido - a exemplo do que houve na reforma das leis alemã, espanhola, francesa e argentina - a tutela do direito concursal ao devedor, que desenvolve atividade econômica, seja ou não empresária.

Mas o que importa é relevar que não há dúvida de que a falência, enquanto procedimento liquidatório destinado a pagamento dos credores de um devedor em crise insuperável passou a ter como foco a manutenção da atividade produtiva. Essa afirmação fica evidente, ainda, por todos os mecanismos analisados de que a lei concursal lança mão para concretizar tal objetivo, tais como: a inexistência de sucessão das obrigações, a ordem prioritária de venda em bloco dos ativos, a possibilidade de formação de sociedade de credores e afins.

${ }^{974}$ TOLEDO, Paulo Fernando Campos Salles de.; ABRÃO, Carlos Henrique (Coord.). Comentários à lei de recuperação de empresas e falência. 4. edição, São Paulo: Saraiva, 2010, p. 50. 


\section{CAPÍTULO QUARTO \\ CONSIDERAÇÕES FINAIS: A FALÊNCIA PODE SER CONSIDERADA TAMBÉM MEIO DE PRESERVAÇÃO DE EMPRESAS?}

4.1 A falência e a recuperação judicial como procedimentos recuperatórios: o que as distingue?

Como distinguir o fundamento pelo qual uma empresa deva sujeitar-se à recuperação ou à falência no direito concursal brasileiro em vigor? Em que medida o saneamento por reorganização ou a liquidação pela falência poderá selar o destino do devedor em crise? A distinção é meramente procedimental ou é teleológica?

Sem qualquer pretensão de esgotar o debate sobre a matéria, são propostas aqui algumas ideias que parecem, ao menos, encaminhar para uma solução satisfatória das indagações sugeridas. Conveniente, antes, relembrar as funções do direito concursal, em particular, da falência.

Em seu nascimento, a função da falência restaria justificada em razão da necessidade de assegurar tratamento igualitário entre os credores ${ }^{975}$, eis que, uma vez caracterizada a impossibilidade de satisfação integral destes, seria essencial garantir a par

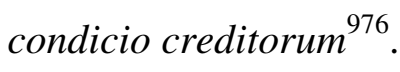

Outro aspecto funcional da quebra, de semelhante relevo, era a necessidade de preservação do tráfico mercantil seguro, de modo que era preciso afastar o devedor 'desonesto', o que justificava o caráter punitivo das regras falimentares, em particular observadas no direito medievo e que se perpetuaram em muitos sistemas legislativos.

Inegavelmente, a paridade dos credores é ainda objeto de tutela na atualidade do direito concursal; porém, tal aspecto cada vez mais se desloca do centro de

\footnotetext{
975 DASSO, Ariel Ángel. Derecho concursal comparado, Tomo I, Buenos Aires: Legis, 2009, p. 04.

${ }^{976}$ FERRARA, Francesco. Il fallimento, Milano, 1959, p. 43.
} 
interesses de maior relevo para um patamar secundário na análise do direito das empresas em crise ${ }^{977}$.

Igualmente, perdeu relevo, na falência, a função de caráter punitivo do devedor desonesto em desequilíbrio financeiro ou, como relata Ariel Dasso: "Aquel criterio del deudor 'onesto e sventurato' de arcaico itálico, 'malhereux mais de bonne foi', em su versión francesa, pierde pues sus últimos reflejos",978.

Em argumentação extremamente bem fundamentada, Nicola Jaeger contrapõe as funções antes referidas que reconhece vivas, no entanto insuficientes para justificar o nascimento (e a manutenção) da falência como um instituto com regras próprias.

Para o autor, a maior função que distingue e justifica a existência da falência como procedimento concursal de credores é assegurar o crédito ${ }^{979}$, cujo pressuposto fundamental e indissociável é a confiança (fiducia) entre os agentes do mercado.

O próprio nascimento do direito falimentar está indissociavelmente relacionado ao conceito de tutela e proteção do crédito. No direito medievo, as atividades mercantis eram fundamentalmente baseadas na confiança entre os mercadores contratantes, o que se justificava e era explicado pela dificuldade na segurança da comunicação, inerente aos recursos da época.

As características do direito falimentar foram sendo delineadas ante os costumes dos mercadores, tomando especial importância, por exemplo, a publicidade da declaração da quebra, o que se fazia para preservar o tráfico mercantil seguro, mediante proclamação e divulgação da decisão de falência nas praças públicas das cidades. Tal ocorria porque a publicidade sinalizava, ao mercado, a perda do crédito que sofria o falido.

\footnotetext{
${ }^{977}$ DASSO, Ariel Ángel. Derecho concursal comparado, Tomo II, Buenos Aires: Legis, 2009, pp. 917 e 924. $\mathrm{O}$ autor, com efeito, afirma textualmente que o tradicional princípio da par condicio creditorum, nos sistemas concursais analisados, vem admitindo exceções de forma crescente, o que o torna cada vez mais esvanecido. ${ }_{978}$ DASSO, Ariel Ángel. Derecho concursal comparado. Tomo II, Buenos Aires: Legis, 2009, p. 922.

979 JAEGER, Nicola. Il fallimento e le altre forme di tutela giurisdizionale. Milano: Casa Editrice Dr. Francesco Vallardi, 1964, pp. 65, 73, 82, 84.
} 
Em Veneza e Gênova, adotou-se o procedimento de quebrar a banca do devedor em lugar público ("banco rotto", de que, provavelmente, se originou a expressão bancarrota), para demonstrar, simbolicamente, que aquele mercador não mais estava habilitado a exercer suas atividades, já que não tinha condições de honrar as obrigações assumidas.

Assim sendo, dar publicidade da falência a terceiros tinha por fim impedir que novos negócios fossem realizados com o devedor, de modo a preservar a segurança das relações mercantis. Desde então, a tutela do crédito passou a ser uma das preocupações centrais do instituto da falência: com os meios disponíveis na época, a divulgação da quebra tinha por objetivo advertir os demais mercadores de que o falido não mais estava em condições de honrar suas obrigações, estando, portanto, sem crédito na praça.

O ideal de defesa do tráfico mercantil está na origem do próprio direito comercial, como aponta Paula Andrea Forgioni: "Desde a sua origem, o direito comercial liga-se ao mercado ${ }^{980}$, ordenando a dinâmica estabelecida entre os mercadores. Seu objetivo sempre se relacionou à tutela do trafico econômico, ou seja, à defesa do “interesse geral do comércio”, na expressão de Carvalho de Mendonça. Por essa razão, Teixeira de Freitas advertia que a proteção liberalizada pelo Código Comercial era em favor do comércio e não dos comerciantes" $" 981$.

Mais adiante, a professora completa: "O direito mercantil não é concebido para socorrer o agente individualmente considerado, mas o 'funcionamento do mercado'; o interesse da empresa é protegido na medida em que implica o bem do tráfico mercantil". Em seguida, ela finaliza com a seguinte conclusão: “Alcançaríamos sempre a mesma conclusão: o direito mercantil não busca a proteção dos agentes econômicos singularmente considerados, mas da torrente de suas relações” 982

\footnotetext{
${ }^{980}$ Como também anotava Tullio Ascarelli: "A atividade do empresário é, além disso, sempre dirigida ao mercado..." (ASCARELLI, Tullio. "A atividade do empresário" (tradução de Erasmo Valladão A. N. e França). Revista de direito mercantil, industrial econômico e financeiro, São Paulo, vol. 132, ano XLII (nova série), out/dez, 2003, p. 206).

${ }^{981}$ A evolução do direito comercial brasileiro: da mercancia ao mercado. São Paulo: Revista dos Tribunais, 2009 , pp. 14.

${ }^{982}$ A evolução do direito comercial brasileiro: da mercancia ao mercado. São Paulo: Revista dos Tribunais, 2009, pp. 15 (destaques da autora).
} 
O equilíbrio dessa torrente de relações é de capital importância para a boa compreensão do direito da crise das empresas, na medida em que busca este a tutela dos diversos interesses em jogo e não apenas de uma relação bilateral decorrente do direito das obrigações entre o devedor e seus credores ${ }^{983}$.

O já citado Nicola Jaeger é categórico ao afirmar que a própria tutela adequada da par condicio creditorum, objetivada na falência, somente tem significado para tornar possível a segurança do crédito ${ }^{984}$.

Assim, o sistema que integra o direito falimentar consiste em um regramento apto a fortalecer a garantia de pagamento dos credores, pois, parte-se da premissa de que não haverá recursos para pagamento de todos, o que torna necessário fixar regras para impedir que somente alguns, mais diligentes, se beneficiem. Em decorrência, um bom sistema concursal impedirá que a organização dos ativos seja desmantelada pela atuação isolada de um ou outro credor.

Em consequência, o processo concursal cria (ou deveria criar, quando eficiente) um estado geral de confiança entre os agentes econômicos, de tal sorte que um dos objetivos a ser alcançado, se eficiente, resultará na preservação do tráfico mercantil seguro, o que constitui medida de estímulo à atividade de produção e troca.

A argúcia de Carvalho de Mendonça já mostrava que a insolvência não é causa da falência, pois o devedor pode dispor de meios para pagar, se gozar de confiança suficiente para obter crédito: "do crédito depende a manutenção da vida industrial; não o perde aquele que tem muitas dívidas, mas quem realmente se coloca na situação de não

\footnotetext{
${ }^{983}$ Lorenzo Stanghellini afirma que a lei concursal é necessária "per dare ai creditori la massima probalità di avere quanto a loro spetta, in termini di capitali e interessi. In sintesi, la legge è necessaria perché, in presenza di una molteplicità di creditori di un imprenditori, le regole ordinarie in materia de inadiempimento delle obbligazioni, disegnati per regolari situazioni enormemente meno complesse, non funzionerebbero adeguatamente, o funzionerebbero con costi elevadissimi che verrebbero sostenuti dai creditori." (STANGHELLINI, Lorenzo. Le crisi di impresa fra diritto ed economia (le procedure di insolvenza). Bologna: Il Mulino, 2007, p. 30). Em tradução livre: 'para dar aos credores a máxima probabilidade de recebimento de sua espectativa, em termos de capital e juros. Em síntese, a lei é necessária porque na presença de uma multiplicidade de credores de um empresário, as regras comuns em matéria de inadimplemento de obrigações, desenhadas para regular situações enormemente menos complexas, não funcionariam adequadamente, ou funcionarim com custos elevadíssimos, que seriam suportados pelos credores.'

${ }_{984}$ JAEGER, Nicola. Il fallimento e le altre forme di tutela giurisdizionale. Milano: Casa Editrice Dr. Francesco Vallardi, 1964, pp. 88-89.
} 
poder pagar o que deve. O devedor que não possui dinheiro, não dispõe de valores realizáveis, ou não goza de crédito que lhe permita antecipar sobre esses valores, fica impossibilitado de pagar, tem de parar o curso dos seus negócios e cessar o comércio, manifestando, destarte, o seu estado de falência nos termos da lei" ${ }^{985}$.

A esta altura, pode-se reafirmar o que tantos já disseram, que, inegavelmente, uma das funções precípuas do direito concursal é a de tutela do crédito ${ }^{986}$ ${ }^{987}$, seja do ponto de vista da segurança do mercado (da preservação do tráfego mercantil seguro), seja da perspectiva de possibilidade de satisfação organizada dos direitos dos credores (que poderá se alcançada por um procedimento liquidatório ou por um reorganizatório). Não há, portanto, como afastar os credores ou a discussão sobre o crédito de que são titulares da situação de insolvência ou de crise do devedor.

O crédito, que tem como pressuposto indissociável a confiança, é exatamente o elemento divisor que definirá o destino da empresa em crise, pela falência ou pela recuperação, na concepção da atual lei concursal brasileira. Esse é o elemento de

\footnotetext{
985 J. X. Carvalho de Mendonça. Tratado de direito comercial brasileiro. 5. edição, São Paulo: Livraria Freitas Bastos, 1954, vol. VII, p. 193.

${ }^{986}$ VALVERDE, Trajano de Miranda. Comentários à lei de falências. 4. edição atualizada por J. A Penalva dos Santos e Paulo Penalva Santos. Rio de Janeiro: Forense, 1999. vol. I, p. 01; CARVALHO DE MENDONÇA, José Xavier. Das falências e dos meios preventivos de sua declaração. São Paulo: Typografia Brasil de Carlos Guerke \& Cia., 1899, p. 11; CARVALHO DE MENDONÇA, José Xavier. Tratado de direito comercial brasileiro. Vols. 7/8, n. 03; LOBO, Jorge ('in' obra coletiva coord. TOLEDO, Paulo Fernando Campos Salles de.; ABRÃO, Carlos Henrique, Comentários à lei de recuperação de empresas e falência, São Paulo: Saraiva, 4. edição, 2010, p. 211); FRANCO, Vera Helena de Mello e SZTAJN, Rachel. Falência e recuperação de empresa em crise. Rio de Janeiro: Elsevier Campus, 2008, p. 01; NERY, Sandra de Medeiros. "Concordata preventiva e suspensiva (Alguns Aspectos econômicos e contábeis". Revista de direito mercantil, industrial econômico e financeiro. São Paulo, vol. 118, Ano XXXIX (nova série), pp. 199218, julh/set 2000; CASTRO, Carlos Alberto Farracha. "O desvirtuamento da falência frustrada e a necessidade de adequação do rito ordinário". Revista de direito mercantil, industrial, econômico e financeiro. Vol. 122, Ano XL (nova série), abril/jun 2001, p. 60; JEANTIN, Michel; LE CANNU, Paul. Entreprises en dificulté, 7. edicion, Paris: Dalloz, p.135; DASSO, Ariel A. Derecho Concursal Comparado, Tomo I, Buenos Aires: Legis, 2009, p. 02; Ariel A. Derecho Concursal Comparado, Tomo II, Buenos Aires: Legis, 2009, p. 923; BARBIERI, Pablo C. Concursos y Quiebras - Ley 24.522 Comentada y Concordada, Buenos Aires: Editorial Universidad, 2006, pp. 232,234,260; FERNANDES, Luís A. Carvalho; LABAREDA, João. Código da Insolvência e da Recuperação das Empresas Anotado, Lisboa: Quid Juris, 2009, p. 22; ALEMÁN MONTERREAL, Ana. La Insolvencia - Una Questión de Terminologia Jurídica. Santiago de Compostela, Andavira Editora, 2010, pp. 127-131.

987 "Lo stato de insolvenza non è dunque rilevante di per sé, ma è rilevante in quanto l'ordinamento lo guarda attraverso il prisma del mercato finanziario, che ha espresso un giudizio negativo sulla solvabilità dell'imprenditor anche a scadenze lunghe". (STANGHELLINI, Lorenzo. Le crisi di impresa fra diritto ed economia (le procedure di insolvenza), Bologna: Il Mulino, 2007, p.126). Em tradução livre: 'O estado de insolvência não é, assim, relevante por si só, mas é relevante enquanto o ordenamento o analisa sob a óptica do mercado de financiamento, que expressou um juízo de valor negativo sobre a solvabilidade do empresário, também a longo prazo.'
} 
essência, enquanto outros fatores também colaborarão para o desfecho, na medida em que os credores deliberam com base nos resultados que advirão de uma ou outra escolha.

Ora, um plano de recuperação não é apenas uma promessa de pagamento (para composição do passivo), mas representa um cenário mais amplo, em que o devedor conquista (ou reconquista), em maior ou menor grau, a confiança de seus credores, na retomada de suas atividades, em certo prazo, em condições de manter (ou retomar) suas relações negociais e, mormente, para gerar recursos suficientes não apenas para efetuar pagamentos do passivo, mas para dar continuidade à atividade econômica.

Essa confiança desdobra-se em um aspecto subjetivo, relacionado ao comportamento do devedor (predominantemente na transparência das informações prestadas a respeito do cenário da crise, tais como suas causas e a fotografia real de sua situação econômico-financeira); como também sob o aspecto objetivo, de viabilidade no cumprimento das medidas de saneamento propostas para superação da crise e satisfação dos credores (há uma avaliação projetada de saneamento do negócio, que se projeta, basicamente, na possibilidade futura de satisfação das obrigações, sejam aquelas vencidas, sejam aquelas nascentes).

O saneamento da crise da empresa não se resume a um critério de adimplemento das obrigações originalmente avençadas. Trata-se, sobretudo, de um juízo de valor que os credores fazem a respeito do futuro e expressam a confiança que depositam em um negócio e no seu dirigente (quando se pretenda mantê-lo à frente da operação), para avaliar a possibilidade de conceder-lhe, ou não, crédito, autorizando-lhe, ou não, a reorganização pela via da recuperação judicial.

O binômio crédito e confiança são, indiscutivelmente, inseparáveis e constituem "Questão central no exercício de atividades econômicas, alvo de tutela específica, a confiança, particularmente, quando se traduz na concessão de crédito, antecede, em muito, a organização das empresas. Tanto é que desde a Antiguidade 
existiam normas predispostas para estimular os devedores a adimplir.", como anota Rachel Sztajn ${ }^{988}$.

De fato, se os credores decidirem que não têm suficiente confiança no devedor e no plano por ele apresentado ${ }^{989}$, a desaprovação poderá ${ }^{990}$ resultar na falência.

Ao lado e paralelamente a essa questão, da confiabilidade, a ser demonstrada pelo devedor, os credores certamente farão uma análise de risco das perdas a que se sujeitarão, para tomar sua decisão quanto à proposta do devedor. Isso significa que o procedimento reorganizatório, em que o devedor permanece à frente dos negócios, não poderá ser mais oneroso para os credores do que um processo de liquidação pela falência.

Portanto, se houver possibilidade de minimização das perdas com a adoção de um procedimento reorganizatório, sempre levando em conta a fidúcia (credibilidade) que o plano apresentado pelo devedor desperta, esta será a opção dos credores. Caso contrário, a falência, ou seja, um procedimento liquidatório, será o caminho.

Essa ideia destaca o fato de que a falência, enquanto procedimento de liquidação, do ponto de vista da análise econômica que se costuma fazer a respeito dos interesses em jogo, é o instituto de maior relevância, pois os credores partem de uma análise desta para fazer sua escolha no que respeita à admissão de um procedimento reorganizatório do devedor. Vale dizer: os credores questionam se terão alguma vantagem no procedimento reorganizatório em relação ao resultado que obteriam na falência. Por isso, a quebra acaba sendo o ponto de partida na análise feita pelo credor.

Nesse sentido, para Lorenzo Stanghellini: “tale funzionamento [de escolha dos credores] si comprende meglio se si comincia ad analizzare la dialética fra debitore e creditore partendo dall'ultimo fotogramma: quello della liquidazione. $\grave{E}$ questa, $e i$

\footnotetext{
${ }^{988}$ FRANCO, Vera Helena de Mello e SZTAJN, Rachel. Falência e recuperação de empresa em crise. Rio de Janeiro: Elsevier Campus, 2008, p. 01).

${ }^{989}$ No direito norte-americano, no início do procedimento reorganizatório previsto no Chapter 11 ocorre uma audiência, com a presença dos dirigentes do devedor, na qual devem prestar todos os esclarecimentos solicitados pelos credores. Esta audiência está calcada na ideia de 'disclosure' das informações que cercam a situação de crise do devedor, para que os credores possam tomar uma decisão consciente em suas deliberações. No pano de fundo, entretanto, há um elemento psicológico envolvido, que é exatamente o da confiança de que o devedor conseguirá transmitir aos credores, quanto a viabilidade de seu plano.

${ }^{990}$ Exceto se houver previsão, no ordenamento, de sistemas de aprovação judicial, tal como o cram-down, originário do direito norte-americano.
} 
risultati cui conduce, che costituice per i creditori la pietra di paragone della convenienza di tutte le soluzione che intendono distacarsene." 991

Em outras palavras, o critério de conveniência da decisão dos credores para análise de resultado do destino do devedor parte da hipótese da falência. Disto resulta que esse procedimento é adotado como elemento inicial de comparação com todas as demais possibilidades de futuro em relação ao devedor. Essa visão é causa da diversificação de interesses entre os próprios credores, no seio de um procedimento concursal, o que justifica sejam divididos em classes.

Dessa maneira, é natural que o credor com maior possibilidade de recuperação de seu crédito na falência tenha por esta uma preferência, ao invés de assumir os riscos de um procedimento reorganizatório. De outro lado, os credores com menores perspectivas de recebimento na falência tendem a ser mais receptivos às propostas de composição apresentadas pelo devedor.

Assim, a divisão dos credores em classes, de acordo com os interesses distintos que seus créditos proporcionem, tenderá a trazer maior equilíbrio às deliberações no processo concursal, o que é de grande relevância.

Além disso, a falência "è senz'altro la procedura piú importante, e per più motivi: perchè 'in astratto' si applica al maggior numero di impresi, perchè 'in concreto' statistiche internazionali mostrano che, sebbene sia importante lasciare aperta la porta a um risanamento dell'impresa, circa il novanta per cento delle imprese finisce per essere liquidato." 992

${ }^{991}$ STANGHELLINI, Lorenzo. Le crisi di impresa fra diritto ed economia (le procedure di insolvenza). Bologna: Il Mulino, 2007, pp. 183-184. Em tradução livre: 'tal funcionamento se compreende melhor se se começa a analisar a dialética entre devedor e credores partindo desta última fotografia: o da liquidação. É essa e os resultados a que esta conduz que constituem para os credores a pedra de escolha da conveniência de todas das soluções que pretendam adotar.'

${ }_{992}$ STANGHELLINI, Lorenzo. Le crisi di impresa fra diritto ed economia (le procedure di insolvenza), Il Mulino, Bologna, 2007, p. 355. Em tradução livre: 'esse é, sem dúvida, o procedimento mais importante, e por vários motivos: porque em abstrato aplica-se a um maior número de empresas, porque em concreto, estatísticas internacionais revelam que, se bem que seja importante deixar a porta aberta ao saneamento da empresa, cerca de $90 \%$ destas terminam por serem liquidadas." 
Em virtude isso, é primordial que um sistema de direito concursal permita formas intermediárias de reabilitação, inclusive em procedimento de liquidação (como é o caso da cessão do estabelecimento no direito francês), bem como admita, em procedimento reorganizatório, métodos de alienação de ativos, de forma organizada e coordenada, em benefício dos credores ${ }^{993}$.

Verifica-se, então, a distinção entre a liquidação e a reorganização, como soluções possíveis ao destino do devedor em crise, está muito além da questão meramente procedimental $^{994}$.

Ainda que do ponto de vista procedimental até seja possível manter soluções individualizadas para a crise do devedor empresário, do ponto de vista de análise do direito material envolvido, ambas as respostas - reoganização e liquidação - não constituem (ou não deveriam constituir) departamentos estanques entre si.

Isso porque, na verdade, o que interessa no processo concursal é encontrar o delicado equilíbrio entre a solução de pagamento dos credores, da forma mais vantajosa possível, e, ao mesmo tempo, tentar preservar, tanto quanto possível, a posição que a devedora ocupa na relação da cadeia econômica, em particular se o negócio mostrar-se rentável e de interesse para o mercado.

Luigi Farenga sustenta que nem sempre a liquidação ${ }^{995}$ constitui a resposta mais adequada para a situação de insolvência da empresa. No entender do autor, a melhor solução somente será encontrada depois da análise das causas que levaram à situação de

\footnotetext{
993 "Infatti, liquidazione e riabilitazione sono talvolta semplicemente esiti di procedure suscettibili di vari indirizzi. In più esiste una serie di forme intermedie tra questi due esiti...". Em tradução livre: 'De fato, liquidação e saneamento são, às vezes, simplesmente uma forma exitosa de resultado de procedimentos suscetíveis de várias soluções. Em vários deles há uma série de modos intermediários entre tais dois resultados...' (STANGHELLINI, Lorenzo. Le crisi di impresa fra diritto ed economia (le procedure di insolvenza), Il Mulino, Bologna, 2007, p. 204).

994 "O procedimento é, nesse quadro, apenas o meio extrínseco pelo qual se instaura, desenvolve-se e termina o processo; é a manifestação extrínseca deste, a sua realidade fenomenológica perceptível. A noção de processo é essencialmente teleológica, porque ele se caracteriza por sua finalidade de exercício do poder (no caso, o jurisdicional). A noção de procedimento é puramente formal, não passando da coordenação de atos que se sucedem. Conclui-se, portanto, que o procedimento (aspecto formal do processo) é o meio pelo qual a lei estampa os atos e fórmulas da ordem legal do processo." (ARAÚJO CINTRA, Antonio Carlos de; PELEGRINI GRINOVER, Ada; DINAMARCO, Cândido Rangel. Teoria geral do processo, 27. edição, São Paulo: Malheiros, 2011, p. 301).

${ }_{995}$ Ora empregada no sentido de venda pura e simples dos ativos, conforme, por exemplo, prevê o Chapter 7 do direito norte-americano.
} 
insolvência, que poderiam ser de natureza financeira (geralmente superáveis) ou econômica (de difícil superação, por comprometerem mais diretamente a funcionalidade da estrutura empresarial) ${ }^{996}$.

Para exemplicar, o autor invoca a hipótese de crise de natureza financeira em operações de grande porte, cuja exploração é dividida em grupos de sociedades. Muitas vezes, nessa situação, a sociedade com saúde equilibrada financia as demais sociedades do grupo, cuja operação esteja em crise, comprometendo, em decorrência, a solvabilidade de todas: "In questi casi è evidente che l'insolvenza deriva da un anomalo indebitamento del tutto estraneo al ciclo economico dell'impresa, così la cessione dei complessi aziendali depurati dei debiti risulta sufficiente, unitamente ad un valido piano industriale e finanziario programmato dal cessionario, a permettere il ritorno alla reddivitità dell'impresa". 997

No exemplo mencionado, dependendo das condições em que se desenvolva o procedimento concursal, poderia ser deliberada e aceita a via da reorganização (com venda a terceiros das unidades produtivas rentáveis e pagamento dos credores sob a égide de um plano, com total modificação da ordem de vocação daquela que seria imposta pela falência, o que, possivelmente, resultaria em melhor distribuição do pagamento dos credores); ou então, por outra via, dar-se a preservação do negócio em um procedimento de liquidação (mediante alienação de estabelecimento em bloco).

Como defende Lorenzo Stanghellini, “ad esempio, una liquidazione può non solo consentire una conservazione dell'organismo produttivo (cosa que già abbiamo visto) mas può perfino celare una conservazione degli stessi assetti imprenditoriali (e si parla allora di 'sindrome della fenice'). ${ }^{998}{ }^{999}$.

\footnotetext{
${ }^{996}$ BAIRD, Douglas G., JACKSON, Thomas H., e ADLER, Barry E. Bankruptcy, cases, problems and materials. 3. edition, New York: Foundation Press, 2000. University Casebook Series, p. 27.

${ }_{997} \mathrm{O}$ autor cita o exemplo da Parmalat. (FARENGA, Luigi. "La reforma del diritto fallimentare in Italia: una visione de mercato". Revista de Direito Mercantil, Industrial Econômico e Financeiro, vol. 145, Ano XLVI (nova série), jan/mar 2007, p.13). Em tradução livre: "Nesses casos é evidente que a insolvência resulta de um anômalo endividamento que é estranho ao ciclo econômico da empresa, por isso que a cessãodo complexo aziendal da empresa, livre dos débitos, resulta suficiente, juntamente com válido plano industrial e financeiro programado pelo cessionário, a permitir o retorno à atividade da empresa."

998 STANGHELLINI, Lorenzo. Le crisi di impresa fra diritto ed economia (le procedure di insolvenza), Il Mulino, Bologna, 2007, p. 205. Em tradução livre: "por exemplo, uma liquidação pode não apenas permitir a conservação do organismo produtivo (tema já estudado), mas até selar uma conservação dos mesmos bens empresariais (e se fala aqui da 'sindrome da fênix').
} 
$\mathrm{O}$ citado autor prossegue destacando a ideia reversa, de que "un'aparente "riabilitazione" del debitore può nascondere una finalità importantissima: quella di consertirgli di procedura a una liquidazione ordinata (cioè non forzata) del suo patrimonio, assicurando ai creditori, quando ciò sia possibile, il mantenimento del 'going concern value'. Il fenomeno dei piani di cessioni dell'impresa che altro no son che 'liquidazioni mascherate' è difuso in Francia, e, anche se ciò è poco noto, una delle finalitá piú importante del Chapter 11 è próprio quella di consentire una ottimale monetizzazione dei cespiti, inclusa l'azienda, con sucessiva distribuizione del ricavato ai creditori" ${ }^{\prime \prime 000}$

No pano de fundo, não há uma perfeita distinção entre liquidação e reorganização, e o que se verifica, nos sistemas dualistas, é que há uma diferenciação de caráter meramente procedimental, por opção legislativa.

O direito brasileiro, que adotou o sistema procedimental dualista, parece ter caminhado para tentar distinguir a liquidação (falência) da reorganização (recuperação) pela ideia de 'afastamento do devedor', conforme se pode extrair da primeira leitura do artigo 75 da Lei n. 11.101/05.

O critério adotado entretanto, é claramente deficiente, na medida em que, per se, não é suficiente para destacar uma perfeita distinção entre um e outro instituto. Como já se pontuou, o afastamento do devedor poderá ocorrer também na recuperação judicial, nas seguintes hipóteses: (i) previsão no plano (artigo 64, VI, da Lei n. 11.101/05), (ii) determinação judicial, ante a incidência das hipóteses legais, previstas em 'numerus clausus' no artigo 64, incisos I a V do mesmo diploma, ou (iii) alienação da empresa ou de estabelecimentos (artigo 50, incisos VII, X, XI e XVI).

\footnotetext{
${ }^{999}$ Como ocorre no plano de cessão, no procedimento concursal francês. (JEANTIN, Michel; LE CANNU, Paul. Entreprises en difficulté. 7. édicion, Paris: Dalloz, 2007, p. 635).

${ }^{1000}$ Idem, p. 206. Em tradução livre: "Uma aparente 'reorganização de saneamento' do devedor pode esconder uma finalidade importantíssima: a de consentir a este uma liquidação ordenada (isto é, não forçada) de seu patrimônio assegurando aos credores, quando seja possível, a manutenção do 'going concern value'. O fenômeno do plano de cessão da empresa, que outra coisa não é senão uma 'liquidação mascarada' é difundida em França e, ainda que pouco notado, é uma das finalidades do Chapter 11 que é permitir a otimização dos ganhos na transformação em dinheiro, inclusive do estabelecimento, com consequente distribuição dos resultados aos credores".
} 
Poder-se-ia argumentar que, na falência, o afastamento do devedor é a regra, enquanto na recuperação judicial esta hipótese é medida de exceção. Nesse caso, observese então, que o traço distintivo não é propriamente o afastamento do devedor, mas a situação de compulsoreidade deste, como resultado da falência.

Veja-se, assim, que no sistema brasileiro poderá ocorrer preservação dos organismos produtivos, mediante afastamento do devedor, tanto na falência quanto na recuperação judicial.

Por essa razão, a nosso ver, não é possível declinar, no direito brasileiro, o afastamento do devedor como um traço distintivo, decisivo e fundamental entre a falência e a recuperação judicial. Trata-se, evidentemente, de uma diferença, mas não de um traço de distinção suficiente.

Voltando-se ao tema das funções do direito falimentar: ao lado de sua função de preservação do crédito - como método de manter hígida e saudável a torrente de relações entre os empresários visando a segurança do tráfego mercanti1 ${ }^{1001}$, e como consequência indissociável desta, - está a necessidade de manutenção dos organismos produtivos, cuja funcionalidade se preste a integrar, de forma saudável, os elos da cadeia de relações do mercado.

Assim, parece lícito afirmar, nesse ponto da pesquisa, que outra função do direito concursal moderno, de igual importância à de preservação do crédito, é a de favorecimento das condições de preservação de agentes econômicos aptos a preencher sua função de criação e circulação de bens, serviços e riquezas para o mercado.

Percebe-se, mesmo nos sistemas de pendor declaradamente pró-credor (alemão e espanhol, com maior ênfase), que há clara ideia de que é necessário (e não conveniente, como ocorre nos sistemas pró-devedor) proporcionar métodos de preservação da empresa. É a consciência de que a destruição de um agente econômico que possa atuar (ou voltar a atuar) eficientemente no mercado constitui uma perda que a ninguém interessa.

${ }^{1001}$ FORGIONI, Paula Andrea. A evolução do direito comercial brasileiro: da mercancia ao mercado. São Paulo: Revista dos Tribunais, 2009, pp. 14-16. 
Assim, de fato, que se busca no moderno direito concursal e, em particular, na solução brasileira é encontrar uma resposta para a empresa em crise que possa atender e equilibrar o interesse dos credores e, simultaneamente, gerar condições de preservação da empresa, quando possível. Em nosso direito, a via pela qual esse equilíbrio poderá ser alcançado dar-se-á pela recuperação ou falência, já que, tanto em um como em outro procedimento, busca-se um equacionamento entre a satisfação dos credores e a manutenção do negócio.

Assim, e considerando que as soluções judiciais para a crise da empresa no direito brasileiro, pela recuperação ou pela falência, não parecem ser compartimentos estanques, exceto do ponto de vista estritamente procedimental, cumpre analisar essa opção legislativa.

4.2 O procedimento unificado e a crise como pressuposto.

Alberto Jorio destaca que "La questione di fondo di ogni moderna disciplina dela crisi dell'impresa sta nella ricerca di una accetabile composizione delle due fondamentali esigenze che scaturiscono dal dissesto: la tutela dei creditori e la preservazione, ove possibile, degli organismi produttivi.,"1002.

Essa afirmação, que se considera irreparável, remete ao questionamento quanto à necessidade de procedimento dúplice no processo concursal, leia-se, um voltado para a reorganização e outro voltado para a liquidação (ou falência).

O processo não é, como se sabe, um fim em si mesmo ${ }^{1003}$, mas um instrumento de realização, aplicação, do direito material controvertido.

Ora, se o direito concursal busca uma solução para tutela dos interesses dos credores ao mesmo tempo em que visa a preservação da empresa, o equilíbrio destes dois vetores poderia, em tese, ser melhor aquilatado caso fosse desenvolvido sob a via de um

\footnotetext{
${ }^{1002}$ Em tradução livre: "A questão de fundo de toda a moderna disciplina da crise da empresa está na busca de uma aceitável composição entre duas fundamentais exigências que surgem em desequilíbrio: a tutela dos credores e a preservação, contanto que possível, dos organismos produtivos" (Le crisi d'impresa e il fallimento, Giuffrè, 2000, p. 1.).

${ }_{1003}$ DINAMARCO, Cândido Rangel. A instrumentalidade do processo. 2. edição, São Paulo: Revista dos Tribunais, 1990.
} 
procedimento único, a exemplo da experiência de alguns dos sistemas estrangeiros analisados.

O direito brasileiro não se aparta inteiramente dessa tendência, já que prevê disciplina processual comum para a verificação dos créditos e relativamente aos órgãos de atuação da falência e recuperação judicial ${ }^{1004}$. Essa circunstância é reveladora de uma verdadeira unicidade conceitual que aproveita a ambos os procedimentos, e que integram um único instituto, o do direito das empresas em crise.

A dicotomia procedimental que, no direito brasileiro, distingue duas vias de solução - 'falência' e 'recuperação' - acaba, ainda que não intencionalmente, colocando foco na velha concepção que relaciona o falido ao fracasso ou à fraude. Alimenta-se, segundo penso, o estigma negativo que cerca o devedor como resultado da quebra.

Por outro lado, se tanto a recuperação judicial quanto a falência são inspiradas pelo princípio da preservação da empresa, justifica-se avaliar a possibilidade de unificação do sistema procedimental, de modo a tentar proporcionar uma solução de concretização harmônica desse princípio.

O concurso teria, então, a seguinte feição: constatação de uma situação de crise, diagnóstico das soluções possíveis e aplicação deste, mediante reorganização ou liquidação.

Para tanto, seria necessário centralizar o pressuposto material do processo concursal na noção de crise. Este conceito, que é mais amplo do que os de insolvência, insolvabilidade ${ }^{1005}$, cessação de pagamentos e impontualidade fundamentaria a instauração de concurso de credores por iniciativa do próprio devedor, em princípio. Naturalmente, é preciso manter aberta a porta para a iniciativa do credor, caso em que, poderiam ser preservados os critérios de exteriorização de insolvência, já consagrados pelo direito brasileiro.

\footnotetext{
${ }^{1004}$ DASSO, Ariel Ángel. Derecho concursal comparado, Tomo I, Buenos Aires: Legis, 2009, p.224.

${ }^{1005}$ FONSECA, José Júlio Borges da. "Da recuperação da empresa em crise”. Revista de Direito Mercantil, Industrial, Econômico e Financeiro, São Paulo, vol. 87, Ano XXXI (nova série), jul/set 1992, p.73.
} 
Assim, e para que um sistema unificado funcionasse adequadamente, a fixação da crise como pressuposto objetivo da instauração do concurso deve ser faculdade atribuída somente ao devedor. Ao credor deverão remanescer as hipóteses de fatos concretos que exteriorizam a crise, tais como a impontualidade (do sistema brasileiro), a cessação de pagamentos (França) ou a insolvência ou inadimplência (Alemanha).

No direito brasileiro, critica-se o pedido de falência com fundamento na impontualidade, que poderia ensejar, em tese, a possibilidade de decreto da quebra de um empresário solvável ${ }^{1006}$. Essa circunstância coloca em evidência a longa discussão, travada há anos, de utilização do pedido de falência como meio de cobrança, que desde há muito tempo é considerado abusivo, "por desvio da finalidade do instituto falimentar"1007.

O conceito de crise de que ora se trata como suficiente para a instauração de um procedimento concursal pelo próprio devedor equivaleria, em termos conceituais, à ameaça de inadimplência ( $\$ 18$ da InsO), prevista no direito alemão e que consiste em uma presunção de que o devedor não estará em condições de cumprir as obrigações vincendas na data pactuada. Aproxima-se, ainda, do conceito do direito francês de 'dificuldades ${ }^{1008}$ 1009 , que possam conduzir a uma situação de cessação de pagamentos no futuro, ensejadoras da abertura do procedimento de sauvegard pelo devedor.

Instaurado o procedimento e aberto o foro de negociação judicial com os credores, a busca de uma solução deveria resultar na reorganização do negócio (sob a mesma titularidade) ou na liquidação de ativos (sendo uma das possibilidades a cessão de estabelecimento e, portanto, com preservação do negócio ou parte dele); mas, sempre buscando compor o princípio da preservação da empresa com a satisfação dos credores.

A satisfação dos credores é um elemento inafastável na composição de interesses do direito concursal, pois, "La procedura d'insolvenza fa si che $i$ creditori, divenuti per effetto delle perdite, in sostanza, i veri "soci" (investitori di capitale di

\footnotetext{
${ }^{1006}$ Criticado por Sergio Campinho, como acima já pontuamos.

1007 MORAES, Mauro Delphim de. Comentário a Acórdão RE. 87.405-RJ, Primeira Turma, Rel. Ministro Xavier Albuquerque. Revista de Direito Mercantil, Industrial, Econômico e Financeiro, São Paulo, vol. 40, Ano XIX (nova série), pp. 132- 140, out/dez 1980.

1008 Ou seja, financeiras, econômicas, comerciais, industriais, sociais, de meio, que possam motivar o pedido. (JEANTIN, Michel; LE CANNU, Paul. Entreprises en dificulte. 7. édicion, Paris: Dalloz, 2007, p. 176).

${ }^{1009}$ Artigo L.620-1, alínea $1^{\mathrm{er}}$.
} 
rischio) senza però alcun diritto, assumano il controllo dell'impresa in crisi: essa produce coattivamente questo trasferimento e crea uma "organizzazione" attraverso la quale $i$ creditori-controllanti possono esercitare i poteri che spettano agli investitori". ${ }^{1010}$

Os credores, na situação de crise da empresa, tornam-se titulares de uma espécie de poder de controle ${ }^{1011}$ externo ${ }^{1012}{ }^{1013}$, na medida em que passam a ter o direito de fiscalizar ou até mesmo de gerir (na hipótese de afastamento) o patrimônio do devedor, que é garantia da satisfação de seus créditos ${ }^{1014}$.

O fundamento do direito concursal está na formulação de um sistema regrado e organizado para proporcionar a abertura de um foro de negociação entre o devedor e seus credores ${ }^{1015}$. E isto se faz para que seja possível buscar uma solução para a crise do primeiro, não apenas considerando as relações obrigacionais privadas com estes últimos, mas também harmonizando esta solução com os interesses de uma cadeia econômica que o devedor integra, ou seja, com preservação dos múltiplos interesses envolvidos na esfera da empresa.

${ }^{1010}$ STANGHELLINI, Lorenzo. Le crisi di impresa fra diritto ed economia (le procedure di insolvenza). Bologna: Il Mulino, 2007, p. 51. Em tradução livre: 'O procedimento de insolvência faz com que os credores, por efeito das perdas, tornem-se, em substância, os verdadeiros "sócios" (investidores de capital de risco), e mesmo sem direito algum, assumam o controle da empresa em crise': essa [a crise] produz coercitivamente essa transferência e cria uma "organização" pela qual os 'credores-controladores' possam exercitar os poderes que se outorgam aos investidores'.

1011 “A firm's creditors have a dual role in relation do the other participants in the enterprise. Under ordinary circumstances, most creditors are no more than contractual counterparties. However, if the firm defauts on payment obligations, its creditors become entitled to seize and sell its assets. At this point, the creditors chage roles: they become, in a meaningful sense, the owners of the firm's assets." (The Anatomy of Corporate Law: a comparative and functional approach. 2. edition, New York: Oxford, 2009, pp. 115-116). Em tradução livre: 'Os credores de uma empresa têm dois papeis em relação aos demais participantes desta. Em situação normal, a maioria dos credores não passa de uma parte contratante. No entanto, se a empresa torna-se inadimplente em suas obrigações, seus credores ficam autorizados a apoderar-se de seus bens e vendê-los. Nesse ponto, os credores mudam de papel: tornam-se, em um senso significativo, os donos dos ativos da empresa.'

1012 "Há, assim, em primeiro lugar, toda uma séria de hipóteses em que o controle externo resulta de uma situação de endividamento da sociedade. Em razão de seu direito de crédito, cuja execução forçada pode levar a companhia à falência, o credor passa, muitas vezes, a dominar a devedora, comandando sua exploração empresarial." (COMPARATO, Fabio Konder. O poder de controle na sociedade anônima. 4. edição, atual. por Calixto Salomão Filho. Rio de Janeiro: Forense, 2005, pp. 90-91).

${ }_{1013}$ JEANTIN, Michel; LE CANNU, Paul. Entreprises en difficulté. 7. édicion, Paris: Dalloz, 2007, p. 635.

1014 STANGHELLINI, Lorenzo. Le crisi di impresa fra diritto ed economia (le procedure di insolvenza). Bologna: Il Mulino, 2007, p. 177.

${ }^{1015}$ Até mesmo no direito francês, em que a aprovação do plano é de apreciação judicial, a reforma de 2005 proporcionou maior participação dos credores, com a formação de comitês que atuam no feito. 
A noção de crise, sob esse enfoque, é a que revela uma problemática não pontual, mas de caráter geral, que justificaria a convocação, pelo devedor, da coletividade de credores ${ }^{1016}$.

É preciso, então, manter a mente aberta, para buscar no direito concursal uma metodologia para o delicado equilíbrio entre a composição dos interesses dos credores (que integram um complexo de relações jurídicas, como um elo de uma corrente de um sistema maior que compõe o mercado), e a salvaguarda da atividade econômica (empresa, respectivamente nas acepções de perfil funcional e objetivo, a que se refere Asquini).

A solução a ser encontrada poderá ser de manter o negócio sob a condução do devedor, ou, mediante seu afastamento; prevendo-se a possibilidade de transferência do negócio a terceiros, por um plano de cessão ou por um plano de liquidação e, neste último caso, aplicável quando o empresário não esteja em condições, ele próprio, de desincumbirse de uma solução reorganizatória.

Sob essa óptica, duas observações se impõem. A primeira é a de que para acolher a noção de crise como fundamento suficiente para a instauração do concurso de credores, pelo devedor, seria obrigatório renunciar a associação psicológica que usualmente se faz entre um procedimento concursal e a noção de boa ou má-fé do devedor. A ideia não é tolerar atos abusivos ou ilícitos, mas simplesmente separar a eventual apuração e aplicação das sanções cabíveis ao devedor, do destino que se pretenda dar ao negócio (empresa) que foi atingido pela crise ${ }^{1017}$.

\footnotetext{
1016 "El interés de los acreedores como bien jurídico tutelado del procedimiento concursal se satisfacía con el presupuesto tradicional de la cesación de pagos que no reclamaba otros puntos de partida para justificar la convocatoria de los acreedores al procedimiento colectivo. Pero la aparición de la empresa, como eje de la primera revolución industrial, reclamó para sí la télesis del sistema que, primero en dogma y después en norma, convierte a su salvatage en el objetivo prioritario del concurso, y para la nueva télesis, el presupueste adjetivado en la cesación de pagos resulta ya insuficiente, por tardío." (DASSO, Ariel Ángel. Derecho Concursal Comparado, Tomo II, Legis, Buenos Aires, Argentina, 2009, p. 923).

${ }_{1017}$ Ariel A. Dasso, apoiado em Stefania Pacchi, questiona, em certa medida, a excessiva atenção que se presta, no direito concursal, à aplicação de sanções ao falido ou à verificação da regularidade de seus registros ou atos, naquelas hipóteses em tais sejam irrelevantes para favorecer as negociações econômicas que possam conduzir a um cenário de superação da crise. (Derecho concursal comparado, Tomo II, Buenos Aires: Legis, 2009, p. 922).
} 
A segunda observação é que deve existir uma preocupação quanto ao momento ideal para a deflagração de um procedimento concursal ${ }^{1018}$, eis que, em tese, quanto mais cedo instaurado, melhor condição haveria para posibilitar a composição de uma solução mais equilibrada ao binômio 'satisfação dos credores' e 'preservação da empresa'.

Com efeito, acentua Ariel A. Dasso que “A pesar de la insatisfacción de las fórmulas, el salvatage de la empresa se persigue a través del prematuro diagnóstico de las dificultades en orden a la puesta en marcha de los procedimientos de salvaguarda y así se advierte en la modernísima legislación concursal." 1019

Assim, a noção de crise como pressuposto único e suficiente para instauração de um procedimento concursal pelo devedor ${ }^{1020}$ teria plena condição de atender a essa inquietação, desde que somente ao próprio devedor fosse possível sua instauração nas hipóteses em que há uma suspeita de que não estará, em futuro próximo, em condições de cumprir suas obrigações conforme pactuadas ${ }^{1021}$, como ocorre no direito francês e também no alemão, reservando-se a legitimidade dos credores às hipóteses de inadimplemento caracterizado ou atos de falência.

A solução de procedimento unificado, com mecanismos eficientes de deflagração precoce da crise por iniciativa do devedor, poderia ter como efeito a vantagem de afastar a feição negativa psicológica, que, em geral, está associada ao 'decreto de falência' do devedor.

\footnotetext{
${ }^{1018}$ Essa é, sem dúvida, um dos aspectos que mobilizou a reforma de 2005 do direito francês, e também a mais recente reforma do direito alemão, em que tais sistemas buscam antecipar e estimular o ajuizamento de medidas, exatamente com a finalidade de impedir que a crise torne-se insuperável. Vide, ainda, as anotações de Ariel A. Dasso a respeito, em Derecho concursal comparado, Tomo II, Buenos Aires: Legis, 2009, pp. 923-924.

${ }^{1019}$ Derecho concursal comparado, Tomo II, Buenos Aires: Legis, 2009, pp. 925.

${ }^{1020}$ Nesse sentido, Nelson Abrão já afirmava "Na realidade, as noções de 'insolvência', de 'impontualidade', de 'inadimplemento', perfeitamente ajustadas no cenário concursal de concepção privatista (relação devedor-credores) estão hoje superadas pela de 'crise econômica da empresa'. Já não se fala em 'insolvência', fala-se de 'situação de crise econômica', conceito metajurídico e - o que é mais importante sem possibilidade de ser confundido com os que habitualmente utilizam as Leis Concursais. A insolvência não esgota a patologia da empresa moderna e, em consequência, não pode ser pressuposto único - ou principal - para abertura do concurso". (Nova disciplina jurídica da crise da econômica da empresa, São Paulo: Rumo Gráfica Ed., 1984, pp. 30-31).

${ }^{1021}$ Ou seja, corresponde ao critério de 'ameaça de inadimplência' previsto no $\$ 18$ da InsO (direito alemão).
} 
De fato, na medida em que a instauração de um procedimento concursal não resulte, necessariamente, nos prejuízos que os credores geralmente experimentam com a liquidação pura e simples de ativos, em regra feita em momento posterior ao desmatelamento da empresa, não haveria motivo para a pecha negativa que acompanha o direito concursal.

Até mesmo do ponto de vista da terminologia, ameniza-se o impacto negativo arraigado à expressão 'falência'. O direito concursal francês, por exemplo, trata da disciplina sob a temática do direito das 'empresas em dificuldade' (“droit des entreprises en difficultê" ${ }^{1022}$ ).

A propósito, António Menezes Cordeiro, autor português, analisa positivamente o movimento de unificação procedimental do sistema concursal daquele país ao considerar que a própria expressão "insolvência", agora adotada, é, do ponto de vista valorativo, neutra quando comparada à falência ${ }^{1023}$.

De fato, as expressões insolvência ${ }^{1024}$ ou insolvabilidade ${ }^{1025}$ tendem a minorar a pecha com a qual se associa, em regra, a "falência" ou "quebra". Mas, ainda mais adequada parece a expressão adotada por Paulo Fernando Campos Salles de Toledo, que é 'crise das empresas' ${ }^{1026}$, eis que já acolhida, de certa forma, pelo direito brasileiro.

Parece-nos que a noção de procedimento único torna mais fácil acolher a ideia de que a crise é uma condição fisiológica do mercado, associada ao risco de qualquer

\footnotetext{
${ }^{1022}$ Em tradução livre: O direito das empresas em dificuldade.

${ }^{1023}$ Manual de direito comercial, 2. edição, Coimbra: Almedina, 2009, p. 409.

${ }^{1024}$ Fábio Konder Comparato ensina que "a insolvência é o inadimplemento qualificado pela falta de razão de direito; enquanto a insolvabilidade é a inaptidão econômica a adimplir, seja em virtude de deficiência patrimonial, seja pela falta de meios líquidos para cumprir a prestação. No direito falimentar brasileiro, a quebra pode ser declarada tanto pela insolvência caracterizada pelo protesto (a impontualidade) (art. 94, inciso I da Lei 11.101/05, quanto pela insolvabilidade (art. 94, incisos II e III), ensejando procedimentos diversos ( $\$ \$ 3^{\circ}$ a $5 .^{\circ}$ do artigo 94$)$ " (O poder de controle na sociedade anônima. 4. edição, Rio de Janeiro: Forense, p. 435, nota 4).

${ }^{1025}$ Para Paulo Fernando Campos Salles de Toledo, a insolvência caracteriza-se como "a impossibilidade momentânea (ou melhor, não definitiva, eis que pode ser mais ou menos duradoura) de solver os compromissos", e "corresponde a dificuldades de natureza financeira", enquanto a insolvabilidade "refere-se à impossibilidade de solver as obrigações, em decorrência de um déficit patrimonial", razão pela qual esta é uma dificuldade "de ordem econômica: o ativo do devedor é insuficiente para cobrir o seu passivo" ("Da caracterização da insolvabilidade civil. Pressupostos objetivos e subjetivos do processo de execução concursal", Revista de Direito Mercantil. n. 57, p. 42, jan.-mar. 1985).

${ }^{1026}$ Conforme já pregava Paulo Fernando Campos Salles de Toledo desde sua Dissertação de Mestrado. (A empresa em crise no direito francês e americano. Dissertação de Mestrado. São Paulo: Fadusp, 1987).
} 
empreendimento negocial - como ocorre nas origens do direito concursal anglo-saxão ${ }^{1027}$ 1028 -, afastando-se, por conseguinte, a ideia de que o procedimento concursal transparece como um fenômeno mórbido da insolvência.

Feitas essas considerações e partindo da premissa de que a crise constituiria um pressuposto suficiente para a instauração do concurso pelo próprio devedor, pode-se concluir que a adoção de um procedimento unificado complementa o ideal de melhor equilíbrio na equação ‘satisfação dos credores' e 'preservação da empresa'.

Além disso, sob a égide de um procedimento unificado, parece possível melhorar a possibilidade de preservação da empresa, mantendo-se hígido o patrimônio, que é garantia dos credores. Isso porque, o estímulo para antecipação de providências, em tese, faria com que os procedimentos fossem deflagrados antes que as dificuldades fossem irreversíveis e antes de dilapidação patrimonial.

Com efeito, se os ativos constituem garantia dos credores - e esta deve ser uma das preocupações do direito concursal, como, aliás, ficou evidenciado na reforma do direito alemão de 1999, em que a prevenção da insuficiência de ativos foi um de seus principais focos - é preciso estabelecer métodos de prevenção da dissipação de bens, e o estímulo para que o devedor antecipe providências, ante a crise, é um destes meios.

A instauração de um procedimento único sinaliza a ideia de que há uma situação particular na empresa, ou seja, de crise, que justifica plenamente uma orientação diferenciada na condução dos negócios do devedor, mas não obrigatoriamente implica adoção de medidas drásticas ou irreversíveis, ao menos em um primeiro momento.

O concurso, pela via de procedimento único traz ínsita a conotação de que é primordial transparência nos negócios da devedora para bom termo de uma negociação com os credores, pois neste se decidirá pela adoção de medidas de saneamento e

${ }^{1027}$ VIVANTE, Cesare. Trattato di diritto commerciale, 5. ed., Milano, Dott. Francesco Vallardi, 1934, vol. I - I commercianti, p. 327-328.

${ }^{1028}$ CORDEIRO, António Menezes. Manual de direito comercial. 2. edição, Coimbra: Almedina, 2009, pp. 416-417. 
manutenção da empresa sob a mesma titularidade ou de terceiros ${ }^{1029}$, ou, ainda, destinadas à simples liquidação dos ativos.

O procedimento único teria a vantagem, ainda, de colocar sob maior destaque o princípio que prevê a separação entre a empresa e o empresário, na medida em que torna possível decidir de forma mais objetiva e simplificada pela mudança de titularidade da empresa (enquanto organização de bens ou atividade) ${ }^{1030}$. Assim, a adoção da liquidação de bens isoladamente seria hipótese reservada aos casos em que nenhuma utilidade possa ter a preservação dos ativos organizados, restando apenas pagar os credores com o produto da venda individualizada destes.

Repita-se, em hipótese alguma se pode perder de vista que um elemento inseparável de qualquer procedimento concursal é a satisfação dos credores ${ }^{1031}$, de modo que a preservação da empresa deve perseguir esse objetivo.

Não seria razoável que eventual preservação ocorresse à custa de sacrifício dos credores, cuja satisfação deve ser um dos objetivos em foco no procedimento. Ao contrário, tem-se de buscar uma solução negociada de saneamento (mantendo-se a empresa sob mesma titularidade), mas é possível que a solução seja de afastamento do devedor, ou seja, mantendo-se a organização dos bens, mas sob nova titularidade, na hipótese em que o

\footnotetext{
${ }^{1029}$ Anote-se, no direito concursal espanhol, cujo procedimento é unificado, a posição de Ibon Hualde López, ao comentar a possibilidade de alienação unitária da empresa, que ocorre tanto na fase de convenio, quanto na de liquidación: "De hecho, uno de los rasgos que diferencian la solución de convenio de la de liquidación es que en la primera de ellas el mantenimiento de la actividad empresarial o professional como médio para la satisfacción de los acreedores cuenta com la implicación de deudor, siendo éste el sujeto passivo del clausulado de obligaciones contenido en la propia propuesta de convenio. En este sentido, tal solución envuelve un voto de confianza hacia el concursado, cuyo compromisso em la gestión de la atividade que viniera ejercendo se presume va a tener la virtualidade de provocar na conclusión 'nornal' del procedimento, previa la verificación judicial de la realidade del cumplimiento del convenio. A 'sensu contrario', la solución de liquidación implica la perdida de confianza en el hacer del deudor. De manera que, llegado el processo a esta fase, la eventual continuidade de la actividad professional o empresarial prescinde de su participación, considerando-se indispensable, a esos efectos, la transmissión de la empresa a un terceiro que se haga en cargo de una labor que el concursado no tuvo habilidad de afrontar con êxito." (HUALDE LÓPEZ, Ibon. Régimen jurídico de la administración concursal en la fase de liquidación del concurso. Estudios de derecho concursal. 1. edición, Espanha: Thomson Civitas, 2009, p. 307).

${ }^{1030}$ Se faz aqui uma breve nota para reforçar o argumento ora suscitado: A Lei n. 11.101/05, no artigo 50, incisos VII, X e XVI, prevê, como meio de recuperação, a alteração de titularidade da empresa (trespasse, constituição de sociedade de credores ou de sociedade de propósito específico para adjudicação dos ativos). Por outro lado, a falência caracteriza-se pelo afastamento do devedor (art. 75), também com a finalidade de preservar a empresa (organização de bens, perfil objetivo de Asquini), promovendo-se, prioritariamente, a alienação dos ativos em bloco. Desse modo, por qual razão se justifica manter procedimentos distintos para alcançar uma única solução? Em ambos os casos, a decisão resulta de deliberação dos credores, seja por aprovação de plano na recuperação judicial, seja por aprovação de meio de realização do ativo na falência.

${ }^{1031}$ DASSO, Ariel Angél. Derecho concursal comparado, Tomo II, Buenos Aires: Legis, 2009, p. 922.
} 
devedor não tenha conseguido conquistar a confiabilidade dos credores para a aprovação de um plano que ele próprio venha a implementar.

Essa última ideia, aliás, não é nova, pois "la base teórica de 'Unternehmen na sich' que asigna a la empresa un valor jurídico autónomo merecedor de la tutela en derecho (selbständiges schutzwürdiges Rechsgut), sus epígonos lanzaron un slogan asombroso e impactante: "la defensa de la empresa contra sus proprietários" (Eigentümer) $^{, 1032}$.

Ora, a via do procedimento único torna essa visão ainda mais clara (por se tratar de um objetivo linear, com pelo menos três alternativas de possível desfecho ${ }^{1033}$ ) em que, por certo, seria possível alcançar tais objetivos de modo mais simplificado e, possivelmente, mais de forma mais célere (e, consequentemente, menos onerosa para os credores, que custeiam, direta ou indiretamente, o procedimento).

O processo coletivo da empresa em crise, assim, teria a seguinte feição: crise $\rightarrow$ diagnóstico $\rightarrow$ solução. A solução, naturalmente, poderia ser de reorganização ou liquidação. Na liquidação, poderia haver cessão, total ou parcial, hipótese em que se preserva o negócio, sob nova titularidade.

Confesso que sempre me impressionei com a situação que nasce de um decreto de falência: cria-se um cenário de desolação, em que tudo (ou quase tudo) parece perdido. Esse, por certo, não é um sentimento isolado, pois até o consumidor já se familiarizou com os nocivos efeitos da quebra: falta de garantia dos produtos, inexistência de peças de reposição, serviços não entregues e de difícil indenização, e por aí afora.

Todo esse ambiente que se forma em torno da quebra pode dificultar, ou até mesmo impedir, em certas circunstâncias, a possibilidade de aproveitamento dos ativos organizados da falida. Por exemplo, há chance de ocorrer depreciação da imagen, com

\footnotetext{
1032 DASSO, Ariel Angél. Derecho concursal comparado, Tomo II, Buenos Aires: Legis, 2009, p. 913. O autor prossegue o raciocínio para concluir que "La laboriosa y perseverante investigación doctrinaria logra, sobre la base de pequeños y lentos consensos, elaborar un sustento dogmático suficiente como para pensarla (empresa) independiente del titular" (idem, p. 914).

1033 (i) liquidação pura e simples dos ativos indivualizados; (ii) cessão de estabelecimento na liquidação (preservação sob nova titularidade); (iii) reorganização, com saneamento sob a mesma titularidade.
} 
mácula para a marca e os sinais distintivos da falida, pois há risco de o consumidor vir a identificá-los com falta de confiabilidade.

Em um procedimento unificado, não se correria esse mesmo risco, ainda que a solução fosse o trespasse do negócio, ou seja, mesmo que se decida pelo afastamento do devedor, por entenderem os credores de não confiar na proposta feita pelo devedor (nesse caso, note-se, o devedor não goza de crédito). Desta feita, seria possível dar continuidade à atividade negocial, o que, como se disse, melhor destaca a perfeita distinção entre os interesses da empresa em relação aos do empresário.

4.3 A falência como solução alternativa de satisfação dos credores e preservação da empresa.

Já se disse que no direito brasileiro a falência é a solução prevista na Lei n. 11.101/05 às empresas economicamente inviáveis, como leitura contrario sensu à admissibilidade da recuperação judicial. O legislador brasileiro preferiu adotar um sistema dualista, apartando o procedimento da falência do da recuperação. Mas enquanto houver falência e recuperação de empresas, deve-se entender que esta última é uma solução alternativa de recuperação.

Mesmo que se possa afirmar que a quebra constitui medida de exceção no sistema brasileiro, eis que esse prestigia as soluções reorganizatórias ${ }^{1034}$, é imperioso ressalvar, como já se teve ocasião de dizer ${ }^{1035}$, que a recuperação judicial não cabe para toda e qualquer empresa, pois, na hipótese de inviabilidade econômico-financeira do devedor, a solução dada pelo sistema, claramente é a da falência.

\footnotetext{
1034 "RECUPERAÇÃO JUDICIAL - OBJETIVO PRIMORDIAL - CONCESSÃO - REQUISITOS LEGAIS OBSERVADOS - LEI 11.101/2005 - ESCOPO DE PRIVILEGIAR A RECUPERAÇÃO JUDICIAL EM RELAÇÃO À FALÊNCIA - RECURSO DESPROVIDO. - A doutrina e jurisprudência, tendo em vista a legislação atual que rege a espécie (Lei 11.101/2005), são no sentido de privilegiar e dar preferência à recuperação judicial da empresa em relação à falência, que só deve ser decretada em último caso e depois de esgotados todos os esforços para o objetivo principal da recuperação. Se foram cumpridos todos os requisitos legais, com aprovação do plano de recuperação judicial pela Assembleia Geral dos credores, com acompanhamento mensal, não há que se falar em vícios a inquinar o plano, com azo a cumprir a teleologia da Lei 11.101/2005, precipuamente os preceitos encartados em seu art. 47' (TJ/MG, Agravo de Instrumento n. 1.0024.10.073244-5/004, Rel. Des. Geraldo Augusto, j. 26/04/2011).

${ }^{1035}$ Dissertação de mestrado. A evolução do tratamento jurídico da empresa em crise no direito brasileiro. São Paulo: Fadusp, 2006.
} 
Essa ideia é defendida por Fábio Ulhoa Coelho, para quem “A recuperação da empresa não deve ser um valor jurídico a ser buscado a qualquer custo. (...). Quando o aparato estatal é utilizado para garantir a permanência de empresas insolventes inviáveis, opera-se uma inversão inaceitável: o risco da atividade empresarial transfere-se do empresário para os seus credores ${ }^{\prime 1036}$.

Entretanto, mesmo tendo o sistema brasileiro adotado a solução procedimental dualista, isso não significa que a falência deva resultar no desaparecimento, por completo, de uma organização de bens e pessoas, de uma fábrica, de uma marca, em suma, de um determinado "negócio". Como se demonstrou ao longo dessa pesquisa, mesmo na falência há mecanismos de preservação da empresa, enquanto organização econômica, do que resulta, inquestionavelmente, sua manutenção.

Nesse caso, a preservação do negócio será realizada, de modo similar ao que prevê o direito francês, mediante cessão da empresa para terceiros, que se encarregarão de lhe dar continuidade.

A diferença fundamental - e que revela, nesse particular, a superioridade do sistema francês - está no fato de que no plan de cession há obrigatoriedade de previsão expressa de como será realizada a manutenção da atividade e a preservação dos postos de trabalho. Por essa característica, a doutrina daquele país consagrou a ideia de que a cessão da empresa na liquidation judiciaire não consiste em mera técnica de realização dos ativos, mas em método de preservação da empresa.

Ora, o plan de cession tem o mesmo conteúdo tanto no redressement quanto na liquidation, de maneira que a diferença entre ambos está no fato de que a lei expressamente determina que na liquidation a preservação da empresa se realiza por terceiro, pois o devedor não está em condições de fazê-lo: "dans l'impossibilité d'én assurer lui-même le redressement."1037

\footnotetext{
${ }^{1036}$ COELHO, Fabio Ulhoa. Comentários à nova lei de falências e de recuperação de empresas, São Paulo: Saraiva, 2011, 8. edição, p. 173.

${ }^{1037}$ Artigo L.631-22. Al. $1^{\text {er }}$, C. Com. Em tradução livre: 'na impossibilidade de ele próprio [o devedor], assegurar o redressement'.
} 
De igual modo, um sistema concursal que prestigie uma perfeita distinção entre a empresa e o empresário deve considerar "a possibilidade de o devedor aportar recursos novos para reerguimento da empresa, podendo, assim, opor-se à alienação da empresa"1038; entretanto, caso não o faça, devem ser prestigiadas soluções de cessão a terceiros que tenham condições de promover a reorganização da empresa, enquanto negócio.

Pelo fato de apresentar-se com uma nova feição e com objetivos inteiramente distintos daqueles previstos no ordenamento jurídico precedente ${ }^{1039}$, a falência no direito brasileiro poderá apresentar-se como um método de preservação do negócio (nesse caso, mediante o afastamento compulsório do devedor).

Para tanto, insista-se, a acepção do termo 'empresa', empregada no artigo 75 da Lei n. 11.101/05, mais se aproxima da definição do perfil objetivo (organização de bens) a que se referia Asquini ${ }^{1040}$, ainda que, como visto ao longo desse trabalho, a noção do termo vai além desta acepção. Lembremos, na medida em que é permitida a transferência compulsória de contratos estratégicos formalizados pelo devedor, a exemplo do que ocorre no plan de cession do direito francês, o conceito de empresa toma sentido de maior alcance, vinculada à sua natureza econômica, de exploração destinada à produção ou à circulação de bens ou serviços, para o mercado.

Diante disso, é evidente que a falência deverá representar uma solução de pagamento aos credores (sob a óptica da satisfação de seu crédito), mas não apenas isso; poderá constituir-se como alternativa de preservação da atividade econômica, eis que, sem dúvida, esse é um dos fundamentos da lei brasileira. Busca-se, na falência, a tutela dos interesses que gravitam em torno da 'empresa', como a manutenção da fonte produtora,

\footnotetext{
${ }^{1038}$ FONSECA, José Júlio Borges da. "Da recuperação da empresa em crise". Revista de direito mercantil, industrial, econômico e financeiro. São Paulo, vol. 87, Ano XXXI (nova série), jul/set, 1992, p. 83.

${ }^{1039}$ A propósito, vide obra coletiva, (coord.) TOLEDO, Paulo Fernando C. Salles de; ABRÃO, Carlos Henrique. Comentários à lei de recuperação de empresas e falência. São Paulo: Saraiva, 2005, p. 2.

1040 “.... a empresa, enquanto atividade, não existe na falencia. Passa a haver, com a quebra, de um lado, um completo de bens (a massa falida objetiva) e, de outro, uma coletividade de credores (a massa falida subjetiva). $O$ devedor é desapossado de seus bens, que passam a integrar a massa falida. $O$ devedor é desapossado de seus bens, que passam a integrar a massa falida. São esses bens que devem, nos termos do art. 75 da LRE, ser preservados, tendo em vista, ainda, a possibilidade de sua utilização produtiva." (TOLEDO, Paulo Fernando Campos Salles. "A preservação da empresa, mesmo na falência", em Direito recuperacional, ob. coletiva, coord. DE LUCCA, Newton; DOMINGUES, Alessandra de Azevedo. São Paulo: Quartier Latin, 2009, p. 521).
} 
dos empregos e da própria cadeia produtiva a benefício do tráfico mercantil. Finalmente, para o devedor, a falência constitui meio de obtenção da extinção de suas obrigações, conforme artigo 158 da lei.

Assim, muitas das alterações e inovações havidas no âmbito da quebra revelam que o legislador priorizou a preservação da atividade produtiva tanto quanto possível, mesmo na falência.

Não é outra a leitura que se pode fazer da regra explícita do artigo 75 da lei, pelo qual fica evidenciado que o objetivo da falência não deverá impor, necessariamente, a extinção da empresa. Pelo sistema brasileiro, impõe-se, com a falência, o afastamento compusório de seu titular, abrindo-se a possibilidade de preservação e otimização da organização dos bens, inclusive dos intangíveis, sempre que esta alternativa mostre-se possível por terceiros.

O critério de aferição entre a recuperação e a falência repousa, fundamentalmente, no crédito (ou credibilidade) que o devedor consegue demonstrar preservada em relação a seus credores e parceiros empresariais. Isto seja porque o credor decidiu ajuizar pedido de falência (se preenchidos os requisitos legais), seja porque, no curso de uma recuperação judicial, o plano não conta com as adesões suficientes para aprovação (direta ou mediante cram-down ${ }^{1041}{ }_{-}^{1042}$ ); o fundamento que decide o destino do devedor é o crédito que os credores estão dispostos a lhe conceder.

O próprio conceito de viabilidade, exigido para a concessão da recuperação judicial, não está relacionado à empresa em si, mas ao plano que o devedor apresenta. Os

\footnotetext{
1041 "ao contrário do que se verifica na disciplina adotada por outros países acerca do mesmo instituto, mantém fundamentalmente o poder de decisão com a assembléia geral de credores, quase que estabelecendo um 'quorum' alternativo de aprovação do plano em relação ao previsto no art. 45; não se abre nenhuma margem para a apreciação pelo juiz da situação econômico-financeira concreta do devedor”. (Comentários à Lei de recuperação de empresas e falência. Obra coletiva, coord. SOUZA JR., Francisco Satiro; PITOMBO, Antonio Sergio A. de Moraes. 2. edição, São Paulo: Revista dos Tribunais, pp. 285/286).

${ }^{1042}$ E a jurisprudência do tribunal paulista vem confirmando a orientação (AI n. 500.624-4/8-00, 26/03/08, Relator Des. Lino Machado) de que não cabe ao Judiciário adentrar a análise de mérito da viabilidade do plano, tendo em vista que tal apreciação constitui matéria de atribuição dos credores, razão pela qual o Magistrado deveria abster-se da "magistratura econômica". Em outra decisão (AI 558.460, 24/09/08, Relator Des. Elliot Akel), ficou decidido que cabe aos credores a apreciação do plano de devedor e sua viabilidade econômico-financeira, e a Corte Paulista decretou a quebra sob o argumento de que, uma vez rejeitado o plano pela assembleia e inexistindo quórum para aplicação do $\S 1^{\circ}$ do arquivo 58 , o juiz não tem discricionariedade para conceder a recuperação judicial.
} 
credores confiam na factibilidade do plano e acreditam que o devedor se desincumbirá de sua aplicação.

Daí resulta a ideia de que não havendo essa confiança, a falência será a solução para a crise do devedor, embora exista, na organização empresarial, um negócio com boas perspectivas de rentabilidade. É isso que os potenciais adquirentes do "negócio" da falida apreciam em relação à unidade de produção (estabelecimento) que se pretenda alienar $^{1043}$. Ou seja, o negócio deve mostrar-se habilitado a, per se ou com pequena readequação, gerar lucro no futuro.

Desse modo, a preservação do negócio em um procedimento falimentar terá lugar na hipótese em que o devedor não logre conquistar crédito por parte de seus credores.

A falência surge, assim, como forma ordenada de satisfação dos credores (quando o acordo não for ou não puder ser obtido) e preservação quando o negócio apresente condições dignas de se preservar. Por exemplo, nos casos em que os credores tornam-se acionistas do negócio, por versão de bens a uma nova sociedade, há uma visão 'ex post' da tutela de seus direitos, pois, mesmo que seus créditos sejam pagos com participação social, isso ocorre porque há uma perspectiva de receitas no futuro (dividendos), além da manutenção de vínculos contratuais potencialmente interessantes.

Constatada essa possibilidade, o processo de falência deverá conduzir-se prestigiando a solução jurídica que, do ponto de vista prático, permita que possam ser atingidos seus fins - satisfação dos credores e preservação da utilização produtiva dos bens -, de forma mais célere e econômica possível (§ único do artigo 75).

E para que isso ocorra, o legislador criou inúmeros mecanismos estudados nesse trabalho, aptos a atender tais finalidades, como, por exemplo, a alienação antecipada dos bens, a priorização da venda em bloco dos ativos do devedor, a inexistência de sucessão fiscal e trabalhista e assim por diante. Há espaço, como visto, para aperfeiçoamento do sistema, o que não deve retirar o mérito do grande avanço que o direito

${ }^{1043}$ Que é, na opinião de André Jacquemont, o que ocorre na venda da empresa por cessão no curso de um procedimento de liquidation. (JACQUEMONT, André. Droit des entreprises en difficiulté. 6. édicion, Paris: Litec Group Lexisnexis, 2009, p. 429). 
brasileiro alcançou com a Lei n. 11.101/05, por haver elegido o princípio da preservação da empresa como corolário, cuidando de fixar mecanismos viabilizadores da manutenção da atividade econômica.

De modo geral os mecanismos criados pela lei para preservar a organização dos bens, na falência, buscam manter o elo de unidade econômica que lhes resulta em valor agregado da empresa, além de impedir sua obsolescência, tentar manteros ativos intangíveis (marca, clientela e know-how) e preservar contratos estratégicos à operação do negócio.

Há uma presunção de que, mantido o going concern, que resulta da organização de bens de um estabelecimento com potencialidade para gerar lucro, a sua realização na falência poderá resultar em melhor preço de venda em benefício dos credores.

A preservação da empresa e a satisfação dos credores, na falência, são circunstâncias amalgamadas, pois a possibilidade de venda de uma unidade produtiva que possua valor de aviamento viabiliza, em tese, a melhor satisfação dos credores ${ }^{1044}$, seja porque o preço de alienação tende a ser maior, seja porque serão mantidos vínculos contratuais que podem ser de interesse.

A afirmação de que a satisfação dos credores seria impedimento para a preservação da empresa constitui um "falso problema", conforme anota Lorenzo Stanghellini ${ }^{1045}$.

1044 Apesar de o caso "Parmalat" ter se desenvolvido sob a égide de um procedimento recuperatório (artigo 4-bis, Legge 39/2004, prevê 'un concordato' no âmbito da amministrazione straordinaria delle grandi imprese); na essência, a ideia aqui mencionada aplica-se, pois a empresa possuía um EBTIDA positivo e a insolvência tinha causa principalmente em uma gestão financeira ruinosa. Ocorreu, assim, uma reestruturação sem o consentimento do devedor e com a criação de outra sociedade, a 'nova Parmalat', para a qual foram vertidos todos os ativos da devedora, tendo os credores sido pagos com a participação na nova empresa. (STANGHELLINI, Lorenzo. Le crisi di impresa fra diritto ed economia (le procedure di insolvenza). Bologna: Il Mulino, 2007, pp. 215-218).

${ }^{1045}$ Lorenzo Stanghelini afirma que há uma contradição apenas aparente entre esses valores, pois não serão necessariamente contrapostos entre si, embora nem sempre sejam coincidentes. (STANGHELLINI, Lorenzo. Le crisi di impresa fra diritto ed economia (le procedure di insolvenza). Bologna: Il Mulino, 2007, pp. 7890). Para o autor, “[...] non ha senso parlare di un 'autonomo' interesse alla conservazione dell'impresa o alla conservazione dei posti di lavoro: siamo in presenza di un falso problema. In questo caso, mediante la continuazione dell'atività (al riparo delle azioni disgregatrici dei creditori singoli), i creditori come gruppo possono monetizzare (mediante una ristrutturazione o una vendita) il suo valore d'avviamento, $i$ dipendenti conservano il loro posto di lavoro, i fornitori e i clienti mantengono i loro rapporti con l'impresa, la crisi 
Há inúmeras previsões legais que resultam na potencialização do valor dos ativos (inexistência de sucessão, venda em bloco e outras) e que constituem em elemento facilitador de sua realização na falência. Em consequência, a expectativa de pagamento dos credores aumenta, além de, naturalmente, contribuir-se para a utilização produtiva dos bens, em cumprimento ao objetivo preconizado pelo artigo 75 da lei concursal brasileira.

Pode-se afirmar que, constatado o estado de crise econômico-financeira insuperável do empresário (não há condições de uma solução negociada), a falência deve ser decretada. Porém, se o negócio evidenciar, no todo ou em parte, rentabilidade, sua alienação em bloco deverá ser prestigiada, de modo que os credores sejam satisfeitos de acordo com a ordem legal e o negócio deverá prosseguir, sob nova titularidade, sem qualquer vínculo obrigacional com o passado da falida.

Tal é o sistema e é sob essa visão que se pode afirmar que o objetivo da falência é a recuperação, na qual se busca estabelecer meios de otimização do uso produtivo dos ativos da devedora.

O ideal preservacionista da falência está, na maximização do valor dos ativos, pela preservação do going concern value ${ }^{1046}$. Esta peculiaridade pode ser verificada, com clareza, em todos os sistemas analisados nessa pesquisa tanto nos que adotam a via dúplice procedimental quanto nos que optaram pela unificação. No direito brasileiro, a dicotomia procedimental foi adotada, mas de forma bastante curiosa, eis que o mesmo objetivo - de manutenção do organismo produtivo - poderá ser alcançado em um e outro procedimento.

dell'impresa viene circoscritta e non si propaga a imprese situate a monte o a valle nel ciclo produttivo." (obra citada, p. 69). Em tradução livre não há senso falar em um autônomo interesse de conservação da empresa ou a conservação de postos de trabalho: estamos na presença de um falso problema. Neste caso, mediante a continuação da atividade (ao abrigo da ação desagregadora dos credores atuando singularmente), os credores como grupo podem capitalizar (mediante uma reestruturação ou venda) o valor do aviammento, os empregados conservam seus postos de trabalho, os fornecedores e clientes mantêm os seus vínculos com a empresa, a crise da empresa fica circunscrita e não se propaga a empresas relacionadas direta ou indiretamente no círculo produtivo."

1046 "Compito delle procedure di liquidazione, d'altro canto, è non soltanto riallocare il patrimonio rapidamente, ma anche e sopratutto rialocarlo a valori quanto piú possibile prossimi a quelli che lo stesso debitori ritieni congrui, magari mediante una vendita dell'azienda in esercizio." (STANGHELLINI, Lorenzo. Le crisi di impresa fra diritto ed economia (le procedure di insolvenza). Bologna: Il Mulino, 2007, p. 239). Em tradução livre: 'A tarefa do procedimento de liquidação, por outro lado, é não apenas realocar o patrimônio rapidamente, mas também, e sobretudo, realocá-lo por um valor o mais próximo possível àquele que o próprio devedor entende suficiente, talvez mediante a venda do estabelecimento em exercício.' 
Uma das funções do direito concursal moderno é assegurar que em um processo concursal possa ser preservado o going concern value ${ }^{1047}$.

A preservação do negócio na falência não só é compatível, mas desejável, sempre que esta medida possa resultar na maximização da satisfação dos credores e na melhor alocação dos ativos, preservando sua organização.

${ }^{1047}$ A propósito, observa-se similitude de propósitos nas regras de proteção da empresa em se tratando de desarmonia entre os sócios ou atuação dos credores, na liquidação: "This liquidation protection rules serves to protect the 'going concern value' of the firm against destruction either by individual shareholers or their creditors." (The anatomy of corporate law: a comparative and functional approach, 2. edition, New York: Oxford, 2009, p.07). Em tradução livre: 'As regras de proteção na liquidação servem para proteger o 'going concern value' da empresa contra a destrução pelo sócio ou por seus credores'. 


\section{RESUMO}

O fenômeno da crise das empresas é universal. Acrescente-se a esse fato, que a globalização das relações empresariais é uma realidade a qual, a cada dia, vincula, sem encontrar fronteiras, um incontável feixe de negócios e contratos que movem a economia, promovendo a circulação de riquezas, bens e serviços. Desses dois fatos incontestáveis resulta a inafastável importância do tema escolhido para análise nesta tese: a falência.

Os efeitos da crise da empresa espraiam-se ao redor de um extenso leque de interesses correlatos (trabalhadores, fornecedores, fisco, agentes financeiros e outros), justificando análise com a finalidde de aprofundar o tema e aprimorar o regramento do direito concursal.

Assim, a análise desenvolvida nesta tese consiste em demonstrar que, sob a vigência da Lei brasileira n. 11.101/2005, o instituto da falência foi inteiramente renovado.

A originalidade do trabalho ${ }^{1048}$, assim, repousa na circunstância de analisarse a falência sob a ótica do direito concursal moderno, inaugurado no sistema brasileiro pela Lei n. 11.101/05, e em como esse antigo instituto do direito concursal reformulou seus objetivos, resultando em um tratamento diferenciado das prioridades da empresa em crise cuja inviabilidade, ou algum outro percalço, impeça-a de valer-se do instituto da Recuperação.

Com efeito, a nova disciplina jurídica em estudo evidencia uma ruptura com a tradição dos primórdios da falência, nascida no direito medievo como um procedimento liquidatório voltado precipuamente ao pagamento dos credores, no qual o devedor insolvente era considerado um verdadeiro réprobo social, pois a quebra em si mesma era considerada delito.

A mudança que se faz sentir na falência resulta do fato de que o direito concursal brasileiro alargou seu foco de tutela (partindo da estrtita relação: devedor e

1048 MARCHI, Eduardo C. Silveira. Guia de Metodologia Jurídica, Milano: Edizione del Grifo, 2004, pp. $30 / 31$. 
credores), para centrar-se na empresa: esse feixe de negócios e contratos que movem a economia.

Note-se, o estudo da letra dos artigos 47 e 75 do diploma concursal brasileiro evidencia que tanto a recuperação judicial quanto a falência estão informadas pelo mesmo princípio e diretriz, que é o da preservação da empresa.

Essa aparente contradição faz nascer a seguinte indagação: em que medida existiria compatibilidade entre dois institutos cujas finalidades e funções parecem ser tão diferentes, a ponto de serem informados pelo mesmo princípio?

$\mathrm{Na}$ pesquisa desenvolvida verifica-se que esse intrigante aspecto do direito concursal brasileiro não é uma resposta isolada, mas encontra eco em soluções similares em outros sistemas analisados. É verdade, cada sistema possui suas particularidades, amalgamadas à sua própria cultura, regime econômico, e tradição jurídica. Todavia, ainda assim, é possível neles identificar traços coincidentes e que têm origem no mesmo foco de tutela: garantir o aproveitamento das organizações empresariais, sempre que possível.

Realmente, o direito brasileiro abandonou em definitivo a visão de caráter meramente procedimental da falência (como processo de "execução coletiva") e foca a tutela nos efeitos da crise das empresas, disciplinando tanto a possibilidade de superação (com a recuperação judicial e extrajudicial), quanto os meios de liquidação (falência) que possam resultar no aproveitamento da organização empresarial. Assim, a falência, conquanto mantenha seu caráter de procedimento liquidatório, passa a ter também o objetivo de criar mecanismos de manutenção e otimização dos ativos organizados e préexistentes à quebra, sempre que possível. Esse novo objeto revela, como acima mencionado, a compatibilidade de manutenção da empresa, na falência.

Desse modo, mesmo na falência a lei brasileira estabelece mecanismos de possível manutenção da organização econômica pré-estabelecida, pois o art. 75 da LRE fixa um novo objetivo do processo falimentar: "A falência, ao promover o afastamento do devedor de suas atividades, visa a preservar e otimizar a utilização produtiva dos bens, ativos e recursos produtivos, inclusive os intangíveis, da empresa." 
Aliás, é esse mesmo fenômeno, embora com particularidade e distinções próprias de cada um dos sistemas analisados, que é identificado no direito concursal estrangeiro.

Daí porque se torna possível afirmar que a falência --- essa antiga conhecida do direito concursal, em particular no direito brasileiro, como fica pontuado no trabalho --ingressou em uma nova fase do direito concursal moderno. Pode-se dizer, assim, que a novidade da legislação concursal brasileira não está apenas na criação dos institutos recuperatórios, mas, encontra-se também na falência, pois muito além da introdução dos institutos de recuperação, foram atingidas as raízes da falência, na medida em que seu objetivo foi reformulado e disto resultaram modificações expressivas.

A tese demonstra que a atualização do instituto da falência é de tal ordem que, sob sua égide, é possível não apenas estabelecer uma solução de pagamento dos credores (chegando à liquidação da devedora) mas, também, preservar a organização de bens pré-existentes. Portanto, o estudo desenvolve-se com a análise geral de alguns sistemas estrangeiros e, após, do sistema brasileiro com enfoque nos métodos encontrados pela Lei para tornar efetivo o princípio insculpido no art. 75, ou seja, de que o afastamento do devedor não será óbice à preservação e otimização da utilização produtiva dos bens da devedora, mas, ao contrário, estimula esta solução.

Em decorrência da análise, questiona-se a adoção de um sistema dualista, no direito brasileiro, quanto aos procedimentos concursais pois havendo um único objetivo final (liquidar ou preservar), parece que não se justifica a mencionada dualidade.

Realmente, a identidade de princípio que a lei brasileira adota tanto na Recuperação judicial quanto na falência (preservação da empresa), não justifica a existência de dualidade procedimental.

Parece-nos, ao final da análise, que a unificação procedimental, do ponto de vista substancial, traria melhor aproveitamento dos atos processuais e maior celeridade; e, no plano sistemático, implicaria o fim da dicotomia quebra versus recuperação para busca de soluções para a crise das empresas. 
Enfim, há uma 'nova' falência no direito brasileiro pelo modo como este instituto foi recepcionado na lei agora em vigor. Além disso, esse não é um movimento isolado do direito brasileiro, o que se demonstra com as referências feitas a outros sistemas.

Portanto, a tese evidencia de modo incontroverso que a falência deixou de ser um mero método de pagamento de credores ('execução coletiva') que resulta na liquidação do devedor, e passou a ser um modelo de quitação das obrigações compatível com a preservação da empresa, mediante manutenção da organização de bens préexistentes do devedor, para exploração por um novo empresário, sempre que possível. 


\section{SUMMARY}

The phenomenon of enterprise crisis is universal. Add to this the fact that present globalization of entrepreneurial relations daily links, without boundaries, a whole gamut of negotiations and contracts that move the economy, promoting the circulation of wealth, goods and services. From these two incontestable facts ensues the inevitable importance of the theme chosen for analysis in this thesis: bankruptcy.

The effects of enterprise crisis have far reach and are evidenced in a wide range of interrelated areas (workers, suppliers, treasury, financial agents and others), justifying deeper analysis of the issue aiming to improve bankruptcy and recovery regulations.

Within such, the analysis developed in this thesis sets out to demonstrate that under present Brazilian Law n. 11.101/2005, bankruptcy law was entirely renovated.

The originality of this work lies ${ }^{1049}$, thus, on analysis of bankruptcy (falência) from the stance of modern bankruptcy and recovery law, introduced to the Brazilian system under Law n. 11.101/05, and in showing how the old bankruptcy and recovery system, in reformulating its objectives, has led to a differentiated treatment of the priorities of the distressed enterprise whose impracticability, or some other mishap, keeps it from availing itself of the Recovery regulation.

Indeed, the new legal discipline under study shows a break with the tradition from the starts of bankruptcy, conceived in medieval law as a liquidation process focused on payment of creditors, in which the insolvent owner was considered a true social reprobate, and going broke itself an offense.

The change that is evidenced in bankruptcy results from the fact that Brazilian bankruptcy and recovery law widened its regulatory focus (from the strict relation: debtor and creditors), to center on the enterprise: a whole gamut of negotiations and contracts which move the economy.

${ }^{1049}$ MARCHI, Eduardo C. Silveira. Guia de Metodologia Jurídica, Milano: Edizione del Grifo, 2004, pp. $30 / 31$. 
It is to be noted that close reading of Brazilian bankruptcy and recovery articles 45 and 75 shows that legal recovery as well as bankruptcy are informed on the same principle and directive, which is the preservation of the enterprise.

This apparent contradiction gives rise to the following question: to what extent would there be compatibility between two differents solutions (reorganization or liquidation) under brasilian bankruptcy law, the ends and function of which seem so diverse, to the point that they are based on the same principle (preservation of the enterprise)?

Research carried out for this thesis reveals that this intriguing aspect of Brazilian bankruptcy and recovery law is not an isolated happening, but finds echoes in similar solutions in other systems analyzed. Surely, each system has its own specificities, linked with its own culture, economic regime and legal tradition. However, even so, it is possible to identify in them coinciding traits, originating from the same legislative focus: to guarantee optimum usage of the entrepreneurial organization, whenever possible.

Truly, Brazilian law abandoned definitely the solely procedural vision of bankruptcy (as a process of "collective execution") to center on the effects of enterprise crisis, disciplining the possibility of overcoming (with judicial and extra judicial recovery), as well as finding means of bankruptcy that can lead to best usage of the business (re)organization. As such, bankruptcy law, while maintaining its liquidation procedure characteristic, takes on the aim of creating mechanisms to maintain and optimize assets organized and pre-existent to the insolvency, whenever possible. This new objective reveals, as above mentioned, the compatibility at one and the same time of maintenance and bankruptcy of the enterprise.

Thus, even under bankruptcy, Brazilian law establishes mechanisms for safeguarding and sustaining the pre-established economic organization, in that art. 75 of the L.R.E fixes a new bankruptcy process objective: "Bankruptcy, in promoting the removal of the debtor from his activities, aims to preserve and optimize the utilization of goods, assets and productive resources, including the intangibles, of the enterprise." 
Indeed, it is this same phenomenon, though with specificities and distinctions inherent to each of the systems analyzed, which is identified in foreign bankruptcy and recovery law.

This is why it may be affirmed that bankruptcy (falência) — age-old, familiar, bankruptcy and recovery law, especially in Brazilian legislation, as made clear in this work-entered a new phase of modern bankruptcy and recovery law. The novelty thus of Brazilian bankruptcy and recovery law lies not only in the creation of recovery regulations, but also in bankruptcy itself, for beyond the introduction of recovery statutes, the very roots of bankruptcy were affected, in that its objective was reformulated and from such ensued substantial changes.

This thesis shows that the updating of bankruptcy law is of such order, that under its aegis not only is it possible to establish a solution for payment of creditors (including the liquidation of the debtor) but, also, preserve the organization's preexisting goods and assets. Beginning with a general analysis of a few foreign systems, the study then turns to the Brazilian system, focusing on methods found by Law to make effective the principle inscribed in art. 75; that is, that the removal of the debtor will not be an obstacle to the preservation and optimization of the productive usage of goods of the debtor, but, to the contrary, stimulates this relation.

As a result of the analysis, a question arises regarding the adoption of a dualist system in Brazilian law vis-à-vis bankruptcy and recovery procedures, for having a single final objective (liquidate or preserve), it seems the mentioned duality is not justified.

Truly, the singleness of the principle that the Brazilian law adopts both in judicial recovery and in bankruptcy (preservation of the company), does not justify the existence of procedural duality.

It seems to us, on ending the analysis, that procedural unification, from a substantial point of view, would lead to greater benefits from procedural acts and to more celerity in solutions; and, on the systematic level, would imply the end of the dichotomy bankruptcy versus recovery in the search for solutions to enterprise crises. 
Finally, there is a 'new' Brazilian bankruptcy law as seen in the manner it was conceived in legislation now in force. Furthermore, this is not an isolated movement of Brazilian law, as shown in references to other systems.

This thesis evidences clearly that bankruptcy left off being a mere method of payment of creditors ("collective execution") which results in the liquidation of the debtor, to become a model for acquitting obligations compatible with the preservation of the company, by maintaining the organization of pre- existing assets and goods of debtor for exploration by a new entrepreneur, always when possible. 


\section{RÉSUMÉ}

Le phénomène de la crise des entreprises est universel. En plus, la mondialisation des relations des entreprises est une réalité qui met en contact, quotidiennement, et sans imposer de frontières, un large éventail d'affaires et de contrats qui font bouger l'économie et favorisent la circulation des richesses, des biens et services. De ces deux faits incontestables résulte l'importance incontournable du sujet choisi et qui fait l'objet de l'analyse de cette thèse : la faillitte.

Les effets de la crise de l'entreprise se dispersent autour d'une gamme d'intérêts corrélés (les travailleurs, les fournisseurs, le fisc, les agents financiers et d'autres), ce qui justifie cette analyse dans le but d'approfondir le sujet et perfectionner le règlement du droit des faillites.

Ainsi, l'analyse développée dans cette thèse consiste à démontrer que, sous la Loi brésilienne $\mathrm{n}^{\mathrm{o}} 11.101 / 2005$ en vigueur, l'institut de la faillite a été entièrement renouvelé.

L'originalité du travail ${ }^{1050}$ se fonde ainsi sur la circonstance d'analyser la faillite sous l'optique du droit moderne des faillites, mis en oeuvre dans le système brésilien par la Loi n. 11.101/05, et sur la façon dont cet ancien institut du droit des faillites a reformulé ses objectifs, ce qui résulte en un traitement différent des priorités de l'entreprise en crise dont la non-viabilité, ou tout contretemps, l'empêcherait d'utiliser l'institut du redressement.

En effet, la nouvelle discipline juridique en étude met en évidence une rupture avec la tradition de l'origine de la faillite, issue du droit médiéval en tant que procédure de liquidation dans le but essentiel de payer les créanciers, et par le biais duquel le débiteur insolvable était considéré comme un véritable réprouvé social, car la faillite en soi était considérée comme un délit.

${ }^{1050}$ MARCHI, Eduardo C. Silveira. Guia de Metodologia Jurídica, Milano: Edizione del Grifo, 2004 , pp. $30 / 31$. 
Le changement qui se fait sentir pour ce qui est de la faillite résulte du fait que ce droit brésilien a élargi sa portée de tutelle (en prenant comme point de départ le strict rapport : le débiteur et les créanciers) afin de se centrer sur l'entreprise : cet éventail d'affaires et de contrats qui font bouger l'économie.

Il faut noter que l'étude du texte des articles 47 et 75 de la loi brésilienne des faillites met en évidence que le redressement judiciaire ainsi que la faillite sont informés par le même principe et la même directive, autrement dit, la préservation de l'entreprise.

Telle contradiction apparente suscite la question suivante: dans quelle mesure y aurait-il une compatibilité entre deux instituts dont les buts et les fonctions semblent être si différents, à tel point qu'ils sont informés par le même principe ?

L'on constate, au niveau de la recherche entamée, que cet intrigant aspect du droit brésilien des faillites n'est pas une réponse isolée, mais qu'il trouve plutôt un écho dans des solutions pareilles d'autres systèmes analysés. En effet, chaque système a ses particularités, amalgamées à la propre culture, au regime économique et à la tradition juridique. Cependant, il est encore possible d'y identifier des caractéristiques coïncidentes issues de la même origine de la tutelle : assurer que l'on puisse se servir des organisations sociétaires, dans la mesure du possible.

En fait, le droit brésilien a définitivement renoncé à la vision de caractère simplement procédural de la faillite (en tant que processus «d'exécution collective »), et centre la tutelle sur les effets de la crise des entreprises, disciplinant aussi bien la possibilité de dépassement (par le biais du redressement judiciaire et extrajudiciaire) que les moyens de liquidation (la faillite) qui peuvent résulter du fait de se servir de l'organisation sociétaire. Ainsi, la faillite, nonobstant le maintien de son caractère de procédure de liquidation, désormais intègre également le but de créer des mécanismes de maintien et d'optimisation des actifs organisés et pré-existants à la faillite, dans la mesure du possible. Comme susmentionné, ce nouvel objet révèle la compatibilité du maintien de l'entreprise, lors de la faillite. 
Par conséquent, même lors de la faillite, la loi brésilienne établit des mécanismes qui rendent possible de maintenir l'organisation économique pré-établie, car l'article 75 de la LRE (Loi de la réhabilitation et de la faillite des entreprises) fixe un nouvel objectif du procès de dépôt de bilan: "Lorsqu'elle éloigne le débiteur des ses activités, la faillite vise à préserver et optimiser l'utilisation productive des biens, des actifs et des ressources de production, y compris des actifs incorporels de l'entreprise. »

D'ailleurs, c'est ce même phénomène, quoique doté de particularités et de différences propres à chacun des systèmes analysés, que l'on identifie dans le droit étranger des faillites.

D'où la possibilite d'affirmer que la faillite a franchi une nouvelle étape du droit moderne le concernant. Il s'agit de cette ancienne connaissance du droit des faillites, particulièrement dans le droit brésilien, comme nous le signalons ici. L'on peut donc affirmer que la nouveauté de la législation brésilienne dans ce domaine ne se restreint pas à la création des instituts du redressement, mais se retrouve aussi dans la faillite, car bien audelà de l'introduction des instituts de redressement, ce sont les racines même de la faillite que l'on a atteint, dans la mesure où son objectif a été reformulé, et que des modifications éloquentes y sont issues.

La thèse démontre que la mise à jour de l'institut de la faillite est de tel ordre qu'il est possible, sous son égide, non seulement d'établir une solution de paiement des créanciers (et d'aboutir même à la liquidation du débiteur), mais aussi de préserver l'organisation des biens pré-existants. Par conséquent, l'étude se développe et se penche sur l'analyse générale de quelques systèmes étrangers, et, ensuite, sur celle du système brésilien, se concentrant sur les méthodes trouvées par la loi afin de rendre effectif le príncipe inscrit dans la l'article 75, autrement dit, que l'éloignement du débiteur n'est pas une entrave à la préservation et optimisation de l'utilisation productive des biens du débiteur, mais, au contraire, qu'il encourage cette solution.

Suite à l'analyse, l'adoption d'un système dualiste au sein du droit brésilien est remise enm cause, pour ce qui est des procédures de faillite, car comme il n'y a qu'un seul but (liquider ou préserver), cette dualité semble ne pas se justifier. 
En effet, l'identité du príncipe que la loi brésilieene adopte aussi bien le redressement judiciaire que la faillite (préservation de l'entreprise) ne justifie pas l'existence de la dualité procédurale.

Il nous semble, en fin d'analyse, que du point de vue substantiel l'unification procédurale permettrait de tirer meilleur profit des actes de procédure et d'imprimer plus de vitesse ; et, sur le plan sytémique, cela entrânerait la fin de la dichotomie entre la faillite et le redressement, en quête de solutions pour la crise des entreprises.

Enfin, une 'nouvelle' faillite existe au sein du droit brésilien d'après la façon dont cet institut a été accueilli dans la loi en vigueur à l'heure actuelle. En outre, il ne s'agit pas d'un mouvement isolé du droit brésilien, ce qui se démontre par les références par rapport à d'autres systèmes.

Ainsi, la thèse met en évidence de façon indiscutable que la faillite a cessé d'être une simple méthode de paiement aux créanciers ('exécution collective') dont le résultat est la liquidation du débiteur, et s'est transformée em un modèle de quittance des obligations compatible avec la préservation de l'entreprise, par le biais du maintien par l'organisation des biens pré-existants du débiteur, permettant ainsi qu'un autre entrepreneur poursuive l'exploitation, dans la mesure du possible. 


\section{RIASSUNTO}

Il fenomeno della crisi delle aziende è universale. Ci si può aggiungere che la globalizzazione dei rapporti aziendali sia una realtà alla quale, ogni giorno, vincola, senza trovarne barriere, un incomputabile fascia di affari e contratti che muovono l'economia, promuovendo la circolazione di ricchezze, beni e servizi. Da questi due fatti incontestabili risolta l'incontrastata importanza del tema scelto per analisi in questa tese: il fallimento.

Gli effetti della crisi dell'azienda si estendono intorno di uno stesso ventaglio di interessi correlati (lavoratori, fornitori, fisco, agenti finanziari ed altri) giustificando l'analisi con la finalità di approfondire il tema e affinare il regolamento del diritto concorsuale.

In questo modo, l'analisi sviluppata in questa tese consiste in dimostrare che, sotto il vigore della legge brasiliana n. 11.101/2005, l'istituto del fallimento fu interamente rinnovato.

L'originalità di questa tese $\mathrm{e}^{1051}$, in questo senso, riposa nella circostanza di analizzarsi il fallimento sotto l'ottica del diritto concorsuale moderno, inaugurato nel sistema brasiliano dalla legge n. 11.101/05, e in come questo antico istituto del diritto concausale riformulò i suoi obbiettivi, risultando in un trattamento differenziato delle priorità del`azienda in crisi, la quale invalidità oppure qualche altro intralcio, la impedisca di valersi dell istituto del Recupero.

In effetti, la nuova disciplina giuridica in studio evidenzia una rottura ai primordi del fallimento, nato dal diritto del medievo come un procedimento liquidatore rivolto previamente al pagamento dei creditori, nel quale il debitore insolvente era considerato un vero rebropo sociale, visto che la rottura in sè era considerata delito.

Il cambiamento che si fa sentire nel fallimento deriva dal fatto che il diritto concorsuale brasiliano ampliò il suo filone di tutela (partendo dello stretto legame: debitori

1051 MARCHI, Eduardo C. Silveira. Guia de Metodologia Jurídica, Milano: Edizione del Grifo, 2004, pp. $30 / 31$. 
e creditori), per centralizzarsi all' azienda: questo fascio di affari e contratti che muovono l'economia.

Si potrebbe notare che, lo studio della lettera degli articoli 47 e 75 del diploma concorsuale brasiliano mette in evidenza che sia il recupero giudiziale sia il fallimento sono informati dallo stesso principio e direttrice che quello della preservazione dell'azienda.

Quest' apparente contraddizione fa nascere la seguente indagine: in che misura potrebbe esistere compatibilità tra due istituti i quali le finalità e funzioni sembrino essere cosi diverse, fino al punto di essere informati dallo stesso principio?

Nella ricerca sviluppata si verifica che questo intrigante aspetto del diritto concorsuale brasiliano non è una risposta isolata, ma trova eco in delle soluzioni simili in degli altri sistemi analizzati. È vero, ogni sistema possiede le sue particolarità amalgamate alla sua cultura, regime economico e tradizione giuridica. Tuttavia è possibile identificare in essi i tratti coincidenti e che hanno origine nello stesso filone di tutela: garantire il profitto delle organizzazioni aziendali, sempre che sia possibile.

In effetti, il diritto brasiliano abbandonò in definitivo l'ottica di carattere semplicemente procedurale del fallimento (come processo dell'esecuzione collettiva") e si rivolge alla tutela negli effetti della crisi delle aziende, disciplinando sia la possibilità (come il recupero giudiziale ed extragiudiziale), che i mezzi di liquidazione (fallimento) che possono risultare nel profitto dell'organizzazione aziendale. In questo modo, il fallimento, finché mantenga, sempre che possibile, il suo carattere di provvedimento e ottimizzazione degli attivi organizzati e preesistenti alla rottura. Questo nuovo oggetto rivela, come sopracitato, la compatibilità di manutenzione dell'azienda, nel fallimento.

In questo modo, anche nel fallimento, la legge brasiliana stabilisce meccanismi di manutenzioni possibili dell'organizzazione economica prestabilita, visto che l'art. 75 della LRE fissa un obbiettivo nuovo del processo fallimentare: "il fallimento, nel promuovere l'allontanamento del debitore dalle sue attività, intenta preservare e ottimizzare l'utilizzo produttivo dei beni attivi e dei ricorsi prodottivi, incluso quegli inafferrabili, dell'azienda". 
Anzi, è il fenomeno stesso, anche se con particolarità e distinzioni proprie di ciascuno dei sitemi analizzati, che viene identificato nel diritto concorsuale straniero.

Da esso si mostra possibile affermare che il fallimento --- questo conosciuto instituto dal diritto concorsuale, particolarmente nel diritto brasiliano, come sottolineato in questa tese --- ingressò in una nuova fase del diritto concorsuale moderno. Si potrebbe allora affermare che la novità della legislazione concorsuale brasiliana non appare soltanto nella creazione degli istinti ricuperatori, ma si trova pure nel fallimento, giacché oltre l'introduzione degli istinti di ricupero, furono colpite le ardisci del fallimento, nella misura in cui il suo obbiettivo fu riformulato e espressive modificazioni ne furono risultato.

La tese dimostra che l'attualizzazione dell'istinto del fallimento è tale che sotto la sua egida è possibile non soltanto stabilire una soluzione di pagamento dei creditori (essendo possibile arrivare alla liquidazione della debitrice) ma anche osservare l'organizzazione dei beni pre-esistenti. pertanto lo studio si sviluppa con l'analisi generale dei sistemi stranieri dopodiché verrà trattato il sistema brasiliano stesso con l'enfasi nei metodi trovati dalla Legge per far si che sia effettivo il principio scolpito nell'art. 75, ossia, che la lontananza del debitore non sarà obice alla preservazione e ottimizzazione dell'utilizzo produttivo dei beni della debitrice, anzi, la stimola.

In decorrenza dell'analisi, si questiona l'adozione di un sistema dualistico, nel diritto brasiliano, quanto ai procedimenti concorsuali giacché avendo un solo obbiettivo finale (liquidarlo o preservalo), sembra che non si giustifichi la dualità.

Infatti l'identità del principio che la legge brasiliana adotta sia nel Recupero giudiziale che nel fallimento ( preservazione dell'azienda) non giustifica l'esistenza della dualità procedurale.

Ci sembra, alla fine di quest'analisi, che l'unificazione procedurale, dall'ottica sostanziale, trarrebbe migliori profitti degli atti processuali e maggior celerità; e nel piano sistematico, implicherebbe la fine della dicotomia rottura in opposizione (vs) al recupero per la ricerca di soluzioni alla crisi delle aziende. 
Infine, esiste un "nuovo" fallimento nel diritto brasiliano dal modo con che quest'istituto fu accolto dalla legge in vigore. Oltre a esso, non è un movimento isolato del diritto brasiliano, il che si dimostra con le referenze fatte ad altri sistemi.

Perciò la tese mette in luce in modo incontroverso che il fallimento al posto di essere un mero metodo di pagamento da creditori ("esecuzione collettiva") che risolta nella liquidazione del debitore, viene ad essere un modello di annichilamento degli obblighi compatibile con la preservazione dell'azienda, mediante la manutenzione dell'organizzazione di beni preesistenti del debitore, per l'esplorazione da un nuovo, sempre che ne sia possibile. 


\section{BIBLIOGRAFIA}

ABRÃO, Nelson. A continuação do negócio na falência. São Paulo: Leud, 1975.

. Curso de direito falimentar. 2. edição, São Paulo: Saraiva, 1980.

. "Declaração Judicial da Falência". Revista de Direito Mercantil, Industrial,

Econômico e Financeiro. Vol. 35, Ano XVIII (nova série), pp. 25-27, jul/set,1979.

. Nova disciplina jurídica da crise econômica da empresa. São Paulo, Leud, 1984.

O novo direito falimentar. São Paulo: Revista dos Tribunais, 1985.

"A nova lei argentina sobre procedimentos concursais". Revista de Direito

Mercantil, Industrial, Econômico e Financeiro. São Paulo, vol. 9, Ano XII (nova série), pp. 143-145, 1973.

ADAMEK, Marcelo Vieira Von. "Os empresários do setor aéreo e os contratos de arrendamento de aeronaves na lei de recuperação de empresas e falências (Lei $n$. 11.101/02005, art. 199)". Revista de Direito Mercantil, Industrial, Econômico e Financeiro. São Paulo, vols. 151/152, Ano XLVIII (nova série), pp. 187-202, jan/dez, 2009.

ADLER, Barry E. Foundations of bankruptcy law. New York: Foundation Press, 2005.

AGUGLIA, Enrico. Il processo per la dichiarazione di fallimento. Padova: Cedam, 2001.

ALBERTI, Alfredo Maffei. Commentario breve alla legge fallimentare (e alla legge sull'amministrazione straordinaria delle grandi imprese in crisi). 4. edição, Padova: Cedam, 2000.

ALEMÁN MONTERREAL, Ana. La insolvencia, una cuestión de terminología jurídica. Santiago de Compostela: Andavira Editora, 2010. 
ALMEIDA, Amador Paes de. Curso de falência e concordata. 14. edição, São Paulo: Saraiva, 1996.

ALMEIDA, Gustavo Milaré. “Anotações sobre o principio da função social da empresa na doutrina e na jurisprudência brasileira”. Revista de Direito Mercantil, Industrial Econômico e Financeiro. São Paulo, vols. 153/154, Ano XLIX (nova série), pp. 240-286, /jun, 2010.

ALMEIDA. Betyna Ribeiro de. "Aspectos da teoria jurídica da empresa". Revista de Direito Mercantil, Industrial Econômico e Financeiro. São Paulo, vol. 119, Ano XXXIX (nova série), pp. 236-254, jul/set, 2000.

ALONSO, Carmen; ESTEBAN, Gaudência (coord.). Gobierno corporativo y crisis empresariales, II seminário Harvard-Complutense de Derecho Mercantil. Madrid: Marcial Pons, 2006.

ALVARES, Walter. Direito falimentar. São Paulo: Sugestões Literárias, 1966.

AMADEO, José Luis. Honorarios en los concursos según la jurisprudencial. 2. ed., Buenos Aires: Adhoc, 2005.

AMBROSINI, Stefano; DEMARCHI, Paolo Giovanni. Il nuovo concordato preventivo e gli accordi di ristrutturazione dei debiti. Milano: Giuffrè, 2005.

ANDRADE, Jorge Pereira. Direito falimentar. São Paulo: Brasiliense, 1986.

APPROBATO MACHADO, Rubens (Coord). Comentários à nova lei de falências $e$ recuperação de empresas. São Paulo: Quartier Latin, 2005.

ARAÚJO, José Francelino de. Comentários à lei de falências e recuperação de empresas. São Paulo: Saraiva, 2009. 
ARAÚJO, Luiz Antonio Mattos Pimenta. "A responsabilidade tributária na sucessão das empresas". Revista de Direito Mercantil, Industrial, Econômico e Financeiro. Vol. 76, Ano XXVIII (nova série), pp. 93-101, out/dez, 1989.

ARIZA COLMENAREJO, Maria Jesús; GALÁN GONZÁLEZ, Candela (Coord.). Reflexiones para la Reforma Concursal. Madrid: Editorial Reus S/A, 2010.

ASCARELLI, Tullio. Apresentação do Brasil. Trad. da 2. edição italiana por Olinto de Castro. Edições SAL, 1952.

Corso di diritto commerciale - introduzione e teoria dell'impresa. 3. edição, Milano: Giuffrè, 1962.

Problemas das sociedades anônimas e direito comparado. São Paulo: Saraiva \& Cia. Saraiva Acadêmica, 1945.

__ "Norma giuridica e realtà sociale, Il diritto dell'economia". Rivista di Dottrina e di Giurisprudenza, ano I, n. 10, 1955.

. "A atividade do empresário" (tradução de Erasmo Valladão A. N. e França). Revista de Direito Mercantil, Industrial Econômico e Financeiro. São Paulo, vol. 132, ano XLII (nova série), pp. 201-215, out/dez, 2003.

— "O empresário" (tradução de Fábio Konder Comparato). Revista de Direito Mercantil, Industrial, Econômico e Financeiro. São Paulo, vol. 109, Ano XXXVI (nova série), pp. 183-189, jan/mar, 1998.

ASQUINI, Alberto. "Os perfis da empresa". Trad. Fábio Konder Comparato. Revista de Direito Mercantil, Industrial, Econômico e Financeiro. São Paulo, n. 104, pp. 109-126, 1996.

AZEVEDO e NOVAES FRANÇA, Erasmo Valladão. Temas de direito societário, falimentar e teoria da empresa. São Paulo: Malheiros Editores, 2009. 
" "A assembleia-geral de credores na nova lei falimentar". Revista de Direito Mercantil, Industrial Econômico e Financeiro. São Paulo, vol. 138, Ano XLIV (nova série), pp. 71-83, abril/junho, 2005.

AZNAR GINER, Eduardo. La comunicación del artículo 5.3 de la ley concursal. Valencia: Tirant lo Blanch, 2011.

AZZOLINA, Umberto. Il fallimento e le altre procedure concursuali. Torino: Tomo 1, 1953.

BAIRD, Douglas G.; JACKSON, Thomas H.; ADLER, Barry E. Bankruptcy, cases, problems and materials. 3. edição, New York: Foundation Press, 2000. University Casebook Series.

The elements of bankruptcy, 4. ed. New York: Foundation Press, 2006.

BAIRD, Douglas; RASMUSSEN, Robert K. “The end of bankruptcy”, em Chicago - John M. Olin \& Economics Working Paper n. 173 (2D series), em $<$ http://www.law.uchicago.edu/Lawecon/index.html $>$.

BALBÍN, Sebastián. Quiebra y responsabilidad de administradores y terceros. Buenos Aires: Adhoc, 2005.

BANCO MUNDIAL. Principles and guidelines for effective insolvency and creditor rights systems, 2001. Disponível em <http://www.worldbank.org/ifa/ipg_esp.pdf $>$ (ou "A Reforma da Legislação Falimentar". Revista de Direito Mercantil, Industrial, Econômico e Financeiro. São Paulo, vol. 122, Ano XL, pp. 75-167, abril/jun, 2001).

BAPTISTA DA SILVA, Ovídio A. Curso de processo civil. 4. edição, São Paulo: Revista dos Tribunais, 1998. vol. 1.

BARBIERI. Pablo C., Concursos y quiebras (Ley 24.522 comentada y concordada), Buenos Aires: Editorial Universidad, 2006. 
BARRETO FILHO, Oscar. Teoria do estabelecimento comercial. São Paulo: Max Limonad, 1969.

_. "A dignidade do direito mercantil". Revista de Direito Mercantil, Industrial, Econômico e Financeiro. São Paulo, vol. 11, Ano XII (nova série), pp. 11-21, 1973.

BARRICHELLO, Stefania Eugenia. "Análise econômica da nova lei brasileira de falências e recuperação de empresas". Revista de Direito Mercantil, Industrial Econômico e Financeiro. São Paulo, vol. 147, Ano XLVI (nova série), pp. 194-209, julh/set, 2007.

BELTRÁN, Emilio; PAREDES, María Luisa Sánches (Directores). Cinco años de aplicación de la Ley Concursal. Navarra: Thomsom Reuters, 2009.

BERGER, Dora. A insolvência no Brasil e na Alemanha. Porto Alegre: Fabris, 2001.

BERTACCHINI, Elisabetta. Trattato di diritto commerciale $e$ di diritto pubblico dell'economia. Padova: Cedam, 2001. Vol. 27 - Revocatoria fallimentare e stato di insolvenza.

BEVILAQUA, Clovis. Teoria geral do direito civil. 4. edição, Rio de Janeiro: Imprensa Nacional, 1972.

BEZERRA FILHO, Manoel Justino. Lei de falências comentada. São Paulo: Revista dos Tribunais, 2. edição, 2003.

Lei de recuperação e falências comentada. São Paulo: Revista dos Tribunais. 7. edição, São Paulo, 2011.

. Exame crítico do projeto da lei de falências - "Recuperação de empresa” ou “Recuperação do crédito bancário”. Revista dos Tribunais, abril/04, v. 822, pp. 128-138.

BEZERRA FILHO, Manoel Justino; BEZERRA, Adriano Ribeiro Lyra. Lei de falência na jurisprudência. São Paulo: Revista dos Tribunais, 2010. 
BISBAL MENDEZ, Joaquin. La empresa en crisis y el derecho de quiebras. Bolonia: Publicaciones del Real Colegio de Espana, 1986.

BLASCO GASCÓ, Francisco de Paula. Declaración en concurso y contratos - Resolución sin incumplimiento e incumplimiento sin resolución. Valencia: Tirant lo Blanch, 2009.

. “Comentario al articolo 148”. In: Comentarios a la Ley Concursal, (Coord. SAGRERA TIZÓN, J.M.; SALA REIXACHS, A.; FERRER BARRIENDOS, A. Barcelona: Bosch, tomo II, 2004.

BLUM, Brian A. Bankruptcy and debtor/creditor, 4. edição, New York: Aspen Publishers, 2006.

BOITEUX, Fernando Netto. "Função social da empresa e o novo código civil". Revista de Direito Mercantil, Industrial, Econômico e Financeiro. São Paulo, vol. 125, Ano XLI (nova série), pp. 48-57, jan/mar, 2002.

BRUSCHETTA, Ernestino. "L'esenzione' contrattuale dal fallimento". In: "La riforma della Legge Falimentare" - Quaderni di Giurisprudenza Commerciale 282 (Coord. Sido Bonfati e Giovanni Falconi), Milano: Giuffrè, 2005.

BULGARELLI, Waldírio. Sociedades comerciais, empresa e estabelecimento, 3. edição, São Paulo: Atlas, 1987.

_. "A reforma da lei de falências e concordata". Revista de Direito Mercantil, Industrial, Econômico e Financeiro. São Paulo, vol., 85, XXXI (nova série), pp. 49-56, jan/mar, 1992.

. "Ainda a reforma da lei de falimentar". Revista de Direito Mercantil, Industrial, Econômico e Financeiro. São Paulo, n. 111, Ano XXXVI (nova série), pp. 203-230.

__ "A atividade negocial no projeto de código civil brasileiro". Revista de Direito Mercantil, Industrial Econômico e Financeiro. São Paulo, vol. 56, Ano XXIII (nova série), pp. 113-120, out/dez, 2004. 
. "Reforma na lei de falências". Revista de Direito Mercantil, Industrial, Econômico e Financeiro. São Paulo, vol. 83, Ano XXX (nova série), pp. 122-136, jul/set, 1991.

CALDEIRA, Jorge. Mauá, o empresário do império. São Paulo: Companhia das Letras, 2004.

CAMPINHO, Sérgio. Falência e recuperação de empresa - o novo regime da insolvência empresarial, 5. edição, São Paulo: Renovar, 2010.

CAMPOS, Francisco. Direito comercial. Rio de Janeiro: Freitas Bastos, 1957.

CANDELARIO MACÍAS, Maria Isabel. “A articulação entre o regulamento (CE) $n$. 1346/2000, relativo aos processos de insolvência comunitários, e a Ley n. 22/2003, sobre o regime concursal español”. Revista de Direito Mercantil, Industrial Econômico e Financeiro. São Paulo, vols. 155/156, pp. 213-244, ago/dez, 2010.

. “Los nuevos juzgados de lo mercantil en España”. Revista de Direito Mercantil, Industrial Econômico e Financeiro. São Paulo, vol. 138, Ano XLIV (nova série), pp. 25-34, abril/junho, 2005.

CANDIAN, Aurelio. Il proceso di fallimento. Padova: Cedam, 1934.

CANTÙ, Cesare. Historia universal. São Paulo: Ed. das Américas, 1967-1968.

CARVALHO, Dora Martins. "O anteprojeto legislativo de Lei de Concordatas e Falências." Revista de Direito Mercantil, Industrial, Econômico e Financeiro. São Paulo, vol. 88, Ano XXXI (nova série), pp. 88-94, out/dez, 1992.

CARVALHO DE MENDONÇA, José Xavier. Das falências e dos meios preventivos de sua declaração. São Paulo: Typografia Brasil de Carlos Guerke \& Cia., 1899.

. Pareceres. Rio de Janeiro: Freitas Bastos, 1933. vol. I - Fallencias. 
Tratado de direito comercial brasileiro. 4. edição, Rio de Janeiro: Freitas Bastos, 1946. Vols. VII e VIII.

CARVAlHOSA, Modesto. Comentários à lei de sociedades anônimas. 3. edição atual. São Paulo: Saraiva, 2002, vols. 2, 3 e 4, tomo II.

CASANOVA, Salazar. "Abordagem judiciária dos aspectos mais relevantes da marcha processual no novo Código da Insolvência e da Recuperação de Empresas”. Disponível em <http://www.asjp.pt $>$.

CASTRO, Carlos Alberto Farracha de. "Uma nova visão do direito falimentar - a obrigatoriedade de adequação e interpretação à luz da constituição federal". Revista de Direito Mercantil, Industrial, Econômico e Financeiro. São Paulo, vol. 118, Ano XXXIX (nova série), pp. 106-111, abril/jun, 2000.

. "O Desvirtuamento da falência frustrada e a necessidade de adequação do rito ordinário". Revista de Direito Mercantil, Industrial, Econômico e Financeiro. Vol. 122, Ano XL (nova série), pp. 59-74, abril/jun, 2001.

CENSONE, Paolo Felice. "La nuova disciplina del concordato preventivo. Requisiti e procedimento di ammisione (art. 160-176 1.f.)". In: "La riforma della Legge Falimentare" - Quaderni di Giurisprudenza Commerciale 282 (Coord. Sido Bonfati e Giovanni Falconi), Milano: Giuffrè, 2005.

CEREZETTI, Sheila Cristina Neder. "O papel dos credores no Bankruptcy Code”. Revista de Direito Mercantil, Industrial, Econômico e Financeiro. São Paulo, vols. 151/152, Ano XLVIII (nova série), pp. 164-186, jan/dez, 2009.

CINTRA, Antonio Carlos de Araújo; GRINOVER, Ada Pelegrini; DINAMARCO, Cândido Rangel. Teoria geral do processo, 27. edição, São Paulo: Malheiros, 2011.

CHAPUT, Yves. Droit des entreprises en difficulté et faillitè personelle (Collection droit fondomental - droit commercial), Paris: PUF, 1996. 
CLARO, Carlos Roberto. Revocatória falimentar (de acordo com a nova Lei de Falências), 3. edição, Curitiba: Juruá, 2005.

COASE, Ronald. The nature of the firm: origins, evolution and development. Edited by WILLIAMSON, Oliver E. and WINTER, Sidney G. London: Oxford University, 1991.

COELHO, Fábio Ulhoa. Comentários à nova lei de falências e de recuperação de empresas. São Paulo: Saraiva, 8. edição, 2011.

. Curso de direito comercial. 12. edição, 2a tiragem, São Paulo: Saraiva, 2011, vol. III.

Curso de direito comercial. 9. edição, São Paulo: Saraiva, 2005. vol. 1.

COIMBRA, Márcio Chalegre. A recuperação da empresa. Regime jurídicos brasileiro e norte-americano. 1. edição, Porto Alegre: Síntese, 2000.

COMPARATO, Fábio Konder. Aspectos jurídicos da macro-empresa. São Paulo: Revista dos Tribunais, 1970.

. “Falência - legitimidade da Fazenda Pública para requerê-la. Parecer”. São Paulo: Revista dos Tribunais, n. 442, pp. 48-54.

_ "Função social da propriedade dos bens de produção". Revista de Direito Mercantil, Industrial, Econômico e Financeiro. São Paulo, vol. 63, Ano XXV (nova série), pp. 71-79, jul/set, 1986.

O poder de controle na sociedade anônima. 4. edição, atualizada por Calixto Salomão Filho. Rio de Janeiro: Forense, 2005.

CONDE TEJÓN, Antonio. La cesión global de activo y pasivo como operación de modificación estructural (Procedimiento aplicable, sucesión universal y protección de 
acreedores), Madrid: Colegio de Registradores de la Propiedad, Mercantiles y Bienes Muebles de España. 2004.

COPELAND, Tom; KOLLER, Tim; MIRRIN, Jack. Valuation: measuring and managing the value of companies. 2. édition, New York: John Wiley \& Sons, 1995.

CORDEIRO, António Menezes. Manual de direito comercial. 2. edição, Coimbra: Almedina, 2009.

COROTTO, Susana. Modelos de reorganização empresarial brasileiro e alemão. Porto Alegre: Fabris, 2009.

CORRÊA-LIMA, Osmar Brina; CORRÊA-LIMA, Sérgio Mourão (coord.). Comentários à nova lei de falência e recuperação de empresa. Rio de Janeiro: Forense, 2009.

COSTEIRA, Maria José (coautora, Miscelânias nº 06 do Instituto de Direito das Empresas e do Trabalho - IDET). O código da insolvência e da recuperação de empresas revisitado. Coimbra: Almedina, 2010.

DANJAUME, Géraldine. Abus de biens sociaux banqueroute (Guides Essentials). Paris: L'Hérmes, 1996.

DASSO, Ariel Angel. Derecho concursal comparado. Tomos I e II, Buenos Aires: Legis Argentina, 2009.

DE LUCCA, Newton; DOMINGUES, Alessandra de Azevedo (Coord.). Direito recuperacional aspectos teóricos e práticos. São Paulo: Quartier Latin, 2009.

; SIMÃO FILHO, Adalberto (Coord.). Comentários à nova lei de recuperação de empresas e de falências. São Paulo: Quartier Latin, 2005.

—. A reforma do direito falimentar no Brasil. Disponível em: $<$ http://www.juspodium.com.br/novodireitocivil/artigos/convidados/artigo_newton_de_luc ca_reforma_falimentar.pdf $>$. 
DE PLÁCIDO E SILVA. Vocabulário jurídico. Rio de Janeiro: Forense, vol. II.

DINAMARCO, Cândido Rangel. A instrumentalidade do processo. 2. edição, São Paulo: Revista dos Tribunais, 1990.

. Fundamentos do processo civil moderno. São Paulo: Revista dos Tribunais, 1986.

DUARTE, Henrique Vaz. Questões sobre recuperação e falência, 2. edição, Coimbra: Almedina, 2004.

EPIFÂNIO, Maria do Rosário. Manual de direito da insolvência. 2. edição, Coimbra: Almedina, 2010.

EPSTEIN, David G. Bankruptcy and related law in a nutshell. 7. edição, Thomson West, 2005.

EPSTEIN, David G.; NICKLES, Steve H. Principles of bankruptcy law. Thomson West, 2007.

Bankruptcy and related law. 2. edition, Dallas, Thomson West, 2006.

Debtor-creditor law. 3. edition St. Paul: West Publishing Company, 1985.

ESCUTI, Ignácio A.; BAS, Francisco Junyent. Derecho Concursal. Buenos Aires: Astrea, 2006.

ETXARANDIO HERRERA, Edorta J. Manual de derecho concursal. 2. edición, Madrid: La Ley, 2009.

EZON, Jack S.; DWECK, Jeffrey S. E-Z Rules for the Bankruptcy Code. Wolters Kluwer Law \& Business, Nwe York: Aspen Publishers, 2009. 
FARENGA, Luigi. "La reforma del diritto fallimentare in Italia: una visione de mercato". Revista de Direito Mercantil, Industrial Econômico e Financeiro. São Paulo, vol. 145, Ano XLVI (nova série), pp. 9-16, jan/mar, 2007.

FAVIER-DUBOIS, Eduardo M. Concursos y quiebras. Ley 24522 actualizada comentada con jurisprudencia y bibliografía (Colección Biblioteca Profesional y Empresaria), 2. edición, Buenos Aires: Errepar, 2005.

FARIA, Bento de. Direito comercial: falência e concordata. Vol. 4, Rio de Janeiro,1947.

FAZZIO JUNIOR, Waldo. Lei de falências e concordatas comentada. 3. edição, São Paulo: Atlas, 2003. . Nova lei de falência e recuperação de empresas. São Paulo: Atlas, 2005.

FERNANDES, Jean Carlos. "Reflexões sobre a nova lei falimentar: os efeitos da homologação do plano de recuperação extrajudicial". Revista de Direito Mercantil, Industrial Econômico e Financeiro. São Paulo, vol. 141, Ano XLIV (nova série), pp. 167184, jan/mar, 2006.

FERNANDES, Luís A. Carvalho; LABAREDA, João. Colectânea de estudos sobre a insolvência. Reimpressão, Lisboa: Quid Juris, 2011.

Código da insolvência e da recuperação de empresas anotado. Reimpressão, Lisboa: Quid Juris, 2009.

Insolvências transfronteiriças - Regulamento (CE) n. 1346/2000 do Conselho anotado. Lisboa: Quid Juris, 2003.

FERNÁNDEZ PRIETO, Marta. La transmisión de empresas en crisis: incidencia de la ley concursal. Espanha: Ediciones Laborum, 2004.

FERRARA, Francesco. Il fallimento. Milano: Giuffre, 1959. 
FERRAZ, Luiz Augusto de Souza Queiroz. "Da Arrecadação, avaliação e realização do ativo". Revista do Advogado-AASP, ano XXV, n. 83, pp. 66-72, set., 2005.

FERREIRA, Waldemar. Instituições de direito comercial. Rio de Janeiro: Freitas Bastos, vol. V - A Falência, 1951.

Tratado de direito comercial. São Paulo: Saraiva, 1966. vol. 15.

FERRI, Giuseppe. Manuale di diritto commerciale. 9. edição. Torino: UTET, 1993.

FONSECA, Humberto Lucena Pereira; KÖHLER, Marcos Antônio. "A nova Lei de Falências e o Instituto da Recuperação Extrajudicial". Revista de Direito Mercantil, Industrial Econômico e Financeiro. São Paulo, vol. 138, Ano XLIV (nova série), pp.84101, abril/junho, 2005.

FONSECA, Humberto Lucena Pereira. "Alienação da Empresa na Falência e Sucessão Tributária". Revista de Direito Mercantil, Industrial Econômico e Financeiro. São Paulo, vol. 132, Ano XLII (nova série), pp. 87-95, out/dez, 2003.

FONSECA, José Júlio Borges da. "Da recuperação da empresa em crise". Revista de Direito Mercantil, Industrial, Econômico e Financeiro. São Paulo, vol. 87, Ano XXXI (nova série) pp. 70-86, jul/set, 1992.

FORGIONI, Paula Andrea. A evolução do direito comercial: da mercancia ao mercado. São Paulo: Revista dos Tribunais, 2009.

. Contrato de distribuição. São Paulo: Revista dos Tribunais, 2005.

Os fundamentos do antitruste. São Paulo: Revista dos Tribunais, 1998.

FRAIMOUT, Jean-Jacques. Droit des entreprises en difficulté. Paris: Ellipses, 2007.

FRANCO, Vera Helena de Mello; SZTAJN, Rachel. Falência e recuperação de empresa em crise. Rio de Janeiro: Elsevier/Campus, 2008. 
FRANCO, Vera Helena de Mello. "Liquidação, encerramento e extinção das obrigações do falido". Revista de Direito Mercantil, Industrial Econômico e Financeiro. São Paulo, vol. 140, Ano XLIV (nova série), pp. 110-117, out/dez, 2005.

FRANCO DA FONSECA, José Roberto. Natureza jurídica da falência. Dissertação à Livre-Docência de Direito Judiciária Civil pela Fadusp, São Paulo, 1969.

FRONTINI, Paulo Salvador. "O caso da falência da Sanderson e as tendências atuais do direito falimentar". Revista de Direito Mercantil, Industrial, Econômico e Financeiro. n. 15-16, pp. 243-251.

—. "Do 'Estado de Falido': Sua configuração - inovações da nova lei de recuperação e falência". Revista de Direito Mercantil, Industrial Econômico e Financeiro. São Paulo, vol. 138, Ano XLIV (nova série), pp. 7-24, abril/junho, 2005.

. "A atividade negocial e seus pressupostos econômicos e políticos". Revista de Direito Mercantil, Industrial, Económico e Financeiro. São Paulo, vol. 18, Ano XIV (nova série), pp. 31-38, 1975.

. "Novas vantagens para o fisco em matéria falimentar". Revista de Direito Mercantil, Industrial, Econômico e Financeiro. São Paulo, vol. 44, Ano XX (nova série), pp. 123-125, out/dez, 1981.

_ "Reflexões sobre a reforma da lei de falências". Revista de Direito Mercantil, Industrial, Econômico e Financeiro. São Paulo, v. 31, Ano XVII (nova série), pp. 43-51, 1978.

FURTADO, Celso. Formação econômica da América Latina. 2. edição, Rio de Janeiro: LIA, 1970.

GALGANO, Francesco. Trattato di diritto commerciale e di diritto pubblico dell'economia. Padova: Cedam/Dott. Antonio Milani, 1978. Vol. II - L’Impresa. 
GARCÍA MARTÍNEZ, Roberto. Derecho Concursal. Buenos Aires: Abeledo-Perrot, 1997.

GENNARI, Francesco. I patrimônio destinati ad uno specifico affare. Padova: Cedam, 2005.

GIBRILA, Deen. Droit des entreprises en difficulté. Paris: Defrénois, Lextenso éditions, 2009.

GOMES, Orlando. Introdução ao direito civil. 7. edição, Rio de Janeiro: Forense, 1983.

GONÇALVES NETO, Alfredo de Assis. Direito de empresa - comentários aos artigos 966 a 1.195 do código civil. 2. edição, São Paulo: Revista dos Tribunais, 2008.

GONTIJO, Vinícius José Marques. "Efeitos da falência do empregador na ação de execução de crédito trabalhista". Revista de Direito Mercantil, Industrial Econômico e Financeiro. São Paulo, vol. 146, Ano XLVI (nova série), pp. 128-145, abril/junh, 2007.

__ "A compensação na falência: subclasse no quadro geral de credores". Revista de Direito Mercantil, Industrial Econômico e Financeiro. São Paulo, vol. 147, Ano XLVI (nova série), pp. 181-193, junh/set, 2007.

GONZÁLEZ PASCUAL, Julián. El concurso de acreedores. Una nueva solución para las empresas insolventes. Madrid: Ediciones Estudios Financieros, 2003.

GOODE, Roy. Il diritto commerciale del terzo millennio. Tradução de Joelma d'Almeida. Milano: Giuffrè, 2003.

Principles of Corporate Insolvency Law. Student Edition, Thompson Sweet \& Maxwell, 2005.

GORON, Lívio Goellner. “Constituição e Interpretação: uma análise da decisão do STF sobre a nova lei de falências e recuperação de empresas (ADI 3934-DF)". Revista de 
Direito Mercantil, Industrial Econômico e Financeiro. São Paulo, vol. 157, ano L, pp. 150166, jan/mar, 2011.

GRAU, Eros Roberto. A ordem econômica na Constituição de 1988. 6. edição, São Paulo: Malheiros, 2001.

Ensaio e discurso sobre a interpretação/aplicação do direito. 3. edição, São Paulo: Malheiros, 2005.

. O direito posto e o direito pressuposto. 5. edição, São Paulo: Malheiros, 2003.

; FORGIONI, Paula Andrea. O Estado, a empresa e o contrato. São Paulo: Malheiros, 2005.

GRAZIABILE, Darío J. Derecho concursal. Tomo I, Buenos Aires: Lexis Nexis, 2006.

GRISPO, Jorge Daniel; BALBÍN, Sebastían. Extensión de la quiebra. Buenos Aires: Adhoc, 2000.

GUGLIELMUCCI, Lino. Legge tedesca sull'insolvenza (insolvenzordnung del 5 ottobre 1994). Milano: Giuffrè, 2000.

GUIMARÃES, Maria Celeste Morais. "Entraves à eficacia da lei de recuperação de empresas em crise. Como superá-los?". Revista de Direito Mercantil, Industrial Econômico e Financeiro. São Paulo, vol. 142, Ano XLIV (nova série), pp. 155-187, abril/junh, 2006.

GUTIERREZ GILSANZ, Andrés. Tutela de los acreedores frente al convenio concursal: oposición, nulidade y declaración de incumplimiento. Madrid: La Ley grupo Wolters Kluwer, 2008.

HARADA, Kiyoshi. Aspectos tributários da nova lei de falências - comentários à LC 118, de 09/02/2005, 2ª tiragem, Curitiba: Juruá, 2006. 
HART, Oliver. Different approaches to bankruptcy. National Bureau of Economic Research Working Paper Series. 2000. Disponível em $<$ http://www.nber.org/papers/w7921>.

HAUSMANN, Christian; TORRE, Philippe. Les garanties de passif, Négotiation et rédacion des conventions de garantie em matière de transmission d'entreprises. Paris: Édition Formation Entreprise, 2007.

HEREDIA, Pablo D. Tratado exegético de derecho concursal. $2^{\mathrm{a}}$ tiragem, Buenos Aires: Depalma, 2000.

HUALDE LÓPEZ, Ibon. Régimen Jurídico de la administración concursal en la fase de liquidación del concurso. Estudios de Derecho Concursal. 1. edición, Espanha: Thomson Civitas, 2009.

La fase de liquidación en el proceso concursal. Navarra: Thomson Aranzadi, 2008

IANNIELLO, Barbara. Il nuovo diritto fallimentare (guida alla riforma delle procedure concorsuali). Milano: Giuffrè, 2006.

IMHOF, Cristiano. Lei de falências e de recuperação de empresas e sua interpretação judicial. Florianópolis: Conceito, 2009.

IRTI, Natalino. L'età della decodificazione. 4. edição Milano: Giuffre, 1999.

IUDÍCIBUS, Sergio de; MARION, José Carlos. Curso de contabilidade para não contadores para as áreas de administração, economia, direito e engenharia. 3. edição, São Paulo: Atlas, 2000.

JACQUEMONT, André. Droit des entreprises en difficulté. 6. édicion, Paris: Litec Group Lexisnexis, 2009. 
JAEGER, Nicola. Il Fallimento e le altre forme di tutela giurisdizionale. Milano, Casa Editrice Dr. Francesco Vallardi, 1964.

JEANTIN, Michel; LE CANNU, Paul. Entreprises en difficulté. 7. édicion, Paris: Dalloz, 2007.

JORIO, Alberto. Le crisi d'impresa e il fallimento. Milano: Giuffrè, 2000.

JUNYENT BAS, Francisco; SANDOVAL, Carlos A. Molina. Sistema de ineficacia concursal: la retroacción en la quiebra. Buenos Aires: Rubinzal-Culzoni, 2002.

KRAAKMAN, Reinier (ob. coletiva). The anatomy of corporate law: a comparative and functional approach. 2. edition, New York: Oxford, 2009.

LARENZ, Karl. Derecho civil - parte general. Madrid: Editorial Revista de Derecho Privado/ Editoriales de Derecho Reunidas, 1978.

LEÃES, Luiz Gastão Paes de Barros. "A disciplina do direito de empresa no novo código civil brasileiro". Revista de Direito Mercantil, Industrial Econômico e Financeiro. São Paulo, vol. 128, Ano XLI (nova série), pp. 7-14, out/dez, 2002.

. Estudos e pareceres sobre sociedades anônimas. São Paulo: Revista dos Tribunais, 1989.

LE CORRE, Pierre-Michel. La reforme du droit des entreprises en difficulté. Paris: Dalloz, 2009.

Droit e pratique des procédures collectives. Paris: Dalloz, 2011.

LE CORRE, Pierre-Michel; LE CORRE-BROLY, Emmanuelle. Droit des entreprises en difficulté, 2. edition, Paris: Sirey Université, 2006.

LEITÃO, Luís Manuel Teles de Menezes. Direito da insolvência. 3. edição, Coimbra: Almedina, 2011. 
LOBO, Jorge. Direito concursal. Rio de Janeiro: Forense, 1996.

_. "A empresa: novo instituto jurídico". Revista de Direito Mercantil, Industrial, Econômico e Financeiro. São Paulo, vol. 125, Ano XLI (nova série), pp. 29-40, jan/mar, 2002.

. "Direito da crise econômica da empresa". Revista de Direito Mercantil, Industrial, Econômico e Financeiro. São Paulo, vol. 109, Ano XXXVI (nova série), pp. 6492, jan/mar, 1998.

— "Direito da crise econômica da empresa". Revista dos Tribunais, São Paulo, Revista dos Tribunais, n. 754, Ano 87, p. 11-44, agosto de 1998.

. "Dos pressupostos da falência". Revista dos Tribunais. São Paulo: Revista dos Tribunais, n. 702, p. 28.

_. "Efeitos da concordata e da falência em relação aos contratos bilaterais do concordatário e do falido". Revista de Direito Mercantil, Industrial, Econômico e Financeiro, São Paulo, vol. 110, Ano XXXVI (nova série), pp. 32-42, abril/jun, 1998.

"O moderno direito concursal". Revista de Direito Mercantil, Industrial, Econômico e Financeiro. São Paulo, vol. 99, Ano XXXIV, pp. 87-97, jul/set, 1995.

—. "Responsabilidade por obrigações e dívidas da sociedade empresária na recuperação extrajudicial, na recuperação judicial e na falência”. Revista de Direito Mercantil, Industrial Econômico e Financeiro. São Paulo, vol. 144, Ano XLV (nova série), pp. 138-145, out/dez, 2006.

MAIA, Felipe Fernandes Ribeiro. "O critério da impontualidade na decretação da falência no direito contemporâneo: O projeto de lei n. 071/2003 do Senado Federal". Revista de Direito Mercantil, Industrial Econômico e Financeiro. Vols. 153/154, Ano XLIX (nova série), pp. 142-163, jan/jul, 2010. 
MAIDA, Fernando. Pesadelo ou realidade ao comercializar com empresas estrangeiras no Mercosul. Disponível em < $<$ www.fiscosoft.com.br $>$.

MANDEL, Julio. Nova lei de falências e recuperação de empresas anotada. São Paulo: Saraiva, 2005.

MANGE. Renato Luiz de Macedo Mange. "Sobre recuperação e falência de empresas no Brasil". Revista de Direito Mercantil, Industrial Econômico e Financeiro. São Paulo, vol. 127, Ano XLI (nova série), pp. 56-62, julh/set, 2002.

MARCONDES, Sylvio. Problemas de Direito Mercantil. São Paulo: Max Limonad, 1970. Questões de direito mercantil. São Paulo: Saraiva, 1977.

MARCHI, Eduardo C. Silveira. Guia de metodologia jurídica. Lecce: Edizione del Grifo, 2004.

MARQUES, José Frederico. Manual de direito processual civil. 10. ed. São Paulo: Saraiva, 1983. 1 - Teoria Geral do Processo Civil.

MARTIN, Nathalie; TAMA, Ocean. Inside Bankruptcy Law - What Matters and Why, Wolters Kluwer Law \& Business. New York: Aspen Publishers, 2008.

. The Glannon Guide to Bankruptcy. 2. edição, Wolters Kluwer Law \& Business. New York: Aspen Publishers, 2007.

MARTINS, Fran. Títulos de crédito. 3. edição, Rio de Janeiro: Forense, 1991. vol. I.

MARTINS, Luís M., Processo de insolvência. 2. edição, Coimbra: Almedina, 2010.

MAXIMILIANO, Carlos. Hermenêutica e aplicação do direito. 16. edição, Rio de Janeiro: Forense, 1997. 
MEDEIROS, Wanderley Pinto. "A insolvência das empresas brasileiras e o papel dos bancos em desenvolvimento". Revista de Direito Mercantil, Industrial, Econômico e Financeiro. São Paulo, vol.72, Ano XXVII (nova série), pp. 48-56, out/dez, 1998.

MESSINEO, Francesco. Trattato di diritto civile e commerciale. Il contratto in genere. Milano: Giuffrè, 1973. vol. XXI, tomo 1.

MENDES, Bernardo Bicalho de Alvarenga. "A importância do administrador judicial como órgão auxiliar ao juízo falimentar na busca da eficacia dos procesos falimentares $e$ de recuperação judicial de empresas”. Revista de Direito Mercantil, Industrial Econômico e Financeiro. São Paulo, vols. 155/156, pp. 263-268, ago/dez, 2010.

MENDES, Octavio. Fallencias e concordatas (de acordo com o Decreto n. 5.745, de 9 de dezembro de 1929). São Paulo: Saraiva \& Cia., 1930.

MIGUEL, Paula Castello. O Estabelecimento Comercial. Revista de Direito Mercantil, Industrial Econômico e Financeiro. São Paulo, vol. 118, Ano XXXIX (nova série), pp. 0761, abril/jun, 2000.

MILANI, Mario Sergio. Lei de recuperação judicial, recuperação extrajudicial e falência comentada. São Paulo: Malheiros, 2011.

MIRANDA, Maria Bernadete. A reorganização da empresa como objetivo principal do processo falimentar. Dissertação de Mestrado em Direito Comercial, sob orientação de Newton de Lucca. São Paulo: Pontifícia Universidade Católica, 1993.

MONTEIRO DE CASTRO, Rodrigo; ARAGÃO, Leandro Santos (coord.). Direito societário e a nova lei de falências e recuperação de empresas. São Paulo: Quartier Latin, 2006.

MORAES, José Rubens de. Evolução histórica da execução civil no direito lusitano. Dissertação de Mestrado sob orientação de Roque Komatsu. São Paulo: Faculdade de Direito da USP, 2005. 
MORAES, Mauro Delphim de. Comentário a Acórdão RE. 87.405-RJ, Primeira Turma, Rel. Ministro Xavier Albuquerque. Revista de Direito Mercantil, Industrial, Econômico e Financeiro. São Paulo, vol. 40, Ano XIX (nova série), pp. 132- 140, out/dez, 1980.

MORO, Carlos E.. Ley 26.086. Concursos y Quiebras. Modificación de la ley 24.522. Buenos Aires: Adhoc, 2006.

MÜLLER, Elisa. Moedas e bancos no Rio de Janeiro no século XIX. Disponível em $<$ http://www.ie.ufrj.br>.

MUNHOZ, Eduardo Secchi. “Anotações sobre os limites do poder jurisdicional”, Revista de Direito Bancário e do Mercado de Capitais, ano 10, n. 36, abr-jun/2007. São Paulo: Revista dos Tribunais, pp. 185/199.

NEDEL, Oscar. Ley de Concursos y Quiebras Comentada, 2. ed. Buenos Aires: La Ley, 2007.

NEGRÃO, Ricardo. Manual de Direito Comercial e de empresa, vol. 3, 5. edição. São Paulo: Saraiva, 2010.

Aspectos objetivos da lei de recuperação de empresas e de falências. 5. edição. São Paulo: Saraiva, 2010.

NERY, Sandra de Medeiros. "Concordata preventiva e suspensiva (alguns aspectos econômicos e contábeis". Revista de Direito Mercantil, Industrial Econômico e Financeiro. São Paulo, vol. 118, Ano XXXIX (nova série), pp. 199-218, julh/set, 2000.

NUNES, Marcelo Guedes; BARRETO, Marco Aurélio Freire. Direito societário e a nova lei de falência e recuperação de empresas. "Alguns apontamentos sobre comunhão de credores e viabilidade econômica", obra coletiva (Coord. Rodrigo R. Monteiro de Castro e Leandro Santos de Aragão) São Paulo: Quartier Latin - IDSA, 2006.

NUSDEO, Fábio. Curso de economia - introdução ao direito econômico. 3. edição, São Paulo: Revista dos Tribunais, 2001. 
PACHECO, José da Silva. Processo de concordata e falência. 6. edição, Rio de Janeiro: Forense, 1996.

_. Processo de recuperação judicial, extrajudicial e falência. 3. edição. Rio de Janeiro: Forense, 2009.

PAJARDI, Piero. Radici e ideologie del fallimento. 2. edição, Milano: Giuffrè, 2002.

; KLEIDERMARCHER, Arnoldo; FARCHÍ DE MONTALBÁN, Diana; GEBHARDT, Marcelo; HUALDE, Paula M; MARTÍN PARDUCCI, Diego. Derecho Concursal, verificación, liquidación, distribuición y clausura - Tomo 3, Buenos Aires: Editorial Ábaco de Rodolfo de Palma, 2011.

PARRA, Maria Ángeles. Persona y patrimonio en el concurso de acreedores. Estudios de Derecho Concursal. 1. edição, Espanha: Thomson Reuters, 2009.

PELUSO, Cezar (Coord.). Código civil comentado, 3. edição, São Paulo: Manole, 2009.

PENALVA SANTOS, Paulo (Coord). A nova lei de falências e de recuperação de empresas - Lei n. 11.101/2005, Rio de Janeiro: Forense, 2006.

- "O novo projeto de recuperação da empresa". Revista de Direito Mercantil, Industrial, Econômico e Financeiro. Vol. 117, Ano XXXIX (nova série), pp. 126-135, jan/mar, 2000.

PENTEADO, Mauro Rodrigues. Dissolução e liquidação de sociedades. Brasília: Brasília Jurídica, 1995.

PEREIRA, Caio Mário da Silva. Instituições de direito civil. Vol. I, 15. edição, Rio de Janeiro: Forense, 1994.

PEREIRA CALÇAS, Manoel de Queiroz. Sociedade Limitada no Novo Código Civil. São Paulo, Atlas, 2003. 
PEREIRA DA SILVA, José. Análise financeira das empresas. 6. edição, São Paulo: Atlas, 2004.

PERIN JUNIOR, Ecio. Preservação de Empresas na Lei de Falências. São Paulo: Saraiva, 2009.

. Curso de Direito Falimentar e Recuperação de Empresas, 3. edição, São Paulo: Método, 2006.

PÉROCHON, Françoise e BONHOMME, Régine. Entreprise en difficultè: instruments de crédit et de paiement, 3. édicion, Paris: LGDJ, 2006.

PESTANA DE VASCONCELOS, Luís Miguel D.P. A cessão de créditos em garantia e a insolvência, em particular da posição do cessionário na insolvência do cedente. Portugal: Coimbra Editora, 2007.

PÉTEL, Philippe. Procédures Collectives. 6. édicion, Paris: Dalloz, 2009.

PETRAZZINI, Verónica F. Martínez. Ley de Concursos y Quiebras n. 24.522: comentario analítico y comparativo de la reforma, Buenos Aires: Ediciones Macchi, 1995.

PIMENTA, Eduardo Goulart. Recuperação de Empresas - Um estudo sistematizado da nova lei de falências, São Paulo: Thomson/IOB, 2006.

PONTES DE MIRANDA, Francisco. Tratado das ações. Tomo 3, edição atualizada por Vilson Rodrigues Alves, Campinas: Bookseller, 1998. Tratado das ações. São Paulo: Revista dos Tribunais, 1972. . Tratado de direito privado. Tomo XV, Rio de Janeiro: Borsoi, 1956. . Tratado de direito privado. Tomos XXVII e XXIX, São Paulo: Revista dos Tribunais, 1984. 
POSNER, Richard A.; ADLER, Barry. Corporate bankruptcy, economic and legal perspectives. Ed. Por Jagdeep S. Bhandari and Lawrence A. Weiss. Cambridge: Cambridge University Press, 1996.

PRADO JÚNIOR, Caio. História econômica do Brasil. 46. reimpr. São Paulo: Brasiliense, atualizado em 1970, 2004.

PROENÇA, José Marcelo Martins. "Os novos horizontes do direito concursal - uma crítica ao continuismo prescrito pela Lei 11.101/2005". Revista de Direito Mercantil, Industrial Econômico e Financeiro. São Paulo, vols. 151/152, Ano XLVIII (nova série, pp. 47-64), jan/dez, 2009.

PROVINCIALI, Renzo. Manuale di diritto fallimentare. 3. edição, Milano: Giuffrè, 1955.

PUGLIESI GARDINO, Adriana Valéria. A evolução do tratamento jurídico da empresa em crise no direito brasileiro. Dissertação de Mestrado, Universidade de São Paulo, 2006.

—_ "Superendividamento do consumidor: breves reflexões". Revista da Ajuris (Associação dos juízes do Rio Grande do Sul), Porto Alegre, vol. 121, Ano XXXVIII, pp. 13-46, março 2011.

RAGUSA MAGGIORE, Giuseppe; TORTORICI, Giovanni et al. Crisi d'impresa e procedure concorsuali in Italia e in Europa - Prospettive di riforma. Padova: Cedam, 2002.

REALE, Miguel. Lições preliminares de direito. 7. edição, São Paulo: Saraiva, 1980.

REQUIÃO, Rubens. "A crise do direito falimentar brasileiro - reforma da lei de falências". Revista de Direito Mercantil, Industrial Econômico e Financeiro. São Paulo, vol. 14, Ano XIII (nova série), pp. 23-33, 1974.

Curso de direito falimentar. 16. edição. São Paulo: Saraiva, 1995. vols. I e II. 
Insolvência e preservação da empresa: aspectos modernos de direito comercial. São Paulo: Saraiva, 1986.

Comentário ao AI n. 196.641 publicado na RT 427/137. Revista de Direito Mercantil, Industrial Econômico e Financeiro. São Paulo, Ano XI (nova série), vol. 07, pp. 77-78, 1972.

- Comentário ao AI n. 37/73, TJPR. Revista de Direito Mercantil, Industrial Econômico e Financeiro. São Paulo, Ano XII (nova série), vol. 12, pp. 130-134, 1973.

RIBEIRO, Renato Ventura. "Falência de sociedades civis". Revista de Direito Mercantil, Industrial, Econômico e Financeiro. São Paulo, vol. 142, Ano XLIV (nova série), pp. 256281, abril/junh, 2006.

RIVERA, Julio César. El derecho concursal: una rama cuya legislación está en permanente cambio. Disponível em <http://www.rivera.com.ar/publications.pdf >, Revista de Derecho Comparado, Rubinzal Culzoni, nº 15, p. 11.

ROBBE, Alberto J. Nova Lei de Fallencias (Decr. 5746, de 9 de Dezembro de 1929) ANNOTADA. São Paulo: Revista dos Impostos Federaes, 1930.

ROCCO, Alfredo. Princípios de direito comercial. São Paulo: LZN, 2003.

RODRIGUES, Frederico Viana. "Reflexões sobre a viabilidade econômica da empresa no novo regime concursal brasileiro". Revista de Direito Mercantil, Industrial Econômico e Financeiro. São Paulo, vol. 138, Ano XLIV (nova série), pp. 102-122, abril/junho, 2005.

RODRÍGUES, Fernando Soler. "La fase común en el procedimiento concursal”. Boletín del Ilustre Colegio de Abogados de Madrid, n. 31, 3. Octubre 2005.

RODRIGUEZ, Mónica Sofía. "Armonización Legislativa en materia de salvataje de empresas en el MERCOSUR: ¿Una quimera o una necesidad?". Edición electrónica gratuita, 2010. Texto completo en <www.eumed.net/tesis/2010/msr/>. 
RONCONI, Sara. "I pressuposti causalli dell'instaurazione della procedura di liquidazione coatta amministrativa e la rilevanza (o irrelevanza) dello stato di insolvenza dell'impresa." DIRITTO \& DIRITTI - Rivista giuridica on line. Disponível em $<$ http:///www.diritto.it>.

ROSSI, Riccardo. Insolvenza, crisi di impresa e risanamento. Milano: Giuffrè, 2003.

ROUILLON, Adolfo A.N. Derecho concursal (homenage a Guilhermo Mosso), Buenos Aires: La Ley, 2004.

SABINA, Fabrício Gonçalves de Souza. "Da compensação na falência no âmbito do sistema financeiro nacional". Revista de Direito Mercantil, Industrial Econômico e Financeiro. São Paulo, vol. 143, Ano XLV (nova série), pp. 137-155, julh/set, 2006.

SAINT-ALARY-HOUIN, Corinne. Droit des entreprises en difficulté, 6. édicion, Paris, Montchrestien, 2009.

SALGADO DE SOMOZA, Francisco. Labyrintus creditorum concurrentium ad litem per debitorem. Edicio Novissima, Tupis Ioannis Baptistae Tramontini, M.DC.LXXXVI. Tomos I e II.

SALAMACHA, José Eli. “Débitos fiscais e a recuperação judicial de empresas". Revista de Direito Mercantil, Industrial Econômico e Financeiro. São Paulo, vol. 140, Ano XLIV (nova série), pp. 118-125, out/dez, 2005.

SAMPAIO DE LACERDA, J. C. Manual de direito falimentar. 12. ed., Rio de Janeiro: Freitas Bastos, 1985.

SÁNCHEZ-MORALEDA, Ana Moreno. Los Efectos de la declaración de concurso el los contratos bilaterales. Valencia: Tirant lo blanch, 2010.

SANTARELLI, Umberto. Per la storia del fallimento nelle legislazione italiane dell'età intermédia. Padova: Cedam, 1964. 
SANT'ANA, Rubens. "A falência da empresa: realidade contemporânea e perspectivas futuras". Revista de Direito Mercantil, Industrial, Econômico e Financeiro. São Paulo, vol. 64, Ano XXV (nova série), pp. 37-46, out/dez, 1986.

SANTIAGO DANTAS, F. C. de. Problemas de direito positivo-estudos e pareceres. Rio de Janeiro: Forense, 1953.

SANTO, Luís Filipe Espírito (Coord.). Contratos comerciais, direito bancário e insolvência - jurisprudência 2000-2009. Colectânea de Jurisprudência, Edições. Portugal: Coimbra Editora, 2009.

SATIRO DE SOUZA JR., Francisco; PITOMBO, Antonio Sergio A. de Moraes (Coord.). Comentários à lei de recuperação de empresas e falência, 2. edição, São Paulo: Revista dos Tribunais, 2007.

SATTA, Salvatore. Diritto fallimentare. 3. edição, Padova: Cedam, 1996. . Instituzioni di diritto fallimentare. 3. edição, Roma, 1948, n. 10.

SCARBERRY, Mark S.; KLEE, Kenneth N.; NEWTON, Grant W; NICKLES, Steve H. Business reorganization in bankrutpty, 2. edition, USA: W Group, 2001.

SCARPINELLA BUENO, Cássio. In: MARCATO, Antonio Carlos (Coord.). Código de processo civil interpretado. São Paulo: Atlas, 2004.

SEGAL, Rubén. Acuerdos preventivos extrajudiciales - analisis y metodología de superación de las crisis empresarias. Buenos Aires: Abeledo-Perrot, 1998.

SERRA, Catarina. O novo regime português da insolvência: uma introdução. 4. edição, Portugal: Coimbra Editora, 2011.

A falência no quadro da tutela jurisdicional dos direitos de crédito. O problema da natureza do processo de liquidação aplicável à insolvência no direito português. Portugal: Coimbra Editora, 2009. 
SERRANO SÁNCHEZ, Manuela. Aspectos concursales del patrimônio del insolvente, el concurso de acreedores tras cinco años de vigencia de la ley concursal. Granada: Editorial Comares, 2009.

SIMIONATO, Frederico Augusto Monte. “A disciplina da reorganização da empresa em crise econômica no projeto de lei concursal’. Revista de Direito Mercantil, Industrial, Econômico e Financeiro. São Paulo, vol. 111, Ano XXXVI (nova série), p. 138, jul/set, 1998.

- "A reforma da lei de falências frente à reorganização econômica da empresa". Revista de Direito Mercantil, Industrial, Econômico e Financeiro. São Paulo, vol. 108, Ano XXXVI (nova série), pp. 16-62, out/dez, 1997.

SOUZA, Marcelo Papaléo de. A nova lei de recuperação e falência e as suas consequências no direito e no processo do trabalho. São Paulo: LTR, 2006.

SOUWEINE, Carole. Droit de l'entreprise en difficulté, 2. edition, Grenoble: PUG - Press Universitaires de Grenoble, 2007.

STANGHELLINI, Lorenzo. Le crisi di impresa fra diritto ed economia (le procedure di insolvenza). Bologna: Il Mulino, 2007.

STURZENEGGER, Luiz Carlos. Doutrina do patrimônio de afetação e o novo sistema de pagamentos brasileiro. Revista de Direito Bancário, do Marcado de Capitais e da Arbitragem, v. 11, São Paulo: Revista dos Tribunais, 2001.

SZTAJN, Rachel. Teoria jurídica da empresa - atividade empresária e mercados. São Paulo: Atlas, 2004.

Ensaios sobre a natureza da empresa - organização contemporânea da atividade.

São Paulo, Tese para concurso de professor titular do Departamento de Direito Comercial da Faculdade de Direito da Universidade de São Paulo, 2001. 
Contrato de sociedade e formas societárias. São Paulo: Saraiva, 1989.

. "Função social do contrato e direito de empresa". Revista de Direito Mercantil, Industrial, Econômico e Financeiro. São Paulo, vol. 139, Ano XLIV (nova série), pp. 2949, julh/set, 2005.

"Notas sobre as assembleias de credores na lei de recuperação de empresas". Revista de Direito Mercantil, Industrial, Econômico e Financeiro. São Paulo, vol. 138, Ano XLIV (nova série), pp. 53-70, abril/junho, 2005.

_ "Law and economics". Revista de Direito Mercantil, Industrial, Econômico e Financeiro. São Paulo, vol. 137, Ano XLIV (nova série), pp. 227-231, jan/março, 2005.

- "Codificação, decodificação, recodificação: a empresa no código civil brasileiro". Revista de Direito Mercantil, Industrial, Econômico e Financeiro. São Paulo, vol. 145, Ano XLV (nova série), pp. 11-20, jul/set, 2006.

TABB, Charles Jordan. The law of bankruptcy. Westbury (NY): The Foundation Press, 1997. University Textbook Series.

TEDESCHI, Guido Uberto. Manuale di diritto fallimentare. Padova: Cedam, 2001.

TEPEDINO, Ricardo. "A recuperação da empresa em crise diante do Decreto-lei 7.661/1945”. Revista de Direito Mercantil, Industrial, Econômico e Financeiro. São Paulo, vol. 128, Ano, XLI (nova série), pp. 165-173, out/dez, 2002.

TOLEDO, Paulo Fernando Campos Salles de. A empresa em crise no direito francês $e$ americano. Dissertação de Mestrado. São Paulo: Fadusp, 1987.

. "Da personificação da massa falida". Revista de Direito Mercantil, Industrial, Econômico e Financeiro. São Paulo, vol. 78, ano XXIX (nova série), pp. 46-51, abril/junho, 1990. 
" "A desconsideração da personalidade jurídica na falência". Revista de Direito Mercantil, Industrial, Econômico e Financeiro. São Paulo, vol. 134, Ano XLIII (nova série), pp. 222-233, abril/jun, 2004.

—. "A disciplina jurídica das empresas em crise no Brasil: sua estrutura institucional". Revista de Direito Mercantil, Industrial, Econômico e Financeiro. São Paulo, vol. 122, Ano XL (nova série), pp. 168-172, abril/junho, 2001.

. "A nova lei de falências e de recuperação de empresas". Revista do Advogado AASP, ano XXV, n. 83, pp. 98-106, set., 2005.

_. "A reforma da lei de falências e a experiência do direito estrangeiro". Revista do Advogado, n. 36, p. 82, mar., 1992.

. "Da caracterização da insolvabilidade civil. Pressupostos objetivos e subjetivos do processo de execução concursal". Revista de Direito Mercantil, Industrial, Econômico e Financeiro. São Paulo, vol. 57, Ano XXIV (nova série) pp. 42-50, jan/mar, 1985.

_ _Lei de falências - alienação de estabelecimento da concordatária". Revista de Direito Mercantil, Industrial, Econômico e Financeiro. São Paulo, vol. 128, Ano XLI (nova série), pp. 275-286, out/dez, 2002.

"Liquidação extrajudicial de instituições financeiras: alguns aspectos polêmicos".

Revista de Direito Mercantil, Industrial, Econômico e Financeiro. São Paulo, vol. 60, ano XXIV (nova série), pp. 24-38, out/dez, 1985.

. "A empresa e o empresário no código civil". Obra coletiva Coord. Elizabeth Accioli, Direito no Século XXI - Em homenagem ao professor Werter Faria, Curitiba: Juruá, 2009.

; ABRÃO, Carlos Henrique (Coord.). Comentários à lei de recuperação de empresas e falência, 4. edição, São Paulo: Saraiva, 2010.

TOMAZETTE, Marlon. Curso de Direito Empresarial, vol. 3, São Paulo: Atlas, 2011. 
TORRENTE, Andrea; SCHLESINGER, Piero. Manuale di diritto privato. 17. edição, Milano: Giuffrè, 2004.

VALLANSAN, Jocelyne. Difficultés des entreprises, commentaire article par article du livre VI du code de commerce (avec la collaboration de Pierre Gagnoli, Laurence FonLanger et Corinne Regnaut-Moutier), 5. édition, Paris: LexisNexis, 2009.

VALENTE DE PAIVA, Luiz Fernando (Coord.). Direito falimentar e a nova Lei de Falências e Recuperação de Empresas. São Paulo: Quartier Latin, 2005.

VALVERDE, Trajano de Miranda. Comentários à lei de falências. 4. edição atualizada por J. A Penalva dos Santos e Paulo Penalva Santos. Rio de Janeiro: Forense, 1999. Vols. I, II e III.

VALLENS, Jean-Luc (Direction de), obra coletiva. Crise du crédit et entreprises, les réponses du droit. France: Éditions Lamy, 2010.

VASCONCELOS, Ronaldo, Direito processual falimentar (de acordo com a Lei n. 11.101, de 9 de fevereiro de 2005). São Paulo: Quartier Latin, 2008.

VÉLAZ NEGUERUELA, Jose Luis. El concurso de acreedores y la insolvencia. Barcelona: Bosch, 2009.

VERÇOSA, Haroldo Malheiros. "Falência - desconsideração da personalidade jurídica". Revista de Direito Mercantil, Industrial, Econômico e Financeiro. São Paulo, vol. 120, Ano XXXIV (nova série), pp. 120-172, out/dez, 2000.

. "Atividade mercantil. Ato de comércio. Mercancia. Matéria de comércio. Comerciante." Revista de Direito Mercantil, Industrial Econômico e Financeiro. São Paulo, vol. 47, Ano XXI (nova série), pp. 29-39, jan/dez, 2009.

VIDAL, Dominique. Droit de l'entreprise en difficulté, 3. édition, Paris: Gualino Lextenso Éditions, 2010. 
VIEIRA, Andréia Costa. Civil Law e Common Law: os dois grandes sistemas legais comparados, Porto Alegre: S.A. Fabris, 2007.

VIGIL NETO, Luiz Inácio. Teoria falimentar e regimes recuperatórios. Porto Alegre: Livraria do Advogado, 2008.

VILAS BOAS, Daniel Rivorêdo. A continuação dos negócios da falida: critérios e condições, em obra coletiva Coord. DIAS DO AMARAL, Paulo Adyr; FLORIANO NETO, Alex. Direito empresarial: teoria, práticas e estratégias, Belo Horizonte: Del Rey, 2010.

VÍTOLO, Daniel R.; BOQUIN, Gabriela F.; DUBOIS, Eduardo M. Favier; BALONAS, Daniel; VILLOLDO, J. Marcelo; MORO, Carlos E. La tutela de los acreedores en los procesos concursales, Buenos Aires: Adhoc, 2006.

; RICHARD, Efraín H (Directores); ANDREANI, Patricia Fernandéz de (Coord.). Acciones de recomposición patrimonial y conflictos laborales em la quiebra, Buenos Aires: Adhoc, 2005.

VIVANTE, Cesare. Trattato di diritto commerciale. 5. edição, Milano: Dott. Francesco Vallardi, 1934. vol. I - Il Commerciante.

WARREN, Willian D.; BUSSEL, Daniel J. Bankruptcy, 7. edition. New York: F Press, 2006.

WAXMAN, Ned W. Bankruptcy. Gilbert Law Summaries, Chicago: Thomson West, fifth edition, 2002.

ZANETTI, Robson. A determinação da falência do devedor comerciante diante da não nomeação de bens à penhora dentro do prazo legal no processo de execução singular. Disponível em<http://www.forense.com.br/atualida/artigos_DCOM/falencia.htm>. 
ZILBERBERG, Eduardo. “Uma análise do principio da preservação da empresa viável no contexto da nova Lei de Recuperação de Empresas". Revista de Direito Mercantil, Industrial, Econômico e Financeiro. São Paulo. Vol. 141, Ano XLIV (nova série), pp. 185212, jan/mar, 2006.

ZYLBERSZTAJN, Decio; SZTAJN, Rachel. Direito e economia: análise econômica do direito e das organizações. Obra coletiva (coord.), São Paulo: Elsevier, 2005.

ZYWICKI, Todd. "The past, present, and the future of Bankruptcy Law in America", George Mason University School of Law, em <http://ssrn.com/abstract_id=327233 >. 